

$$
\begin{aligned}
& \text { Pebound } 1938 \\
& \text { Alex. Agassiz. } \\
& \text { apibrariy of the ittuseum } \\
& \text { of }
\end{aligned}
$$

\section{COMPARATIVE ZOÖLOGY,}

AT HARVARD COLLBGE, CAIIBRIDGE, MaSS.

Jountod bư pribate subscription, in $\mathbf{1 8 6 1}$.

Deposited by ALEX. AGASSIZ.

$$
\text { II } / 5 / 86
$$


VoL. 1.

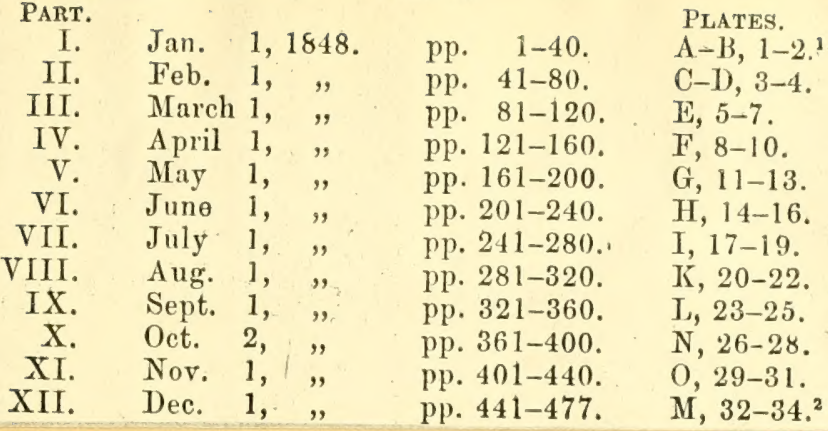

\section{8, proc mal. Sóc. London 13}

25

ON THE DATES OF ISSUE OF THE PARTS OF FORBES AND HANLEY'S HISTORY OF BRITISH MOLLUSCA.

Br Alexander Riyniliz.

Read 9th November, 1917.

So far as I know, no detailed particulars of the parts and dates of issue of this work have ever been recorded. though Mr. B. B. Woodmard communicated some information, founded on narticulars obtained from Wiegmann's "Archiv für Naturgeschichte" and an incomplete copy with the original covers in possession of Mr. W. E. Horle. 'This information was read before the Conchological Society, published in their Journal (vol. x, p. 47, 1901).

A complete copy in the original parts haring come into my possession I am able to supplement these particulars. Unfortunately I had them bound before setting down my information, and the binder divorced the plates from each part and followed the "instructions to the binder"; but as far as Vol. I is concerned, I am able to give dates of issue of the plates from another incomplete cops. The rolumes and parts appeared as follows:- 

A. Qpasir

hakaut Jube $11 / 6$

pon boge. 

A

\section{HISTOR Y}

OF

\section{BRITISH MOLLUSCA,}

AND THEIR SHELLS. 



\section{H I S T O R Y}

OF

\section{BRITISH M OLLUSCA,}

AND THEIR SHELLS.

BY

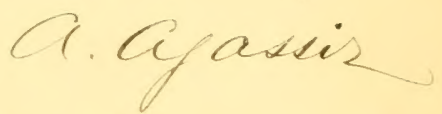

PROFESSOR EDWARD FORBES, F.R.S.,

OF KING'S COLLEGE, LONDON ;

AND

SYLVANUS HANLEY, B.A., F.L.S.,

OF WADHAM COLLEGE, OXFORD.

VOLUME I.

INCLUDING THE TUNICATA, AND THE FAMILIES OF LAMELLIBRANCHIATA AS FAR AS CYPRINID㤅,

LONDON :

JOHN VAN VOORST, PATERNOSTER ROW. 
Pe: $1-L \times x \times, 478-486, \ldots e \cdot 1853$

Diste of plater quiver. on each pente

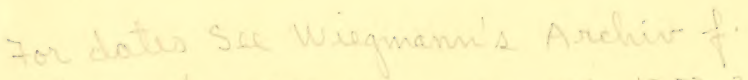
Naturgesely. $1849,2,12 p, 77+106 ; 1853,2$.

LONDON :

Printed by SAMUel Bestrey and $\mathrm{C}$.

Bangor House, Shoe Lane. 
JOHN GWYN JEFFREYS, EsQ., F.R.S.,

AND

JOSHUA ALDER, Ese,

NATURALISTS

EMINENTLY DISTINGUISHED FOR TIIEIR KNOWLEDGE OF

THE BRITISII MOLLUSCA,

TIIESE VOLUMES ARE DEDICATED BY

THE AUTHORS. 
is 


\section{PR E F A E.}

Almhough our work is long, our Preface need not be so ; nor, indeed, need it be more than a grateful record of the obligations we are under to the many friends who have assisted in our task. That a History of the British Mollusca in accordance with the present state of Natural History Science, and of the present knowledge of our native species was required, will, we are confident, be denied by no person qualified to offer an opinion upon the matter. Materials for such a work have long been in course of collection, and amply amassed by ourselves and others. We entered upon the task diffidently, and not before the field was fairly open, those best qualified for the labour urging. us to attempt what had almost become a duty. The invaluable and classical collection of British shells in the possession of Mr. Gwyn Jeffreys, and the extensive experience of its liberal proprietor, placed within the reach of that energetic investigator, materials for a work like this, such as no other naturalist could command, but the imperious demands of professional avocations withheld the leisure where there was both will and ample knowlerge. Mr. Alder, too, profoundly versed in British Malacology, and gifted with the power of delineating, at once accurately and artistically, the animals whose external clothing and internal structure had alike engaged his attention, was already occupied with a section of the subject that 
had become the work of years. Mr. Clark had abandoned the field in which he had years ago laboured so diligently and skilfully, though now, fortunately for science, he has returned to it with renewed vigour and enthnsiasm. To all these gentlemen we offer our warmest thanks for their most generous contributions of original materials. The choicest specimens in Mr. Jeffreys' cabinet have been placed at our disposal for figuring, without reserve, and the pencil of Mr. Alder has, in many instances, embellished our illustrations with figures exceedingly precious, since from no other source could they be procured.

Our valued and lamented friend, the late William Thompson, of Belfast, who had devoted years of study to the British Mollnsks, aided us, as long as he lived, witl every possible assistance that lay in his power. In all that concerns the distribution of Irish species, his hand may be traced, and advice, notes and specimens were constantly coming from him for our use. For many of the details that we are enabled to give respecting the distribution and range of the species described, we owe the fullest thanks to Mr. M'Andrew, of Liverpool, who, with a zeal too rarely imitated, has for years spared neither expense nor labour in searching out marine animals in their deepest recesses, a work, often-times, of no small risk and danger.

The veteran conchologist of Scarborough, Mr. William Bean, has liberally aided us in numerous instances. The precious cabinets of $\mathrm{Mr}$. Cuming hare been opened to us most freely for consultation. Specimens of peculiar value and interest, have been confided to us by Sir Walter Trevelyan, Dr. Robert Ball, Dr. Farran, Mr. Albany Hancock, Mr. Warren of Dublin, and Mr. Conch. We owe 
many obligations to the liberality of labourers in the same field, and heartily thank (as we do all who have assisted in this work), the veteran investigators of British Mollusca, Dr. Fleming, Capt. Thomas Brown, and the Rev. Leonard Jenyns. To Lieut. Thomas, R.N., Mr. Spence Bate, Mr. Barlee, Mr. W. Thomson of London, and Dr. Knapp, we are indebted for extensive information on subjects of much consequence to the completion of our inquiries. To three ladies, viz., the Marchioness of Hastings, Mrs. Griffiths, and Mrs. Gulson, we return many thanks for their interesting communications. A long list of friends who have contributed valuable notes or specimens remains unenumerated. Professor Allman, Professor Bell, Dr. Battersby, Mr. Byerly, Mr. W. H. Baily, Mr. Cocks of Falmonth, Mr. Darbyshire, Mr. W. C. Eyton, Mr. Gibbs, Mr. Howse, Mr. Hyndman, the Rev. T. Hincks, Mr. Hopkins of Dublin, Dr. Johnston of Berwick, Prof. King of Galway, Mr. Lowe of Nottingham, Mr. F. D. Lukis of Guernsey, the Rev. David Landsborough, Mr. Metcalfe, Mr. Mackie of Folkstone, Mr. Pickering, Mr. R. Patterson of Belfast, Mr. Peach, Mr. Reeve of Worcester, Mr. Smith of Jordan-hill, Mr. J. de C. Sowerby, Professor Strickland, and Mr. S. P. Woodward.

We may have omitted to mention some to whom thanks are equally due, and whose names are mentioned in the body of the work. 



\section{IN'TRODUCTION.}

OF the great or primary assemblages into which all animals may be grouped, the Mollusca constitute one. They rank inferior to the VERTEBRATA, partially inferior to the Articulata, and mainly superior to the Radiata and Aмоврноzод. From the vertebrate animals they are conspicuously distinguished by their limb-less bodies, and the absence of a jointed internal skeleton; from the articulate animals, by their inarticulated exoskeleton, and bodies not divided into segments; from the radiate animals, zoophytes and sponges, by their more complex organization and subsymmetrical non-radiated forms. Between them and certain animals of all the other groups, there are, how ever, striking resemblances of analogy. The mollusks are all provided with a well-defined nervous system, the distinctive feature of which is that of being heterogangliate. They possess distinct organs of digestion, respiration, and circulation. The rapid anamorphosis of the entire group, shown by the progression from a low type of organization, such as is seen in the Bryozoa, to one comparatively very high, as exhibited by the Cephalopoda, necessarily implies varied manifestations of internal structure and external form. Hence the subdivisions of the Mollusca display remarkable contrasts in their diagnostic characters, and the aspect of a member of one of the lower divisions 
is singularly different from that of its relative among the higher orders of its class. 'The more important sections are distinguished by the absenee, presence, or degree of development of a distinct head, a character correspondent to the degree of the derelopment of the nervous system, and consequent degree of perfection of the organs of sense, and by modifications of the respiratory organs. Most Mollusca are furnished with a shell, which is usually composed of a single piece in the higher groups, and is bivalve in the lower. 'l'his shell, whether internal or external, may be regarded as a pneumoskcleton, its principal office being that of serving as a shield, or case, for the protection of the respiratory organs, although it often serves as a defensive covering for the whole of the soft parts. 'The names Testacea, and "shell-fish," have been bestowed upon the Mollusca on account of their shells, whose elegance of form, richness of sculpture, beauty of colouring and durability of substance have for ages attracted the notice of the curious, and led to their collection and study by lovers of Nature. But whilst the shelly portion of the body of the Mollusk was carefully inspected, treasured, and delineated, the more perishable parts were sadly neglected, and although some of our earlier English naturalists, especially the illustrious Lister, attended to the organization of the entire creature, the shell alone occupied the attention of the majority of observers, even from the time of Linnæus until within comparatively few years ago. 'The indefatigable and acute Montagu was indeed inclined to be an honourable exception, and the anatomical studies of Leach led this energetic maturalist to a truer appreciation of the subjects of his researches. The works of Turton, Donovan, and others, frequently eited in the following pages, are monuments of the attention, on the other laund, deroted almost exclu- 
sively to the shells. The naked Mollusks of all tribes were but seldom sought for. Montagu and Leach, it is true, called attention in England to the beauty and peculiarities of these animals; Jameson and Fleming did the same service for these and still less attractive tribes in Scotland, but until within the last twenty years neither the Mollusks without shells, nor the soft parts of the testaceous families could be said to be estimated at their due importance, or to be regarded with systematic attention. How much has been done since, and how much is being done now, we have endeavoured to record, as far as our limits would admit, in the following history.

In like manner, but little was known of the habits, range, and distribution, geographical and bathymetrical, of the Mollusks indigenous to our seas. They were looked upon too frequently as objects of mere elegant curiosity, to be made the subjects of laborious research and observations conducted amid their native haunts. The importance of a knowledge of the facts of their mode of life, and the physical conditions aflecting their diffusion, was not nuderstood, nor indeed, until geology called loudly for information so necessary to the progress of that world-dissecting science, was the inquiry deemed of sufficient interest to attract the attention of more than some half a dozen observer's. British naturalists can now boast of having investigated the phenomena of the molluscous fauna of their native islands more thoroughly than has been done by their colleagues in any foreign country. The number of facts now recorded respecting the distribution of the species inhabiting our seas is very considerable, and sufficient to warrant extensive generalizations. We offer the following brief review of the principal results of our present acquaintance with this peculiarly interesting branch of inquiry, 
as an appropriate introduction to the descriptive details that follow.

'The Mollusea of the British seas are numerous and abumdant. The raried conformation of the coasts of Great Britain and Ireland, and of the sea-bed surrounding these islands, is peculiarly favourable for the nourishment of a multiplicity of linds of these animals. The climatal conditions of our area are such as to encourage the presence and perpetuation of both northern and southern temperate types, and the influence of very different ancient conditions is manifested by the presence among them of not a few shell-fish of boreal or arctic origin. Our Mollusca are, when taken collectirely, not remarkable for brilliancy of painting, magnitude of dimensions, or singularity of contour ; although in all these respects we can boast of striking exceptions, and among our minute species can show many of exquisite elegance and curious sculpture. By far the larger part of our marine Mollusks are tiny species. Our nudibranchs are, however, distinguished for the beauty of their colouring, and even among the despised ascidians there are some whose coats are tinged with the brightest or else the most delicate hues. The euttle-fishes that live around us are too excursive and oceanic in their habits to be claimed as exclusively, or even chiefly, our own. Those that frequent our sea-bed are mostly animals of considerable size for Mollusea, and certainly among the most astonishing and beautiful of the inhabitants of the sea. They are, however, seldom seen by the easual observer, whose knowledge of our Mollusean treasures is mainly derived from sorry specimens of shells, cast upon the seabeach by the wares.

'The land-shells of the British islands are still less striking than the testacea of the surrounding seas. Their hues 
are dull when compared with those of more southern countries, and their shapes but seldom attractive for eccentricity of outline or ornament. They exhibit but few peculiarities, and reckon among their number but few rarities. This is not the case with our marine species, among which are numerous sorts that have either not been noticed elsewhere, or are rarely to be met with, and which, even when of pigmy dimensions, are among the most prized gems of a good conchological cabinet. In the grand system of Nature size is of small account, and elephants and mites, however different in bigness, reckon of equal value as links in the chain of organization. God's works are never left unfinished. None is too minute for the display of infinite perfection. The microscope has exhibited to our wondering eyes beauties of structure that have been concealed from mortal sight for long ages. It would almost seem as if only glimpses of those excellencies of creation are permitted to man to behold, whilst the full contemplation of such wondrous charms is reserved for immortal and invisible admirers.

Although, in consequence of the great number of Mollusks that are common to all parts of the British seas, provided we compare localities where conditions of sea-bottom and depth are similar, it might seem that there is little evidence of a peculiar distribution within the limits of our area, if we regard its shell-fish either in mass or analyze the relations of the several species to foreign and surrounding regions, we shall find very distinct manifestations of peculiarities within the boundaries of our own. TVere a conchologist desirous of accumulating personally and rapidly a complete collection of British shells, he would fail in his object if he confined his researches to any one locality, even though it embraced a considerable reach of 
coast and variety of sea-bottom. Four districts, at least, would have to be visited. 'J'o the Chamnel Islands he would have to go for several forms that are almost extraBritish. On the south-west coasts of England he would find not a few shells that he would seek for in vain in more northern or eastern seas. Only on the west coasts of Scotland, many species of great interest and peculiarity could be readily obtained. In the extreme province of the Ketland Isles he would gather some of our most remarkable larities; and possibly, after all, he would have to visit as much of the northern half of the German Ocean as may be claimed for our natural history province, and the west coasts of Ireland, before his cabinets could be fairly filled.

In reality, our Molluscan fauna is a composite assemblage, in which immigrants from the north and from the south intermingle with the aboriginal inhabitants, and descendants of a pre-Adamite fauna survive amongst them. 'Those forms that have travelled northwards and those that have journeyed southwards have not all made their way with equal speed. Consequently as we proceed either way we find a number of species gradually disappear, and differences instituted, both positive, by the presence of peculiar types, and negative by the absence of others, that serve to mark a sub-division of provinces within our area. Even among many of the species that are widely and almost universally spread throughout our seas, we find the frequency of their occurrence diminishing one way or other according to their origin. As a general rule the northern influence prevails over the southern in the British fauna, and gives greater peculiarities to the zoology of the Scottish than to that of the English seas. 'The central portion of our area-the Irish sea-is a sort of neutral ground, from which several forms are absent that are to be 
found both to the sonth and to the north of it. But such types, mostly of sonthern origin, can be traced in the course of their migration along the Atlantic coasts of Ireland, where their progress northwards has been favoured by the genial influence of warm currents. The most unproductive district is the southern half of the eastern coast,

Our marine Molluscan fauna, when considered with respect to its home arrangements, may be said to be composed of examples of no fewer than nine types;-

I. The Lusitanian type, exemplified in species which are to be met with only in the extreme south, members of the Lusitanian and Mediterranean faunas, whose northern limits just impinge upon our area. Haliotis tuberculata, IIurex corallinus, Lachesis minima, Rissoa lactea and striatula, Pandora rostrata, Donax politus, Ervilia castanea, Lucina divaricata, MLactra helvacea, Avicula Tarentina, Galeomma Turtoni, Trochus striatus, Truncatella Blontagui, and Onchidium Celticum, may be cited as the principal representatives of this assemblage.

II. The South-British type; to this belong species of southern origin with a somewhat wider diffusion than the last, occupying a limited but well-marked range along the southern and south-western coasts of England, and southern and western shores of Ireland, many of them entering St. George's Channel, but few passing the confines of South Wales. Such are Adeorbis subcarinata, Bulla hydatis, Cardium aculeatum and rusticum, Chiton discrepans, $C y$ therea Chione, Dentalium Tarentinum, Diodonta fragilis, Diplodonta rotundata, Emarginula rosea, Gastrochena Modiolina, Lepton squamosum, Modiola barbata, Nassa pygmaea, Ovula patula, Petricola lithoplaga, Pholadidea papyracea, Rissoa costulata, Trochus exigurus and lineatus, Venerupis Irus, and Venus verrucosa. 
III. The Europeax type, represented by species that are equally diffused and abundant in most parts of the British Seas, and which at the same time have a wide range along the shores of Europe, although none of them cross the Atlantic. To this section belong, among others, the Aporrais pes-pelecani, Artemis exoleta and lincta, Cardium echinatum, edule, fasciatum and Norvegicum, Chiton fascirularis, Corbula nuclens, Cylichna rylindracea, Cyprea

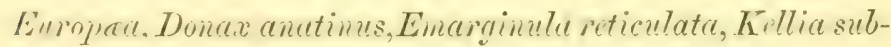
orlicularis, Lucinopsis undata, Lutraria elliptica, Mactra solida, stulturum and subtruncuta, Mennglia linearis, Mrasse reticulata, Natica nitida, Nucula mucleus, Patella vulgata, Pecten opercularis and pusio, Pectunculus glycimeris, Pileopsis IIunduricus, Psammobia Ferroensis, Solen silique, Syndosmya alba, Tapes virginea, Tellina Donacina, tenuis and solidula, Tornatella fasciata, Trochus cinerarius, tumidus: and zizyphinus, Turitella communis, Yonus fasciate, ovate and striatula. Several of our Nudibranchiate Mollusks, and some Ascidians, probably belong to this group. Many of the above-cited species are remarkably prolific, and the individuals of them often constitute a large proportion of the contents of the dredge, or are to be gathered numerously on the shore.

IV. Along with the last, and most of them as plentiful, are the members of the CeLTIC type, a group especially characteristic of our area. This assemblage consists of species that are essentially Atlantic. They are most prolific and at home within the Celtic provinee, of which the British Islands constitute an important portion. They have a tendency to diffuse themselves rather northwards than south wards. multiplying rather in the boreal than in the Lusitanian province. Many of them are of ancient origin, and well known in the fossil state. As examples we may 
cite Acmaa virginea, Astarte sulcata, Buccinum undatum, Chiton cinereus and ruber, Crenella decussata and discors, Fusus antiquus and Islandicus; the various species of Lacuna, Littorina littoralis, littorea and rudis, Lucina borealis, Mactra elliptica and solida, Mangelia turricula, Modiola modiolus, Mya arenaria and truncata, Mytilus edulis, Natica monilifera, Nassa incrassata, Ostrea edulis, Patella pellucida, Pecten maximus, Pholas crispata and candida, Purpura lapillus, Rissoa cingillus and striata, Saxicava arctica and rugosa, Scaphander lignarius, Skenew planorbis, Solen ensis, Syndosmya prismatica, Tapes pullastra, Thracia distorta, Trophon clathratus and muricatus, Velutina lavigata and Venus casina. Many of our naked Mollusks take their place here.

V. Peculiarly Britrsu may be styled the assemblage of species little known elsewhere, or even unknown out of our own seas. The list is considerable but very fallacious, since it is swelled by minute or critical forms, that in all probability enjoy a wider range, but have as yet escaped observation on stranger shores. In this category we may place many of the Odostomice and Montacute, hitherto unrecognised on other coasts than our own. Every year discovers that the parentage of some cherished species is not so exclusively British as patriotic naturalists fondly imagined. Excluding, however, all critical types or forms liable from resemblance to others to be overlooked, the following remarkable Testacea have not as yet been noticed beyond our limits:-Assiminea Grayana, Astarte crebricostata (probably arctic), Buccinum fusiforme, Fusus Berniciensis, Fusus Turtoni (the three last will probably prove to be members of a more northern Fauna); the species of Jeffreysia, Lepton Clarkia, Megathyris cistellula, Natica Kingii (probably aretic); Otina otis, Pecten niveus, Pro- 
pilidium Ancyloide (probably arctic); a few species of Rissoa, and of so-called Skenere, Stylifer Turtoni, Syndosmya tenuis and Thracia villosiuscula, the two last probably much more diffused. Species well known in a few localities elsewhere, but most abundant in the British seas, such as Trochus Montagui and millegranus, Scalaria Trevelyana, Natica Montagui, Astarte triangularis, and Pecten tigrinus and striatus, might possibly be cited with even more propriety as representatives of a British type.

VI. A considerable number of our marine Mollusea are sufficiently common on the western coasts of Britain, though scarce in the Irish Sea, and for the most part absent from the German Ocean, or, at least, from the more central portions of our eastern const. Most of these liave a considerable range to the southward of the British Islands. Some of them, however, such as Trochus umbilicatus, are confined to the oceanic coasts of Europe. The whole assemblage seems to have a spread, in part indicative of an ancient trend of land westwards, and in part of the course and influence of the extension of the Gulf stream. This assemblage may be styled the Atrantic type. Many instances may be adduced, such as Akera bullata, Arca tetragona, Cerithiopsis tuberculare, Cerithium adversum and reticulatum, Circe minima, Fissurella reticulata, Isacardia cor, Lima hians and subauriculata, Lucina spinifera, Mangelia attenuata, gracilis and purpurea, Modiola tulipa, Natica sordida, the species of Neara?, Nucula decussata, Nucula radiata?, Pinna pectinata, Psammolia costulate and tellinella, Rissoce labiosa, meflabrum and vitrea, Scalaria clathratula, Solen marginatus, Solecurtus candidus and coarctatus, Tapes aurea and decussata, Tellina balaustina and incarnata, Terebratula caput serpentis.

VII. The few Pelagic Mollusca that are driven towards 
or habitually frequent our seas are also to be found mainly upon our western boundaries. They constitute an OCEANIC type. Our native and occasional Pteropods, as Hyalaa trispinosa, and the three species of Spirialis; our few pelagic Gasteropods, as Ianthina communis, exigua and pallida, and, just possibly, Scissurella crispata; the Nudibranchous Mollusk, Scylloca pelagica; the tunicated swimmer, Salpa runcinata; borers in floating wood, such as the various species of Teredo and the Tylophaga dorsalis; and, lastly, our twelve species of Cephalopods may be ranked in this interesting group.

VIII. We have before remarked that in the northern division of the British Seas there are many species either not found more to the south, or else becoming rarer as we proceed southwards. Some of them, too, are only to be met with in peculiar and limited localities, grouped together like isolated colonists. The majority of these northern forms belong to an assemblage that constitutes the Boreal type of our Mollusean fauna. They are all species that thrive best in seas to the north of Britain, and many of them range across the Boreal Atlantic, or, at least, are found on both sides, but only within cold waters. They are not, however, to be considered as strictly Arctic. To this group we may assign such examples as Acmaa testudinalis, Astarte compressa and elliptica, Cardium Suecicum, Cerithium metula, Chemnitzia fulvocincta? Chiton Hanleyi and marmoreus, Crania anomala, Crenella nigra, Cyprina Islandica, Emarginula crassa, Fusus Norvegicus and propinquus, Hypothyris psittacea, Leda caudata and pygmea, Mangelia nana, Natica Helicoides, Nucula tenuis, Panopea Norvegica, Pecten Danicus? Philine quadrata and scabra, Pilidium fulvum, Puncturella Noachina, Syndosmya intermedia, Thracia convexa, Trichotropis borealis, 
Trochus alubastrum, helicinus and undulatus, and I'clutina Aexilis. A considerable portion of our Ascidians belong to this type.

IX. A few of our most northern shells may be regarded as belonging to a still more northern, an Ancric type. Astarte aretica, S'atica pusilla, Scalaria Gicanlandica and Terebratula cranium, may be accepted as representatives of this group.

Our land and freshwater Mollusks may likewise be grouped under several types, which, however, we shall sufficiently indicate hereafter when noticing their foreign relations.

The main text of this work is occupied with the descriptions and history of the species which are true and indigenous members of these several types. Only such can fairly be considered as British Mollusca. In this division of the animal kingdom, unlike what may happen in the higher and more mobile sections of our fauna, there is little danger of the intrusion of stragglers, although a few of oceanic habits, or else transported through the unconscious agency of man, acting as their carrier through the medium of his sea-traversing ships, do find their way legitimately into our seas. A few land-snails also transported in timber, or about the roots of plants, have established themselves, though only for a limited period, on our soil. Such legitimised foreigners we have, in almost every instance, described in a supplementary shape at the end of the genera to which they belong. A residue of unlawful and confusing intruders remains to be accounted for.

The number of exotic shells erroneously introduced into our fauma is very large, our earlier writers having frecuently considered them as indigenous upon very slender grounds of evidence. When once the species was inserted in our lists, 
it was admitted as a native into the cabinets of local collectors with even a less degree of circumspection than previously, and subsequent authors, misled by the assertions of their self-deceived friends (too often willingly deceived, for a specimen worthless as exotic, was quickly metamorphosed into a rarity, when supposed to represent a locally scarce species), added the weight of their authority to promulgate the original error. Montagu, in one of his letters, written subsequently to the publication of his great quarto work on "British Conchology," laments the too easy credence he had given to the accounts of his friends, and earnestly deprecates any further attempts at augmenting our fauna, without strict investigation and mature deliberation.

Peculiar pains have been bestowed, throughout this work, to arrive at sound conclusions in regard to the retention or rejection as indigenous of the many species hitherto doubtfully allowed to remain in our catalogues. The original specimens of the hypothetically spurious species have been sought for and examined, that their worn or perfect condition might seive as an auxiliary means of eliminating the truth, in balancing the probabilities of their having been tempest-driven upon our coast (the spoils of some wrecked merchantman), or calmly wafted upon our sands from their native depths. The importance of this actual examination may be inferred from the fact that Dr. Leach took fragments of foreign coral* from several of Montagu's own specimens! The different value at which we must rate the testimony

* "It is well known that some Conchologists shamefully imposed upon Montagu, and that Dr. Leach took fragments of foreign coral from several of the shells that had been in his possession." (Bean's Letter.) "General Bingham was notorious for being imposed on as to indigenousness." (Jeffreys" Letter.)

+ As a general rule, the unsupported testimony of Laskey or Bryer is not to be depended upon. 
of each individual informant of an author, has been estimated upon the opinion entertained by surviving contemporaries, of his veracity and caution; the several shades of difference between an author"s positive declaration, that he himself has dredged the species in a living state, and the mere picking up, by some unlearned friend of his, of single valves upon the beach, are duly taken into our estimate; the competency for the determination of species, at the date of publication, of parties who have re-admitted such into their local catalogues, has been, as far as possible, scrutinized; the improbability of a Boreal species being discovered on our Southern shores, or of a tropical one upon our Northern coast, the unlikelihood of a known littoral shell being dredged in deep water at many miles from the land, has been poised in the balance of conflicting testimonies: in fine, an almost unanimous verdict from the chief living writers upon British Conchology, and the most zealous and trustworthy collectors, has preluded and sanctioned our expulsion of any species which has ever been improperly regarded as a veritable inhabitant of the soil or waters of our Islands.

Were we to preface such species with a circumstantial detail of the evidences upon which our conclusions have been grounded, a larger portion of our work would be occupied by the spurious than by the genuine British Testacer. IVith a similar view of economising space, without the omission of any matter important to Conchology, those of the former, which are universally known, are simply defined by a synonomy based upon the re-examination of the types (or where that was impracticable, careful study of the published descriptions), and not merely founded upon the surmise that the British writer had correctly divined the previous names bestowed upon them by Linnæus and 
the earlier writers. To other rejected species, where deemed advisable, a more or less brief description has been appended, that continental authors may at length definitively ascertain what was actually intended by Montagu, Turton, their predecessors and contemporaries.

The distribution, in depth, of Mollusca in the British seas, has been made the subject of numerous and minute researches. Under each marine species described in this work, full particulars of its bathymetrical range are usually given, and instances illustrative of its habitat at different and distant points. Those of our readers who would study this interesting subject in all its bearings, should consult the essay "On the Connection between the Distribution of the existing Fanna and Flora of the British Isles, with the Geological Changes that have affected their Area," contained in the first volume of the "Memoirs of the Geological Survey of Great Britain," and the "Report on the Investigation of British Marine Zoology by means of the Dredge," in the volume of "British Association Reports for 1850." There is also a very interesting paper on this subject detailing the results of extensive experience, by $\mathrm{Mr}$. M'Andrew, published in the "Transactions of the Literary and Philosophical Society of Liverpool."

A few remarks will serve to explain the notes on bathymetrical range, appended to our descriptions of species. Marine Mollusea are mentioned as inhabiting a depth of water of so many fathoms, or as having been dredged from such a depth. We need scarcely remind our readers that the term fathom, in depth, is applied to a vertical measure of six feet. It is employed in preference to other terms, because it is in general use among sailors, and is the measure commonly inscribed upon hydrographical charts. Marine Mollusea are also mentioned as inhabiting different Zones 
or Regions of Depth. By this phrase is understood the sereral belts or spaces margining the land, or occupying the floor of the sea, distinguished from each other by the presence of peculiar features dependent on arrangements of their animal and regetable inhabitants.

The highest of these belts is the space between tidemarks, an interval of very great importance in the marine Fauna of our Islands, and inhabited by numerous peculiar species of plants as well as animals. It is termed the Littonal Zone. Its features vary with the geological or rather mineralogical character of the coast, and its population, both as to kinds and numbers, varies correspondently. Where it is rocky, it is inlabited by numerous gasteropodous mollusks; where muddy, or sandy, by burrowing bivalves, or, in such localities, is not unfrequently devoid of testacea. 'The common limpet, Patella vulgata, the various species of periwinkle (Littorina), the dog-whelk, Purpura lapillus, certain forms of Trochus and Rissoa, the little slienea planorbis, the common mussel and the minute Kellia rubra inhabit this zone on hard rocky ground universally in the British seas. Local forms and occasional stragglers from lower regions are here and there mingled with them. On sandy and muddy shores numerous bivalves are often thrown up by the waves, not a few of which are to be found alive in the lower division of this zone. In places where the water is brackish, it swarms with Rissod ulva. It is capable of being divided into several sub-regions, each marked by prevailing forms of animals and plants. The uppermost is distinguished by the presence of the smaller varieties of Littorina mulis and L. Neritoides; a second belt by the abundance of Mrytilus edulis, and the larger forms of Littorina rudis; a third by the prevalence of Littorina littorea and Purpura lapillus; a fourth, and 
lowermost, by the dominance of Littorina littoralis, various Rissoce, especially Rissoa parra, and Trochus cinerarius, accompanied in the west by Trochus umbilicatus, and in the south-west by Trochus lineatus.

A second region is the Crrcum-Littoral or Laminarian ZoNE; so called from the abundance of tangles or sea-weeds of the genus Laminaria, that flourish in it around the shores of Europe. On sandy ground these are replaced by the Grass-Wrack or Zostera. Vegetable-feeding shell-fish and naked Mollusca are exceedingly numerous in this space. It is indeed highly productive of various types of animal and also of vegetable life. Its usual vertical extent may be stated as between low-water mark and fifteen fathoms. In its lower portion the coral-weed, or Nullipora, becomes very abundant, and furnishes a ground often chosen by fishes for their spawning haunts. The genera Lacuna (except one species), Calyptrea, Aplysia, Scrobicularia and Donax do not range, in our seas, below this belt; and Rissoa, Chiton, Bulla, Trochus, Mactra, Venus and Cardium have the majority of their British representatives within its precincts. The sub-genus of Patella, called Patina, is entirely confined to it.

A third region is the Median or Coralline Zone, occupying the space between fifteen and fifty fathoms. Seaweeds, properly so called, are scarce within it, and absent from its greater portion, but much of it is clothed with an animal-vegetation, so to speak, in the shape of corallines, or hydroid-zoophytes. It abounds in shell-fish, and many of our rarest and most valued kinds are procured from it. In its upper portion Trochus zisiphinus and tumidus, Chiton asellus, Acmsa virginea, Turritella communis, Venus ovata and V. fasciata, Pecten opercularis, Modiola modiolus, the common form of Crenella, Pectunculus glycimeris 
and Nucula nucleus, are characteristic testacea, and in its lower half Solen pellucidus, Pecten varius, Modiola modiolus, Dentalium and DIactra elliptica. It is marked more by the peculiarities of its species than by the exclusive presence of genera.

The fourth region is the Infra-medin, also called the region of deep-sea corals, since in our seas (though not in those of the tropies) the principal stony corals, whether of zoophytic or bryozoan production, are procured from it. Its most characteristic portions, within the British area, are in the extreme north. There appear, however, to be very few species of Mollusks peculiar to it within our seas. Those that are found are, for the most part, of rather small dimensions, and remarkable for being of dull or pale colouring.

Beneath this zone is the Anyssal Region, which can scarcely be said to be developed within the British area.

The greater part of the floor of the British seas is occupied by the Coralline or Median zone. The Infra-median belt is of less, though considerable, extent. The Abyssal or deep-sea region occupies but an insignificant portion of their area. Hence the very small number of our Mollusks that can be fairly regarded as characteristic abyssal species. The coast-line of the British Islands is exceedingly varied, in consequence of the numerous formations of various mineral constitution and geological age of which the land is composed. A corresponding variety in the species, and abundance of distinct specific types, are the result, and our Molluscan fauna, in consequence, becomes an exceedingly rich one. The very shallowness of a considerable extent of our seas is in favour of their richness, when combined, as it is, with considerable variety of sea-bed. An inspection of hydrographical charts will readily illustrate this 
feature, since the letters inscribed upon them, indicative of a bottom consisting of sand, sandy mud, rock, stones, gravel, muddy gravel, shelly ground, and "coral," i.e., nullipore or vegetable coral, mark as many spaces in which certain forms of Mollusks multiply or prevail in preference to other types. As a general rule univalve testacea and naked Mollusea flourish most upon hard, bivalve testacea upon soft ground, and this appears to hold true, at least with respect to the species described in this work, through all gradations of depth.

Besides these several sub-divisions of the floor of the Ocean, there are the high levels of the sea-water itself, inhabited by a small assemblage of Mollusks. The genera Ianthina and Spirialis, among our testacea, and our solitary species of Salpa, as well as the curious and anomalous Appendicularia among Tunicata, are inhabitants of this marine atmosphere. All these forms are, however, very local around our coasts. In more southern seas, the waves often swarm with pelagic Mollusca.

To the two uppermost zones are confined all the representatives of several genera, whilst the species which live in the lower belts belong to genera which have also members in the Littoral and Laminarian zones. In the two uppermost zones the great majority of testaceous species is found; in the second, or Laminarian belt the majority of naked and tunicated Mollusks. In the higher zones many of the species, both of univalve and bivalve testacea, are exceedingly prolific, and their individuals gregarious, so that large numbers of one kind of shell are found assembled together within a limited area, sometimes almost to the exclusion of other sorts. The proportion of gregarious species to those of solitary or scattered diffusion is much greater in the littoral than in any of the other belts. All the zones of 
depth are in a manner linked together by species common to two or more of them. Bivalve Mollusks would appear to be more extensively distributed in depth, and to constitute more constant links between zone and zone than univalves.

The foreign relations of our marine Mollusean fauna may be stated approximately as follows:-

Our catalogue of Tunicata, a group to which comparatively little attention has been given, and of which our account is intended to serve only as a Prodromus, includes seventy-four species. There are, doubtless, many more inhabiting the British seas. Out of those which we have enumerated, more than one-third are unnoticed as members of any extra-British fauna, and of those that have been observed elserwhere, the majority is Celtic or else boreal. In the main we may regard our Ascidians as immigrants fiom more northern seas.

The number of our indigenous Acephala, or bivalved shell-fish, may be stated at a hundred and sixty species, after expunging doubtful, introduced, and spurious forms. Out of this number very few indeed, not more than about seven species, are known only as inhabitants of the British seas, and as these are critical or very rare types, they may fairly be considered as having escaped notice on foreign coasts, rather than as peculiar to our own. About eighty of our bivalves extend their range in the European seas both northwards and southwards of our area; forty range southwards into the Lusitanian province, but are not known to the north of the Celtic area; thirteen inhabit the Scandinavian seas, but do not range to the south of Britain, nor, so far as known, across the Atlantic; twenty-seven are common to the seas of Boreal and Aretic America, and those of Boreal and Celtic Europe. The few remaining species are such as have been only observed so far with- 
out an area on the continental coasts of the Celtic province.

The distribution of the four Pteropoda that find a place in this work is oceanic. Two of them are, however, as yet unrecorded as extra-British, though it is probable that they will be found widely diffused in the Atlantic, if indeed they be not identical with the oceanic forms referred to in our descriptions.

The number of our species of testaceous marine Gasteropoda may be stated at two hundred and thirty-two. Out of these a considerable proportion, not ferver than fifty-five, has no place in any account of foreign Mollusea. It is exceedingly unlikely that all of this number can be peculiarly British, though in all probability many of them are peculiarly Celtic. The members of some of our genera of minute univalves, especially Odostomia, have not yet received sufficient attention from foreign naturalists to enable us to say, with any approach to certainty, whether they are found on continental coasts or not; and out of the fifty-five species above mentioned no fewer than nineteen are Odostomia. There are fifty-four species common to the seas both north and south of Britain, mostly ranging southwards to the Mediterranean, the few exceptions ceasing on the coast of Spain, certain kinds of Littorina and Patella especially. No fewer than fifty-two species range to the sonthwards of the British Islands, but do not occur northwards of them; whilst thirty-four range northwards into the Boreal and European province, but do not extend south of our area. Some twenty-eight or thirty are inhabitants of arctic and boreal seas, and are common to both sides of the Atlantic, within those provinces. The few remaining are species observed in extra-British portions of the Celtic province, but not elsewhere. 
IVe have enumerated and characterized ninety British Nudibranchiate and Pellibranchiate Gasteropoda. Of these more than two-thirds have as yet been noticed only in the British seas. It is quite impossible to institute any comparison of this portion of our fama with the accounts of the corresponding portion of any extra-British fauna, since the minute and elaborate researches of Messrs. Alder and Hancock have given us an overwhelming advantage.

Our single marine naked pulmonated Mollusk is not known at present, we believe, out of the Celtic province; but, as it has been seldom songht for, may have escaped notice. Our two testaceous marine Pulmonifera range sonthward of Britain, and one of them is found on the opposite shores of the Atlantic.

Our fourteen species of Cephalopoda are, with one exception, found beyond our limits. At least four of them may be regarded as common to all the seas around us, whilst six are apparently immigrants from more southern, and three from more northern provinces. 'There are still hopes of our acquiring, in the course of natural history research, a few additions to our list in this interesting portion of the fauna, one that has been in a great measure neglected. The interesting and curious genus Onychoteutlis especially may be expected to furnish a British representative. We would urgently press upon our younger naturalists to let no cuttle-fish pass unexamined.

Our land and fresh-water Mollusks present but few peculiarities, and are almost all continental. The Helix fusca was supposed to be exclusively British, and is stated to be so in our text, but it appears now that the shell referred to under the name of Helix revelata (a very distinct species) by Bouchard Chantereaux is really fusca. It is indeed very doubtful whether any of our land shells can be 
claimed as truly confined to the British Islands. One remarkable slug, the Geomalacus maculosus, has never been met with out of the south-west of Ireland, and is there exceedingly scarce. We think it not unlikely that this curious animal will eventually be found to be a member of the Lusitanian fauna. A very curious fresh-water shell, Lymneus involutus, is also, at present, confined to the same portion of Ireland, and another species of the same genus, L. Burnetti, is reputed peculiar to Britain. In these instances we are possibly dealing with monstrosities, or extreme varieties of the widely distributed $L$. pereger. One fresh-water bivalve, a species of Pisidium, has not been noticed beyond our limits; but in this genus the characters are too critical to warrant our inferring that it has not been passed over abroad. Within our own areas, several of our land and fresh-water shells do not range north to Scotland.

At least fifty species of our land and fresh-water Mollusks may be regarded as generally distributed throughout Europe, and as ranging both to the north and south of the British Isles. None can be said to come from the north exclusively. About eighteen are members of the fauna of Nortliern and Central Europe; some fourteen are Central European species, not ranging far northwards or southwards; about sixteen belong to Central and Southern Europe; not more than four are decidedly of southern origin exclusively ; some seven or eight species are reported to extend their range into the New World; but, except in the instances of one or two aquatic types, they have probably been introduced through the agency of man. Indeed, some of our smaller snails have found their way through the same unconscious assistance even into Australia. Several of our aquatic species have a wide range into the further parts of the Asiatic continent. The provinces of Asia and Africa that 
border on the Mediteranean, participate in the presence of such of our species as form part of the fauna of that region,

In alpine regions, of higher elevation than those that diversify the surface of the British Islands, a distinct and positive distribution in altitude of land and fresh-water Mollusea may be clearly made out, peculiar species appearing for the first time in definite zones of elevation. On our mountains, deficiencies only can be observed; they can boast of no peculiar types. The few Mollusks that are found on their higher portions are such as may be collected in the northernmost regions of Europe; but, at the same time, are equally members of the fauma of our low districts, and the neighbourhood of our shores.

Whilst the early history of our naked and unpreservable Mollusks has perished without a record, the genealogy of not a few of our testacea may be traced unerringly in fossiliferous formations. The area of the British Islands exhibits a long series of ancient seaberls that tell unmistakably of the changes that have taken place within its bounds. By far the greater part of these show, in their contents, no instances of specific identity with our existing Nollusca, and the farther we recede in time, the more different was our submarine population. The first approach to an existing' British species is seen in the Terebratula striatula, of the upper cretaceous strata, a form scarcely distinguishable in essential features from the Terebratula caput-serpentis. It is not, however, until we seek among our tertiary strata, that we find true homologues of our living Mollusea. Some three or four Eocene shells, especially forms of Eutima and Cylichna, come exceedingly close to recent species, and are possibly identical. There is a doubt, however; the forms themselves being what are termed critical types, and their 
Eocene associates of less questionable character, being assuredly wholly distinct from any now living. Our Eocene land and fiesh-water shells (as well as the fresh-water forms of previous epochs), although several, especially certain Paludino and Planorbides, very closely, almost too closely, approach existing types, are all regarded as distinct from those that live upon our land now. It is a very remarkable fact, that among them, as shown by Mr. Searles Wood and Mr. Frederic Edwards, there are species which cannot be separated from existing American forms. The true source of our Molluscan fauna was first mauifested by the assemblage of testacea preserved in the deposit called Coralline Crag, a formation at first regarded as Miocene, but now held to be of older Pliocene age. In that ancient sea-bed are to found many of the ancestors of oum living shell-fish, mostly of them forms which we regard as southern types. Some of these seemed to have lived on continuously to our own time, but the majority, after struggling with the advent of less favourable conditions during the deposition of the succeeding Red Crag, were banished from our seas, when the frigid conditions of the glacial epoch set in, and did not return until the restoration of new ages of summer. With glacial conditions came Arctic species, many of which linger still within our area. It seems very probable that some of these are gradually being extinguished, and that a few of our testacea, such as Pecten Danicus, of which the number of dead specimens taken is quite disproportioned to the rarity of living examples, are close upon the time of their final extirpation, whilst others, such as Pecten Islandicus, and Leda oblonga, may have been blotted from the lists of the living, even since the occupation of the British Isles by man.

Our land and fresh-water testacea, although we cannot 
track them as far back in time as we can our marine species, have, nevertheless, survived in many instances prodigions changes, and been the companions of larger animals that have long ceased to inlabit our earth. Some of our commonest snails, such as Helix nomoralis, H. hispida, Zonites cellaria, and Zua lubrica, occur abundantly in deposits buried beneath the gravel, in which the remains of extinct elephants, and other quadrupeds, strikingly different from the wild beasts now living in Central Europe, are abundantly found. Still older, possibly, are those that are associated with the Cyrena of the Nile, and the Unio littoralis in the fresh-water deposits of the valley of the 'Thames. Geology has, as yet, scarcely approached towards an estimate of the vast duration of these comparatively modern epochs. They have but lately received anything like a due share of attention, and the nearer we approach our own times in our gropings amid geological antiquity, the more complex seem to become our calculations of the length of those periods during which the progenitors of still-existing forms of life flourished, along with creatures that have disappeared for ever. When we learn how long has been the existence upon the world's surface of some of our little shell-fish, our wonder is not that they should be so widely spread over it now, but ruther that there should be any spot eapable of supporting their life from which they should be absent. 


\title{
GENERAL INDEX.
}

\author{
THE SYNONYMS ARE IN ITALICS.
}

Abra profundissima, i. 319.

ACEPHALA LAMELLIBRANCHIATA, i. 55.

ACEPHALA PALLIOBRANCHIATA, ii. 339.

ACEPHALA TUNICATA, i. 1.

Achatina, iv. 130.

acicula, iv. 130 : iv. 289.

folliculus, iv. 176 .

Goodallii, iv, 128.

lubrioa, iv. 126 .

octona, iv. 178 .

semitarum, iv. 179.

tridens, iv. 128.

Acicula cburnea, iv. 131.

acicula, iv. 131.

AcLls, iii. 217.

ascaris, iii. 219 ; iv. 271.

nitidissima, iii. 223.

supranitida, iii. 219,220 ; iv. 273.

unica, iii. 223 ; iv. 273.

ACM EA, ii. 433 .

fulva, ii. 441.

pellucida, ii. 430.

testudinalis, ii. 434 .

virginea, ii. 437 .

ACME, iv. 204.

fusca, iv. 205.

lineata, iv. 204.

mimuta, iv, 205.

Actcon, iii. 613.

viridis, iii, 614.

Acteon bidentatus, iv. 191. heteroclita, iii. 526.

denticulatus, iv. 194.

tornatilis, iii. 524 .

triplicatus, iv. 197.

ACteonia, iii. 615. corrugata, iii. 615.

ADEORBIS, ii. 541 .

striatus, iii. 161.

subcarinatus, ii. 541 .

无GIRUS, iii. 574.

punctilucens, iii. 574 .

Agina purpurea, i. 1.1.

AKERA, iii. 527.
Arera continued.

bullata, iii. 527 : iv. 287 .

Alexilis, iii. 528 .

Hanleyi, iii. 528.

Ala corvi pendula, ii. 260.

Alasmodonta arcuata, ii. 147.

Alasmodon margaritiferus, ii. 147

Alcyonium Ascidioides, i. 19.

Borlasii, i. 21.

conglomeratum, i. 21.

constellatum, i. 21.

distomum, i. 19.

ficus, i. 11.

pulmonaria, i. 11.

pulmonis, \&c. i. 11.

Schlosseri, i. 19.

Alderia, iii. 610 amphibia, iii. 611 . modesta, iii. 610 .

Alcea antivertigo, iv. 109 cylindrica, iv. 105 . edentula, iv. 103. marginata, iv. 98. minutissima, iv. 105. nitida, iv, 103.

palustris, iv. 109. pygmaa, iv. 106. revoluta, iv, 103. substriata, iv. 108. vulgaris, iv. 106.

Alpidium ficus, i. 11.

Alvania ascaris, iii. 220.

Europac, iii. 148.

Freminvillea, iii. 149 .

mamillata, iii. 148.

rufilabrum, iii. 106.

supranitida, iii. 220.

Amalliea maxima, ii. 495.

Amoroucium, i. 15.

Argus, i. 16.

Nordmanni, i. 15.

proliferum, i. 15.

Amphibulina ollonga, iv. 137 putris, iv. 133.

Amplicilesma allum, i. 316. Boysii, i. 316. 


\section{xxrviii}

Amphilesma continued.

converum, i. 229.

Corbuloides, i. 214.

declivis, i. 221.

elistortum, i. 231 .

Donacilla, i. 348.

flexuosa, ii. 54 .

intermedia, i. 319.

Lucinalis, ii. 58.

phaseolina, i. 221

pratemue, i. 235.

prismatica, i. 321 .

pulescens, i. 226 .

reticulatum, i. 329.

tenze, i. 323.

transecrsum, i. 326.

truncatum, i. 325.

Amplipeplea glutinosa, iv. 183. ineoluta, iv. 184.

lueustris, iv. 173.

Avpursprysa, iii. 520.

hyalina, iii. 521 .

pellucida, iii. 521 .

Analine aretica, i. 1.1.

Urevirostris, i. 195.

convexa, i, 229 .

declivis, i. 221 .

distorta, i. 231 .

Myalis, i. 226.

Norrerfice, i. 214.

pratenuis, i. 235.

mulescens, i. 226 .

mupicola, i. 231.

truncata, i. 214, 231.

villosiuscula, i. 224.

ANATINID E, i. 229.

Ancilus fluviatilis, iv. 187. sinuosus, iv. 187.

ANCULA, iii. 580 . cristata, iii. 580 .

Ancruts, iv, 185. fluviatilis, iv. 186. lacustris, is. 188. oblongus, iv. 188. sinuosus, iv. 187.

ANUDONT, ] ii. 155. and

Anodon unatina, ii. 156.

Aronensis, ii. 160 .

Cellensis, ii. 158.

cygnea, ii. 155.

intermedia, ii. 156. valudose, ii. 156, 160 .

piscinalis, ii. 150 .

ponelerose, ii. 160 .

iostrate, ii. 159.

sulcela, ii. $15 \%$.

ventricosa, ii. 156.

Axouแ , ii. 32 ?

\section{INDEX.}

A nomia contimed.

aculeata, ii. 332.

caput-serpentis, ii. 353.

cepa, ii. 326 .

coronata, i. 327.

cranium, ii. 357 .

cylindrice, ii. 327 .

cymbiformis, ii. 327.

electrica, 3i. 326.

ephippium, ii. 325

feruosa, ii. 326.

fornicata, ii. 327.

inflate, ii. 337.

margaritacea, ii. 327.

patellaris, ii. 327.

1'atelliformis, ii. 334 , 336. polymorpha, ii. 327.

psiltacea, ii. 346 .

mubescens, ii. 353 .

punctata, ii. 326 .

pyriformis, ii. 327.

retusa, ii. 353 .

rostrum psittaci, ii. 346.

rugosa, ii. 326 .

scabrclla, ii. 327.

squema, ii. 336.

squamula, ii. 326 .

struta, ii. 336 .

striolutu, ii. 333.

terebratula, ii. 358 .

tubularis, ii. 327.

tunica-cepe, ii. 326.

turbinatu, ii. 366.

undulata, ii. 334.

undulatim striata, ii. 334 .

ANTIOPA, iii. 608.

cristata, iv. 287.

splendida, iii. 609 : iv. 287.

A pherodita columba, ii. 39.

Aplea hypnonum, iv. 144. rivalis, iv. 144.

A plexus lyymorum, iv. 144. rixalis, iv. 144.

ArLIDIu, i. 10.

fallax, i. 11.

ficus, i. 11.

nutans, i. 12.

verrucosum, i. 13.

API Y SIAD R, iii. 552 .

ArLYsid, iii. 552 .

depilans, iii. 55t.

hybridn, iii. 554 .

mustelina, iii. 554 .

neaa, iii. 554 .

punctata, iii. 554.

viridis, iii. 614 .

Aporizhas, iii. 185.

pes-carbonis, iii. 186 .

pes-pelecani, iii. 188. 


\section{INDEX.}

Aporrhais continued. quadrifulus, iii. 189.

APPENDICULARIA, iv. 245.

Arca, ii. 233.

barbata, ii. $238,243$.

Britannica, ii. 235

Cardissce, ii. 234.

caudata, ii. 227.

crinite, ii. 238.

fusca, ii. 234.

Gaimardi, ii. 238.

glycimeris, ii. 245. imbricate, ii. 234.

lactea, ii. 238.

marmorata, ii. 245.

minima, ii. 246.

minuta, ii. 226.

modiolus, ii. 238.

navicularis, ii. 235.

NOR, ii. 234.

nucleus, ii. 2l5, 220.

papillosa, ii. 234.

Pectunculoides, ii. 241.

perforans, ii. 238.

pilosa, ii. 245 .

Quoyi, ii. 238.

raridentata, ii. 241 ; iv. 257.

reticulata, ii. 243.

rhombea, ii. 235.

rostrcta, ii. 232.

tenuis, ii. 223.

tetrngona, ii. 234.

tortuosa, ii. 234.

unciata, ii. 245.

ARCADE, ii. 214.

A rcopagia crassa, i. 289. ovata, i. 289.

Argiope, iv, 257. cistellula, iv. 257.

Arianta arbustorum, iv, 48.

ArION, iv. 7.

ater, iv. 7.

empiricorum, iv. 7.

flavus, iv. 9 ; iv. 287.

hortensis, iv. 10 .

Artenis, i. 427.

exoleta, i. 428.

ferruginosa, ii. 60.

lincta, i. 431.

undata, i. 435 .

Arthemis exoleta, i. 423.

lincta, i. 431 .

Ascidia, i. 30.

aggregata, i. 41

albida, ii. 373.

ampulla, i. 40.

arachnoidea, i. 32.

aspersa, i. 35 .

canina, i. 31.
Ascidia continued.

communis, i. 32 .

conchilega, i. 35.

corrugata, i. 31 .

depressa, ii. 373.

echinata, i. 35 .

elliptica, ii. 374.

gelatinos $\alpha$, i. 27.

grossularia, i. 40.

intestinalis, i. 31.

Lepadiformis, i. 26.

mammillaris, i. 40.

mentula, i. 32.

microcosmus, i, 37.

monachus, i. 32.

opalina, i. 33 .

orbicularis, i. 34.

parallelogramma, i. 34.

pellucida, ii. 374.

prunum, i. 32, 34 .

rustica, i. 39.

scabra, i. 33.

sordida, ii. 372.

tubulosa, i. 36.

venosa, i. 31.

virescens, i. 31.

virginea, i. 33.

vitrea, i. 35.

ASCIDIAD无, i. 29 .

ASCIDIANS (COMPOUND), i, 8. (SOCIAL), i. 25.

Assminea, iii. 69.

Grayana, iij. 70.

littorea, iv. 266.

Astarte, i. 450.

arctica, i. 461.

Banksii, i. 465.

Lorealis, i. 462 .

castanea, i. 470.

compressa, i. $462,463,464$.

corrugata, i. 462.

crebricostata, i. 456 .

Cyprinoides, i. 461.

Danmoniensis, ii. 376 ; i. 452.

elliptica, i. 459 .

Gairensis, 461.

multicostata, i. 465.

plana, i. 462 .

Scotica, i. 452.

semisulcata, i. 459,464 .

striata, i. 464.

sulcata, i. 452,470 ; iv. 254.

triangularis, i. 467.

Withami, i. 462 .

Auricella carychium, iv. 198.

Auricula, \&c., iii. 524.

Aurieula alba, iv. 191.

bidentata, iv. 191.

Bivone, iv. 194. 
Arricula continued.

Bullaoides, iv. 197.

cinculuta, iv. 197.

coroidea, iii. 260.

denticulata, iv. $194,195$.

dubia, iv. 19l.

crosa, ir. 191.

fusca, iv. 204.

heleroclita, iii. 526.

lineute, iv. 204.

Micheli, iv. 191.

minima, iv. 198.

myosotis, iv. 194, 195, 196.

nitens, iv. 197 .

oliva, iv. 197.

ovulu, iv. 197.

personata, iv. 194.

tenella, iv. 194.

AURICULID IE, iv, 190.

Auris marina, fic, ii. 486.

A uris porei, ii. 321.

Avicula, ii. 251.

aculeate, ii. 252.

Anglica, ii. 252.

Atlantica, ii. 252.

fulcata, ii. 252.

tirunto, ii. 251.

Morio, ii. 254.

Tarentina, ii. 251.

AVICULACE 3 , ii. 250.

Axinus flexuosus, ii. 55.

AzECA, iv. 127 .

Goodallii, iv. 128.

Matoni, iv. 128.

tridens, iv. 127.

1sor antiquatus, i. 260.

BALEA, iY. 1] 4. fragilis, iv, 114. perversa, iv. 115.

Balea fragilis, iv. 114. perierse, iv, 115.

Bela, iii. 450 .

Berthella porosa, iii. 559 .

BrTHINI, iii. 12.

Leachii, jii. 16.

tentaculata, iii. 14.

ventricos $\alpha$, iii. 16 .

Bithynia jaculator, iii. 14.

Bornia inflate, ii. 87. seminulum, ii. 194.

I3OTRY LLII) A, i. 8.

BOTRYLLOIDES, i. 23. allicans, i. 24.

Leachii, i. 23.

radiata, ii. 371.

ramosa, ii. 372.

rotifern, i. 24.

rubrum, i. 24.
Botrylues, i. 19.

birittatus, i. 23.

castaneus, ii. 371 .

conglomeratus, i. 21.

gemmeus, i. '2.).

Leachii, i, 23.

polycyclus, i. 21.

rubens, ii. 370 .

Schlosseri, i. 19.

smaragdus, i. 22.

stellatus, i. 19, 21 .

violaceus, i. 22.

virescens, ii, 370 .

BRACHIOPODA, ii. 339.

Bralybana Branonensis, iv. 50.

Cantiana, iv. 50.

Carthusiana, iv. 5:.

circinatu, ir. 67.

cocluta, iv. 67.

lispidde, iy. 69.

limbata, iv. 85.

rufescens, iv. 67.

Brochus anmulatus, iii. 181.

ascuutus, iii. 18:2.

glabrus, iii. 182.

laris, iii. 182.

reticulatus, iii. 181.

striatus, iii. 178.

trachiformis, iii. 178.

Buccinum, iii. 399.

acicula, iv. 130 .

acuminatum, iii. 402

ambiguum, iii. 397.

Anglicanum, iii. 402 .

Ascanias, iii. 391.

asperulum, iii. 391.

auricula, iv. 170 .

bilineatum, iii. 447 .

Bornianum, iii. 402 .

breve, iii. $392,414$.

brunneum, iii. 377.

canaliculatum gracile, iii. 416 .

canaliculatum masmum, iii. 42.1.

canaliculatum purpuro-buecinum, iii. 380 .

canaliculatum vulgare, iii. 402.

carinatum, iii. 402,414 .

ciliatum, jii. 411 .

cinctum, iii. 445 .

coccinella, iii. 391.

costatum, iii. 485.

Dalei, iii. 408 : iv. 284.

Donorani, iii. 414.

filosum, iii. 381 .

fusiforme iii. 408,412 .

glabrum, iv. 173.

glaciale, iii. 413.

glutinosum, iv, 182

hepaticum, iii. 397. 
INDEX.

Buccinurs continued.

Humphreysianum, iii. 410 ;iv. 285. imperiale, iii. 402.

incrassatum, iii. 391.

Jacksonianum, iii. 398.

I.abradorense, iii. 402.

Lacepedii, iii. 391.

lave, iii. 414.

lapillus, iii. 380 .

lineatum, iii, 397.

longirostrum porcatum, iii. 371 .

longiusculum, iv, 289.

macula, iii. 391 .

minimum, iii. 377.

minutum, iii. 391, 414.

monile, iii. 398.

nanum, iii. 391.

obtusissimum, iii. 414.

obtusulum, iv. 127.

ovum, iii. 408 .

palustre, iv. 180.

pediculare, iii. 397.

perdix, iii. 446.

peregrum, iv. 165 .

pictum, iii. 444.

porcatum, iii. 447 .

pulchellum, iii. 444 .

pullus, iii. 388.

pyramidale, iii. 402.

recurvirostrum lincatum, iv. 397

recurvirostrum reticulatum, iii. 380.

reticulatum, iii. 388 .

riparium, iii. 391.

roseo-labiatum, iv. 174.

rubrum, iii. 377.

stagnale, iv. 174.

striatum, iii, 402 .

strigosum, iii. 397.

tenerum, iii. 402.

terrestre, iv, 130.

tessulatum, iii. 388.

truncatulum, iv. 177.

tuberculatum, iii. 395: iv, 284.

tubulosum, iii. 414.

undatum, iii. 401.

ventricosum, iii. 411.

from Zetland, iii. 402 .

Buliminus obscurus, iv. 91.

Bulimulus montanus, iv. 89.

obscurus, iv. 91.

Bulmus, iv. 86.

acicula, iv. 130.

acutus, iv. 86 .

articulatus, iv. 87.

auricularius, iv. 170 .

bidens, iv. 116.

clavulus, iv, 93.

decollatus, iv. 93 .
Bulimus continued.

detritus, iv, 93 .

exilis, iv. 92, 165 .

fasciatus, iv. 87.

fragilis, iv. 174.

Goodalli, iv. 93.

Guadaloupensis, iv. 92.

Guildingii, iv. 94.

hordeaceus, iv. 91.

Lackhamensis, iv. 89.

leucostoma, iv. 179.

limosus, iv. 166.

lineatus, iv. 205.

littoralis, iv, 87.

lubricus, iv. 125.

Montacuti, iv. 89.

montanus, iv. 89.

muscorum, iv. 95, 97 .

obscurus, iv. 89,90 .

peregrus, iv. 166 .

perversus, iv. 114.

pupa, iซ. 94.

Siculus, iv. 166.

succineus, iv. 133.

tornatilis, iii. 524 .

truncatus, iv. 177.

tuberculatus, iv. 94.

turritella, iv. 87.

undatus, iv. 165 .

ventricosus, iv. 94 .

ventrosus, iv. 94 .

zebra, iv. 165.

Bulinus acioula, iv, 130 .

lubricus, iv. 126.

obseurus, iv. 91.

perla, iv. 141.

signatus, iv. 94.

variabilis, iv. 87.

Bulla, iii. 530 .

acuminata, iii. 500 .

Alera, iii. 527.

alba, iii. 535.

ampulla, iii. 531, 535 .

amygdalus, iii. 535.

aperta, iii. 539 .

bulla, iii. 539 .

candida, iii. 495.

catena, iii. 545 .

Columnæ, iii. 535.

conulus, iii. 517.

cornea, iii. 531.

coriacea, iii. 352.

corticata, iii. 520 .

Cranchii, iii. 533 .

cylindracea, iii. 505, 508 .

cylindrica, iii. 508,510 .

debilis, iii. 522 .

denticulata, iii. 550 .

diaphana, iii. 495. 
Butat continued. dilutute, iii. 543. clegans, iii. 535. emerginata, iii. 55l. flexilis, iii. 350 . fluxialilis, ir. 14] frasilitis, iii. 528 .

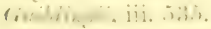

Ilatiotoilea, iii. 355.

Hunleyi, iii. 52r. hyalina, iii, 521.

hydatis, iii. 530 .

liypmorum, iv, 143.

-Jeverensis, iii. 51:2.

lignarie, iii. 536.

mammillata, iii. 514.

media, iii. 535 .

membranacea, iii. 558.

minute, iii. 5:1.

maricula, iii. 5i31.

Nomergica, iii. 527.

dilonra. \&c.. iii, 537.

nletuse, iii. 512.

olira, iii. 508 .

pallida, iii. 505 .

qalula, iii. 498.

vectinata, iii. 543

gelluciela, iii, 510, 521.

pertenuis, iv. 236.

plicatilis, iii. 350.

plumule, iii. 559 .

mroducta, iii. 509 .

mrinosa, iii. 549 .

munctata, iii. 545,547 .

punctura, iii. 533 .

qualluata, iii. 541 .

heuplbiensis, iv. 286 .

nellim, iii. .i-ii.

retuse, iii. 510.

rivalis, ir. 145 .

Sirrii, iii. jell.

seabra, jii. 543 .

sculpta, iii. $5 \$ 6$.

semisulcatu, iii. 510.

striata, iii. $533,535$.

strigella, iii. 513.

sulangulata, iii. 52\%

tentaculata, iii. 358.

triticed, iii. 520 .

truncata, iii. 510

truncatula, iii. 510, 514.

umbilicata, iii. $509,515,519$.

melutina, iii. 347.

voluta, jii. 502.

roluta parra, iii. 527.

Zonaria, iii. 538.

Bullea angustata, iii. 545.

aperte, iii. 53!.

cutena, iii. 545 .
Bulloa continual.

catenate, iii. 545 .

caterulifer $a$, jii. 543

gramelosa, iii. 5) tis.

limnaria, iii. 537.

vectinata, iii. 543 .

Planciana, iii. 539)

muinosa, iii. 5.49.

menctute, iii. 546,547 .

quatrata, iii. 541 .

Bullea aperta, iii. 5:39.

[3ULLID E, iii. 506.

Bullina cylindracer, iii. 508 . productu, iii. 505 . pellucida, iii. 510. truncata, iii. 510. umbilicata, iii. 519.

Byssomye pholatis, i. 146.

CECUN, iii. 176 . glabrum, iii. 181. trachea, iii. 178.

Calliopea dendritica, iii. 60?

Calyptrati, ii. 463 .

Chinensis, ii. 463.

larigata, ii. 463.

Sinensis, ii. 463 .

CALYP'TREID A, ii. 457.

CANCELLARIAD A, iii. 360.

Cancellaria Jiyalina, iii. 445.

Cantareus Naticoides, iv. 43. (a) , ii. $46^{\circ}$.

Capsa castanea, i. 341. complanata, i. 336 . deflorata, i. 330. trunculus, i. 338.

Capulus intortus, ii. 462 . IIungaricus, ii. 459. militaris, ii. 459,461 . Ungaricus, ii. 459.

CARDIAD I:, ii. 1.

Cardium, ii. 2 aculeatum, ii. 4. amnicum, ii. 111, 133. arcuatum, ii. 15, 52. Belticum, ij. 18. carneosum, i. 313. ciliare, ii, 4. cornoum, ii. 111, 113. citrinum, ii. 39 . crenulatum, ii. 15. discors, i. 312. echinatum, ii. 7,11 . edentulum, ii. 39 . edule, ii. $15,18$. clongatum, ii. 25. cximuum, ii. 29. fasciatum, ii. 25. glaucum, ii. 18. 
Cardium continued.

Grœnlandicum, ii. 39 .

humanum, i. 472.

lacustre, ii. 116.

levigatum, ii. 35, 39.

Lumarckii, ii. 18.

Loreni, ii. 33.

medium, ii. 39.

mucronatum, ii. 7 .

muricatulum, ii. 32.

muricatum, ii. 40 .

nodosum, ii. 22 .

Norvegicum, ii. 35 .

nux, ii. 111

obliqunm, ii. 15.

oblongum, ii. 35.

oborale, ii. 25

ovale, ii. 25.

parvum, ii. 5, 25.

pectinatum, ii. 15 .

P'ennantii, ii. 36.

pvgmæum, ii. 29 : iv. 254

rubrum, ii. 25,94 .

rusticum, ii. 11, 15 .

scabrum, ii. 22.

serratum, ii. 35, 39.

spinosum, ii. 7.

stultorum, i. 362.

Suecicum, ii. 33.

Swediense, ii. 33.

tuberculare, ii. 11.

tuberculatum, ii. 11, 12 .

vitellinum, ii. 36.

vulgare, ii. 15.

zoratum, ii. 15.

Cardita cor, i. 473.

Carocolla elegans, iv. 76. lapicida, iv. 65.

Carpchium, if. 198. cochlea, iv. 204.

fuscum, iv. 205.

lineatum, iv. 204

Menkeanum, iv. 128.

minimum, iv. 198.

myosote, iv. 195

personatum, iv. 194.

politum, iv. 128.

Cassidaria lavis, iii. 414.

minuta, iii, 414

oblusissima, iii. 414.

Cussis bilineata, iii, 447. recurvirostrum, iii. 447. testiculus, iii. 447 .

Cavolina, iii. 597.

Cecilioides acicula, ir. 131.

Cemoria Flemingii, ii. 474. Noachine, ii. 474.

CENIA, iii. 616.

Cocksii, iii. (illi.
CEPHALOPODA DIBRANCHIA-

TA, iv. 207

Cepaa nemoralis, iv, 54.

hortensis, iv. 54.

Ceratisolen, i. 255.

legumen, i. 256.

CERITHIAD䇥, 184

Cerithiopsis, iii. 364.

Clarkiii, iii. 368.

tuberculare, iii. 365.

Cerithium, iii. 191.

adversum, iii. 195 ; iv. 272.

ambiguum, iii. 200.

angustissimum, iv. 272.

cancellatum, iii. 198.

costatum, iii. 200.

clegans, iii. 201.

fuscatum, iii. 202.

Lafondii, iii. 200 .

Latreillii, iii. 192.

lima, iii. 192.

metula, iii. 198.

minutissimum, iii. 198.

nitidum, iii. 198.

pygmaeum, iii. 365 .

radula, iii. 202.

reticulatum, iii. 192 ; iv. 273

scalrum, iii. 192.

subulatum, iii. 201.

tuberculare, iii. 365.

turliforme, iii. 200.

Chama arenaria, i. 169.

cor, i. 472.

magne, i. 374 .

parea, i. 132.

solen, i. 259.

truncata, i. 164.

Сиемxitzia, iii. 239; ; iv, 27:3.

acicula, iii. 311 .

Barleci, iv. 278.

clathrata, iii. 258 ; iv. $274,27 i$.

curvicostata, iii. 255.

elegantissima, iii. 242 ; iv. 275.

eximia, iv. 278.

fenestrata, iii. 249 ; iv. 277.

formosa, iii. 248 ; iv. 274.

fulvocincta, iii. 245 ; iv. 274 , 276.

gracilis, iii. 243 ; iv. 275.

Gulsone, iv. 279.

indistincta, iii. 255 ; iv. 274,277 , 278.

Jeffieysii, iii. 251.

MíAndrai, iii. 300.

nitidissima, iii, 224.

pallida, iv. 274

pusilla, iii. 243 ; iv. 275.

rufa, iii. 245 ; iv. $274,276$.

rufescens, iii. 253 ; jv. 274 . 
Cueyritzu continued. scalaris, iii. 251 ; iv. 27 t, 277 simillima, iv. 277 unica, iii. 22.2.

Chenopus pes-pelecani, iii. 186, 189. Sorresianus, iii. 186.

Chilostoma pulchellum, iv. 78, 79.

Chilotrema lrupicide, iv. 65.

Curtos, ii. 391

achatimus, ii. 412 .

albus, ii. $405,407,410$; iv. 258 . aselloides, ii. 405 .

asellus, ii. 407 .

cancellatus, ii. 410 .

cincreus, ii. $100,402,407$.

corallinus, ii, 112 .

crinitus, ji. 393, 396.

discors, ii. 4] 3 .

discrepans, ii. 396.

ex rubro et albo marmoratus, ii. 414

fascicularis, ii. $393,396$.

futminatus, ii. 41.4

fuscatus, ii. 402 .

Hanleyi, ii. 398 ; iv. 258.

latus, ii. 414 .

levigatus, ii. 414,416 .

levis, ii. 400,411 .

marginatus, ii. 402, 412.

marmoreus, ii. 414 .

minimus, ii. 400,407 .

pictus, ji. 415 .

punctalus, ii. 417 .

quinqueralris, ii. 404.

ruber, ii. $399,414$.

septemvalvis, ii. 413 .

sagrinatus, ii. 405.

CIITONID E, ii. 389.

Chondrus secale, iv. 101.

Cingula all $\alpha$, iii. 98.

aculeus, ii. 97.

arctica, ii. 97.

curicularis, iv. 263 .

Írcenti, iii. 'st.

Bruguieri, iii. 146.

Bryerece, iii. 149.

calathiscus, iii. 149.

carinata, iii, 92 .

cimex, iii. 80

cincilla, iii. 122.

conifera, iii. 147.

costata, iii. 92 .

denticulata, iii. 150

disjunct $t$, iii. 1.40 .

dispar, iii. 54.

fulgidu, iii. 128

Ilerreyi, iii. 305.

intervupule, iii. 100.

latioser, iii, Jos!
Cingule continued. marginata, iii. 1.18 minuta, iii. 138. muriatiea, iii. 140. nivosa, iii, 287. pallida, iii. 307 parva, iii. 98. pulchra, iii. 117. pulla, ii. 538. punctura, iii. 89. reticulata, iii. 89 . rubra, iii. 120. rufilabris, iii. 100 . scalariformis, iii. 78 . semicostaler, iii. 95 . semistriata, iii. ] 17. striate, iii. 95. striatule, iii. 73

sulcarinata, ii. 511 . subumbilicata, iii. 137. ulva, iii. 141 . unifasciata, iii. 120. ventricosa, iii. 138. vitrea (erroneously glabrata), iii. 125.

Ciona intestinalis, i. 31.

Cionella acicula, iv. 131. Goodalli, iv. 128. lubrica, iv. 126.

CIRCE, ii. 446. minima, i. 4.46 . triangularis, i. 417.

Circinaria pulchelle, iv. 79

Clausilia, iv. 116.

bidens, iv. 1$] 6,124$.

biplicata, iv. 118.

cordata, iv. 119.

corrugata, iv. 120.

crassule, iv. 322. cruciata, iv. 122.

derugata, iv. 117 dubia, iv. 122 .

Everettii, iv. 122.

fraryilis, iv. 114. infulaformis, iv. 119. Iphigenia fiolohii, iv. 120.

labiata, iv. 124.

laminata, iv. 116.

lucidu, iv. 117.

nigricans, it. 121.

obtusa, iv. 122.

papillaris, iv. 124 . parvula, iv. ] ] 4, 122. perversa, iv. $115,118,122$. plicutu, iv, 118 .

plicatula, iv. 120, 12:. rusedralu, iv, 119 redicuns, iv. 119 Rolphiz, iv. 120 . 
Cla a silia continued.

roscida, iv, 122 .

rostratee, iv. 119.

rugosa, iv. 122.

similis, iv. 118.

similis Montagui, iv. 118 .

solida, iv. 124 .

ungulata, iv. 117.

uniplicata, iv. 115.

ventricosa, iv. 118, 124.

vivipara, iv. 118.

vulnerata, iv. $] 19$

Clausina, ii. 376.

abyssicola, ii. 60 .

Croulinensis, ii. 60.

ferruginosa, ii. 60 .

Clavatula brachystoma, iii. 480 . nebula, iii. 476 .

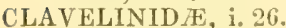

Clavelina, i. 26. Lepadiformis, i. 26.

Savigniana, i. 27.

producta, i. 27.

punilio, i. 27.

Rissoana, i. 27.

Clio borealis, iv. 292.

limacina, iv. 292.

retusc, iv. 292

Cochlea, iii. 330.

fasciata, iv. 54.

parva, iii. 58.

pomatio, iv. 47

unifasciata, iv. 48 .

vulgaris, iv. 45 .

Cochlicella acuta, iv. 86. meridionalis, iv. 87.

turricula, iv. 87.

Coclilicellus acutus, iv, 87.

Cochlicopa lubrica, iv. 125, 126.

Cochlodesma, i. 235.

prætenue, i. 235.

Cochlodina derugata, iv. 117.

Cochlodonta muscorum, iv. 97.

Cochlohydra putris, iv. 132.

Columbella cincta, iii. 445 . hyalina, iii. 445 .

lavis, iii. 503.

picta, iii. 444.

pulchella, iii. 444.

Columna acicula, iv. 131. lubrica, iv. 126.

Cominia hyalina, iii. 445 .

CONID E, iii. 448 .

Conatoria aspersa, iv. 45. Niticoides, iv. 43.

pomatia, iv. 47.

Conovulus, iv. 190.

allus, iv. 191.

bidentatus, iv, 191.
Conovulus continued.

Bullaoides, iv. 197.

denticulatus, iv. 194.

pusillus, iv. 197.

Conbula, i. 179.

Binghami, i. 190.

costellata, i. 199.

granulata, i. 204.

incequivalvis, i. 181.

nucleus, i. 181.

Olymipica, i. 181.

ovata, i. 187.

rosea, i. 185.

rotundata, i. 185.

striata, i. 181.

ustulata, i. 189.

CORBULID $\approx$, i. 179

Coriocella flexilis, iii. 350 . perspicua, iii. 355.

tentaculata, iii. 358.

Corneola pulchella, iv. 79.

Cormulus fulvus, iv. 76 .

Cornuoides major, iii. 182.

CRANIAD正, ii. 364.

Crania, ii. 365.

anomala, ii. 366.

Norregica, ii. 366.

personata, ii. 366.

rostrata, ii. 366.

Crassina arctica, i. 461 .

borealis, i. 461.

castanea, i. 470 .

compressa, i. 462, 465.

corrugata, i. 462 .

Danmoniensis, i. 452.

depressa, i. 471 .

elliptica, i. 459.

Montagui, i. 464.

ovata, i. 459 .

Scotica, i. 452

striata, i. 467.

subrhomboidea, i. 426.

sulcato, i. $452,459,470$.

Crassine crassatellee, i. 452.

Crenatula Travisii, ii. 260.

Crenella, ii. 194.

costulata, ii. 205.

decussata, ii. 210.

discors, ii. 195.

elliptica, ii. 210.

faba, iv. 256.

marmorata, ii. 198.

nigra, ii. 202.

rhombea, ii. 208.

Crepidula calceolina, ii. 466. candida, ii. 466.

plana, ii. 466.

Protea, ii. 466.

sinzosa, ii. 466 . 
Crepidula continued. unguiformis, ii. 466.

Criopus unomalus, ii. 366.

C'ryptodon flemosum, ii. 55.

Cryptomphalus nemoralis, iv. 53 .

Caneus fiesciutus, i. 388.

foliatus, i. 156 .

reticulutus, i. 379 .

truncatus, i. 340.

vittutus, i. 332.

Cyemium? minutum, ii. 81.

CYCLADID R, ii. 110.

Crelas, ii. 110

amnica, ii. 13:3.

appendiculuta, ii. 131 .

caliculata, ii. 114.

cinerea, ii. 125.

citrime, ii. 114.

cornea, ii. 11], J13.

fluvescens, ii. I] 4 .

fontinalis, ii. 123, 128 . vilba, ii. 123 .

lacustris, ii. 1] 6, 118.

nitirle, ii. 126 .

oblinze, ii. 133 .

abuselis, ii. 120 .

palustris, ii. 133.

pulchellu, ii. 128 .

pusille, ji. 12\%.

rizalis, ii. ] 1 :

rivicoli, ii, 111 .

Crclostoma, iv. 201.

achatinum, iii. 11

acutum, iii. 138.

unatimum, iii. 134.

elegans, iv. 201.

ferruminea, iv. 204.

ferrugineum, iv. 204.

impurzm, iii. 14.

lineatum, iv. 205

oltusum, iii. 19.

productum, iv. 204

subeylindricum, iii. 319.

trencatulum, iii. 317.

vivijarem, iii. 9.

CYCLOSTOMIIA, iv, 200.

Cyclostreme Zetlandice, iii. 78 .

Cricicina, iii. 507,551.

acuminute, iii. 500 .

ulba, iii. 5:0.

conulus, iii. 517 .

cylindracea, iii. 508.

nitidula, iii. 515 .

obtusa, iii. 512 ; iv. 192, 286.

strigella, iii. 518.

truncata, iii. 510.

umbilicata, iii. 515, 519.

CYNTHIA, i. 37.

aggregrati, i. 41.
Cyimua continued.

ampulla, i. 40.

claudicans, i. 37 .

coriacea, ii. $: 375$.

grossularia, i. 40.

informis, i. 33 .

Limacina, i. 39.

mammillaris, j. 40 .

microcosmus, i. 37.

norus, j. 39.

quadrangularis, i. 38.

rustica, i. 39.

tessellata, $i .33$.

tuberosa, i. 37.

CyRRA, iii. 494.

arctica, iii. 495.

bullate, iii. 495.

coccinclle, iii. 495.

Europea, iii. 495.

Norrenica, iii. 495.

pediculus, iii. $495^{\circ}, 496$. umbilicalis, iii. 495.

CYPRAAD İ, iii. 493.

Cyprina, i. 440.

compressa, i, 464.

Islandica, i. 141; ii. 375

minima, i. 447 .

orlicularis, ii. 62.

tricungularis, i. 417.

vulfuris, i. 441.

Cuprine d'Islande, i. 411.

CYPRINID R, i. 439.

Crtinerea, i. 395.

apicalis, i. 447.

Chione, i. 396.

circinata, i. 399

Cyrilli, i. 447.

cxolcta, i. 428.

Guineensis, i. 399.

linctu, i. 431.

minimu, i. 447.

minuta, i. 447 .

nitidula, i. 396.

orticularis, ii. 62.

ovete, i. 419 .

reflexa, i. 405.

sinuata, i. 431.

tigerina, ii. 64.

triangularis, i. 447 .

undate, i. 435.

Cylherée fuuve, i. 396.

Defrancia nobilis, iii. 450 . scularis, iii. 450 .

rellii, iii. 4.5?.

Woodiana, iii. 450

Delomplualus pygmaus, iv. 83. rolundatus, iv. 30.

rupestris, iv. 82. 
Delomphalus continued. saxatilis, iv. 82.

Delphinoidea depressa, iii. 157. resupinata, iv. 84 . Serpuloides, iii. 161. unispiralis, iv. 269.

Delphinula calcar, ii. 536 . lavis, iii. 165.

Dendronotus, iii. 586 . arlorescens, iii. 586 .

DENTALIAD $\mathrm{E}, \mathrm{ii}, 446$.

Dentalium, ii. 448. album, ii. 456.

apvinum, ii. 455. clausum, ii. 454. dentalis, ii. 452 . elurneum, ii. 456 . entalis, ii. $449,451,452$. gadus, ii. 4.51. glabrum, iii. 182. imperforatum, iii. 178 . labiatum, ii. 452 . lave, ii. 452 . minutum, iii. 181. octangulatum, ii. 455 . octogonum, ii. 455 . politum, ii. 452 . semistriatum, ii. 454. striatum, ii. 452 . striatulum, ii. 455 . subulatum, ii. 454. Tarentinum, ii. 451 . trachea, iii. 178. variabile, ii. 456 . vulgare, ii. 451.

Detrucia Bullaoides, iv. 197.

Diaphana candida, iii. 521. pellucida, iii. 521 .

Diastropha contorta, iv. 146.

DIODONTA, i. 283. fragilis, i. 284 ; iv. 251.

DiploDONTA, ii. 64. dilatata, ii. 66 . rotundata, ii. 65 .

Difhyllidia, iv. 290. lineata, iv. 290. Ncapolitana, iv. 290.

Discina Norvegica, ii. 368. Ostrcoides, ii. 366.

Discus crystallinus, iv. 42. pygmaus, iv. 83. rotundatus, iv. 80 .

Distoma, i. 18. rubrum, i. 18. variolosum, i. 18.

Dolium perdix, iii. 446 .

Dolium, \&c. iii. 446 .

DONACID 2, i. 331.

Donacilla Lamarckii, i. 348.
DoNAx, j. 33] .

anatinus, i. 332 .

castanca, i. 341 .

complanatus, i. 336.

crenulata, i. 340.

denticulatus, i. 340 .

Irus, i. 156.

lonna, i. 336 .

Martinicensis, i. 313

plebeia, i. 348.

politus, i. 336.

punctata, i. 340 .

rhomboides, i. 141.

ruber, i. 332.

trunculus, i. 332, 338.

DORIDID Æ, iii. 562 .

Doris, iii. 563.

arborescens, iii. 586 . argo, iii. 563.

argus, iii. 564.

aspera, iii. 567.

Barvicensis, jii. 572.

bifide, iii. 610 .

bilamellata, iii. 567 .

olavigera, iii. 573.

coccinea, iii. 565 .

corulea, iii. 603 .

cornuta, iii. 576 .

coronata, iii. 587.

depressa, iii. 568 .

diaphana, iii. 567.

flammea, iii. 564 .

Aava, iii. 576 .

Flemingii, iii. 570 .

fusca, iii. 567 .

inconspicua, iii. 569.

Johnstoni, iii. 564 .

longicornis, iii. 592 .

maura, iii. 574.

mera, iii. 564.

nigricans, iii. 570 .

nodosa, iii. 572.

oblonga, iii. 568 .

obvelata, iii. 564.

papillosa, iii. 590.

pilosa, iii. 570 .

planata, iii. 565 .

pusilla, iii. 569 .

quadrilineata, iii. 576 .

repanda, iii. 566 .

sparsa, iii. 570 .

subquadrata, iii. 571.

tuberculata, iii. 563 .

Ulidiana, iii. 566 .

vermigera, iii. 590 .

verrucos $\alpha$, iii. 568 .

Dото, iii. 587.

coronata, iij. 587.

fragilis, iii. 588 . 


\section{xlviii}

DREISSENA, ii. 163. polymorpha, ii. 165.

ELEDONe, ir. 211. Aldrovandi. iv. 2]3. cirrhosus, iv. 211. moschatus, iv. 214. I'ennantii, iv. 211. rentricosa, iv. 211.

ELYSIAD RE, iii. 613.

Elysia, iii. 613. viridis, iii. 614.

Ematiginula, ii. 476. capuliformis, ii. 479

crassa, ii. 481. conica, ii. 479. curvirostris, ii. 478 . fissura, ii. 477 . lavis, ii. 478 . pileolus, ii. 479 reticulata, ii. 477 . rosea, ii. 479 .

Embla Korcnii, iv. 256.

EMBLETONIA, iii. 606. minuta, iii. 607 . pulchra, iii. 607 .

Ena montana, iv. 89. obscura, iv, 91.

Eolida coronata, iii. 592. papillose, iii. 590.

Eolidia cristata, iv, 287. Embletoni, iii. 593. minuta, iii. 607 . rufibranchialis, iii. 593.

EOLIDID RE, iii. 585.

Eol1s, iii. 539. alla, iii. 597. amana, iii. 602 . amethystina, iii. 604. angulata, iii. 598 . arenicola, iii. 602. aurantiaca, iii. 600 . cingulata, iii. 600 . concinna, iii. 598. corulea, iii. 603 . coronata, iii. 592 . curta, iii. 593. despecta, iii. 605 . Drummondi, iii. 593. elegans, iii. 595. exigua, iii. 606 . Farrani, iii. 605. glauca, iii. 591. Glossensis, iii. 601 gracilis, iii. 595. histrix, iii. 600. inomata, $\mathrm{iii} .598$. Landsburgi, iii. 596. lineata, iii. 594.

\section{INDEX.}

For continued. longicornis, iii. 592 . minuta, iii. 603 .

nana, iii. 599 .

Northumbrica, iii. 602.

obtusalis, iii. 590 . olivacen, iii. 599. pellide, iii. 603. papillosa, iii. 590 . Peachii. iii. 59?. pellucida, iii. 596 . pictá, iii. 603.

punctata, iii. 594. purpurascens, iii. 597 . rosea, iii. 590. rufibranchialis, iii. 5.93 . smaragdina, iii. 595. stipata, iii. 597 . tenuibranchialis, iii. 593 . tricolor, iii. 604. violacea, iii. 604. viridis, iii. 603. vittata, iii. 601 . Zetlandica, iii. 590.

Erato Cyproola, iii. 502, 503. leeris, iii. 503.

Eruca muscomm, iv. 105. umbilicata, iv. 96.

Ervilia, i. 341. castanea, i. 341 ; iv. 253. nitens, i. 344 . pellucida, i. 345 .

Erycina bidentata, ii, 75 . cuspidata, i. 195. ferruginosa, ii. 72 . plebeia, i. 348 . murpurea, ii. 81. substriata, ii. 77.

Eubranclus tricolor, iii. 604.

Eulima, iii. 228. acicula, iii. 311. affinis, iii. 313. Anglica, iii. 229 bilineata, iii. 237 . crassula, iii. 309. distorta, iii. 232. clegantissima, iii. 243. lineata, iii. 235, 237.

$\boldsymbol{M}^{6}$ Andrai, iii. 309. nitida, iii. 231 ; iv. 273. nitidissima, iii. 317. politr, iii. 229,233 ; iv. 273. Scilla, iii. 309. subulata, iii. 235, 237.

Eulmella, iii. 308 ; iv. 276. acicula, iii. 311 ; iv. 283. aftinis, iii. 313 ; iv. $274,283$. clavula, iii. 311,314 ; iv. 283. 
Eulmalia continted. crassula, iii. 309. gracilis, iii. 313. Scillæ, iii. 309.

Eumenis flavidus, iii. 586. marmorata, iii. 585 .

Euparypha rhodostoma, iv. 56. Euplocamus claviger, iii. 573. plumosus, iii. 573.

Euryomphala pygmea, iv. 83. rotundata, iv. 80 . rupestris, iv. 82. umbilicata, iv. 82.

Fissurella, ii. 468. apertura, ii. 469. Europea, ii. 469. Grace, ii. 469. marginata, iv. 259. nimbosa, ii. 472.

Noachina, ii. 474 . nubecula, ii. 472 . reticulata, ii. 469 . rosea, ii. 472 . Zetlantica, iv. 259.

FISSURELLID E, ii. 467 .

Flabellina, iii. 592.

Fruticola aculeata, iv. 74. Cantiana, iv. 50. Carthusianella, iv. 52. circinata, iv. 67. hispida, iv. 69. limbata, iv. 85 . sericea, iv. 72.

Fusulus fragilis, iv. 115.

Fusus, iii. 415. accinctus, iii. 491. albus, iii. 445, 461 . antiquus, iii. 416,423 . asperrimus, iii. 465. attenuatus, iii. 488. Babylonicus, iii. 424. Bamfius, iii. 436. Bamffius, iii. 436. Banffius, iii. 436.

Barvicensis, iii. 442.

Berniciensis, iii. 421 ; iv. 286.

Boothii, iii. 463.

Branscombri, iii. 473.

Buchanensis, iii. 471 . carinalus, iii. 424,434 . castaneus, iii. 455 . chordula, iii. 455 . contrarius, iii. 424. corallinus, iii. 3'4. corneus, iii. 416, 419 . costatus, iii. 485.

Cranchii, iii. 455 . crassus, iv. 490 .
Fusus continued.

decemcostatus, iii. 434.

decussatus, iii. 440 .

despectus, iii. 434.

discors, iil. 455.

discrepans, iii. 455 .

echinatus, iii. 439.

clegans, iii. 473.

fasciatus, iii. 490.

fenestratus, iii. 412.

fornicatus, iii. 434.

fuscus, iii. 455 . gracilis, iii. 416.

gyrinus, iii. 374 ; iv. 284.

Islandicus, iii. $416,419,421$.

Laskeyi, iii. 361.

lavatus, iii. 374.

linearis, iii. 471 .

lineatus, iii. 492.

Listeri, iii. 416.

lyratus, iii. 434 .

minimeus, iii. 377 ; iii, 455 .

minutus, iii. 490 .

multicarinatus, iii. 434.

multilinearis, iii. 490 .

muricatus, iii. 439 .

nebula, iii. 476 .

Norvegicus, iii. 428.

Pleurotomarius, iii. 455 . propinquus, iii. 419 .

proximus, iii. 479. punctatus, iii. 490.

purpureus, iii. 465 .

pyramidatus, iii. 476 .

pyrulatus, iii. 440 .

retroversus, ii. 384.

rostratus, iii. 440 .

mufus, iii. 455 .

Sabini, iii. 419.

scalariformis, iii. 438.

septangularis, iii. 458 . subnigris, iii. 377.

turricola, iii. 450 .

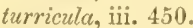

turriculus, iii. 450 .

turritellatus, iii. 377.

Turtoni, iii. 431.

umbilicatus, iii. 361 .

? iii. 433.

Galeomara, ii. 104, 105.

Turtoni, ii. 105.

Galericulum lavigatum, iii. 348. ovatum, iii. 321. otis, iii. 321 .

GASTEROPODA, OPISTHOBRANCHIATA, iii. 506.

GAsteropoda l'rosobranchiata, ii. 387 . 
INDEX.

GASTEROPODA PUIAIONIFE-

RA, iv. 1.

Gastrochena, i. 130.

dulia, i. 132.

lians, i. 132.

Modiolina, i. 132.

pholatiu, i. 132.

GAS'TROCH ENID E, i. 129.

Geomalacus, ir. 11 . maculosus, iv. 11.

Gilbula, ii. 490.

Glycimeris arctica, i. 174. argentea, ii. 216. orbicularis, ii. 245.

Goviodoris, iii. 571 . castanea, iii. 572 . nodosa, iii. 572 .

Gonostoma obrolutum, iv. 63.

Goodallia minutissima, i. 468. trianguluris, i. 468.

Granaria secale, iv. 101.

Gulnaria auricula, iv, 170 .

Gyraulus hispidus, iv. 149 .

IIatia Flemingiana, iii. 408 .

HALIOTID RE, ii. 484.

HALIOTIS, ii. 485.

tuberculata, ii. 485 .

vulgaris, ii. 486 .

Ireminea hydatis, iii. 5.31.

Ilelicella allinria, iv. 35.

cellaria, iv. 33 .

crystallina, iv, 42.

Draparnaulii, iv. 33.

ericetorum, iv. 62.

glabra, iv, 35.

hispida, iv. 69.

lavicida, iv. 65.

montana, iv. 67 .

nitisla, iv. 40 .

nitidlosa, iv. 37.

nitidula, iv. 36 .

pygmea, ir. 8:?.

revelata, iv. 70 .

rotundata, iv, 80 .

sericea, iv. 71 .

succinea, iv. 40 .

IIELICID IE, iv. 29.

Ilelicodonta obroluta, iv. 63.

IIelicogena hortensis, iv. 53, 54 . hylrida, is. 54.

lapicida, iv. 65.

libellulu, iv. 54 .

nemoralis, iv. 53,54 .

pomatia, iv. 47.

Helicolimax Audebardi, iv, 30. major, iv. 30 .

pellucida, iv. 30 .

HELIX, iv, 43.
HFire continued. acieulu, iv. 130 . aculeata, iv. 74. ceuta, iv. 65,86 . affinis, iv. 65 . alba, iv, 149 . albella, iv. 26, 56 . Alboranensis, iv. 56 . aliena, ir. 82. alliacea, iv. 34. alliaria, iv. 34. alpestris, iv, 48 . Altenana, iv. 67. aperta, iv. 43. arbustorum, iv. 48 . arenarite, iii. 303.

aspersa, iv. 44. auricula, iv. 166. auricularia, iv. 169. badiella, iv. 70 . barbara, iv. 86. licolor, iv, 269. bifusciata, iF. 87. brevijes, iv. 31. buccinate, iv. 89.

Bullaoides, iv. 141. canalis, iii. 62.

Cantiana, iv. 50 .

caperata, ir. 59.

carinata, ir. 154.

Carthusiana, iv. 51.

Carthusianella, iv. 51. cellaria, iv. 33. cespitum, iv. 62 . chersina, ir. 76. cincta, iv. 54.

cingenda, iv. 56 . circinata, iv. 67.

clandestina, iv. 66,67 . coarctata, ir. 84. cochleu, iv. 156 . colata, jv. 67 . compactilis, iii. 11. complanata, iv, 155 . complanatus, iv. 162. concinna, iv. 69. contorta, iv. 160 . cornea, iv. 147. cormu-arietis, iv. 147. corrugata, iv. 67. corvus, iv. 181. costatu, iv. 78. crussu, iv, 160. crenella, iv. 78. crenulata, iv. 60. crepuscularis, iv. 50. cretacea, iv. 86 . crisiallina, iv, 42. cristate, iii. 21. 
Hewix continued. crystallina, iv. 37, 41, 78 . cylindrica, iv. 101 .

decollata, iv. 93. decussata, iii. 147. depressa, iii. 157. depilata, iv. 69. derugata, iv. 117. diaphana, iv. 30.

Draparnaldi, iv. 30.

Draparnaudi, iv. 155. detrita, iv. 92. detritus, iv, 165. dubia, iv. 62 . eburnea, iv, 42 . electrina, iv. 37. elegans, iv. 85. elegantissima, iii. 24:2. elliptica, iv. 30. elongata, iv. 137. erica, iv. 62 . ericetorum, iv. 58,61 . excavata, iv. 40 . eximua, iv. 103. exilis, iv, 92. fasciata, iii. 58. flarocincta, iii. 235. foetida, iv. 35 . fontana, iv. 161. fontinalis, iv. 181. fossaria, iv. 177. fragitis, iv. 174, 176, 181 . fulgida, iii. 128. fulva, iv. 75 . fusca, iv. $54,77,289$. glabra, iv. 34 . glabrata, iii. 125, 283. globosa, iv. 84. globularis, iv. 72. glutinosa, iv. 182. Goodalli, iv. 93.

Goodallii, iv. 128. Gothica, iv. 48. granulata, iv. 72 . grisea, iv. 44.

Gypsii, iv. 51 . Haliotoides, iii. 347.

Hammonis, iv. 39. hispida, iv. 68, 71 . hortensis, iv. 44, 53 . hybrida, iv. 54. ianthina, ii. 549 . intersecta, iv. 60. inflata, iv. 166. Itala, iv, 61 .

Ithmia cylindrica, iv, 106. Jererana, iii. 141.

Kirtri, iv. 83.

latiosa, iii. 109.
HeLIX continued.

Lackhumensis, iv, 89.

lacuna, iii. 59 .

lamellata, iv. 73.

lapicida, iv. 65 .

lenticula, iv. 37.

lenticularis, iv. 162.

limbata, iv. 85, 155 .

limosa, iv. 133, 166 .

littorina, iii. 132.

lavigata, iii. 347 ; iv. 286.

lubrica, iv. 125.

lucida, iv. 33, 39, 41 .

lucifuga, iv. 54.

lucortm, iv, 44.

lurida, iv. 35.

lutea, iv. 166, 169.

Mandratisci, iv. 76 .

margarita, ii. 531.

marmorata, iv. 144.

minuta, iv. 78.83.

monilifere, iv. 58.

montana, iv. 67.

Mortoni, iv. 76.

muscorum, iv. 97 . mutabilis, iv. 54.

nana, iv. 147.

Naticoides, iv, 43.

Nautileus, iv. 152.

nemoralis, iv. 51,53 .

Neritoides, iv. 43.

nitens, iv. 33, 35, 39.

nitida, iv. $33,39,41,51,163$.

nitidissima, iii. 158.

nitidos $\alpha$, iv. 37 .

nitidula, iv. $36,37,75$.

nivea, iv. 62 .

obscura, iv. 89, 90.

obvoluta, iv. 63 .

octanfracta, iv. 179.

octona, iv. $130,178$.

Offtonensis, iv, 103.

Olivieri, iv, 51.

otis, iii. 321 .

pallida, iv. 50 .

paludos $\alpha$, iv. 78.

palustris, iv. 180 .

Parreysii, iv. 67. pella, iii. 122 .

pellucida, iv. 30 . peregrina, iv. 179. peregra, iv. 166. perspicua, iii. 355. perversa, iv. 120. petholata, iv. 56 . petrea, iii. 26.

Pisana, iv. 56, 58 . piscinalis, iii. 19. planato, iv, 154. 
HERTX continted? planorlis, iv, 153, 155, 158. plebeinm, iv. 69. politu, iii. $229,232$. pomatia, iv 46 . pulchella, ir. 78 . prupa, ir. 94. puru, iv. $37,38$. putris, is. $132,133,166$. pygmaa, iv. 88.

quinquefasciata, iv. 54. radiata, iv. 80 .

radiatula, ir. 38 . resupinata, iii. 302 ; iv. 84 . reticulata, iv. 84 . revelata, iv. 70 .

Thenana, ir. 65. rhodostome, ir. 56. rotundata, ix. 80 . rufescens, iv. 66,69 . rufilabris, iv. 51 . rufina, iv. 67 . rupestris, iv, 81.

Scarburgensis, iv. 73. secule, iv. 101.

seminulum, ir. 73. sericea, iv, 69, 71,989.

Serpuloides, iii. 161.

Siculus, iv. 166. spinulosu, iv. 74. spirorbis, iv. 159. spirula, ir. 82. splendidula, iv. 125. stagnalis, iv. 174, 180. stagnorum, iv. 92. striata, iii. 300 ; iv. $58,60,62$. strigata, iv. 56. striolata, iv, 67.

sulullida, iv. 58. subcarinatus, ii. 541.

subcylindrica, iii. 317, 319; iv. $125,283$.

subglotosa, iv. 54.

subrufescens, ir. 7\%.

sululata, iii. 235, 237. succinea, iv. 40,132 .

syluestris, iv. 89.

tenera, iv. 35.

tentaculuta, iii. 14.

tenuis, ir, 40 .

terrestris, iv. $43,74,76,85$.

lerrestris Listeri, iv. 75 . terrestris tertius, iv. 76 . terebra, iv. 156.

teres, iv. 166.

Tereerii, iv. 58.

lvigonophore, iv. 63.

Trochiformis, iv. 75 . livehilus, iv. 76 .
HELIX continued.

Trochulus, iv, 75.

truncatula, iv. 177 .

tubuluta, ir. 269.

turgidula, ir. 49.

Turtoni, if. 80.

turturum, iv. 67 .

uree, iii. 141.

umbilicata, iv. $60,81,96$. unispiralis, iv. 269.

variabilis, iv. 58. veriegata, iii. 145 ; ir. 44 .

vertigo, iv. 111.

virgata, iv. 57, 289.

virilula, iv. 37 .

vitrea, iii. 125; iv. 42 .

vivipare, iii. 8, 11 .

rortex, iv. 157.

Wittmanni, ir. 48.

Yatartii, iv. 18.

Kenobia bimarginata, iv. 5:2.

Zonaria, iv. 56, 57.

HERM

bifida, iii. 610 .

dendritica, iii. 609 .

Iliatelle, i. 141 .

Hiatella arctica, i. 14l.

minuta, i. 141 .

l'olii, ji. 105.

oblonga, i. 146 .

rugose, i. 146.

llinnites musio, ii. 278. sinuosus, ii. 278.

IIipponyic milrula, ii. 462.

HYALEA, ii. 379.

depresse, ii. 380.

mueronata, ii. 380 .

triacenthe, ii. 380.

trispinosa, ii. 380 .

IIyales a trois pointes, ii. 380 .

HYPOTHYRIS, ii. 344 . psittacen, ii. 346.

I ANTHINA, ii. 548 . bicolor, ii. 549

Britennica, iү.. 260 .

communis, ii. 549 ; iv. 260 . exigua, ii. 555.

franilis, ii. 549 .

nitens, ii. 553.

pallida, ii. 553 .

petula, ii. 553.

Icutline, ii. 5.49.

Ientline naine, ii. 555. violelte, ii. 549,555 .

IAN'THNII) $/$, ii. 547 .

IDAL1A, iii. 578 .

aspersa, iii. 578.

inequalis, iii. 579 
IDALIA, continued. quadricornis, iii. 580 .

Infundibulum rectum, ii. 464. Sinense, ii. 464.

IsOCARDIA, i. 472. cor, i. 472.

Hibernica, i. 473 .

Jaminia alba, iv. 192. bidentata, iv, 191. denticulata, iv. 195. insculpto, iii. 289. interstincta, iii. 296. longiuscula, iv. 285, 289. muscorum, iv. 98. oblonga, iii. 296. obtusa, iii. 296. plicata, iii. 271. plicatula, iii. 299. pulla, iii. 308. quinquedens, iv. 195. scalaris, iii. 284. secale, ir. 101.

Janus Spinole, iv. 287.

JEFFREYSIA, iii. 15]. diaphana, iii. 152 . globularis, iv. 268. opalina, iii. 154 ; iv. 267.

KELLIA，ii。 84. ferruginos $\alpha$,ii. 60 . nitja, ii. 92 . rubra, ii. 94. suborbicularis, ii. 87.

KELLIAD 2 , ii. 69.

Klaffende hammuschel, ii. 268.

LACHESIS, iii. 376. minima, iii. 377 .

LACUNA, iii. 55 . bifasciata, iii. 63 . canalis, iii. 63 . cornea, iii. 63. crassior, iii. 67 . divaricata, iii. 63. fasciata, iii. 59 . labiosa, iii. 65. Montacuti, iii. 59 Montagni, iii. 59 . pallidula, iii. 56 . patula, iii. 57. pertusa, iii. 63 . puteolus, iii. 58 . quadrifasciata, iii. 63. retusa, iii. 68 . striata, iii. 63. sulcata, iii. 59. vincta, iii. 62 ; iv. 262

LAMIELLARIA, iii. 353.
LAMELLARYa, continued. membranacea, iii. 558. perspicua, iii. 355 . tentaculata, iii. 358 .

Laplysia depilans, iii. 554.

Lasca rubra, ii, 94.

Latomus lapicida, iv. 65.

Lavigno calcinella, i. 326.

IEDA, ii. 226.

caudata, ii. 226.

complanata, ii. 227. minuto, ii. 227.

Montagui, ii. 232. oblonga, ii. 233.

pygniæa, ii. 230.

tenuis, ii. 230 .

truncata, ii. 233.

Lenticula lapicida, iv. 65 .

Lepas, \&c., ii. 459, 462 .

LeptocliNum, i. 16.

asperum, i. 17.

aureum, i. 17

gelatinosum, i. 17.

Listerianum, i. 17 maculosum, i. 16. punctatum, i. 18.

LEPTON, ii. 97.

Clarkiæ, iv. 255. convexum, ii. 102 ; iv. 255.

nitidum, ii. 92. squammeux, ii. 98. squamosum, ii. 98.

Lesca minuta, ii. 81.

Ligula distorta, i. 229. pretenuis, i. 236. prismatica, i. 321.

Lima, ii. 262.

aperta, ii. 268.

bullata, ii. 265, 268.

exilis, ii. 268.

fragitis, ii. 265, 268.

hians, ii. 268.

inflate, ii. 268.

Loscombii, ii. 265.

nivea, ii. 263.

oblonga, ii. 268.

Sarsii, ii. 268.

subauriculata, ii. 263.

sulcata, ii. 263.

sulculus, ii. 263.

tenera, if. 268.

vitrina, ii. 268.

Limacella concava, iv. 13, 20, 288. obliqua, iv. 288.

parma, iv. 15 . unguiculata, iv, 19.

Limacellus obliquus, iv. 13, 288. variegatus, iv. 19, 288. zunguiculus, iv. 288. 
LIJI $A$ CID $A$, iv. 6.

Limacina pellucida, iv. 30.

Limarosta, iii. 614. nigra, iii. 614.

Timatula suluerviculata, ii. 263.

LLMAx, iv. 12.

agrestis, iv. $13,288$.

allus, iv. 7 .

antiquorum, is. 15.

arboreus, iv. 17.

arborum, iv. 17, 289.

ater, iv. 17

brumneus, iv. 20.

curinatus, iv. 22, 289.

einereo-niyer, iv. 15.

cinereus, iv. 15,19 .

circumscriptus, iv. 10 .

fusciutus, iv. 10.

flarus, iv. 9, 19.

gagates, ir, 24, 238.

maculatus, iv. 15.

marginatus, iv. 17, 22.

maximus, iv. 15.

prapillosus, iii. 590.

rufus, iv, 7.

salicotum, ir. 17 .

subfuseus, ir. 7.

succineus, iv. 7.

Sowerbii, iv. 22.

tenellus, iv. 21.

rariegatus, iv, 19 .

Limnaca Burneti, iv. 172.

elongate, iv. 179.

perespa, iv. 170.

truncatula, iv. 177 .

LIMNAADE, iv. 139 .

Lmaxus, iv. 164.

auricularius, iv. 169 .

Burnetti, iv. 172.

elongatus, iv. 179.

fragilis, ir. 181.

glaber, iv. 178 .

glutinosus, iv. 182.

involutus, iv. 184, 290 .

limosus, iv. $\mathrm{J} 77$.

minutus, iv. 177

neatus, iv. $166,163$.

palustris, iv. 180.

pereger, iv. $165,170,173$.

stagnalis, iv. 174,176 .

truncatulus, iv, 177 .

vulgaris, iv. 166.

Limnce uricularia, iv. 170 .

detrita, iv. 92 .

clongata, iv. 179.

fontinalis, iv. 141 .

fossaria, iv. 177.

frayilis, iv. 175.

olutinose, iv. 183.
Limnea continued.

intermedia, iv. 167.

loucostoma, iv. 179.

limosa, iv. 167.

lineata, iv. 167, 168.

luteu, ir. 167, 169 .

maryinatu, iv. 167, 169.

minuta, ir. $17 \%$.

octone, iv. 179.

orutu, iv. 167.

palustris, iv. 181 .

pereyra, iv. 167.

rivalis, iv, 145.

stagralis, iv. 175 .

turrita, if. 14.4.

Limneus acutus, iv. 170, 171. auricularius, iv. 170 . commenis, iv. 181.

elctritus, iv. $93,165$. clodes, iv. 182.

clongutus, iv. 179.

fossurizes, iv, 177 .

frugilis, iv. 175.

glutinosus, iv. 182.

Grayanus, iii. 70.

incolutus, iv. 184 .

major, iv. 175 .

ovalus, iv. 166.

palustris, iv. 181.

pereger, iv. 166.

reflexus, iv. 182.

scaturiginum, iv. 176.

stugnalis, iv. 174.

tinctus, iv. 181.

truncatulus, iv. 177.

umbrosus, iv. 182.

vulyaris, iv. 167.

Limpet, common, ii. 421 . blue-rayed, ii. 430 .

large foolscap, ii. 159.

small foolscap, ii. 462 .

listera compressa, i. 326 .

Lithodomus aristatus, ii. 212. caudigerus, ii. 212.

fuscus, ii. 213.

lithophagus, ii. 212.

Iitorina litorea, iii. 29. zic $\approx u c$, iii. 54 .

Littorina, iii. 25, 339 . anatine, iii. 134 .

Basteroti, iii. 26.

Beanii, iii. 49.

carulea, iii, 26.

carulescens, iii. 26.

dispar, iii. 54 .

fabalis, iii. 49,53 ; iv. 262 .

lalriata, iii. 36.

littoralis, iii. 45.

littorea, iii. $29,: 2$. 
Littorina continued. muriatica, iii. 140 . neglecta, iii. 43 .

Neritaformis, iii. 47.

Neritoides, iii. 26, 45, 52 .

nigrolineata, iii. 32.

obtusata, iii. 46.

palliata, iii. 51 ; iv. 262.

patula, iii. 36, 53 .

petrcea, iii. 26.

rudis, iii. 32,53 .

rudissima, iii. 36 .

saxatilis, iii. 43,53 .

striatula, iii. 73.

tenebrosa, iii. 53 .

ulve, iii. 141.

ventricosa, iii. 41.

vulgaris, iii. 29.

ziczac, iii. 54.

zonaria, iii. 32 .

LITTORINID Ai, iii. 24.

Lobaria quadrilobata, iii. 539.

Loligo, iv. 225.

Brogniartii, iv. 232.

Coindetii, iv. 233.

Elance, iv. 235.

harpago, iv, 233.

illecebrosa, iv. 233.

Marmoræ, iv. 230.

media, iv. 228.

parra, iv. 228.

piscatorum, iv. 233.

sagittata, iv. 232,233 .

sepiola, iv. 220.

subulata, iv. 228 .

todarus, iv. 234.

vulgaris, iv. 226

Lomonotus, iii. 585. flavidus, iii. 586 .

marmoratus, iii. 585.

Loripes lactea, ii. 58. rotundata, ii. 66 .

Lottia pulchella, ii. 437. virginea, ii. 437 .

Lucina, ii. 43.

alba, ii. 46 .

Amplidesmoides, ii. 58. antiquata, ii. 46. arcuata, ii. 52.

balaustina, i. 290.

borealis, ii. 46 .

carnaria, i. 313.

commutata, ii. 52.

divaricata, ii. 52,54 .

ferruginosa, ii. 60 .

flexuosa, ii. 54 .

Hiatelloides. ii. 49.

lactea, ii. 56, 66 .

leucoma, ii. 57.
Lucina continued.

orbicularis, ii. 62.

pisiformis, i. 312.

radula, ii. 46.

rotundata, ii. 66 .

sinuata, ii. 54.

sinuosa, ii. 55.

spinifera, ii. 49.

squamosa, ii. 62 .

tigerina, ii. 61.

undata, i. 435.

LUCINID AE, ii. 41 .

LuCINopsis, i. 433. undata, i. 435 .

LUTRARIA, i. 369. compressa, i. 326. elliptica, i. 370 ; iv. $25 \%$.

hians, i. 374.

Listeri, i. 326.

oblonga, i. 374.

piperata, i. 326.

Solenoides, i. 374 .

squamosa, ii. 98

vulgaris, i. 370.

Lutraire elliptique, i. 370 .

Lutricola compressa, i. 326. Solenoides, i. 374.

Lux vespertina, i. 271.

Lymnce auricularia, iv. 170. intermedia, iv. 167. involuta, iv. 184.

leucostom $\alpha$, iv. 179. minuta, iv. 177. ovata, iv. I67. peregra, iv. 166. putris, iv. 167 stagnalis, iv. 175.

Lymnaus ovatus, iv. 167.

Lymnea fragilis, iv. 181. glutinosa, iv. 183. lacustris, iv, 167. minuta, iv. 177. ovata, ir. 167. peregra, iv. 167. succinea, iv, 133. vulgaris, iv. 167.

Lymneus auricularius, iv. 170. minutus, iv. 177. ovatus, iv. 166. stagnalis, iv. 174 .

LYONSIA, i. 2 ] 3. coruscans, i. 214. elongata, i. 214.

Norvegica, i. 214. plicata, i. 218. striata, i. 214.

Macroma tenera, i. 307.

Mactra, i. 350. 
MLACTra continued.

alba, i. 3] 6 .

Boysii, i. 316 .

Braziliana, i. 368 .

cinerea, i. 36:3.

compressa, i. 326.

cornea, i. 348.

crassa, i. 354.

crassatella, i. 359.

cuncata, i. 359 .

deallata, i. 368.

deaurata, i. 346.

denticulata, i. 316 .

dubia, i. 351.

elliptica, i. 356.

fragilis, i. 368 .

glauca, i. 366 .

helvacea, i. 366.

tians, i. 374.

lactea, i. 359.

Iisteri, i. 326.

lutraria, i. 370 .

magna, i. 363.

minutissima, i. 468 .

Neapolitana, i. 366.

oralis, i. 351 .

piperata, i. 326.

radiata, ii. 39.

solida, i. 351,356 .

striate, i. 361 .

stultorum, i. 363, 359.

subtruncata, i. 354, 35?.

tonuis, i. 323.

triangula, i. 359 .

triangularis, j. 467.

truncata, i. 351,354 ; iv. 253.

Veneriformis, i. 464 .

MACTRID五, i. 349 .

Mactrina minutissima, i. 468. triangularis, i. 468 .

Magdala striala, i. 214.

MANGELIA, jii. 448 ; iv. $2 \xi 6$.

accincta, iij. 491.

attenuata, iii. 488 .

balteata, iii. 486 .

brachystoma, iii. 480 .

costata, iii. 485 .

costulata, iii. 484.

Ginnaniana, iii. 476 .

gracilis, iii. 473 .

Leufroyi, iii. 468.

linearis, iii. 470 .

nana, iii. 461: ir. 286.

nebula, iii. 476 .

purpurea, iii. 465 : iv. 286.

musilla, iii. 486

rufa, iii. 454 .

septangularis, iii. 458.

striolata, iii. 483.3.
MaNgelia contimued.

teres, iii. 462 .

Trevelliana, iii. 45:.

turricula, iii. 450.

Mangilia nebula, iii. 476 .

tiarula, iii. 480 .

Margarita, ii. 489.

alabastrum, ii. 497 .

arelica, ii. 531.

aurea, ii. 535 ; iv. 259 .

carnea, ii. 328 .

? costulata, iii. 167 .

eleguntissima, iii. 168.

Ilelicina, ii. 531 .

margarita, ii. 531.

minutissima, iii. 168.

olivacea, ii. 335 .

mesillu, ii. 534.

striata, ii. 528.

undulata, ii. $513,515,529$.

vulyaris, ii. 531 .

Margaritana margaritifera, ii. 147.

MaRgINelLa, iii. 502 .

catenata, iii. 505 .

Donor'uni, iii, 502 .

lævis, iii. 502 .

muscaria, iii. 502 .

pallida, iii. 505 .

Toluta, iii. 502.

MEGATHYRIs, ii. 359 .

cistellula, ii. $36 \mathrm{I}$; iv. 257.

Melampus Bulla, iv, 197.

Melania acieula, iii. 311.

lioscii, iii. 2-2!!.

Cambessedesii, iii. 235.

Campanella, iii. 242.

distorta, iii. 232.

1)onovani, iii. 235.

elegantissima, iii. 242.

fusca, iii. 202.

Matoni, iii. 202.

rufa, iii. 245 ; iv. 276 .

scaluris, iii. 251.

Melibaa coronata, iii. 587. ornata, iii. 537.

pinnatifule, iii. 588.

Merdigera olseura, iv. 91.

Mesodesma castunea, i. 311.

cornea, i. 3-48.

deaurata, i. 346.

denticulata, i. 346.

donacillum, i. 348.

Jauresii, i. 347.

Modrola, ii. 181 .

agglutinans, ii. 193.

Americana, ii. 187.

arctice, iv. 257.

Ballii, ii. 193.

barbata, ii. 183, 190. 
INDEX.

Modiola continued. castanea, ii. 194. caudigerc, ii. 212. cicercula, ii. 210. cinnamoneu, ii. 213 compressa, ii. 202 . costulata, ii. 205. depressa, ii. 202. discors, ii. 198. discrepans, ii. 195, 198, 202. faba, ii. 210 ; iv. 257. fusca, ii. 213 .

Giblsii, ii. 190 . glandula, ii. 210. marmorata, ii. 198. minuta, ii. 195.

Modiolus, ii. 182, 183.

nigra, ii. 202.

Papuana, ii. 183, 187.

phaseolina, ii. 186 ; iv. 256. Poliane, ii. 198.

Pridecuriana, ii. 203. radiata, ii. 187.

rhombea, ii. 208. tulipa, ii. 187.

tumida, ii. 198. restita, ii. 192, 193. vulgaris, ii. 183.

Molgula, i. 36.

arenosa, ii. 374. oculata, i. 36. tubulosa, i. 36.

Monachu Carthusianella, iv, 52. sericca, iv. 72.

Monoceros hepaticus, iii. 398.

Monodonta Bellixi, iv. 259.

Monodonta crassa, ii. 525. lugubris, ii. 525.

Montacuta, ii. 71, 376. bidentata, ii. 75 . ferruginosa, ii. 72 ; iv. 254. glabra, ii. 72. oblonga, ii. 72 . purpurea, ii. 81. substriata, ii. 77 .

Montagua longicornis, iii. 592. carulea, iii. 603.

Moule d'Áfrique, ii. $18 \mathrm{l}$.

Murex, iii. 369.

accinctus, iii. 491. aciculatus, iii. 488. acuminatus, iv. 286. adversus, iii. 195. angulatus, iii. 450 . antiquus, iii. 434, 423, 435 . attenuatus, iii. 488. badius, iii. 374 .

Bamffius, iii. 436. carica, iii. 447.
Murex continued. carinatus, iii, 361, 424, 434, 435. chordula, iii. 454 . cingulifenus, iii. 371. clathratus, iii. 436 . corallinus, iii. 374 ; iv, 233. corneus, iii. 416 . costatus, iii. 458,485 . cutacens, iii. $4-16$. decollatus, iii. 424. despectus, iii. $424,434,435$. duplicatus, iii. 435 . elegans, iii. 470 . emarginatus, iii. 473 . erinaceus, iii. 350 . fornicatus, iii. 434. fuscatus, iii. 202. fuscus, iii. 202 . gracilis, iii. 47 : granulatus, iii. 202. gyrinus, iii. 374,376 ; iv. 233. inconspicuus, iii. 374 . Islardicus, iii. 416. lamellatus, iii. 438. linearis, iii. 470 .

Massence, iii. 374. minutissimus, iii. 198 . muricatus, iii. 439 . nebula, iii. 476 . proximus, iii. 479 . purpureus, iii. 465. radula, iii. 202. reticulatus, iii. 192. rufus, iii. 454 . scaber, iii. 192. sepiansularis, iii. 458. septemangulatus, iii. 458 . simuosus, iii. 492 .

Smithii, iii. 483. subantiquatus, iii. 435. subulatus, iii. 201. Tarentinus, iii. 371. tubereularis, iii. 365. turricula, iii. 450 . undatus, iii. 402 .

MURICID Æ, iii. 369 。

Mussel, common, ii. 170 .

MYA, i. 162. acuta, i. 169. aretica, i. 141. arenaria, it. 168. Batara, ii. 154. bidentata, ii. 75 . byssifera, i. 146. conrexa, i. 229. dectivis, i. $221,226$. decussata, i. 151 . depressa, ii. 140. distorta, i. $23 \mathrm{I}$. 


\section{lviii}

Mra continned.

dubia, i. 13:.

ferreninose, ii. $7 \cdot 2$

Gaditune, i. 326.

glycimeris, i. 178.

Hispanicu, i. 326.

incequiralvis, i, 181 .

margaritifere, ii. 1.16.

mercenaria, i. 169 .

nitens, i. 344.

nitide, i. 319, 214.

Norvegien, i. 17t, 214.

oblongu, i. 374.

oralis, i. 164; ii. 140, 143.

orete, ii. 1.40 .

pellucida, i. 214

pholarliu, i. 132.

pictorum, ii. 142, 153.

pratemeis, i. 235.

prismatica, i. 321.

pubescons, i. 221, 226.

purpurea, ii. 81 .

striata, i. 214.

suborlicularis, ii. $8 \overline{7}$.

substriatu, ii. 77 .

truncata, i. 163.

MYAD 2 i. i. 160.

Myctella Montagui, i. 214.

Mye ales sables, i. 169. tronquéc, i, 164.

Myrtece spinifera, ii. 49.

Mysere ovecuta, ii. 140. pictorum, ii. 143. solida, ii. 140 .

MIYTILID Ai, ii. 162.

Mrrilus, ii. 168.

abbreriutus, ii. 171.

uchatimus, ii. 170 .

Afer, ii. 181.

Africanus, ii. 181.

combiguus, i. 132.

anatimus, ii. 155 .

Area, ii. 165 .

aristutus, ii. 212.

Aromensis, ii. 160.

barbutus, ii. 182, 190.

billens, ii. 178 .

crenatus, ii. 180.

cristergalli, ii. 321 .

curtus, ii. 182.

curvirostrutus, ii. 182.

cygnens, ii. 155.

recussatus, ii, 210.

dentutus, ii. 156 .

dilutatus, ii. 171 .

discors, ii. 195, 198; ii. 202.

diserepans, ii. 195,198 ; ii. 202 .

edulis, ii, 170 .

e furio Volyce, ii. 165.

\section{INDEX.}

Mrtrus continued. coustus, ii. 179. fuba, iv. 256.

flarus, ii. 171 .

frons, ii. 321 .

fuseus, ii. 213.

Gullopravincialis, ii. 171 .

lesperiunus, ii. 171 .

Ilageni, ii. 165.

hirundo, ii. 251.

hirundo e Mari
Wediterraneo, ii. 251

incrussatus, ii. 160 .

incurvatus, ii. 171 .

lineatus, ii. 165.

lithoplatuns striatus, ii. 212.

macule, ii. 159.

Modiolus, ii. 182, 187.

Morio, ii. 254.

Papucumus, ii. 1833.

pollucidus, ii. 170.

pholadis, i. 146 .

plicatus, i. 218 ; iv. 249.

polymorpleus, ii. 165.

precisus, i. 161.

retusus, ii. 171 .

rurgosus, i. 146.

sargittutus, ii. 171 .

stagnalis, ii. 156 .

striutulus, ii. 178.

striatus, ii. 173.

subsaratilis, ii. 171 .

umbilicalus, ii. 182.

unevelatus, ii. 170, 181.

ungulinus, ii. 170

Folgensis, ii. 165

velyaris, ii. 171 .

Zcllensis, ii. 158.

Naricu slaberrima, iii. 345 . granulosa, iii. 345. sulcater, iii. 345 .

tuberosissima, iii. 345 .

Nassa, \&c., iii. 338, 397.

N.ASsA, iii. 387.

ambigua, iii. 397.

lim rii, iii. 1 19. +15,

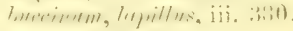

cincta, iii. 4.45.

hepatica, iii. 397.

incrassuta, iii. $391,395$.

lineata, iii. 397.

macule, iii. 391.

minime, iii. 377.

picta, iii. 444 .

pygmxa, iii. 394 ; iv. 284.

reticulata, iii. 388.

raricos $\alpha$, iii. 395.

NATICA, iii. 325. 


\section{INDEX.}

NATICA continued. acuta, iii. 332. alba, iii. 34].

Alderi, iii. 330 . ampullaria, iii. 326.

canaliculata, iii. 339. castanea, iii. 326, 330 .

caten $\alpha$, ii. 326. cornea, iii. 339.

fulva, iii. 334.

glabrissima, iii. 345.

glaucina, iii. 326,330 .

Groenlandica, iii. 341 ; iv. 286.

Helicoides, iii. 339 ; iv. 286.

intermedia, iii. 330 .

intricata, iii. 344.

Kingii, iii, 343 .

lactec, iii. 332.

lacuna, iii. 59.

livida, iii. 341 .

Marochiensis, iii. 330 .

monilifera, iii. 326,330 .

Montagui, iii. 336.

nitida, jii. 330.

pallidula, iii. 56.

Plitippiana, iii. 332.

plumbea, iii. 334.

proxima, iii. 334.

pusilla, iii. 341.

rutilis, iii. 336.

sordida, iii. 334.

squulida, iii. 326 .

subcarinate, ii. 542.

sulcata, iii. 345 .

luberosissima, iii. 345 .

Tulenciennesii, iii. 344 .

NATICID $/ \mathrm{E}$, iii. 324.

N'uutilus lacustris, iv. 163. spirula, iv. 242.

NEARA, i. 194.

abbreviata, i. 201.

brevirostris, i. 195.

costellata, i. 199.

cuspidata, i. 195.

sulcata, i. 199.

vitrea, i. 201.

Nerita alla, iii. 69.

canrena, iii. $326,344,345$.

catena, iii. 326,330 .

elegans, iv. 201.

fasciata, iii. 11.

fluviatilis, iii. 7.

glabrissima, iii. 345 .

glaucina, iii. 326, 330 .

intricata, iii. 344.

jaculator, iii. 14.

lavida, iii. 332.

littoralis, iii. 45 .

nitila, iii. 330 .
Nerita continued.

mammilla, iii. $330,333$.

pallidula, iii. 56.

pellucida, iii. 69 .

piscinalis, iii. 19.

rufu, iii. 59, 336 .

sulcata, iii. 345 .

Syncera hepatica, iii. 70. tuberosissima, iii. 345.

valvata, iii. 21 .

virginea, iii. 6 .

vivipara, iii. 9,11 .

NERITID E, iii. 1.

Neritina, iii. 2 ; iv. 261.

Dalmatica, iii. 3.

fluviatilis, iii. 3.

fontinatis, iii. 3 .

Mildvichie, iii. 5.

intexta, iii. 5 .

Mertoniana, iii. 6.

Mittreana, iii. 5.

Numidica, iii. 5.

Peloponensis, iii, 5.

Sardoa, iii. 5.

thermalis, iii. 5 .

trifasciata, iii. 5 .

zebrina, iii. 5 .

Nesca gramulata, iii. 377.

mamillata, iii. 377.

Nicania striata, i. 467.

Nucula, ii. 214.

argentea, ii. 218.

curvirostra, ii. 232.

decussata, ii. 221.

gilbosa, ii. 230.

lenticula, ii. 230.

margaritacee, ii. $216,2: 0$.

minuta, ii. 227.

nitida, ii. 218.

nuclea, ii. 220.

nucleus, ii. $215,220$.

oblonga, ii. 233.

Polii, ii. 221.

pygmcea, ii. 230.

radiata, ii. 220 .

recurva, ii. 232.

rostrata, ii. 227, 232.

sulcata, ii. 221.

tenera, ii. 223.

tenuis, ii. $223,230$.

truncata, ii. 233.

OCTOPODIDÆ, ir. 208.

Octopus, iv. 208.

cirrhosus, iv. 211.

octopodia, iv. 211.

ventricosus, iv, 211.

vulgaris, iv. 209.

Odoncineta papyracea, i. 221. 
Odontidium larissimum, iii. 182. rugulosum, iii. 178.

Onostoma, iii. 259 ; iv. 276. acicula, iii. 311 .

acuta, iii. 269.

affinis, iii. 313.

alba, iii. 278 ; iv. 274.

albellu, iii. 2 î 6.

Ama, iii. 271.

carychizm, iv. 198.

cleveru, 3ii. 314.

clathrate, iii. 258.

conoiden, iii. 260.

conspicua, iii. 263 ; iv. 274.

crasse, iii. 273.

cylindrica, iii. 287.

decorata, iii. 292.

decussata, iii. 303; is. 281.

diap)liane, jii. 291.

dolioliformis, iii. 301 ; iv. 281 .

dubia, iii. 276 ; iv. $274,279$.

Eulinoides, iii. 261, 273 ; iv. 274 .

excavata, iii. 305.

fenestrata, iii. 249.

formosa, iii. 243.

glabrata, iii.283; iv. 274 .

Gulsone, iv, 231.

indistincta, iii. 255 .

insculpta, iii. 289 : iv. 280.

interstincta, iii. 220 .

latiala, iv. 124.

lactea, iii. 243.

Marione, iii. 95.

nigricans, iv. 122.

nitida, iii. 280 ; ir. 274.

nirosa, iv, 274.

notuta, iii. 273.

obliqua, iii. 291,292 ; iv. 280 .

oblonra, iii. 296.

pallida, iii. 273,307 .

pellucicila, iii. 303.

pereersa, iv. 111.

plicata, iii. 261, 264, 27 1 .

plicutulu, iii. 299 .

mepu, iii. 305.

Rissoides, iii. 284; iv. 274, 279. rufa, iii. 245 ; iv. 276 .

Sandricensis, iii. 301.

scalaris, iii. $251,253,234$.

Scille, iii. 309.

semicostutu, iii. 95.

spiralis, iii. 299

striolata, iii. 267 ; iv. 274 .

truncatula, iii, 29t; iv, 274 .

turrita, iii. 267, 287; iv. 274. umbilicate, iii. 270 .

unidentata, iii. $263,264,273$.

Warenii, iii. 292 ; iv. 280.

OITHONA, iii. 549.
OITHONA contimued. nobilis, iii. 589 .

OMmastremes, iv, 23l.

Eblana, iv. 23. 25.

sagittatus, ir. 231.

todarus, iv. 233.

ONCHIDIADA;, is. :2.

Oxchidum, ir. 2.

Celticum, iv. 3.

Orticula Norregica, ii. 366 .

striata, ii. 368 .

glabra, iii. 18:-

imperforata, iii. 173.

trachea, iii. 180.

Osteodesma Corluloides, i. 21.1. corruscens, i. 214.

Ostéodesme Corbuloide, i. 214.

Ostrea, ii. 306. aleter, ii. 260.

cimnelarine, ii. 303.

clarata, ii. 289.

corallina, ii. 289.9.

crista-galli, ii. :3:1.

deformis, ii. 306.

distorta, ii. 278 .

edulis, ii. 306.

crucelle, ii. 321.

folizm, ii. 321 .

fragitis, ii. 265 .

frons, ii. 32l.

fice $i$, ii. 281.

glubra, ii. 239.

hippopes, ii. 306 .

liylbride, ii. 289.

infleata, ii. 289.

Islandica, ii. 303 .

Jacolece, ii. 305.

Jacobi, ii. 305.

lavis, ii. 285, 288.

limacella, ii. 321 .

lineata, ii. 299.

maxime, ii. 296.

obsoletu, ii. 285.

opercularis, ii. 299.

parasitice, ii. 306.

perne, ii. 260.

musio, ii. 278.

reluella, ii. $3: 21$.

sanguinea, ii. 299.

semplemradiatu, ji. 289.

sinuosa, ii. 278.

stricta, ï. $3: 4$.

subauriculata, ji. 263.

subrufu, ii. '299.

tiyrina, ii. 285.5.

triradiatu, ii. 239.

tumida, ii. 29)3.

variu, ii. 273.

(IS'RKADA, ii. 261. 
INDEX.

Ostreum striatum, ii. 334. vulgare, ii. 307.

OTINA, iii. 320 . otis, iii. 321 .

Oratella bidentata, iv. 194.

Ovula, jii. 497. acuminata, iii. 500 patula, iii. 498.

Ovulum patulum, iii. 499.

Oxinoe glabra, iii. 355.

Oxychilus cellaria, iv. 33. ericetorum, iv. 62. lucidus, iv. 40. nitidulus, iv. 36.

Pallium citreum, ii. 281.

Paludina, iii. 7. achatina, iii. 9, 11. acuta, iii, 16.

anatina, iii. 134.

Balthica, iii. 143. erystallina, iii, 9. fasciata, iii. 11. glabrata, iii. 26. Grayana, iii. 70. impura, iii. 14.

Listeri, iii. 8 ; iv. 261 .

Michumlii, iii. 135. muriatica, iii. 138. octona, iii. 138. stagnalis, iii. 143. stagnorum, iii. 138. tentaculata, iii. 14 . Troscheliana, iii. 16 ulve, iii. 141 . ventricosa, iii. 16 . vivipara, iii. 9,11 ; iv. 261 .

PALUDINIDE, iii. 8.

Pandocia conchilega, i. 32 .

Pandora, i. 206.

incequiralvis, i. 208. obtusa, i. 210. margaritacea, i. 208. rostrata, i. 207.

Pandore rostrée, i. 208.

PANDORIDE, i. 206.

Pandorina coruscans, i. 214.

PANOPEA, i. 173.

Aldrovandi, i. 178.

arctica, i. 175.

Bivonce, i. 175.

glycimeris, i. 175, 178.

Norvegica, i. 174; iv, 249.

Spengleri, i. 175.

Panopée d'Aldrovande, i. 178.

Parthenice crenatu, iii. 245 ; iv. 276. clegantissima, iii. 242.

turvita, iii. 305.

Purthenope formosa, ii. 105.
Patella, ii. 420. aqualis, ii. 437. albida, ii. 463. amona, ii. 435 . Ancyloides, ii. 443. anomala, ii. 366. apertura, ii. 469. aspera, ii. 426. athletica, ii. 425 . limaculata, ii. 430. candida, ii. 443. cced, ii. 443. coerulea, ii. 430 . caruleata, ii. 430 . cerea, ii. 444.

Chinensis, ii. 463.

Clealundi, ii. 435 .

clypers, ii. 435. cornea, ii. 430.

crepidula, ii. 466 . depressa, ii. $42 \mathrm{I}$. distorta, ii. 366. elliptica, ii. 430 . elongata, ii. 430 . exigua, ii. 444. extinctorium, ii. 483 . fissura, ii. 477,479 . fissurella, ii. 474. Aluviatilis, iv, 187. Forbesii, ii. 441. fulva, ii. 441 .

Groca, ii. 469

Hungarica, ii. 459. intorta, ii. 433.

lacustris, iv. 186, 189.

laris, ii. 430 .

larea reticulata, ii. 469. marginata, iv. 259 militaris, ii. 461 . mitrula, ii. 462.

muricata, ii. 464.

Noachina, ii, 474

nulecul $\alpha$, ii. 47:2.

ollonga, iv. 188.

orbiculata, ii. 483.

parva, ii. 437.

pectinata, ii. 433. pellucida, ii. 429. pileus morionis major, ii. 459 . pulchella, $\mathrm{ii}_{\text {. } 437 .}$

reticulata, ii. 469

Sinensis, ii. 463. spirata, ii. 462 .

tessellata, ii. $4: 4$.

testrulinalis, ii. 434 .

testudinaria, ii. 434.

lestudinaria Grœenlandica, ii. 435.

tricornis, ii. 483.

Ungarica, ii. 459 . 
PAtella continucel. viryinea, ii. 437 . evelyuris, ii. 421,464 . vulgata, ii. $4: 21,4: 26$. Zetlantica, ir. 259.

PA'TLLLID.E, ii, 418.

P'atula pygmad, iv. 83. rotundata, iv. 30. rupestris, iv. 82.

Pecten, ii. 272. aculeatus, ii. 281. udspersus, ii. 289. Armoricunus, ii. 285. Andouinii, ii. 300 . Danicus, ii. 288. listortus, $\mathrm{ii} .278$. tomesticus, ii. 285. Dumasiz, ii. 289. fragilis, ii. 265. fuci, ii. 281.

furtivus, ii. 284. glaber, ii. 289, 292.

Cirecnlandicus, ii. 294. Isabella, ii. 278 .

Islandicus, ii. 303.

Jacobxus, ii. 305.

Jumesoni, ii. 289.

lavis, ii. 285, 288, 296.

Landsburgi, ii. 281 .

lineatus, ii. 299.

Macrilliwrai, ii. 302.

maximus, ii. 296.

monotis, ii. 273.

nelulosus, ii. 289.

niveus, ii. 276 .

obsoletus, ii. 285.

opercularis, ii. 299.

parzus, ii. 285.

'Pculii, ii. 303 .

pes-felis, ii. 289.

pictus, ii. 299.

plebeius, ii. 300.

pusio, ii. 278.

rimulosus, ii. 281.

sanguineus, ii. 299.

septemradiatus, ii. 288.

similis, ii. 293.

sinuosus, ii. 278 .

spinosus, ii. $278,281$.

striutus, ii. 278.

striatus, ii. 281.

suticuriculatus, ii. 263.

sutrufus, ii. 300.

sulcutus, ii. 300 .

tigrinus, ii. 285.

lumidus, ii. 293.

trirceliutus, ii. 288.

varius, ii. 27 's.

rulyuris, ii. 296.
P'ECTUNCULUs, ii. 244 .

cupillaceus, i. 4.28.

crassus, i. 441 .

decussutus, ii. 246 .

depressus, i. 288.

fasciatus, j. 415 .

glaber, i. 396.

glycimeris, ii. 245 .

membranaceus, i. 405 .

nummarius, ii. '246.

pilosus, ii. 245.

striatulus, i. 408.

strigosus, i. 101.

sulcatus, i. 452, 453.

undatus, ii. 246 .

variubilis, ii. 246.

l'cigne operculaire, ii. 300.

P'ELONAIAD E, i. 4:.

Pelonaia, i. 43. corrugata, i. 43,46 . glalora, i. 43 .

Pelte, iii. 612.

I'eracle Flemingii, ii. 38.4 .

Perlenmuschel, ii. 146 .

Perna alata, ii. 260. ephippium, ii. 260. oblique, ii. 260. striatula, ii. 179. unsulina, ii. 171.

PerophorA, i. 28. Listeri, i. 28.

I'es-pelecani, iii. 189.

P'etecsice trochiformis, iv. 76 .

Petricola, i. 151 . bidentata, ii. 75 .

costellata, i. 152.

Irus, i. 156 .

lithophaga, i. 151 . ochroleuce, i. 284. roccellaria, i. 152. ruperella, i. 152. striata, i. 151.

P'tricole costellée, i. 15:2.

Pluellusia canina, i. 31. intestinalis, i. 31 . mentulu, i. 32 .

moncellus, i. 32. rusticu, i. 39.

Pirasianelia, ii. 537 . decussate, iii. 147. fusciata, iii. 59. lincata, iii. 54. pallida, iii. 307. politu, iii. 229. pullus, ii. 538. stylifera, iii. 227 . silututu, iii. 237.

PHILNE, iii. 5339 . aperta, iii. 539 . 
INDEX.

Philine continued. catena, iii. $5+5$.

formosa, iv. 287. pruinosa, iii. 549 . punctata, iii. 547 . quadrata, iii. 541 ; ir. 287. quadripartita, iii. 539. scabra, iii. 543 . scutulum, iii. $5+1$. ventrosa, iii. 550 .

Pholade dactyle, i. 108. striee, i. 123.

PHOLADID $\mathbb{E}$, i. 57.

Pholadidea, i. 122. Goodallii, 1. 123.

Loscombiana, i. 123. papyracea, i. 123 ; iv. 248.

Pholas, i. 94. bifrons, i. 114. callosa, i. 108. candida, i. 117. clarata, i. 120. crenulata, i. 111. crispata, i. 114. dactyloides, i. 111. dactylus, i. 108. conoides, i. 120. faba, i. 132. Goodallii, i. 123. hians, i. 108. lamellata, i. 123. ligamentina, i. 111. lignorum, i. 120. nana, i. 120.

papyracea, i. 117, 123. parva, i. 111,114 . pusilla, i. 120. striata, i. 120, 123 . sulcata, i. 128. tuberculata, i. 111. xylophaga, i. 90.

Phoreus margarita, ii. 531.

PH Y LLIDID E, iv. 290.

PHYsa, iv, 140. acuta, iv. 142,146 . alba, iv. 145 .

Antonii, iv, 145.

contorta, iv, 146 . elongata, iv. 145 . fontinalis, iv. 140,146 . hypnorum, iv. 143 . rivalis, iv. 145 . scaturiginum, iv. 176. Soverbiana, iv. 145. subopaca, iv. 146.

Prileopsis, ii. 457. antiquata, ii. 459,462 . Hungarica, ii. 459 . intorta, ji. 462 .
Pileopsis continued. militaris, ii. 461 mitrula, ii. $46: 2$. ungarica, ii. 459 .

Pilidium, ii. 440. fulvum, ij. 441 .

Pinna, ii. 254.

carnea, ii. 259.

elegans, ii. 256.

fabellum, ii. 259.

fragilis, ii. 255 .

haud ignobilis, ii. 259.

ingens, ii. 256 .

lavis, ii. 256.

muricata, ii. 256, 259 .

papyracea, ii. 256.

pectinata, ii. 255 .

rotundata, ii. 256

saccata, ii. 259.

Pisidium, ii. 120. acutum, ii. 131.

amnicum, ii. 133.

cinereum, ii. 125.

fontinale, ii. 128 .

Henslowianum, ii. 131.

Jenymsii, ii. 128.

Johannis, ii. 128

nitidum, ii. 126.

obtusale, ii. 120.

obliquum, ii. 133.

pusillum, ii. 123.

pulchellum, ii. 128.

Planaria alba, jii. 170 . pellucida, iii. 170.

Planaxis lineata, iii. $39 \%$.

Planorle cornée, iv. 147.

Planoris, iv. 146.

albus, iv. 149 .

bulla, iv. 140 .

carinatus, iv. 153 .

clausulatus, iv. 163.

complanatus, iv. 155, 162 .

compressus, iv. 158.

contortus, iv. 160.

corneus, iv. 147.

cristatus, iv, 152

disciformis, iv. 154.

Draparnaldi, iv. 155.

fontanus, iv, 162 .

glaber, iv. 150, 289.

lirsutus, iv. 149.

hispidus, iv. 149.

imbricatus, iv. 152.

lacustris, iv. 162, 289.

lenticularis, iv. 162.

leucostomus, iv. 159.

lineutus, iv. 163.

lavis, iv. 150.

lutescens, iv, 154. 
Pianonis continued. marginatus, iv. 155. Nautileus, iv. 152, 163, 289.

Noutilus, iv, 15\%. nitidus, iv. 16 ], 162 . plenatus, iv. 154. purpureus, iv. 1.77 . rhombeus, is. 155. similis, iv, 147. spirorbis, ir, 159. turvitus, iv, 14.t. turgidlus, iv. 155. umbilicatus, iv. 155. rortex, iv. 157,159 .

PLEUROHR ANCHIDA, iii. 557.

Pleurobraxcmus, iii. 557. membranaceus, iii. 558 . plumula, iii. 559.

Pleurotoma attenuata, iii. 489. Banflum, iii. 436 .

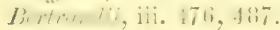

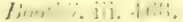

lu, wi n!ii. Mi-.

brachystoma, iii. 480 . courctute, iii, -185 . cervelans, iii. 487.

Comarmonti, iii. 473.

concinne, iii. 470 .

Cordieri, jii. 467.

costulutum, iii. 484 .

decussata, iii. 452 .

Eirrmini, iii, tias.

Furlesir iii fire.

Forthicnsis, iii. 491.

Ginnanianum, iii. 476. gracilis, iii. $473,489$.

heptayona, iii. 458 . inflate, iii. 468.

larigatum, iii. 476 . leucostoma, iii. 453 .

Leufroy, iii. 468.

linearis, iii. 470.

Metealfei, iii. 485. multilineolate, iii. 492. nebula, iii. 476 . nigra, iii. 455 .

Phillerti, iii. 465. purpurea, iii. 465. reticulata, iii. 452,467 . rudis, iii. 467.

mugulata, iii. 450 .

scabrum, iii. 471. septangularis, iii. 458 . sinuosa, iii. 452, 473, 492 . s...ill ii, iii, Jii::.

strioluta, iii. 483. suturalis, iii. 47\%.

teres, iii. 462 .

Trevellianum, iii. $450,452$.
Pleurotoma contintied. turricula, iii. 4.50 . Ulideane, iii. 455 . Yulle, int ins. variegatum, iii. 465 rersicolor, iii. 465 . rilliersi, iii. 188. vulpecula, iii, 473.

Polita cellaria, iv. 33. crystallina, ir. 42. fulva, iv. 76 . glabra, iv. 35. lucida, iv. 40. nitidose, iv. 37. nitidula, iv. 36.

Polycera, iii. 576 . citrina, iii. 577 . cornuta, iii. 576 . cristatc, iii. 580 . fara, iii. 576 .

L. lineata, iii. 576 . modesta, iii. 577 . ocellata, iii. 578. ornate, iii. 576 . punctilucens, iii. 574 . quadrilincata, iii. 576 . typica, iii. 576 .

Polyclinum, i. 14, 17. aurantium, i. 14.

Polycyclus, i. 21.

Polyphemus acicula, ir. 131.

Polypus octopodice, iv. 209.

Polyzona rariolosa, i. 19.

Pomatia adspersa, ir. 45. aperta, iv. 43.

Porcellana, \&c. iii. 495.

Poromsis, i. $20 \%$. Anctinoides, i. 204. granulata, i, 204: iv. 250.

Poronia rubra, ii. 94.

Proctoxotes, jii. 60\%. mucroniferus, iii. 608 .

Propilidium, ii. 443. Ancyloide, ii. 443 ; iv. 259.

PSAMMOBIA, i. 270. antiquata, i, 260 . costulata, i. 279 . declivis, i. 267. deflorate, i. 330 . discors, i. 279.

Ferroensis, i. 274. floride, i. $271,277$. firailis, i. 284. jugosa, i. 284. Laskeyi, i. 281. legumen, i. 256. polita, i. :336. polygone, i. 286. 
INDEX.

Psamrobia continued, rotundata, ii. 66 . rugosa, i. 330. scopula, i. 263. solidula, i. 304 . strigilata, i. 263. terniata, i. 266.

Tellinella, i. 277. vespertina, i. 271.

Psammotiea Tarentina, i. 284.

Pseud-Amusium, ii. 288.

PTEROPODA, ii. 377.

Ptychina biplicata, ii. 55 .

Pullastra aurea, i. 392. decussata, i. 379. Irus, i. 156 . perforans, i. 383. virginea, i. 388. vulyaris, i. 383.

Puncturella, ii. 473. Noachina, ii. 474.

PupA, iv. 95.

Anglica, iv. 99, 289. antivertigo, iv. 109. badia, iv. 98 . bidens, iv. 116.

bidentata, iv. 96, 98.

Britannica, iv. 128.

cinerea, iv. 113.

edentula, iv. 103.

fragilis, iv. 114.

Goodallii, iv. 128.

juniperi, iv. 101.

marginata, iv. 97.

Menkeana, iv. 128.

minutissima, iv. 104.

muscorum, iv. 96, 97, 104 .

obtusa, iv. 104.

pusilla, iv. 111.

pygmæa, iv. 106.

quinquedentata, iv. 106.

ringens, iv. 99.

secale, iv. 101.

sexdentata, iv. 108.

substriata, iv. 108.

umbilicata, iv. 95 .

unidentata, iv. 98.

Venetzii, iv. 112

vertigo, iv. $109,111$.

Pupilla marginata, iv. 98. muscorum, iv. 98. umbilicata, iv. 96.

Purfura, iii. 379.

bizonalis, iii. 381.

imbricata, iii. 381.

lapillus, iii. $380 ; \mathrm{iv.} 284$.

picta, iii. 444.

scalata, \&c., iii. 371.

Pyramidula rupestris, iv. 82.
Pyramis acutissimus, iii. 219. candidus, iii. 95. cingillus, iii. 122.

crenatus, iii. 245 ; iv. 276 .

discors, iii. 95.

elegantissimus, iii. 243.

indistinctus, iii. 255.

lacteus, iii. 259.

Lemerclii, iii. 296.

nitidissimus, iii. $22 \pm$.

nirosus, iii. 287.

simillimus, iii. 245.

spiralinus, iii. 249.

subarcuatus, iii. 244.

subtruncatus, iii. 320.

subulatus, iii. 237.

truncatus, iii. 320 .

unicus, iii. 222

Pyrula carica, iii. 447.

Aruana, iii. 447.

Pythia denticulatu, iv. 194.

Ranella pygmac, iii. 394. tuberculata, iii. 446.

Rimule Flemingii, ii. 474. Noachina, ii. 474 .

RISSOA, iii. 72.

abyssicola, iii. 86. acicula, iii. 148.

acuta, iii. 148.

Adamsii, iii. 145.

alata, iii. 147.

alba, iii. 98.

albelle, iii. 153 .

anatina, iii. 134.

approxima, iii. 90.

arenaria, iii. 303.

auriscalpium, iii. 148.

Balliae, iv. 278.

Barleei, iii. 141.

Beanii, iii. 84 ; iv. 263

Binghami, iii. 146.

Boscii, iii, 229.

Bruguieri, iii. 146.

Bryerea, iii. 149.

calathisca, iii. 149 .

calathiscus, iii. 148 .

calathus, iii. 82.

cancellata, iii. 76, 149 .

candida, iii. 146.

carinatula, iii. 146.

Chesnelii, iii. 149.

cimex, iii. 80 .

cingilus, iii. 122.

cingillata, iii. 122 .

cingillus, iii. 122.

communis, iii. 95.

conifera, iii. 147.

costata, iii. 92 ; iv. 263. 
Risco i continued. costulata, iii. 103, 169. crenulata, iii. 80. crysiallina, iii. 125. cyclostomala, iii. 78. decussalu, iii. 95, $146,1+7$. deformis, iii. 147 . denticulata, iii. 149 . Desheryesiuna, iii. 305. diapluena, iii. 152. discrepuans, iii. 102 disjuncta, iii. 140 . clata, iii. 111. eleguns, iii. 26. ricuruta, iii. 305. exigue, iii. 92. eximiu, iv. 278. fulyida, iii. 129, 169. fulva, jii. 120 fuscuta, iii. 98. glabra, iii. 152. glabruta, iii. 283 globularis, iii. 132 ? gracilis, iii. 95. gramulata, iii. 149. graptica, iii. 122. grosse, iii, 111. Gruerinii, iii. 103.

IKareyiz, iii. 305. hyalina, iii. 106. inconspicua, iii. 113 . interrujta, iii. 101. Iabiala, iii. 74.

labiosa, iii. 109. lacter, iii. $76,1+6$.

lilacine, iii. 106 . littorea, iii. 13:2 ; iv. 265. mucululu, iii 113. murginat $a$, iii. 148. membrunuceu, jii. 109. minutissimu, iii. 9.5. olseura, iii. 98. oltuse, iii. 146 . opalina, iii. 154. pallida, iii. 307. parka, iii. 98. pellucilla, iii. 140. plicutula, iii. 111. proxina, jii. 127 ; ir. 264. pulcherrima, iii. 129. puller, iji. 109. vullus, ii. 538 punctatu, iii. 106 . punctutum, iii. 125, 283. punctura, iii. 89. munctureter, iii. 89. pusille, iii. 149 . jyramidilla, iii. 1.48. reticulata, iii. 89.
RISsOA continned. reliformis, iii. 145. rubra, iii. $1: 0$. rufilalorum, iii. 106. mepestris, iii. 12:2. Sandricensis, iii. 301. Sirri, iii. [11]. sculpta, iii. 838 semicostuta, iii. 95. semistriata, iii. 117 ; iv. 263. similis, iii. 103, 113 . soluta, iii. 131 ; iv. 265. Souleyctana, iii. 111. spiralis, iii. 29 ?. striata, iii. 94,300 . striatula, iii. $73,1: 7$. strigute, iii. 145. sulverufu, iii. 1.55. subsulcute, iii. 118. subulater, iii. 237. subumbilicale, jii, 137, 141. sulcata, iii. 146 . tristriata, iii. 117. trochlea, iii. 74 . truncata, iii. 317. turriculu, iii, 146 ulya, iii. 14t. unifusciata, iii. 120. vittata, iii. $] 196$. ventricos $\alpha$, iii. 138 . ventrosa, iii. 138 ; ir. 266 . venusta, iii. 111. viminea, iii. 127. vitrea, iii. 125 ; iv. 264 . vittuta, iii. 122.

Herreniz, iii. 29 ?. Zetlandica, iii. 78 .

Ropan, ii. 212.

Rossid, iv. $2 \cdot 21$. Jacolii, iv. 222 . macrosoma, iv. 222. Owenii, iv. 22\%.

Rostellaria pes-pelecani, iii. 186, 189. Serresiana, iii. 186.

RunciNA, iii. 611. IIancockii, iii. 612.

SALPA, i, 47 moniliformis, i. 52 . runcinata, i. 53. spinosu, i. 53.

SALPID/E, i. 47.

Sanguinoluire rilée, i. 330.

Sanguinolaria deflorata, i. 330. rugosa, i. 330. sordida, i. 307. vespertinc, i. 271.

SAXICAVA, i. 136. arctica, i. 141. 


\section{INDEX.}

SAXICAVA continued.

dislortu, i. 146 .

Gallicana, i. 146.

pholadis, i. 146.

plicata, i. 218.

purpurea, i. 14 l ; ii. 81 .

rhomboides, i. 141.

rubra, i. 141.

rugosa, i. 146.

? i. 149 ; iv. 248 .

Saxicave ridée, i. 146.

Scalaria, iii. 203.

clathratula, jii. 209.

clathrus, iii. 207.

communis, iii. 204, 206.

minuta, iii. 209.

Greenlandica, iii. 211.

Gronlandica, iii. 211.

planicosta, iii. 204, 211.

pulchella, iii. 209.

similis, iii. 211.

subulata, iii. 211.

tenuicostata, iii. 204.

Trevelyana, iii. 213.

Turtoni, iii. 204.

Turtonis, iii. 204.

SCALARIAD E, iii. 203.

SCAPHANDER, iii. 536 .

Ciunclii, iii. 533.

lignarius, iii. 536. pectinata, iii. 543 .

ScIssurella, ii. 543 . crispata, ii. 544.

Schildkröten Patelle, ii. 435.

Scaa stenogyra, ii. 384.

Scrontcularia, i. 325. piperata, i. 326 .

SCYLLEA, iii. 584 . pelagica, iii. 584

Segmentina lineata, iv. 163.

SEPIA, iv. 237.

bisserialis, iv. 241.

cirrhosa, iv. 211.

elegans, iv. 241.

loligo, iv. 226, 231.

media, iv. 228,230 .

octopodia, iv. 209, 211.

octopus, iv. 209 ,

officinalis, iv. 238.

Orbignyana, iv. 241 .

rubens, iv. 241.

rupellaris, iv. 241.

sepiola, iv. 219, 220.

subulata, iv. 228

SEPIAD无, iv. 237.

Sepiola, iv. 215, 220.

Atlantica, iv. 217.

macrosoma, iv. 222

Rondeletii, iv. 217, 220 .
Sepiola continued. vulgaris, iv. 217.

Serpula incurzate, iii. 182.

Sidny um, i. 13.

turbinatum, i. 14; ii. 369.

Sigaretus flexilis, iii. 350 . Haliotoideus, iii. 355.

Kindelianus, iii 355 .

Neritoideus, iii. 355.

perspicuus, iii. 355 .

tentaculatus, iii. 358 .

Sipho Noaclina, ii. 474. radiata, ii. 469 .

Srenea, iii. 155.

? costulata, iii. 167 ; iv. 271 .

depresse, iii. 157.

? divisa, iii. 161 ; iv. 269.

Cutleriana, iii. 164; iv. 270.

? levis, iii. 164.

? nitidissima, iii. 158 ; iv. 269.

planorbis, iii. 156.

? rota, iii. 160 .

Serpuloides, ii. 5]3; iii. 161, 162.

Solecurte rose, i. 263.

SOLECURTID E, i. 255.

Solecurtus, i. 259.

antiquatus, i. 261.

bidens, i. 266.

candidus, i. 263.

Caribeus, i. 267.

coaretatus, i. 259.

gibbus, i. 267.

strigilatus, i. 268.

Solen, i. 240.

angustior, \&c. i. 260.

antiquatus, i. 260.

bidens, i. 266.

Bouchardi, i. 267.

candidus, i. 263.

Caribaus, i. 267.

centralis, i, 266.

coarctatus, i. 260.

cultellus, i. 259.

declivis, i, 267.

divisus, i. 266.

emarginatus, i. 260 .

ensis, i. 250 .

fragilis, i. 266.

gibbus, i. 267.

gousse, i, 256.

Guineensis, i. 267.

legumen, i. 256.

ligula, i. 246.

marginatus, i. 242.

minutus, i. 141 .

novacula, i. 246.

pellucidus, i. 253.

pictus, i. 271.

Pinna, i. 210. 


\section{lxviii}

Sorfy continued. purpurcus, i. 141. mygmeeus, i. 253.

Sabre, i. 250.

scopula, i. 263.

siliqua, i. 246.

squamosus, ii. 98 .

strigilatus, i. 263, 268.

tenuis, i. 253.

ragince, i. 242.

respertinus, i. 271 .

SOLENIDE, i. 239.

Solenocurtus legumen, i. 256 .

Speo lifasciatus, iii. 524 .

SPIIENIA, i. 189.

Binghami, i. 190; iv, 250 .

costulata, ii. 77 .

decussata, i. 152.

Succinsoni, i. 164.

Spire ticolor, iv. 269

corerctata, iv. 84.

globosa, iv. 84 .

nitzilissima, iii. 158.

reticulata, ix. 84.

fubulata, iv. 269.

varieyata, iii. 145 .

SPIRILIS, ii. 382.

Flemingii, ii. 384 ; iv. 258 .

Nac Andrei, ii. 385.

Jeffreysii, ii. 336.

Spirula Australis, iv. $2 \pm 2$.

Peronii, iv. 242.

Sphyrectium edentulum, iv. 103. muscorum, iv. 104.

Syuama magna, ii. 336.

Stiliger modestus, iii, 611.

Stagnicola vulguris, iv. 175 .

Stomodonta antivertigo, iv. 109. edentula, iv. 103.

fragilis, iv. 115.

marginata, iv. 98.

pygmaa, iv. 106.

muscortum, iv. 10.5 .

plicatula, iv. 120.

secale, iv. 101.

umbilicata, iv. 96 .

Strigilla carnavia, i. 313. pisiformis, i. 312.

Sirombiformis allus, iii. 229.

bicurinalus, iii. 175.

cinctus, iii. 176.

clathratus, iii. 206.

gluber, iii. 235.

perersus, iv. 121.

reticulatus, iii. 19-2.

terebra, iii. 172.

Strombus costatus, iii. 200.

Norregicus, iii. 428.

pes-pelicani, iii. 188.

\section{INDEX.}

Slrombus continued. reticulatus, iii, 146.

Turboformis, iii. 200.

STYLIFER, iii. 225.

astericola, iii. 226 .

globosts, iii. 226.

stylifera, iii. $2: 26,2: 28$.

Turtoni, iii. 226.

styloides lubricus, iv. 126 .

SUCCINEA, iv. 132.

amplitia, iv. ]33.

arenaria, is. 137.

gracilis, iw. 133.

Levantina, iv. 133.

oblonga, iv. $133,137$.

Ifeifferi, ir. 133.

putris, iv. 132.

Symplionota cygnea, ii. 156.

SYNDOSMYA, i. 315.

alba, i. 316 .

intermedia, i. 319.

nitisla, i. 319.

prismatica, i. 321 .

temuis, i. 32:3.

truncata, i. 325.

SrNTETHYs, ir. 244.

S. Hebridicus, iv. 245 .

Tuchea hortensis, iv. 54.

Tanychlamys lucida, iv. 40.

Tupada putris, iv. 133.

TAPES, i. 379.

aurea, $i .392$

decussata, i. 379.

pullastra, i. 382 .

virginea, i. 3338.

Tarel bipalmulé, i. 86. de P'ondicherry, i. 86.

Teba Granatelli, iv. 74. spinulosa, iv. 'it.

Tectura fulea, ii. 441 virginea, ii. 437 .

Tellimya bidentata, ii. 75 . clliptica, ii. $7: 2$.

ylabra, ii. 72.

lactea, ii. 89.

suborbicularis, ii. 87.

sulstriata, ii. 77 .

tenuis, ii. 89.

Telliva, i. 286.

albida, i. 271.

amnica, ii. 133.

angulosa, i. 313.

anomala, i. 330.

balaustina, i. 290, 300; iv. 251 .

Balthice, i. 304.

bimaculata, i. 309 .

Braziliana, i. 314.

calcarca, i. 307 ; iv. 25:2. 
INDEX.

TELLINA continued. carnaria, ii. 304, 313 cornea, ii. 111, 113. Cornubiensis, i. 156. coruscans, i. 214. crassa, i. 288. cuspidatu, i. 195. depressa, i. $271,298$. discors, i. 302. divaricata, ii. 52, 54 . Donacina, i. 292 . elliptica, i. 388. exigua, i. 300 . fabula, i. 302.

fausta, i. 313 .

Ferroensis, i. 274.

Fervensis, i. 27 .

fragilis, i. 274, 284, 311 .

Gari, i. 27].

gibba, i. 181.

Guinaica, i. 286.

Henslowiana, ii. 131. incarnata, i. 274, 298, 300 . inæquistriata, i. 314. incquivalvis, i. 207. jurnos $\alpha$, i. 284. lactea, ii. 57. lacustris, ii. 116, 117. leta, i. 313. lavis, i. 313.

Laskeyi, i. 281. lata, i. 307 ; iv. 252.

lineata, i. 314 .

Llantivyi, i. 292.

maculata, i. 288.

ochroleuca, i. 284.

obliqua, i. 307.

obtusa, i. 288.

ovalis, i. 307.

orata, i. 307.

pellucida, i. 346 .

pisiformis, i. 312.

plana, i. 326.

planata, i. 300 .

polita, i. 300, 336 .

polygona, i. 286.

proficua, i. 329.

proxima, i. 307 ; iv. 25 l.

punicea, i. $313,314$.

pusilla, ii. 123.

pygmæa, i. 295 ; iv. 251.

radiata, i. 362, 274.

radula, ii. 46.

remies, i. 313.

reticulata, i. 329 .

vigida, i. 288.

rivalis, ii. 113, 133.

rotundata, ii. 66 .

rubra, ii. 94,304 .
Tellina continued. rugosa, i. 382.

sanguinea, i. 314. sexradiata, i. 310.

similis, i. 314.

solidula, i. 304.

sordide, i. 307 ; iv. 252.

squalida, i. 298.

stagnicola, ii. 114.

striata, i. $313,314$.

suborlicularis, ii. 87.

tenuis, i. 300 .

trifusciata, i. 274, 292.

truncata, i. 274.

undata, ii. 66 .

variabilis, i. 271 .

variegata, i. 292.

zonata, i. 304 .

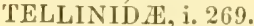

Terebra fuscata, iii. 202. perversa, iii. 195. reticulata, iii. 192. speciosa, iii. 255. suluulata, iii. 201. tubercularis, iii. 365.

Terebratula, ii. 349 . aurita, ii. 353 . caput-serpentis, ii. 353. costata, ii. 353. cranium, ii. 357 ; iv. 257. detruncata, ii. 362 . psittacea, ii. 346. pubescens, ii. 353 . vitrea, ii. 357.

TEREBRATULID $\mathrm{E}$, ii. 343.

Terebratulina caput-serpentis, ii. 354.

Teredo, i. 58.

Batava, i. 74.

bipalmulata, i. 66 .

bipennata, i. 80

Brugieri, i. 67.

dorsalis, i. 90 .

malleolus, i. 84.

megotara, i. 77 ; iv. 246.

nana, i. 77 .

navalis, i. $67,74,77,80$; iv. 246 . Norvagica, i. 66 ; iv. 246. palmulata, i. 86.

Tergipes, iii. 605 . claviger, iii. 573 lacinulatus, iii. 606 .

Testacella, iv. 26.

Europeca, iv. 26.

Haliotidea, iv. 26.

Haliotides, iv. 27.

Maugei, iv. 28.

scutulum, iv. 27

TESTACELLID $\mathrm{E}$, iv, 26.

Testacellus Europaus, iv. 26. 
Testacellus continuel. Maliotideus, iv, 27 . Maugei, iv. 28.

TEUTHID E, iv. 215.

Theba Cuntiuna, iv. 50. Curthusiunella, iv. 52. Charpentieri, iv. 52? cricetorum, iv. $\left(0^{\circ}\right)$ intersectu, iv. 60. Pisuna, is. 56 . Teverii, iv. 58. virgatu, ir. $5 \%$.

THECACERA, iii. 575. pennigera, iii. 575 . virescens, iii. 576 .

Theorloxus Latetianus, iii. '3.

'l'mRACIA, i. 2-20.

Beaniance, i. 238.

brevirostra, i. 195.

convexa, i. 229.

declivis, i. $221,2.26,2 \cdot 29$

distorta, i. 231; iv. 249 .

orate, i. 2.24.

phaseolina, i. 22-21.

pubescens, i. 22.1, 226 .

Turtoniane, i. 238 .

[runcata, i. 23].

villosiuscula, i. 2:24.

Tiehogonia Chemnitzii, ii. 165.

TORNATELLA, iii. 523.

Bulluoides, iv. 197.

fasciatat, iii. 523.

pellucida, iii. 523 .

musilla, iii. 523.

tomalilis, iii. 523 .

Tornatina mammillata, iii. 514. truncata, iii. 510.

Torquatella marginata, iF. 98.

Torquilla secule, is. 101

Tralia pusilla, iv. 197.

Trichia circinata, iv. 67. clundestina, ir. 67.

Тигсотroms, iii. 360 . acuminate, iii. 361. Allantice, iii. 361 . borealis, iii. 361. conica, iii, 361 . costellata, iii. 361 . umbilicake, iii. 361.

Triyonella gellina, i. 351 . plana, i. 326 ruerliata, i. 362 .

zonaria, i. 351 .

T'riqonostomu abrolutum, iv, 63 .

Triopa, iii. 573 .

claviger, iii. 55:3.

Triphoris udverses, iii. 195.

Triton cuticeus, iii. 14 ti. princecus, iii. :371.
Triton continued. elegans, iii. $4 \pm 3$.

Tritonia cutacea, iii. 456 . retricosa, iii. 395.

Tritonia, iii. 582. aborescens, iii. 586. bifida, iii. 610 . felina, iii, 586 . Hombergi, iii. 582. luctea, iii. 586.

lineata, iii. 583. papillosu, iii. 590. pinualifida, iii. 588 . plebeia, iii. 582. pulchellu, iii. 586. pulchra, iii. 58:.

TRITONIAD E, jii. 582.

Tritonium untigum, iii. $4: 24$. Asectius, iii. 392.

Burvicense, iii. 4.2. clathratum, iii. 436 . culaceum, iii. 446 . decemcostutum, iii. 434 . despectum, iii. 424, 434,435 . macile, iii. 416 .

IIumphreysiumum, iii. 402, 410 . Islandicum, iii. 416. nemem, iii. 461.

Norveyicum, iii. 4:28. fornicutum, iii. 434 . ovum, iii. 408 . pes-pelecani, iii. 189. veticulatum, iii. 389 . undatum, iii. 402.

TROCH1D A, ii. 489 .

Trochitu Clinensis, ii. 463.

Trocius, ii. 489 . alabastrum, ii. 497 . albidus, ii. 491 . cinerarius, ii. $516,519$. cinereus, ii. 536.

Clelandi, ii. 502. conicus, ii. 508. conuloides, ii. 491. conulus, ii. $491,495,505$. crassus, ii. 525 cremulalus, ii. 507 . deprictus, ii. 508. discrepans, ii. 491. elcetissimus, ii. 516. crythroleucus, ii. $505,509 \%$. cxasperutus, ii. 505. excarcutus, ii. 536. exiguus, ii. 505. formosus, ii. 497 . fragilis, ii. 500 . granulatus, ji. 499 . 11 elicinus, ii. 531 . infatus, ii. 516 . 
INDEX.

T'rocrus continued.

interruptus, ii. 505.

lineatus, ii. 516, 525; iii. 53.

lineolatus, ii. 516 .

littoralis, ii. 516 .

Lyonsii, ii. 491 .

Magus, ii. 522.

margaritus, ii. 531.

Martini, ii. 502.

Matoni, ii. 507.

millegranus, ii. 502.

minutus, ii. 505 .

Montagui, ii. 5] 1.

Nassavionsis, ii. 513.

Neritoideus, ii. 531 .

nitens, ii. 513 .

oblique radiatus, ii. 519.

obliquatus, ii. 519.

occidentalis, ii. 497 .

parvus, ii. 508.

papillosus, ii. 499.

patholatus, ii. 513.

perforatus, ii. 516.

menctulatus, ii. 525 .

pusillus, ii. 534; iv. 270.

pyramidatus, ii. 507.

quadricinctus, ji. 497 .

Rackettii, ii. 513.

rugosus, ii. 541 .

Sartorii, ii. 508.

Sedgrickii, ii. 491.

Sisyphinus, ii. 491.

striatus, ii. 508, 511 .

subcarinatus, ii. 542.

temuis, ii. 500.

terrestris, iv. 74, 76, 85 .

terrestris Listeri, iv. 75.

tricalor, ii. 507.

tuberculatus, ii. 523 .

tumidus, ii. 5l3.; iv. 259.

umbriticalis, ij. 519.

umbilicaris, ii. 519 .

umbilicatus, ii. 519

undulatus, ii. 528 .

zezyphinus, ii. 491 .

zic $\approx a c$, iii. 54 .

ziziphinus, ii. 491 ; iii. 53 .

zizyphinus, ii. 491.

zyziphimus, ii. 491.

Trophos, iii. 435.

antiquum, iii. 424.

Barvicensis, iii. 442.

clathratus, iii. 436 .

gracile, iii. 416 .

muricatus, ii. $439,453$.

Truncatella, iii. 316.

? atomus, iii. 158.

Caribaensis, iii. 319.

Montagui, ii. 317 ; iv. 283.
Truncateria continued. succinea, iv. 283.

truncatula, iii. 319

Turbo achatimes, iii. 11. acutus, iii. 242.

delemsii, iii. 14.5. adversus, iv. 140 . cereus, iii. 98.

albulus, iii. 113.

allus, iii. 229 ; iv. 275.

Anglicus, iv. 99.

arcuatus, iii. 148 .

arenurius, iii. ] 47, 303.

armatus, ii. 536.

ascaris, iii. 219.

auricularis, iv. 262

bicolor, iv, 269.

bidens, iv. 116, 121, 124.

biplicatus, iv. 118.

Brycreus, iii. 149.

carulescens, iii. 26.

calatliscus, iii. 148.

calcar, ii. 536 .

canaliculatus, iii. 296.

conalis, iii. 62 .

cancellatus, iii. 76,80 .

carinatulus, iii. ] 45, 244.

carinatus, iii. 73 .

carnens, ii. 528.

carychizum, iv. 198.

castanea, ii. 536.

chirysalis, iv. 97.

cime $x$, iii. $30,148$.

cinctus, iii. 176.

cingillus, iii. 122.

clathratus, iii. 206.

clatherus, iii. 206.

clathrus Grœelandicus, iii. 211.

clathratulus, iii. 209.

coarctatus, iv. 84.

coniferus, iii. 147.

conversus, iv. 120.

costatus, iii. $92,93,103,109,149$.

crassior, iii. 67.

crenulatus, ii. 537 .

cristatus, iii, 22.

cylindraceus, iv. 95.

cylindricus, iv. $10 \mathrm{l}$.

decussatus, iii. 147, 303.

denticulatus, iii. 149 .

depressus, iii. 157 .

disjunctus, iii. 140 ; iv. 267.

dispar, iii. 54.

divaricatus, iii. 62 .

divisus, iii. 161.

duplicatus, iii. 175 ; iv. 286.

cluu'neus, iv, 266.

edentulus, iv. 103.

elegans, iii. 145 ; iv. 201. 
Turbo continued.

elegantissimus, iii. 242.

exoletus, iii. 176.

fabalis, iii. 49,53 .

fuscialus, iii. 59 ; if. 86 .

fontinalis, iii. 19.

fulcidus, iii. 128.

fulcus, ir. 204.

fuseus, iv. 204, 259.

glolosus, iv. 84.

srapleicus, iii. 122.

Helicinus, ii. 531 ; it. 78 .

hiprocastanum, ii. 537.

imbricatus, iii. 176 .

incarnatus, ii. 529 .

insculptus, iii. 289.

interruptus, iii. 100.

interstinctus, iii. 296.

jugosus, iii. 34, 36 .

juniperi, ir. 10].

labiutus, iv. 122, 124.

labiosus, iii. 109.

lacteus, iii. $98,242$.

lecunu, iii. 59 .

laris, iv, 269, 286.

laminatus, iv. 116.

Leachii, iii. 16.

lineatus, ii. 525.

littoreus, iii. 29, 32, 39 .

lunaris, ii. 385.

mammillatus, ii. 536.

margarita, ii. 531 .

marginatus, iii. 148 ; iv. 98.

membrunaceus, iii. 109.

monilis, iii. 73 .

muscorum, iv. 95, 97, 125.

myrmecidis, iv. 82.

Nuntileus, iv. 152.

Neritoides, iii. 26, 45 .

mingicuns, iv. 12:2.

nitidissimus, iii. ] 58, 222.

nitidus, iv, 281, 283.

nivosus, iii. 287.

mecleus, iii. 14.

obtusatus, iii. 45.

oralis, iii. 524 .

palliatus, iii. 51 .

pallidulus, iii. 56.

pallidus, iii. 67, 273, 307; iv. 274.

paludosus, iv. 79.

parzus, iii. 98.

patulus, iv. 170 .

pellucidus, iii. 303.

pentangularis, iii. 216.

perversus, iv, 114, 116, 121.

petraus, iii. 26.

pictus, ii. 538.

planortis, iii. 156 .

plicalus, iii. $92,271$.
'Jurbo continued.

politus, iii. 229.

pullus, ii. 538 .

punctutus, iii. 192 ; iv. 272 .

puncture, iii. 89.

putcolus, iii. 59.

qualrifasciatus, iii. 62 .

reflexus, is. 201.

resupinatus, iv, 84 .

reticulatus, iii. 89,195 ; iv. 84.

retiformis, iii. 145 .

relusus, iii. 45.

rivulus, iv, 185 .

ruber, iii. 120.

rudis, iii. 29, 32 .

rugosus, ii. 536 .

rupium, iv. 90

Sandeicensis, iii. 301.

sunguinezs, iv, 259.

scriptus, iii. 130 .

semicostatus, iii. 94.

semistriatus, iii. 117.

Serpuloides, iii. 161.

sexdentatus, is. 106.

simillimus, iii. 245.

spircelis, iii. 299.

sturnalis, iv. 174.

striatulus, iii. 73 .

striatus, iii. 94,300 ; iv. 201.

strigatus, iii, 145 .

suburcuatus, iii. 241.

subluteus, iii. 08.

subrufus, iii. 145 .

subtruncatus, iii. 317.

subulatus, iii. 235.

sutnumbilicutus, iii. 137.

succinea, iv. 283.

terelra, iii. 172, 176 .

tenclrosus, iii. 39.

thermalis, iii. 19.

trianfractus, iv. 166.

tridens, iv. 128 .

trifascialus, iii. 235.

truncalus, iii. 317.

tuberculatus, iii. 202.

tubulatus, iv, 269.

tumidus, iพ. 201.

turricula MIaroccana, iv. 87.

Turtonis, iii. 204.

ulva, iii. 141 .

ungulinus, iii. 173.

unicus, iii, 222 .

unidentatus, iii. 264.

unifasciutus, iii. 120.

ustulatus, iii. 29,45 .

variabilis, iii. 103.

variegutus, iii. $145,176$.

ventricosus, iii. 138.

rentrosus, iii. 138. 
INDEX.

'l'urbo continued. vertigo, iv. 111,112

vestitus, iii. 39 , vinctus, iii. 62,63 . vitreus, iii. 125 . vittalus, iii. 122. Zetlandicus, iii. 78.

Turbonilla albella, iii. 286. clavela, iii. 314. crenata, iii. 245. interrupta, iii. 253 . obliqua, iii. 292. plicato, iii. 261. reticulata, iv. 273 . rufa, iv. 276.

Scilla, iii. 309.

TURrItELLA, iii. 172. ascaris, iii. 219. auriscalpium, iii. 148 . bicingulata, iii. 176 . carinatula, iii. 146.

cincta, iii. 176 . communis, iii. 172 ; iv 271 . conifera, iii. 147. comea, iii. 173.

duplicata, iii. 175 .

clegantissima, iii. 242. exoleta, iii. 176.

fulvocincta, iii. 245 ; iv. 276 imbricata, iii. 176 . indistincta, iii. 253.

Linncei, iii. 173.

minor, iv. 271.

nitidissima, iii. 223 .

simillima, iii. 245.

subtruncata, iii. 317 .

terebra, iii. 173.

Iruncata, iii. 255, 317.

ungulina, iii. 173.

unica, iii. 222.

variegata, iii. 176 .

TURRITELLID丑, jii. 171 .

Turtonia, ii. 80 .

minuta, ii. 81

purpurea, ii. 375.

Utriculus, \&c., iii. 380.

Utriculus candidus, iii. 521.

discors, iii. 512.

hyalinus, iii. 521.

lima, iii. 551 .

minutus, iii. 521.

obtusus, iii. 512 .

pellucidus, iii. 521 .

plicatus, iii. 512.

UN10, ii. 138.

Batavus, ii. 154 .

Deshayesiz, ii. 143.

elongata, ii. 147 .

VOL. I.
UN10 continued.

limosus, ii. 143.

longirostris, ii. 143 .

margaritiferus, ii. 146 .

ovalis, ii. 140 .

pictorum, ii. 142 .

Roissyi, ii. 147.

rostrute, ii. 143 .

sinuata, ii. 147.

tumidus, ii. 140.

UNIONIDE, ii. 136 .

VALVATa, iii. 18. cristata, iii. 21. minuta, iii. 23, 16:2.

obtusa, iii. 19.

piscinalis, iii. 19 .

planorbis, iii. 21. spirorlis, iii. 21.

? striata, iii. 161 .

Talvée piscinale, iii. 19.

Velletia laeustris, iv. $] 89$

VELUTINA, iii. 346.

capuloidea, iii. 347 .

Hexilis, iii. 350 .

Haliotoides, iii. 348.

lævigata, jii. 347 .

otis, iii. 321 .

plicatilis, iii. 350.

rupicola, iii. 348.

striate, iii. 348.

stylifera, iii. 226.

VELUTINID E, iii. 346 .

VENERID E, i. 377.

Vénérupe pétricole, i. 152.

VENERYPIS, i. 155.

decussata, i. 15.9, 379.

Irus, i. 156.

nucleus, i. 383.

perforans, i. 383 .

pullastra, i. 383.

Sarnicnsis, i. 388.

substriata, i. 159.

virginea, i. 388.

vulgaris, i. 383.

VENUs, i. 399.

anea, i. 392.

aurea, i. 392.

borcalis, i. $326,452,461$; ii, 46 .

Brogniarti, i. 415.

cancellata, i. 401, 425 .

casina, i. $405,408$.

custanea, i. 470.

Chione, i. 396.

cingendu, i. 425 .

circinata, i. 399.

compresse, i, 461, 164.

costata, i. 409.

Danmoniu, i. 452. 
Ixxiv

Vexus continued. decussata, i. 379 . deflorata, i. 330. discinu, i. 405.

Dysera, i. 425. clerate, i. 425.

Erycina, i. 401. exoletu, i. 428,431 . fasciata, i. 415 . florilla, i. 379. fragilis, ii. 66 . gallina, i. 408. granulata, i. 425 .

Guincensis, i. 399 incompla, i. 435 .

Islandica, i. 441 ; ii. 39. lactea, i. 405.

luminosa, i. 408.

Lenanii, i. 401.

lincta, i. 431 .

lithophaga, i. 151 .

litteruta, i. 379.

Marica, i. 425.

Marica spuria, i. 425.

mercenaria, i. 441 .

minima, i. 446 .

minuta, ii. 81 .

Montarzi, i. 464

nebulosa, i. 392.

nitens, i. 392.

orticularis, ii. 62.

ovata, i. $41 \%$.

pallida, i. 422 .

palustris, i. 383.

Paphia, i. 415, 425.

peclinula, i. 415.

Pennantii, i. 408.

perforuns, i. 382.

plagia, i. 383.

P'rideumxiana, i. 409.

pullastra, i. 382.

racliata, i. 415,423 .

reflexa, i. 405.

rhomboides, i. 388.

ruyosa, i. 409.

Rusterncii, i. 405.

Sarnicnsis, i. 388.

Scotica, i. 452.

Senegalensis, i. 382.

sinuata, i. 392,431 .

sinuosa, i. 435 ; ii. 54.

spinifere, ii. 49.

striatula, i. 408

subcorduta, i. 423.

subrtiomloulea, i. 426.

substriate, i. 158.

sulcate, i. 409, 452, 470.

tigerina, ii. (i.4.

trienguluris, i. 446 .
INDEX.

VENUS continued.

undata, i. 4:35.

verrucosa, i. 401 .

vetula, i. 425.

virago, i. 388.

virginea, i. 388 .

valyaris, i.383.

Vermetida, iii. 216.

Termiculum incurvatum, iii. 182.

Vertigo alpestris, iv. 106.

Anglica, iv. 99.

angustior, iv. 112.

antivertigo, iv. 109.

curta, iv, 108.

cylindrica, iv. 104.

edentula, iv. 103 .

hamata, iv. 112.

heterostropha, iv. 111.

lepidula, iv. 103.

minutissima, iv. 105.

muscorum, iv. 105.

nitide, iv. 103.

octodentata, iv. 109.

palustris, iv. 109.

plicata, iv. 112.

pupule, iv. 105.

pusilla, iv. 111.

pyymaca, iv. 106.

quedridentute, iv. 106.

quinquedentatu. iv. 106.

secale, iv. 101.

septemelentute, iv 109.

sexdentatu, iv. 108, 109.

substriata, iv, 108.

Venetzit, iv. 112.

VITRINA, iv. 29.

Audebardi, iv. 30.

Dillerynii, iv. 30.

Drapurnaldi, iv. 30.

elongata, iv, 30, 32.

major, iv. 30.

Mülleri, iv. 30.

pellucida, iv. 30.

Tolute alsa, iv. 191. ambifua, iii. 307.

bidentate, iv. 191.

Bullaoides, iv. 197.

catenata, iii. 505.

denticulata, iv, 194, 195.

fusiformis, iii. 502 .

heteroclita, iii. 526 .

hyalina, iii. 445 .

insculpta, iii. 289.

interstineta, iii. 296.

lonensis, iv. 287.

laris, iii. 502.

palliela, iii. 505.

pelluerde, iii. 299

plicale, iii. 271. 


\section{INDEX .}

Toluta continued.

plicatula, iii. 271. pusilla, iv. 197.

reflexa, iv. 194.

ringens, iv. 194.

spiralis, iii. 299.

tornatilis, iii. 523.

triplicata, iv. 197.

unidentata, iii. 264.

Volva patula, iii. 498.

Volvaria alba, iii. 520; iv. 191, 192. catenata, iii. 505.

cylindrica, iii. 508.

Donovani, iii. 502.

pallida, iii. 505 .

pellucida, iii. 511 .

retusa, iii. 510 .

subcylindrica, iii. 519.

truncata, iii. 510 .

umbilicata, iii. 519.

Volvula acuminata, iii. 500 .

Vortex obvoluta, iv. 63.

Teroplita ericetorum, iv. 62.

$P$ isana, iv. 56.

striata, iv. 60 .
Yeroplila continued.

Terverii, iv. 58.

variabilis, iv. 58 .

X ylophaga, i. 89.

dorsalis, i. 90 ; ii. 375 .

Xylophage dorsale, i. 90.

Yoldia pygmaa, ii. 230.

ZoNites, iv. 32.

alliarius, iv. 34 .

cellarius, iv. 33.

crystallinus, iv. 41 .

excavatus, iv, 40, 289.

fuscus, iv. 77 .

lucidus, iv. 40.

nitidulus, iv. 36 .

nitidus, iv. 39 .

purus, iv. 37.

pygme us, iv. 83.

radiatulus, iv. 38 .

rotundatus, iv. 80 .

umbilicatus, iv. 82.

Zud, iv. 125.

Zua lubrica, iv. 125.

\section{ERRA'TA.}

Index, page Ixvii, line 17, for Greenlandica read Grœnlandica.

" $, 18,$, Gronlandica, Groenlandica.

" " Ixviii, "27, , S. Hebridicus ", Hebridicus.

In Plates of Animals, page 483, vol. i., line 18, for 7, reul 7 ;

"484, " "6, for 3. M. (Bela septangularis) read 3. M. (Bela) septangularis.

"485, ", ,37, ,Ancylus read Conovulus bidentatus. 



\title{
CON'TENTS OF THE FIRST VOLUME,
}

\author{
EXHIBITING THE FINAL CORRECTIONS AND ADDITIONS,
}

Species of questionable indigenousness are printed in italics; spurious and unrecognized species in nonpareil. The addition of (A. i.) to a species refers the reader to the first Appendix, or Supplementary Notes on the Acephala, in the Second Volume, (A. ii.) to the Appendix at the end of the work.

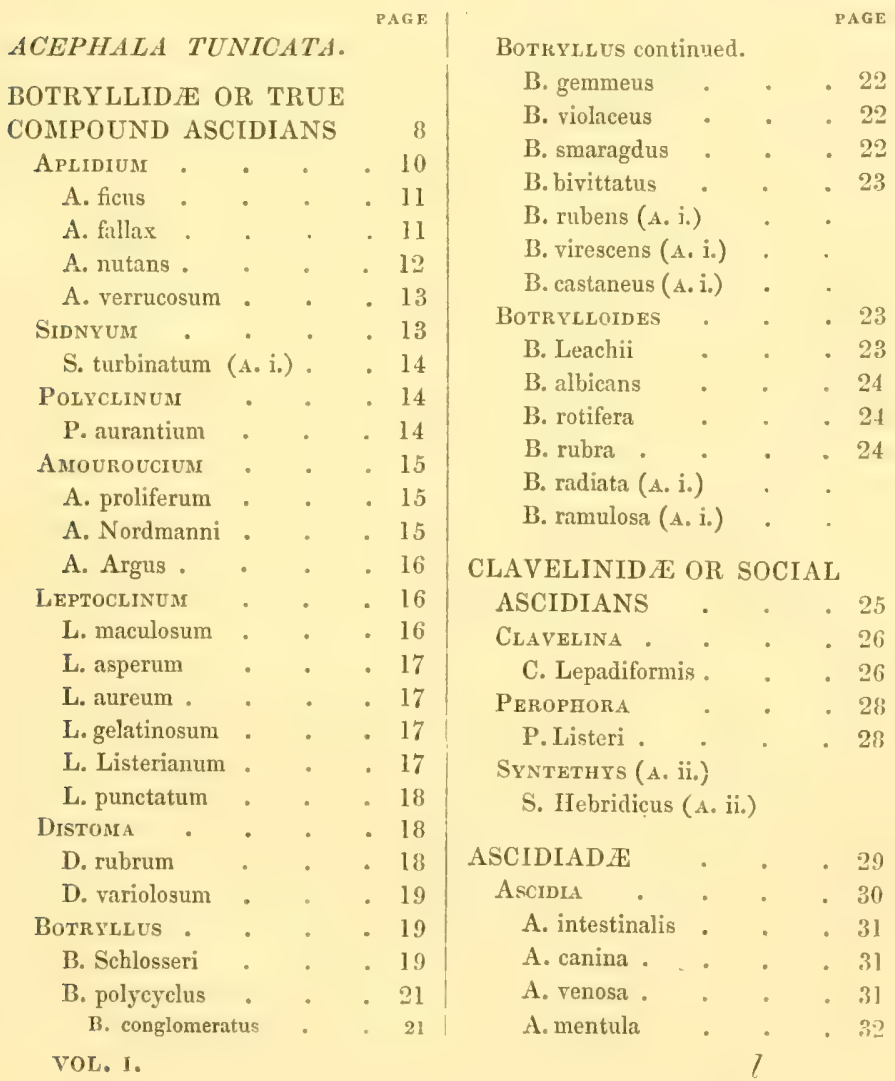


Ascrnis continted.

A. arachnoidea . . . 32

A. scalura . . . $: 3: 3$

A. virginea . . 33

A. parallelogramma . . 34

A. prunum . . 34

A. orbicularis . . 34

A. aspersa . . . 35

A. vitrea . . . 35

A. conchilega . . 35

A.echinata . . 35

A. sordida (A. i.)

A. albida (A. i.)

A. depressa (A.i.)

A. elliptica (A. i.)

A. pellucida (A, i.)

Molgula . . . . 36

M. oculata - . 36

M. arenosa (A, i.) as tubulosa 36

CrNтHA . . 37

C. microcosmus . . . 37

C. claudicans . $\quad .37$

C. tubulosa . . . 37

C. quadrangularis . . 38

C. informis . . 38

C. tessellata . . 38

C. Limacina - . 39

C. morus . . 39

C. rustica . . . 89

C. grossularia . . 40

C. ampulla . . 40

C. mammillaris . . 40

C. aggregata . . . 41

C. coriacea (A. i.)

PELONAIADA * * . 42

PELONAIA . . . 43

P. corrugata - . . 43

l'glabra . . . 43

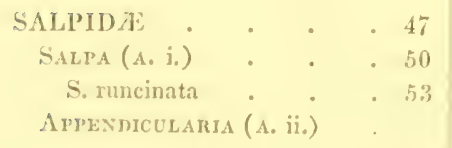

PAGE

ACEPIILA IATELLIBIRANCIIIATA . . . 55 PIOLADIDAE . . . 57 Teredo . . . . 58

T. Norragica (A. ii.) . . 66

T. navalis (A. ii.) . . 74

T. megotara (A.ii.) . . 77

T. bipennata . . . 80

T. malloolus . . . 34

T. palmulate . . . 36

Xrloriaga. . . . 89

X. dorsalis (A. i.) . . 90

Pholas . . . . 94

P. dactylus . . . 108

P. parva . . . 111

P. crispata . . 11 t

P. candida . . . 117

1. striati . . . 120

Plioldididea . . 122

P. papyracea (A. ii.) . 123

Pholas sulcata . . . 128

GASTROCHANIDE . . 129

GASTROCHANA . . . 130

G. Modiolina. . . . 132

SAXicava . . . 136

S. arctica . . . . 141

S. rugosa . . . . 146

? fry (A.ii.) . . . 149

Petricola . . . . 15]

P. lithophaga . . . 151

VENERUPIS . . . 155

V. Irus . . . . 156

V. substriata . . . 159

MYADIE . . . . 160

MYA . . . . 162

M. truncata . . . 163

M. arenaria . . . 168

PANOLA . . . . 173

P. Norvegica (A. ii.) . $\quad 174$

$\mathrm{l}$. Aldrovandi , . 178

CORBULIDE . . 179

Conbula . . . . 179

C. nucleus. . . . 180

C. rosea . . . 185

C. orate . . . . 187 


\begin{tabular}{|c|c|c|c|c|c|c|c|}
\hline \multicolumn{7}{|l|}{ 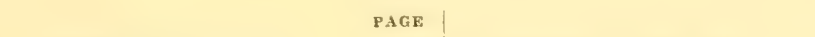 } & \multirow{2}{*}{ PAGE } \\
\hline SPIHENIA & & & .189 & Psamiobra contin & ined. & & \\
\hline S. Binghami (A & .ii.) & & .190 & P. costulata & & . & .279 \\
\hline Nexira & . & . & . 194 & P. Laskeyi & . & . & . 251 \\
\hline N. cuspidata & . & . & .195 & DIODONTA & & . & . 283 \\
\hline N. costellata & . & . & .199 & D. fragilis ( & & . & . 284 \\
\hline N. abbreviata & . & - & .201 & Tellina polygon & & & . 386 \\
\hline Poronya . & . & & .203 & TELLINA & . & . & 2866 \\
\hline P. granulata (A. & ii.) & & .204 & $\begin{array}{l}\text { T. crassa } \\
\text { T. balaustina (A }\end{array}$ & ii.) & & $\begin{array}{l}.288 \\
.290\end{array}$ \\
\hline PANDORIDÆ & . & . & .206 & T. Donacina & . & . & . 292 \\
\hline PANDORA & . & & .206 & T. pygmæa (A. i & & . & 295 \\
\hline P. rostrata . & . & . & . 207 & T. incarnata & . & . & 298 \\
\hline P. obtusa . & . & $\cdot$ & .210 & T. tenuis . & . & . & .300 \\
\hline Lyonsia & . & & .213 & T. fabula . & . & . & 302 \\
\hline L. Norvegica & . & & .214 & T. solidula . & . & . & .304 \\
\hline L. plicata (A. ii & & & - 218 & T. proxima (A. i & & . & 307 \\
\hline ANATINID压 & . & . & .219 & T. bimaculata & & . & 309 \\
\hline THRACIA & . & • & $2: 20$ & T. fragilis : & & . & 311 \\
\hline T', phaseolina & . & . & $.2: 1$ & $\begin{array}{l}\text { T. pisiformis } \\
\text { T. carnaria }\end{array}$ & . & . & 312 \\
\hline T. villosiuscula & . & . & .224 & $\begin{array}{l}\text { T. carnaria } \\
\text { T. fausta. }\end{array}$ & : & : & $\begin{array}{l}.313 \\
. \quad 313\end{array}$ \\
\hline T. pubescens & . & & .226 & T. striata . & . & . & $\begin{array}{l}513 \\
. \quad 313\end{array}$ \\
\hline T. convexa & . & . & 229 & T. punicea & . & . & 314 \\
\hline T. distorta . & . & . & .231 & T. inæquistriata & & . & . 314 \\
\hline Cochlodesma & . & . & & T. similis & . & . & . 314 \\
\hline C. protenuis & . & & $\cdot 235$ & T. lineata. & . & & 314 \\
\hline & & & .235 & Syndosmya & . & . & . 315 \\
\hline SOLENIDIE & . & . & .239 & S. alba : & . & & .316 \\
\hline SOLEN & . & . & $\begin{array}{r}.259 \\
.240\end{array}$ & S. intermedia & . & - & . 319 \\
\hline S. marginatus & . & . & $\begin{array}{r}-2 \pm 0 \\
.242\end{array}$ & S. prismatica & . & - & $3 \geq 1$ \\
\hline S. siliqua . & . & . & .246 & S. tenuis . & . & - & 323 \\
\hline S. ensis . & . & . & .250 & Anphidesma tru & incatun & & 325 \\
\hline S. pellucidus & . & . & . 252 & $\begin{array}{l}\text { Scrobicularia } \\
\text { S. pinerata. }\end{array}$ & - & • & $\begin{array}{ll}320 \\
306\end{array}$ \\
\hline & & & & $\begin{array}{l}\text { S. piperata. } \\
\text { Amphidesma ret }\end{array}$ & ticulatu & & $\begin{array}{l}326 \\
329\end{array}$ \\
\hline SOLECURTID $\nRightarrow$ & . & & . 255 & Sanguinolaria d & leflorat. & & . 329 \\
\hline Cerratisolen & . & & $\cdot 255$ & & & & \\
\hline C. legumen & - & & .256 & DONACID E . & - & & . 331 \\
\hline Solkcurtus . & . & & .259 & Donax & . & & 331 \\
\hline S. coarctatus & . & & . 259 & D. anatinus & . & - & 332 \\
\hline S. candidus & . & & .263 & D. politus . & . & & 336 \\
\hline S. bidens & & & . 266 & D. trunculus & . & & .339 \\
\hline S. gibbus & . & & . 267 & D. denticulatus & . & & - 340 \\
\hline S. strigilatus & . & & . 268 & ERVILIA & . & & .341 \\
\hline TELLINID暱 。 & . & & & E. castanea $(\Delta$. & & & . 341 \\
\hline Psammobia & . & & $\begin{array}{r}-269 \\
.270\end{array}$ & E. nitens. & . & & 344 \\
\hline P. vespertina & . & & .271 & E. pellucida & & & \\
\hline P. Ferroensis & . & & 274 & $\begin{array}{l}\text { Mesodesma dea } \\
\text { II. corneum }\end{array}$ & turatum & & 318 \\
\hline P. Tellinella & . & & .277 & MACTRIDA. & . & & \\
\hline
\end{tabular}




\section{$\operatorname{lxxx}$}

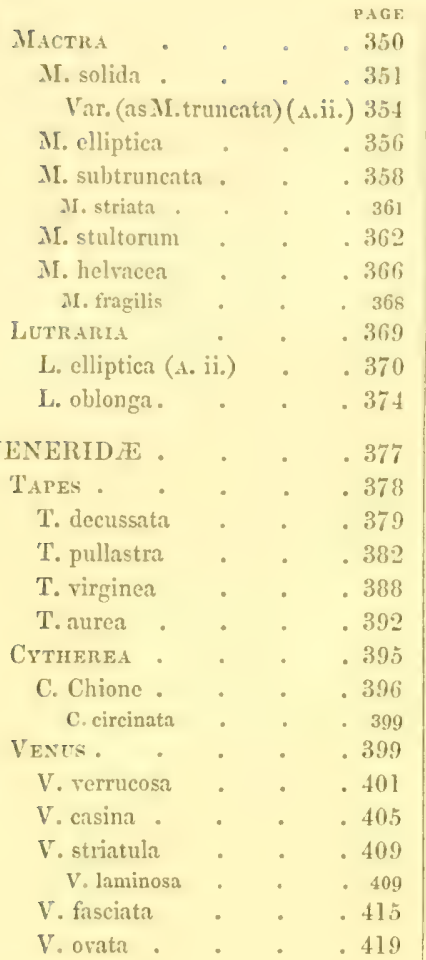

pige:

Varus continned.

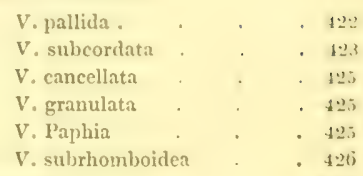

ARTEMIS . . . $4: 27$

A. exoleta. . . . 428

A. lincta . . . . 431

Lucinorsis . . . 433

L. undata . . . . 435

CYPRINIDE E . . . 43!

Cyprina . . . . 4111

C. Islandica (A. i.) . . 141

Circe . . . 446

C. minima . . . 446

Astakte . . . 4.ti

A. $\operatorname{sulcata}$ (A. i. ii.) . . 452

A. crebricostata . . $456 \mathrm{j}$

A. elliptica. . . 459

A. arctica . . . 46 ]

A. compressa . . . 464

A. triangularis (A. i.) . . 467

A. castanea . . . 471

Crassina depressa . . 47

IsOCARDIA . . . . 172

I. $\operatorname{cor} .472$ 


\section{BRITISH MOLLUSCA.}

\section{ACEPHALA TUNICATA.}

Is every class of organised beings there are creatures so constituted as to link the group to which they belong with some other, or even to render their true position a matter of question. Especially at the extremities, at the lowest and highest portions of considerable sections, do we find such beings. In so great a subdivision of the animal kingdom as the Mollusca, we must expect to meet with anomalous or connecting creatures; and were we to begin this history of our native species, in which we propose to treat of them in the order of their ascent in the animal series, with such as seem to us to mark the commencement of their type, we should have to extract a very considerable chapter from our esteemed friend Dr. Johnston's "History of the British Zoophytes." For the curious beings called Bryozon, or Ascidian Polypes, present so many characters in common with certain undoubted Mollusea, especially with the Tunicata, and so few comparatively with true zoophytes, that in a natural classification they could not with propriety be separated from the former class. Even that which was supposed essentially to distinguish them from true Mollusca, the absence of ganglia in their nervous system, has been shewn to be incorrect, since Van Beneden and Professor Allman have demonstrated the presence of a distinet nervous system with a ganglion in certain species of Bryozoa.

Still the Bryozoa may be regarded as a lowest order of Mollusca, linking that great class with the Zoophyta, and distinguished from the true tunicated mollusks by the

VOL. I. 
rown of lone viliated tentalenla -momemeling their months, and forming so conspicuous a part of the animals, which, agregated, constitute the plant-like bodies familiar to all frequenters of the sea-shore, and linown as Flustra. Some of these bodies, such as the Alcyonidium, are extremely difficult to distinguish at a glance from masses or systems of organisms belonging to the true 'I'micata. And were activity to be the test of a creature's position in the animal series, the little Bryozoa, which form the corallines called F'lu-tra, would stamel higher than the Compouml 'T'micatal. for they are intinitely more lively creatures, and apparently even more intelligent. Though their existence be fixed it is active; whereas the majority of tunicated molluslis, even of the higher and more independent forms, lead a passive and apathetic life, at least when they have attained their perfect development. for, like many other invertehrated animals, they are much more free and lively in their earlier stages, passing through a tadpole state, but eventually undergoing what, in some respects, may be regarded as a retrograde metamorphosis.

Some very distinguished authorities would separate the whole of the Tunicata from the Mollusea, and place them as an intermediate class, or sub-class, between that great group and the Zoophyta. Professor Milne-Edwards, whose researches on Ascidians are second in point of merit only to those of Savigny, and, indeed, equal in value, has come to such a conclusion. In his admirable memoir on the "Ascidiens Composées," printed in the eighteenth volume of the "Memoirs of the Institute of France," (1st.2, ) he sums up as follows:- "The facts which I have made known in this memoir shew that the Ascidians have less intimate analogies with the Mollusea, properly so called, than is usually believed. They resemble, it is true, these animals in the arrangement of their digestive apparatus, and in some peculiarities of the respiratory system; but they depart from the Mollusean type in mode of circulation, in the metamorphosis which the fry undergo, and, above all, in the singulax power which most of them possess, of multiplying 
by gemmation. In these latter characters, so very important in a physiological point of view, they approach closely polypes; and if we compare the general conformation of their bodies with that of the Escharæ, Vesicularix, Halorlactyles, Pedicellarix, and other zoophytes, for which I have proposed the designation of 'Polypes 'Tuniciers,' one cannot but perceive other analogies not less strikingthe mode of aggregation through which most of them are mited in societies, and their phytoid aspect. To harmonise the zoological classification with our anatomical knowledge, it seems to me convenient no longer to confound, with Cuvier, the Tunicata with the Mollusca, but to follow Lamarck, and constitute for them a special division intermediate between the bivalve Mollusea and the polypes." The force of this proposal, however, depents mainly upon the view to be taken of the classification of the zoophytes themselves. And, in the present state of our knowledge, a blank would occur in such a series of works on the Natural History of Britain as that of which this forms a part, unlens some account of the Ascidians were therein given.

We shall commence, then, our history with a short notice of the Mollusea of the order 'T'unicata. Our main object in this work is to give a full account of the Testaceous Mollusks of the Irritish Islands, but it is necessary, in order to connect them in zoological order, to notice the shell-less tribes. To treat the latter fully, or on nearly the same scale with the shelled species, would be to extend these volumes to an encyclopedic length; nor is it necessary, for the beantiful monograph of the "Nudibranchiate Mollusca," by our friends Mr. Alder and Mr. Hancock, exhausts one portion of the subject, whilst for the other, equal in extent, that of the Tunicated Mollusks of the British seas, which we are now about to outline, though great masses of materials have been collected by the combined labours of many naturalists, and are now safely in charge of Professor Goodsir, by whom, we trust, they will before long be worthily examined and made linown, to worli them will be a labour of several years, and many more ob- 
servations must be made upon them in the living state before they can be published. Nevertheless, an outline of the present extent of our knowledge of British species may be serviceable, as directing attention to a very interesting and but partially explored department of our native zoology, and as fumishing some guide for future researches.

The Tunicata are Mollusca which have no true shell, but are enveloped in a coriaceous tunic or mantle; whence their name. This is constructed in the form of a sae with two openings, or else is shaped like a tube, of greater or less dimensions, open at both ends. Within the tumic we find

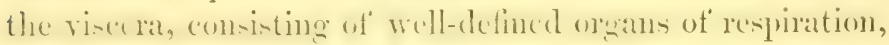
circulation, and digestion, and a muscular and a nervous system. The branchial organ is usually in the form of a sac, placed at the commencement of the alimentary canal, of which it forms, as it were, the antechamber, and is never arranged in distinct leaflets, as it is in the lamellibranchiate Conchifera. The circulation of their blood is remarkable, on account of its fluctuations and periodical changes of direction. They have no distinct head, and no organs serving as arms or feet. Sometimes they are free, more usually fixed; but in all cases free during some portion of their existence. Some are simple, some present various degrees of combination; some are simple in one generation, combined in another. They are all dwellers in the sea. Their various states and structures enable naturalists to group them under several well-marked tribes, of most of which we have examples in the British seas. The best classification of them is that proposed by Professor Milne-Edwards. He divides them into three sub-orders, of which the Salpa, the Ascidia, and the Pyrosoma are the types, and subdivides the Ascidians proper into simple, social, and compound. Of all, except the Pyrosoma, we have British examples.

These animals attracted the notice of the all-observing Aristotle. Like most philosophic naturalists, the question of the distinction between the animal and regetable king- 


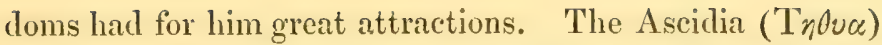
was one of the many creatures which he examined, in the hopes of gaining definite information respecting such distinction. Its inert and sponge-like form, rooted to the ground, seemed to indicate a vegetable nature; but Aristotle was not content with a mere external survey-he explored its internal structure, and soon perceived its highly animal condition. His description of the Tnovce is wonderfully correct: it occurs in the fourth book of his "History of Auimals." There he distinctly recognises the Ascidians to be Mollusca, of which, he says, "they are the only kind whose whole body is enclosed in the shell, and that shell of a substance between true shell and leather: it may be cut like dry leather." What comparison could be more graphic or more true? "They are attached to rocks by their shell. They have two separate openings, which are very small and difficult to notice, the one to take in, the other to eject the water.***** If we open them, we find a nervous membrame lining this leathery case, and fixed to it at two points corresponding to the openings, one of which may be looked upon as the mouth and the other as the vent." And then he makes further remarks on their anatomy. His appreciation of the nature of the Ascidians is an interesting proof of the wonderful sagacity and minute observation of the great Father of Natural History.

It is worthy of remark, that very lately the Ascidians have again played a part in that much-vexed question of the distinction between animals and regetables. After Aristotle's demonstration of their affinity with ordinary Mollusca, they had escaped being dragged into this very unsatisfactory discussion. As the sciences liave progressed they have approximated, and chemistry has been called to the aid of natural history for the solving of this linotty point. The Ascidians have been obliged to submit to a new cross-examination, and with very unexpected results; for they have shewn in the composition of their tissues an unlooked-for relation with vegetable structures. In 1845, Dr. Schmidt, in a work entitled "Zur vergleichenden 
Physiologic der wirhellosen 'Thiere," put forward the novel statement, that he had discovered in the tunic of an Ascidian mollusk (the Phallusia mamillaris) a ternary substance identical with cellulose. He inferred thence that no chemical distinction could be drawn between animals and vegetables; and, as he had previously shewn that on no other structural or physiological gromel any line between the two lingdoms could be drawn, he put forward the somewhat loold dogma, that "P'sychology only is competent to trace a limit between plants and animals; and that the only difference admissible is, that the animal possesses, besides the vegetable form-i.e. cellule-a $\psi v \chi \eta$."

Whaterer naturalists might think of Dr. Schmirlt's hypotheofical definition, it lecame them to look to his statement respecting the presence of cellulose in the Ascidian tunic. Fortunately the inquiry was undertaken by two most competent ols-erers, Professors Löwig and Albert Kolliker: the result was to confirm the statement and extend it. 'They toumd cellulose undoubtedly present in the envelopes of many 'T'unicata, both simple and compoume, inclucling the genera Phallusia, Cynthia, Clavelina, Diazona, Botryllus, Pyrosoma, and Salpa. But they sought in vain fir collulose in animals of interior organisation, although in some of the above-named creatures it formed a very considerable part of the animal tissues.**

The explanation oflered ly Löwig and Kolliker of these very anomalous facts is extremely incenions, and probably very near the truth. It is to the following effect:- I'micata

* The memoir of MIM. Löwig and Kolliker was examined by a committee of the French Institute, consisting of Dumas, Milne-Ldwards, Boussingault, and Payen: the last-named eminent philosopher drew up the report. In it he gives the following formula of the composition of the envelopes of the Tunicata:-

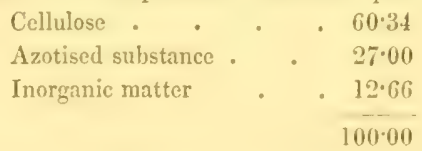

If remarks that the establishment of the existence of cellulose in the 'runicata is a "fait capital" in science, very important in its bearing on future researches into the comparative physiology of the two kingdoms. 
live entirely upon vegetable organisms. The contents of the stomachs of the Phallusix, Claveline, and Diazone examined consisted of particles of florideous algre, which had probably found their way there by chance, and a great quantity of microscopic plants of low position in the series, species of Navicula, Frustulia, Baccilaria, Closterium, Eze. These minnte vegetable organisms have been shewn by Nageli and Schmilt to contain cellulose. This is probably dissolved by the gastric juice, that is to say, changed into sugar or gum; in which state it circulates with the blood, and is afterwards introduced into the tunics, either directly by the sanguiferous canals (as in Phallusia), or by their prolongations ramified in the walls of the common borly (as in Diazona and Botryllus), which thus, as Milne-Edwards has shewn, contain also blood in their cavity, probably penetrating by imbibition when the envelopes have no blood-ressels. The presence of cellulose in the tunics of the Ascidian Mollusca, then, cannot be taken as an evidence of an approach to a vegetable nature in those bodies. It affords us, however, a wholesome warning against the placing of confidence in asserted chemical distinctions between the great kingdoms of nature.

If we consider our British Ascidians in ascending order, they will rank as follows:- 1st, those lower and compound forms which constitute the "Ascidiens Composées" of Milne-Edwards; 2nd, a few species belonging to his social group; 3rd, a considerable number of simple Ascidians, properly so called; 4th, a genus (Pelonaia) of Tunicata, including as yet only two forms, which, on account of important peculiarities of orgmisation to be hereafter noticed, cannot take its place in any of Milne-Edwards's sections, but must rank as the type of a special section; and, 5th, a solitary example of the great and very numerous tribe of Salpida. 


\title{
I. BOTRYLLIDE;
}

\author{
OR, TRUE COMPOUND ASCIDIANS.
}

If, when walking on the sea-shore about low-water mark, we turn over large stones, or look moler projecting eaves of rock, we are almost sure to sce translueent jelly-like massess of various hues of orange, purple, yellow, blue, grey, and green, sometimes nearly miform in tint, sometimes beautifully viriegated, and very frequently pencilled as if with stars of gorgeons device; now encrusting the surface of the rock, now depending from it in icicle-like projections. These are Compound Ascidians. A tangle, or broad-leaved fucus, torn from its rocky bed, or gathered on the sands where the waves have cast it after storms, will shew us similar bodies, mostly those star-figured, investing its stallis, winding among the intricacies of its roots, or clothing with a glary coat the expanse of its foliated extremities. If we licep some of these bodies alive in a vessel of sea-water, we find them lie there as apathetie as sponges, giving few signs of vitality beyond the slightly pouting ont of tubelike membranes, around apertures which become visible on their surfices, though a closer and microscopie examination will shew us currents in active motion in the water around those apertures, streams ejected and whirlpools rushing in, indicating, that, however torpid the creature may externally appear, all the machinery of life, the respiratory wheels and circulatory pumps, are hard at work in its inmost recesses. In the course of our cxamination, especially if we cut up the mass, we find that it is not a single animal which lies lefore us, lut a commonwealth of beings, bound together ly common and vital ties. Fach stur is a family, each group of stars a community. Individuals are linked 
together in systems, systems combined into masses. Each member of the commonwealth has its own peculiar duties, but shares also in operations which relate to the interest and well-being of the mass. Anatomical investigation shew's us the details of these curious structures and arrangements, beautiful as wise. Indeed, few bodies among the lower forms of animal life exhibit such exquisite and kaliedoscopic figures as those which we see displayed in the combinations of the compound Ascidians.

The merit of first understanding and interpreting the true nature of these curious bodies is due to Jules César Sarigny, an illustrious French naturalist, whose zeal in the cause of minute investigation eventually deprived him of sight, and the world of many profound and philosophical researches. Savigny carried on his enquiries chiefly in Egypt, when a member of the band of philosophers, whom Napoleon, anxious to palliate the crime of conquest by extending, through their aid, the realms of knowledge, gathered around him in the land of the Pharaohs. The account of Savigny's researches among the Tunicata is contained in his celebrated "Mémoires sur les Animaux sans Vertèbres," to which the anthor might well, indeed, prefix his motto of "Patientia." Two parts only of that laborious work appeared, though more were promised to be issued at irregular intervals; "for," wrote the noble-spirited naturalist, "obligations too imperious paralyse the faculties, and seem to alter the will itself. If good observations are the fruit of patience, they are also that of full and entire liberty. Venena servitus, libertas poma." Alas! the sad catastrophe already mentioned prevented the realisation of the many labours he had planned.

Before Savigny's time the Botryllidæ had been confounded with polypes, and regarded as forms of the genus Alcyonium, to which, indeed, the masses bore a striking resemblance. The earliest distinct figures of these forms appeared in the "Philosophical Transactions" for $175 \%$, where they were published by Schlosser; and in 1758 , that curious observer, Borlase, gave descriptions sufficiently graphic, and rude but unmistakcable figures of several species, in his

voL. I. 
interesting folio on "The Natural History of Cornwall." 'The first naturalist who indicated their compound nature, and held forth a clue to their true affinities, was the famous botanist Gaertner, whose zoological observations on marine animals, communicated to, and published by Pallas, (in 1774 , ) are of the highest degree of merit. Gaertner, however, did not follow up his enquiries in these bodies, though to him we owe the generic groups Botryllus and Distomus. The Italian naturalist, Renieri, (in 1793,) harl a similax obscure perception of their affinities.

The memoir of Savigny, published in 1816, however, there entirely new and unanticipated light on their nature. Ite the wer that they wereessentially Ascillians, dillering from the simple forms only in being united into more or lese complicated systems. The researches of Milne-Edwards "On the Compound Ascidie of the Chamel," read betore the Institute of Liance, 1839), have fully confirmed those of Savigny, and have also greatly extended our knorledge of these creatures. 'The figures given by both these naturalists are among the most leautiful and minutely accurate that have ever illustrated and adorned natural history essays.

\section{APLiDiUM, SAVignY.}

'This genus belongs to the constellated section of the tribe of "Polycliniens" in the arrangement of Milne-Edwards. The individual animals of that tribe have a body composed of three distinct parts: 1st, a thorax, with branchial apparatus; 2nd, a superior almomen, with digestive organs; and. sid, a post-aldemen, with heart and reprodurtive organs.

"The common mass of the Aplidia is sessile, gelatinous or cartilaginous, polymorphous, and composed of very numerous, slightly prominent, annular, sub-elliptic systems, which have no central cavity, but have a distinct circumscription. The animals (three to twenty-five) are placed in a single row, at equal distances from the centre and their common axis. Each has a six-rayed branchial, and a simple indistinct anal orifice."- SAVIGNY. 
The British species of this genus require careful re-examination. We have thought it best to reprint the original descriptions of them. In pl. A, fig. 1, we have figured an Aplidiun from the Isle of Man, apparently identical with $A$. fallax, and in pl. B, fig. 1, one of the separated Ascidians of this genus, as drawn by Savigny.

\section{A. ficus, Linnæus, (Sp.)}

Alcyonium ficus, Linnæus S. N. 12th ed. t. i. p. 1295.-Alcyonium pulmonis instar lobatum, Ellis, Corallines, p. 82, pl. 17, fig. b, B. C. D.-Alcyonium pulmonaria, Solander and Ellis, p. 175, No. 2.-Aplidium ficus, Savigny, Mém. pt. 2, p. 183.-Alpidium ficus, Fleming, Brit. An. p. 470.

"This sea production is of a dark olive-colour, of a fleshy substance, and smells very disagreeably when it is opened; the inside is full of little oblong yellow particles, from whence it borrows its name of sea-fig among the fishermen, from whom it was procured, with many other things of the same kind, at Whitstable. When I applied my glass to it, I found the whole surface covered with small stars of six rays, like small polypes of six claws. Upon opening it, I found the inside consisted of little bags of a yellowish colour, full of a clear viscid liquor; in the midst of this was a small duct, leading to the centre of the star at the top of each. On examining one of these bags attentively, I discovered several regular figures like shells in this inner tube or duct, placed upon one another; but whether they are the food of the animal in the gut or stomach, or whether it is the ovary, I am not certain."Ellits.

\section{A. fallax, Johnston.}

Mag. Nat. Hist. 1st series, vol, vii. p. 15, fig. 4.

"Common body sub-globose or papillary, gelatinous, of a clear honey-yellow colour, marked on the upper surface with white and brown specks, from the contained animals ; orifices circular, protuberant, plain, and entire. Animals distinet, seattered irregularly, each in its proper cell, perpendicular, about two lines long. Branchial aperture divided into six equal short segments; the sae large, white, netted ou the sides with minute square meshes, which, however, are very obscure; oesophagus narrow, entering laterally 
at the upper side of the stomach, which is large, yellowishbrown, and mottled; intestine dark-coloured, wide, flexuose, recurved, and winding up at the base of the branchial sac; anal aperture elongate, linear, entire, lateral, and near the mouth; ovary white, cellulose, at the base of the intestine, with a long white tubular canal running up and along the middle of the intestine, and terminating in the branchial cavity. Differs from the Aplidium ficus in having the apertures in the common envelope entire, whereas in the A. ficus they are distinctly cut into six equal rays. (See Ellis, Corall. tab. 17, fig. B. C. D.) Hab., affixed to old shells, dcc. from deep water in Berwick Bay."-Joinston.

\section{A. nutans, Johnston.}

Mag. Nat. IIist. 1st series, vol. vii. p. 16, fig. 5.

"Common body adherent by a broad base, knob-like or pearshaped, nearly an inch high, and half that in diameter, smooth, gelatinous, pellucid, of a straw-yellow colour, tinted with brown, and marked with whitish streaks from the immersed animal. There are no fibres nor spicula to strengthen this common mass; neither are there any visible orifices on the surface; but by ripping up the skin with a needle, the contained animals may be removed entire without difficulty. These are of a long thread-like shape, with a bulging and nutant head, scattered irregularly in the substance of the jelly, in which they lie horizontally, or nearly so. The length of a single individual is about four-tenths of an inch. The mouth is cut into six equal segments, and placed on the ulper sile of the large hranchial sac, which is an oval lag filled in the specimens examined with innumerable minute granules. When the animalcule was compressed between plates of glass, these granules escaped abundantly from the mouth, and from a prominent aperture a little below it on the side. The walls of the branchial sac are marked with several lines or plaits in a longitudinal direction, but I saw no traces of any vascular network. On the inner side of the branchial sac there is an obscure appearance of an intestine or ressel winding up it, to end at the anal aperture; and near the base of the sac there is a considerable orangecoloured spot marked with longitudinal lines, and presumed to be the stomach. Immediately below this, the body is suddenly con- 
tracted into a very long and linear tail, as it may be called, in which, when compressed, we perceive a dark intestine-like mark, mottled with darker and lighter shades on each side, and a clear space between them; but I cannot trace any distinct termination of these organs (which are the ovaries) in the branchial sac, although the shadings at the base of this part indicate the existence and situation of some distinct organs. This species has a great resemblance to A pliclium effusum of Savigny, but I cannot consider them identical.-Hab., Berwick Bay, in deep water."JoHNSTON.

In the twenty-sixth volume of the "Edinburgh New Philosophical Journal," (p. 152, ) Sir John Dalyell gives an account of a compound Ascidian, from the Frith of Forth, under the name of "Aplidium verrucosum." He describes it as "a gelatinous-looking, but solid, compact substance, which, being suspended by silk threads in a jar of sea-water, proved of an olive-green colour, and approached the form of an irregular parallelopiped above three inches long, and equalling perhaps three cubical inches of solid contents. The whole mass covered with very low prominences, almost even with the surface. In a short time the prominences developed as a profusion of short, projecting, cylindrical orifices, each fashioned as a lip, with a smooth, even edge, wherein were attracted by a powerful current, and absorber, the neighbouring buoyant particles."

\section{SIDNYUM, SAVIGNY.}

This genus was made known by Savigny in a note supplementary to his memoir. He founded it for a British Ascidian received from Dr. Leach, but did not figure the species. It belongs to the unistellated section of the tribe "Polycliniens" in the arrangement of Milne-Edwards.

The mass presents the appearance of a number of heads of madrepore or cladocora, each formed of a simple cone truncated and starred at the summit, rising from a common encrusting base, 
the whole being grouped closely together. Each cone is composed of a fascicle of individuals, varying in number from five or six to ten or twelve, and forming a margin round a depressed centre. The whole mass is translucent, gelatinous, and of a rich amber or orange colour; the individuals are somewhat paler, but marked by dark visceral specks; they partake of the characters of those of Symoicum and Aptidium, resembling the former in the structure of their stomach, and the latter in their branchial sac. Each has an S-toothed branchial orifice, and a simple tubulose vent folded against the thorax. The ovary is peduncled, and very conspicuous at the extremity of the animal.

\section{S. turbinatum, Savigny.}

Mem. pt. ii. p. 238. Flem. Br. An. p. 469.

Plate $\Lambda$, fig. 2 , and plate $B$, fig. 2 .

The above description is taken from this species, which occurs abundantly on the under surface of shelving rocks, exposed at low-water during spring-tides, on the north coast of the Isle of Nan, isle of Islay, Dr. Flening; Strangford Lough, W. Thompson ; Belfast Bay, Dr. Drummond. Dr. Leach probably procured it on the south coast of England.

\section{POLYCLINUM, SAVIGNY.}

"Mass sessile, gelatinous, or cartilaginous, polymorphous, composed of more or less multiplied systems, convex, radiated, each having a central carity, and being more or less distinctly circumscribed. Individuals (ten to one humdred and fifty) placed at very unequal distances from a common centre: branchial orifice 6-angled and 6-rayed ; anal prolonged horizontally, irregularly cut, and aiding in forming the prominent and fringed border of the cavity of the system."-S $\Delta$ IVIGN.

\section{P. aurantuum, Milne-Edwards.}

Mem. Asc. Comp. p. 292, pl. 1, fig. 6.

Plate $\Lambda$, fig. 3 , and plate $B$, fig. 3 .

"Little orange masses, more or less spherical, fixed to rocks by a short and thick peduncle; the aninals composing them undis- 
tinguishable by the naked eye, but when the surface is examined with a lens, a number of little holes, ranged in linear series, are seen; the mouths of the animals united in a common mass grouped round one or many systems, each opening into a common cloaca ; tegument coriaceous."-MILNE-EDWARDS.

Mr. Alder finds a species, which seems to be a pale, fuscous, yellow variety of this, at Cullercoats.

\section{AMoUroucium, Milne-Edwards.}

Mass lobed or encrusting, sessile or pedunculated, fleshy or cartilaginous, composed of many systems, more or less circumscribed, each having a central cavity; the individuals, more or less numerous, placed at unequal distances from the common centre; their anal orifices open into a common cloaca; branchial orifice six-rayed; post-abdomen not pedunculate, but following superior abdomen, as in Aplidium. [See pl. B, fig. 4.]

1. A. Proliferum, Milne-Edwards.

Mem. Asc. Comp. p. 287, pl. 1, fig. 3, and pl. 3, fig. 2.

Yellowish or red fleshy masses, sometimes encrusting, sometimes lobed, with orange elongated spots on their upper surface. Individuals with a red thorax.

"Belfast Bay," W. Thompson, in Ann. N. Hist. vol. xiii. (1844) p. 485. "Not uncommon in Cornwall," Mr. Alder.

\section{A. Nordmanni, Milne-Edwards.}

Mem. Asc. Comp. p. 289, pl. 1, fig. 5 .

"Thick encrusting masses, broader than high, of a light rosecolour, tinged with yellow towards the base. Systems few, and usually arranged in a single row, so as to represent a more or less elongated ellipsoid, usually several in a mass, and distinctly circumscribed. The oral opening of these Ascidians is but slightly prominent, and the lobes of the membranous border are obtuse and white, so as to constitute a circle of six white rounded spots around the mouth, contrasting with the general rose-colour; the tegumentary tissue is yellowish, and the prevailing rose-colour depends on the tint of the thoracic portion of the bodies of the Ascidians."-M.-E.

At Falmouth, Mr. Alder. 


\section{A. Argus, Milne-Edwards.}

Mem. Asc. Comp. p. 291, pl. 1, fig. $4^{\text {a }}$.

Plate $A$, fig. 4.

General colour olive-yellow towards the base of the mass, passing into orange near its free extremity, which is nearly white, speckled with little red points. The individuals are grouped nearly circularly round a common cloaca, usually a single system of them to a mass. Each individual is prominent on the common surface, and the border of the buccal opening is deeply divided into six nearly triangular lohes; around these are ranged the red eye-like spots, four to each animal.

At Falmouth, Mr. Alder. This species appears to have a wide range : it occurs in the Egean, E. F.

\section{LEPTOCLINUM, MLNE-Edwards.}

MIass thin, sessile, encrusting, polymorphous, coriaceous or gelatinous, composed of many systems. Anal orifices of the individuals opening into a common eloaca, more or less ramified. Branchial orifices 6-lobed. [Pl. B, fig. 5.]

This genus belongs to the tribe of "Didemniens" in the arrangement of Milne-Edwarls, composed of those compound Ascidians which have the body distinctly dirided into two portions, a thorax and an abdomen: "They approach very nearly the Clavellinæ, and are distinguished from the Polycliniens by the absence of a post-abdomen, and by the position of the generative apparatus and heart, which are placed beside the intestine."MI.-E.

\section{L. maculosum, Milne-Edwards.}

Mem. Asc. Comp. p. 297, pl. 8, fig. 2.

A thin, hard, leathery crust, investing the roots of Laminarix, variegated with white and blue. The substance of the crust is strengthened with calcareous raphides.

Cummon on most parts of our coast, but first recorled as British by Mr. W. Thompson, who noted it as occurring plentifully on the roots of Laminarix in Belfast Bay and the north of Ireland generally, in the 13 th volume of the "Amnals of Natural IIistory," (1844.) 
2. L. ASPERUM, Milne-Edwards.

Mem. Asc. Comp. p. 298, pl. 8, fig. 3, 33.

Closely resembling the last, with which it occurs, but usually white or pale, and rough with conical tubcrcles placed near each of the buccal orifices.

Common; first recorded as British by Mr. W. Thompson, who found it in the same localities with the last species.

\section{L. Aureum, Milne-Edwards.}

Mém. Asc. Comp. p. 298, pl. 8, fig.4, 4".

Similar to the two last species, but distinguished by its uniform chamois-yellow colour. The buccal orifices are closer than in $L$. asperum, and more deeply lobed.

Dredged in Strangford Lough by Mr. Hyndman and Mr. WV. Thompson.

4. L. gelatinosum, Milne-Edwards.

Mém. Asc. Comp. p. 299, pl. 8, fig. 1, 12.

Plate A, fig. 5 .

Distinguished from all the other species by its gelatinous consistence, and the semi-transparency of the common integument. The individuals have yellow abdominal riscera, and are arranged irregularly around a common cloaca.

"On the roots of Laminarie in Belfast Bay," W. Thompson, Ann. Nat. Hist., 1844. "A gelatinous compound Ascidian, probably $L$. gelatinosum, is common on the south coast of England," Mr. Alder.

\section{L. Listerianum, Milne-Edwards.}

"Polyclinum," Lister, Philosophical Transactions for 1834, pt. 2, p. 382, pl. 12, fig. 1 .

A grey slimy crust, speckled with white and black; a circle of dark spots around the buccal orifice of each individual.

Investing alga at Brighton, Mr. Lister. An interesting account of the structure and economy of this species is given by the most accurate microscopical observer who first discovered it.

vOL. I. 


\section{L. punctatum, Forbes.}

A thin, shining, translucent crust, investing stones at low water. The animals, minute, are placed in pairs, each individual marked with a conspicuous black spot.

Isle of Man, E. F. Cullercoats, Mr. Alder.

Distoma, GaertNer.

This genus, which is one of the two genera of Compound Ascidians distinguished by Gaertner, belongs to the unistellated section of the group styled by Milne-Edwards "Didemnians."

The common body, or mass, of Distoma is sessile, semicartilaginous, polymorplions, and composed of many systems, usually circular. The individual animals are placed in one or two ranls, at unequal distances from a common centre. They present the striking and distinctive cha. racter of having both branchial and anal orifices regularly and equally six-rayed. The species inhabit the European seas.

\section{D. rubrum, Savigny.}

Mém. 2nd part, p. 177, pl. 3, fig. 1, and pl. 13.

Plate A, fig. 6, and plate B, fig. 6 .

"Mass compressed; various shades of red, with slightly-prominent, oval, yellowish points (individuals) scattered on the two sides, and grouped in systems of from three to twelve. Orifices obtusely rayed, tinted with purple.

"Mass four to five inches across, and half an inch thick. Individuals, two lines."-SAVIGNY.

This species was communicated to Savigny by Dr. Leach. To it the French naturalist referred the "Aleyonium rubrum, pulposun, conicum plerumque " of Plancus. (Conch. Min. Not. t. 10, f. B. d.) Mr. W. Thompson has recorded it as occurring on Laminaria digitata in Belfast Bay, where it was found by Mr. Getty. IIe remarks that the specimens are not so lively in colour as those figured by Savigny. (Ann. Nat. Ilist, vol. v. p. 95.) 


\section{D. variolosum, Gaertner.}

Alcyonium ascidioildes, Pallas, Sp. Zool. f. 10, p. 40, f. 4, f. 7, a, A. - A. distomum, Brugière, Enc. Méth. - Distoma variolosum, Savigny, Mém. 2nd part, p. 178.-Polyzona variolosa, Fleming, Br. An. p. 469.

Mass coriaceous, not thick, flat beneath, warty above; pale reddish, or yellowish-white. Individuals orange-red. Systems not distinctly circumscribed.

"Common on Fucus palmatus, and on that plant only, enveloping sometimes the entire stem," according to Gaertner. "A Distoma, apparently, from description, of this species, has occurred to me investing Fucus serratus in Belfast Bay: the colour was always whitish-yellow," W. Thompson, Ann. N. H. vol. v. p. 95.

\section{Botry Llus, Gaertner.}

This genus, one of the first established among the Compound Ascidians, is the type of the tribe of " Botryllians" in the arrangement of Milne-Edwards. The individual animals present no distinction between abdomen and thorax. Their viscera are accumulated in the thoracic cavity, and form with it an ovoid mass. Their branchial orifices are simple: they are ranged round a common cloaca. In the genus Botryllus they are grouped in simple stars, and lie horizontally, with the vent far from the branchial orifice.

\section{B. Schlosseri, Pallas, (Sp.)*}

chlosser, Phil. Trans. vol. xlix. pt. 2, 1757, p. 447, t. 14, fig. $A-C$; Borlase, Nat. Hist. Cornwall, p. 254, t. 25, f. 1, 2, 3, 4.-Alcyonium Schlosseri, Pallas, Elench. Zooph. No. 208.-Botryllus stellatus, Gaertner in Pallas, Spic. Zool. fasc. 10 , p. 37 , t. 4 , f. 1-5.-B. stellatus, Brugière, Enc. Méth. 1 ; Lamarck.-B. Schlosseri, Savigny, Mém. pt. 2, p. 200, pl. 20, f. 5 ; Fleming, Brit. An. p. 470,-Alcyonium Schlosseri, Linnæus, Syst. Nat. 12th ed.-A. Schlosseri, Ellis and Solander, Nat. Hist. Zooph. p. 177.

Plate A, fig. 7, and plate B, fig. 7 .

Mass a thick, gelatinous, semi-transparent, glaucous crust, with yellow marginal tubes. Systems numerous, composed of from ten

* In the forty-ninth volume of the "Philosophical Transactions" (for 1756) occurs the first notice of the Compound Ascidians, being the description of this Botryllus, with a very characteristic figure. The paper is entitled, "An account of a curious 
to twenty or more individuals, yellowish and reddish. Branchial aperture white, surrounder hy a circle of hroad ferruginous spots; a red spot on the centre of each individual. Mass often measuring several inches across; individuals one-twentieth of an inch in diameter.

fleshy, coral-like substance; in a letter to Mr. Peter Collinson, F.R.S., from Dr. Allort Schlosser, MI.D., F.R.S., with some observations on it communicated to Mr. Collinson by Mr. John Ellis, F.R.S." Being short, we quote it :-

" "Dear Sir, - I hired some fishermen to dredge for me in this harbour, in order to examine the small English coral, or Corallizm nostras of Hay"s "Synopsis," recent in the microscope. The first time they hauled in the dredge, I discovered a most extraordinary sea production surrounding the stem of an old Fucus teres: it was of a hardish but fleshy substance, and more than an inch thick, of a light brown or ash-colour, the whole surface covered over with bright yellow, shining, and star-like bodies, which induced me to believe it to be an undescribed species of Alcyonium. I put it immediately into a bucket of sea-water, expecting every moment that the polypes, which I thought to lodge in those little stars, would extend and shew themselves like those of the Alcyonium No. 2 of Ray's "Synopsis," commonly called "dead man's hand;" but after more than half-an-hour"s attention, the vessel lying very quiet all the time, I did not perceive the least appearance of any polypes; upon which I brought them to shore in the sea-water, and then, by means of my microscope, I discovered every one of those stars to be a true animal, and much more beautiful than any polype, but quite of a different structure, which I shall now describe to you.

" "Every one of those stars is composed of many thin hollow radii, of a pear-shape form, from five to twelve or more in number, all united intimately at their smaller end; every radius appears broad at the extreme part from the centre, and a little convex in the middle of this raised broad part. When the animal is alive there appears a circular little hole, which contracts and opens itself frequently. All the radii are of this structure; but their common centre, which is formed by a combination of the emall converging extremities, exhibits an opening of a circular, oval, or oblong figure, forming a kind of rising rim like a cup, which, when the animal is alive and at rest, contracts and expands itself to many different degrees, with great alertness and velocity, though sometimes it remains a great while expanded or contracted. In all these holes, the central large one, as well as the smaller ones, (which last I take to be the mouths of the animals,) I could not perceive any tentacula, or claws, on the outside; but, by looking into them very narrowly, I saw something like very tender little fibres moving at the bottom of their insides.

" By comparing and examining all the various pieces I had collected of this fleshy substance, with its shining stars, I observed that the size and colour, as well as the very figure of these stars, varied greatly, but the structure of the leaf-like radii, and that of their mouths, and their motions, were perfectly the same in every one individual. 
Very common on stones and sea-weeds near low water-mark, all round the British Islands.*

\section{B. polycycuus, Savigny.}

"Botryllus stellatus, Renieri, Le Sueur, and Desmarest."-Polycyclus, Lamarck, Mém. du Mus. t. i. p. 340。 - Botryllus polycyclus, Savigny, Mém. pt. 2, p. 202, pl. 4, fig. 5, and pl. 21 .

A gelatinous, translucent, grey crust, with reddish and purple marginal tubes. Systems numerous, of from eight to twenty or more individuals. Oval; bluish or purple. Orifices bordered by purple; the branchial aperture surrounded by eight large white or bluish spots, divided by deep purple spaces: radial line similarly coloured. Mass grows to several inches. Individuals onetwelfth of an inch or less.

"Much more common in the north of Ireland than B. Schlosseri : chiefly on the leaves of Laminaria digitata," W. Thomp-

" Many of these bodies I have found so thick and large as to resemble the great branched madrepora coral, especially as they are generally to be met with covering and enclosing the stem and branches of this stiff, ramose fucus.' Thus far Dr. Schlosser.

"6 'I have had an opportunity lately of examining this curious, fleshy, coral-like figure in the microscope, and find that all the interstices between the stars are filled with eggs of different sizes, each adhering by one end to a very fine capillary filament. The smallest eggs are globular, and as they advance in size, change to an oval figure; from thence they assume the shape of one of the radii of the stars.

"In several of these stars I have observed a smaller radius, as it were, endeavouring to get into the circle; and notwithstanding their seeming connexion in the centre as one animal, I believe I'shall soon be able to shew you, in a drawing from the microscope, that each radius is a distinct animal by itself.

$$
\begin{aligned}
& \text { "I am, dear Sir, } \\
& \text { "Your most affectionate friend, } \\
& \text { "JoHN ELLis." }
\end{aligned}
$$

\section{* Botryllus conglomeratus, Gaertner.}

Gaertner in Pallas, Spic. Zool. fasc. 10, p. 39, t. 4, f. 6, a. A.-Alcyonium conglomeratum, Gmelin.-Botryllus conglomeratus, Lamarck; Savigny, Mém. pt. 2, p. 204 ; Fleming, Brit. An. 470.

"B. dactylis conglomeratis osculis edentulis terminalibus; corpus gelatinosum, molle, convexum ; plantis marinis adnatum." The true nature of this Ascidian, if it be one, is very doubtful. It was taken by Gaertner on the Cornish coast. The "Alcyonium Borlasii" and "A. constellatum" are supposed species of Botryllus, instituted by Dr. Turton from the rude figures of Borlase. 
son. Very generally distributed around our shores: it ranges to the Mediterranean.

\section{B. Gemineus, Savigny.}

Mém. pt. ii. p. 203.

"Body forming a thin, gelatinous, sub-orbicular greyish crust, with yellowish marginal tubes. Systems isolated, or few and scattered, commonly composed of from five to twelve or more individuals, with oval summits of a yellow or golden-grey colour. Orifices terminated with white ; radial line bordered with white." -SAVIGaY.

Diameter of mass, according to Savigny, not exceeding an inch; but it occurs much larger. Individuals one-thirtieth of an inch.

"Adhering to fuci dredged in Belfast Bay by Mr. Getty," W. Thompson, Annals, 184t. Ballaugh, Isle of Man, adhering to stones at low-water, E. F.

\section{B. vrolaceus, Milne-Edwards.}

Mém. Asc. Comp. p. 306, pl. 6, fig. 4, 4³

Common integument pale greenish-grey. Tunics of individuals deep blue, except around the cloacal opening, where they are yellowish-white; and between that opening and the mouth there is a radiating space of the same colour, divided by a violet line, so that each system forms a blue rosette, with a yellow central star. Animals small.

"Common on the Cornish coast," Mr. Alder.

\section{B. smaragdus, Milne-Edwards.}

Mém. Asc. Comp. p. 307, pl. 6, fig. 6, 6a

General integument yellowish-green. Individuals much larger than in the last species; their tunics apple-green or yellowish, bright yellow round the mouth, and between the mouth and the cluacal orifice presenting an oval yellow space, divided by green lines, radiating from a central vermilion or orange spot.

On fuci. "A green species, which I think is the smaragdus, is common on the Cornish coast," Mr. Alder. "North of Ireland," Mr. Thompson. 


\section{B. Bivittatus, Milne-Edwards.}

Mém. Asc. Comp. p. 308, pl. 6, fig. 7, $7^{\mathrm{B}}$.

General integument ash-grey. Systems appearing as small stars, with linear yellow rays and dark centres. Individuals coloured like the common integument, but marked between and around their mouths and the common cloaca with two narrow yellow bands.

Belfast Bay, Mr. W. Thompson. At Torquay and Falmouth, Mr. Alder.

\section{BOTRYLLOÏDES, MiLne-Edwards.}

This genus belongs to the same tribe as the last, but the stars formed by the systems of animals are irregular and ramifying. The individuals also differ in position and structure, having their bodies placed vertically and their two orifices approximated. [Pl. B, fig. 8.]

\section{B. Leachil, Savigny, (Sp.)}

Botryllus Leachii, Sav. Mém. 2nd part, p. 199, pl. 4, fig. 6, and pl. 20, fig. 4.

"Mass forming a gelatinous crust, hyaline, with a purple tint, ornamented with a great number of yellowish vascular tubes. Systems very numerous and closely packed, composed commonly of from ten to twelve individuals, and sometimes of from twentyfive to thirty; their summits claviform and variegated with white and yellow. Branchial orifice white, with a yellow collar encircled by white ; the radial line bordered with white."-SAVIGNy.

Mass two to three inches across; size of individuals one-fourth of a line.

Communicated to Savigny by Leach, probably from the English coast. "North-east coast of Ireland, occasionally investing the roots of Laminaria digitata, \&c. When dried it has somewhat the appearance of a sponge," W. Thompson in Ann. Nat. Hist. vol. v. p. 95. ? Common on the Northumberland coast, Mr. Alder. 
2. B. albicans, Milne-Edwards.

Mién. p. 304, pl. 6, fig. 2.

Plate $A$, fig. 8.

White stars on a transparent ground.

"On June 16th, 1816, I found this species attached to the under side of a stone in a pool, between tide-marks, at Springvale, county of Down. It was likewise attached to fuci (Fucus vesiculosus, drc.) growing in the rock-pools, and was in much smaller masses than the following species; generally but one system of individuals existed in each mass. On the small branches of fuci to which it was attached, there was not room for more; nor was there, indeed, on the broadest portion of the main stem, whence the leading branches of the plant issued : the latter is its farourite position," W. Thompson, Ann. Nat. Hist. 1846, vol. xviii. p. 385 .

\section{B. notifera, Milne-Edwards.}

Mém. Asc. Comp. p. 301, pl. 6, fig. 1 and 1a.

Mass gelatinous, yellowish; individuals having semi-transparent tunics, speckled with red; the red specks form a ring round the mouth.

"On the under side of the same stone with the last, and covering several square inches of its surface. I mark it with doubt, on account of some little difference in colour. The 'consistence gelatineuse' was hyaline rather than 'jaunitre.' 'Ihe individual forms were more of a uniform red than in Edwards's figure, and were each as brightly coloured as in B. rubrum, Edw., and of the tint that it is represented to be. The individuals being arranged in a scattered manner, and not thrown into masses as in B. rubmum, was a striking character," W. Thompson, loc. cit. "There is a species with wheel-like rays on this (Northumberland) and the Cornish coast, but it is yellow without red markings, as in $B$. rotifera," Mr. Alder in letter.

\section{B. rumen, Milne-Edwards. \\ Mém. Asc. Comp. p. 304, pl. 6, fig. 3, 3a}

Common tunic opaque, and throughout of an intense orpiment red. Systems more distinct than in the last species.

Common at Falmouth, Mr. Alder. 


\title{
II. CLAVELINID压;
}

\author{
OR, SOCIAL ASCIDIANS.
}

The Compound Ascidians are not so far removed from the Simple as to be uncomnected by intermediate forms. It was supposed until very lately that the curious animals of this class, of which one species had been described by Pallas under the name of Ascidia clavata, and another by Otho Frederic Müller under that of Ascidia lepadiformis, belonged to the latter section; but Milne-Edwards has shewn that the individuals of the genus Clarelina, to which Savigny referred the species first named, are not always, nor, indeed, usually separated from each other, but spring, as it were, from a common creeping root, and multiply by gemmation in the manner of the truly compound Ascidians. Some years previously, Mr. Lister, in his valuable paper on "The structure and functions of tubular and cellular Polypi and of Ascidix," described and figured a remarkable Ascidian which he had found at Brighton on Conferva elongata, and which seemed to combine the characters of simple and compound Tunicata. He described it as occurring in groups consisting of several individuals, each having its own heart, respiration, and system of nutrition, but fixed on a peduncle that branches from a common creeping stem, and all being connected by a circulation that extends throughout. Their parts are of such transparency, that their interior is easily seen. Their external shape resembles a pouch, compressed at the sides and fixed at the hind part of the base upon the peduncle.

The affinity of this curious animal, or rather group of animals, with Clavelina was demonstrated by Milne-Edwards in the memoir already cited, wherein he elevated

* Philosophical Transactions, 1834.

VOL. I. 
these two genera into a separate and most natural group, under the name of "Ascidies sociales."

\section{CLAVELINA, SAVIGNY.}

Individuals and groups connected by creeping, radiciform prolongations; the Ascidians arising from them having clongated, erect, more or less peduneulated bodies. Branchial and anal orifices without rays. Outer tunic smooth and transprarent. Thorax usually marked with coloured lines.

\section{Lepadiformis, O. F. Müller, (Sp.)}

Ascidia lepadiformis, O. F. Mrïler, Zool. Dan. t. 79, fo 5.-Clavelina lepadiformis, Savigny, Mém. pt. 2, p. 174; Fleming, Brit. An. p. 468 ; MilneEdwards, (Mém. Asc. Comp̨.,) Mém. Inst. vol. xriii.p. 266, pl. 1, fig. 1, and pl.2, fig. $1,1^{\mathrm{h}}$.

Plate E, fig. 1.

Thorax forming a third part of the length of the adult individual, and marked with yellow lines; stomach of a bright orange, placen near the middle of the abdominal portion of the animal; part of the intestine of the same colour.

Usual length from one-half to three-fourths of an inch. Abundant on rocks and stones at low-water in many places, especially on the west coast of Scotland. Strangford Lough, Mr. W. Thompson. Connemara. "Very generally diffused; I have met with it on the Devonshire, Cornish, and Northumberland coasts, and in Lamlash, Rothesay, and Oban bays in Scotland," Mr. Alder.

The morle of germination of this species has been well described by Milne-Edwards. "If we examine with care the foot of a $\mathrm{Cla}_{\mathrm{a}}$ velina lepadiformis, we see that the animal adheres to the soil by more or less numerous radiciform prolongations of the tegumentary tunic; and usually we find also cylindrical filaments, which, mingled with these roots, and formed externally by the same tissue, creep also on the surface of the soil, but are hollow, and internally furnished with a membranous tube. This tube is continuous with the internal tunic of the Ascidian; and the circulation which is seen in the interior of the abdomen of the latter is erinally continued into the appendicular canal. This stalk-like 
body, which is closed at the extremity, is at first simple, but ramifies as it elongates. When its growth is more advanced, we see developing at the extremities of its branches, or even at different points of its length, tubercles containing in their interior a little organised mass in connexion with the internal tube. These tubercles elongate, elevate themselves vertically, and become claviform; the blood which circulates in the stem penetrates the soft and pyriform central mass; but this mass, at first pedunculated and adhering to the inner tunic of the principal canal, soon separates itself, and no longer participates in the circulation of the individual to which it owed its origin. Nevertheless, its development continues, and we soon distinguish in it all the principal charac. teristic traits of Ascidian structure; the branchial sac becomes perfectly outlined without being as yet in communication with the interior; a curved digestive tube is seen beneath the thorax. At length a buccal opening is formed, and the general shape of the young animal approaches more and more nearly that of the adult. Thus there is produced, by process of budding, a new individual, linked with its parent by a radiciform prolongation of the tegumentary tunic, and which, during the first years of its life, has a circulation in common with the mother-ascidian, but in the end enjoys an independent existence. Still, however, it may remain in connexion with the individual which produced it, through the medium of its roots, or it may become completely free by their rupture, without any change of consequence in its mode of life." (Mémoires de l'Institut, vol. xviii. p. 262.)

In the memoir cited, Milne-Edwards has distinguished several species of Clavelina, most of which are likely to occur on our coast. One is the Clavelina Savigniana, the abdominal portion of whose body is four or five times as long as the thorax, and the thoracic lines probably white. A second, Clavelina producta, has the thorax very short and as broad as long, and the abdomen very long. Clavelina pumilio, on the other hand, is nearly sessile and square. We have gathered a species, probably identical with the last, though much larger than the specimens described by Milne-Edwards, at low water in the island of Herm. Clavelina Rissoana is a Mediterranean species, resembling 
C. Repulifurmis, but having white thoracic lines: as the latter, on our own const, has these lines rery frequently so pale as to be nearly white, this may be only a variety. The figure usually quoted from Mïller, of the original l.pulifurmis, does not so closely represent the common appearance of British specimens as that given under the name of Ascielie relatinose, in the fourth part of the "Zoologia Danica," edited by Rathke.

\section{PEROPHORA, WIEGMANN.}

Individuals peduneulated, suhorbicular, compressed, attached by their pedicles to creeping tubular processes of the common tunic, throngh which the blood circulates. Thorax not lineated by granular bands.

\section{P. Listeri, Wiegmann.}

J. Lister, on the Structure and Functions of tubular and cellular Polypi and of Ascidix, Philosophical Transactions, 1834. [The author gave no name to his Ascidian. When his paper was translated into the German journals, Professor Wiegmann proposed the appellations here adopted.]

\section{Plate E, fig. 2.}

WTe have already noticed the characters of this curious Jittle animal or group of animals, so well described by Mr. Lister. His account of the structure and economy of Perophora may be studied with advantage for its minute accuracy. It threw light on the true nature of Clavelina, which hat previonsly been referred to the Simple Ascidians. The P'erntlore Listeri is a minute creature. It occurs not rarely on the south coast of England, and we have taken it in the Irish Sea. Mr. M'Andrew and Professor E. Forbes drerlged it adhering to weed on the coast of An(n) the weed like little specks of jelly dotted with orange and brown, and linked by a winding silvery thread. When dried, as it may often be met with on sea-weed cast on shore, these borlies appear like the minute ova of some mollusk. 


\section{ASCIDIADA.}

Rarely is the dredge drawn up from any sea-bed at all prolific in sub-marine creatures, without containing few or many irregularly shaped leathery bodies, fixed to sea-weed, rock, or shell by one extremity or by one side, free at the other, and presenting two more or less prominent orifices, from which on the slightest pressure the sea-water is ejected with great force. On the sea-shore, when the tide is out, we find similar bodies attached to the under surface of rough stones. They are variously, often splendidly coloured, but otherwise are unattractive or even repulsive in aspect. These creatures are Ascidice, properly so called. Numbers of them are often found clustering among tangles, like bunches of some strange semi-transparent fruit. They are very apathetic and inactive, living upon microscopic creatures drawn in with currents of water by means of their ciliated respiratory organs.

The leathery case is often encrusted with stones and shells, decorated with parasitical though ornamental plumes of corallines, and not seldom perforated by bivalves, which lodge themselves snugly in the tough but smooth skin; it is the analogue of the true shell of conchiferous Mollusca. It is a sac, closed except at two orifices, one of which is branchial, the other anal. This elastic gelatinous or coriaceous envelope is called the test, and encloses a second tunic or mantle, which is muscular and adheres to the first only near the orifices. The branchial sac lines the interior of the mantle in part. It is both respiratory and pharyngeal. The remainder of the cavity is occupied with the principal organs of digestion, circulation, and generation. The chief nervous centre is situated between the two openings of the muscular tunic. The sexes of Ascidia are distinct. 
In 1828 Milne-Edwards and Audouin * made the important discovery that the Compound Ascidians did not begin their life as fixed animals, but originated from independent tarpole-like embryos. In 183.5 a similar account of their early history was given by the Norwegian naturalist, Sars ; and in 18:39 Sir John Graham Dalyell, + of Edinburgh, published his observations on the development of Ascidia, both simple and compound, with the same results. Since then many observers have noticed the metamorphoses of the Tunicuta-metamorphoses which account for the wide diffusion of these apparently sedentary animals. The tadpole as it appears in the egg is at first an oval disk; a tail is som after observed; arm-like projections spring from the head of the ereature, which then presents a striking analogy with the form of a hydroid zoophyte; it becomes free and swims aloout by means of its rapidly vibrating tail; it fixes itself to rocks or sea-weeds by its arms; the tail disappears; that which was the head, or nucleus, sends out root-like projections; orifices appear in it, and its final form as an Ascidian begins to be manifested. Such are the successive stages of the metamorphosis. $§$

\section{ASCIDIA, BASTER.}

(coros, a leather bag.)

Body sessile, covered with a coriaceous or gelatinous tunic. Branchial orifice 8-lobed and 6-lobed. [Branchial sac not plicated, surmounted by a circle of simple tentacular filaments; meshes of the respiratory sac papillated.] This is the genus Pirallusia of Savigny.

* Annales des Sciences Naturales, t. xv. p. 10.

† Sars, Beskrivelser ag jagttagelser, \&c. Bergen, 1835.

¥ Edinburgh New Philosophical Journal, 1835.

$\S$ For a clear and full abstract of the observations on this subject, see Owen's Lectures on the Invertebrata, p. 273. 


\section{A. integtinalis, Linnæus.}

Ascidia intestinalis, Lin. Syst. Nat. 12th ed. (previously described by Bohadsch, An. Mar. p. 132, t. x. f. 4-5) ; Cuvier, Mém. du Mus. t. ii.pl. 2, f.4-7.A. corrugata, Müller, Zool. Dan. t. 79, f. 3-4.-A. virescens, Brugière, Enc. Méth. pl. 64, f. 4-6.-Phallusia intestinalis, Savigny, Mém. pt. 2, p. 169, pl. 11, f. L.-Ciona intestinalis, Fleming, Brit. An. p. 468.-Ascidia intestinalis, Macgillivray, Mol. Aberdeen, p. 313.

Body elongated, cylindrical; outer tunic thin, soft, gelatinous, smooth, transparent, usually pale green or yellow. Orifices terminal, placed close together on rather short tubes, usually bordered with bright yellow: the branchial with eight lobes and eight red ocelli; the anal with six. Elongated fibrous bands shine through the outer tunic.

It grows to the length of five or six inches, but commonly to not more than three. It adheres to rocks, shells, fuci at various depths. It is found on most parts of our coast, but is especially abundant in the north.

2. A. canina, O. F. Müller.

Zool. Dan. t. 55, fig. 1-6 (copied in Enc. Méth. pl. 64, f. 1-3),-Phallusia canina, Savigny, Mém. pt. 2, p.171.

Body elongated, cylindrical, flaccid; outer tunic stronger than that of the last species, more or less tinged with red, especially about the approximated, terminal, and much corrugated orifices. Three to four inches in length. Adhering to fuci in from three to seven fathoms water.

Strangford Lough, W. Thompson. Clew Bay, County Mayo, W. T., R. Ball, E. F. Kirkwall Bay, Orkney, J. Goodsir and E.F. (1839). In the Solent, (1847,) Capt. James, R. E., and E. F.

3. A. venosa, O. F. Müller.

Zool. Dan. t. 25.

Body elongated, sub-cylindrical; outer tunic sub-cartilaginous, smooth, pellucid, so lineated with red vascular ramifications as to appear of a red hue all over. Branchial orifice terminal, anal lateral; both sessile, tinged with red, and more or less corrugated. Inner tunic crimson. Length about two inches. Usually gregarious.

"Obtained by dredging in the loughs of Strangford and Bel- 
fast. First distinguished as an Irish species by Dr. J. L. Drummond," W. Thompson, Ann. Nat. Hist. vol. v. 1840. Bay of Killery, Connemara, II. T., R. Ball, E. F. (1\&40). Hebrides, R. M'Andrew and E. F. (1845.)

\section{A. mentula, O. F. Mïller.}

Zool. Dan. t. 8, f. 1-4 (copied in Enc. Méth. pl. 62, f. 2-4).-Ascidia monachus, Cuvier, Mém. du Mus. t. ii. p. 32.-Phallusia monachus, Sarigny, Mém. pt. 2, p. 16\%, pl. 10, f. 2._Pandocia conchilega and Phallusia mentula, Fleming, Brit. An. p. 468. ?-Ascidia prunum, Macgillivray, Mol, Ab. p. 312.?

Plate C, fig. 1 .

Body oblong. Outer tunic very thick, cartilaginous, translucent, varying in colour from pale greenish-white to dark brown; [often containing imbededed Modiola marmorata, and freeuently covered by investing corallines.] Orifices distinct, sessile; the branchial terminal, S-lobed; the indentations of the lobes presenting the ocelli, which are yellow, with a red central spot; the tentacular filaments are rery conspicuous between the ocelli, as they are also in the 6-lobed and 6-ocellated anal orifice, which is placed laterally at a considerable distance from the branchial, and usually on a bulging of the side. Grows to the length of six inches, and even longer. This is the commonest of our deepwater Ascidians, occurring plentifully in from fifteen to twenty fathoms water in many parts of the coast. Miiller's description of his $A$. mentula applies so well to it, that, although the figure be rather puzzling, and not good at best, one can hardly doubt their identity; "Ascidiarum singularissima. Massu informis cinereoflavescens, quarlratum irregulare sistens; substantia crassa gelatinosa, luriuscula, subpellucida, rejectamentis corallinarum et fucorum passim obsita."

"Belfast Bay; Roundstone Bay, County Galway, arlhering to a stone between tide-marks (? if the same); Ascidia communis, Forbes' MSS., Clew Bay," W. Thompson, in Ann. Nat. Hist., 1844. Isle of Man, Zetland, Orkney, east and west coasts of Scotland, E. F.

\section{A. aracinoinea, E. Forbes.}

Oblong, resembling the last in form. Outer tunic very thick, cartilaginous, hard, smooth, undulated as if ubsoletely tuberculated, 
opaline, with a porcelain-like lustre, either milk-white, or marked with reticulating lines, as if it were covered by a spider's web. Branchial orifice terminal; anal lateral and distinct; both with very strongly-marked lobes: ocelli inconspicuous. "Inner tunic soft and dark blue."-(Mr. Alder.)

Three inches in length. A very beautiful species. On the south coast of England, Mr. Borwerbank. "Not uncommon on the Cornish and Devonshire coasts. I have also found it at Lamlash, Arran," Mr. Alder. [Taken in the Egean, E. F., 1842.]

\section{A. scabra, O. F. Müller.}

Zool. Dan. t. 65, f. 3.

Plate C, fig. 3.

Body ovate, compressed, adhering by the side. Test tough, white, transparent, scabrous, shewing the reddish branchial sac shining through. Orifices sessile, approximate, near one extremity. An inch to an inch and a half in length.

Strangford and Belfast Loughs, W. Thompson. On fronds of Laminaria in Killery Bay, west coast of Ireland, W. Thompson, R. Ball, E. F. (1840). Irish Sea, not rare; west coast of Scotland, E. F.

\section{A. virgrnea, O. F. Müller.}

Zool. Dan. t. 49, f. 4.-A. opalina, Macgillivray, Mol. Ab. p. 312.

Plate C, fig. 2.

Body irregularly tetragonal, compressed, adhering by base, and sometimes partly by the side. Tunic smooth, glossy, crystalline, firm, yellowish-hyaline. Through it the branchial sac, beautifully marbled with crimson, and banded with white, is seen. Orifices terminal, sessile, rather distant; ocelli red. Length and breadth often two inches.

"Hæc frustam glaciei visu, tactu et ipso frigore refert, vix ulli pulchritudine secunda."-MüLLER.

Dredged, adhering to dead shells, in twenty fathoms, four miles from land, Ballaugh, Isle of Man, $(1839$,$) E. F. Hebrides and$ Zetland, R. M'Andrew and E. F. Moray Firth, Captain Otter, R.N. "Abundant in deep water off Aberdeen," Macgillivray.

VoL. I. 


\section{A. paraldetogmama, O, F. Miiller.}

Zool, Dan. t. 49, f. 1, 2, 3.

Body more or less tetragonal, sub-compressed, adhering by base. Tunic smooth, glossy, pellucid, exhibiting the branchial siac ornamented conspicususly with rectungular reticulating white lines, and occasionally bright yellow or crimson spots. Orifices terminal, rather distinct, not conspicuously ocellated. About an inch and a half in length.

"Ascidiarum pelluciditate, consistentiat, colorumyue splendore spectatissimus."-MüLLER.

Attached to algæ in Strangford Loch, W. Thompson, Ann. Nat. Hist. vol. v. (1840) p. 94. Roundstone Bay, Connemara, TI. T., R. Ball, E. F. (1sto). Zetlands, (1Rt.), Ri. M['Andrew and E. F.

\section{A. prunum, Müller?}

O. F. Müuller, Zool. Dan. t. 34, f. 1, 2, 3.-Pirena prunum, Fleming, Brit. An. p. 468 ?

Body ovate, depressed, adhering to the side. Tunic very smooth, hyaline, the branchial sac shining white through the tunic. Orifices sessile, or nearly so, approximate, bordered with yellow, the branchial with eight red ocelli and eight tubercles in the tunic around it; the anal with six red ocelli and six surrounding tubercles. Usually about an inch in lengtl.

Common on most parts of our coast, adhering to the under surface of stones at low-water; often gregarious. Isle of Man, Bristol Channel, west and east coast of Scotland, Zetlands, E. F. 1)redgerl in the Lochs of strang ford and Belfast, W. Thompson. Northumberland, Mr. Alder, who objects to this species being referred to the prunum of Miiller.

\section{A. ormicularis, Miiller.}

Zool. Dan. t. 79, f. 1, 2.

Body orbicular, depressed, adhering. 'Tunic hyaline, pellucid, with an opaque disk, "scabrous." Orifices approximate, sessile. One inch across.

"On Zostera marina in Strangford Lough," W. Thompson, Ann. Nat. Hist. vol. v. (1840) p. 94. 
11. A. aspersa, Müller.

Zool. Dan. t. 65, f. 2.

Body ovate, sub-compressed, adhering obliquely at base. Tunic slightly scabrous, white, transparent, shewing the red spotted branchial sac. Orifices papillose, nearly sessile, terminal. Gregarious. An inch in length.

Loughs of Strangford and Belfast, W. Thompson, Ann. Nat. Hist. vol. v. (1840) p. 94.

\section{A. vitrea, ${ }^{\circ}$ Van Beneden.}

Mem. Acad. Roy. Belg. t. xx. (1847) p. 59, pl. 4, f. 1-5.

Body globose or sub-compressed, attached by a very small base. Outer tunic thin, transparent, membranous, hyaline; tubes terminal, placed rather apart, the branchial projecting most, but both short. Orifices with red ocelli. Half an inch in length.

On Alcyonidium in Killery Bay, $(1840$,$) R. Ball, W. Thomp-$ son, and E. F. Probably not uncommon on many parts of our coast.

13. A. conchilegta, O. F. Müller.

Zool. Dan. t. 30,4, f. 4, 5, 6 .

"Compressed, infested with fragments of shells; inner tunic white, passing to blue." This species requires elucidation.

"Coast of Down and Antrim," W. Thompson, in Ann. Nat. Hist., 1844.

\section{A. echinata, Linnæus.}

\section{Zool. Dan.t. 130, f. 1.}

Plate C, fig. 4.

Body globose, adhering by base. Tunic tough, yellowish, opargue-white, studded with conical eminences or papille, which bear upon their summits a circle of from four to seven radiating bristles. Orifices sessile, tinged and rayed with deep crimson; the oral with eight, the anal with six rays or notches; the interspaces tubercular : the branchial orifice is much the most conspicuous. About an inch in height. 
Zetland, (1837,) J. Goodsir and E. F. "Parasitic on one of" the larger Ascidice; dredged in strangford Lough," W. Thompson, Aun. Nat. Hist. vol. v. (18t0) p. 91.

\section{MOLGULA, E. Forbes.}

(Diminutive of Mor yos, a bag of skin.)

Body more or less globular, attached or free, with a membranous tunic, usually invested with extraneous matter; orifices on very contractile and naked tubes; the branchial 6-lobed, the anal 4-lobed.

1. M. oculats, E. Forbes.

Plate D, fig. 6.

Body $y$ lobe, allhering by base ; test closely encrusted with sand, shells, and gravel, except a smooth, oblong, reniform, regularly bounded, depressed space, within which the very short but rather wide orifices project. This space is very tender, translucent, bluish or purplish, mottled with orange; the orifices are short tubes, similarly coloured, the one 6-lobed, the other 4-lobed; lobes acute. Two inches and a half across.

This curious species, the orifices of which seem like dark eyes within a spectacle-formed frame, was dredged off Plymouth, adhering to a scallop, in twenty-five fathoms, (1846,) R. M'Andrew and E. F.

\section{M. túnulosa, Ratlike, (Sp.)}

Ascidia tubulosa, Zool. Dan, t. 130, f. 3.

Plate C, fig. 5.

Body perfectly globular, not adhering, but buried in sand or mud. 'Test hyaline, encrusted with fine sand, smooth, except the -hort conical approximated orifices, which are makerl, bluish, and beautifully reticulated; their edges are bordered with yellowish tubercles, $(6+4$.$) The branchial opening is the largest.$

This curious species occurs abundantly in muddy lochs and bays on the west coast of Scotland. When it comes up in the dredge, it resembles a little ball of sand; when the sand is rubbed away, it seems like a little transparent bullet, in the interior of which the viscera are seen winding. The description in the Zoologia Danica does not agree with our species so well as the figure. 


\section{CYNTHIA, SAYIGNY.}

Body sessile, covered with a coriaceous tunic; branchial and anal orifices opening in four rays or lobes. [Branchial sac longitudinally plicated, surmounted by a circle of tentacular filaments; meshes of the respiratory tissue not furnished with papillæ.]

\section{C. microcosmus, Savigny.}

Cynthia microcosmus, Sav. Mém. pt. 2, p. 144, pl. 2, f. 1, and pl. 6, f. 2.Ascidia microcosmus, Cuv. Mém. MIus. t. ii, pl, 1, f. 1-6?

Body tuberous; test deeply and unequally wrinkled across, glabrous, yellowish-grey, hard, opaque; orifices 4-cleft, small, on prominent, tuberculated, conical, hirsute projections, rayed interiorly with blue and purple. British specimens are rarely larger than two or three inches in height.

South coast of England? Ireland, W. Thompson.

\section{C. claudicans, Savigny.}

Sav. Mém. pt. ii. p. 150, pl. 2, f. 1.

Body tuberous; test wrinkled and furrowed in every direction, finely bristly, of a greyish or ashy-red or brownish colour, thick, opaque, often encrusted with sand and fragments of shells; orifices small, deeply 4-lobed, reddish, placed on slightly prominent conical projections. Usually ahout an inch in height.

On oysters, especially in the south. "Not uncommon on oysters and other shell-fish taken on the north coast of Ireland," W. Thompson. West coast of Scotland, R. M`Andrew and E. F.

\section{C. tuberosa, Macgillivray.}

Macg. Mollusca of Áberdeen, p. 311.

"Greyish-white or grey, sessile, sub-ovate and hemispheric, very densely cartilaginous, covered with irregular prominences or tubercles of various sizes. Length one inch."-MacGillivray.

Deep water off Aberdeen. A reddish-brown Cynthia with red 
apertures, having a very thick outer tunic, in which Modiola marmorata is generally embedded, is not uncommon at Cullercoats, according to Mr. Alder, and is probably the adult of Professor Macgillivray's species.

\section{C. quadrangularis, E. Forbes.}

$$
\text { Pl. D, fig. } 1 .
$$

Body conical ; test thick, coriaceous, dark reddish-brown, warty; orifices rather large, on produced conical quadrangular eminenees, the angles formed by strong ribs composed of united warts; rims of orifices white, with a fine crimson bordering line. Length nearly two inches.

Dreager in Loch Fine, from a depth of thirty fathoms, (1815,) R. M['Andrew and E. F.

\section{C. informis, E. Forbes.}

Body rudely conical, subtuberous; test thick, coriaceous, crimson, covered with rather undefined, oblong, large warts ; orifices on conical, obtuse projections, 4-lobed, deep crimson. Length two inches.

Dredged in from seven to nine fathoms water in Zetland and in Stromness Bay, Orkneys, J. Goodsir and E. F. (1839.)

\section{C. tessellata, E. Forbes.}

$$
\text { Il. D, fig. } 3 .
$$

Body transversely ovate, and shaped not unlike the Psolus squetmatus; test coriaccous, tessellated by regular, smooth, hexagonal, oblong, depressed spaces or warts, each of which is darkly tinted in the centre, so that the creature appears to be tawny, speckled with regular purple spots; orifices quadrangular, with deep crimson margins, on rather short and distinct conical eminences, which are more deeply tinted with purple than the body. Length half an inch.

Dredged, adhering to a stone, in twenty-five fathoms water, Mount's Bay, Cornwall, $(1846$,$) R. M'Andrew and E. F.$ 
7. C. mimacina, E. Forbes.

Plate D, fig. 4.

Body depressed, expanded, doridiform ; test coriaceous, orange, with dark-brown reticulating markings, enclosing uumerous small depressed warts of various sizes; orifices quadrangular, papillose, almost sessile, brown. Three-quarters of an inch in length.

On a rlead shell in twenty-five fathoms, Hount's Bay, Cornwall, (1846,) R. M'Andrew and E. Forbes.

\section{C. norus, E. Forbes.}

Plate D, fig. 2.

Body oblong, attached throughout the length of its base, rugose, with more or less rounded tubercular spaces, rose-red ; orifices nearly sessile, distinct, placed at about the same level, banded with alternate stripes of orange and red; tunic very tough.

Length three-quarters of an inch, height half an inch.

Mounts Bay, Cornwall, on stones in twenty-five fathoms water, R. M'Andrew and E. Forbes. "Taken on an oyster at Fowey by Mr. Peach. Very like a raspberry when contracted," Mr. Alder.

\section{C. rustica, Linnæus, (Sp.)}

Ascidia rustica, Müller, Zool. Dan. pl. 15, f. 1.-Phallusia rusticn, Fleming, Brit. An. p. 469.

Body more or less globular or botryoidal, rugose, usually of a rusty red; apertures sessile, placed apart, deeply tinged with rose-red. From half an inch to two inches in length.

A coriaceous, white, smooth, but nodulose, botryoidal ascidian occurs in deep water on the coast of Cornwall, apparently a variety of this species. There is considerable confusion, however, about Cynthia mustica. It is very doubtful whether the figures of Müller really represent only one species. Lamarck has wrongly referred Ascidia scabra, A. aspersa, and $A$. patula to varieties of rustica.

Common on most parts of our coast, on fuci. 


\section{C. grossularia, Vam Beneden, (Sp.)}

Ascidia grossularia, Van Beneden, MIém. Acad. Roy. Belg. t. xx. (1847) p. 61, pl. 4 , f. $7-11$.

Body oral, depressed, often lenticular, sessile, and attached by the entire lower surface; outer tunic corneous, smooth, rose-red; apertures sessile. Forming disks about a quarter of an inch across. Very common on oysters everywhere, and on stones at low water. Usually regarded in this country as the fry of $C$. rustica, but probably distinct. Professor Van Beneden states that the branchial sac is without folds.

\section{C. ampulla, Brugière, (Sp.)}

Baster, Opusc. p. 84, t. 10, f. 5, a, b, c, d. (cop. in Encyc. Méth. pl. 63, f. 1-3.) Ascidia ampulla, Lamarck, An. sans Vert. vol. iii. (in 2nd ed. p. 528.)

Body more or less ovate or globular, unattached; outer tunic hairy; orifices tubular, produced, placed close together, yellowish, speckled with red. About an inch in length.

"Common at Cullercoats, Northumberland; brought in on fishermen's lines. Inattached, and sometimes covered with sand to the depth of half an inch," Mr. Alder.

\section{C. mammillaris, Pallas, (Sp.)}

Ascidia mammillaris, Pallas, Sp. Zool. fasc. 10, p. 24, t. 1, f. 15, (copied in Encyc. Méth. f. 62, f。 1.)

Body oblong, depressed, sessile, attached throughout its length, rugose, gibbous; the outer tunic coriaceous, clothed with soft hairs; colour dirty white or pale yellow; orifices nearly sessile, approximate, scarlet within. About an inch in length. Very irritable.

"On submarine rocks in Cornwall," Gaertner. This species requires to be sought for and re-observed. 
13. C. AGGREgata, Rathke. (Sp.)

Ascidiâ aggregata. Rathke, Zool. Dan. t. 130, f. 2.

Plate D. f. 5.

Body bottle-shaped, cylindrical, with terminal approximate orifices; base of attachment small, sending out many fibres; outer tunic membranous, smooth, of an uniform brilliant orange ; the orifices quadrangular, bordered with still brighter orange and edged with red; the anal placed more obliquely than the branchial : no ocelli. About an inch in height.

Gregarious in vast numbers under large stones in twelve fathoms water at Dartmouth, R. M'Andrew and E. F. (1846.) Sometimes forming large free bunches, in consequence of the interlacing of the rootfibres. The description in the "Zoologia Danica" well expresses this habit:-" Siquidem nunquam solitariam, semper vero plures, sæpius viginti ad triginti, mediantibus radiculis tendineis invicem junctas deprehenderit, eam aggregatam appellari voluit."

On many of the branching root-fibres are small, tough, globular, imperforate, orange bodies, of various sizes, full of granules. Are not these intermediate states of this Ascidian? The Ascidians we examined were full of tadpoles in various stages of development.

This form seems intermediate between the simple and social Ascidians, and should probably rank as the type of a distinct genus. 


\section{PELONATADAE.}

We have now to notice the British species of a very ('mions group of Tunicut!, one which seems to have escaped the observation of most naturalists, and hitherto to have been onitted from systematic arangements of the Mollusea, partly through the rarity of the creatures themselves, partly from the only published aceount of them having been overlooked. These are two animals, both inhabitants of the Scottish seas, one of which was first observed by Professor E. Forbes, and the other by Professor Goodsir, who jointly constituted for their reception the genus $P c$ Ionceic.* Whilst in many of their characters they approach the true Ascidians, especially the unattached species of the genus Cynthia, in others they indicate a relationship with the cirhograde Echinodermata. They present the remarkalle positive anatomical character of a union of mantle with test; so that there can be little question of their right to be regarded as members of a listinct family of Tunicuta.† As no account of them is to be found out of the original paper, we reprint it entire :-

"Among the Ascidian Mollusca which we have collected together, with a view to a complete investigation of the British Tunicata, are two remarkable animals, which appear to represent a very natural genus, as yet unrecorded.

"They differ from their allies in the tribe chiefly by their not being fixed, and by their form, which reminds one more of that of a Siphunculus than of an Ascidia; indeed, they may be re-

* See Jameson"s Ed. New Phil. Journal, vol. xxxi. (for 1841), p. 29.

+ It is worthy of notice, that Mr. Macleay, in his valuable remarks on the arrangement of the Tunicata, (Linnæan Trans, vol. xiv., ) had hypothetically indicated such a group as this now constituted. 
garded as analogous to certain Siphunculidce, and in that point of view the details of their form and structure are of much interest to the naturalist.

"They are both of a cylindrical shape, having their orifices on the same plane, elevated on papillose eminences at one extremity of the body. No rays or tentacula surround either of the [4cleft] orifices. Their posterior extremities terminate in a blunt point. They live buried in mud, quite unattached to any other body, and are extremely apathetic animals, presenting scarcely any appearance of motion.

"We have styled the genus Pelonaia, and define it as follows:"Test cylindrical, unattached.

"Orifices without rays, on two equal approximated papillose eminences at the anterior extremity.

"Species I. P. corrugata [Pl. E, fig.4. ].-Test deep brown, much elongated, rudely wrinkled transversely.

"In the mud-filled cavities of old shells from deep water, Anstruther. It has also been taken by Dr. Johnston at Berwick. [Northumberland, Mr. Alder.]

"Sp. II. P. gLabra [Pl. E, fig. 3.].-Test greenish-yellow, smooth, pilose, not nearly so much elongated as the last.

"Dredged in seven fathoms water, in mud, Rothesay Bay.

\section{Anatomy of $P$. glabra.}

"1. Muscular System. - The mantle is similar to that of other Ascidice, possessing longitudinal and circular fibres. A strong band of transverse fibres passes round it, immediately below the anal orifice, encroaching on the cavity principally on that side. The chief peculiarity of the mantle is its firm adhesion to the test.

"2. Digestive and Respiratory Systems. - The respiratory opening is of small size, and exhibits no folds or tentacular fringes. The respiratory sac is elongated, cylindrical, contracting rather suddenly towards one side to become continuous with the œsophagus. On the external surface of the sac there are about thirty parallel transverse ridges, which give it the appearance of a plaited frill. These plaits are less apparent along the course of the branchial artery and branchial vein, but midway between 
them on each side they are very prominent, and are tied each by a minute cord to the inner surface of the mantle. The internal surface of the sac exhibits along one side the serpentine double cord which contains the branchial vein; along the other side the branchial artery; and from these primary and secondary perpendicular branches proceed, as in the other Ascidice. The transverse plaits on the external surface of the sac correspond to the primary or tranverse branches of the vessels on the internal sur. face. The animal was not examined while alive, but cilia, without doubt, exist in great abuntance on the edges of the lozenge-shaped spaces of the sac.

"The cesolhagus commences by a white plicated opening at the lower end, and on one side of the sac. It is curved in a sigmoidal form, and exhibits longitudinal rugn through its coats. Near the lower end of the mantle-cavity it terminates by suddenly dilating into the stomach, which is pear-shaped, and directed obliquely upwards towards the side opposite to the esophagus. The internal surface of the stomach presents longitudinal plicæ, and is succeeded by the intestine, which at first curves upward, then down to the bottom of the mantle cavity, up along the œsophageal side of that cavity, and between its walls and the branchial artery, terminating about the anterior third of the animal in a funnel-shaped anus, which is cut into ten or eleven processes, like the petals of a flower. The first part of the intestine is white and longitudinally plieated; the rectum is dilated with attenuated coats.

"3. Vascular System.-The vascular system resembles that of the true Ascidice, except that there is no heart. It consists of two sets of ressels, with four sets of capillaries, a circle in fact twice interrupterl, once in the respiratory sac, and again thronghout the body. The branchial veins run along the transverse plaits of the sac, receiving secondary and ternary twigs at right angles. The primary branchial venous branches empty themselves on each side into the branchial trunk, which runs in the substance of the double cord which coasts the superior aspect of the sac. This double cord terminates in an abrupt manner anteriorly near the oral orifice, and in a similar manner, but after becoming smaller near the orifice leading to the oesophagus. At this point the vein becomes an artery, and probably sends back vessels to nourish the 
sac. It now runs along the osophagus, supplying the stomach and intestine, and giving off in its course branches to the cloak. The veins arising from the arterial capillaries of the body meet near the commencement of the osophagus in one trunk, which, passing along the inferior wall of the respiratory sac, opposite to the branchial vein, performs the functions of a branchial artery. It is interesting to observe here the differences between the modes in which the branches enter the branchial vein, and strike off from the branchial artery. In the former, just before the branches enter the trunk, they give off a number of vessels, which enter the trunk alongside of the parent trunk, the combination forming a sort of delta: in the latter they leave the trunk singly, and send off their branches in a radiating direction. At a little distance from the trunks of both artery and vein, the secondary branches become parallel to one another, and perpendicular to their primary branches, the more minute divisions following the same mode of ramification.

"Not having examined the animal when alive, we have no information as to the nature of its blood.

"4. Nervous System.-This system consists, as in other Ascidice, of a ganglion situated in the substance of the mantle, between the oral and anal orifices. It is globular, and sends off nervous twigs, 1. to the respiratory orifice of the mantle ; 2 . to the respiratory sac, where it begins to exhibit the transverse plaits; and, 3, to the anal orifice of the mantle.

"5. Generative System.-The generative organs consist of two elongated tubes, closed at one end, open at the other, and having a great number of close-set parallel cxeca arranged at right angles, and opening into them along each side. These tubes are attached to the internal surface of the mantle; their mouths are free for a short distance, and prominent, the rest of their extent and the attached cæca adherent. The orifices of these organs are situate at the junction of the first with the second quarter of the animal, and one third of the other end of each turns in toward its neighbour, and then proceeds forward parallel to itself. The branchial vein runs midway between the generative tubes above, and the branchial artery in a corresponding course below, so that the threads of attachment of the plaits on the external surface of the sac are fixed into the tubes in a series on each side. 


\section{Anatomy of $P$. corrugata.}

"The structure of this species liffers very little from that of $l$. glulire. The animal being elongated, the organs are placed more longitudinally. The respiratory sac is longer; the stomach is longer, and is not placed so much across the body. The esophagus runs down to the bottom of the sac before it terminates. The rectum is very long, and of considerable width, but just before it terminates in the anus it becomes very much contracted. The mantle exhibits no ridge or shelf below the anal orifice, but its longitudinal fibres are very strong, and form a thick bundle at their origin round the respiratory opening. The test, instead of being thin and diaphanous like parchment, as in $P$. glubre, is thick and cartilaginous, coloured brown, and transversely wrinkled externally.

"From the details of structure which we have now given, it is evident that the Pelonaice are Ascidice. Their anatomy is important, as it explains the nature of the parts and organs in the Tunicutu. They differ from the other Ascidiue more particularly in being bi-lateral. The generative organs are symmetrical, and open one on each side of the anus, which is directed toward the ventral surface of the animal, in a line with the month and nervous ganglion. The latter is thus proved to be an abdominal or sub-cosophageal ganglion, corresponding to, or forming one of the chains of ganglia on the abdominal surface of the Articuluta. In the same manner, the branchial artery or heart is proved to be the pulsating dorsal vessel, and the branchial vein the abdominal vessel (when that ressel exists), in the Annulosa. It is interesting also to perceive, that, co-existing with this decided approach to the annular type of form, we have the transverse plaits of the respiratory sac corresponding to the rings of an articulated animal. The disappearance of a separate test is also a departure from the plan of formation in the Ascidia, and an approach to other types of form, and more particularly to the cirrhograde Echinodermate, with certain of which P'elonerice has at least an analogical relation, in the water-filled body and in the external form.

"Pelonaia, in fine, is one of those connecting genera so valuable as filling up gaps in the system, and supplying links in the chain of structures which runs through the series of organised bodies." 


\section{SALPIDA.}

Very different from the simple, the social, or true compound Ascidians, are the animals of the genus Salpa. They are free, and habitually swim in the waters of the ocean. In form they resemble short but rather wide tubes, often of considerable size. The tube is composed of the test or tunic, semi-cartilaginous or gelatinous in structure, seeming as if carved in crystal, lined with the mantle, which in this tribe is adherent throughout. Each end of the tube is open, often terminating in a conical more or less produced process. Within we find two narrow, oblique, unequal, leaf-like branchire, attached to the anterior and posterior walls of the respiratory cavity. The branchial orifice is protected by a valve. Near one extremity is the principal visceral mass or nucleus, conspicuous owing to the brilliant orange, brown, or reddish hues of the liver. Not unfrequently we find Salpe making their way through the waters deprived of their nuclei by birds or fishes, retaining their vitality for a considerable time, and exercising their muscular powers when the organs of digestion, circulation, and reproduction have been torn away. Peculiar crustaceans make use of the cavity of the Salpa as a dwelling-place and carriage; and the number of minute phosphorescent animals which lodge themselves within it is often so great, as to mislead the observer into the belief that it is the mollusk itself which gives out phosphorescent flashes.

A great interest is attached to the natural history of the Salpa, on account of their singular mode of reproduction, discovered by the German naturalist Chamisso, and the extraordinary generalisation to which that discovery in a great measure gave rise. Previous observers had noticed that these animals were sometimes found solitary, at others 


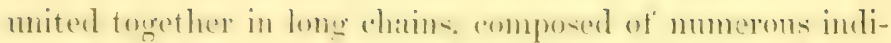
viduals of -imilar form. each an independent being, thomeh constantly associated, and linearly aggregated, with its companions. The lone chains swim thromgh the tranquil water with regular serpentine movements, for the creatures of which they are composerl contract and expand simultaneously, lieeping time, as it were, like a regiment of soldiers upon parade. Each chain seems consequently to be as single being, acting through the influence of an unique will, and hence sailors often look upon it as a reptile, and in many seas the salpa-chains are called sea-serpents. But when taken out of the water, the links of the chain fall asunder, the several distinct animals of which it is composed suddenly losing their power of adhesion. In consequence of accidents, broken-up chains and separated nembers of such communities are not unfrequently met in seas where Salpe are numerous. But other Salpe are also met with very dissimilar in form, and never united together in chains. Now, the discovery of Chamisso was, that such constantly solitary Salpe did not belong to species distinct from those mited in chains, however disimilar, (and they are so dissimilar usually as to appear even generically distinct,) but were either the parents or the progeny, as the case might be, of the aggregate forms; that chaincel sulpee dirl not produce chained sielpa, but solitary selpre, which, in their turu, did not produce solitary beings, but chained. Conserpuently, as Chamisso greaphically observed, "A Sulpee mother is not like its daughter or its own mother, but resembles its sister, its gramdlaughter, and its grandmother." So surprising, so paradoxical an assertion, a statement so contrary to what naturalists fincied to be the larws of nature, could scarcely expect to be received with credulity. Nor was it. 'There was a general outery against it; it was treated as a wild assertion resulting from the incorrect observations of a man with more imagination than judgment. In vain Chamisso offered the most careful researches and minute details of his observations. The heavy-headed in science stigmatised him as a poet and romancer, who 
carried his day-dreams into the world of reality, and thus conjured up his wonderful vision of Salpa. More than twenty years had to pass away before his statements were fairly treated. Men ungifted with the poetic insight which characterised Chamisso, collected and watched Salpre in vain. Working in a spirit of unbelief, they saw what they wished, and what was accordant with their ideas of what ought to be; whereas the poet-naturalist had worked in the spirit of faith, and therefore was unsurprised when he met with facts and phenomena inconsistent with received human knowledge. Working before his time, he was misunderstood; but the time came when not only were his observations proved to be true, but when a great impulse was given to natural history through them. It was the history over again of all great impulses in our science. Linnæus proclaimed the metamorphosis of plants unlistened to; Goethe, more happy in his time, unravelled the same great mystery, and was understood, though not by all. The poetic spirit, working alike in Limnaus and in Goethe, did these things; so also in Chamisso. It required a similar spirit to renew the impulse in the zoological instance, as in the botanical. That spirit has appeared in Steenstrup, the germ of whose theory of the alternation of generations is to be found in Chamisso's discovery of the alternation of generations in the Salpa.**

The recent researches of Krohn on the Salpre of the coast of Sicily fully confirm the statements of Chamisso. Krohn found that every Salpa which came under his observation was viviparous, and that each species propagated itself by an alternate succession of dissimilar generations. One of these generations is represented by isolated, the other by aggregate individuals (forming chains). Each isolated in-

* Chamisso's observations were published in 1819: "De animalibus quibusdam e classe vermium Linnæana, fase. i. de Salpa." We owe to the Ray Society and Mr. Busk an English version of Steenstrup's most interesting treatise.

* Krohn, Observations sur la Génération et le Développenent des Biphores Ann. Sc. Nat., August, 1846.

VOL. I. 
dividual prorluces an aggregate assemblage, and each of the members of such a group produces isolated inclividuals. The members of the one generation are very dissimilar from those of the other; consequently specific names have been doubly multiplied.

'The recently published observations on Salpe by the Norwegian naturalist, Sars, one of the most original and philosophical of living zoologists, have thrown great light on the habits and development of these curious creatures. They are to be found in the first part of his beautiful "Famma littoralis Norwegixe," and should be carefully suclied by the British naturalist who may be fortmate enough to meet with our native species.

Salpe were first observed in the British seas by the (minent geologist, 1)r. Maceulloch. His account of them is given in lis work on the Western Islands, in that part which relates to the natural history of Jura.* It is accompanied by a very rude fignre, insufficient for the determination of the species, but putting the genus beyond question. The description which the doctor there gives is so interesting and original, that we think it right to extract it entire in his own words :-

"Some marine animals occur in these seas which remain still unrecorded in the catalogue of British zoology. Among these, indeed, it is probable that a few will be found still undeseribed hy maturalists, since fresh additions are even yet occasionally made to our catalogue of these obscurer parts of the creation. Many of these animals have occasionally fallen under my notice, but amid pur:uits which rendered it impossible to attend either to their examination or preservation. I have, however, preserved a memorial of one, as it appears to form a new species in a tribe of which no individual has yet been observed within the limits of the British seas. It belongs apparently to the genus Salpa, and the accompanying drawing would be sufficient to distinguish it, even without a specific definition. +

* Western Isles, vol. ii.p. 187.

+ Plate 29. 
"The mode in which the republic is linked together is observed to be constant in each species; and it is sufficiently remarkable in this one to distinguish it from the rest of the genus as far as it is yet described. Each individual adheres to the preceding by a regular sequence of superposition lengthwise, so that the whole forms a long simple chain; the adhesion continuing, as in the ovarium, for some time after hatching. They were found from the middle to the latter end of August, and always linked together. It is probable that their separation takes place at a later season of the year, but I did not observe them in that state. The individual is amongst the most simple in shape of those yet described, presenting an oval-lanceolate and slightly rhomboidal flattened figure, without appendages. The anal opening is of a bright brown and circular, being placed at some distance from the extremity; and when the chain is linked together, all these apertures are directed the same way. The animal is perfectly hyaline and tender, and the adhesion of the chain so slight, that the individuals are easily separated. The act of swimming is known to result from the introduction and emission of water by each ani$\mathrm{mal}$; and as the republic swims together by an undulating motion resembling that of a serpent, the chain often extending to many feet in length, it is evident that this motion must arise from the unequal manner in which the different individuals act throughout the whole line.

"The species now described is most analogous to the $S$. polycre $t$ tica and to the S. confederata of Forskahl. It differs, however, from the former in the want of the caudal denticle, in its hyaline appearance, and in the absence of the rigid portion which attends that one. From the latter it is readily distinguished by its longitudinal concatenation, since, in that species, the individuals adhere by their sides, so as to form a row in a lateral direction, while there are at the same time important differences in the structure of the two.

"I had occasion to remark of this animal, that, like the $M e$ dusce and analogous tribes, it cannot bear to be confined in a limited portion of water, as it died, even in the ship's bucket, in less than half an hour; a very remarkable circumstance in the economy of these imperfect animals.

"Hitherto, this genus is only known as the inhabitant of hot 
climates and of the Mediterranean Sea. I found it in great abundance in the harbours of Camna and Campbeltown, rising to the surface in calm weather, and crowding the water, as the Medusce often do at the same time of the year. It may be called Salpa moniliformis, and defined as follows :-

"S. ovato-lanceolata, ano fusco, absque appendice terminali.

"I was desirous of observing whether this animal, like many other of the marine worms, emitted light, but had no opportunity of ascertaining the fact, as they seemed always to retire to the bottom at sunset, and those which were taken on board died, as I have already observed, in a very short time."

During a voyage round the coast of Scotland, in 1821, Dr. Fleming, who gave a very interesting account of his journey in the "Edinburgh Philosophical Journal," observed Salpe in great numbers on the coast of Caithness. He describes them as occurring abmulantly in spring, when they form chains of a foot and more in length. The separated individuals are about an inch in length, and shaped like a cylinder, with a long conical process at each extremity, the anteal one being rather more produced than the other. 'The nucleus is of a dark brownish-orange colour, and, as well as the branchial band, is distinctly seen through the transparent gelatinons body. The sulpe are gregarious, in company with "Eutimena quadrangularis" (Beroe cucumis). 'I'hey seem, however, to be very ealpricious in their appearance. During three voyages which we have made in the Seottish seas, although eontinually and anxiously on the look-out for these creatures, we have never encountered them. Lately they have been met with, but only occasionally, by Mr. M'Andrew; and Lieutenant Thomas, R.N., has taken them in the Orkneys, and sucreeded in preserving them in both their solitary and aggregate forms. An examination of specimens, lindly communicated by that active officer and observant naturalist, has enabled us to identify them certainly with the Salpa muncincete, which Sars has found so abundantly, and figured so well, from the coast of Norway. The figures we have given 
we have taken from Lientenant Thomas's preserved specimens, guided and corrected by the drawing from the living animal by Sars, whose description we think it best to follow.

\section{Salpa runcinata, Chamisso.}

Chamisso, de Salpa, p. 16, f. 5.—Quoy and Gaimard, Voy. Astrol. Zool. 3, pl. 87, f. 1-5.-Sars, Fauna littoralis Norwegiæ, pl. 8, f. 44, 45, and pl. 9, f. 1-24.

Solitary. State. (Pl. E, fig. 5.) -Body oblong, anterior extremity rounded, posterior truncated, beneath gelatinous and flat, above depressed in front, elevated and cartilaginous behind, where it is furnished with seven keels, gradually disappearing anteally, produced into short spines posteally. Both apertures of the branchial sac terminal. Muscles of respiration nine, placed in the ventral side, three anterior and three posterior, approximated in the middle.

Aggregate State. (Pl. E, fig. 6: the individuals represented are not so elongated as when full grown.)-Body gelatinous, ovate, slightly depressed; beneath plane, above convex, produced at each extremity into a conical acuminated appendage. Orifices of the branchial sac beneath, at the bases of the appendages. MIuscles of respiration (besides those of the apertures) six, placed in the ventral side, four anterior and two posterior, approximated in the middle.

Sars has found another species, which he refers to the Salpa spinosa of Otto, in the Norwegian seas. It will very probably be found also among the Hebrides. The posterior extremity of the solitary individual is furnished with two long straight spines; the aggregate individuals have an ovate body, rounded anteriorly, produced into a short pyramidal cartilaginous spine posteriorly. These characters will enable our naturalists to recognise it.

The preceding enumeration of the British species of Tunicata, though far exceeding in detail any account of them hitherto published, is offered as a mere outline of a 
very extensive and interesting tribe of Mollusea, one so little examined, that the identification of well-linown species with the figures and descriptions of O. F. Miiller, and other authors quoted, is disputed by some of our ablest naturalists. The whole subject has to be re-investigated: the brief notices and slight figures given by the older naturalists are insufficient for accurate determination. Several years must elapse before the task can be undertaken with success. In the mean time this outline may be serviceable. 


\section{ACEPHALA LAMELLIBRANCHIATA.}

Were the test of an Ascidia to be converted into hard shell, symmetrically divided into two plates connected together dorsally by cartilage, and capable of separation so as to expose the mantle along a ventral mesial line, whilst the orifices protruded at one extremity, it would present the closest similarity with many bivalve shell-fish. We pass by a very natural transition from the Ascidians to the Lamellibranchiate Acephala.

This great section of the headless mollusks is so styled, because of the peculiar arrangement of the respiratory organs in the creatures composing it. The branchial leaflets are four in number, usually forming expanded laminæ, arranged in pairs on each side of the main mass of viscera. If the number, as in a fer species, appear fewer than four, it is so by habitual suppression; if more, by reduplication.

This peculiar respiratory apparatus is included within the mantle, but quite free from it. The mantle secretes and is protected by a bivalve shell, the two valves of which are applied to the two sides of the animal. These valves are almost always moveably articulated together at their dorsal edges by a more or less complicated hinge, connected by a more or less developed ligament, and are held close by powerful adductor muscles passing from the inner surface of one valve to that of the opposite, either one or two in number. The edges of the lobes of the mantle are more or less united, and in certain genera and families are free. Its extreme margin, in a great many, is prolonged in the shape of two 
tubes forming the un-ealled siphens, capable of lewing retracted by special muscles. Through one of the tules water is inhaled, through the other ejected. In such of the $L a-$ mellibranchiata as have only one adductor muscle, there are no tubes, and in several of those with two adductors. The mass of the body is placed in the decper and central part of the cavity of the shell, and consists of variously modified digestive, reproductive, and secretory organs, ressels, and nerves. The liver and generative glands constitute the greater part. In a majority of species, a single linguiform muscular orean is developed for locomotion on the ventral side of the viscera. This is the foot. It has been olserved that the development of the nervous and respiratory systems corresponds in degree with that of the locomotive organ. The degree of the development of the nervous system varies much among these bivalves. The principal ganglion (the branchial) is present in all, so are usually two labial ganglia. The presence of a pertal ganglion depends on the presence of a foot. The organs of sense are very variously developed. There are almost always around the mouth, which is to be sought for at the opporite extrenity of the borly from that where the siphons project, more or less developed lips, usually four in number. Ocelli, imperfect organs of sight, are present in the majority of bivalves, and very conspicuous in some genera, arrangerl along the margin of the mantle, or dotting the edges of the siphonal orifices, exactly as in the Asciclia. Minute sacs, with vibrating otolites (rudimentary organs of henring), have been observed in several species, and are possibly present in all. The sexes are either separate or combined. 1ll the lamellibranchiate bivalves molergo an imperfect metanorphosis. They live upon infusorier and microscopic plants. 


\section{PHOLADIDÆ.}

\section{THE PHOLAS TRIBE.}

The first tribe of lamellibranchiate bivalves is that of which the Pholcs is the type. Such an arrangement does not exactly imply that the Pholes and its allies are lower in organisation than all other Conchiferc, but rather that they are among an assemblage of tribes which seem to take their place as it were at the bottom of the table, and to link the Tunicato with the higher mollusks. In many respects a MIyo resembles more nearly an Ascidian, than a Pholas does; but the customary arrangement is most convenient, and not so far from the truth as to call for alteration.

The Pholadide are shelled acephalous mollusks, having more or less elongated bodies, produced posteriorly into a long siphonal tube, divided at its extremity, the orifices being cirrhated. Anteriorly the mantle is closed, except where a small orifice is left for the passage of a clavate and truncate, sometimes nearly obsolete, foot. Other characters are such as belong to the class, or are peculiar to particular genera. The shells are equivalve and inequilateral, always more or less gaping. They have no true hinge, and the ligament is almost or altogether suppressed. Beneath the summit of each valve there is a curved calcareous process.

All the members of this tribe are borers into stone, clay, wood, or other substances. Their habits and history are described under the several genera.

vol. I. 
TEREDO, ADANSON.

Shell glohular or amulula, regular, composed of two equal much-curved polygonal valves, their outer surfaces striated in various directions, the immer surface presenting only one di-tinct muscular impression. No true hinge; ligament obsolete; a curved process beneath the bealis of each valve. No accessory valves at the back of the shell.

Animal rermiform; mantle tubular, slightly open anteriorly; siphons very long, bifureating at their extremities. orifices fringed; a museular ring, into which are inserted two varionsly shaped calcarcous ossicles (pallets), at the pat where the siphons divide; branchias continued into the siphonal tube; foot rudimentary, sucker-shaped.

Tube calcareous, cylindrical, lining the cell in which the animal is lodged.

The genus Terecto is the most abnormal of all the lamellibranchiate bivalves; nor is it to be wondered at that the ancients, and the older writers among the moderns, regarded it as a worm rather than as a mollusk. The resemblance of its tube to that constructed by the Serpula, and the worm-shaped body of the creature itself, naturally suggested the notion that it was an annellid, while even the valves of the shell seemed rather like the jaws of some curions and voracious worm, which, by means of them, eat its way into the planks of ships and piles of harbours, than like the shells familiar to casual observers. The powers of the creature to do mischief aided the prevalent fancy; and the terror which its ravages seem in all ages to have inspired, blinderl the half-instructed naturalists, who curiously examined it, to its true affinities.

'Jlue researches of anitomists during the last and present 
century, however, have made known to us its true organisation, and have proved that it is a true mollusk, and a bivalve, closely allied to the Pholas. The supposed head is now known to be the main part of the body, including all the viscera except a portion of the respiratory organs; the fancied tongue, or sucker, is the foot; the reputed "jaws" are the valves of the shell; the "body" is the main part of" the siphonal tubes; the "tail" their bifurcated extremity; whilst the tube, upon which so much stress was laid, turns ont to be the least important part of the whole creature, and, in fact, a mere appendage. Most "chimœras dire," when thus closely pressed, and forced to dwindle into their true proportions, lose all their ancient terrors; not so with the Teredo. It still pursues its destructive course, ummindful of the scalpel of the naturalist, sinking many a goodly ship, and shaking many a stately pier. With the evil, however, comes good, for it acts as a clearer of the seas, breaking down into small fragments the useless masses of floating timber and fragments of wreck, which might otherwise prove serious and dangerous impediments to navigation.

The abnormal character of the animal of Teredo does not lie merely in its vermiform shape, of which we had a parallel instance in the Ascidian genus Pelonaia, but also in peculiarities of its internal organisation. Thus, whilst in other lamellibranchiate bivalves the gills inclose the intestines and other viscera, in this they are in a great measure placed apart, so that the intestinal sac comes directly into contact with the mantle, whilst the respiratory organs are continued posteriorily, or into the tubes. In this relative pasition of the branchire and the mass of the viscera, we see an affinity with the Tunicata indicated, borne out by the minute structure of the external covering or mantle, which, according to the observations of Frey and Leuck- 
hart, remarkably resembles that of the tunie in the genus Ascidia. The gills themselves are very peculiar, presenting the appearance of long, brown, fleshy cords; so different, inteed, from the usual appearance of those organs, that Sir Everard Home mistook portions of them for male reproductive bodies, and Sellius and Delle Chirji for the ovaria, misled in part by finding the eggs lodged there after protrusion. The true ovarium is a bright white, fatty, cylindrical body, placed in the main mass of the viscera. The heart, as P'rofessor Van Beneden has shewn, is placed quite distinct from the intestine, and is not pierced by the latter. The circulating system is extremely simple. The blood was stated by IIome to be red, but this is denied by recent observers. The month is furnished with labial processes, and internally with a curious cartilaginous club-shaped body, which is peculiar to the Teredo, but may possibly be analogous to the tongue of higher Mollusca. The asophagus is a long thin tube, furnished with a salivary gland; there are two distinct stomachs, one of which is invested with the liver. The foot is very rudimentary, and shaped like a sucker, so that Deshayes, we think wrongly, describes the animal as liaring no foot. The anterior adluctor muscle is strongly developed, and the posterior but slightly, so as to leave scarcely any traces in the shells. The presence of two calcareous styles, called "pallettes" by Adanson, "calamules" by Deshayes, in the muscular ring which surromels the base of the bifureating extremities of the siphons, is a remarliable feature, and, as will he seen in the following descriptions of the species, one of no small importance as a source of specific distinction.

On the ground of the many peculiarities of the anatomy of T'eredo, M. Deshayes has constituted it the type of a distinet fanily. Nerertheless, the relations of this genus 
with Tylophage and Pholas are so evident and close, that we prefer placing it along with them, regarding the differences, however important, rather as such as mark the rapid anamorphoses of organisation exhibited by most outlying families of every order, than as grounds for the establishment of this genus alone as the type of an isolated group.

The Teredo was known to the ancients, though it is difficult to separate the allusions made to it in Greek and Latin authors from those alluding to wood-perforating insects. Aristotle has frequently been quoted as mentioning the Teredo under the name of Tsvogndow, in the ninth book of the "History of Animals;" but the animal there spoken of is evidently some flying vespiform insect. The mention by Theophrastus, of "worms which corrupt wood in the sea," is more likely to refer to our animal. Of Pliny's large-headed Teredo, "which gnaws with teeth, and lives only in the sea," there can be no mistake; nor respecting the allusion to ship-worms by Ovid. The question, whether the Teredo was known to the ancients, was once much discussed, for it was a popular fancy, at the commencement of the last century, that this mollusk had been newly imported into Europe from the Eastern seas-evidently one of those rapid and absurd conclusions every now and then taken up by great bodies of people without ground or inquiry; for, as Deshayes has pointed out, Dutch writers, as long ago as 1580 , complained that the shipworm was damaging Holland. The argument of Deshayes, that the presence of fossil Teredines in the tertiaries of Europe is proof sufficient of their constant presence from antiquity in our seas, is not so sound, although it has been very generally received with favour. For it is now known that numerous Mollusca, identieal with existing species, retired from the seas of Europe in the interval between the mio- 
cene and pliocene epochs, on the one hand, and the present, on the other, not returning until after the close of the glacial period.

The modern history of the Teredo dates chicfly from the coimmeneement of the eighteenth century. In 1715 we fund it alluded to by the celebrated Valisnieri, and, in $1 \% 20$, mistakes were made about it by Deslandes. It attained its mąjority, and came out with great éclat, however, in 1733 , when no fewer than three elaborate treatises on the Teredo were published, by as many authors. In that year Holland was seriously threatened by the boring of our little shell-fish, and Dutchmen by that of its biographers. Strange to say, its history, "civil and natural," was worked out not by zoologists, but by political writers; and with much credit did they execute their task. The investigators were Pierre Massuet, Jean Rousset, and Godfrey Sellius. 'They worked independently of each other. All three were remarkable men, worthy of a passing notice. Massuet was a Belgian, and had been a Benedictine monk, but became a Protestant, and took refuge in Holland, where he studied medicine under Boerhare. Ile was fortumate; for, dividing his time between his patients and his researches, he saved enough to buy a seigneurie and to die rich. He wrote on history and natural philosophy. Rousset began life as a soldier, and quitted the sword for the birch. Ruling school-boys, however, did not satisfy his ambition; he turned politician, and lectured lings and staten. IIe was successful for a time, but, like most politicians, got at length into trouble, and was obliged to conceal limself, which he did effectually, for nobody knows where he died. IJe wrote many worlis, geographical, historical, and political, and edited a translation of "Paradise Lost." He would not have meddled with the T'eredu, but that it took part itself in 
the political prospects of Europe, by undermining the piles and interests of Holland. Sellius was a native of Dantzic, very learned, but very unfortunate. He began life wealthy, but ruined himself by the expenses of his studies and travels. He was versed in all ancient and modern literature, and wrote many learned works on law and history, besides very numerous translations. He was at one time a professor in the university of Gottingen, and afterwards in Halle, but lis difficulties would not let him remain long in one place: he retreated to Paris, and, sad to tell, died mad in the hospital at Charenton. His work on the Teredo, a small quarto of 360 pages, is a most remarkable production. In it all the learuing of the ancients and of the moderns, up to his time, is brought to bear upon the history of the shipworm, or to ornament, by apt quotation, the digressions suggested by his subject. Nearly two hundred authors are cited. More than once, among the many scraps of ancient poetry with which he lightens the tedium of his monograph, he quotes with admiration those lines of Ovid in which the poet makes unquestionable mention of the Teredo; they were singularly applicable to his own history:-

"Estur ut occulta vitiata teredine navis; Equorei scopulos ut cavat unda salis;

Roditur ut scabra positum rubigine ferrum;

Conditus ut tineæ carpitur ore liber:

Sic mea perpetuos curarum pectora morsus, Fine quibus nullo conficiantur, habent.". *

* Ovid. Epist. ex Pont. Lib. 1, Ep. 1.

An imitation, though rude, may not be unacceptable :-

For as the ship by hidden shipworm spoil'd; Or as the rock by briny wavelet mined

Or as the rested sword by rust is soil'd;

Or book unread the tiny moths unbind:

So gnawed and nibbled, without hope of rest,

By cares unceasing, is my tortured breast. 
The essay of Sellins is highly original: it is a very perfect monograph for its time. He was the first to attempt to develope the organiwation, internal and extemal, of the Teredo, and lie illustrated his book with elaborate figures from his own drawings, which, as well as his descriptions, are executed in good faith and with judgment. It must be borne in mind that the nature of the Teredo was entirely misunderstood, and its history lost in obscurity and fable, at the time when Scllins attempted to work out the subject in all its details. No after-writer had equal difficulties to contend with, for he cleared the way. Few monographs on single species are even now attempted to be worked in such elaboration; and the example set by this civil historian, tuming his attention suddenly to a difficult zoological research, is too remarkable an event in malacology to be passed over without full praise. He was the first to hold and prove that the Teredo is a mollusk, thus anticipating $\Lambda$ danson, and shewing more sagacity than Limneus, who long after persisted in placing the ship-worm alongside of the Dentalium and the Serpula. Adanson was not aware of the determination of Sellius; and in his "Natural History of Senegal," (1757,) claims to have arranged the T'redo among bivalve Testacer. With his usual ability he at once recognised both the true nature of the several external parts of the animal, and the true position of the genus alongside of Pholas. The truth of Adanson's view was more completely demonstrated by Cuvier, and tardily admitted by Lamarek. Except in England, where the followers of Linneus forgot the spirit and adhered to the letter of the works of the illustrious Swede-a proceeding most contrary to the example he harl set in his own course-the mollusean nature of $T_{C}$ realo, and its place alongside of Pholas, was everywhere understood, in the early part of the present century. The 
important researches of Sir Everard Home* redeemed us, however, from the slur of neglect of the study of the animal, and were the greatest steps made towards a knowledge of its anatomy. Lately, M. Deshayes has given an elaborately detailed account of its organisation, $\uparrow$ with gorgeous, but often redundant, figures; and an excellent essay, in which full justice is done to the labour's of Sellius on the same subject, has been published by Drs. Frey and Leuckhart.+

The older writers give many details of the habits and ravages of this destructive mollusk. They believed that it ate up the wood into which it bored, a notion which has long been disproved, and which was first opposed by Adanson. How the Teredo bores is a much disputed point even now, and very conflicting opinions have been put forward on this interesting subject, the examination of which it is convenient to defer until we come to treat of kindred mollusks, the Pholades. It is a question of no small importance, in an economic as well as in a physiological point of view. The operations of the Teredo in 1730 threatened to submerge Holland, and, as we have seen, led to the first careful researches into the structure of the animal. Our friend Mr. W. Thompson has given a very full account of its proceedings on the British coast, especially in the harbour of Port Patrick; $§$ and previously Sir Everard Home and Mr. Osler had, in the "Philosophical Transactions," noticed many instances of its destructive power. It does not appear that the kind of wood makes very much difference with the Teredo. Its rule of boring seems to be to follow the grain if possible, though when an impediment comes in

\footnotetext{
* Philosophical Transactions.

$\ddagger$ Beitrage zur Kenntniss Wiebelloser Thiere, 1847 .

$\S$ Edinburgh New Phil. Journ., 1835.

VOL. I. 
the way, it can change its course, and work round the obstacle. 'The tube is the lining of' the tumel in which it lives anml conducts it operations. The destructive character of its work is well illustrated by an instance narrated by Mr. Thompun. I piece of pine wood nine inches in diameter, after having been employed as a pile for five years and a half, was so reduced by the perforations of Teredines, as to contain not more than about an inch of solid timber in any frirt, and in several places was completely bored through. This pole was placed fifteen feet below high water-mark, and left dry only during low water at spring-tides. Montagn remarlis that sound piles will be found completely perforated by Teredines after four or five years submergence. Well might Limneus style it "calamitas navimm!" Remedies and preventives of many linds lave been proposed, most of them various ways of preparing timber. It is doubttul whether any have proved successful, though it lias lately been asserted that creasoted timber is not touchard by the ship-worm. Baster, who published a paper on the sulpecet in the "Philosophical Transaretions" for 1739-40, mentions, that most of the proposed specifics against the Teredo in his day were mercurial; but states they had proved of no use, and recommends varnishing the wood. 'The only efficient protection for piles seems to be the studding of their surface closely with broad-headed nails.

\section{Teredo norvagica, Spengler.}

Valves:-Body or fang-shaped portion of moderate length, not slender and produced; auricle seated on the posterior shoulder, not dilated nor defined externally; internally parted off by a distinct carina; its base scarcely, if at all, lower than that of the projecting front triangle. Subumbonal blade rather wide, presenting its broader surface to the inner disk.

Pallets testaceous, flask-shaped, not forked at the base. 
Tube semi-concamerated at its narrower end; posterior aperture contracted in the middle.

Plate IV. figs. 1-5.

Teredo norvagicus, SPENGLER, Skrivter af Naturhistorie selskabet, (1792) vol.

ii. pt. 1, p. 102 , pl. 2, f. $4,5,6$, B.

, navalis (not of Linnæus, Home, nor Spengler), Montagu, Testac. Brittan. p. 527, and Supplement, p. 7.-TurT. Conch. Diction. p. 183. -Turt. Dithyra Brit. p. 14, pl. 2, f. 1-3.-Fleming, Brit. Anim. p. 454.-Brit. Marine Conch. p. 28.-Brown, Ill. Conch. G. Brit. p. 116, pl. 50, f. 3, 6, 7.-Crovch, Introd. Lam. Conch. pl. 2, f. 10.-Sow er Bx, Genera Shells.-Magaz. Nat. Hist. vol. ii. p. 23, f. 7.-Conch. Systemat. pl. 21.Mawe, Conch. pl. 35.-Lamarck, Anim. s. Vert. ed. 2, vol. vi. p. 38 (not synonyms).-Gould, Invert. Massach. p. 26.Gray, Philosoph. Magaz. 1827, p. 410,-Humphrey's Conch. pl, 10, f. 2, 3.-Sowerby, Conch. Manual, f. 48.-Hanley, Recent Shells, p. 3.-DeraY, New York Moll. p. 34, f. 325.

"Brugieri, Delle Chiaje Memorie, vol. iv. pp. 28, 32, pl. 54, f. 9-12.-

Philippi, Moll. Sicil. vol. i. p. 2, and vol. ii. p. 3.

The united valves of the Teredines have fancifully, and not inaptly, been compared to a helmet, the bodies or middle fang-shaped portions constituting the headpiece, the two trigonal areas of the anterior side composing the crown, and the posterior auricle forming a kind of rude ornament, or support for the crest.

This similitude we have adopted, not alone from its conveying the best idea of the general contour of the valves, but also from its indicating the three extemal component parts, viz. the triangular area or anterior commencement, the body or central unguiform surface, and the auricle or posterior extremity.

The first of these is typically rather large, but varies greatly in relative size, increasing usually with age at the expense of the auricle, which is generally best developed in individuals which have not quite attained to maturity. Its base is not particularly oblique, and displays but little convexity, being nearly, but not quite, rectilinear. The borly, 
although far less lnoad in some individuals than in others, and generally narrower than in the two following species, is never slender and produced, as in bipennata. In specimens which have adranced to maturity under circumstances apparently fincumble to the developement of the matural proportions, the distance from the beaks to the ventral apex deciltedly exceeds that from the angular tip of the triangle to the opposite edge of the auricle. The lower edge of the anterior side is straight, and inclines but very slightly hinderward, forming with the lower posterior one, which slopes (at first somewhat retusely, and then a little convexly) to meet it, a rather blunt but gradually attenuated apex. The auricle, which is never peculiarly large, rarely exereding the size of the front triangle, is always situated high "1) on the posterior side, its base being nearly on the same level with that of the triangular area : the lower posterior margin is consequently longer in proportion than in the two succeeding species. It is ordinarily rather narrow, is more or less ear-shaped, and although usually a little below the level of the beaks, will occasionally be found rising slightly above them; but even in that case no risk is incurred of confounding it with megotara, as the auricle in that species descends likewise far below the base of the triangular area. No abrupt lowering of surface indicates, as in navalis, its anterior commencement; a slight concavity precentes its teminal reflexion. Internally it is sharply defined by a more or less oblique carina, which, although projecting near the beaks a little over the inner dise, neither forms al continuous shelf-like ledge, nor an appressed overlajpling margin. Both dorsil edges are eoneave; the front one is deciledly sloping, and not remarkably abbreviated.

The texture is tolerably firm, and in large specimens even solid; the sufface is rather glossy, and covered, in fine and 
typical specimens, (more so in foreign than in strictly British examples,) with an olivaceous epidermis, beneath which it is equally devoid of colour with the rest of its genus. The front triangular area is concentrically traversed by elevated and rather closely-set striæ, which diverge from the anterior dorsal edge : to these succeed another series of the most crowded and exquisitely engraved lines imaginable, which under a powerful glass exhibit a distinct microscopic subgranular decussation; these latter, uninterrupted by either linear callosity or impressed strix, unite almost at right angles with the former, and occupy a more or less narrow triangular strip of surface, extending from the beaks to the ventral tubercle. Posteriorly these fine lines diverge, and form concentric and rather distant arches, with occasionally intermediate striulæ, which very quickly become obsolete, leaving the hinder side comparatively smooth and destitute of any decided sculpture; there is, nevertheless, a not unfrequent tendency in the surface of the auricle and immediately adjacent parts to rise up in confluent verrucose granules.

Internally, there is a kind of prolongation of the beaks, in the shape of a protuberant callosity, which leans towards the interior, and does not project above the dorsal line; this is terminated in the right valve by a narrow shelf-like rim, and in the left by a projecting and recurved tubercular lamina, which juts out rather obliquely from the posterior side of the callosity. The subumbonal blade is moderately but not peculiarly oblique, and presents its broader side to the imner disc. It is very thin, and rather wide, swelling out a little at its anterior edge, which is simple and not jagged, but usually bending back again near its termination, so that the apex is not broadly clavate, but a little attenuated. The tubercle which terminates the 
ventral edge is very solid, and not broad. The tube is long. slender, tapering, and flexuous, divided at the narrow end by thin. close-set, transverse, circular partitions, ten or twelve in number, which do not oceupy the entire area, but leave a large oval orifice in the middle; the posterior aperture is contracted in the middle. The pallets, or caudal appendages, are somewhat spoon-shaped, being convex on one side, and concave on the other; a rib-like elevation rumning down the centre of the latter projects above it, and forms a slender, cylindrical, and oftentimes flexuous handle opposite to the straightish or slightly convex base.

The length of the valves in our British or Irish specimens rarely excects half, and the breadth four-sevenths of an inch; and tubes exceeding a foot in length are very seldom, if ever, to be met with in our cabinets.

The opinion appears to be prevalent among British naturalists, that the Teredo norvagice was originally of foreign importation, and that, although decidedly naturalised for a season in the harbours of Plymouth and Falmouth, it has at length, through the strenuous exertions of government, become entirely extirpated. Mr. Osler, in the "Philoso-

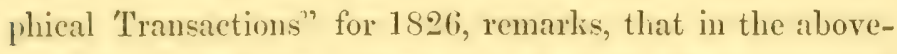
mentioned larbours, where it was once so perniciously alumdant, it is now no longer to be found; and at Devonport the few specimens long ago extracted from one of the piles, are now, from its utter extinction, treasured and exhibited as curiosities. Several of our earlice writers, indeed, (Pulteney, Da Costa, Sc.,) only knew it as obtained from foreign timbers, and consequently regarded it as a doubtful native, and Pennant, who first introduced it into systematic Conchology as an inhabitant of Great Britain, defined it by neither figure nor description. Montagu, however, who described the chanacters from naturalised 
Plymouth examples, and Turton, who furnishes an admirable diagnosis from specimens living in a tree of British oak, regained at Teignmouth after a long immersion, satisfy us by their descriptions that it is not only indigenous, or, at least, long naturalised, but that it is the true $T$. norvagica of Spengler, a fact not ascertainable from the language or the drawings of any of our previous writers upon British Conchology; the delineation in Donovan's "British Shells," vol. v. pl. 145, and that in Pulteney's "Dorset Catalogue, pl. 18, f. 21, being equally suitable to any species of this genus. In truth, the microscopic serutiny, so peculiarly demanded for the valves of this genus, has rarely been bestowed upon them; writers of the Linnæan school, both British and foreign, (with the honourable exception of Spengler,) contenting themselves with classing all the shipworms under the one appellation navalis, describing the tube, but neglecting the more important anterior valves and the characteristic pallets. But whether extinct or not in those spots from which our cabinets were formerly supplied, its devastations are continued to the present day in the little harbour of Port Patrick, on the coast of Wigtonshire, where several of the piles used in the formation of the pier have been materially injured, and some even utterly destroyed. The tubes in this locality had, in some cases, attained the extraordinary length of nearly two feet and a half; and the valves of three-quarters of an inch in diameter. $\mathrm{Mr}$. Thompson, in the interesting paper* from which we have derived our knowledge of this habitat, thus describes them :-

"The greatest diameter of the testaceous tube or case, at the larger end, is seven-eighths of an inch; at the smaller, it varies from one and a half to two lines. All of the spe-

* W. Thompson, in the Edinburgh New Philos. Journal, January, 1835. 
cimens have from one and a half to two inches and upwards of the smaller end of the tule greatly contracted within by lamina, also the partition producing the double aperture extending but a fer lines from the very extremity. The greatest thickness of the shell is at the smaller end, where, at the commencement of the limine, its consistence is from one-twentieth to one-fortieth part of an inch: from this it becomes gradually thimner towards the greater end, which in the very largest specimens is found to be elosed up; but in several others there is no deposition whatever of testa ceous matter for some distance from the termination of the cell. In one perforation, about twenty inches long, the body of the animal has had no testaceons covering for the last three and a half inches; in two other cells, of about two feet, no deposition appears for four and a half and four inches and three-quarter from their termination. All the timber at Portpatrick in which the Teredo had formed its habitation is pine; and perhaps to this circumstance the superior size of the animal may chiefly be attributed. Though it is well known that the Teredo bores ir the direction of the grain, it may be observed that it does so whether the position of the wood be perpendicular or otherwise. Captain Fayrer remarked that it has a decided disposition to work horizontally. It is, however, often obliged to deviate from a straightforward course, to avoid such obstruetions as nails, timber-linots, and the tubes of its fellows, and make a winding or angular habitation, according as such impediments occur; but these circumstances seem not eventually to impede the progress of the animal, as some of the very largest specimens I lave examined are the most tortuous. During the nine or ten years that the Teredo has been established at Portpatrick, it has not degenerated, as specimens just received, which were alive in their native 
element a few days ago, are of equal size to those sent from the same place five years since, shewing that it has not been affected by the cold of the winter season, as we might reasonably expect were the animal truly exotic. If this animal had been originally introduced, and has been preserved only by occasional importations, should we not rather look for it in those ports of the United Kingdom where vessels from every quarter of the globe are congregated, than in the obscure harbour of Portpatrick, which has never been visited by a foreign craft."

That the species is not extinct also in England, was clearly proved during a recent visit to Torquay, when a large stalk of timber, to which the cables of vessels were wont to be attached, having been removed as unsound, a living specimen was extracted from it, and several individuals have since been discovered in the same log, and forwarded to $\mathrm{Mr}$. Hanley by Mrs. Griffiths, with the important information that it was by that species the late destruction of the bridge at Teignmouth had been effected. Almost all our evidence tends to prove that the $T$. norvagica, so far from being an exotic species, imported from warmer climates, and lingering for a few generations in our less congenial waters, is actually more abundant as we proceed northwards, its distribution extending to England and other temperate countries of Europe, where it propagates now at least, even if not strictly indigenous from the most ancient periods. Nevertheless, it must be regarded as one of our rarer shells, the greater number of collections being only provided with individuals taken from ships' timbers and other foreign sources, and very few indeed with specimens derived from the piles of jetties, submerged trees, or other legitimately indigenous habitats. Hence great caution is required in * S. H.

VOL. I. 
the mention of localities; individuals, however, have been taken ly. Mr. Jetheys, near Swansea, in floating wool, of so immature a growth as to render their foreign origin at leat pute-tionable; and others are recorded by Mr. 'Thompson as having been met with at Achill, in the west of Ireland. Dr. 'Turton states "that fragments of a wreck known to have been buried in the ocean for nearly half a century have lately (1822) been dragged up filled with magnificent specimens in their most perfect state."

\section{T. navalis, Linnæus.}

Valves:-Body short, and rounded at its lower extremity; auricle in typical examples projecting laterally, never dorsally, externally defined by the abrupt sinking of the level of its surface, internally by a broad overlapping margin, which is more or less appressed.

Pallets small, testaceous, forked, and very solid at the base; stalk cylindrical.

Tube simple, strong, not chambered at its narrow end.

Plate. IV. figs. 7, 8, and Plate XVIII. figs. 3, 4.

Beschreibung Holländischen, See oder Pfahl-Wurms, (Nurnberg, 1733,) plate 3, f. 19, 20.-Rousset, Observations sur les Vers de Mer, pp. 15, 16, 17, f. 1, 2, 3, 4, 10.-Ditto, English Translat., (1733,) pp. 13, 14, figs. 1, 2, 3, 4, 10.

-Bexкmeer, Natuur-kundige Verhandel. Zee Worm, pl. 2, f. \%, 8, 9.Selduus, Ilist. Nat. Teredin. pl. 2, f. 2, 3, 6.

Teredo naralis, Linv. Syst. Nat., ed. 12, p. 1267 (not of British authors).II ome, Phil. Trans. 1806, pl. I2, f. 7, 8, 9, 10.-ChidJE Mcmorie, vol. iv. pp. 23, 32, pl. 54, f. 2, 8.-P'Hulpr, Moll. Sicil. vol i. p. 2, and vol. ii. p. 3.

"Batara, Spengler, Skrivt. Naturhist. Selskab. (1792), vol. ii. pt. 1, p. 103, pl. 2, fig. C.

'The widely overlapping margin of the auricle, as viewerl intermally, readily distinguishes the true navalis of Linnitus, from that erroneously regarded as it by the earlier British conchologists; a mistake which we are enabled to rectify, not only by a careful comparison of the Teredines with the figures of Sellius, on whose iconography the spe- 
cies, inadequately defined by the language of its author, and only specifically limited by his references to the engravings of that author and of Vallisnieri, the latter irrecognisable, depends, but also by personal examination of the examples still preserved in the cabinet of the illustrious Swede.

The casque-shaped valves (as well as the tube and pallets) are of an uniform white; the sculpture of the former exhibits no peculiar features, the front triangular area being finely and rather closely lyrated concentrically; the succeeding, oblique, and crowded strix, which run parallel to the lower anterior edge, and subrectangularly to the lyræ, being minutely decussated, or even subgranulated, and the remainder of the surface comparatively smooth, although, in some of the younger examples, the strix of growth are so developed, as almost to give a finely plicated appearance to that portion of the shell.

The front triangular area is in general rather large, abruptly severed, as it were, from the body by a more or less impressed line, and having its base more convex than in the succeeding or preceding species, not particularly oblique, and always much above the level of that of the auricle. The lower anterior erge slopes a little backwards, and forms a rounded point with the short and somewhat arcuated lower margin of the hinder side. The auricle, whose commencement is easily perceived by the abrupt sinking of the level, is of a moderate size, somewhat pear-shaped internally, laterally and never dorsally projecting, and in typical examples seated low down, so that the general inclination of the posterior hinge margin is more sloping than in most of the known Teredines. Its lower edge is more or less arched; its upper, whether it runs retusely, straightly, or more rarely convexly to the beaks, forms an uninterrupted line with the 
dorsal margin, and is never seemingly truncated in front by any abrupt ascension of the dorsal margin. Its anterior limit is most distinctly indicated internally by a loroad and appressed rim, which overlaps the edge of the body or medial portion of the valves. This latter is never greatly elongeaterl, the breadth and length of the valves being frequently equal to each other.

The subumbonal blade, or tooth-like apophysis, is thin, broad, arched, and nearly of equal breadth throughout, neither being clavate nor much attenuated at its termination, nor jarged along its erlge, which runs nearly parallel to the lower front, and presents its sharp and not its broader surface to the inner disc. The cardinal denticle and lunate rim, and likewise the ventral tubercle, do not appear to differ much firom those of Jorecrica. The pallets, or caudal appendages, are each composed of a thick, suboval, shelly plate, bifurcated at its extremity, and seated upon a slender and more or less short, flexuous, cylindrical stalk. 'This plate is flat upon one side, and convex upon the other, but devoid of any central rib.

The tulce or sheath is long, flexuous, tapering, and devoid of internal concameration; it is usually rather solid.

We are not aware that this has hitherto been published as british, although individuals may exist in some of the less noted collections, mixed up with those of Norvagica. The only locality we know, is in the piles of the pier at Herne Bay, from whence Mr. Hanley took them, along with their animals, about four years ago. The tubes were about eight inches long, and about one-sixth of an inch in diameter at their broader extremity. 'The valves dirl not ("ven those which wore the alpeneance of age) very much exceed a quarter of an inch, which latter measurement was the full length of the caudal appendages. 
3. T. megotara, * Hanley.

Valves rather short, rapidly diminishing to a moderately attenuated extremity; auricles very large, rising dorsally above the level of the beaks, and extending ventrally far below the base of the triangular area, concave near the body, strongly reflected at their extremities, not marginated intermally, nor abruptly defined externally.

Pallets nearly resembling those of $T$. Norvagica.

Tube simple, not concamerated posteriorly.

Plate IV. fig. 6, and Plate XVIII. figs. 1, 2.

Teredo nana, Turt. Dithyr. Brit. p. 16, pl. 2, f. 6, 7.-Fuem. Brit. Anim. p. 455.

-Brit. Marine Conch. p. 29.-Brown, Ill. Conch. G. B. p. 116, pl. 50, f. 14, 15.-Grax, Philosoph. Magaz. (1827,) p. 410.-

Hant. Recent Shells, p. 4, suppl. pl. 11, f. 23, 24 (copied from Turton).

" navalis, Cuvier, Règne Animal, ed. gr., pl. 114, f. 2.

It is with reluctance that we have changed the name of this beautiful and comparatively large species, from the prior, but very inappropriate name of $T$. nan $\alpha$, bestowed upon its young by the late Dr. Turton, whose specimens were so small and imperfect, that nothing but actual comparison of them with a series commencing with perfect individuals of a similar size, could have proved their identity with the magnificent examples from whence our drawings and descriptions have been derived. So broken were they, that their most characteristic feature, the ample auricles, were denied to them in the body of his work, (Conchylia Dithyra, p. 16 ;) this statement is, however, corrected in the Addenda.

The entire surface of the valves is of an ivory-white, and often highly polished. The triangular area, or anterior extremity, which is not severed from the body by any impressed line, is marked, as in the other Teredines, with

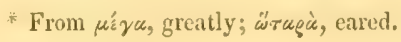


elevated concentric approximate lines, which are more closely set as they recede from the apex of the valves; the slightly raisect. narrow, ray-like strip, which slirts the lower half of the anterior side, passing upwards to the beaks, is likewise erowded with very delicate elevated oblique lines, decussated (though searcely so closely as in Sorcurica) with microscopic striula. Behind these, another narrow ray-lilie space appears, extending from the beals to the most projecting part of the ventral margin, and usually lying about the middle of the valyes. This area is rather distantly traversed, in a concentric direction, by arched and imbricated elevated strie, and obsoletely and radiatingly subdivided by the hinder portion being distinetly concave. and the front rendered slightly duller in surface, from the intervals of the strix being filled up in the adult with microscopic striulæ. The remaining or posterior surface, which is smooth and glossy, but sometimes traversed by remote and obsolete lines of growth, is again convex, the gradual cessation of which convexity marks the commencement of the auricle, which is not otherwise externally defined, and is only so internally by its immediate reflexion, and the previous thicliening of the body or middle part of the valves at that point; there being neither carination present, nor the slightest appearance of an overlapping margin. 'The extraordinary development of the auricle is evidently the typical chameteristic of the species. Decidedly reflected at its outer extremity, its surfice, in consequence, is retuse or concave; its margin, arching out latcrally in one uninterrupted sweep from its base to its summit, towers a little above the beaks, and being met, not far from them, by the short, ascending, and derply incurved dorsal edge, seems retusely subtruncated near its highest elevation. It thus projects both laterally 
and dorsally, and (in the adult, at least) occupies more than one-half of the posterior side. The front triangular area is small, and acutely pointed; its base, which is peculiarly straight and oblique, lying much above the level of that of the auricle. The front dorsal line is very short, and scarcely, if at all, declining; the lower anterior edge is rectilinear, and rarely inclining inwards to meet the more or less convex and rapidly sloping margin of the posterior side, with which it forms a somewhat rounded point.

The subumbonal blade is so placed as to present its broader surface to the inner dise; it is narrow, not particularly elongated, tapering, and not at all jagged at the edge. The callosity of the hinge-margin is well developed, projects above the dorsal level, and slants with a strong posteriorward inclination : the ventral callosity is solid and prominent, but not widely expanded.

The pallets, which, like those of Norvagica, resemble the shape of a battledore, approach so nearly to those of that species, as with difficulty to be distinguished, except by direct comparison. We may then perceive that the handle or stalk is much less elongated in proportion, and tapers to a fine point at its apex, (in the other it is blunt at its termination, and solid throughout.) In the only five specimens of this portion which we have hitherto seen, and which, not being above a quarter of an inch long, we cannot pronounce adult, the position of the stalk upon the interior surface of the broader terminal plate is most distinctly manifested throughout, and externally there is a ristinct groove on either side of it at its insertion in the plate. The latter, which is somewhat abbreviated in form, has its sides curling inwards, somewhat in the fashion of those of malleolus, (the stalk is, however, not bent as in that rare species; ) and, although the base is almost straight, 
there is rather a large triangular depressed hasal surfaed, and in the younge, a small. but deep inemration in the middle.

The tubes are strong, and without concameration.

The finest specimens we have ever met with were obtained ly Mr. Inanley from timber. which, having formed a portion of the piles of the pier at IIerne Bay, in Kent, had been removed in consequence of its destruction by these animals. One tube was nearly half a yard in length, and the valves rather more than half an inch in diameter in each direction, their length and breatth being nearly equal. The locality mentioned by 'Turton is simply " wood in Torbay:" to this may be added,- - from wood drifted on shore at Exmouth. (Clink;) from drifted wood in Swansea Bay, (Jetfreys;) and from some stalies near the jetty at Broadstairs, (Metcalfe.)

Species not proved to be of British origin.

4. T. mipennata, Turton.

Valves with the body or medial portion narrow and elongated. Auricle typically projecting higher than the beaks: its upper inter11al eilge most strongly reflected ontwards; the lower internal edge scarcely sloping, and projecting shelf-fashion over the body. 'Triangular area extending as low down as the auricle, not large, its outer edge very oblique; tooth-like apophysis greatly slanting posteriorwards. Pallets very large, quill-shaped, of a spongy texture.

Plate IV. figs. 9, 10, 11.

Teredo bipennata, Turton, Conch. Dictionary, p. 184, f. 38, 39, 40.-Turт. Dithyra. Britann. p. ]5.-Flem. Brit. Anim. p. 454; Brit. Marine Conch. p. 28.- Brown, Ill. Conch. G. Brit. p. 116. —Gray, Philosoph. Magaz. (1827,) p. 411. - Hanley, 11l. and Dese. Cat. Recent Sh. p. 4; suppl. pl. 9, f. 51.

"navalis (2), Speng. Skrivt. af Naturhis. Selsk. vol. ii.pt. 1, pl. 2, f. 1, 2, 3, A.

'The indigenousness of this very interesting ship-worm is ly no metms sati-factorily establisherl, althongh, from its beinge frequently foum alive in floating wood. it is by no 
means improbable that it may have established itself equally with the two preceding in the timber of our jetties, \&c.; unfortunately, too many who have the opportunities of taling these animals upon the renewal of the piles, satisfy their curiosity by preserving merely the perforated wood, or the testaceous tubes, leaving us still in doubt by what species the cavities have been effected. It is with some little hesitation, then, that we include this and the succeeding in our Fauna, which we are induced to do, rather from the example of preceding writers, and the fact that they are not noticed in any known continental work as natives of another country, than from any positive proof of strict naturalisation.

The shape of the valves is very different from that of Norvagica or Batava, the medial portion being decidedly more elongated, and the lower end of the auricle slightly more remote from the ventral tubercle than is that of the front triangle. This latter occupies less than two-fifths of an imaginary line drawn from the beaks to the base of the shell, and is concentrically traversed by raised strix, or narrow lyrx, which are moderately close-set, and not much arcuated below, but more distant and more curved towards the commencement of the series. These are succeeded by another set of minutely decussated striæ, which occupy the narrow strip situated between the lateral triangle and the internal radiating groove, and are produced thence along the front margin of the shell. Then follows a still narrower strip, which, together with the preceding, is elevater towards the beaks above the remainder of the surface, covered with very oblique, distant, raised, concentric striulæ, often with finer intermediate ones, which, after passing the central, shallow, groove-like, radiating area, are more or less distinctly continued over the remainder of the VOL. I. 
surface as far as the auricle. This latter, which is smooth, small, and ear-shaped, projects at its upper part above the summit of the leak, and is internally cut off as it were from the body of the shell by its lower edge, which almost straight, and scaredy declining. projects like a ledge over the subumbonal region. Its basal line is thus almost at right angles to the hinder margin, whilst its much areuated posterior outline runs nearly parallel to the base of the lateral triangle. This ear-shaped alpendage is also most strongly reflected outwards, and is internally rather closely groored with concentric costella ; its hinder termination is attenuately rounded, and its front extremity is in the adult concavely, in the young subrectilinearly, more or less obliquely subtruncated.

The entire shell is white, and faintly glos:y ; there is an extremely oblinue lamina surmounted by a tooth-like process upon the hinge margin, ruming at acute angles to the very oblique and flat subumbonal blade, which latter is clavate, and in the most perfect specimens we have met with either tuberenlated or jagged at its edge near its termination. Both the posterior and anterior edges of the ralves, which are inclined to soliclity, are rectilinear, the front being nearly perpendicular, the hinder much more oblique; lout in the young these sides are rather more parallel, and the central, or linguiform portion of the shell, much more narrow. The ventral apex is narrow, but not acute, and its internal tubercle rather broad and compressed. The pallets are very curious, and of a sponge-like look and colour. They are remarkably large, in some measure resemble a quill in shape, are usually more or less curved, and have their stalk or unbarbed portion most minutely tuberculated. The upper portion, which is usually about one laalf of the entire length, and even at its broarlest part 
searcely wider than the stalk, is closely articulated; the upper and concave edge of each joint terminating at either extremity in an ascending filament, is adorned on one side with a very fine fringe of similar, but more minute filaments. The joints towards the extremity appear in the few specimens we have seen, to lose their lateral filament, and the concavity of the upper edges so increases as to form a decided angle near their middle.

The tube, which we have not seen ourselves, is declared by Dr. Turton to be thicker and stronger than that of Norvagica, and simple at its outer orifice; and by $\mathrm{Mr}$. Gray, in the Annals of Philosophy for 1827, to be not concamerated. The diameter of the valves from whence our description was drawn up, is about four-sevenths of an inch, whilst the pallets are actually three inches in length, and about two lines broad at the widest part. These dimensious, however, especially that of the pallet, are greatly exceeder in the Sumatran examples, from whence we may reasonably conclude that that country is in all probability its native habitat. Specimens are extremely rare; those of Dr. Turton, are recorded by him to have been taken from a piece of fir timber, which, covered with Anatifa lavis, had been drifted into the river Ex. Mr. Bean writes us word that he has met with it on the coast of Scarborough ; and Mr. Thompson informs us that he has only acquired his from wood washed upon shore at Youghal, and at Miltown Malbay in Clare, at the former of which places it was found by Mr. R. Ball, and at the latter by Mr. Harvey. Valves marked "Waterford" are likewise to be seen in a collection formed by Mr. Humphreys, of Cork, and now in the possession of Mr. Jeffreys. The British Museum, and the extensive collection of Mr. Metcalfe, equally inclurle it; the specimens of the former were taken by Mr. Bulwer 
from drifted wood in the British Channel. Mr. Bean, of Scarborough, has taken it alive from a plank of oak.

\section{T. malleolus, Turton.}

Valves similar to those of bipennata.

Pallets testaceous, consisting of a mallet-shaped plate, or a more or less expanded, thin, incurved lamina surmounting, at an obtuse angle, a short and filiform stalk.

Plate I. Figs. 12, 13, 14.

Tercdo malleolus, Turtox; Dithy. Brit. p. 255, pl. 2, f. 19.-Brown, Illus. Conch. G. Brit. p. 116, pl. 50, f. 16.-Fuex. Brit. Anim. p. 454.-Brit. Mar. Conch. p. 28.-Gray, Philosoph. Magaz. 1827 , p. 410.-Hanlex, Des. and Ill. Cat. Recent Sh. p. 4, suppl. pl. 11, f. 25 (copied from Turton).

The valves of this very rare Teredo, are so precisely similar to those of bipennate, that it has been conjectured that Turton fabricated this species from the young anterior appendages of that shell, and some distorted tail plates of Nurcagica. An examination of the interesting collection of Mrs.Griffith of Torquay, disproves this erroneous impression, as that lady possesses several specimens with the valves and pallets united by the shrivelled animals. The few individuals we have been enabled to inspect, and which possibly may not be adult, although several exhibited all the indications of maturity, only appear to differ from bipennata in respect to their valves, by being invariably much smaller, with their auricle less developed, and running in a concave line above, almost on a level with the apices of the beaks; internally, too, it does not seem plicated or scarcely so, and is much excavated and but little reflected ontwards. The external surface is smooth posteriorly, and the subumbonal tooth-like apophysis, is typically most strongly clavate at its termination. The pallet, which is white and of a testaceous suljstance, frequently, but not necessarily, bears a consider- 
able likeness to a mallet, from which resemblance the name malleolus is derived. It consists of a thin plate or lamina, varying much in shape, but always laterally enlarging towards its base, and more or less angular above. From the upper portion of it springs a short, compressed, filiform stalk, which rises centrally about an equal distance from the angle, to that of the latter from the basal termination of the lamina. This stalk is not in the same plane with the plate, but forms a more or less obtuse angle with it, an important character for distinguishing it from all the stages of growth in the caudal appendage of Norvagica. The two sides which form the angle of the lamina, are usually in the younger and more symmetrical examples (for the pallets of the Teredines vary with their growth), much incurved near the stalk, and bowed out as they recede from it; the basal line appears sinuous and not rectilinear, in some specimens being incurved in the middle, and convex or arcuated at one or both extremities; in others, swollen in the centre, and concave at the extremities. The sides of the lamina bend towards the more concave area. The tube is stated by Dr. Turton to be composed of a slight testaceous deposit on the inside of the chamber it has excavated, the terminal portion of which is slightly semi-concamerated.

We cannot regard this species as strictly indigenous, since hitherto it has been almost exclusively extracted from foreign wrecks or floating timber from uncertain localities. The native habitat is Sumatra, (so prolific in Teredines,) and it is by no means probable that a species from so warm a climate should ever become naturalised in our less genial waters. The original describer of malleolus, obtained it from a piece of spar supposed to have formed part of the Venerable man-of-war which was drifted into Torquay during the prevalence of some heavy gales, that vessel having' 
been wrecked in Torbay about fifteen years previously. 'The other anthors we have eited have evidently solely derived their knowledge of it from the Conchylia Dithyja of I)r. Turton. We are acquainted only with four collections which contain it, that of Mrs. Griffith, who similarly procured it from Torquay; the original types now in the cabinet of Mr. Jeftreys, some very fine ones, without any indicated halbitat, which, formerly in the possession of the Rev. F. Stainforth, now belong to Mr. Metcalfe, of Lincoln's-im, and some decidedly exotic ones in our National Museum.

\section{6. 'I. palmulata, Lamarck.}

Valves similar to those of Navalis.

Pallets small, in shape resembling a short stalk of barley ; their stem short and filiform, their broader end pinnately articulated and compressed.

Flate II. figs. 9, 10, 11.

Turet de Pondicherry, Adanson, Acad. Roy. des Sciences, 1759, p. 276, pl. 9, f. 11,12 .

Terelo palmulutu, Lasarck, Anim. s. Vert. ed. 2, vol. vi. p. 33.-Gray, Philosoph. Magaz. 1827, p. 410.-Cuvier, Règne Anim. (ed. Henders.) pl. 40, f. 8.-HANLEY, Recent Shells, p. 4, suppl. pl. 11, f. 13 (copied from Blainv.) - Phinippi, Moll. Sicil. vol. i. p. 2 , pl. 1, f. 8 , and vol. ii. p. 3 ?

"Lipalmulata, Delle Chiaje Memorie, vol. iv. p. 28, pl. 54, f. 18, 22, 23, 24.-Thompson in Annals N. Hist. October, 1847, (corrected from ' $\mathrm{T}$. malleolus in the September number).

Turet bipulmulé, Bratsville, Man. Malacolog. pl. 80, bis, f. 8 (copied from Adanson).-Griffiti's Anim. K. vol. 12. pl. 7. f. 5 (pallet).

So closely do the valves of this species resemble those of nacalis, not merely in general aspect but in separate features, that it is almost imponsible to distinguish it from the latter, excepting hy the aid of its characteristic pallets. Their surface, however, appears of scarcely so pure and glossy a white, and the overlapping internal edge of the auricle is not so elosely appressed, but a little elevated. 
This ear-shaped appendage varies in its outlines similarly to navalis, rising, in the adult, above the dorsal line, and, in the immature shells, sinking far below the level of the beaks, owing to the then greatly declining curve of the dorsal edge.

There is one fact with regard to the shipworms which has rendered their investigation peculiarly laborious, namely, that no reliance can be placed upon the relative proportions of their several parts for specific definition. If we take at random about fifty valves of norvagica for instance, we shall find that in some the oblique decussated strix occupy twice the space of the succecling strip, in others this is reversed, in many these are both contracted, and a large posterior smooth area is exhibited; in other's again, almost the entire surface is occupied by the two former, to the great diminution of the hinder portion. Hence it is absolutely necessary to examine very numerous examples, in order to elicit the real and permanent specific characters, and the valves alone are rarely adequate for the determination of the species.

The pallets, which are extremely fragile, and never attain to any considerable dimensions, closely resemble diminutive specimens of those of bipennatr. They vary much with age and circumstances in regard to the number of articulations, their closeness or laxity of approach to cach other, and even in their individual shapes. In the smaller specimens, (and almost all hitherto taken in our seas belong to this class, not exceeding half an inch in length,) the stem resembles a piece of fine thread, and is about equally long with the broader pinnated portion which surmounts it. This latter is composed of numerous somewhat triangular pieces, of which the narrower end is jointed as it were to the broader opposite extrenity of the preceding one, which 
is more or less deeply incurved in the middle, and has, in consequenee, its lateral terminations more or less strongly forked. The basal articulation is often peeuliarly graceful in shape, the lateral outline being formed by two convex lines of corresponding curve on either side. The number of these joints may average about a dozen, some apparently having only eight distinet ones, whilst others (chiefly the larger) have nearly twice that number. The articulated portion is usually about three times as broad as the stalk, and tapers towards its termination, where the joints likewise are smaller and more closely set. In the larger pallets, where the articulations are more remote from each other, their forked extremities, instead of embracing (as in the young) the succeeding joint, project on either side beyond the narrow bases, so as to cause the lateral edges to appear serrated; in certain specimens where the joints are peculiarly distant, and their subtrigonal forms have become in consequence less distinct, these forked terminations are produced in narrow filaments, and the central concavities are clothed with a more or less fringed membrane, which in some measure conceals the depth of incurvation. So various then are the aspects of both the pallets and the valves of this interesting Teredo, that nothing but the long suite of specimens in various stages of growth which we have had the good fortme to inspect and mutually compare, conld have enabled us to detect their specific identity. None of the valves we have hitherto seen at all equal the dimensions of our three first species, and the longest pallet was under two inches in length. Those which have been delineated in our plates, are very young, and are some of a large numbere extracted by Mr. Thompson, in Ireland, from the timbers of a resisel retumed from a foreign voyage. Some fincer ones are in Mr. Jeffrey's collection, taken by Mr. Clark, at 
Exmouth, and others in Mr. Hanley's cabinet, which he procured from ship-timber at Bristol. Strictly speaking then, this ought not to be included in our Fauna, as we have no evidence of its propagation in this country. The terminal portion of the tube was concamerated in the wood which accompanied Mr. Clark's examples; we confess, however, we perceived no indication of such structure in the very small perforations of the Irish specimens; in both the testaceous matter was sparingly deposited.

\section{XYLOPHAGA, Turton.}

Shell globular, closed posteriorly, much and angularly open anteriorly, composed of two equal, much-curved, anteriorly emarginate valves, their outer surfaces divided into various ornamented and smooth portions, the inner strengthened by a strong longitudinal rib or apopliysis running from beak to ventral margin; muscular impressions two, posterior large, round, anterior small, submarginal. A single distinct and curved denticle beneath, but not under, the beak. Back of the shell anteriorly furnished with two (complicated) accessory valves. No tube.

The animal of our British species, according to a note kindly communicated by the Rev. David Landsborough, is, with the exception of the siphons, entirely included within the shell. The foot is large, and pillar-shaped; its extremity tinged with buff. It occupies the greater part of the anterior opening, and may be protruded to some length. The margin of the mantle around it appears to be plicated. The rest of the animal is white. The siphons are very extensible; sometimes assuming a length of three-quarters of an inch, more usually resting at about the third of those dimensions. Such an animal has evidently much closer VOL. I. 
affinity with Pholes than with Teredo, though at first glance the shell bears most resemblance to the latter. The tertiary fossil genus, Joucunttia, is in some respects intermediate between Terulo and Tylophaga, of which no extinct species are known.

\section{Xylopilaga Donsalis, Turton.}

Plate II. figs. 3, 4 .

Teredo dorsalis, TurT. Conch. Diction. p. 185 , (erroneously as to tube) ; Dithyr. Brit. p. 16, pl. 2, f. 4,5 .

Sylophaga, TurT. Dithyra Brit. p. 253.-Fuen. Brit. Anim. p. 455.-Brit. Marine Conch. p. 32.-Annals of Nat. Hist. Septem. 1847.Brown, Ill. Conch. G. B. p. 117, pl. 50, f. 8 to 13.-Sowenzy, Genera Shells.-Reeve, Conch. Syst. vol. i. pl. 22.Sow. Conch. Manual, f. 50,51,-Hanl. Recent Shells, p. 10, supp. pl. 11, f, 21, 22 .

Pholas xylophaga, Desur. Lam. Anim. s. Vert. ed. 2, rol. vi. p. 47. Xylophage dorsal. Crievu. Traité Elem. p. 40. f. 122, 123.

$\Lambda$ hasty glance at this interesting and uncommon shell would induce us to place it with Teredo, and the elosing of its posterior side, where there is not the slightest gape, will probably be the first differential point to attract our attention to its generic as well as specific distinctness. The general shape (allowing for the subrectangular incision at the anterior side) is subrotund, the distance from the extreme points of the front and hinder margins being at least equal to that fiom the umbo to the opposite edge. The texture is remarkably fragile, devoid of colour, and but little glossy, even when the specimens are fresh. The valves are tumid, but not quite hemispherieal, and strengthened internally by a narrow, but strong, prominent, somewhat jointed rib, which, running perpendicularly from the umbo to the ventral margin, divides the shell into two very unequal portions, the hinder being thrice the bigness of the anterior one. The surface is externally marked with two 
nearly vertical, slightly-diverging, approximate costeller, which radiate from the anterior side of the umbones to the greatly arcuated ventral margin, and vary greatly in size and elevation in different examples. The hinder is, however, invariably the most distinct, the anterior one being, in some specimens, almost entirely obsolete. The narrow space between them is usually depressed; which is also not unfrequently the case with that portion of the shell which immediately succeeds the posterior rib. The perfect smoothness of the general surface is relieved by the fine and crowded elevated lines which striate the front triangular area and the strip which lies between that and the anterior costella; those of the former (whose base is scarcely convex, and but little oblique) are concentric, and closely set; those of the latter, which are delicate, crowded, and not at all crenulated (as in the Teredines), run obliquely downwards, diverging slightly as they advance. The umbones are broad, and very promineut. The dorsal edge, which is scarcely at all sloping, is very short, and reflected in front, and nearly straight (but, in the young, tumid) behind. The posterior side is simply and exactly rounded in the young; but in fine specimens is slightly subangulated at the upper extremity. The rectilinear lower margin of the anterior side, (which, as in Teredo, is furnished with a subrectangular incision, leaving a triangular area near the beaks,) contrary to its direction in that genus, is nearly vertical, almost forming a rectangle with the ascending ventral, which latter being more tumid posteriorly, renders the contour of the valves a little oblique. The hinge margin presents a single, distinct, and curved, tusklike denticle, just beneath the beaks, which, springing from beneath the margin in one valve, leans over to the opposite one.

The accessory plates, which, however, are rarely present 
in cabinet specimens, being very easily detached, are rather complicated in structure, and are situated dorsally in front of the shell. They are two in number, covered with a yellow skin, and nearly smooth; their surface, except centrally, is a little depressed; in form they remind us of the single valves, examined laterally, of that common exotic shell, the Curdium cardissa. They are not simple plates, or Iamine, as in most of the Pholades, but double; the edge where they fold forming an acute carina, from the intensity of the compression. Each, examined separately and externally, may be likened to a short wing; the two longer sides, of which the more produced is arcuated, and the other retuse or incurved, forming a more or less acute or obtuse point at their junction. The posterior extremity, or beak, as it were, resembles the outer angles of a quarter of a circle, beneath which, internally, is a very sharp, toothlike projection. In front of this the inner margin, which at this point is not greatly compresserl, and adipts itself to the shape of the reflected front dorsal edges of the shell, is most strongly incurver, again swelling out, however, near its front extremity, a little beyond the line of the corresponding external edge.

Like the Teredines, it penetrates wood which has been immersed for any considerable period in salt water; wherein it forms for itself an oval receptacle, or cavity, having a small and single extemal orifice, and nowhere lined with any shelly deposition.

The original types were procured by Dr. Turton from the fragments of a wreck known to have been submerged for nearly fifty years off Berry Head, near the entrance of Torbay; other specimens have been taken by Mr. Clark off Exmonth in floating timber. It is oceasionally obtained at 'scarborough (Bean); Mr. M'Andrew has taken it in 
Loch Fyne; but our cabinets have hitherto been chiefly supplied from Ireland ("Ringsend in Dublin Bay, Waterford, and Bantry Bay," Thompson and Humphreys) : a new and prolific habitat has just been communicated by Mr. Thompson, in the September number of the "Annals of Natural History for 1847."

"Early in the month of May last, Major Martin of Ardrossan, in Ayrshire-a gentleman well known as a lover of natural history, and as a successful collector of objects of zoological and botanical interest-sent me a piece of wood perforated by the $\boldsymbol{X}$ ylophaga dorsalis, and labelled as from the dock-gates, Ardrossan. Not having before heard of this animal attacking the fixed timber of our harbours (it has been found in drift-wood, or portions of vessels cast ashore), I made immediate inquiry respecting it. The piece of wood sent was a portion of the dock-gates. The Tylophaga has been known to be consuming them since the docks were opened in March, 18t4. It has been known for a very considerable time along this coast, where there is no fresh water. It attacks timber of all kinds: for instance, the wooden pier (the supporters of which are nearly destroyed) and other timbers that are under water about the quays, and have been placed there without any preservative coating. It appears to prefer black birch to any other timber, but does not like African or American oak. The only successful preventive made use of for preserving the dock-gates against the Teredo, Xylophaga, \&ce, is Muntz's patent yellow metal sheathing, which is put on to the height of thirteen feet; it lasts for ten or twelve years. The timber that is perforated is always covered by water. The depth of water in the docks is from sixteen to eighteen feet. It may give some idea of the frequency of the Tylophaga's perforations in the different pieces of wood, to mention, 
that on an average at least one-half is occupied by its burrows. The Iylophaga has never, lilie the Terdo, been observed by my correspondent to form a testaceous tube, or lining to its cell. Many of the chambers of the Iylophaga befiore me are one inch and a half in length, thus exceeding by one-half the longest noticed by Turton. The shells of my largest specimens are $5 \frac{1}{2}$ lines in length: the two valves joined at the hinge occupy a space of $5 \frac{1}{2}$ lines in diameter. This species differs from Tcredo nuvalis (Turton), by boring anainst the grain of the wood (all of which is pine), in a diagonal manner."

Liven enumerates Tylophaga dorsalis among the inhabitants of the seas of Norway.

Only one more species of this genus ( $X$. globosa) is as yet known to us, which, judging from its very brief liannosis in the Zoological Proceedings for 1585, appears prin(cipally to differ from our own by the greater slope of its posterior dorsal margin.

\section{PHOLAS, LiNNeUs.}

Valres oval or elongated, (rarely suborloicular, equivalve, inequilateral, gaping, especially anteriorly; external surfares of the shell more or less ornamented by transverse laminated ridges and longitudinal furrows; the inner surfaces presenting two distinct muscular impressions, very distant, the posterior one largest, connected by a pallial impression, which is deeply sinuated posteriorly, narrow, oblique, and tongue-shaped centrally. A curved free -prow-shaped apophysis springing from beneath the beaks in each valve, and directed forwards. Bealis covered by a callosity reflected from the interior. No hinge. Ligament obscure or rudimentary. Accessory valves or plates more or less developed at the back of the shell. 
Animal thick and claviform; the lobes of the mantle united in front, except for a small space anteriorly, through which the foot is protruded; reflected dorsally to cover the beaks, and form callosities and accessory valves. Siphonal tube long, very extensile, divided externally only nearer the extremity; orifices bordered with cirrhi, but not surrounder by a cirrhigerous disk. Foot often considerably developed, thick, short, and truncated at its extremity. No tube.

The genus Plolas, and its immerliate allies, Xylophaga and Pholadidea, form a natural and graduated link between such abnormal and worm-like mollusks as the Teredo, and the more ordinary and typical genera of Lamellibranchiate Mollusca. The shells of some Pholades very closely resemble those of certain Petricola. The animal, whilst it retains some of the peculiarities of the Teredo, especially in its branchial arrangements, in most respects assimilates closely to the normal lamellibranchiate types. Its mantle is more highly organised than that of Teredo, and the visceral mass more concentrated. The latter, including the liver, the digestive organs, the large reproductive glands, \&c., is surmounted by a well-developed, but peculiar foot, having a sucker-shaped truncated disk which, however, is not provided with a foliaceous border like that of Teredo. The stomach of Pholas is simple. The anterior ardductor muscle, in this genus, makes up for the deficiency of ligament. The labial tentacles are largely developed.

The species of Pholas are numerous and widely distributed. The genus may be said to be cosmopolitan. Its range in depth extends from low water, between tides, where the majority of the species are found, to twenty-five, or, perhaps, thirty fathoms. Geologically, it dates from the oolitic period. The species increase in numbers as they 
approach existing times. Some of those now living commenced their existence within our area as far back as the epoch of the coralline crag. Extinet, like recent species, lived in carities excavated by themselves, and fitting their dimensions.

All the species of Pholas are endowed with the remarkable power of perforating rarious substances of considerable hardness, such as stone, shale or wood; some indifferently, some selecting one or other for their habitations. They are never naturally found free. This habit of boring is common to the whole tribe of which Pholas is the type, and is presented also by certain nembers of other tribes. The majority of Lamellibranchiate Mollusea may be said to be borers, so far as the power of burying themselves in sand, clay, mul, or gravel, can give them a claim to such appellation, but the boring of the Pholas, Terecto, Irylophara, Pholadidea, of the Gastrochana, and its allies, and of certain species of Mytilida, appears to be effected by very different means. The question how the boring mollusea excavate their dwelling-places has long been discussed, and is still at issue among naturalists; and the name Pholas, (from $Q \omega i \varepsilon \omega$, to bore, was applied by the ancients to certain shell-fish whose power of perforating the solir rock attracted their notice. A shell-fish is mentioned by Atheneus under the name of Pholas, probably not one of the members of the genus now so called, but the Lithodomus lithophargus, or date-shell, which is very abundant in the seas of Greece, and used by the people for food, whilst the true Pholades are very scarce in the Figean, and not likely to have attracted popular attention.

The earliest observations made upon the boring of Pholus were those by the celebrated Reaumur, one of the most excellent of practical naturalists. They are published 
in the Memoirs of the French Academy for 1812. He figures the Pholas candidus in its cavity, and attempts to account for its presence there. He remarks that it is always found in cavities, either of soft stone or clay; that these are made by the efforts of the animal itself, and by means of its foot, for when it was placed by him upon soft clay, it buried itself in that substance by the action of its foot. He argues that they bore only in soft clay, and that their presence in stone (soft stone, which he terms "la Banche,") is owing to the former having petrified around the Pholades. He shews that the dimensions of the cavity in which the full-grown Pholas is found are, as compared with shell and aperture, such that the former must have remained in it since it first perforated, and could not have changed its habitation. He states that the young are always found in clay, and the old in stone, and concludes that the stone is only clay petrified by means of a viscous matter derived from sea-water. It need not be said now that Reaumur's observations and conclusions were fallacious, but as a first step in the inquiry they had great merit.

Mr. John Edward Gray, in an interesting paper on the habits of Mollusca, published by him in the "Philosophical Transactions," for 1833, gives his opinion on this question. He holds that Pholades, Petricola, Venerupis, and Lithodomus, bore into shells and calcareous rocks by dissolving them. His reasons for holding this opinion are several ;1st. because the animals of most of them are furnished with a large foot more or less expanded at the end; 2nd. because the holes fit the shell-in Petricola and Gastrochance - so as to prevent rotation, and the use of the asperities on its surface; 3rd. because all borers are covered with a periostracum, (thin in Teredo, Pholas, and Lasea ; thick vol. I. 
in Lithendomins;) which would be rubbed oft during the operation of boring; 4th. because, though some borers have spiny shells, others have smooth ones: 5 th. because all bore into calcareous substances, wood excepted; and into simblotone only when it has lain a long time under the sea, and become as soft as clay. These objections of Mr. Gray to the mechanical theory are some good, some bad; several not consistent with a correct lnowledge of the habits and structure of the genera he quotes. The same naturalist, in a paper on the structure of Pholades, in the 1st volume of the "\%oologieal Journal," 1825, held an opposite view to that quoted above; for he here maintains that the Plucludes bore by means of rasping. Dr. Fleming's most recently-expressed opinion on this subject, ${ }^{*}$ is in favour of rasping and rotatory motion.

Among the best memoirs on the subject of the boring mollusks, is that by Mr. Osler, published in the "Philosophical Transactions" for 1826.† It is entitled "On Burrowing and Boring Marine Animals," and contains the fruit of much careful and original observation. According to this gentleman, the instinct to bore is exhibited at a very early stage of the animal's life. He found Ploclades completely buried when so minute as to be almost invisible. IIe regards the curved proceses, or apophyses, within the shell of Pletes, as characteristic of an animal which bores mechanically by employing its shell as a rasp, holding that the shell is the chicf instrument by means of which Ploolas bores. He remarks with respect to Pholas candidus, a species whose habits he observed with great care, that it is by means of the anterior and lower part of the shell, which is thicker and spiny, the boring is effected. IIe considers the peculiar arrangement of the muscles, and the suppres-

\footnotetext{
- Molluscous Animals, p. 114.

+ Vol. cxvii. p. 356.
} 
sion of the ligament in this genus, as peculiarities in its organisation connected with its perforating habits. Teredo, he holds, bores in like manner with Pholas, and by the same means, effecting the stroke during the operation by the contraction of the posterior adductor muscle. The boring of Saxicava, however, Mr. Osler maintains to be effected by very different means, most probably by an acid solvent. Its hole is not round; and if there are siliceous particles in the stone they are left projecting into the cavity. Mr. Osler was unable, nevertheless, to detect any direct evidences of free acid, either by the test of litmuspaper, or by any experiments he could devise.

The account given by Mr. Osler of the operations of Pholas when boring is so circumstantial, that we quote it in his own words :-

"The Pholas has two methods of boring. In the first, it fixes itself by the foot, and raises itself almost perpendicularly, thus pressing the operative part of the shell upon the substance to which it adheres: it now proceeds to execute a succession of partial rotatory motions, effected by the alternate contraction of the lateral muscles, employing one valve only, by turning on its side, and immediately regaining the erect position. I have observed that this method is almost exclusively employed by the very young animals; and it certainly is peculiarly adapted for penetrating in a direction nearly perpendicular, so that they may be completely buried in the shortest possible time. It may be observed that the posterior extremities of the valves are much less produced in the very minute Pholades than they afterwards become; and thus the time required to complete a labitation is still further diminished.

"But when the Pholades have exceeded two, or at the must three, lines in length, I have never observer them to 
work in the manner I have described; the altered figure of the shell, and the inereased weight of that part of the animal behind the hinge, woukd prevent it from raising itself so perpendicularly as at first, independent of the narrow space which it occupies. In the motions required to enlarge its habitation, the adductors perform a very essential part. The animal being attached by the foot, brings the anterior part of the shell into contact. The lateral muscles now contract, and, raising the posterior adductor, bring the dorsal margins of the valves into contact, so that the strong rasp-like portions are suddenly separated, and scrape rapidly and forcibly over the substance on which they press. As soon as this is effected, the posterior extremity sinks, and the stroke is immediately repented by the successive contraction of the anterior adductor, the lateral, and the posterior adductor muscles.

"The particles rubbed off, and which, in a short time, completely clog the shell, are removed in a very simple manner. When the projected syphon is distended with water, the Pholas closes the orifices of the tubes, and retracts them suddenly. The water, which they contained, is thus ejected forcibly from the opening in the mantle; and the jet is prolonged by the gradual closure of the valves, to expel the water contained within the shells. The chamber occupied by the animal is thus completely cleansed; but as many of the particles washed out of it will be deposited before they reach the month of the hole, the passage along which the Pholes projects its siphon is constantly found to be lined with a soft mud."

In a valuable paper on the anatomy of the lamellibranchiate mollusea published by Mr. Garner in the second bl. of the \%oulogical Tramsatetions, that excellent observer hiats some short remanks on the neans by which Pholas and 
other mollusks bore. He mentions that the boring is effected by currents produced by vibratile cilia, aided in some cases by rasping. He remarks that the valves of Lithodomus are not adapted for mechanical boring; that the crypts of Saxicava are not circular; that the valves of Teredo probably do not correspond to the bore; that Pholas conoides is often found in hard timber, though its valves are not adapted for any boring or filing. He further observes "there is a cartilage between the two small spinous processes of the hinge in the Pholas candidus: in other species of Pholas which have no rudiment of it, and allied genera which have a particular character of articulation, I consider the motion of the valves as but a secondary cause in the perforation of the substances in which the animals are found." *

Mr. G. B. Sowerby objected to the notion that the cavities of Pholas were produced by rotatory motions of the shell, since they are fitted to the latter, and since some of the shell bones are externally smooth. He also objected to the notion of a solvent.

Mr. W. Thompson, in his paper on Teredo cited under the account of that genus, expresses his belief that the smoothly rounded termination of the cell made by that animal, is due to "the action of a solvent supplied by the proboscis, which thus acts as a pioneer in mining the passage that is afterwards increased to its final dimensions by the boring action of the primary valves."

Dr. Drummond, in his "Letters to a Young Naturalist," suggested the possibility of the animal of the boring mollusks decomposing the sea salt, as its wants may require, and applying the liberated muriatic acid to the solution of the calcareous rock. 
M. Deshayes, in his splendid work upon the mollusen of Algeria, maintains that the Teredo bores by means of a solvent. The foot (which, however, he regards not as such, but as a special secreting organ) presents a circular smooth surface surrounded by a thick fleshy ring, so as to constitute a sucker, by means of which the animal attaches it self to the rood, and denudes the anterior extremity of the gallery it inhalits. He believes that the contact long prolonger of this part of the animal with the wood, macerates and render's it friable, by the action of a special secretion, of which the product impregnates the leaflets of the fleshy ring, and does not diffince itself, or become dissolver in water.

M. F. Caillaud* holds a similar opinion with respect to the perforating power of animals of the genus Clavagella, which he maintains perforate by a solvent acid. This acid lie supposes to be developed in very small quantities at a time, for otherwise the shell itself would be attacked by it. IIe belieres the animal has the power of applying the acid to the point where it wishes to work, and that it can dilute the solvent with water in ease it threatens to endanger the shell.

In the "Annales des Sciences Naturelles" for 1839, M. L. A. Necker published some very interesting and important observations on the mineralogieal nature of the shells of mollusca, in which he points out differences of structure as indicated by polarization of light. In it he has the following observations on the subject in question : "It is very remarliable that two genera of perforating shells, the Plutus and the Tenerupis, radiate strongly calcspar. Thus the asperities which ronghen their shells may with the aid of the acids with which they are provided, excavate the calcareous rocks inhabited by them. The 
notion that their shells are formed of calc-spar (chanx carbonate spathique) scems to render impossible the perforation by the shells themselves, of calcareous rocks equally hard with the bodies perforating. But now that we know these shells are composed of arragonite, it is plain that they can act mechanically even on the hardest lime-stones."

Sir Henry de la Beche has given a table of the specific gravity of some shells, as observed by himself, * in which he states that of Pholas crispata to be 2.82 , and of a number of other bivalves and univalves to be nearly the same; indicating a constitution which, allowance being made for amount of animal matter, approximates their shells much more nearly to arragonite than to calc-spar, the former having a specific gravity of 2.93 , and the latter of $2 \cdot 71$. +

Mr. Albany Hancock has put forward one of the most definite and important opinions ever expressed on this disputed question. He states that- " The excavating instrument of Pholas and Teredo is formed of the anterior portion of the animal, in the surface of which are imbedded siliceous particles. The particles penetrating the skin, give to it much the character of rasping paper. The whole forms a rubbing surface, which being applied closely to the bottom of the cavity by the adhesion of the foot, cnables the animal to rub down, and so penetrate, shale, chalk, wood, or even the hardest lime-stones and marble.

"Saxicava rugosa is also furnished with a rasping surface covered with silicious particles. This surface, however, in this species, is formed entirely of the anterior portion of the mantle, the margins of which being united, are

* Theoretical Researches, p. 75.

+ Mr. Trenham Reeks has lately examined the specific gravity of several species of Pholas, and has kindly communicated the results: he finds that of $P$. crispata to be $2 \cdot 76 ; P$.dactylus, $2 \cdot 45 ; P$. candida $2 \cdot 70$; and Pholadidea papyracea $2 \cdot 64$. 
so much thickened, forming a sort of cushion capable of considerable protrusion at the will of the animal. The foot is mall, and pasing through a much constrieted orifice, gives origin to a bystus, which anchors the shell close to the base of the excavation, and thus holds the rubbing apparatus in immediate contact with the part to be excavated."

Such are the opinions expressed on this sulject, worthy of note for their own weight, or on aceount of the reputation of their authors, of whose chemical acquirements, at least, sereral of them are not fitvourable specimens. They may all he classed under five conclusions: 1st. That the boring mollusea perforate by means of the rotation of the valves of their shells, which serve as augers. 2nd. That the holes are male by rasping effected by siliceous particles studding the substance of certain parts of the animals. 3rd. That currents of water, set in action by the motions of vibratile cilia, are the agents. 4th. That the animal secretes a chemical solvent, an acid which dissolves the substance into which it bores. 5th. That the combined action of a secreted solvent, and rasping by the valves, effects the perforations.

Of all these theories, the chemical one, so far as a secreted solvent is concerned, bears least examination in the case of the Pholadide. The substances perforated are wood, limestomes hard and soft, argillaceous shales, clays, sandstone, and, in the ease of a Pholes in the magnificent collection of Mr. Cuming, wax. The notion of a secreted solvent, that would act indifferently on all these substances, is, at present at least, purely hypothetical; and, since all attempted tests lave failed to detect an acid, gratuitouly so: for we can liardly suppose that any of those who have taken this view of the cause would maintain that 
the animals have the power of secreting different acids at will, according to the substance they have to attack. Yet this notion has been most favoured by naturalists, who, sceptical as to the perforating power of such fragile instruments as are the shells of many of these creatures, endowed the animals with supernatural chemical qualifications. Even good experimental observers,-Mr. Osler for one,whilst they proved that the Pholas could bore mechanically by the rotation of its valves, could not free their minds from the prejudice in favour of a solvent. The important statement put forward by Mr. Albany Hancock respecting the instruments by which mollusea bore, and which, so far as Gasteropoda are concerned, appear to furnish us with a true explanation, namely, that it was effected by means of siliceous particles, variously arranged in certain portions of the animal's body, led us to hope that a better cause than any yet alleged had been discovered. But we cannot bear it out with respect to the Pholadida. We can find no such particles in the mantle of Teredo, nor have any been noticed by Home or Deshayes, or by the most recent observers, Frey and Leuckart, who paid especial attention to the structure of the tissues in this genus. Nor could we, although aided by the anatomical and microscopical skill of Mr. Busk, detect any siliceous particles in either the mantle, foot, or siphon tube of Pholas candida. If present in any species, therefore, they are exceptional, so far as the genus Pholas and its allies are concerned. The shells of several British species of Pholas, and that of Pholadidea, have been chemically examined by our friend, Mr. Trenham Reeks, with a negative result as regards the presence of particles of silex in their substance, where, after the statement of Mr. Hancock respecting the structure of the mantle, we thought they voL. I. 
might possibly be found. On the other hand, taking into consideration its mineralogical nature, as stated by $\mathbf{M}$. Neclier, there is no reason for supposing that the shell of the Pholudide is so weak a perforating instrument as some have fancied. With its peculiar form, and the saw-like asperities of its surface, especially of its anteal extremity, it is well adapted for an anger, when wielded fresh and elastic by its well-muscled animal inhabitant, whose foot in all the members of this tribe, even in Terelo, where it is least developed, scems specially organized to serve as a fulcrum. We have no evidence that they perforate any substances essentially harder than their shells, or so hard. The sandstones in which they occasionally occur are either friable or marly when fresh, though cabinet specimens seem so solid. The explanation of Necker accounts for their perforations in the hardest limestones. Wood, wax, and other substances in which they occur, offer no difficulty. The statements put forward respecting their boring in lava and granite have long ago been shewn to be mistakes. That they exhibit a rotatory motion during the action of boring, has been proved by competent observers; and the cavities they excavate, if examined when fresh, invariably show transverse groovings, which could have been caused only by such motions. Currents of water set in motion by cilia doubtless aid materially the animal's operations, and possibly may be the means by which the larve effect their first lodgement; but, considering the arrangements of the parts of the body in the adult animal, it scems to us that Mr. Garner's view of their being the primary cause of the perforation, whilst the rasping of the valves is secondary, should be reversed. Such currents must be most effective in clearing away loosened and loosening particles. If there be any chemical action aiding, it must be due to the carbo- 
nic acid set free during the respiratory process. Evidence of a secreted solvent there is none.

Pholades are often described as occurring in sand, in instances where their true habitat is in clays or soft rock, as lias or pleistocene marl, immediately beneath the sand. This was first noticed, in the case of Pholas candidc and P. dactylus, by Audouin and Milne Edwards.* The wood and peat in which they occur not unfrequently on the British shores, are usually the remains of submerged forests.

A remarkable property of the animals of this genus, and one which has long attracted notice, is their plosphorescence when placed in the dark. This phenomenon is exhibited by some other acephalous mollusks, and by the compound tunicated genus Pyrosoma. The light is of a bluish-white hue, and is regarded by Mayen to proceed from a luminous mucous, like that given off by the Medusa. This mucus is thrown off into the surrounding water, so that the currents proceeding from the animal are luminous. Dr. Coldstream states t that the light is given out most strongly by the internal surfaces of the respiratory tubes, and that it is strongest in summer. Professor John Mïller has observed that when Pholades are placed in a vacuum the light disappears, but re-appears on the admission of air; also, that when dried, they recover their luminous property on being rubbed or moistened.

All our Pholades might be used as articles of food, though we are not aware of their being eaten in this country. A very large West Indian species, the Plolas costate, is much prized as such, and is regularly sold in the markets of Havannah.

* Hist. Nat. du Littoral de France, t. i. p, 233.

+ Cyclopædia of Anatomy and Physiology.-Art. Luminous Animals, 


\section{Pholas dactylus, Linnous.}

Valves beaked : umbonal region crested by a series of subquadrangular cells: dorsal plates 4 in number.*

\section{Plate III.}

Pholas ductylus, Lins. Syst. Nat. ed. 12, p. 1110.-Pens. Br. Zool. ed. 1, 177, vol. iv. p. 76. pl. 39, f. 10.-DA CostA, Br. Conch. p. 244. pl. 16, f. 2.-Donov. Br. Shells, vol. iv, pl. 118.-Mont. Test. Brit. p. 20 and 528.-Linn. Trans. vol, viii. p. 30. Dorset Catal. p. 27, pl. 3, f. 2.-Tur T. Conch. Dict. p. 143. Dithỹ. Brit. p. 8. - FLEM, Brit. Anim. p. 457. - Brit. Marine Conch. p. 31.-Brown, Ill. Conch. G. B. p. 115 , pl. 49, f. 1, 2, 3.-Born, Mus. Cxs.p. 14. pl. 1, f. 7.-Chems. Conch. Cab. viii. p. 353, pl. 101, f. 859. - SpENGL. Skrivt. Naturhist. Selsk. vol. ii. part 1, p. 85.--Pou, Test. Sicil. pl. 1, f. 1 to 5.-Woon, General Conch. p. 77, pl. 13.Dillw. Recent Shells, vol. i. p. 35.-Lam. Anim. s. Vert. ed. 2, p. 43.-MAwe, Conch. pl. 3, f. 3.- Index Testac. pl. 2, Phol. f. l.--Sowerb. Gen. Sh. Pholas. f. J.-Reeve, Conch. System, pl. 24.-Sow. Conch. Manual, fo 55.-PнuL. Moll. Sicil. vol. i. p. 3, and vol, ii. p. 4.-Desr. Exp. Sci. Algér. Moll. p. 107, pl. ix. C. E. and G., f. 1, 2, 3 (animal).

Pholas hians, Pultex, Dorset, p. 26.

" callosa, Cuv. R. Anim. ed. Croch. pl. 113, f. 1.

Plolade dactyle, Chenu, Traité Elem. p. 38, f. 111.

Lister, Hist. Conch. pl.433, f. 276.

This ancient and universally-known species of Pholas is much elongated in shape, rather inflated, not very fragile, dull white, and extremely inequilateral. The entire surface is sculptured by concentric lamellar strie, which, moderately distant posteriorly, become approximated in front, where they form short vaulted spines, arranged in close-set radiating rows. The convexity of the valves is simple, that is to say, they are not divided into distinct areas by a radiating furrow, or concavity. The anterior side, which is the more tumid, is very short, and forms a distinct beak, through the large ventral hiatus incurving that margin; the posterior side is much pronluced, and tapers to a rounded

- 'These dingnoses refer to the British species only. 
extremity ; the gape is moderate, and both the margins are slightly convex. The front dorsal edge is incurved, and moderately sloping; its edge recurved, and spread over the umbonal region, the summit of which is crested by a series of about a dozen deeply-excavated, square-mouthed cells, formed by a dorsal arch supported by perpendicular laminæ. The accessory valves are four in number; the two principal, which are exactly similar, large, peculiarly fragile, membranaceous, elongated, somewhat wedge-shaped, and almost smooth, or merely marked with the lines of increase, are in fine specimens divided into areas by an oblique posterior line, and a more or less shallow or profound anterior excavation, which runs to the extremities of the inner margin (where the valves touch each other), from a slightly-projecting point, situated not far from the middle of the opposite margin. Their exact contour varies according to age, the lateral edges being more nearly parallel in the adult; the anteal extremity, however, is always attenuated to an obtuse point, and the hinder so biangulated that the outer angle is the more prominent; the interior lateral edge is nearly straight, with a slight retusion near the middle, the exterior one convex and sloping in front, subretuse and straight behind. A solid, transverse, hammer-shaped, testaceous plate, most closely attached to their hinder termination, and dove-tailed above into the inner posterior angles, completes the concealment of the cells and umbonal region. This is immediately followed by a narrow and very thin shelly plate, which extends thence more than half-way the distance to the end of the shell. Subumbonal blade is rather large, and moderately wide and elongated, spatulate, curved, flat, broader at its termination, where in expanding it becomes thinner, and internally concave : the hinge-plate is marked with several raised sulci. 
A stunted variety is found, which is abbreviated posteriorly, and has its beak narrow, and peculiarly prominent. Its strix, too, are so crowded as to present no interstices.

This is by far the largest of our British Pholudes, the shell attaining to five or six inches in length, and one and a latf in breadth. The number of the accessory plates, and the possession of dorsal cells, are its salient characteristics.

"Animal elongated, subcylintrical, pale-bluish white, laving the mantle closed throughout, except a passage in the anterior ventral range for an oval foot, with a thick, fleshy, subcylintrical base. The mantle posteriorly is prolonged into a very long, thick, rounded tube, which terminates in two orifices, whereof the branchial one is the largest, having from ten to fourteen large rays, each of which have three, four, five, six, or seven cilia on one side; besides the principal rays, there are between each one or two minor ones. The anal, or upper tube, is short, just scparate at its extremity from the branchial one, curves a little upwards, and las its orifice plain. This tube is eminently contractile, capable of great extension; sometimes to doulle the length of the shell, sometimes it is shortened and inflated with water to a diameter as great, or even greater, than the thickest part of the shell. When contracted it has a corrugated aspect; when extended it is of a pearly-white colour, with the orifices and rays dusky. For an inch or two towards the extremity it is papillose, the prapille so disposed as to have a squamous aspect."CLark's MISS., communicated by Mr. Jeffreys.

On the south coasts of England it is not only the comnnnest species of the genus, but one of the most abundant of shells, being found in profusion near low-water mark, imberled in challk, red-sandstune, liss, lecayed wood, and 
even in pure sand, \&c. Among its numerous localities we may mention Margate, and most parts of the Kentish coast (S. H.) ; Hastings (S. H.), Weymouth (S. H.), Exmouth (Clark), Lyme Regis (E. F.). In Wales it is found in Cardigan and Swansea Bays (Jeffreys). In Ireland, at Belfast and Dublin Bays (Thompson), coast of Cork (R. Ball), and Ballycotton Bay (Jeff. Cab.). It is of rare occurrence on the coast of Scotland; Frith of Forth (Laskey), Clyde (Smith). It occurs fossil in (true) raised beaches on the coast of Ayrshire. It ranges throughout the European seas.

\section{Pholas parva, Pennant.}

Valves beaked; surface not divided by a radiating sulcus front dorsal edge recurved, but not cellular; dorsal plate single.

Plate IV. figs. 1, 2, and Plate II. fig. 2, and (Animal) Plate F. f. 3, and 3, A.

Pholas parva, PENn. Brit. Zool. ed. 1, vol. iv. p. 77, pl. 40, f. 13.-Mont. Test.

Brit. p. 22, pl. 1, f. 7, 8.-Linn. Trans. viii. p. 33.-TurT.

Conch. Dict. p. 143 ; Dithyr. Brit. p. 9.-Flem. Br. Anim. p. 457.-Br. Marine Conch. p. 32, f. 71.-Brown, Ill. Conch. G. B. p. 115, pl. 48, f. 11, 12,-Wood, General Conch. p. 82.DiLLw. Recent Shells, vol. i. p. 38.-Haxt. Recent Shells, p.5.

" cremulata, Spengl. Skrivt. Naturhis. Selsk. vol. ii. part 1. p. 92.

" dactyloides, LaM. Anim. s. Vert. ed. 2, vol. vi. p. 45, (description not note).

" ligamentina, Desr. Elem. Conch. pl. 3, f. 11, 12.

" tuberculata, Turт. Dithyr. Brit. p. 5, pl. I, f. 7, 8.-F LeMr. Br. Anim. p. 457.-Brown, Ill. Conch. G. B. p. 115, pl. 49, f. 12, 13. -Brit. Marine Conch. p. 30.-Ind. Testac. sup. pl. 1, Phol. f. 2.-HANL. Recent Shells, p. 9, sup. pl. 1, Phol.f. 2.

In common with all our English Pholades, and, indeed, with the mass of lnown species in this genus, the shell we are describing is of a lustreless white, often stained, however, with brick-red, from the nature of its habitat. It is elongated oblong, thin, fragile, gibbous in front, and then at 
ahout two-fifth the distance from that extremity, without any intervening radiating channel, suddenly diminishes in convexity. The anterior space is more or less closely set with radiating lines and concentric elevated stria, of which the former are generally the more strongly marlied, and the latter in typical examples are usually remarkably delicate. Neither of these traverse the entire surface; but, after muricating by their intersection the gibbous portion of the shell, become obsolete shortly after passing it, and leave the posterior third smooth, or merely wrinkled with the lines of increase. The sides, although unequal, are less so than is nsual with the Pholudes; the posterior is attenuated, but rounded at its extremity (and more rarely abbreviated, searcely tapering, and broadly rounded at its termination,) its arcuated dorsal and convex ventral edges sloping with almost equal inclination. The anterior end forms a short and obtuse beak, the ventral edge, which encloses an hiatus which occupies one-half the length of the shell, being greatly incurved, and the dorsal moderately but deciderlly sloping, and very slightly retuse. The accessory valve is solitary, umbonal, excessively fragile, and resembling that of $P$. candida, but is proportionally narrower, and the central excavation almost or entirely invisible. The linge-margin, which is reflected slightly over the umbones and anteriorward, but not generally appressed, is internally provided with a callous tubercle; but is destitute of teeth. The subumbonal blade is slender, curved, and not concave, and expands but little at its apex.

Animal dongated, white; body oblong; mantle white anteally, tinged with fiww-colour posteally, open centrally at the widest part, for the passage of a thick, nearly round, or widely oval truncated white foot. Line of suture of sides of mantle anteriorly strongly marked by a whitish band. 
Siphonal tubes tawny; their orifices very unequal; the margin of the branchial bordered by scalloped lobes, which are not prolonged into rays, except a pair contiguous to each other on each side, on a line with the anal. The orifice of the branchial tube and the foot distinguish it from all its British congeners.

We regard this as not only a more local species than dactylus, candida or crispata, but as specifically less abundant. We have found it in company with the two former; but in a wide disproportion of number. The only spot where Montagu met with it-and more successfully than our subsequent collectors, -in considerable abundance, was near the town of Salcombe in South Devon, in decayed wood, a substance greatly affected by most of the species of this genus. Pennant, the original discoverer and describer of it, states that he found it in fossil-wood at Abergelly in Denbighshire. It is not uncommon on the shores at Torquay, embedded in red sandstone (S. H.) ; is taken also at Exmouth, and other places on the Devonshire coast (Clark); likewise, though rarely, at Margate (S. H.), and has been dredged alive in fifteen fathoms water in hard turf, at the west bay of Portland (M'Andrew). Pridmouth, near Fowey, in Cornwall (C. W. Peach), Oxwich, in Glamorganshire (Jeffreys), Belfast Bay (Thomps. in Amm. N. H., vol. 13, p. 434), may also be included among its habitats; a single example (perhaps from ballast) is likewise recorded by Captain Brown as taken at St. Cyrus, in Kincardineshire. Although scarcely mentioned in foreign works, the species is not confined to the British Isles; Mr. M'Andrew has taken it also on the coast of Spain. In general appearance it is intermediate between crispata and dactylus; but, besides differing in the dorsal plate, which, from its extreme brittleness, is too frequently broken in cabinets, is devoid of VOL. I. 
the cells of the former, and of the channel of the latter ; compared to which, it is narrower and smaller, the average size rarely exceeding an inch and a quarter in length, and about half an inch in breadth. The Pholes tuberculate of Turton is only a monstrosity of this species, as we have ascertained by the examination of his own unique specimen, which, together with the rest of his collection, is now in the possession of Mr. Gwyn Jeffreys, of Norton, near Swansea.

The description given by Lamarck of his $P /$. callosa sufficiently aceords with the characteristies of this speeies; the synonymy of the recent edition of the "Animaux sans Vertebres" indicates, however, a mere variety of dactylus.

\section{Pholas Crispata, Linnæus.}

Talves abbreviated, beaked, divided by a radiating grove without dorsal cells: dorsal plate rudimentary.

Plate IV. figs. 3, 4, 5.

Pholas crispata, Linn. Syst. Nat. p. 1111.-Penn. Br. Zool. ed. 1, vol. iv. p 77 , pl. 40, f. 12.-Donov. Br. Shells, rol. ii. pl. 62-PULTeney, Dorset, p. 27.-Mont. Test. Brit. p. 23.- Jimn. Trans. vol. viii. p. 32.-TurT. Conch. Dict. p. 146 ; Ditlyy. Brit. p. 6.-FleM. Brit. Anim. p. 456.-Brown, Ill. Conch. G. B. p. 114, pl. 48, f. 1 to 5. - M'G. Moll. Aberd.p. 306 ; Brit. Marine Conch. p. 29.-Dillw. Recent Shells, i. p. 40. Wood, Gen. Conch, p. 81, pl. 15, f. 3, 4, 5.-II ANu. Recent Shells, p. 7, pl. 2, Phol. f. 5 ; Index Testac. pl. 2, Phol. f. 5. Spengl. Skrivt. Naturhist. Selsk. vol. ii. part 1, p. 96.Lair. Anim. s. Vert. ed. 2, vol. vi. p. 46,-Cinens. Conch. Cab. rol. viii. p. 369, pl. 102, f. 372, 373, 874.-Gould, Invert. Massach. p. 27.-Cuv, Règne Anim, ed, grande, pl. 113, f. 3 (animal).-Deray, New York Mollusc. p. 247, pl. 32, f. 506 .

" lisfrons, Di Costa, Brit. Shells, p. 242, pl. 16, f. 4.

" parra, " $" \quad$ p. 247.-Dovov. Brit. Shells, ii. pl. 69. -Encycl. Méth. Vers. pl. 169, f. 5.-List. IIist. Conch. pl. 436, f. 279.

This coarse-looking shell is of a somewhat oval shape, rather strong (often becoming thick and heavy in aged individuals), greatly inflated, dull whitish, inequilateral, and 
so excessively gaping at both ends that the valves only tonch each other at the linge and in the middle of the opposite margin. The surface is rather obliquely divided into two nearly equal portions by a broad groove-like channel which, proceeding from the umbones to the middle of the extremely-arcuated ventral margin, is internally indicated by a corresponding costa or rib-like elevation. The anterior portion, which is eminently tumid, is covered with rather close-set concentric laminar strix, whose free edge is less closely dentated in radiating rows, which do not quite extend to the dividing channel, posterior to which the shell is flatter, and only marked with the concentric wrinkles of increase. The anterior extremity forms a very short obtuse beak, and the posterior termination broadly rounded. The dorsal edges, which are but little sloping, are incurved near the hinge. The hinge-margin is broadly reflected, simple, and unprovided with denticles. The subumbonal tooth is long, flat, subspatulate, but little concave at its extremity, and much curved. The single testaceous accessory plate is small, but solid, and is situated at the end of the skin which covers the front dorsal gape; it appears trigonal when imbedded, the sides being nearly straight, and meeting in a rectangle, whose apex forms the posterior termination of the plate, but when detached from the shell more nearly approaches the form of an arrow-head, the concealed underlapping portion constituting very elongated barbs. The animal is dusky-white, its siphon tinged with brown and rough with papillæ.

Our largest examples exceed three inches in length by about one and three quarters in breadth. On the southern shores of England it is reckoned among the less common shells, but is occasionally found in smaller numbers imberderl along with the other Pholales at the Reculvers (S. H.), 
Hastings (S. H.), Sc. In the north it appears to be more abundant. and is taken at Liverpool (M'Andrew), Scarborough (Bean), in sand near Hartlepool in Durham (Jeffreys, cab.), in the shale rocks of Northumberland and Durham (Alder).

In Ireland it is dug from pure sand in an estuary near Dublin (from which vicinity lave come some of the finest examples known to us), and is obtained, likewise, from Belfast and Dublin Bay (Thompson), the coast of Cork (R, Ball), \&c.

Dead valves are frequently cast ashore on the Isle of Man (E. F).

In Scotland, among other localities, may be mentioned the Murray Frith (M'Andrews), Frith of Forth, where it is found in abundance burrowing in the coal-shales exposed at low water, in company with $P$. crispata (E. F.), Clyde (Smith), Aberdeenshire (M·Gillivray).

Mr. Clark has obtained this species at Guernscy, "from the sandstone, from which the waterproof cement is made."

The Photas crispate is distributed generally throughout the European seas, and is the only one of our Pholades which ranges to the shores of North America. It occurs on the coasts of Massachussets and New Jersey. This wide distribution is connected with its geological history. It is one of the species which ranged thronghout the upper part of the northern hemisphere during the pleistocene or glacial epoch, in the ancient sea-berds of which time it is a common fossil. Before that period it had lived within our area during the successive epochs of the coralline and red crags. It is an interesting instance of a littoral, or sublittoral hell, capable of bearing many varieties of climate, having consequently a great range in time, and in the end a wide and peculiar geographical distribution. 


\section{Pholas Candida, Linnæus.}

Valves not beaked; surface not divided by a radiating grove ; dorsal plate single.

\section{Plate IV. figures I, 2.}

Pholas candila, Linn. Syst. Nat. ed. 12, p. 111 1(not Spengler).-Penn. Brit.Zol. ed. 1, vol. iv. p. 76, pl. 39, f. 11. - DA Cost 4 , Brit. Conch. p. 246. Pulteney, in Hutchin's Hist.Dorset, p 26.-Dunov, Brit. Shells, vol. iv. pl. 132. - Mont. Test. Brit. p. 2.--Dorset Catal. p. 27, pl. 1, f. 12.-Linn. Tr. vol. viii. p. 31.-TurT. Conch. Diction. p. 144, f. 79 ; Dithyr. Brit. p. 10.-FLEM. Brit. Anim. p. 457. - M ${ }^{6}$ Gis. Moll. Aberd. p. 306. - Brit. Marine Conch. p. 31.-Brown, 1ll. Conch. G. B. p. 115, pl. 48 , f. $6,7,8,9,10 .-$ Снемл. Conch. Cabinet, vol. viii. p. 358 (not variety), pl. 101, f. 361.-Woon, General Conch. p. 79, pl. 14, f. 3, 4.-Dillw. Recent Shells, vol. i. p. 36. (not variety),-Lam. Anim. s. Vert. ed. 2, vol. vi. p. 44.Burrows, Elem. Conch. pl. 3, fo 4.-Mawe, Introd. Conch. pl. 3, f. 2.-Wood, Ind. Testac. pl. 2, Phol. f. 3.-Сrouch, Introd. Conch. pl. 2, f. 11.-Philippr, Moll. Sicil. vol. i. p. 3, and vol. ii. p. 4.-Hanl. Recent Shells, p. 5, pl. 2, Phol. f. 3. -Desh. Exp. Sc. Algér. p. 109, pl. IX. D. I. f. 4, 5 (animal). "papyracea, Spengl. Skrivt. Naturhist. Selskab. vol. ii, part 1, pl, 1, f. 4 (not of his diagnosis),-LIst. Hist. Conch. pl. 435, f, 278.

The outline of this fragile shell varies from oblong to elongated oblong; it is thin, semi-pellucid, dull white, and moderately inflated. Its posterior gape is the more considerable, the valves being nearly closed anteriorly. Their surface is simple, covered with fine moderately-distant radiating lines, and closer set concentric sublaminar strix, which, at their intersection, give birth to very short and rather broad prickles or spines, which are chiefly evident at the front of the shell, where the radiating lines are broader and, in most specimens, more distant. The ventral edge is uniformly convex or subarcuated, and slopes upwards anteriorly: the dorsal edges are convex, but little sloping behind, more so in front. The sides are very unequal, and both are rounded at their termination; the posterior end 
is the more attenuated. The hinge-margin is reflected, but neither chambered, nor extending over any considerable portion of the umbonal region. The solitary accessory plate, which rests upon the front dorsal edges, is rather large, fragile, testaceous, elongated, tapering off to a more or less rounderl point anteriorly, and posteriorly subtruncated and bending inwards. Its sides are retuse in the middle; the surfice concentrically striolated, and divided lengthways by a distinct, shallow, groove-like excavation. The subumbonal tooth-like apophysis is peculiarly slender, flat, arcuated, rather oblique, and but little expanding at its extremity. The hinge-margins are armed with an extremely oblique tooth-like process, attached by its entire length, and only projecting above it in one valre.

Animal elongated, white, body oblong; siphonal tube very long, pale brown, minutely dotted with tawny or red; covered with closely-studded papilla (which, under the microscope, appear hollow), towards the extremity. Orifices dusky-rayed, or longitudinally banded with purplishbrown, internally; the branchial with twelve rays or long cirrhi, and intermediate smaller ones; the anal plain. Mintle in front dotted with opaque, white specks, foot oblong-lanceolate, truncate. This animal can close its shell much more completely than the other British Pholudes lut its siphon is scarcely so retractile. It is highly muscular. Ploolas candidus is very active, rapid in its motions within its hole, withdrawing to its immost recesses speedily on being disturbed.

The absence of a beak, combined with the possession of a single accessorial plate, ensily distinguish the shell of this species from its English comgeners. It never attains to any ronsiderable size, rarely exceeding two inches in length, and live-rixths of an inch in liealth, and is much more usually 
only obtained of by far smaller dimensions. Although common, its range does not appear so extended as that of dactylus, in whose company, however, it is often taken. It is met with towards low-water mark, embedded in chalk, limestone, red sandstone, hard clay, decayed wood, \&c., in many parts of England, and is peculiarly plentiful at Margate and other parts of the Kentish coast (S. H.), is found also at Weymouth (S. H.), Liverpool (M'Andrew), Torquay (S. H.), Exmouth, in pure sand (Clark), Salcombe, Hastings (S. H.), Lyme Regis, in lias (E. F.), Scarborough (Bean), in the shale-rocks of Northumberland and Durham (Alder). In Wales, at Oxwich Bay, in Glamorganshire (Jeffreys). In Ireland, Dublin Bay (Thompson), Youghal (R. Ball), Ballycotton (Jeff. cab.), Waterford, Belfast, and Birterbie Bay (Dr. Farran). In Scotland, it occurs plentifully boring in the coal-shales of the Frith of Forth (E. F.), Aberdeenshire (M'Gillivray), Loch Ryan (Smith).

This species made its first appearance in the British seas during the epoch of the red crag. It is now distributed throughout the seas of Europe.

Under the manuscript name of $P$. Nana of Solander, Dr. Pulteney, in 1799, first introduced this species to us as British, in his catalogue of the birds and shells of Dorsetshire, defining it, however, rather by his synonymy than by his very bald diagnosis. At that period a less strict regard was paid to the necessity of confining the term indigenous to such species as actually propagate upon our coast, and of not bestowing it alike upon all such as may be discovered, however manifestly of casual foreign importation, in a living state within our waters, Nevertheless, the doctor cautiously modifies his introduction with, "I doubt whether they breed upon the English coast. I have seen it in the 
sides of the shipe, whilst eareening, in great numbers, both at Poole and Weymouth." Montagu, after an accurate description of it, adds, "Whether this species can strictly be said to be British may be doubted." The eareful and long-continued observations of our living naturalists confirm the justice of these doubts; it being universally now acknowledged to be solely taken, "occasionally alive" (Buan), from ressels which have entered our harbours from foreign ports, or "from woor washed ashore only" ('Thompon), as was the ease with the specimens recorded in the "Annals of Natural History," vol. xiii. p. 434, to have been discovered "in water-logged mahogany, near Killala, Sligo; also on the coast of Clare (IV. T'hompson). Montagu has remarked the fact, that whilst the general habit of the shipworms is to bore parallel with the grain, the Pholes perforates the wood across the grain.

Although known to Linnæus, and referred to in his "Systema Naturæ," it was first clearly characterised by Parsons who, in the "Acta Anglica," gives us an excellent representation of it, not, however, as an English shell, but as avowedly taken out of a Spanish vessel.

\section{P. Striat八, Linnæus.}

Pholas striata, Linn. Syst. Nat. 1111.-Mont. Test. Brit. p. 26 and 559.Dorset Catal. p. 27, pl. 1, f. 7.-Linn. Trans, vol. viii. p. 31. -Turт. Conch. Diction. p. 147 ; Dithyra Brit. p. 11.-Brit. Marine Conch. p. 31.-Brown, Illus. Conch. G. B. p. 115, pl. 49, f. 5, 3.-Wood, General Conch. p. 83, pl. 16, f. 1, 2, 3, 4, 8. -Mawe, Conch. pl. 3, f. 1.-Index Testac. pl. 2, Phol. f. 7. -Rees, Cyclop. Shells, pl. 3.-Sowerby, Genera Sh. Pholas. f. 1, 2.-ReEve, Conch. System, pl. 24, f. 2 .

"nana, Pultener, Dorset. p. 27.

" pusilla, Lins. Syst. Nat. p. 1111,-Donov, Brit. Shells, vol, iv. pl, 117. -Criexn. Conch. Cab. vol. viii. p. 365, pl. 102, f. 867 to 871.

—Siexgler, Skrivt. Naturhist. Selskalo vol. ii. part 1, p. 95.

-Drclw. Recent Shells, vol. i. p. 38.

". lignorum, SPENG Ler, Breschaft. Berlin Ges.Naturf. vol. iv. pl. 5, f. 1 to 5.

., conoides, Flem. Brit. Animals, p. 457.

" clavatu, Lavarck, Anim. s. Vert. ed. 2, p. 46 (excluding var. C.).Hant. Recent Shells, p. T.-Enyclop. Méthod. Mollusq. pl. 170, Phol. f. 1, 2, 3. 
The shape is somewhat conoid, being broad, and rounded in front, and strongly tapering to a more or less obtuse point posteriorly. The valves are similarly compressed behind, but ventricose, or even tumid anteriorly; their texture is very thin and fragile, and under a more or less distinctly visible yellow epidermis, they are of a dull white. The surface is vertically divided a little before the middle by an extreme and abrupt difference of sculpture; the posterior area being distinguished by concentric elevated plicæ, which become more or less obsolete as they recede from the beaks and the line of separation, where they are strongly indicated; whilst the anterior portion is more or less closely covered with rather strong oblique laminar crenulated strix, which form distinct angles towards their middle, at which point the foremost ones diverge, and the following ones converge. A thin, smooth, tumid, triangular space near the front ventral margin, covers in the adult the vast gape which is there present in the immature examples. The extremity of the posterior side, which is greatly the longer, is slightly hiant, and the ventral edges are prevented approaching each other by an elongated testaceous accessory plate, which lies between their hinder edges. There is a kind of double appressed reflection of the front dorsal edge over the umbones, which supports the large and somewhat heart-shaped shield which entirely conceals them. This latter, which is rather blunted in front, and profoundly incurved behind, is followed by a third accessory testaceous plate, which separates the posterior dorsal margins, and is elongated and narrow in shape. The subumbonal toothlike apophysis is flattened but slender; and there is a deep umbilicus-like impression in front of the beak, caused by the primary and more abrupt reflection of the dorsal margin.

At the first glance this species bears a strong resemblance to the P. cuneiformis (Journ. Ac. Sci. Philad. vol.ii. p. 322.-Dekay, New York Moll. p. 248) of Say, which, not being very clearly characterized by its author, seems but little known in England; it may, however, readily be distinguished by the acuminated hinder termination of its smaller and more solid umbonal shield, and in all stages of growth by the non-angulation of its elevated anterior striæ.

The specimens taken in England rarely exceed an inch in length, and even the more strictly exotic ones are not greatly larger. They peculiarly affect mahogany.

VOL. I, 
Shell more or less glohose or oblong, equivalve, inequilateral, surface of valres similar to those of Pholus; their beaks not corered by callosities; accessory plates small. Muscular impressions as in Pholas. Anterior extremity open in the immature, but closed in the adult shell by a thin papyraceous permanent shelly coat, with a small opening centrally and anteriorly for the foot. Posterior extremity truncated and gaping, usually furnished with an expanded coriaceous cup.

Animal claviform; the mantle closed in front, except a small opening for the passage of a truncated suckershiped foot. Siphonal tube long, terminating in a disk surrounded by cirrhi, encircling the openings of the branchial and anal siphons, each of which are also surrounded by radiating cirrhi.

The separation of the calyciferous Pholades from their allies of the last-described genus, was, we believe, first suggested on conchological gromits, ly Dr. Goodall to Dr. Turton, who, in his "Conchological Dictionary," gives the name of Pholadidea Loscombiana to our British species. In the thirty-ninth volume of the "Diction. des Sciences Naturelles," the group is characterised under the name of Pholudidea, and made a sub-genus of Pholas. Swainson, in his "Elements of Conchology" (18:55) called the genus Pholidere, and in lis more recent "Treatise on Malacology" in Lardner's Cyclopedia, writes it Pholidac, and refurs to Leach as the founder.

The genus is a good one, sceing that both shell and animal afford excellent distinctive characters, which are pre- 
sented equally by British and exotic species. The remarkable cup-shaped appendage surrounding the base of the united siphons may be regarded as a rudimentary tube for their protection-especially for the protection of the complicated cirrhigerous disk which surrounds the openings of the branchial and anal siphons in Pholadidece, and which is so characteristic of them. M. Deshayes regards this group as intermediate between Pholas and Teredina, whilst the latter is intermediate between Pholadidea and Teredo.* In some respects, however, the passage seems rather from Plotas towards Gastrochana and its allies, and in such a position we have placed it here.

\section{P. papyracea, Solander.}

Plate V. Figs. 3, 4, 5, 6, and Plate II. Fig. 1, and (animal) Plate F. f. 4.

Pholas papyracea, Turt. Dithyr. Brit. p. 2, pl. 1, f. 1 to 4.-Brown, Ill. Conch. G. B. p. 114, pl. 49, f. 4, 6, 7, 9. - Brit. Marine Conch. p. 29.-Sowerb. Gen. Shells. Pholas, f. 3.Reeve, Conch. System. pl. 24, f. 3. - Mawe, Conch. pl. 3, f. 5.-Sow. Conch. Man. f. 56.- Hanl. Recent Sh. p. 9, sup. pl. 1. Phol. f. 1, 3.-Ind. Testac. sup. pl. 1. Phol. f. 1.

" Lamellata, Turt. Dithyr. Brit. p. 4, pl. 1, f. 5, 6.-FleM. Br. Anim. p. 456. - Brown, Ill. Conch. G. B. p. 114, pl. 49, f. 10, 11 . -Ind. Testac. sup. pl. 1. Phol. f. 3.

Pholadidca Loscombiana, TurT. Conch. Dict. p. 147.

Pholas (Pholadidea) Goodallii, Dict. Sc. Nat. vol, xxxvii. p. 532.

" striata, Cuv. Anim. King. (edit. Griffith) pl. 8, f. 1,-Cuv. Anim. King.

(Henderson's edit.) pl, 4l, fol.

Pholade striée, Blainv. Manuel Malacol. pl. 80 bis, f. 7 .

This delicate and remarkable shell, whose different aspects in its mature and undeveloped state, have caused so much controversy among English conchologists, is of an elongated ovate shape, ventricose, very thin, not glossy,

* Traité Elementaire de Conchyliologie, p. 75. 
whitish, and moderately inequilateral. It is closed and tumid in front, somewhat lincarly gaping, and provided with a cup-like appentage behind, which, projecting about three-eighths of an inch beyond the extremity of the shell, and composed of two papyraceous vaulted lamina of a very pale brown colour, suggests the idea of the attachment of a portion of another specimen to its valves. An oblique line from the umbones, forming a rib internally, divides the surface into two nearly equal parts, the hinder of which is merely marked with broad and not very close concentric wrinliles; the anterior, however, is again diagonally subdivided, the portion nearer the beaks being most clusely and obliquely sculptured with curling laminar strix, whilst the excessively thin and almost semi-transparent matter, which in the alult fills up the expanded front ventral gape of the immature shell, is perfectly smooth. The ventral margin is nearly straight or but slightly convex; the hinder dorsal, whose edges being turned outwards cause a lip-like projection near the beals, is similarly but slightly convex, and is but little inclined. The posterior extremity is obtusely biangulated, the anterior peculiarly rounded. 'The front linge-margin, which is elevated above the dorsal line, and at first reflected towards the umbones, again recurves, and forms a kind of crest which is abruptly truncated posteriorly at the beals, where it is terminated by two minute somewhat rhomboidal testaceous accessory valves. The hinge is furnished with a rather large, erect, thin, subtriangular tooth-like lamina in one valve, and a smaller and more caducons one in the other. The subumbonal blade is short, flat, curved, and scarcely expanding at the tip.

The young of this beantiful shell (which stage constitutes the Pholes lamellata of Turton) assumes so different an aspect, that few would recognize it from a description or 
figure of the adult. As yet unprovided with the calyx, its posterior end, instead of being truncated, is rounded and somewhat attenuated, whilst the dome-like structure of its anterior extremity is replaced by a gaping expanse, above which the side is obtusely angulated.

This non-formation of parts and deferred enclosure of the gape with shelly matter, until the last stage of growth, is not confined to $P$. papyracea, but prevails likewise in many Pholadida of the American seas.

Dr. Turton's specimen of his Pholas lamellata is not merely the young of this species, but seemingly a lind of monstrosity, or at least a specimen of an unusual growth; for instead of the animal attempting as usual to enclose the front ventral gape with testaceous matter, upon the completion of the immature stage of growth, it has contented itself with solidifying the entire shell, and reflecting the edge of its anterior ventral margin. This form is extremely rare, but differs in no other respects from the ordinary aspect of the young papyracec. There is a dwarf variety figured in our plates which, instead of being littoral, is taken by the dredge in detached lumps of rock five or six miles from the shore. This is supposed by many collectors, who regard lamellata as a distinct species, to be the true young of papyracea, and not an adult form depanperated by the unfavourable influence of an unnatural locality.

Mrs. Griffith has kindly furnished us with coloured drawings of the animals of the two forms taken from life, and Dr. Battersby with good specimens of $P$. papyracea in spirits. Mrs. Griffith regards both shells and animals of each as indicating distinct species; but the apparent differences presented in the figures of the latter seem to depend upon different states of the creatures at the moment when pourtrayed, for the characters noticed as distinctive of 
the form lamellate are all present in that termed papyracea, as we have convinced ourselves by an examination of preserverl specimens, and as Mr. Clark had previously observed and drawn from life in each variety. The account of them in the manuscripts of that excellent malacologist, communicated by Mr. Jeffreys, is so full and clear, and his opinion in consequence so important on this disputed point, that we camnot do better than give it in his own words, though at the risk of some repetition:- "This animal, in consequence of its shell having been taken under very different appearances of form, has, when from circumstances it has not formed the testaceous membrane that often covers its anterior ventral gape and the testaceous cup-like process at the posterior end, been considered a distinct species, and named by Dr. Turton and others the Plodes lemellate; but when it had acquired those appendages, it was named Pholas papyracea. But having this summer (1835) studied the animal under both forms, we are fully enabled to confirm Mr. G. B. Sowerby's opinion, stated in lis 'Genera,' that the two shells are one species muder different forms. IVe do not, however, think that the form styled $P$. lamellate is the young of the shell styled $P$. papyraced, but that they cach maintain their respective forms when of all sizes, from circumstances dependent on peculiarities of animal ceonomy. In corroboration of this opinion, we can state that we have seen what is called the $P$. lemellata equal in size to the largest papyrecee, and, on the other hamd, we have seen what is called the $I^{\prime}$. Papyracea completely formed, with the cup and testitceous ventral membrane not more than a quarter of an inch in length; and we believe that when peculiar circumstance's, most probably attendant on habitat and animal economy arise, the animal has then the power of forming 
the cup and membrane. The cup we consider as nothing more than an incipient shelly lining of its habitation for the protection of some part of its tubes, probably the ciliated orifices, which are more complex in this species than in any of the others, and is, in some measure, analogous to the shelly linings of the Teredo and Gastrochona. An inspection of the tubes of the animals which are precisely similar, and which differ most conspicuously from all the other Pholads, will at once convince the most sceptical of their identity. The orifices of the two tubes are placed in a distinct finely-fringed circle, unlike in this to all our other Pholades. The branchial tube has around its orifice twelve rays, with a smaller one between each. The upper or anal tube is plain and closely united to the lower, and both are placed within a finely white-fringed circle. The tube is pale reddish brown to within about a quarter of an inch of its extremity, where it is of a pearly white. The rays and orifices within the white-fringed circle are pale reddish brown. The foot is small, oval, and somewhat pointed before and behind. The belly of the animal is white, mottled with intensely white flaky points or dots, as in Pholas candida."

Pholadidea papyracea must be considered not only a very local shell, but one difficult to procure even at most of the spots from whence only it can be obtained. It is met with at very low tides imbedded in reddish sandstone (Trias) at Exmouth, Teignmouth, Torquay, and other towns of the South Devon coast; but its extreme fragility renders its safe extraction, and the subsequent removal of the animal matter, a work of delicate manipulation. The dwarf variety we have figured was dredged some five or six miles from land in lumps of indurated red clay, by Mr. Clark, of Exmouth. Portrush, in the north of Ire- 
land, is likewise giren as a locality for the species in the "Annals of Natural History," on the authority of two specimens thus labelled in the Ordnance Mnseum ; and an example, believed to have been dredged between Howth and Lambay, was taken from a tishing-boat in Dublin Bay, imberled in a sandy conglomerate of shelly matter. (IV. Thompson, in Amm. N. H. vol. xiii. p. 434.) Few specimens attain to greater dimensions than an inch and a half in length, and about lialf that breadth.

In Captain Brown's "Conchological Illustrations" is a Pholas sulcata* (p. 115, pl. 48, f. 17, 18), which more nearly agrees with the young of this than with any of our known Inritish Pholades. Its Scotch locality (I)unluar; in the collection of Iavid Falconer, of Carlowrie,) is, however, against this supposition.

* Since writing the above paragraph, we have received a letter from Captain Brown, in which he assures us that this species, of which only a single valve was found, is neither a fossil nor a variety of papyracea. We append, therefore, his description, much regretting that the specimen is inaccessible to us.

"P. sulcata, Brown, Ill. Conch. G. B. p. 115, pl. 48, f. 17, 18.

"Oblong-ovate; hinge-line nearly parallel; almost equally rounded at both extremities; a thickening and slight Hexure of the superior margin, extending to the anterior side; from the umbonal region emanate two obliquely longitudinal narrow furrows, and terminate on the basal margin, at which point the shell is longest; anterior to the sulci the surface is covered with close-set waved transverse strix, and the posterior side with irregular broken concentric strix; external surface of a yellowish or pale brown hue; inside smooth, white; a curved flattened, tooth-like process under the umbones, a small denticle at the central point of the umbonal region, and an oblique longitudinal rib, corresponding to the external furrows." - This shell was found at Dunbar, and is in the collection of David Fulconer, Esq. of Curlowrie. 


\section{GASTROCHÆNID E.}

$W_{E}$ have seen that several of the mollusks of the preceding family secrete a testaceous tube, which lines their habitations and protects their siphons. This character was laid undue stress upon by Lamarck, who united with the tube-forming species of Pholadidre the genera Fistulana, Clavagella and Aspergillum, and constituted thus his family of Tubicola. This family was afterwards reformed by Deshayes, and restricted to the three last-named Lamarckian genera, which were retained by him as $A$ spergillum, Clavagella, and Gastrochana. The tube-making character is, however, as unessential here as it is in the Pholadida; and, as we shall see presently, the genus Saxicava, which is always free, must take rank next after and along with Gastrochcena, whilst Petricola, and probably Venerupis, have strong claims to a similar position.

The animals of this family are oblong or claviform, and often provided with very long siphons, united almost to their extremities, where their orifices are ornamented with cirrhi. The mantle is closed in front, except a small opening for the passage of a very small digitiform foot, very different from that of the Plolas tribe. The margin of the mantle around this opening is plain. The shell is equivalve and often gaping, with valves often very inequilateral, united by a simple rudiment, or in some cases a toothed linge, often variable even in the species of a single genus. They have no spoon-shaped apophysis under the beaks, nor accessory plates behind them, A calcareous

voL. I. 
tube sometimes protects the valves, and in certain genera unites with them. These tubes are very regular and curious in some of the exotic species, especially in those which live buried in sand. This halit is not merely the living habitually and freely in sand, as the razor fish do, but rather the treating of it in the manner of a substance bored into, and the tubes are to be regarded as the linings of the perforations so made. All the species of the family are borers, most of them preferring calcareous rock.

\section{GASTIROCII JENA, STENGLER.}

Shell cuneiform, equivalve, widely gaping, valves very inequilateral; hinge simple, linear, toothless, lut fumished with a small spathulate lamina; ligament external, long; muscular impressions small, distant, comected by a slightlymarkerl, sinuated, palleal impression.

Tube calcareous, claviform, free or fixed, often incomplete.

Animal cuneiform, or when the siphons, which are separate only at their extremities, are extended, elongated; orifices fringed; mantle closed, and thickened when exposed; with a very small opening for the small, pointed, rurved, funger-shaped foot, which sometimes spins a delicate lysisus. Nouth with two equal, simple lips, and a pair of sickle-shaped labial tentacula.

This genus is chiefly interesting on account of the curious tulues which are formed by the several species, often enveloping them in the manner of a flask. M. Deshayes helieves" that the animal, at certain periods, can dissolve a part of its tube, and so cularge its capacity, observing with

\footnotetext{
* Mollusques d'Algerie, p. 24.
} 
respect to the allied genus Clavagella, in which the valves of the shell adhere to the tube, that we cannot otherwise understand their growth, since it becomes necessary that the wall of the tube should disappear; then it is replaced by the shell. He deseribes a peculiar organ connected with the mantle, which he believes to secrete an acid for the purpose of destroying a part of the tube, and permitting of the enlargement of the cavity inhabited by the animal. This organ he supposes to have alternations of activity and repose. Such an explanation, however, is too hypothetical to be admitted without question, and the purpose of the structure, which the distinguished French malacologist terms an acid-secreting organ, is by no means clearly made out. We should rather be inclined to believe that the enlargement of the tube was effected by some process of absorption and replacement; but for light upon this as upon many other obscure though highly interesting phenomena in the economy of these mollusks, we must wait for furtler researches and careful observations on the habits of living animals. In the British seas Gastrockance are not so generally distributed or so plentiful as to aford convenient opportunities for such observations; but the naturalists who live on the coasts of the Mediterranean would do well to direct their attention to the subject.

The genus, though including comparatively few species, is almost cosmopolitan, having representatives in most seas. Geological researches shew that it was even less extensively developed in the pre-adamic epochs than now. 


\section{G. Modiolins, Lamarek.}

Plate II. figs. 5, 6, 7, 8 ; and (animal) Plate F. f. 5.

Mya dubia, Pess. Brit. Zool. ed. 1777, vol. iv. p. 82, pl. 44, f. 19.-Donov. Br. Shells, rol. iii.pl. 108,-Dorset. Catal. p. 27, pl. 1, f. 11.-Linn, Trans. vol. viii. p. 33. - TurT. Conch. Diction. p. 104.-Wood. General Conch. p. 102, pl. 25, f. $2,3$.

Chama parea, DA Cost A, Brit. Conch. p. 234.

Mya pholadia, MIont. Test. Brit. vol。 i. pp. 28, 559, and Suppl. p. 20.

Pholas faba, Pultenex, Hutchin's Hist. Dorset, p. 27.

Nytilus ambigurus, DrLlw. Recent Shells, vol, i. p. 304.

Gastrochana modiolina, Lar. Anim. s. Vert. ed. 2, vol. iv. p. 49.-Sow. Genera Shells, Gastrochæna, f. 1, 2; Conch. Manual, f. 52.-ReEve, Conch. System, pl. 20, f. 1, 2.HANu. Recent Shells, p. 10.-Brit. Marine Conch. p. 33 .

Nat. Hist. vol. vi. p. 404, f. $52,-$ Brown, Ill.

Conch. G. B. p. 116, pl. 48, f. 13, 14.

$" \quad$ dulia, Desh. Traité Elem. Conch. pl. 2, f. 4, 5.-Philippr, in Wiegman Archiv. Natur. 1845, pl. 7, f. 1.

The paucity of known species belonging to the genus Ciastrucherna, gives an interest, independent of peculiarities of habitat and infrequency of oceurrence, to the only one inhabiting our British seas. This is obliquely oval-oblong, in shape, cuneiform in convexity, being ventricose in front, and compressed behind, rather thin and fragile, and of a somewhat opaque white. The surface, which in living examples is very slightly glossy, is merely marked with fine concentric wrinkles, which are chiefly evident in front and below. The large hiatus, which is fig-shaped, being rounded in fiont, and produced and tapering behind to an acuminated point, occupies nealy the entire ventral margin; the shell is strictly closed at its posterior termination. The sirles are excessively mequal, but the umbones which are decidedly prominent and curving forward, are not 
quite terminal, as there exists a very short front dorsal edge, about equal to one-sixth of the hinder dorsal line as measured from the beaks to the extreme termination of the shell. The edges of this short dorsal line, which is scarcely convex and but very slightly declining, are reflected, and in consequence the small surrounding region appears somewhat excavated. The hinder dorsal margin, which for a considerable distance is straightish and not at all sloping but rather ascending, finally forming one line with the posterior, sweeps downward with a convex curve, attenuating the rounded extremity of the hinder side. The ventral margin, just by its anterior termination, is rounded, and very obliquely ascends in a scarcely convex line towards the front dorsal, by its juncture with which the anterior end is rather sharply angulated. The ligament is rufous, rather long, and slightly prominent: there is not the slightest indication of an umbonal ridge. The hinge consists of a not peculiarly small, somewhat spoon-shaped lamina, which projects inwards at some little distance from the anterior extremity.

The valves rarely exceed three quarters of an inch in length, and about half that measurement in breadth.

The valves are entirely concealed in a bottle-shaped sheath, of which the bulb is usually an excavation lined with shelly matter, and the neck which projects from the imbedded mass, a bipartite tube, resembling two cylinders laterally fastened together with their touching edges filed away. Authors do not appear to have universally noticed the existence of this envelope, which, however curious in its structure, is certainly a generic and not a specific characteristic, since we possess other Gastrochence of exotic origin, which, although perfectly distinct in the form and charactex of their valves, have their protecting cells of precisely similar 
architecture. On the sulject of these eases, there may be found an interesting paper in the sixth volume of the "Magazine of Natural History," written by Mr. Lulis, a gentleman from whose cabinet, Dr. Turton derived a consilerable portion of his information upon the shells of the Chamnel Islands. From that paper we extract the following sentences, which are equally applicable to the case we have figured (from Irelant,) as to the Guerusey individuals, from which the somewhat rude woorl-cuts referred to in the text were sketched: "In a country destitute of limestone or soft rock, these animals are indebted to other means for supplying them with a habitation. 'The Cr. pleoledia accommodates itself to creviees, not the interior of rocks, where it forms its residence by covering its shell as here exhibited. It is found among madrepores and shelly fragments, thrown up with alluvial sand and rubbish on the sides of rocks. The cases here shewn are composed of broken shells and gravel, mixed with fragments of felspar, hornblende, and sand, (these latter substances are not present in our own examples, strongly aggilutinated together. 'The inside is smooth, and consists of thin layers of the calcareous secretion applied by the animal in the formation of this chamber, which somewhat resembles it flask; the lengthened neck through which the animal passes the double tube, is formed of concentric layers of the same substance, preserving to a certain depth, the same figure as at the summit of it."

The animal of Giastivchene modioline was first observed and figured by Delle Chiaje. It has recently attracted the attention of Philippi and of Deshayes, both of whom have pullished figures and accounts of its structure, external and internal. On the British shores it has been carefully examined by Mr. Clark. 'The body is claviform, broad 
anterierly, tapering posteriorly, the siphonal tube capable of considerable extension. The mantle is entirely closed, with the exception of a small aperture in front, for the passage of the small finger-shaped pointed foot, which has a byssal groove at its base. That part of the mantle which is exposed is strong and thick. "Its inner surface," writes Mr. Clark, " is fortified by a muscular substance of a pale green colour, disposed in folds and rugosities." This is probably the same body which M. Deshayes regards as an acid-secreting organ. The siphonal tubes are capable of being either almost withdrawn into the shell or protruded to three times its length. They are united almost quite to their extremities. Both the orifices are surrounded by cirrhi. These, according to Philippi, are short and red, and appear to spring from the margin of the opening in the lower siphon, but are removed to some distance from it in the upper.* Mr. Clark describes the branchix as of a pale brown colour; they run longitudinally, and nearly parallel to each other, and are of small deptl, the upper one less than the lower. On each side of the mouth is a pair of short finely-pectinated tentacula, nearly equal in length. The body of the animal is of a flaky white hue; the siphons reddish brown, more deeply coloured at their cxtremities.

With regard to its locality, we look upon Torbay as the most prolific seat of it upon the English coast, and Birterbuy Bay, in Connemara, as the most populous of its Irish habitats. From the former, at the depth of ten fathoms, we have taken masses of limestone well honeycombed by its excavations, and tenanted by several individuals, both living and dead; from the latter came numerous examples, dredged by Dr. Farren and Mr. Barlee, of that interesting variety with the more elaborate case, of which a repre-

\footnotetext{
* Philippi, in Wiegman's Archiv. 1845, pl. 187, p. 7, f. 14.
} 
sentation appears among our engrarings (pl. ii. fig. S). It is not, however, to be regarded as common, but few localities yiedding it in any abundance; and the frequent accidental destruction of its tender valves, during the process of disinterring it, renders it of course a less frequent sojourner in the cabinets of the collector. Among other localities we may enumerate, Exmouth (Clark); off Weymouth, alive (M'Andrew); Guernsey, in thick valyes of dead oysters (Hanley); South Isles of Arran, off Galway Bay, and Youghal, County Cork (R. Ball). (IV. T. Amm. N. H. vol. xiii. p. 434.)

It is a common inhabitant of the Lusitanian and Mediterrancan, as well as of a great part of the Celtic regions of the European seas, and occurs fossil in the newer pleistocene berls of Italy. Philippi, however, considers the Mediterranean form a distinct species, and describes it under the name of Poliana.* It was an inhabitant of the British seas during the epochs of the coralline and red crags, but retired for a time, when glacial conditions prevailed.

\section{Saxicava, Fleuriau de Bellevue.}

Shell oblong or rhomboidal, equivalve, more or less inequilateral and gaping: beaks prominent: hinge furnished with cardinal tecth in some stages of its growth, never with lateral: ligament external, more or less projecting: muscular impressions strong, distant, connected by a sintiated pallial impression. No enveloping tube.

Animal oblong or claviform: mantle closed in front, except a very small opening for the passage of a digitiform foot, which is furnished with a byssal groove: siphons united nearly to the extremities: branchial and anal orifices large, margined with a fringe of (simple) cirrhi.

* Wiegmann's Archiv. 1845, p. 186. 
When we compare the animal of Saxicave with that of Gastrochana, we are at once struck with the near resemblance and evident affinity of the two genera, so near, indeed, that it is difficult to draw a well-marked line between them. We find the same structure of mantle, the same form of foot, and very similar siphons in each. The shells are also very similar, and some of the varieties of Saxicava mugosa are so like in every respect to Gastrochcena, that, did we not know their history, it would be difficult, if not impossible, to pronounce on their generic position. But when we attend to the changes which the former shell presents in the course of its growth, and compare the several congeneric species at different ages, we recognise a marked source of distinction, which, combined with the habit in Saxicava of never forming a tube, whilst Gastrochana always, if possible, makes one, warrants the separation of the two genera. Those naturalists who have either not been acquainted with, or have not understood the animal of Saxicava have been extremely puzzled as to its true position, whilst the variable characters of the hinges of our European species have increased the difficulty and led to the institution of several spurious genera. The generic terms Byssomya, Hiatella, Rhomboides, Biapholius, and Agina, have not been proposed as mere synonyms of Saxicava, but as so many allied genera of equal rank, all constituted out of the typical species of the genus; whilst Mya, Solen, Donax, Mytilus, and Anatina, have at various times, and some simultaneously, numbered among their spurious adherents varieties of the same Protean shell. Its true position has been equally misunderstood, its close affinity with Gastrochance having rarely been recognised: more usually it has been placed between Solen and $M Y y a$, a false position assigned to it even by Cuvier. This is the more remarkable, seeing that 
Otto Frederic Miuller had long ago correctly delineated its animal.

The Sucicaic are borers, althongh the habit of boring does not seem necessary to their existence, since we find them very commonly free. If there be a crevice, however, in rock, shell, coral, or seaweed, into which they can thrust themselves, they do so; and if near a limestone rock perforate it, and form erypts in which they live. Mr. Osler states that, when young they are very active animals, and soon commence to perforate. Both that gentleman and Mr. Garner have noticed that their excavations are not round, nor the sides smoothed off like those of the holes made ly Pholas. As for us, we only know of their boring into calcareous rocks, but Mr. Clark has noticed an instance of their perforating triassic sandstone at Exmouth. Whereever we have a sea-coast of mountain limestone, the surfice of the rockis is almost invariably found riddled by Saxicuva. The whole front of the Plymouth breakmater has been attacked by it, and much alarm for its safety excited. Mr. Couch observes that the Saxicava never bores deeper than six inches, and that, consequently, unless a new surface be exposed by the destruction of the perforated part, there is not much danger. Owing, however, to the thinness of the partitions, which often are the only separations between the crypts of these molluslis, there is a great probability of the action of the sea rapilly forming new surfaces in such cases. How they bore has been as much discussed as the question lhow Pleolas bores. The general opinion has been, that Saxicara bores by means of an acid secretion; an opinion held by many who will not admit the probability of such an agent being used by the Pholadida. Mr. Osler, though inclined to such a view, could detect no acid, nor, for reasons previously stated, is it likely. Mr. Hancock, as 
we have seen when treating of Pholas, expressly asserts that the Saxicave bore by rasping, effected by means of siliceous particles contained in the anterior part of the mantle. Mr. Couch entertains a similar view. We have not been able to satisfy ourselves of the presence of such particles, though inclined to regard such a view with favour, as in this case the surface of the shell does not seem devised for rasping as is that of the shells of the last tribe.

Great interest attaches to the British species of this genus in a geological point of view; one, if not both of them, owing a wide distribution, in the present epoch, to events which occurred in pre-adamite ages. The researches of geologists have made known to us, that, previous to the present state of things, within the area of our islands, there existed climatal conditions much more severe than those which now prevail,- that, in fact, the climate of Greenland, and the fauna and flora of the regions in which that climate is now met with, then extended over the greater part of Europe and Northern Asia, having its southern bounds somewhere in a line with the southernmost part of the British Islands as they are now constituted. At that time, however, the greater part of our country was under water, and represented by ridges of land and small islands, rising in the midst of an icy sea. During this chilly epoch the Saxicava extended their range almost round the whole of the northern hemisphere, and, when the bed of the glacial ocean was upheaved,-as geological research proves to hivve been the case, previous to the present arrangements of our region, and preparatory to a more genial assemblage of conditions, - the shells of these mollusks were preserved in the raised sea-beds, and are found in them now, even at elevations of several hundred feet about the level of the present sea. 'Thus we find them in Sweden, where 
their inland position attracted the attention of Limneus, whose all-inquiring mind was deeply impressed with this curious, and, in his time, inexplicable phenomenon ;* in Norway, where the importance of the fact was fully recognised by the great German geologist, Baron Von Buch; in Canada, whence we have seen specimens brought home by Mr. Lyell ; in distant and inland regions of Russia, where the glacial beds were traced by Sir Roderic Murchison and M. de Verneuil; and at home, where numerous observers have noted the inland occurrence of the Saxicava-above all, Mr. Smith of Jordanhill, who, bringing the knowledge of the conchologist, and the discrimination of the fieldnaturalist, to bear upon these critical investigations, was the first to shew that these shells alone, from peculiarities of variation and locality, indicated of themselves that the conditions under which they lived were dissimilar from those now regulating the distribution of animals in our seas. We could scarcely cite a more triumphant instance of the necessity of a minute study of the character and habits of our native shells to the geologist who seeks to interpret the complicated phenomena of the changes which preceded the present epoch; whilst, on the other hand, he may fairly appeal to the naturalist equally to recognise the services rendered, in return, by geological research; for assuredly it is as vain to attempt to explain the distribution of existing beings on the surface of the globe, without the aid of geological science, as it is to work out its physical geography without a careful study of the changes the earth has undergone in time.

* Linnæus, Wast-Gotha Resa. p. 198. 


\section{S. arctica, Linnæus.}

Anterior extremity attenuated and cuneiform, with a lunulelike excavation in front of the prominent beaks; posterior extremity always the broader; ligamental edge almost always incurved ; linear ridges spinous except in very aged individuals; hinge toothed.

Plate VI. figures $4,5,6$.

MYya arctica, LInn. Syst. Nat. p. 1113.-O. FABr. Fauna Grænl. p. 407.Turt. Conch. Diction. p. 104.-Wood, General Conch. p. 95.

Solen minutus, Linn. Syst. Nat. p. 1114.-Mont. Test. Brit. p. 53, pl. 1, f. 4.Spengl. Skrivt. Naturh. Selskab. vol. iii. part 2, p. 113.-Linn. Trans. vol. viii. p. 47.-Turt. Conch. Diction. p. 161.-СhемN. Conch. Cab. vol. vi. p. 67, pl. 6, f. 51, 52_Wood, General Conch. p. 139, pl. 34, f. 5, 6.-DiLLw. Recent Shells, vol, i. p. 69.-Laм. Anim. s. Vert. ed. 2, vol. vi. p. 57. - Index Testaceol. pl. 3, f. 33.

Donax rhomboides, PoLr, Test. Sicil. pl. 15, f. 12, 15.

Mytilus pracisus, Mont. Test. Brit. p. 165.-Linn. Trans. vol. viii. p. 112.Dillw. Recent Shells, p. 305.

ITiatella arctica, Lam. Anim. s. Vert. ed. 2, vol. vi. p. 443.-Fuenr. Brit. Anim. p. 461.-Brit. Marine Conch. p. 59.-Bow dich, Conchology, Biv. fo 40.-Crouch, Introd. Conch. pl. 8, f. 6.- HanL. Recent Shells, p. 150.-Cuvier, R. Anim. (ed. Croch.) pl. 110, f. 1 .

Anatina Aretica, Turt. Dithyra Brit. p. 49, pl. 4, f. 7, 8.-Brit. Mar. Conch.p. 42. Agina purpurea, Turt. Dithyra Brit. p. 54, pl. 4, f. 9.-Brit. Marine Conch.p. 60. Solen purpurcus, Fuem. Brit. Anim. p. 459.

Saxicava rhomboides, Desh. in Lam. ed. 2, vol. vi. p. 153.

Saxicava arctica, Desh. Elem. Conch. pl. 12, f. 8, 9.-PhiL. Moll. Sicil. vol. i. p. 20, pl. 3, f. 3, and vol. ii. p. 19.-MacGirL. Moll. Aber. p. 285.-Loven, Ind. Moll. Sueciæ, p. 40.

Hiatella minuta, Turt. Dithyra Brit. p. 24, pl. 2, f. 12.-Brown, Ill. Conch. G. B. p. 103, pl. 47 . f. 1,16 .

Saxicava purpurea, Brows, Ill. Conch. G. B. pl. 42, f. 30, 31.

Saxicava rubra, Desh. Exp. Algérie, Moll. pl. 66, f. 18, 19 (shell and animal). Hiatelle, Chenu, Traité Element. p. 58, f. 206.

Nothing but the most searching scrutiny will distinguish this closely allied Saxicava from its congener mogos, the young of which is often confused in cabinets with that of 
this species, owing to the erroneous but current belief that arctica is distinguished from mege by being armed with spinous scales. This character, however, is shared, although less strongly so, by the young of the latter, and is completely lost in the aged examples of either species. Neither will the presence of teeth upon the hinge margin of aretica suffice for its ready separation, even though conjoined with the previonsly mentioned character, since the young migosa have likewise teeth, although most feebly developed. It is requisite, then, to discover some permanent distinctive characteristic, which may assist the eye in the determination of the two species, that organ frequently enabling the collecting naturalist to ascertain the aggregate value of specific differences, which neither his tongue nor his pen can analytically define. This method, however allowable to collectors, is most reprehensible in authors, too many of whom have indolently preferred trusting the establishment of their discoveries to the skilful pencil of the artist, rather than themselves laboriously pourtray with their pen those several features, from the combination of which specific identity is constituted; thus entailing upon every anthor of a cyclopeedia of species the necessity of personally examining each individual one, a labour which, lowever possible and desirable in a local or partial Fanna, must, in a general descriptive catalogue, be practically unattainable.

The tangible mark of distinction between arctica and runose consists in the constant presence of an excavated lunule in front of the beaks, which are moreover acute, leaning forward, and, when viewed in front, sufficiently prominent. 'The anterior extremity is more or less cunciform, and is always attenuated; whereas in rugose that portion is usually rounded and frequently broad: in that 
shell, likewise, the downward inclination of the front dorsal margin is almost invariably arcuated or convex, whilst, in the present species it is oblique, and for a considerable distance incurved, only becoming convex near its ventral termination, which consequently is its most projecting part, the chief prominence in rugosa being, on the contrary, usually situated nearer the dorsal side.

The form is rhomboidal, with the length double or triple the breadth of the shell, the former chiefly in the adult, the latter frequently in the younger or immature individuals. The dorsal and ventral margins are more or less subparallel, and both exhibit a decided tendency to incurvation, whenever permitted by the circumstances of growth to assume an unrestricted outline. The valves are tolerably strong (solid in aged specimens, which stage of growth seems by no means common in collections), but rather fragile in the young, opaquely white under a lighter or darker brownish yellow epidermis, coarsely wrinkled concentrically, and otherwise only marked with two widely diverging elevated lines which run from the beaks posteriorward, one diagonally to the ventral side of the hinder extremity, the other adjacent to (but not parallel with) the posterior dorsal margin. These lines are armed (except in aged examples, where even the upper line itself is almost obsolete, and the lower resembles an umbonal ridge,) with rather strong and moderately sized scaly prickles, the narrow triangular area between which series is usually slightly concave. The front side is very short, occupying less more frequently than beyond one quarter of the entire length; the hinder side is greatly produced, and abruptly (not obliquely) subtruncated and bluntly biangulated at its termination, which does not taper off as in the typical rugosa, but is the broader of the two extremities. The 
ligament is small, sunken, and of a yellowish brown; the bealis sharply defined, acute, rather prominent, and leaning forwarl ; having in front of them a deeply impressed, more or less orate lunule. The interior is of a pure glossy white (sometimes subnacreous beneath the umbones), the margin entire, and the hinge, when not entirely obliterated with age (in which case the margin itself displays a considerable callosity), consisting of a single strong acute primary tooth in the right valve, interlocking between a rather smaller and a perfectly rudimentary one in the left valve. This latter minute denticle is sometimes present, but more usually absent, in both valves. The convexity of the valves sometimes amounts to ventricosity, more ordinarily they are but moderately convex, but there is always an appearance of compression upon the umbonal region, owing to the constant concavity of that portion of the surface which precedes the diagonal elevation.

The size of our British specimens is greatly inferior to that of foreign examples, and almost always with us is less than in the succeeding species, the average of individuals not exceeding two-thirds of an inch in length, and twofiftls of an incl, at most, in breadth.

The animal of this species is oblong or cylindrical, its mantle closed in front except a small orifice for the passage of the foot, which is very simall and conical, and fumished with a byssal groove. 'The siphonal tubes are short, nearly equal, and united very nearly to their extremitin's, which are each furnished with about ten or twelve cirrhi. The body and foot are usually white or yellowish, the tubes orange, rose-colour, or brownish, varying much in intensity of colour.

The Iliatella arctica, though distributed throughont the British seas, is far more abundant in the north than in the 
south; the reverse of which is the case with the next species. It is found sometimes imbedded in stones or old shells, as oysters; sometimes and very commonly attached by a slight byssus to corallines, especially Sertularice and Antennularia, also in the meshes of intertwining Serpula, especially in the complicated interlacements of the curious Filopora filograna, and in the interstices of marine plants, such as the coral-like Nullipore and the roots of Laminarix digitata. It ranges from low water mark to very great depths, and appears to prefer gravelly ground. Though found almost every where on our coasts, when conditions are favourable, and consequently enumerated in all our local Faunas, a few localities may be specified in illustration of its habits and range. In the south of England it oceurs boring into hard limestone at Plymouth (Montagu), and red sandstone at Exmouth (Clark); free in twenty fathoms water off the Land's End (R. M'Andrew and E. F.) ; in seven fathoms, stony ground, Weymouth (M'Andrew); Swansea (Jeffreys); Anglesea (Eyton); in twenty-five fathoms, eight miles from land, north of Anglesea ( $\mathrm{MI}^{ } \mathrm{A}_{\mathrm{n}}$. drew); on shell bank, twenty fathoms, north of the Isle of Man, and twelve fathoms south (E. F.). Dead valves in from one hundred and ten to one hundred and forty fathoms, off the Mull of Galloway (Capt. Beechey, R.N.); all round Ireland (Thompson); everywhere in the Hebrides; in fifty fathoms, five miles from land, off Cape Wrath (M' Andrew); in crevices of stones, fifty fathoms on the high banks, and alive in eighty fathoms off the west coast of Zetland (M'Andrew and E. F.); dead valves in one hundred fathoms, twenty-five miles from land off the east coast of Zetland (M'Andrew). This species ranges throughout the boreal and arctic provinees of the North Atlantic. It is found rarely and of small size in the Mediterranean.

VOL. I. 


\section{S. RUgosa, Limnæus.}

Anterior extremity usually broad and rounded, no decided lunule-like excavation in front of the beaks; posterior extremity frefuently the narrower, ligamental elge rarely much incurved, more often convex; linear ridges only spinous in the young shell; linge margin of the mature shell edentulous.

Plate VI. figures 7, 8, and (Animal) Plate F. fig. 6.

Mytilus rugosus, PExN. Brit. Zool. cd.1, vol. iv. p. 110, p. 63, f. 72.-Pultenex, Hutchins Dorset, p. 37.-Movi. Test. Brit. p. 164.-Donov. Brit. Shells, vol. ir. p. 141.-Linn. Trans, vol. riii. p. 105.Dorset Cataloguc, p. 39, pl. 13, f. 5.-T'urT. Conch. Diction. p. 113.-Dillw. Recent Shells, vol, i. p. 304.-Index 'T'esticcolog. pl. 12. Mytil. f. 9.

Mytilus ploladis, Lixx. MIantissa? p. 543.-MIuller, Zool, Danica, pl. 87, f. $1,2,3$.

Myje byssifera, O. Fabric. Fauna Greenland. p. 408.

Saxicura rugosa, LaM. Anim. s. Vert. ed. 2, vol. vi. p. 152.-Turt. Dithyra Brit. p. 20, pl. 2, f.10.-MAcGilliv. Moll. Aberd. p. 285.Broww, Illust. Conch. G. B. p. 103, pl. 47, f. 14, 16.Crouci, Introd. Conch. pl. 5. f. 3.- Soweriby, Genera Shells, Saxicava, f. 2, 3, 4.-Rerve, Conch. Icon. vol, i. pl. 50, f. 2, 3, 4.-H ANL. Recent Shells, p. 50 .

Saricava Gallicana, Lam. Anim.s. Vert. ed. 2, vol. vi. p. 152.-Deles. Rec. Coq. pl. 4, f. 9.-Desir. Elem. Conch. pl. 12, f. 1, 2, 3.H.1NL. Recent Shells, suppl. pl. 9, f. 5.

Saxicara pholadis, Lam. Anim. s. Vert. ed. 2, vol.6, p. 152.-Tunt. Dithym Brit. p. 21, pl. 2, f. 11.-IIANL. Recent Shells, p. 50.

Saxicaze distorta, Govld, Invert. Massach. p. 61, f. 40.

Byssomya pholadis, Bow dicir, Bivalves, f. 43.

IVictelle oblonga, (young) Turt. Dithyra Brit. p. 25, pl. 2, f. 13.

IViatella nugasa, Flex. Brit. Anim. p. 461.-Brit. Marine Conch. p. 58. Serxicare ridée, Culenu, Traité Elem. p. 58, fo 197, 198.

There scarcely exists a molluscous animal, whose testaceous covering is more affected by circumstances of labitation, than this ancient and widely extended species. Sulject to almost every distortion of shape, it has received sereral appellations. The valves, when uninterruptedly developerl, are generally of an oval-olblong shape; they are solid, ventricose, opaque, white, covered with a dull or 
scarcely at all glossy, paler or darker, brownish yellow epidermis, beneath which the surface is utterly devoid of lustre, and very coarsely wrinkled in a concentric direction. From the beals to either sile of the posterior extremity, runs a more or less obsolete elevated line, which is prickled with small and rather elongated vaulted scales, but only entirely so in the very young, and partially so (in the vicinity of the beaks) in the middle-aged specimens, the full grown aged examples rarely presenting the slightest trace of their previous existence. Both the beaks, which are simply incurved, and the umbones, are very far from prominent, and exhibit no trace of a lunule in front of them, the lips of the anterior dorsal edge more frequently on the contrary protruding outwards. The front side is invariably much shorter than the hinder one, which is at the least twice and a half its length, but its proportion to the entire area is generally much greater than in arctica, owing to the anterior extremity being typically round and never sharply cuneiform, the curve of the anterior outline sweeping outwards, not bending inwards. The ventral edge is generally inclined to retusion a little before the middle, and runs nearly parallel to the hinder dorsal, which latter, however retuse it may be near the beaks, always becomes convex before its termination. The hinder extremity is more or less obtusely subbiangulated, but never so distinctly and sharply as in aretica; moreover, it is always, when freely developed, disposed to taper a little just before its termination, and in one narrow variety which has its posterior side greatly produced, and its anterior one correspondingly abbreviated, this attenuation is most distinctly visible. The ligament is brown, (yellowish or ashy brown in the young,) and in typical examples is prominent and forms one piece with the epidermis, but these characters are rarely 
observalble, ats the majority of specimens are rubbed and distorted.

The hinge margin is destitute of any teeth, and is greatly thicliened in the more aged shells; the rery immature ones have usually, however, two or three rudimental primary teeth, but these, in most of our English specimens are very minnte and caducous. The palleal scar is situated very high up, not easily discernible and flexuous. Examples are rarely obtained which exceed an inch in length, and about half an inch in breadth; the proportions are, however, very variable, as the longer shells are often the least wide ones.

'The animal is oblong, somewhat claviform, or, when the siphons are contracted, oval. The mantle is completely closed, except a small round orifice in the centre of the widest part (that occupying the gape of the shell) through which it can protrude a linear, linguiform, triangular pointed foot, having a byssal groove at its base. This foot is sometimes entirely withdrawn, sometimes only protruded as far ats the point, and oceasionally thrust out to a considerable distance. Mr. Clark has observed a substance lining the mantle, similar to that noticed in Gastruchana, but white. That part of the fiont of the mantle, where the edges of the valves approach, is brownish and ligamentous. Immediately beyond it is the base of the mited siphons, which are separated only at their extremities, which are nearly equally, but not quite, on a level. The margins of the branchial and anal orifices are minutely cirrhated; the cirrhi appear to he simple. There are about thirty around each. The whole animal is more or less tinged with yellow, which colour is palest in the central part of the mantle. 'The anterior extremity, and the siphons, are of an orange hue, often very bright and intense. 
On the southern coasts this species may be regarded as a very common and abundant shell; in the north it is not so plentiful. It is found near low-water mark upon the shores of Kent and Sussex, buried in large masses of chalk (S. H.), and is dredged as well as found upon the beach in detached portions of limestone rocks at Torquay, Weymouth, and other parts of Devonshire and Dorset (S. H.): in the west bay of Portland it is dredged alive in twenty fathoms water (R. M'Andrew and E. F.) ; common at Scarborough (Bean); Swansea (Jeffreys); around the Irish Coast (Thompson). In twenty fathoms water off the Isle of Man (E. F.) ; Zetland, Ullapool, Loch Carron, and other localities on the west of Scotland (Jeffreys and Barlee); Lerwick, in seven fathoms, among Laminarice (M'Andrew) ; Frith of Forth, in seven fathoms (E. F.). In local lists, this and the last species are so often mentioned under the same name, that it is difficult to discriminate their several localities.

It ranges throughout the Boreal and Celtic regions of the North Atlantic. Mr. M‘Andrew has dredged it on the north coast of Spain. It is more abundant as a pleistocene fossil than the last species.

Some curious little shells, of which a few pair were dredged by Mr. Hanley, not far from the pier at Ryde, in the Isle of Wight, and an odd valve or two were procured by Mr. Jeffreys in the Island of Skye, have been figured, (Plate VI. figs. 1, 2, 3,) but not designated by us, under the supposition that, however different in aspect, they may prove to be merely the young of the last species. Their shape is ovate-oblong, but more rounded above than below; the texture is thin and fragile, but not transparent, and the 
valves are moderately convex, but compressed subeentrally. Extemally the colour is dirty-whitish, internally of a very slightly nacreous porcelain white. The outer surface is nearly smooth, lut minutely and irregularly wrinkled concentri('ally at the narrower extremity, and in some specimens appears delicately and distantly subliminated, throngh a kind of imbricated elevation of the former stages of growth. This latter feature can, however, be only regarded as an accidental and not a permanent characteristic. The ventral margin is nearly straight, with sometimes a slight retusion towards the front; the anterior dorsal elge slopes but very moderately, and almost in a straight line; the hinder dorsal line is elevaterl above the level of the beaks, ascending from them with a very trifling slope, in nearly a rectilinear or scarcely convex course, and uniting near its close with the posterior margin in a bold and areuated outward sweep to the lower corner of the hinder extremity. The hinder side is thus dilated, and contains nearly quadruple the area of that of the anterior: this latter, which is not more than half as long as the posterior, is narrow, attenuated, and obtusely rounded at it, commencement. The umbonal ridge is remarkally developed, ruming very obliquely and most frominently, so as to cut off a large posterior convex space. Although much elevated, it is not acute, and does not exhibit the slightest trace of any aculeation. Before it, a somewhat triangular suface, oecupying about the same space as that succeding it, is depressed below the level of the remainder of the shell. The beaks are distinet, but small, and apparently do not incline to either side; the umbones appear depressed when examined from the posterior side; but are much raised above the level of the front dorsal margin. 'There is no restige of a lunule, and the ligament is almost minute, of an ashy hue, and scarcely projecting. No tecth 
can be perceived with a lens of the highest power ; there is, however, a distinct callus beneath the ligament.

\section{PETRICOLA, LAMARCK.}

Shell ovate or subtrigonal, ventricose, equivalve, inequilateral, gaping: hinge with two cardinal teeth in each valve, or two in one, and one in the other valve. Ligament external short. Pallial impression, with an ample and rounded sinus.

Animal oval. Mantle closed in front except a small opening for a lanceolate and pointed foot. Siphons united for nearly half their lengths; their orifices fringed with a double series of cirrhi, the longer ones pinnated on one side.

Notwithstanding that the Petricola, from the comparatively impregnable nature of the fortifications in which they entrench themselves, are justly esteemed among the less frequent sojourners in our cabinets, the genus has a very wide distribution, pervading the temperate and southern parts of Europe, the Red Sea, the islauds of the S. Pacific, Australia, and the shores of South-Western and North America.

\section{P. lithophaga, Retzius.}

Plate VI. figs. 9, 10, and (animal) Plate G. f. 1.

I'enus lithophaga, Retzius, Trans. Turin. 1786.

(Unnamed.) PoLI, Test. Sicil. vol. i. pl. 7, f. 14, 15.

Mya decussata, Mont. Test. Brit. Suppl. p. 20, pl. 28. f. 1.-Turt. Conch. Diction. p. 102.-Flem. Brit. Anim. p. 466.-Brit. Marine Conch. p. 41.-Woon, General Conch. p. 99.-Diluw. Recent Shells, vol. i. p. 46.-Index Test. pl. 2, Mya, fo 17.

Petricola striata, Laм. Anim. s. Vert. ed. 2, vol. vi. p. 158.-Deles. Rec. Coquil. pl. 4, f. 11.-IIANL. Recent Shells. p. 52, suppl. pl. $11, \mathrm{f}_{\mathrm{o}} 44$. 
Petricola costelleta, Las. Anim. s. Vert. ed. 2, vol, vi. p. 158.-Deles. Rece. Coriuil. pl. 4, fo 12.-Have. Recent Shells, p. 52, suppl. pl. 11, f. 45.

„ roccellaria, LAx. Anim. s. Vert. ed. 2, vol, vi. p. 158.-Desrr. Elem. Conch. pl. 12, f. 7.-Deles. Rec. Coquil. pl. 4, f. 13.H.tvL. Recent Shells, p. 52, suppl. pl. 11, f. 46.

$"$ ruperella, Lim. Anim. s. Vert. ed. 2, vol. vi. p. 159.-Deles. Rec.

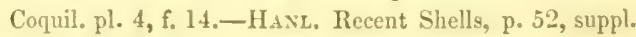
pl. 11, f. 47 .

Vénérupe pélricole, Buarvv. Man. Malac. pl. 76, f. 2.

I'etricola lithophaga, P'mulf pi, Moll. Sicil. vol. i. p. 21, pl. 3, fo 6, and vol, ii. p. 20.-PHu, in Wiegmann Archiv. Naturg, 1845, p. 138, p. 7, f. 11 to 14 (animal). - Exped. Scient. Algérie, Moll. pl. 66, f. 5 to 9 (shell), and pl. 67 (anatomy).

Sphenia decussata, Turt. Dithyra, Brit. p. 38,-Buow, Illust. Conch. G. B. p. 104, pl. 45, f. 3.

Pétricole costcllée, Cuexu, Traité Elem. p. 200, f. 59.

The shape of this Petricola varies from obovate to elongated ovate, and the solidity from rather thin to moderately strong. It is typically very inequilateral, but the inequality of its sides is often rendered less observable: by the impeded development of the hinder one: this character, however, is almost always observalble by noting the direction of the earlier lines of increase. The valves are ventricose, and sometimes even tumid in front, the hinder portion being always less convex. They are of a dull lustreless white, with, in one (the largest) specimen. an internal purplish stain at the posterior extremity. The surfice is roughened by numcrous radiating elevated lines, which, in the only two British examples we have seen, become narrow ribs posteriorly; and gradually diminish in brealth, but with an increasing proximity to each other, towards the anterior extremity, before arriving at which, they become obsolete or very nearly so. A kind of decuscition is produced from these lines being traversed by minute concentric wrinkles and strix of increase, but in ordinary (Mediteranean) specimens this is ly no mean 
a striking characteristic. A narrow strip near the hinder dorsal edge is often free from the radiation, and here the concentric wrinkles are usually the most evident. The ventral edge is much arcuated, ascending at both extremities, but more suddenly so anteriorly. The front dorsal edge is elongated, and not greatly declining, its outline has some disposition to convexity after quitting the ligament which appears to be dark, of moderate size, and rather prominent, but an examination of more specimens is required before this can be asserted with certainty. The (strictly limited) front dorsal edge is extremely short, and scarcely sloping, but it almost forms one sweep with the arcuated anterior margin. The front side of the shell is broad and very short; its extremity is rounded, but not symmetrically so, owing to the upper portion not eurving: equally with the lower. The produced posterior side becomes attenuated towards its extremity, which is more or less bluntly rounded. In the specimen figured this is more attenuated and elongated than is usual in the species, and the elevated radiating lines are coarser than in our Mediterranean examples. The umbones are tumid and rather prominent, and the beaks are small, much inflected, and scarcely leaning to either side. There is neither lunule nor umbonal ridge. The linge consists of two primary teeth in each valve, which are small, narrow, much elevated, projecting inward, and very caducous: the larger of these two, which is the anterior in the left, and the posterior in the right valve, is deeply cloven at its apex, where it is broader than at its base, which sulcus is continued below, even to the linge margin; the smaller tooth is less raised, simple, narrow, and more oblique. The inner margin is not crenated; the palleal sinus is ample and rounded.

VOL. I. 
We have never had an opportunity of observing the animal of this interesting shell in the living state. Philippi has been more fortunate, and we quote his account of it, * and copy the figure appended: "The animal has a mantle which is entirely closed, with the exception of a small aperture in front for the massage of the foot. Posteriorly it is extended into two siphons united for nearly half their length. When I observed the animal alive the free parts alone projected from the shell, and scarcely extended to a third of its length. They were brown towards the apertures, which were surrounded by extremely delieate cirrhi. Between them the margin of each orifice is striped or puckered, and nearer the interior are other comb-like cirrhi, ciliated on one side. The foot, which extends itself about two lines, is thin and sharply pointed. I think it has a byssus." Deshayes has given some figures illustrative of its anatomy in his great work on the Mollusea of Algeria.

The Myc decussate of Montagu, owing to the imperfect dentition of the original specimen, and its inarlequate representation in the "Testacea Britannica," has long been regarded as a lost species, and even its generic appellation has been at most hypothetical. The redis. covery of two specimens, ench by a different individual, have enabled us to ascertain its identity with a petricole, which, although abundant on the opposite coast of France, has rarely been met with upon our own shores. The larger of the examples alluded to was taken by Mr. J. S. Miller, at Bristol, in clay, the other, which is above the average size of the Mediterranean ones, twothirds of an inch long, and not quite half an inch at the broadest part, rewarded the researches of Mr. Hum-

* Wiegmann's Archiv. 1845, p. 188. 
phreys in Cork Harbour. Both shells are now in the almost perfect British collection of our friend, Mr. Jeffireys of Swansea. The only other recorded specimen was the original one obtained by Mr. Laskey from the Frith of Forth, near Dunbar, and described and figured by Col. Montagu. It is very doubtful, however, whether we can regard the Scottish specimen as indigenous, and not improbable, that it was taken out of ballast. The Atlantic coasts of France and Spain, and the Western Mediterranean are the regions where this mollusk is most at home.

VENERUPIS, LAMARCK.

Shell oblong, somewhat compressed, equivalve, inequilateral. Hinge, with two cardinal teeth in one valve and three in the other, or with three cardinal teeth in both valves, the central one more or less bifid. Ligament oblong, external. Palleal impression with a well-marked oblong sinus.

Animal oblong, thick, mantle closed in front for the passage of a compressed and lanceolate foot. Siphons united for about half their lengths, their orifice fringed with a double series of cirrhi, the longer ones pectinated.

This genus and the last approach very closely, and both present features which indicate an affinity with the Veneridle, though the characters of the mantle, and the manners of the species induce us rather to associate them with the family in which we have placed them here. Possibly, when their exotic allies have been more carefully studied, and the characters of their animal inhabitants better known, one or other genus may form the type of a family apart from the Gastrochanida. 


\section{IrUs, Linnæus.}

Plate VII. figs. 1, 2, 3, and (animal) Plate G. f. 2.

Donax Imus, Lixn. Syst. Nat. ed. 12, p. 1128.-Pultenex, Hutchins Dorset, p. 32,-Dovov. Brit. Shells, vol. i. pl. 29, f. 2.-Mont. Test. Brit. pp. 108, 573.-Linn. Trans. vol, viii. p. 77.-Dorset Cat. p. 34, pl. 12, f. 6 (badly).-Turt. Conch. Diction. p. 43.Crienn. Conch. Cab. vol. vi. p. 271, pl. 26, f. 268, 269, 270。Potr, Test. Sicil. pl. 10, f. 1, 2, 3, and pl. 19, f. 25, 26.-Dillw. Recent Shells, vol. i. p. 156.-Index Testaceolog. pl. 6, Donax, f. 21.

Tellina Cormubiensis, Pens. Brit. Zool. ed. 4 (from Borlase's Cornwall, pl. 28, f. 23).

Cuncus foliatus, DA Costa, Brit. Conch. p. 204, pl. 15, f. 6, on the left.

Venerupis Irus, Lax. Anim. s. Vert. ed. 2, vol. vi. p. 163.-Fuem. Brit. Anim. p. 451,-Brit. Marine Conch. p. 60.-Desh. Elem. Conch. pl. 12, f. 16, 17, 18.-Philippi, Moll. Sicil. vol. i.p. 21 ; and vol. ii. p. 20.-HAnt. Recent Shells, p. 54.-Exped. Scient. Algérie, Moll. pI. 66, f. 14 to 17 (animal).

Petricola Irus, Turt. Dithyra Brit. p. 26, pl. 2, f. 14.

Pullastra Irus, Brown, Illust. Conch. G. B. p. 89, pl. 37, f. 9 .

No minute and prolonged investigation is demanded, for the discrimination of this rock-borer from any of the litherto-found Testacen of our shores, the remarkable lamellation of its surface, enabling us immediately to separate it: the chief difficulty rests in discovering strictly permanent characteristics which may distinguish it from its foreign congeners, a few of which might easily be reckoned by the inexperienced, as but aberrant varieties of the same species. The shape is of course modified by that of its habitation, but is typically subrhomboidal, at times its length searcely exceeds its breadth by one-fourth, more nsmally, however, it nearly doubles it, and certain specimens are even still more longitudinally produced. The more beantiful live shells (as they are technically called) are of a pure slightly translucent white; such, however, are rare, and indeed but few specimens comparatively are taken with the animal in them. Most examples are of an uniform opauge dirty-white, or pale drab, externally: 
the interior is of a similar paleness to the exterior, but is always stained with purple or brown on the hinder hinge margin, and is usually tinged or dyed with similar colours near its posterior extremity. It never attains any considerable size. Its surface is more or less convex, at times even ventricose, and is totally devoid of lustre. Its solidity is extremely variable, it being sometimes decidedly thick and strong, but quite as often thin and fragile. The sides are extremely unequal, the front occupying ordinarily about one-fourth the length of the shell. The surface is adorned with thin-edged concentric lamellæ, which vary in approximation from distant to rather close-set, (the commoner form appears to be rather remote, ) and in elevation from depressed to erect. These have a decided tendency to enlarge posteriorly, and are fimbriated by the very crowded radiating striæ, which become elevated in the interstices. The front extremity is always a little narrowed at its termination by the very decided slope of its upper or dorsal margin, and the ascent of its lower one; which latter, although adapting itself to the circumstances of its dwellingplace, is typically rather convex and a little retuse near the middle, as an examination of the direction of the upper or undisturbed lamellie will demonstrate. The hinder extremity is always more or less biangulated, and sometimes a little attenuated: the hinder dorsal margin is straight, convex, or even incurved, but never much declining. The beaks are curved forward, and are not preceded by a lunule; the ligament is small, sunken, and narrow. The hinge consists of three primary diverging teeth in each valve; the central strong, and bifid or even bipartite, the front in one, and the hinder in the other valve, almost equally as large, but not always so evidently bifid, whilst the third in each is simple, narrow, and at times almost 
entirely obsolete. The inner margin is not crenated. Were it not for this last character, the Pectunculus truncatus of Da Costa, who, not delineating the species himself, refiers for its representation to Borlase, whose figure clearly is meant for Irus, might not unreasonably be deemed an old worn example of this Venempis. But as Montagu justly observes, his species is involved in great olscurity; from which uncertainty, the language of its anthor not strictly applicable to any British species, and crpually suited to more than one exotic bivalve, forbids all hope of our being able to extricate it.

Poli has remarked that it is very singular, whilst shells of the renempis irus are cast up in profusion on the coasts of Sicily, the animal is rarely found in them; indeed, he himself had never been able to meet with it. Common as the shell is in the south, few observations have been made upon its constructor. Deshayes has given an outline figure of the animal in his "Mollusques d'Algérie." IIe represents the siphons as united for a considerable length, and when separated of unequal lengths. One of them has the fringe of cirrlie placed immediately around the margin; the other has a tube-like continuation beyond the fringe. The cirrhi themselves are of two orders, the shorter one, reflexed and simple, the longer projecting and pimnate.

The valves rarely exceed half an inch in length and three-guarters of an inch in breadth. They are found imbedded in limestone rockis at Plymonth and other parts of Deronshire (Montagu); in large masses of rock opjosite the old castle at Weymouth (S. H.) Dead shells are frequent in shell sand all along the Southern coast. In S. Wales it has been found at Langland hay, near Swansea (Jeftieys). In Ireland at Youghal (R. Ball); IIowth (Turton); in -ponges and seatweed at Miltown Malbaty (W. Marvey). 
On the whole it may be considered as a southern species so far as the coasts of Britain are concerned. Indeed it does not appear to range further north, and is most abundant in the southern part of the Celtic province (Atlantic coast of France) and in the Lusitanian and Mediterranean regions of the European seas. Geologically it dates as far back as the epoch of the Red Crag, but retired for a time from our seas during the unfavourable conditions of the pleistocene period. It is an inhabitant of the littoral and laminarian zones, and rarely occurs even dead in the dredge, unless in very shallow water and close to shore.

\section{SPURIOUS.}

Venus substriata, Mont. Test. Brit. suppl. p. 48, pl. 29, f. 6.-Turt. Conch. Diction. p. 245. - Turt. Dithyra Brit. p. 152. - FL EM. Brit. Anim. p. 448.-Brit. Marine Conch. p. 91.

Venempis decussata, Philipri, Moll. Sicil. vol. i. p. 22, pl. 3, f. 5 , and vol. ii. p. 20.--Exped. Scien. Algérie, Moll. p. 66. f. 10 to 13 (shell and animal).

Rounded, subquadrangular, solid, opaque, more or less ventricose, rather dull, of an uniform white both within and without, most crowdedly set with radiating elevated strix, which assume a subgranular appearance, especially in front, by being decussated with irregular concentric wrinkles, which are more manifest anteriorly. Ventral margin but little convex, ascending in front, not crenated within: hinder dorsal edge straightish, and not declining ; front dorsal edge straightish, and considerably sloping. Anterior side much attenuated, very small, tolerably rounded at the extremity : posterior termination broadly subbiangulated, the angles being rounded off, and the extreme edge somewhat convex. Ligament almost concealed; umbones prominent; beaks incurved and distinct; no lunule. Two divergent compressed primary teeth in the right valve; three, of which the bifid central is the largest, in the other. Length $\frac{5}{8}$, breadth $\frac{1}{2}$ of an inch. A Mediterranean shell, introduced by Montagu, as dredged by MV. Laskey, off the Isle of May, in the Frith of Forth. Probably brought in ballast. 


\section{IIT. MYADA.}

THE GAPER TRIBE.

T'o arrange Mollusks, or the genera of any other class of animals, in a sequence of their natural affinities, is not possible in a written treatise, and can be done only by means of diagrams. The tribe of bivalve shell-fish which has now to engage our attention is an instance in point, for in many respects the animal of a $M Y y a$ is much more nearly allied to an Ascidia than are most of the genera of the two tribes we have just passed in review. Yet to introduce the Myade between the Pholadide and Gestrochenida would be to separate, by an unnatural break, most natural alliances. The family before us, if indicated in a diagram, would rather take rank alongside the Plolas tribe, and like it be seen conducting us by gradual transitions from the Tunicatre towards the more typical Lamelli branchiata. The aspect of a $M y$ e, when clothed with its coriaceous epidermis is that of an elongated Cynthia, against whose sides two plates of shell have been appressed, and no better mode could be devised of impressing on the tyro in malacology the close affinity of two great sections, so unlilie in most of their proper members, than the placing before him, side by side, examples of the two genera just mentioned.

The popular appellations of "Gapers" may be applied to the whole tribe. The shells are oblong and somewhat rude in appearance, always more or less gaping, and often very 
widely, at the two extremities. Some of the species grow to a very large size. The valves are united by a hinge of variable character. The ligament is in some genera external, in others internal. The animal has its mantle closed in front, except for the passage of a foot, which is seldom developed in proportion to the mass of the body. The siphons are greatly prolonged, and united almost to their extremities; their orifices are fringed. Both body and shell are often invested in a coarse and wrinkled epidermis. All the Mollusks of this tribe bury themselves in sand, gravel, or mud. They are palatable articles of food, and are much sought after in many places.

The evidence of geology would go to shew that this family was much more developed in the earlier epochs of the world than now, since, during the Jurassic period especially, many more species of Myada, mostly belonging to peculiar generic groups, lived than are now known to exist.

Not a few of the extinct forms, even of those oldest in time, bear a striking resemblance to their living allies, and are with difficulty discriminated from one another; a difficulty which is increased by the state in which these fossils are found, being most usually only external casts, so that in a majority of instances the structure of the hinge cannot be perceived. The general similarity of the members of this family depends on the slight amount of variation of shape and sculpture of surface presented by their shells. Professor Agassiz has attempted to group them into many genera, chiefly founder on the modifications of the latter character, but these are too slight and uncertain to permit of the adoption of such sections with safety either by the naturalist or geologist.

Judging from their associates, the Nyada, at the epoch voI. I. 
of their greatest development, were abundant inhabitants of warm seas, and, within the British area at least, gradually dimini-hed in numbers as more temperate conditions prevailed. Now, however, some of the most characteristic forms are among the most aretic of mollusea.

MY A, LINNEUS.

Shell more or less oblong or rhomboidal, equivalve, gaping at the extremities. External surface of the valves more or less furrowed or striated transversely, and furni-herl with a wrinkled epidemis, which is continued over the mantle and tubes of the animal; beak depressed; hinge composed of a dilated, ascending spathulate tooth in the left valve, connected by a short thick internal ligament with a corresponding socket in the right. Muscular impressions distant, well-marked, and comnected by a deeply sinuated palleal impression.

Animal oblong, with long tubes, enclosed in a strong case-like coriaceous epidermis. Mantle closed in front, except anteriorly, where there is an opening for the passage of a small conical foot. Siphons united nearly to their extremities, which have fimbriated orifices. Labial palpi striated.

The genus $M y a$, as originally constituted, included mollusks of very diflerent families, whose shells presented similarities in the construction of the hinge. It is now a limited and very natural group, represented by few, but well-marked species, most of which are inhahitants of the temperate and colder seas of the northern hemisphere. They are all borers in mud and sand, where they live buried beneath the surface in an erect position, their liding-places being indicated hy holes corresponding to the extremities of their tubes. 'They are excellent articles of' 
food; and both the following species are eaten in some parts of Britain and in North America. They are relisher also by animals; and, in Greenland, according to Otho Fabricius, are much sought after by the walrus, the arctic fox, and various northern birds.

Few mollusks are more widely distributed than our mative species of $M_{y a}$, ranging as they do throughout the arctic seas, owing to the same causes which we have noticed as having brought about the extensive distribution of the Saxicava. Their range southwards, however, is not so great, for Cape Cod and New York respectively limit it on the American shores, and neither of the species reach the Mediterranean on those of Europe, although, during the glacial period, the $N y$ a truncete was once an inhabitant of that sea, and has been found by Philippi fossil in very recent tertiaries on the coast of Sicily. It is not improbable that the original centre of the last-named species was on the European side of the Atlantic, and that of Mya arenaria on the American. The power each possesses in a remarkable degree, of enduring changes in the amount of saltness of the water, is no doubt a chief cause of their wide distribution now.

\section{TRUNCATA, Linnæus.}

Valves, when adult, abruptly truncated behind.

Plate X. f. 1, 2, 3, and (animal) Plate H. f. 1.

List. Hist. Conch. pl. 428, f. 269.

Mya truncatc, Linn. Syst. Nat. p. 1112.-PENn. Brit. Zool. ed. 4, vol. iv. p. 78, pl. 41, f. 14.-Pulteney, Dorset, p. 27.-Donov. Brit. Shells, vol. iii. p. 92.-Dorset Catal. p. 27, pl. 3, f. 1.-Mont. Test. Brit. p. 32,-Linn. Trans, vol, viii. p. 35.-Tunt. Conch. Diction. p. 97.- TurT. Dithyra Brit. p. 31.-Flem. Brit. Anim. p. 462.-MacgrL. Moll. Aberd, p. 298.-Brit. Marine Conch. p. 40.-Brown, Illus, Conch. G. B. p. 111, pl. 45, f. 2.-Fabr. Fauna Grænl. p. 404.-Chemn. Conch. Cab. vol. 
vi. p. 8, pl. 1, f. 1, 2.-SpengL. Skrivt. Naturh. Selskab. vol. iii. part 1, p. 28.-Wood, General Conch. p. 90, pl. 17, f. 1, 2.-Dillw. Recent Shells, p. 42.-Lam. Anim. s. Vert. ed. 2, rol. vi, p. 73.-Burrows, Conch. pl. 4, f. 1, 2.-Ind. Testac. pl. 2, Mya f. 2.-Crouch, Introd. Conch. pl. 3, f. 6, 7.-Sow. Conch. Manual, f. 71.-Desir. Elem. Conch. pl. 8, f. 2.Hant. Recent Shells, p. 19, pl. 2, Mya f. 2.-Gould, Invert. Massac. p. 42.-DekaY, New York Mollusc. p. 240, pl. 29, f. 289.

Chama trencata, DA Cost A, Brit. Conch. p. 233, pl. 16, f. 1.

Mya oralis, (nмmature.) Turt. Dithy. Brit. p. 33, pl. 3, f. 1, 2.

Sphania Sicainsoni, (Fry.) Turt. Dithy. Brit. p. 37, pl, 19, f. 2.-Flem. Brit. Anim. p. 466.-Brit. Marine Conch. p. 57.

Mye tronquée, Chenu, Traité Elem. p. 48, f. 152.

Ency. Méth. Vers. pl. 229, f. 2.

This ancient and well-known shell is of a sub-oval form, which is at times produced, but more generally abbreviated, suberquilateral, more or less solid, opaque, and ventricose. This latter characteristic is, however, chiefly manifested towards the rounded end, there being a considerable degree of flattening of the central surface, which, after a slight retusion, again swells out at the truncated tips of the posterior extremity, of which latter the hiatus is extremely large, more or less oval in shape, and not extending below beyond the ventral margin; the lips of this gape are reflexed, and there is not any tendency to stricture. A loose, yellowish-grey epidermis (which is continimed posteriorly beyond the shell to the animal,) covers the entire valves, which beneath it are of a more or less squalid dull uniform white, and concentrically traversed by ineegular but very distinct wrinkles, which are often almost pliciform at the sides, where they are always most developecl. The dorsal and ventral margins are almost parallel; the latter is more or less straight, a little retuse at or behind the midtle, more convex in front, and more ascenting posteriorly. The former, immediately adjacent to the unbones, is subretuse in front, and not at all declining; but, 
after rumning a short distance, bends down in an arcuated curve to the ventral, which does not equally rise to meet it; hence the more or less broad anterior extremity, is well but not symmetrically rounded. The general rirection of the hinder dorsal edge is subretuse or straight, and its slope is almost imperceptible. The hinder side, which is barely the shorter, is truncated at its termination, the truncation being almost direct, and not oblique; the posterior, however, is rather convex than otherwise, and the hinder extremity not absolutely biangulated, but with the angulation a little softened off by the terminal convexity of the upper and lower margins. The posterior side is without any manifest umbonal ridge; but a marked, though broad and undefined, ridge-like elevation very frequently runs anteriorward from the umbones, in a very oblique direction. The umbones are for the most part unequally prominent, the beaks are small, acute, much incurved, and a little inclined forwards; in front of them there is seen a false lunule, being a lind of amorphous depression, which is continued also beneath the beaks to the opposite side. The whole interior is white and glossy; the muscular impressions are not large, the posterior one is by far the more profound; the sinus of the palleal inpression is very large, and somewhat squared. The hinge consists of a very large, broad, solid, erect, complicated tooth in the left valve, of which the lower surface is convex and simple, but the upper is flattened and subdivided, the central triangular portion forming a very shallow pit for the adhesion of the cartilage, bounded by an obliquely-radiating, narrow fold in front, with a similar, but much more obscure one, at its posterior termination; a third well developed fold-like projection is visible at the strengthened posterior extreme. In the right valve there is only a small oblique, fold-like 
tooth, which, scarcely elevated above the hinge-margin, lies in front of the cartilage-pit, which latter shelves down almost at right-angles to the dorsal line.

The proportion of length to breadth is not constant; specimens which are two inches wide, measuring from three and a quarter down to two and a half inches only between their lateral extremities.

The animal is oval with very long siphons, the epidernic coat, which invests the mantle and tubes, is rugose and brown; beneath it the surface is white, or tinged with yellow, so also is the foot. 'The viscera are of a pale brown hue. The mantle is entirely elosed in front except a small aperture anteriorly for the narrow lingniform foot, which is straight, and furnished with a byssal groove. The suture of the united margins of the mantle is conspicuously seen when the investing coat is removed. That part of the sheath which surrounds the siphons is marked dorsally and ventrally by a ridge or suture. The siphonal tubes are united to their extremities, or very nearly so. They are both surrounded at the point of separation by a circle of filaments, the bases of which are tinged with brown. The branchial orifice is especially fumbriated. A tubular membrane is protruded from the interior of the anal orifice. The branchir are partly continued into the tube. The labial tentacles are large, triangular, acute, and striated upon their inner sides.

In Zetland, this animal is boiled and eaten. It is there called "Smurslin." The species is abundant on the coast of Newfoumlland, where it is said to be a favourite food of the cod-fish.

Our association of Syllania Swecinsoni and Mya ovelis with the present species, results from a careful eximination of 'l'urton's original types, which are still preserved and in 
the possession of Mr. Jeffreys. The characteristic truncation of the adult is not present in the earlier stages of growth, which may be seen by examining the earlier concentric stages of growth in the mature valves.

This is both a deep sea and littoral species. It is often found lurking in the sand towards low-water mark, with its shell embedded to the depth of three or four inches. Although actually abundant and very wirlely diffused, fine and perfect examples are not common in the cabinets of collectors, not alone from their proneness to distortion, but rather from the umpleasant and often baffling necessity of digging them out from the wet spots where they are more usually found. We have likewise met them, along with Pholades, in chalk at Margate (S. H.), in which vicinity, and also at Sandwich, the single valves are very common. The species is abundant "at the mouths of rivers and in bays, along with arenaria, in a mixture of gravel and mud" (Alder); Exmouth (Clark); Portsmouth Harbour (Jeffreys); Dartmouth in seven fathoms (E. F. \& R. M'A); Liverpool (M'Andrew); Scarborough (Bean); in twentyfive fathoms water, five miles from land off the coast of Ballaugh, Isle of Man (E. F.); Swansea (Jeffreys); Tenby (Lyons); Anglesea in seven fathoms (M'Andrew); "suitable localities on every side of the Irish coast" (Thompson); Frith of Forth at low water and to a depth of seven fathoms (E. F.); Aberdeenshire (M`Gillivray); "Oban, Ullapool, Lochs Shieldaig, and Carron, Shetland and the Orkneys" (Jeffreys and Barlee); dead valves in thirty-four fathoms, ten miles from shore off Elgin, (R. M'A.) may be enumerated among other habitats. Single valves are occasionally met with at extreme depths. One is recorded by Mr. Thompson (Ann. Nat. Hist. vol. x. p. 22), to have been dredged by Captain Beechey from Beaufort's Dyke at 
the Null of Galloway, in about 145 fathoms of water. $M r$. M'Andrew has taken them in 100 fathoms water, twenty-five miles to the east of Zetland.

This species is not rare in the fossil state; a variety with the posterior end extremely short, is the most freupent fossil form, and still lives in Greenland and the seas of Boreal America. This is the My" Lddecallensis of some authors, examples of which, (but whether recent or fossil is uncertain,) surmisen to have been brought firom a shellbank lying about twenty-five miles to the east of Fern Islankls, were procured by Mr. King from some Northumbrian fishing-boats. (Ann. N. H. 18, p. 236.) As a British species, Mya truncata dates from the epoch of the coralline crag.

\section{M. arenaria, Limmæus.}

Ovate-oblong, subequilateral, not tumid, merely marked with concentric wrinkles of growth, rounded anteriorly, tapering posteriorly to a blunted point.

Plate X. f. 4, 5, 6 .

Mya arenaria, Lisv. Syst. Nat. ed. 12, p. 1112.-PEns. Brit. Zool. ed. 4, vol. iv. p. 79 , pl. 42, f. 16.-Donov. Brit. Shells, vol. iii. pl. 85. -Monr. Test. Brit. p. 30.-Linn. Trans. vol. viii. p. 35.Dorset Catal. p. 28, pl. 4. f. 2.-Tunt. Conch. Diction. p. 98. -Tukt. Dithyra Brit. p. 32.-Flex. Brit. Anim. p. 463. -Macgil. Moll. Aberd. p. 298.-Brit. Marine Conch. p. 40.Brown, Ill. Conch. G. B. p. 111, pl. 45, f. 1.-O. FABr. Fauna Grænl. p. 405.-ChemN. Conch. Cab. vol. vi. p. 10, pl. 1, f. 34. - Sreng L. Skrivt. Naturh. Selskab. vol. iii. part ], p. 30. Wood, General Conch. p. 91, pl. 17, f. 3. - Dillw. Recent Shells, vol. i. p. 42.-LAM. Anim. s. Vert. ed. 2, vol. vi. p. 74. -Index Testac, pl. 2, Mya, f. 2.-Mawe, Conchology, pl. 4, f. 1. - Sowerby, Genera Shells. - Buainv. Man. Malac. pl. 77, f. 1.-ReEve, Conch. System, pl. 33.-Conran, Amer. Mar. Conch. p. 42, pl. 9, f. 1.-Gould, Invert. Massach. p. 40.-Hanf. Recent Shells, p. 19.-Dekav, New York Moll. p. 240, pl. 30, f. 290. 
Chama arenaria, $\mathrm{D}_{\mathrm{A}} \mathrm{CosTA}$, Brit. Conch. p. 232.

Nye des salles, Chen, Traité Elem. p. 48, f. 149, 150 (hinge).

Mya mercenaria, and M. acuta, Siy. J. Ac. N. S. Philad. vol, ii. p. 313 (fide de Gould).

This coarse and homely-looking shell has an oblong-oval contour, and a strong and solid texture, so as not unfrequently to be of considerable weight. The valves, which when most perfect have an ochraceous tint or are of a darker or paler sand colour, are frequently stained black, owing to the nature of the soil in which they are embedded; they are not uncommonly distorted or irregular in their growth, and are more or less ventricose, particularly upon the anterior side. Their surface is entirely devoid of lustre, and is rudely traversed concentrically by irregular wrinkles and lines of increase. The ash-coloured epidermis is but thinly spread over the surface, and is often entirely obsolete, or only visible towards the ventral margin. This latter is more or less retuse a little behind the middle, slightly convex posteriorly, and ascending and arcuated anteriorly. The sides are almost equal, the posterior, if either, being rather the longer, and bluntly acuminated below at its termination; the frout side, which is also the more ample one, is nearly equally rounded above and below at its extremity. The front dorsal edge, which is convex or even arcuated, declines but slightly, the hinder, which is produced and comparatively straight, though still somewhat convex, is decidedly sloping. The umbones are by no means peculiarly prominent, and are often flattened above; the beaks are sometimes almost directly inflected, but more generally incline forwards; there is no vestige of an impression on either side of them; neither is there any distinct umbonal ridge. The shell gapes at both extremities, but much more so upon the narrower side, where neither the upper nor lower edges

VOL. I. 


\section{touch each other from the centre of the shell to its hinder} termination: the posterior dorsal margins bend outwards.* The hinge eonsists of a remarliably large, solid, and erect tooth in the left valve, and an appressed subtriangular and oblique excavation under the umbones of the opposite

* Our friend Dr. Carpenter, whose researches into the microscopic structure of shells rank among the most important of recent contributions to Malacology, has cxamined with great care the structure of this species, and gives the following account of it in his forthcoming report: "The indications of cellular structure are of a peculiarly interesting nature in Mya arenaria, the careful examination of whose shell has thrown much light on several doubtful points of my inquiry. We have here a distinct cellular structure in some parts giving way by such imperceptible gradations to an almost perfectly homogeneous arrangement in others, that no separation can be made between them, so that we must regard the latter as having had the same origin with the former, although its primary characteristic has been lost. Near the external surface of the shell is a layer of cells, having very distinct boundaries and large dark nuclear spots; and yet in other parts of the same layer the boundaries of the cells are completely obliterated, and only the dark nuclear spots remain to shew their original divisions. In some instances the continuous cells seem to coalesce in sinuous rows, so that wavy lines are left (somewhat resembling the boundaries of the furrows of Meandrina) dividing one series from another (fig. 24).* Near the external surface some very large cells are disposed without any regularity, amongst those of which the layer is chiefly made up (fig. 25) ; and the external surface itself is composed of small cells of rounded form, in by no means close approximation with each other. In the tooth, also, we find a considerable variety of structure, in addition to those forms presented by the shell. Thus, in fig. 26, is seen a group of large cells, the calcareous contents of which are disposed in a very regular radiating Aragonite or Wavellite. The borders of this group pass into another cluster of cells (fig. 27) that presents no trace of this curious structure (of which, however, there are some indications in shell); whilst the latter gradually passes, by the obliteration of its cell-boundaries, into a layer of very homogeneous aspect. Besides these, there are several curious forms of elongated cells, some of them with square terminations, as in fig. 28, and some pointed or fusiform, as in fig. 29. In these last may be seen tranverse strix, closely resembling those of the long prismatic cells of Pinna, and probably due to the same cause, namely, the spaces between the strix which indicate their lines of junction. Upon this last circumstance $I$ am disposed to lay much stress, as indicating the really compound nature of the long fusiform cells, of which we have already seen some examples, but which are peculiarly characteristic of the univalve group. Neither in the shells nor the tooth of Mya arenaria is there animal matter enough to give anything more than a delicate membranous residuum, in which no vestige of cell walls can be traced."

* The figures refer to Dr. Carpenter's plate. 
valve. Between them lies the rich brown cartilage, for the reception of which there is a shallow inclentation on the external surface of the greatly projecting tooth. Neither the eartilage receptacle in the right valve, nor the opposing tooth of the left, can be termed simple; there being a broad ledge-like anterior detached margin to the former, whilst the posterior scarcely elevated linear tooth forms a lateral denticle near the base of the latter, which, moreover, is decidedly convex internally, with its apex arcuated and its front almost rectilinear or truneated, and bending over so as to form a margin for the cartilage on that side. The inner surface is white and often glossy, and the sinus of the palleal scar, which is rather remote from the margin and a little undulated in its impression, is elongaterl and narrow.

The animal of this species in its general features resembles the last. When stripped of its epidermis it is of a yellowish-white colour, the orifices tinged with red.

The average size of the shell is about four inches long and two and a third broad, but examples are often found of much larger dimensions. Althongh locally abundant, for it is a gregarious species, and tolerably diffused throughout our coast, it is less frequently met with, especially in fine condition, than might be imaginer. It is dug out of a gravelly, sandy, or clayey bottom near low water mark, usually in or near estuaries, and is found, among other spots, at Herne Bay in Kent (S. H.); "Portsmoutl, the Isle of Wight, Southampton" (Jeffreys' cab. and M'Andrew), where, according to Montagu, they are called "old maids," and are sometimes collected for food; Tenby in Pembrokeshire (S. H.); Red IVharf Bay, Mackruss, Borth (Eyton); "in suitable localities on every side of the Irish coast" (Thompson); Dublin Bay and Cork Harbour (Jeft-- 
reys" cab.); "at Rotheray Bay both this and truncute are used by the fishermen for bait" (Alder); Frith of Forth (E. F.): Aberdeenshire, abundant in the Outer Hebrides (Macgillivray). The specimens found in sand are, as Montagu observes, fin more smooth and regularly grown than those extracted from gravel, and are covered with a distinct epidermis. They are discovered by a small hole on the surfice, throngh which on pressure the animal ejects a considerable quantity of water. It burrows to the depth of more than a foot.

The Mya arenaria is occasionally found in brackish water, and is then subject to dwarfing and distortion. Stich is the condition of the specimens in the Loch of Stennis in Orliney, famous for the part it plays in the scenery of Scott's admirable novel of the "Pirate." In that lake we find Limnei, Neritina, and other fresh-water Mollusks, along with the $I y y_{c}$, which now, however, appear to be nearly, if not altogether, extinct. Before they became so, they had greatly diminished in size, and become variously distorted. In this instance the cause is to be sought for in a very recent elevation of the land, which has gratually converted what was originally an arm of the sea into a brackish pool, only occasionally flooded with salt water, and probably destined eventually to become a fresh-water lake. In Mr. Cuming's collection are some remarkably distorted Myge of this species from the sluices at Ostend, where their deformities are most likely also due to the pernicious influence of fresh water. To the same cause we may attribute the numerous and singular varieties of this shell, such as the so-called species, DI. late and pullus, found in the mamaliferous crag of the east of England, a formation in which many of the mollusca are deformed. 'The melting of the icebergs which then chilled our region 
doubtless furnished the disturbing medium. These dangerous and disastrons consequences of too great an imbibition of the "pure element" present a timely warning to the votaries of teetotalism.

\section{PANOP正A, MeNARD DE LA GROYE.}

Shell transversely oblong, rather compressed, equivalve, more or less inequilateral, gaping at both extremities; surfice of the valves nearly smooth or transversely furrowed, never longitudinally ribbed; pallial impression in each valve very strongly marked, with a deep triangular sinus posteriorly; muscular impressions strong and oblong; linge formed of a conic cardinal tooth in each valve lodged in a cavity in the valve opposite; ligament external, short, prominent, attached to strong nymphal callosities.

Animal oblong, and furnished with a very long and extensible siphonal tube; body and tube invested with a wrinkled brown leathery epidermis, continuous with the shell ; mantle closed throughout its length, except a small opening with thickened lips in front anteally for the passage of a short stout muscular foot; adductor muscles very strong; month surrounded by thickened lips bearing four labial palpi; siphonal tubes united to their extremities; orifices inconspicuously fimbriated.

This genus was founded by Menard de la Groye in the nintl volume of the "Amnales du Museum" (1807), for the reception of an Italian tertiary fossil, closely related to the "Chama glycimeris" of Aldrovandus, a shell which had latterly been known as Mya glycimeris. The founder of the genus recognised their affinity, and also their relationship to Mrya and neighbouring genera. The Panopace indeed closely resemble $M_{y, c}$, both in the generil aspect of 
the shell ame in the principal features of the animal. Their external ligament, and the absence of the spoon-shaped proces of hinge, listingui-h the former: the peculiar strueture of the mantle and foot are characteristic of the latter. The animal of this genus was not linown to Menard, and remined undescribed until $18: 39$, when a valuable monograph on Penopece was published by Valenciennes in the first volume of the "Archives du Museum." In that memoir an account was given of the animal of Panopea resticulis, a suth African species. The oflicers of a French frigate vi-iting l'ont Natal observed the tubes of a Mollusk projecting from the sand in one of the bays. The sailors cndeavoured to draw the creature out of its habitation by the tube, but in vain; for the siphons, after offering considerable resistance, in every instance gave way, and often were withdrawn entire in spite of the grasp of its persecutor. Curious to know the nature of the being which thus cratped them, they dug for it with spades, and at length meovered the Penopac buried several feet below the surfuce of the sand, and gregarious.

'This genus was anciently of more importance than now, for cluring the Jurassic epoch there existed many species in our seas. They gradually decreased in numbers till the present time. The few species known now are natives of the North Atlantic, Lusitanian, South African, Patagenlan, and New Zealand seats, one only inhatbiting each regiols.

\section{P. Norvegics, Spengler.}

Plate XI. (slightly enlarged).

Mya Norregica, Spexgler, Skrivt. Naturh. Selskal. vol. iii. part 1, p. 46, pl. 2", f. $1 \%$.

Gilycimeris ureliuce, Lıм. Anim. s. Vert. (Desh. ed. 2) vol. vi. p. 70. 
Panopea glycimeris, Bean, Mag. Nat. Hist. vol. viii. p. 562, f. 50,51.

Panopea arctica, Gould, Invert. Massach. p. 37, f. 27.-HANL. Recent Shells, p. 18, suppl. 10, f. 43.-Brit. Marine Conch. p. 38.DeKAY, New York Moll.p. 246.

Panopea Spengleri, VALENc. Archiv. de Mus. vol. i. p. 15, pl. 5, f. 3 (not exact). -Chenu, Ill. Conch. Panopæa, p. 4, pl. 4, f. 4.

"Norregica, Loven, Ind. Moll. Sueciæ, p. 49.

"Bivona, Sмıтн, Wern. Mem. vol. viii. p. 107, pl. 2, fig. 4.

The shape of this interesting shell is oblong, with a slight tendency to be rhomboidal behind. It is extremely thick and heavy, and very decidedly inequilateral. The valves are ventricose, and appear peculiarly so when united, as their edges only touch at the callus near the beaks, and at a point in the ventral margin, which is nearly opposite; the shell gaping at every other portion of its margin, and particularly at the hinder extremity, where the bending outwards of the edges of the shell increase the hiatus. The outer surface is rather rough, being marked with coarse concentric wrinkles and somewhat obsolete ridges of growth; but that which chiefly characterises it is the presence of a broad triangular excavated area, which radiates from the beaks subcentrally, and rapidly enlarges as it nears the lower margin. A shallower and narrower space runs likewise to the lower posterior corner from the hinder part of the umbones, and thus the intervening surface assumes the appearance of a broad and very oblique obtuse rib, which parts off about two-fifths of the entire surface. The remaining area is nearly equally divided between the impressed triangle and the convex front terminal surface, the sudden posterior cessation of whose convexity makes it appear similarly but not equally like a perpendicularly rarliating obsolete ridge, which indeed it is generally described as being, but which, from the specimen before us, we do not 
feel ourselves justified in terming it, sines, althomgh there is a slight flattening of the surface between it and the firont. extrenity, there is no defined anterior limit to the so-called ridge. The exterior is of an ashy buff colour, and utterly deroid of lustre; the interior is paler or darker ochraceous, and moderately glossy.

The ventral margin is much incurved in the middle, swelling out at the extremities, and rapidly and obliquely arcending in front. The dorsal margin for the most part runs nearly parallel with the ventral, scarcoly declining at all behind, (where it is incurved, and where the dorsal surface is flattened,) but in front forming an uniform convex or arcuated sweep with the anterior outline, by which that extremity is distinctly rounded, yet not symmetrically so, owing to the trifling declination of the upper portion, compared with the longer and more abrupt curve of the lower one. The hinder side is nearly twice as long as the front, and is rery bluntly liangulated at its termination, which is broal and not at all tapering: the hinder edge is nearly straight, and inclines a little obliquely outward from its dorsal commeneement. The umbones project but slightly above the cardinal edge, being rather flattened above, and the beaks are very small and lean almost directly inwards. The ligament is broad and rather prominent, but not very elongated, and in the few shells we have seen is of a dark colom. Notwithstanding the solidity of the shell, the edges are acute and simple, and for the most part incline outward. The hinge margin is very broad, and is merely provided in each valve with a remarkably small apical tooth, and an adjacent receptacle for that of the opposite one: these occupy but little of the hinge plate, which is there shallowly excavated, with its lower erlge, to which they scarcely reach half way, minutely 
indented beneath the tooth. In addition, there is a remarkably elevated nymphal callosity just under the ligament, to which indeed it serves as a support. One of the larger examples measures three inches and a half in length, and rather more than two and a quarter in breadth. The hinge margin is often obsoletely and minutely denticulated within.

The following graphic account of Mr. Bean's discovery of this extremely scarce species is extracted from the "Magazine of Natural History," wherein the shell was first actually published as a native of our seas, although under the erroneous impression that it was the Panopaa which had been previously figured by Donovan:-" We have obtained at Scarborough three specimens of this, in every sense of the word, gigantic prize. To some of the fishermen of our coast it appeared to be well known by the name of the 'bacca-box, from a fancied resemblance to one of their most useful household gods. They were all caught by the hook, and rescued from destruction in a singular manner. The first, from which our figure was taken, was destined for a tobacco-box; the second had the honour of holding the grease belonging to the boat establishment; and the third, atter amusing them (the member's of a philosophical society) by squirting water to the ceiling, was at last seen by a learned friend, purchased for a trifle, and generously placed in our cabinet. The animal we have not seen, but its colour is black." Three additional individuals have since then been obtained by Mr. Bean from the same locality, and two single valves have been dredged by $\mathrm{Mr}$. $\mathrm{M}^{5}$ Andrew in ninety fathoms water, twenty-five miles east of Zetland. It is likewise captured, though very rarely, in deep water off the Northumberland and Durham coasts (King and Alder).

VOL.I. 


\section{SPURIOUS.}

\section{P. Aldrovandi, Lamarck.}

Lister. Hist. Conch. pl. 414.

Mya glycimeris, Bors, Mus. Cxs. Vind. p. 20, pl. 1, f. 8.-Chems. Conch. Cab. vol. vi. p. 33, pl. 3, f. 25.-Dovov. Brit. Shells, vol. iv. pl. 143.-Mont. Test. Brit. Supp. p. 19.-Linn. Trans, vol, viii. p. 34.-Turt. Conch. Diction. p. 107.-Woon, General Conch. p. 14, pl. 25, f. 1.-DiLLw. Recent Shells, vol. i. p. 4:2.

Panopare Aldrovandi, Lam. Anim.s. Vert. (ed. Desh.) rol. vi.p. 6\%.-Fuex. Brit. Anim. p. 462.-Crouch, Introd. Conch. pl. 3, f. 1.Phil. Moll. Sicil. vol. i. p. 7, pl. 2, f. 2, and vol. ii. p. 6.-Hand. Recent Shells, p. 18.-VALENC. Archiv. de Mus. vol. i. p. 9, pl. 4, f. 1.-Cinenu, Ill. Conch. Panop. p. 1, pl. 1.

"glycimeris, Turt. Dithyra Brit. p. 42,-Desh. Elem. Conch. pl. 7, f. 1 .

Panopée d'Aldrovande, CHenv, Traité Elem. p. 46, f. 144 (hinge).

A Mediterranean shell, introduced by Donovan, from the general and correct belief that a Panopera (evidently Norvegica, which was not at that time distinguished by English writers) had been fished up in the deep waters between the Dogger Bank and the eastem. coast of England. 


\section{CORBULID瓜.}

Tris tribe is composed of bivalves, all of comparatively small dimensions, the majority very small. Most of them have inequivalve shells, and all have their hinder extremities more or less produced, and easily distinguished by the tendency to form a beak from the anterior or buccal end. The last mentioned is the most constant character, for the linge, presence or absence of epidermis, thickness and sculpture of shell, and even position of the ligament, vary considerably in the several genera composing the tribe. The animals of all, however, are very nearly allied, and easily distinguished, for all have extremely short united siphons, with fimbriated extremities, the anal one always provided with a conspicuous membranous tube. The mantle is closed, except a passage for a narrow foot, not unlike that of the Gastrochanida, to which family the Corbule tribe has very close affinity. Most of the British members of this tribe are either rare or very recent discoveries, and several of them we have to figure for the first time as natives of our seas.

\section{CORbula, Bruguiere.}

Shell suborbicular or oval, tumid or depressed, very inequivalve, slightly inequilateral, rounded anteriorly, more or less truncated posteriorly; beaks prominent; surface of the valves more or less furrowed or transversely striated, covered with an epidermis. Hinge composed of a recurved 
primary tooth in one or both valves, with corresponding socket and ligamental pit beside it. Ligament small, interior. Mruscular impressions slightly marked, united by a pallial one with a very slight sinus.

Animal short, with very short united siphonal tubes. Orifices fimbriated. Mantle closed, except in front, where there is an opening for a bony, narrow, thick foot of considerable dimensions. Anal siphon with a conspicuous tubular membrane. Labial tentacles slender.

This is one of those genera which have diminished with the course of time. Corbuld were abundant in the European seas cluring the earlier part of the tertiary epoch, and even before. They are now reduced to a very few species. The genus has more representatives at present in tropical seas.

The microscopic structure of the shell has been examined by $\mathrm{Dr}_{1}$. Carpenter. He finds the outer layer to consist of large fusiform cells; the imner to be nearly homogeneous. "At the lines of junction of the successive additions to the margin is a yellow layer, probably owing its colour to an intermixture of horny matter, such as might, if poured out upon the surface, have formed a periostracum. In this layer there is a very definite and beautiful cellular arrangement, the cells being in some parts polygonal, and having their edges in contact, whilst in others they are rounded and isolated."-(Report, p. 104.)

\section{Nucleus, Lamarck.}

Rather obliquely subtriangular, very solid, not polished, subinequiliteral, whitish, with the larger valve sometimes rayerl with pale crimson, and the smaller one always covered with a stiff umberbrown epidermis: ventral edge arcuated, ascending and straighter posteriorly; dorsal edges moderately and subequally sloping, and nearly straight. Valves excessively unequal, ventri- 
cose ; the smaller one only marked with a few central and rather remote elevated lines : the larger one simply and closely grooved concentrically, its umbo greatly projecting beyond the other. Anterior extremity rounded; posterior termination rapidly attenuated, and obtusely subbiangulated. Umbonal ridge obsolete.

Plate IX., figs. 7 to 12, and (animal) Plate G, fig. 3.

Tellina gibba, OLtvi, Zoolog. Adriat. p. 101.

Mya incequivalvis, Most. Test. Brit. p. 38, suppl. pl, 26, f. 7.-Linn. Trans. vol. viii. p. 40, pl. 1, f. 6.-TUrr. Conch. Diction. p. 107.

-Wood, General Conch. p. 113.-Diluw. Recent Shells, p. 55.-Index Testaceolog. pl. 3, f. 40.

Corbula nucleus, Lam. Anim. s. Vert. (ed. Desh.) vol. vi. p. 139.-Turt. Dithyra Brit. p. 39, pl. 3, f. 8, 9, 10.- Brit. Marine Conch. p. 56.Brown, Ill. Conch. G. B. p. 105, pl. 42, f. 7, 8, 9.-SowerBY, Genera Shells, Corbula, f. 1.-Desir. Elem. Conch. pl. 8, f. 7, 8, 9.-Phil. Moll. Sicil. vol. i. p. 16, and vol. ii. p. 12. -Sowerby, Conch. Manual, f. 89.-Reeve, Conch. Systemat. pl. 36, f. 1.-HaNL. Recent Shells, p. 46.-REeVE, Conch. Iconica, Corbula, pl. 2, f. 10.

" striata, Flem. Brit. Anim. p. 425.-Desh. Exp. Scien. Algérie, Moll. p. 231.

" olympica, Costa, Test. Sicil. p. 27.

" incequivalvis, Macgilliv. Moll. Aberd. p. 303.

" rotundata, Sowerby, Min. Conch. pl. 572.

Encyclopédie Méthodique, Vers, pl. 230, f. 4.

Whilst the naturalist, whose efforts at collecting are confined to the rocks, sands, briny pools, and streamlets of our coast, is apt to regard the species under consideration as of unfrequent occurrence, its extreme prevalence is a subject of almost petulant complaint from the habitual dredger.

The shape of this Corbula is more or less triangular, and its texture very solid and opaque. The valves are remarkably unequal; the right, or larger one, not merely overlapping the other at the base, and exceeding it, ventricose as it is, in profundity, but projecting beyond it at the umbones in a most remarliable manner, its broader beak curling over, and resting, as it were, upon the margin of the lesser valve. They are both of them nearly devoid of 
lustre, and the smaller one is clothed with an umber-brown, tolerably thick epidermis, beneath which the surface is whitish, or a very pale pink madder colour; its only sculpture consists of a few rather distant elevated lines, which radiate, with but little divergence, down the central area of it. The larger valve is of a squalid white, not unfrequently adorned, in fine examples, with more or less broad rays of darker or paler crimson, and closely grooved throughout with simple concentric sulci. The ventral margin is more or less arched, and is typically straighter, and more ascending posteriorly, but is very variable in outline, although usually more tumid in front, from whence proceeds that slight obliquity so generally apparent in its contour. The sides are rarely equal, but usually the anterior, though occasionally the posterior, is the more produced. The dorsal edges are nearly straight, and moderately, but decidedly sloping, the amount of declination not being widely different on either side. The front extremity is rounded, and the linder one attenuated and obtusely biangulated, the posterior edge is slightly convex. The umbonal ridge is obsolete; the beak of the lesser valve is acute: and there is a strong though undefmed depression on either side of the umbones. The interior is almost always devoid of colour; and the palleal scar, without forming a distinct sinus, makes at the posterior extremity a very slightly obtuse angle with the former line of its direction. In the right valve is a posterior, strong, simple, and somewhat recurved, pointed primary tooth, with an arjacent cavity in front, which is partly occupied by the cartilage: in the left valve, behind the receptacle for the opposite tooth, is a lind of cxeavated one, of which the middle portion is hollowed out for containing the cartilage; but the basal and especially the linder rim is elevated above the dorsal surface. 
Common as this mollusk is, it is so excessively shy when taken from its home in the sea-bed, and placed in a vessel of sea-water, that it rarcly exhibits under such circumstances either its foot or its siphons. This is probably the cause of the very contradictory statements which have been offered respecting the animal of this genus, for, when examined in a preserved state, only a very slight lesion of the tissues is apt to lead us to erroneous conclusions with respect to its systematic position. Mr. Clark seems to have been especially happy in his opportunities of observing the creature, and his account of it is so much more complete than either published statements or our own notes furnish, that we cannot do better than give it in his own words. " Animal subtriangular, thick, of a yellowish-white colour, having the mantle closed, except anteriorly, where there is an orifice, whose circumference is finely notched, for the passage of a moderately long, narrow, but rather thick foot; posteriorly it forms two very short, united orifices, with eight or ten rays each. The upper, or anal one, has a tubular retractile membrane, which the animal often protrudes and retracts. We presume the sudden protrusion of this organ is to give force to the propulsion of the faces. On each side of the animal there is a pair of very uncqual branchix, which hang very obliquely from the dorsal line, the upper one being rather narrow, the lower much larger and triangular. They are of a brown colour, and finely pectinated. There are also two rather long and slender labial tentacles on each side. The tubes are yellow, the branchial one having a circle of red around its orifices, and the upper only a red mark or two."

Ordinary specimens of this shell do not exceed half an inch in length, and about one-fourth less in breadth. It is most abundant, often occurring in immense numbers and 
gregarious, in the lower part of the laminarian zone, especially when the bottom is mud or muddy sand. It is frequent in the coralline zone, and ranges even into the region of the deep-sea corals. The greatest depths at which it has been taken alive in our seas are sixty fathoms, twelve miles from shore, off Cape Clear, by Mr. M['Andrew, and eighty fathoms, ten miles from the west coast of Zetland. It is distributed very generally around the British coasts. A few localities may be specified as examples of its range: Guernsey (S. H.); fifteen miles from shore off the coast of Devon, in sand (M'Andrew and E. F.); in ten fathoms off the mouth of the Ex (M'Andrew and E. F.); Torquay (S. H.); West Bay of Portland, in fifteen fathoms, and Weymouth in seven fathoms; off the Thames (Lieut. Thomas, R.N.); Norfolk Coast (Capt. Stanley, R.N.); Scarborough (Bean); Northumberland (Alder); South Wales, at Oxwich and Fishguard (Jeffreys); in twelve fathoms, Anglesey (M'Andrew and E. F.); in fifteen fathoms, Laxey Bay, Isle of Man (E. F.) ; on each side of the Irish Coast, but not generally distributed (IV. Thompson); Dublin Bay, Bantry, Youghal (Humplireys and Jeff. cab.); Frith of Clycle and Gairloch (Smith and E. F.); in from fifteen to twenty fathoms, Oban, Mull, \&c., abundant (II'Andrew and E.F.); Loch Kishon, Loch Alsh, Loch Torridon, Loch Shieldaig (Jeffreys and Barlee); Frith of Forth (E. F.); "On hard ground in rather deep water, Aberdeenshire" (M'Gillivray); Orkneys, in four to fifty fathoms (Lieut. Thomas, R.N.) ; in six fathoms, Balta Sound, Unst (M'Andrew.)*

Corbula gibbe is distributed thronghont the European seas. In the Mediterranean it has been taken ranging

* In citing localities for a common species such as this Corbula, we omit instances already published, unless interesting or important. 
from seven to eighty fathoms (E. F.). To its capacity for enduring many conditions of depth is doubtless due its long range in time, for it has inhabited our area ever since the epoch of the coralline crag.

\section{C. rosea, Brown.}

Subtriangularly oval, subequilateral, but moderately ventricose, glossy, fulvous (when adult), with a short dark roseate streak on each valve, which diverges widely on either side of the umbones, but does not reach to the margin. Valves not peculiarly unequal, the umbo of the larger and slightly more convex one not projecting greatly beyond the other; smaller valve almost smooth; larger valve simply but closely grooved concentrically, the sulci only apparent in the adult towards the margins. Extremities attenuated, the front one rounded, the hinder one most obtusely and subbiangulately pointed. Dorsal slopes moderate, the anterior one nearly straight, the posterior slightly retuse: ventral margin convex or subarcuated. Umbonal ridge obsolete.

Plate IX. figs. 13, 14.

Corbula rosea, Brown, Ill. Conch. G. B. p. 105, pl. 42, f. 6.-HanL. Recent Shells, supp. pl. 12, f. 33.-Loven, Moll. Sueciæ, p. 49 (from specimen).

It is with considerable hesitation that we admit this distinct species of Corbula into our Fauna: we wish it to be regarded, then, as only provisionally included until either clearer proofs of its positive indigenousness, or of the greater probability of its being solely exotic, are afforded, than our own inquiries have been able to eliminate. The original specimens upon which the name rosed was bestowed belonged to Dr. Leach, and are stated to have been dredged at Falmouth: numerous others were in the cabinet of the late Mrs. Loscombe, mixed with nucleus. Those

$$
\text { vol. I. }
$$

B B 
from which we derive our own description and delineation are declared to have been (once) dredged at Weymonth, in Dorsetshire. They are not, however, quite mature, so that it is necessary to amend their characters from adult examples, which appear in tolerable abundance, but without any locality appended, in some of the larger general collections of shells.

The shape is oval, and a little triangular, and the valves for their genus are not much inequilateral or swollen, although both are tolerably ventricose, and their sides clearly unequal. It is, perhaps, less solid than the average of Corbula, but is tolerably strong, oparpue, and when adult of a roseate buff or dark fulvous, with two short rays, of a lrownish rosecolour, which so widely diverge from the beaks on either side as almost to run parallel with the dorsal margins: these rays are of a purplish rose-colour in the young, where the ground is whitish, and the smaller valve at least covered with a glossy yellowish brown epidermis. The inequality of the valves, although manifest, is not greatly displayed at the umbones, that of the larger one not projecting beyond the other in so marked a manner as in nucleus. This distinction, however, although observable in the young, is most evident in the adult, which is extremely glossy, a character not belonging to the preceding species, ant preserved, although faintly, in the younger examples. The smaller valve is almost smooth, the larger is grooved in the young, with fine and closely-disposed simple sulci, which almost entircly disappear in the adult, usually leaving its entire area devoid of seulpture, excepting at the broater end, and closely arljacent to the ventral margin. This latter is moderately arcuated, but always less so than in mecleus. The beaks, which are but slightly inclined and a little acute, being situated only a little in advance of the middle, the sides do not greatly difler in length; both extremitics are attenuated, and the front one is rounderl, but not symmetrieally, whilst the hinder is narrowed to a very bluntly subbiangulated point. Tho ilorsal edges are almost equally and very moderately 
sloping ; that of the anterior side is almost straight; that of the posterior is very slightly retuse. There is no particular depression on either side of the umbones, which latter are tolerably prominent, and not peculiarly unequal in size or projection. The umbonal ridge is obsolete in both valves; the interior surface, which, in the few specimens examined by us, partakes of the external colouring, is said to be typically pink. The small example, from which the enlarged figure has been engraved in our plates, is only a little more than a quarter of an inch in length, and about one-third less in breadth; the width, however, of the fully adult shell is five-sixteenths, and the entire length full seven-sixteenths of an inch.

The supposed Weymouth specimens, collected, as Mr. Jeftreys assures us, by Mrs. Rd. Smith, of Bishopstoke, near Bristol, were found enveloped in a kind of net-work of broken cases of terebella, and other lonse textures of known British origin; a strong, though not conclusive argument, for their being esteemed indigenons. It is taken chiefly in Sweden and the north of Europe.

\section{C. ovata, Forbes.}

Plate IX, Fig. 15.

Corbula ovata, Forbes, Malacol. Monensis, p. 53, pl. 2, f. 8, 9.-Brown, Illust. Conch. G. B. p. 105, pl. 42, f. 32, 33.-REEvE, Conch. Iconica, Corbula, pl. 3, f. 18.

Although the original describer (E. F.) of this shell took it himself from the root of a Laminaria cast ashore at Ballaugh, in the Isle of Man, he prefers leaving it among the doubtful species rather than stamp with the authority of mature deliberation the previous introduction into our Fauma of a species which by its presence there would vio- 
late the probubilitics of geographical distribution. About ten years have now elapsed since the date of its publication (1S38), during which period no second example hats been discovered: should no further specimens then be procured upon our const, the finding of the only recorded one must be attributed to some such incident as the imberdling of the living mollusk in the tangled roots of some fucus clinging to the ovsters or cirrhipedes so wont to congregate upon ship timber, in a foreign port, and the subseguent detachment of the sea-weed, either in the process of eareening, or perchance by the brealing up of the ressel itself.

As but a single specimen of this shell has ever been taken upon the coasts of Great Britain, the following deseription must rather be regarded as the portraiture of an individual than as a specific definition; since the latter may not be depended upon, unless based, not merely upon the characters present in one example, but from the aggregate of features existing in several, which remaining unchanged amid the many modifications of form, colour, or sculpture to which every shell is liable, may reasonably be supposed to be the permanent characteristics.

'The shape is oblong-elliptic, and very nearly, if not quite, equilateral; the valves, which are opaque and not very solid, although rather ventricose at the umbonal region, are but moderately convex upon the whole, and differ but little from each other in either size or profindity; the right one, however, very slightly overlaps the other below, and very slightly projects beyond it above. There is an appearance of crosion at the umbones, which prevents the accurate determination of this latter point. The surface is devoid of sculpture in both valves, unless we reckon a few antiruated lines of growth as such; it is dull white, and is covered with a lustreless skin of squalid white, becoming of an anhy ferruginous cast (possiluly a mere extrancous coating), chiefly in the vicinity of the lower margin of the lesser valve, where it becomes more or less distinctly wrinkled in a concentric direction. 
There is no other painting or division of surface, neither is there any carination of the umbonal ridge, which is by no means strongly marked. The ventral margin is but moderately convex, and neither peculiarly arcuated nor bulging out either laterally or medially. The dorsal slopes are but trifling, and almost equal to each other in declination; the front one is straight; the hinder is slightly convex, but chiefly so near its termination. Both extremities taper a little; the posterior is rounded, the anterior subangulated above, but well rounded below. This subangulation is more evident in the smaller valve. The umbones are not prominent, and there is not the least appearance of a lunule in front of them: the dorsal surface is, however, rather depressed on both sides, but not peculiarly flattened in either valve. The teeth are those of the section (or subgenus?) Potamomya, and appear identical with those of the Corbulce ustulata of Reeve (Conch. Iconica), to the young of which species it altogether bears so remarkable a likeness, that we would not venture to assert its specitic distinctiveness. The anterior subangulation is not, lowever, there present, and the posterior termination has a slight angularity at its lower extremity. The interior of ovata is white, and rather dull. The breadth of the solitary example (which does not appear full grown, and is in a good state of preservation) is one quarter of an inch, and its length is almost twice that measurement.

SPHÆNIA, Tunton.

Shell oblong, inequivalve, inequilateral, more or less gaping anteriorly. Surface of the valve smooth or rugose, covered with an epidermis. Beaks incurved. Hinge com- 
posed of an erect dilated laminar tooth in one valve, with a correponding pit in the other. Ligament internal. Pallial impression with a slight sinuation.

Animal orate; mantle closed in front, except an opening for the passage of a small digitiform foot, furnished with a bysal groove. Siphons united to their extremities; their oritices cirrhated. Anal siphon with a tubular membranous valve projecting beyond the orifice.

This rare and curious genus is as yet but very imperfectly linown, and, thanks to the observations of Mr. Clirk, we are enabled now, for the first time, to give some aceount of its animal. In his manuscripts he offer's the following remarks with respect to its systematic position :"Though not far removed from Mya and Saxicara, the animal is perfectly distinct, and so similar to Corbula, that it is difficult to point out more than a specific difference. Dr. Turton is perfectly right (though, we presume, by (chance) in placing this species of splhania next to Corbula."

The shell has evidently, at a glance, a striking resemblance to the Surcicave, and may be passed over as such; but the notes of Mr. Clark on the animal remove it to another family. In some respects it has considerable affinity with certain exotic forms of the genus Lyonsia, and thus aids in maintaining the passage eviclent in several of the Curbulide from the gapers and borers to Thracia and its allies.

\section{S. Binghami, 'T'urton.}

Sithanic Binghami, Turt. Dithyra Brit. p. 36, pl. 3, fo 3, 4, 5.-Flem. Brit. Anim. p. 465.-Brit. Marine Conch. p. 57, f. 32, 33,Brown, Illust. Conch. G. B. p. 104, pl. 42, f. 17, 18, 22. - Sowerby, Conch. Manual, f. 96.

Corbulc \# I1.inL. Recent Shells, p. 47, suppl. pl. 12, f. 4. 
Typically of a more or less rhomboilal contour, this interesting bivalve is wont notwithstanding to assume from its terebrating powers, and its ability to adapt its shape to the circumstances of habitation, very numerous modifications of its primary form. It is extremely inequilateral, opaque, but not solid, and decidedly inequivalve; the left valve being both smaller and flatter than the right, a character chiefly observable towards the lower margin and posteriorly, the convexity (which is very moderate) being almost equal at the umbones of either valve: these vary, however, in elevation, that of the smaller being the less projecting. Both valves are covered with a dull yellow closely-attached epidermis, beneath which the surface is nearly smooth or merely wrinkled with concentric, and ordinarily rather distant, wrinkles of growth. The ventral margin is usually more or less straightish, and generally ascends a little behind; the produced posterior dorsal edge, which is a little retuse, runs nearly parallel to it; the front dorsal edge, which varies from almost straight to moderately convex, declines so abruptly that the anterior side appears almost truncated.

The extremity of the remarkably short anterior side is occasionally of an abbreviated wedge-shape, but more frequently is rounded off below ; that of the elongated hinder side is broad, and either biangulated or subrectangular above, and more or less rounded off at the lower angle, the front edge being straightish or slightly convex, and but little swerving from the perpendicular. The right umbo projects moderately above the dorsal line; the beaks are acute, and incurved; in front of them lies a sort of lunulelike depression, owing to the inflection of the valves at that point. There is an umbonal ridge in both valves, but it is more or less obtuse, and neither carinated nor suc- 
ceeded by any marked concavity. By this, and the absence of a ligament, its external aspect is most readily distinguishable from Miatella aretica, to whose general features it bears no slight resemblance.

The interior is of an uniform white. The hinge consists, in the left valve, of an erect, subtrigonal, laminar primary tooth, which forms an obtuse angle at its apex, being subtruncated in front, and produced behind. It lies almost entirely on the posterior side, and is subdivided by the slightly more concave anterior portion, forming a shallow cartilage pit: this division is likewise indieated by the flexure of the upper margin, which, more arenated in front, becomes nearly straight posteriorly. A corresponding deeply-seated tooth-receptacle is present in the right valve, with, according to Turton, a denticle in front of it, which latter, however, we have not discerned.

The animal of this curious shell has been observed and examined by Mr. Clark, from whose manuscripts we extract the following account of it, dated, "Exmouth, August 7, 1836: animal elongated, compressed, pale yellowish-white; mantle closed, except a passage anteriorly for a small, narrow, subcylindrical foot of a bluish milliy transparent colour, having at its root a byssal groove, from whence a few rather coarse filaments issue, by which the animal is often attached; posteriorly, the mantle forms the anal and branchial tubes, which are very short and not in the least divided; both are at their margins furnished with alout eight or ten rather rough white cilia; from the anal tule there is frequently protruded a blue, milk-white, transparent, tubular membrane or valve, which is more than twice the length of the tube; it is then suddenly retracted and acain protruded. The branchiae and labia, on account of' the minute size of the shell, could not be observed." 
Individuals exceeding a quarter of an inch in brearth, and four-ninths of an inch in length, must be regarded as fine and uncommon examples. But the relative proportions of length and breadth vary considerably in different specimens; occasionally, the former is greatly increased by the under side being so produced (in which case the posterior termination is much attenuated) as to resemble a dwarf Mya truncata with its tube attached. Indeed, it has been supposed that the present shell is only the fry of the abovementioned bivalve; but, having examined the several stages of $M I_{y}$ truncata, we positively state the contrary, the likeness being confined to the truncated outline of the adult: neither is there any possibility of confounding it with the young of $M$. arenaria.

Very solid and aged single valves of the common oyster seem its favourite burrowing place, from which habitat it has been taken in comparative abundance (for so rare a species) near St. Peter's Port, Guernsey (S. H.); at Torquay it is occasionally found in limestone, dredged in company with Gastrochcence from about ten fathoms depth (S. H.); it is obtained likewise at Scarborough (Bean); Isle of Man, on both north and east coasts, in from twelve to twenty fathoms (E. F.); in twenty-five fathoms, eight miles from the north coast of Anglesey (M'Andrew and E. F.); at Tenby, and in the vicinity of Swansea (Jeffreys).

"Two valves were found at Bray by Mr. W. H. Harvey" (Thompson); Frith of Forth (E. F.).

Mr. M'Andrew (who has taken it likewise in Spain) procured it also from the Frith of Clyde. 
Shell transversely ovato-pyriform, inequiralve, inequilateral, more or less beaked and gaping posteriorly; surfirce smooth, or striated, or ribbed longitudinally, nerer punctated, with or without an epiclermis; valves strengthened internally with a longitudinal rib; hinge composed of a cartilage-fulcrum, usually oblique and spathulate in each valve, sometimes with a minute tooth beside it, and a more or less developed lateral tooth on the rostral side of one or both valves; ligament external, small; muscular impressions large; pallial with a very shallow simus.

Animal oblong, mantle closed in front, except a plainedged orifice for the passage of a lanceolate foot; siphons short, mited, unequal, the branchial largest, both bearing a few long filiform cirrhi at their sides, extending beyond the orifices; anal siphon with a very extensile membranous valve.

When the only speeies of this gents hitherto figured as British, was first made known, our conchologists were inclined to question its indigenousness, and to regard it as accidentally introduced. Yet now not only is the Necre cuspidatc extant in many British collections, but two other species have been added to keep it company within the last three years; of those two, one until very recently was known only in the fossil state, and both till within the last three years were supposed to be peculiar to the Mediterranean Sea. Such advances in our knowledge of a genus so little known to most collectors as Neara lave been due entirely to the more active employment of the dredge, and the greater energy and adventure of the naturalists who have, with such excellent results, kept 
that invaluable instrument of submarine research in continual motion.

The genus before us includes some of the most curious, delicate, and beautiful among the bivalves of our seas. It also includes not a few exotic species, mostly made known for the first time by the late Mr. Hinds, a gentleman whose active and intelligent exertions during the few but productive years that he directed his attention to natural history gave great promise of future researches, too soon to be blighted by death. The amiable spirit of fellowship and kindness in which he pursued his studies calls forth this passing tribute of regret and admiration in comnection with the mention of a genus so ably elucidated by his labours.

Geologically, the genus Necra can be traced as far back as the oolitic period, of which date a large and beautiful species has lately been brought to light by Captain Ibbetson. Since then it' has gradually increased in number of species to the present time.

\section{N. cuspidata, Olivi.}

Of moderate size, strong, fawn coloured; beak more or less produced; surface not sculptured; no radiating linear carina.

Plate VII. figs. 4, 5, 6, and (animal) Plate G, figs. 4, 5, 6, 7.

Tellina cuspidata, OLIvi, Zoolog. Adriatica, p. 101, pl. 4, f. 3, a, b, c.

Erycina cuspidata, Risso, Hist. Nat. de l'Europe Méridion. vol. iv. p. 366, pl. 12, f. 170 .

Anatina brevirostris, Brown, Edinb. Jl. of Nat. and Geograph. Science, vol. i. p. 11, pl. 1, f. 1, 2, 3, 4 .

Thracia brevirostra, Brown, Illust. Conch. G. B. p. 110, pl. 44, f. 11, 12, 13, 14. Necra brevirostris, Loven, Index Moll. Sueciæ, p. 48.

The shape of this graceful shell somewhat resembles a fig, being dilated in front and tapering belind to a very 
narrow termination. Although semi-transparent, and very finr from strong or solid in texture, yet for its genus it is by no means fragile, as fin exceeding in firmmess as in size the remaining Neara of our shores. The broader portion is extremely tumid, and this rentricosity, which prevails over two-thirds of the surfice, is rather suddenly exchanged for compression at the commencement of the beak-like extremity of the hinder side. The external surface is not at all glossy, but possesses a kind of silky lustre upon the epidermis with which it is covered; the latter is of a fiawn colour, varying in intensity according to individuals, but ordinarily paler towards the beaks, and always of a deeper tint upon the right valve; beneath it, the shell is smooth, or merely concentrically striolated, presenting no trace of fiutler sculpture. The umbones are excessively oblinue and decidedly prominent, and the beaks curve both forward and inward; in front of them the valves are somewhat flattened near the dorsal margin. The ventral outline is strongly arcuated, but sinuated near its hinder extremity, where it forms a moderately long, subcentral, straight, and somewhat acuminated rostrum, at its junction with the incurved edge of the posterior dorsal margin, which slopes moderately to its termination. The end of this rostrum is somewhat cylindrical, and a convexly clevated, narrow, sub-triangular area runs from it alongside of the upper margin of the shell; the anterior end is somewhat attenuately rounded, with its upper edge a little convex and greatly declining. The interior is of a somewhat pearly white; the ligament, which although external is so clepressed that one hardly perceives its existence until the valves are opened, is situated in a narrow triangular cavity of the linge margin in one valve, and immediately beneath the beaks; the minute cartilage lies in a very 
small sunken receptacle which inclines hindward, and seems generally to project more below the surface of the hinge-margin in the left valve than in the right. There is but a single tooth, namely, a very large and elongated approximate lateral one, which is laminar and trigonal: it is situated on the posterior side, and leans inwardly with the apex curving again outwards and upwards.

There are two very distinct varieties; the one which is the more frequently obtained has the rostrum remarkably short, and the ventral edge peculiarly bulging out; the other, which we have only received from Loch Fyne, has a much more produced rostrum, and a far more slender shape altogether. It is from the latter then, which is connected with the former variety by imperceptible gradations, that we consider the identity of our species with that of the Mediterranean to be established. Olivi's original figure is somewhat rude, indeed; but, making allowance for the inaccuracies of engraving at that period, sufficiently coincides with our specimens: Risso's rough drawing is not an uncharacteristic representation of the ordinary and larger form.

Animal white, mantle united except for a space anteriorly, where a white lanceolate foot is protruded. Siphons short, united, the branchial largest and longest, tawny with reddish dots. From the anal is protruded a slender pellucid lancet-shaped tube, or veil, with two bright-red dots at its base. These marks are between and among three white filamentary cirrhi with lobed extremities. Four similar organs are placer at either side of the branchial siphon, and all appear to spring as it were from a split sheath.

As a native of Great Britain, the merit of the discovery of this curious and interesting shell is due to $\mathrm{Mr}$. 
James Gerard, who obtained it from the Frith of Forth (Brown), and of its pul,lication as such, to Captain Brown, who admirably described and figured it (October 1829), in the "Elinburgh Journal of Natural and Geographical Science." The same gentleman states in his "Illustrations of the Conchology of Great Britain and Ireland," that he obtained a specimen also near Port Seaton. It is only within a very few years past that any tolerable supply of specimens has been taken. On the English shores it has occurred only on the coast of Northumberland (Alder). Licutenant Thomas has taken it thirty miles from land alive in mud, forty-five fathoms water in latitude of 'lynemouth. The only Irish locality as yet discovered is off Cape Clear, where it was dredged in sixty fathoms water, twelve miles from land, by Mr. M'Andrew. On the east coast of Scotland, besides the locality mentioned, it has oceurred off Fedra, Frith of Fortin in seventeen fathoms, mul (Thomas). On the western side it is more frequent. In the Clyde district, where it was first noticed by Mr. Sinitli, it has been taken frequently (Jeffreys, M'Andrew, Barlee); also around Mull and Skye. At Oban it has occurred in fifteen fathoms water. Off the Zetland Isles it has lueen taken in various depths from twelve to eighty fithom:, and as far as thirty miles from land, living in sand which forms a thick crust aromel it when it is taken up (M'Andrew \& E. F.).

As a foreign species, this shell occurs throughout the Mediterrancan Sea, having a wide range in depth (from 12 to 185 fathoms, E. F.). Loven records it as an inhabitant of the coasts of Norway and Sweden. It is known as a European tossil in beds of the older pliocene epoch. 


\section{N. costellata, Deshayes.}

Small, white, beak produced, surface more or less sculptured with radiating costellæ.

Plate VII. figs. 8, 9 (the smaller figures represent the natural size), and (animal) Plate G, figs. 8, 9.

Corbula costellata, Desh. Exped. Scient. Morée, Mollusques, p. 86, pl. 24, f. I, $2,3$.

Neara costellata, Hinds, Proc. Zoolog. Soc. 1843, p. 77.-Jefrreys, Ann. Nat. Hist. July, 1847, p. 19.

" sulcata, Loven, Index Mollus. Sueciæ, p. 48.

The outline of this extremely rare and recent addition to our Fauna, is rather obliquely pear-shaped, the resemblance to the contour of that fruit not being disturbed as in cuspidata, by any projection of the umbones. The valves are much less inflated than in the other two species, being but moderately ventricose. The epidermis which, however, is rarely preserved, appears when present to be of a pale-ash colour, becoming olivaceous towards the lower margin; the shell itself is white, thin, fragile, and very nearly equilateral; and is adorned with a very variable number of radiating linear ribs, which, commencing anteriorly to the concavity which precedes the rostrum, diminish in elevation, and become more approximate to each other as they recede from that part, either disappearing or changing into mere radiating lines near the anterior extremity, and upon the front umbonal region. The actual costellæ (not the radiating lines), seem to be fewer on the right or larger valve, than on the other one. The ventral margin is moderately subarcuated, the chief swell being near the anterior extremity; it rises posteriorly and, forming a rather profound sinus on arriving at the very oblique linear rib, which is the hindmost of the series of costella, 
again rises with a slightly convex inclination, forming, with the incurved and molerately-sloping opposite dorsal edge a slemeler aml tubular rostrum, of which the somewhat acuminated extremity curves slightly upwards. The anterior dorsal edge runs for a short distance in a nearly straight and slightly ascending direction, forming a trifling angulation with the front margin, which sweeps obliquely and without much areuation to the projecting and well-rounded lower corner of the anterior extremity. The beaks are small, and the umbones, especially that of the smaller valves, are scarcely raised above the dorsal line. The eardinal process is small and depressed, with a short and strong lateral tooth contiguous to it ; the ossicle is strong, solid, elongated, and glossy.

The larger of the specimens from which this account was drawn up measured nearly three-eighths of an inch in length, and rather more than half as broad.

The animal has a white mantle, with its margins united in front, except anteriorly, where there is a passage for a lanceolate white foot. Siphons united the branchial longest, largest, and firmest; the anal short and narrow, but provided with a very fine white extensile membrane to its orifiee, which is protruded at pretty regular intervals even beyond the branchial, and, unless closely observed, appears of a lancet-shape, as if it were a membranous blade. The main part of both siphons is cylindrical, opaque, and of a yellow colour, with reddish or orange markings; the branchial tube is surrounded by several simple white filamentary processes or cirrhi, which extend beyond its extremity.

As yet very few examples of this beautiful shell have been found in the British seas. It was first taken in 184:5 by Mr. M Andrew and Professor E. Forbes in forty 
fathoms water Loch Fyne. Three specimens were found, one alive and in fine condition. Mr. Barlee has since dredged a single example in the same locality. A comparison of British specimens with those of Neara sulcata, sent from Sweden by Professor Loven, and now in the cabinets of Mr. Hanley and Mr. Cuming, has proved the identity of the species, and examples from the Egean, where it was first discovered in a living state by one of the authors, who found it not uncommon, living in various depths of water, through the great range of from 20 to 185 fathoms, agree equally well. The shell varies not a little in shape, and the Mediterranean specimens are usually intermediate in character between those of Norway and of our own seas. The species was originally described and figured by Deshayes from fossil examples brought to France from the tertiaries of Greece. His figures agree well with the recent shell, but that figured by Philippi (Enum. Moll. Sicil. v. ii. p. 13, pl. 13, f. 9), is too doubtful to permit of our quoting it as a synonym. Some species of Necra in the Cumingian cabinet, chiefly from the Indian seas, come remarkably near Neara costellata, especially $N$. concinua, Gouldiana, and Singaporensis.

\section{N. abbreviata, Forbes.}

Very small ; fragile; pale ; beak very short, a radiating linear carina bounding it anteriorly : no ribs nor costellæ.

\section{Plate VII. fig. 7.}

Neara abbreviata, Forbes, Proc. Zoolog. Soc. 1843, p. 75.

" vitrea, Loven, Ind. Moll. Sueciæ, p. 48.

In general shape and appearance this, our smallest Neara, bears no inconsiderable resemblance to the young of cuspidata, but is easily recognised by the linear elevation VOL. I. 
which anteriorly bounds the rostrum by which the hinder side is terminated. The fragility of its valves is exceswive; they are trancparent white, and so peculiarly delicate iti structure as almost to be membranaceous. The epidermis is slightly cincreous, or at most fintly ochraceous, presenting, howerer, scarcely any tinge of colouring; and the surface, which is rather glossy, and elsewhere nearly smooth, exhibits anteriorly, in the fully developed specimens, some obsolete narrow concentric plica. The beaks are acute and incurved, and the umbones sufficiently prominent to disturb, by their projection, the otherwise orate or obovate contour. Behind them, a more or less raised, not particularly oblique line, succeeded by a marked concavity, divides the shell into two portions, which widely differ both in convexity and size; the front being ventricose, and occupying more than three-fourths of the entire area, whilst the hinder one, which is small, triangular, and comparatively compressed, forms a short and very obtuse beak, the lower edge of which is retuse or incurved, the upper convex, and the extremity very distinctly liant. The ventral margin is arcuated, and much ascending at each extremity; the dorsal slopes are consequently very trifling, and deviate but little from the rectilinear, except at their extremities, which are more or less convex. The front side, which is very decidedly the larger, is irregularly rounded at its margin. The lateral tooth is obsolete.

Our British specimens rarely, if ever, exceerl one-third of an inch in length, and somewhat less in breadth: indeed, they are generally of far smaller dimensions. As a native of our Isles, its existence was first published by Mr. Jeffreys, who stated in the "Annals of Natural Ilistory" for May 1847,1 . .314, that Mr. Barlee had taken from seventy 10 eighty individuals in Loch Fyne, fiom which locality 
Mr. M'Andrew had previously procured some examples, dredging them at the depth of forty fathoms. In the Eigean, where it was first met with, dead valves are frequent in mud, taken between the great depths of 80 to 200 fathoms. It is now known also as an inhabitant of the Norwegian seas. The Neara tenuis of Hinds is nearly allied to this species.

POROMYA, Forbes.

Shell ovate or suborbicular, equivalve, inequilateral, slightly produced posteriorly; surface invested with a scabrous epidermis, beneath which it is pearly and minutely punctated; hinge of a minute cardinal ossicle or erect tooth in one valve lodged in a pit or rather impression in the other; no lateral teeth; ligament external; pallial impression very slightly sinuated.

Animal unknown; but probably closely resembling that of Necra.

This genus was founded for the reception of a Mediterranean shell which proved eventually to be identical with the tertiary fossil described by Nyst, under the name of Corbula granulata. Subsequently, the beautiful shell described by Mr. Hinds under the name of Neara hyalina, and now in the Cumingian cabinet, proved to be congeneric, and afforded better opportunities than the fragmentary and rare shell before mentioned, for an investigation of the character of the hinge. Two remarkable cretaceous fossils from Pondicherry, and a European species of the same age, all presenting similar peculiarities of structure, were afterwards associated with it, , and very recently a new living

\footnotetext{
* Forbes on Fossils of Southern India. Geol. Trans. 2nd Ser, vol. vii, p. 140.
} 
-pecies has been brought to light by Sir Edward Beleher. The genus Embla of Loven is possibly nearly allied.

We see in Poromyce characters which conduct us very maturally from Corlute towards Thicke and its allies.

P. Grandlata, Nyst and IVestendorp.

Plate IX. figs. 4, 5, 6.

Corbula? gramulata, Nist and Westendorp (1839), Nouv. Recherch. Coq. foss. d'Anvers, p. 6, no. 10, pl. 3, f. 3.-Nyst, Descr. Coq. foss. des Terr. tert. de la Belgique, 1813, p. 71, pl. 1, f. 6.-JefFreys, Ann. Nat. Hist. vol. xix. p. 314, and vol. $x x$. p. 19.

I'oromya anatinoiles, Forbes, Brit. Associat. Report, 1843, p. 191.

It is to the zeal and science of $\mathrm{Mr}$. Jeffreys, through whose distant and laborious dredgings, natural history has been enriched with many rare and interesting discoveries, whilst his careful guardianship of the collection of 'Turton has thrown full lightit upon the many doubtful and spurious species of that anthor, that the conchologist is indebted for the discovery and publication of this most important generic addition to our Fauna.

The contour of the unique specimen from whence we hate derived our drawing and description, and which at the first glance, might possibly be deemed a variety of Fellia suburlicularis, to which it bears some very slight resemblance in general aspect, is somewhat rhombie, and the length exeeds the breadth hy about one-third. The texture is extremely thin and delicately fragile, yet is not so tramsparent as from its slight liabric might be expected, owing to the nature of its peculiar surface. 'This, which is of a pale clay colour, and utterly devoid of lustre, appears, when highly matgified, to be most minutely and crowdedly 
scabrous, the asperities not being arranged in any determinate figure. Where these have been abraded, the surface appears of a pearly white, pricked over with but slightlyindented wavy punctures. The valves are rather ventricose ; and very inequilateral, and are internally of a nacreous white. The ventral edge is merely convex, but rises a little behind, where for a short space it is slightly incurved as it approaches the extremity of the linear but almost obsolete umbonal ridge, which runs very obliquely from the umbones to the lower corner of the posterior side, behind which the surface is slightly depressed. The hinder side is nearly twice as long as the other, and appears very indistinctly biangulated, its posterior edge being scarcely convex, and its dorsal one but very little sloping, and though slightly curved, not far removed from rectilinear. The anterior extremity is obtusely rounded, the downward curve of the upper margin being subarcuated, and rather sudden. The beaks are acute, prominent, and leaning forward, without any lunule in front of them.

A single living example of this curious shell was dredged by Mr. Jeffreys off the Island of Sliye, in fifty fathoms water. It was first captured in a recent state by Professor E. Forbes in the Fgean, where it occurs at various depths between forty and one hundred and fifty fathoms; chiefly below ninety fathoms. As a fossil it occurs in the upper tertiary beds of Belgium, and in the coralline crag of England, where it was found by Mr. Searles Wood. 


\section{PANDORIDA.}

THE PANDORA TRIBE.

Tre genus Pandora, and its foreign ally, Myodora, present peculiarities which prevent our including them, as many have done, in the tribe of which Corbula is the type. Their extremely unequal and irregular shells, and peculiar modifications of hinge and, above all, the minute structure of the shell, which resembles that of the margaritaceous bivalves, afford sufficient and easily-recognizable characters, derived from the hard parts; whilst the singular conformation of the branchix, partially reduced by suppression, the small foot, and the united tubes with diverging orifices, present a combination of features in the animal strikingly distinguishing it from that of the neighbouring tribes with closed mantles. The small extent of the family, as at present known, is no objection to its claim to rank as such : value of character, and not number of species, must ever be the only sound ground for the limitation of either tribe or gents.

PANDORA, Lamarck.

Shell inequivalve, inequilateral, nacreous; one valve flat, the other more or less convex. Ilinge composed of a primary tooth in each valve, with corresponding pits. Ligament internal. Muscular impressions weak, rounded; palleal with a very slight sinus. 
Animal oval, compressed; the mantle closed, except for the passage of a narrow, tongue-shaped foot. Siphons very short, mited nearly to their orifices, which are divergent and fringed. Branchix of each side united into one. Labial tentacles triangular.

This curious and beantiful genus includes some fifteen species, mostly exotic, though two of them range to our shores. The margaritaceous aspect of the shell is a striking character, and depends on a structure which has been investigated by Dr. Carpenter, according to whom "the exterior presents a regular prismatic arrangement of cellular tissue, the axes of the prisms being perpendicular to the surface. Between these are distinct membranous partitions, forming a tenacious membrane, that is left after decalcification. The interior is truly nacreous." * In the animal of this genus, according to Mr. Garner, + the only appearance of the internal lamine of the branchire consists of two very narrow strips at the base of the others.

\section{P. rostrata, Lamarck.}

Form rather elongated, anterior end the broader, posterior end atlenuated and somewhat beaked; ventral margin most swollen in front and subcentrally; hinder dorsal edge retuse, or incurved, and somewhat declining.

Plate VIII. figs. 1 to 4.

Tellina incequivalvis, LinN. Syst. Nat. ed. 12, p. 1118.-Donov. Brit. Shells, vol. ii. pl. 41, f. 1.-Mont. Test. Brit. p. 75.-Linn. Trans, vol. viii. p. 50.-Turt. Conch. Diction. p. 172. (not remarks).-Chemn. Conch. Cab. vol. vi. p. 115, pl. 11, f. 106. - Sreng. Beschaft Berlinisch. Ges. Natur. vol. iii. pl. 7, f. 25 to 28.-Woop, General Conch. p. 201, pl. 47, f. 2, 3, 4.-Dir Lw. Recent Shells, vol. i. p. 86.-Index Testaceol. pl. 5, f. 97.

* Report Brit. Assoc. for 1846, p. $105 .+$ Zool. Trans, vol. ii. p. 92. 
Pandora rostrata, LAx. Anim. s. Vert. (ed. Desh.) vol. vi.p. 145.-Brit. Marine Conch. p. 58.-Brown, Illust. Conch. G. B. p. 104, pl. 47, f. 5, 12, 13.-Sowerux, Gen. Shells, l'andora, f. 1, 2, 3.Croccir, Introd. Conch. pl. 5, f. 2.-Sowerni, Spec. Conchylior. Pandora, p. 2, f. 7, 8, 9.-Sowerny, Concl. Manual, f. 90.-Desir. Elem. Conch. pl. 8, f. 10, 11.ReEve, Conch. Systemat. pl. 37, f. 1, 2, 3.-HANr. Recent Shells, p. 48.-Desir. Exp. Scient. Algérie, Moll. pl. 24 (animal).

". margaritacea, TurT. Dithyra Brit. p. 40, pl. 3, f. 11 to 14.

" inaquiralvis, Flem. Brit. Anim. p. 466 (chiefly).

Pandore rostréc, Chesu, Traité Element. p. 58, f. 194, 195.

This peculiarly graceful bivalve, which we may reckon among the rarer shells of the British Fauna, is of an rlongater oblong shape, extremely inequivalve, and for its genus sufficiently strong. It is semitransparent, and coated with a thin layer of yellowish white; beneath which it is pearly; and, indeed, the nacreous lustre is more or less visible, especially in the young, upon the outer surface also. The valves are remarkally unequal; the left one being greatly convex, and smooth, with the exception of some irregular concentric striule torards the side; the right being almost flat throughout (a little concave in the young. and towards the bealss), with similar most closely-disposed irregulatr minute striule at the sides, and especially in front, besides obsoletely indented folds toward the upper portion of the area. The ventral margin is not (for a Pandora) greatly arcuated, being even in certain examples a little flattened in the middle of the arch; its chief swell is in front, becoming less convex, lut gradually and most distinetly ascending, posteriorly. A perpendicular let fall from the beaks (which, although by no means prominent, are, nevertheless, through the inflection of the hinder dorsal margin, more manifest than in the succeding species,) would alout erpal a similar one dropped from any other portion of the upper edge, and would sever an anterior 
side of only about one quarter the length of the produced posterior one. The front dorsal edge, at least in the less shallow valve, is convex, and moderately declining; the hinder dorsal edge is more or less (but not profoundly so) concave, and slightly, yet decidedly sloping. The front is the broader extremity, and is subangularly rounded; the hinder is much attenuated, but not very acutely beaked, as there is no distinct ventral inflection beneath it, and the tip is obtuse, more or less squared above, and not very projecting or ascending. The front hinge margin of the left valve is externally sharp, and elevated above that of the other; the hinder of the right valve, as is usual in the genus, is flattened down, and overlaps that of the other; but is not concave, nor at all excavated. The umbonal ridge is best indicated in the more convex valve, where two rather broad and approximate elevated lines run from the beaks to its extremity, becoming more obtuse as they advance; corresponding, but very feeble grooves, are visible in the opposite valve.

The most elongated specimen we possess is an inch and a third in length, and five-eighths of an inch in breadth; the widest is a trifle more broad, and the sixth of an inch less in length.

The animal is figured by Poli, and represented as having yellowish-brown tubes.

Although by common report ascribed to Weymonth and South Devon, we have no certain testimony of its being found in any of these spots; it is, however, abundant on the sandy shores of Gorey and St. Helier, in Jersey (S. H.); Guernsey (Clark). It occurs fossil in both red and coralline crags (S. V. Wood), and ranges at present to the Mediterranean. 
P. ontusa, Leach.

Form somewhat abbreviated; posterior end the broader, anterior end very narrow: rentral margin most swollen behind: hinder dorsal edge rectilinear, and not at all sloping.

Plate VIII. fig. 5, and (Animal) Plate G. fig. 10.

Solen Pinna, Mont. Test. Brit. p. 567.-Linn. Trans. vol. viii. p. 48.-Wood, General Conch. p. 141.-Index Testaceol. pl. 3, f. 35.

Pandora obtusa, LeAcr in Lam. (ed. Desh.), vol. vi. p. 145.-Brit. Marine Conch. p. 57, f. 15.-Sower rr, Species Conch. Pandora, p. 2, f. 1, 2, 3.-Deles. Rec. Coquil. pl. 4, f. 3.-Haxr. Recent Shells, p. 48, pl. 3, f. 35.-Philip I, Moll. Sicil. vol. ii. p. 14, pl. 13, f. 13.

Notwithstamling that several writers upon British conchology have supposed this to be merely the young of the preceding shell, no species of Pandora can be more radically different, a mere glance at the extremities at once determining to which of the two a specimen belongs. 'T'o prevent all chance of the recurrence of such an hypothesis, we have figured the true young of the latter shell.

The shape of $P$.obtusa is subrhombically subovate, and never elongated, and the valves are very dissimilar and unequal, the left one being strongly convex, whilst the right one is actually concave; in colour, lustre, nacre, and general sculpture it is similar to rostsatu, but is decidedly thinner, the flat valve being of considerable tenuity and great fragility; the elevated lines which run along the umbenal ridge of that species are likewise altogether wanting, or at most but feebly evident towards the beaks, the umbonal ridge itself being almost if not quite obsolete. There seem generally, in adult examples, a few raised Aclicate radiating lines towards the lower margin of the concave valve; we hesitate, however, in regarding these 
as permanently characteristic. The ventral margin is greatly arcuated, and swells out chiefly behind, the front portion of it ascending in a much less convex line; the broadest part of the shell is by no means between the beaks and the opposite margin, but not far from the hinder termination, from whence the width gradually diminishes to the very narrow extremity of the anterior side. This latter is sometimes equal to a third, sometimes to a fourth only, of the length of the posterior side, its superficial inequality is infinitely greater; the front dorsal edge is decidedly and retusely sloping; the hinder dorsal margin is straight, and either horizontal or slightly ascending; the posterior end is by far the broader, being expanded, almost rectangular above, and rounded beneath. The umbonal ridge is obsolete, and the beaks depressed; the nacre is within of a silvery pearl, and greatly iridescent; the tooth of the left valve elongated, shelving, subtrigonal, laminar, confined to the anterior side, and truncated behind; that of the right valve is small, narrow, perpendicular, and central; the cartilage is oblique, and not immediately adjacent to the teeth, but forms an acute angle with them at its apex.

The size of rather a large example is seven-eighths of an inch in length, and half an inch across at the broadest part.

Mr. Clark has observed the animal, and describes it as of an elongated suboval form, having the left side much more tumid than the right. The mantle is entirely closed, except a small fissure at the anterior end for the passage of the foot: posteriorly it forms a sheath, from which two very short tubes issue, rounded and very slightly separated at their points ; their extremities have fine white rays, and the tubes themselves are aspersed with exceedingly minute intensely white spots, like grains of sand. [In Mediter- 
ranean examples we have observed vivid orange specks around the orifices of the tubes.] The foot is of a white colour, flat, and tongue-shaped. "There is only one branchial lamina at each side, having a furrow at its uppermost margin, and a very fine rather indented line alove it, which may be the termination of each transrerse thread of the branchial leaf, or possibly the rudiment of an upper branchial plate, which certainly is wanting in this species; at the anterior end on each side there are two small triangular rather rigid labial appendages, each mited with the other by a small membrane around the mouth. They are of precisely equal size, lying one on the other, both (on each side) plain on their outer surfaces, and strongly pectinated on the inner; the labia are so precisely of a size, and cover each other so exactly, that they may be mistaken for a single labium on each side."

It is frequently obtained alive by dredging on many parts of our coast in the west and south, usually on muddy ground. Off Portland (S. H.); in twenty-seven fathoms water, eight miles off' Dartmouth (M'Andrew and E. F.); at Exmouth (Clark); Torbay (S. H.); Cornwall, in seven fathoms, Weymouth (IIAndrew and E. F.); Isle of Man (E. F.) ; Anglesea, in twelve fathoms (M·Andrew); Guernsey (S. H.)

In Ireland it is very rare, specimens have, however, been "dredged off Carrickfergus, Sept. 1835 (Mr. Hyndman); subsequently by Mr. H. and myself in Strangford Lough" (W. T. Ann. Nat. H., vol. v. p. 14); in sixty fathoms off' Cape Clear (M'Andrew); in twenty to twentyfive fathoms, skye, and in ninety fathoms off the south coast of Mull (M'Andrew and E. F.); "Oban, Loch Shieldaig, Inehrides" (Jeffreys); Loch Fyne (Barlee).

It ranges to the Mediterranean. 
Shell inequivalve, more or less inequilateral, both valves convex. Surface often striated and invested with an epidermis. Hinge without teeth, but provided with a movable testaceous ossicle, comnected with each valve by cartilage; ligament internal. Muscular and palleal impressions weakly marked, the latter sinuated.

Animal oblong; mantle closed, except a fimbriated opening anteriorly for the passage of a tongue-shaped grooved foot; siphons very short, united nearly to their orifices, which are fringed. Labial tentacles triangular, small.

Although there are few better marked genera among the European bivalves than this, the nomenclature and synonomy of our native species are singularly varied and confused, owing, chiefly, to the comparative rarity of the shell, and the imperfect state in which it not unfrequently found its way into cabinets. The genus, however, is an excellent one, and important in a systematic point of view, since it constitutes an excellent transition from Pandora to Anatina and its allies. The peculiar nacreous structure of the shell, first examined microscopically by Dr. Carpenter, links it rather with the former tribe, an union which is borne out by features in the anatomy of the animal, especially the peculiarities of its respiratory system.

The species of Lyonsia are few, but distributed through arctic, temperate, and tropical seas. Some forms from the Indian seas indicate a generic affinity with Sphenia. The history of its fossil members has not yet been clearly made out. Some tolerably well marked species occur in strata of the Cretaceous epoch. 


\section{Norvegica, Chemnitz.}

Plate VIII. fig. 6 to 9 , and (animal) Plate H. fig. 3.

Mya Norregica, Chemx. Conch. Cab. vol. x. (1788), p. 345 , pl. 170, f. 1647, 1648. -Turt. Conch. Diction. p. 100, f. 100.-FLem. Brit. Anim. p. 466.-Wood, General Conch. p. 98, pl. 18, f. 4, 5 . -Diclw. Recent Shells, rol. i. p. 48.-Index T'estaceol. pl. 2, Mya, f. 13.

Myce nitida, Fabric. Skrivt. Natur. Selskab.(1798), vol. iv. part 2, pl. 10, f. 10 .

Amplidesma Corbuloides, Lax. Anim. s. Vert. ed. 2, vol. vi. p. 129.

Mfya striata, Monт. Linn. 'Trans. vol. xi. p. 188, pl. 1, f. 13,-T'vnt. Conch. Diction. p. 105.

Mya pellucida, Brows, Mem. Wern. Soc. vol. ii. p. 505, pl. 24 , f. 1.

Lyonsia striata, TurT. Dithyra Brit. p. 35, pl. 3, f. 6, 7 .

Anatina Norregica, Sowerb. Genera Shells, Anatina, f, 2. - Reeve, Conch. System. pl. 34, f. 2.

Osteodesma Corbuloiles, Desir. in Lam. Anim. s. Vert. vol. vi, p. 85.-Desh. Elem. Conch. pl. 8, f. 12, 13, 14.-IIAxL. Recent Shells, p. 24.

Lyonsie Norregica, Sowerb. Conch. Manual, ed. 2, f. 491, 492.-Macgint. Moll. Aberd. p. 300 .

Myatella Montagui, Brown, Illust. Conch. G. B. p. 111, pl, 40, f. 26, 27.

Magdala striata, Brows, Illust. Conch. G. B. p. 111, pl. 44, f. 1, 2, 10.

Ostéclesme Corbuloüde, Chenv, 'Traité Ellem. p. 51, f. 164, 165, 166.

YAR.-Tellina comscans, Scacci. Osserv. Zool. p. 14.

I'andorine " Sc.iccr. Catalog. p. 6.-Ann. N. H. vol. iv. p. 294, pl. 14, f. 1 to 4 .

Osteodesma coruscans, PunLrpr, Moll. Sicil. vol. ii. p. 15, pl. 14, f. 1.

Anatina truncata, LAM. Anim. so Vert. (DEsH. ed.) vol. vi. p. 77 (in part).-Desi. (not Deles, nor Hanl.) Encycl. Méth. vol, ii. p. 40.

Lyonsia elongata, Gray, in British Museum.-HANL. Recent Shells, p. 25, suppl. pl. 13, f. 27 .

" coruscans, DesH. Exped. Scient. Algérie, Moll. pl. 25. A.

From the ossicle of Montagu's shell having been represented as fixed, Captain Brown has instituted a genus hased upon the figured type for its sole reception. IIaring examined Mr. Lyons's own specimen, and conferred with him upon the subject, we are enabled positively to assert its identity with the present species. The general contour is oblong, the texture very thin, brittle, and somewhat translucent, externally dull whitish, and internally of a 
silvery pearl-like nacre. Both valves are decidedly convex, or rather subventricose, but that which is very slightly the less so, is reflexed at the lower edge (which is peculiarly sinuated in its outline when viewed from below), and overlapped by the margin of the larger valve. T'he surface is covered with an extremely thin ash-coloured epidermis, which is much wrinkled concentrically beyond the almost obsolete umbonal ridge, where the valves are compressed, and marked with a shallow excavation. This membrane is frequently covered with grains of sand, and beneath it the shell is closely radiated with delicate raised rugose strix, the interstices of which are microscopically granulated. The dorsal and ventral edges are somewhat parallel; the front superior margin is very retuse, and instead of declining, curves upward at its termination, the hinder dorsal margin is slightly convex, and very moderately sloping. The inferior or ventral margin (looked upon from the larger valve) is arcuated, and rises considerably behind to meet the slightly retuse and reflected posterior edge, which latter almost forms a rectangle with the dorsal margin. The anterior side is regularly rounded at its extremity; the posterior, which is nearly half as long again, gapes at its narrowed and subtruncated termination. The beaks are obliquely inflected, and are preceded by a rather large lanceolate, and but slightly excavated lunule, which is most easily distinguished by the absence of radiating strix. The dorsal edge of the lesser valve somewhat overlaps the other, of which the umbo is decidedly the more prominent. There is no extermal ligament. The hinge is destitute of fixed teeth, but is provided with a movable, somewhat heart-shaped, testaceous ossicle, which is united to both the valves by a cartilaginous deposit.

The animal of this interesting bivalve has received consi- 
derable attention, and has been more or less completely noticed by Philippi, Deshayes, and Gray. We have ourselves examined it in its living state in the British seas, and as long ago as $\mathbf{1 8 3 5}$, it was carefully observed by Mr. Clark. It is oblong, and of a yellowish white hue. The mantle is closed throughout, exeept where there is an opening towards the anterior extremity for the passage of a white linguiform foot, flat and straight, long, rather pointed, and marked by a byssal groove. Deshayes has observed a byssus. Posteriorly the mantle forms two short tubes, which are united nearly to their orifices. These tubes are white, speckled with minute black dots. Both have about twelve cirrhi around their openings. The labial palpi are narrow, and plicated on their internal surfaces. According to Mr. Clark, there is only one elongated branchial leaf on each side, attached to the dorsal range, and rumning straight to the tubes. Each leaf is divided into two equal parts by a depressed groove or firrow, and is coarsely pectinated and doubled upon itself on the inner surface, rather more than half-way up its height, the extent of the duplieation being marked by the external furrow. In consequence of this arrangement, each branchial lamina, though really single, appears as if it were one-and-a-half on each side.

The finest specimens we know of are those dredged off Wermouth, (near Portland,) which measure fully an inch and three-quarters in length, and seven-eighths of an inch in breadth. The species is likewise taken at Cullercoats, near Newcastle (Alder); at Scarborough (Bean); in twenty-seven fathoms, the Coquet (Thomas); in fifteen fathoms West Bay of Portland, and twenty-five fathoms Penzance Bay (M'Andrew and E. F.); in fifteen to twenty fathoms Isle of Man (E. F.). 
It is by no means plentiful at Tenby (its original locality), and although " inhabiting each side of the Irish const, is very scarce" (Thompson). Among other places in Ireland where it may be found, may be specified Birterbuy Bay in Connemara (Barlee); and the bays of Dublin (Jeff.) ; and Bantry (Brown).

In Scotland it is dredged from Oban, Inverary, Lochs Shieldag and Torridon (Jeffreys); the Orkneys, Hebrides, and Shetland Islands ( $\mathrm{M}^{6}$ Andrew), where it has occurred in five, thirty, seventy, and eighty fathoms water, and as far as twenty-five miles from land; also in thirty-four fathoms on the Elginshire coast, Aberdeenshire (Macgillivray).

SPURIOUS.

To this genus belongs the Mytilus plicatus of Laskey and Montagu, a species which we, in common with other students of British Conchology, had regarded as lost to science, until, searching in our national museum for the remnants of Colonel Montagu's collection, we lighted upon a specimen so exactly agreeing with the only extant figure in the Wernerian Memoirs, and named on the tablet "Lyonsia plicata," that the supposition is not unreasonable that it was the identical individual described and figured by our authors. From this and a few other examples, we have described the species, giving a more detailed account of it than is our wont with the spuriously British shells, from our conviction that it is by no means generally known to the authors of works upon general Conchology. It is a native of the West Indies (Guilding). 


\section{L. picate, Montagu.}

Myltilus plicatus, MIoxT. (not Chemn.) Test. Brit. Suppl, p. 70. - LAsiey, Wern. Mem. vol. i. pl. 8, f. 2.-Turt, Conch. Diction. p. 114.

Saxicara plicata, Turx. Dithyra Brit. p. 22

The shape is more or less rhomboidal, but evidently variable, from a liability to distortion ; it is excessively inequilateral, being truncated in front, and dilated and produced behind. The valves seem very nearly, if not quite equal, and are thin, but not transparent, of a subnacreous white, veiled, when perfeet, with a pale yellowish drab-coloured epidermis, beneath which the surface is almost smooth, or, at most, rather distantly antiquated by the concentric layers of growth. The convexity is unequally distributed, the chief elevation, amounting at times to tumidity, being subcentrally from the umbones to the posterior side of the ventral margin; the upper area of the posterior side, as well as the front extremity, is considerably more depressed. The ventral margin, which varies from slightly retuse to actually inflected in front, is more or.less arcuated behind. The anterior edge abruptly slopes from the beaks in a more or less straightish line, (at times subretuse, at times a little convex, ) causing the extremity of the almost truncated anterior side to appear ablreviately sulicuneiform, or rectangular below. The termination of the elongated posterior side is more or less angulated above, and obliquely rounded below, the chief projection being more adjacent to the dorsal than to the ventral margin; the former is produced, more or less ascending, and in the more naturally developed examples straightish, but occasionally convex, or even arcuated. 'The umbones project a little above the dorsal outline; the beaks are small, and much incurved, (in one specimen they lean a little forward,) in front of them is situated a large and distinct lunule-like impression. The interior is of a silvery pearl, the hinder dorsal edges are not inflected, and the hinge plate resembles that of cuneata.

The ossicle of the specimens from whence we have drawn up the above description, is unfortunately wanting. The larger individuals were about five-sevenths of an inch in length, and at most half an inch in breadth. They appear most nearly allied to cuneata, which differs from them in the absence of a lunule, and in the attenuation of its hinder side. 


\section{ANATINIDAE.}

THis tribe consists of a very natural assemblage of acephalous mollusks, closely allied to those of the last two families. The shells it includes are of a more or less oblong form, often tumid, sometimes compressed, mostly fragile in comparison with their dimensions; all inequivalve and gaping at the hinder extremity. The surface is dullcoloured or white, rarely conspicuously ornamented, though often minutely scabrous. The hinge varies, being in some furnished with spoon-shaped fulcra, in others deprived of such substitutes for teeth, and furnished with a free shelly ossicle fixed to each valve by a cartilage. The ligament is internal, or both intemal and external. The animals have mantles, closed, except where the foot, which is more or less linguiform, protrudes. Their siphous are separated, moderately long, and furnished with fringed orifices. They are closely allied to the members of the last family in the characters of the respiratory system, a single branchial leaflet only being developed fully on each side. They live buried in mud or sand, sometimes in cavities of rock, and have a wide range, extending from low water mark to very great depths. Members of this family are distinctly recognized as fossil during the early stages of the oolitic period. 
THLACIA, LEACH.

Shell transversely orate, tumid, or compressed, generally thin, inequivalve, often nearly equilateral, more or less garping posteriorly; surface nearly smooth, or minutely scabrons, sometimes covered by an epridermis. Muscular scars unequal, united by a strongly sinuated palleal impression. Ininge composed of a thickened shelly, more or less prominent fulcrum in each valve; liganent partly internal; cartilage furnished with a free crescentic ossicle. Bealis entire.

Animal ovate. Mantle closed, except for the passage of a compressed linguiform foot. Siphons rather long, separated to their origins, and furnished with fimbriated orifices, which are "often inflated into a globular form" (Clark). A single branchial lamina developed on each side. Labial appendages triangular, pectinated.

The shells of this genus are not remarkable for beauty, being all white or dusky in colour, and not distinguished by any conspicuous ornaments. The scabrous, or shagreenlike structure, which the surfaces of many of them present, has been investigated by $\mathrm{D}_{\mathrm{x}}$. Carpenter, who finds it to depend upon "the presence of numerous large isolated cells, filled with calcareous matter, which form a superficial roating superposed upon the ordinary external layer, the periustracum being eontinued orer them, and sinking down into their intersaces, just ats the human epidermis covers the papillary surface of the true skin. 'The proper external layer is composed of polygonal cells, with sharply defined boundaries having large nuclear spots." 


\section{T. phaseolina, Lamarck.}

Small, white, oblong, rather oblique, more or less glossy, smooth, except posteriorly; anterior side the longer; posterior termination subtruncated: ossicle broader in the middle.

Plate XVII. fig. 5, 6, and (animal) Plate H, fig. 4.

Tellina fragilis? Penn. Brit. Zool. ed. 4, pl. 47, f. 25.

Mya declivis, Turt. Conch. Diction. p. 98.-Index Testac. pl. 2, Mya, f. 4.

" $\quad$ young, Wood, General Conch. pl. 18, f. 3.

"pubescens, young, Тurт. Dithyra Brit. pl. 4, f. 3 .

Anatina declivis, Turt. Dithyra Brit. p. 47.-Brit. Marine Conch. p. 42.

Amphidesma declivis, Frem. Brit. Anim. p. 432.

" phaseolina, LaM. Anim. s. Vert. (ed. Desh.) vol. vi. p. 129 (badly). Thracia phaseolina, Kiener, Coq. Viv. Thracia, pl. 2, f. 4.-Storer, Translat.

Kiener, p. 7.-Desh. Elem. Conch. pl. 9, f. 4, 5.Couthouv, Bost. J. of Nat. Hist. vol, ii, p. 147.-HANL. Recent Shells, p. 22, supp. pl. 10, f. 35-Phimippi, Moll. Sicil. vol. ii. p. 16.-Loven, Ind. Moll. Scandin. p. 46 (probably).

Odoncineta papyracea, Costa, Test. Sicil. p. 23, pl. 2, f. 1, 2, 3, 4 .

Thracia pubescens, Macgilliviay, Moll. Aberd. p. 296.-Brown, Ill. Conch. G. B. p. 110, pl. 44, f. 6 .

" declivis, Brit. Marine Conch. f. 70 .

Dr. Turton, who was the first British writer to detect the specific distinctness of the present species, has curiously enough figured a variety of it as the young of pubescens. Its nearest congener is, however, the $T$. villosiuscula, to which species we refer our readers, for the exposition of their points of difference. The T. phascolina is of an oval oblong shape, very thin and fragile, snowy white under its yellowish epidermis, not at all pellucid, rather glossy, and very inequivalve; the margin of the more convex valve (and both are moderately so) embracing the other throughout its entire circumference. The surface, which is marked with obsolete concentric wrinkles, only appears shagreened when viewed with a powerful lens or microscope. The ventral margin, which in fiont varies from arcuated to moderately convex, and ascends behind in a rectilinear or 
lut slightly convex line, is sometimes, but not invariably. a little retuse. adjacent to the obtusely-biangulated posterior extremity of the shell. The anterior side is rounded; the posterior narrowed, and always decidedly the shorter, although the range of variation as to the extent of inequality is tolerably extensive. The front dorsal edge is typically arcuated, but in some specimens is decidedly sloping, and in others is but slightly convex. The hinder dorsal line slopes but little, and after being exeavated for the insertion of the ligament, curves out gently to the subtruncated and linearly gaping posterior extremity. The bealis are inflected and oblique, the umbone of the larger valve prominent, and the ligament short, somewhat sunlien, and of a yellowish olive colour. The umbonal ridge is very distinetly defined; a shallow excaration divides it from the dorsal erlge. The hinge cousists of a simple, small, not very thick triangular plate, which is slightly hollowed out npon the top, excepting at its broader end, which causes that portion to appear possessed of a denticle, or incipient tooth. This plate is not divided by any medial tooth, and, being entirely posterior, leaves the umbonal eavity exposed. The assicle, or moveable shelly plate, (which lies immediately beneath the beaks in front of the hinge-plate, clasping the edge of either valve so as to present to the eye, when attached, only its arcuated edge,) is moderate in size, and of a broad crescent-shape. When detached (and, unfortunately, this almost always occurs before its capture, or else in the excision of the animal,) it appear's to be very convex on one side, but flat, with a large and deep excavation near the concave edge, on the other. It never attains to any considerable size, and rarely exceeds the dimensions of the specimen we have delineated.

"Animal oval. elongated, moderately thick, having the 
mantle closed throughout, except quite anteriorly, where there is a fissure for the passage of a compressed, not very large linguiform foot; and posteriorly for the issue of two large rather long tubes, which are separate nearly their whole length, and divergent at their extremities, which have each a few rays. The branchiæ consist of only one lobe on each side, which has a longitudinal furrow in the middle, and is reflected for half its height, on the inner surface, precisely in a similar manner with that described as occurring in Lyonsia Norvegica. There are on each side the branchial lobes two small triangular labia. The animal is of a white colour throughout."-Clark MSS.

This is by far the most abundant of our Thracias, being a tolerably plentiful bivalve, and one that is widely diffused. It is taken in Northumberland (AIder); Scarborough (Bean); Weymouth (S. H.); various spots in S. Devon (Jeffreys); and on the sandy shores of both eastern and western coasts, from Cornwall to the Shetland Islands (M·Andrew). A variety is met with at Plymouth, in which the length is twice and a half the breadth (Jeffreys cab.). At Tenby it is peculiarly abundant (S. H.), and is likewise procured at Swansea, and the neighbouring coves (Jeffreys). Among its Irish localities we may specify Belfast, Strangford, Dublin, and Bantry Bays (Thompson), and Cork Harbour (Humphreys). It has a wide range in depth, having been taken alive in five fathoms at Unst, and dead in thirty, seventy, and a hundred fathoms, around the Shetland Isles, sometimes more than twenty miles from land. Lieut. Thomas has dredged it in twentyseven fathoms off the coast of Northumberland.

This species ranges from the coasts of Norway to the Levant. It is the most ancient of our Thracias, being found fossil in the coralline crag. 


\section{T. Yrulosivecula, Macgillivray.}

Like 'T'. phaseolina, but rather shorter, dull, scabrous, and not at all oblique; ossicle not broader in the middle.

\section{Plate XVII. fig. 4,7 .}

Anatine rillosiuscula, MAcGilliv. Edinburgh Philos. Journal (Jameson's), 1827, p. 370, , 1.11, f. 6 .

Thrucia orata, Brow, Illust. Conch. G. 13. p. 110, pl. 4t, f. t.

Although most closely allied to the $T$. phaseolina, this little known species possesses distinctive features, which, although apparently trifling, are nevertheless important from their constancy. These characters had long been noticed by that most accurate observer Mr. Clark, who hat separated it in his cabinet, under the name intermediu. The general outline is nearly oblong, with a tendency to angularity at the bealss; and the valves rather thim, fragile, somewhat inclined to be ventricose, but moderately unequal in area and convexity, and of a dull opaque white. The surface, even when examined with a lens of low power, is distinetly shagreened, and is usually coarse-looking, from the great irregularity of its unsymmetrieally concentric wrinkles of growth, and the indentations by which it is not unfieguently deformed. The ventral margin is more or less inclined to be rectilinear; it is sometimes however decidedly convex, but scarecly ever ascends much at its hinder termination. The dorsal edges are both moderately and nearly equally sloping; the anterior declination is ordinarily the greater; they are both nearly straight, the front being scarcely convex, and the hinder hardly retuse, but with its extremity a little rounded and bending downwards. The sirles are unequal, the anterior always being the longer (and typically much so,) but the amount of inequality is very 
variable; the front extremity is rounded, but rarely symmetrically so, and is almost always attenuated and narrower than the linder termination; this latter is bluntly biangulated, with the upper edge in typical examples projecting beyond the lower, so that a perpendicular line drawn from the dorsal end would fall beyond the rentral margin. The umbonal ridge is distinctly indicated, is not very oblique, and has a rather large area behind it. The beaks project moderately, and do not lean to either side; the ligament is rather large and prominent, elongated, and of a buff yellow. The cardinal plate which supports the ligament is very narrow, peculiarly trigonal, and inclining outwards. The ossicle is solid, longer than in phaseolina, and almost linear, resembling a portion of a broken ring.

The preceding species, although very nearly allied to the present, has a more elongated and oblique contour, a more delicate texture, and a smoother surface. Its dorsal edges are less sloping; the front one, which is convex or even arcuated, scarcely declines at all, so that the anterior side is much the broader; the ventral edge too both rises more behind and swells out more in front. The beaks are more inclined; the ligament smaller and darker; and the ossicle is filled up, as it were, in the middle by shelly matter. In the more typical examples of phaseolina, the hinder termination is usually coated with a rust-like substance, and projects below as much at least as it does above; its dorsal edge inclines upward. The cardinal plate is rather stronger, and produced more under the umbo, making: the sinus more oblique; the muscular impression beneath the beaks is rather broader, and the sinus of the palleal impression more profound and running more to a point below.

The superficial dimensions are almost the same as in the VOL. I. 
preceding, but the shell is rather broader in proportion, from its more abbreviated shape.

The animal, aceording to Mr. Clark, is in every respect similar to that of $T$. phaseolina. It is occasionally taken in deep water upon the Northumbrian coast (Alder); at Exmouth (Clark); and in Cornwall (Alder): Swansei, Bantry bay. Ross shire, and Lerwicli (Jeflreys). It is not uncummon on the went coast of Scotland (Alder), where it was first discovered and named by Professor Macgillivray.

\section{'T. Pubfecens. Pulteney.}

Oval-oblong, biangulated behind, of a pale sand colour, never pure white, devoid of all lustre, scabrous : sides equal or very nearly so; hinder dorsal edge moderately sloping: hinge-plate, notched in front.

\section{Plate XVI, figs. 2, 3.}

2. Mya declivis, Pennant, Brit. Zool. ed. 4, volo iv. p. 79.

Mya pubescens, Pulteney in Ifutchins's Dorset, p. 27.-Mont. Test. Brit. p. 40, and Suppl. p. 166 (chiefly).-Turt. Conch. Diction. p. 99 , f. 35 .

" declixis, Dovov. Brit. Shells, vol. iii. pl. 82.-Linn. Trans, volo viii. p. 36. -Dorset Catal. p. 28, pl. 4, fo 6.-Woon, General Conch. p. 93, pl. 18, f. 1, 2.-Dillw. Recent Shells, vol. i. p. 43 (not variety).

Anatina Myalis, Lar. Anim. s. Vert. (ed. Desh.) vol. vi. p. 80.-Crovcri, Introd. Conch. pl. 4, f. 1.-Deress. Recueil Coquilles, pl, 2, f. 3.

Anatina pubescens, TurT. Dithyra Brit. p. 45,-Brit. Marine Conch. p. 41. Thracia pubescens, KIENer, Cor. Viv. Thracia, p. 5, pl. 2, f. 2.-STorer, translat. Kien. Thracia, p. 5.-Cournour, Boston J. Nat. Hist. vol. ii. p. 135.-Desr. Encyclop. Méthod. Vers, vol. iii. p. 1039.-Exp. Morée Zool. p. 87, 3rd scr. pl. 18, f. 1, 2.-HanL. Recent Shells, p. 21.

Amplidesma pubescens, Flem. Brit. Anim. p. 431.

Thracia declivis, Brows, Ill. Conch. G. B. p. 109, pl. 44, f. 5.

It is by no means improbable that Pennant's Mya declicis was identical with this species; at least, Montagu declares that the Portland specimen, the traditional type of 
that shell, was similar to, though smaller than, his own pubescens. As, however, the last-named author has confused our next species with the present one, and regarded convexa as identical with distorta, we cannot look upon him as a ligh authority upon the Thracias; and the description of Pemmant being so brief and inadequate, we have, in accordance with the opinion of our best conchologists, preferred expunging altogether the name declivis to sanctioning the dangerous practice of hypothetically determining an undefined object.

This large Thracic has an oval-oblong figure, is rather thin, inequivalve, subventricose, devoid of lustre, and of a pale sand-colour; the surface is distinctly shagreened, and marked with coarse, irregular, concentric wrinkles; the ventral edge is almost straight, or even very slightly retuse on the posterior side, and slightly convex on the anterior. These distinctions are most apparent upon the more ventricose valve, which overlaps the lesser one both above and below. The sides of the adult are nearly equal, the front one rounded, the linder tapering and bluntly biangulated at its termination; the dorsal edge, which anteriorly is rery convex and moderately sloping, after permitting by a slight concavity the insertion of the ashcoloured and rather small sunken ligament, rums with but little convexity and very moderate slope to the almost straight posterior edge, the dorsal extremity of which is rather the more projecting; there is a broad depressed umbonal ridge, betreen which and the margin exists a shallow excavation; both these, however, are most readily observable in the more convex valve, the umbo of which is very prominent, and often worn away by the obliquity of the incurver beak of the lesser valve; the surface of the hinder part of the shell is flattened near the dorsal 
edtge; the inside is white. and the linge-plate consists of a large and rery strong prominent tooth-like callus, whose upper surface (which in the lesser valve is above, and in the larger beneath the level of the margins, ) is hollowed out slightly near the middle, and profoundly so in front, for the insertion of the ossicle, the intermediate space thus presenting the appearance of a very blunt tooth ; this callus, being entirely seated upon the angulated side, exposes the eavity of the umbones in front, and is continued posteriorly in a narrow rib-like line, which runs parallel to the margin, and causes the intervening space to appear grooved.

From the very rare occurrence of the young of this species, whose extreme fragility materially diminished the chances of its being captured in a good state of preservation, Montagu erroneously supposed that $T$. phuseotine was its immature state. Turton, too, although separating the species, has delineated a large specimen of that shell as the young of pubescens. This error we have avoided from an examination of the long suite of examples belonging to Mr. Jeffreys (taken at Exmouth by Mr. Clark), from whence we are enabled to specify the points in which they differ from piluesoline of expal length. They are much thimner and excessively brittle, much more scabrous, and furnished with coarse concentric wrinkles, which become folds upon the umbones. Moreover, their shape is very dissimilar, the proportional distance from the beaks to the ventral margin being considerably greater, and the hinder dorsal edges (which are both of them flattened above) being much incurved; the ligament, likewise, is more einereous, and the cartilage plate more solid.

The size of full-grown individuals is occasionally thee inches and a half in length, and two inches and a third in breadtl. 
Devon and Cornwall appear to be the only counties of England which furnish us with this interesting bivalve: in the former it is occasionally taken at Dawlish (Clark), Plymouth (Montagu), and other parts of the southern coast, in the latter at Falmouth (Couch).

In Ireland it is taken on the Dublin coast and in Belfast Bay (Thompson); Birterbuy Bay (Barlee).

\section{T. Convexa, Wood.}

Subtriangular, inflated, cuneiform in convexity, ferruginous, subequilateral; dorsal edges peculiarly sloping: umbones excessively prominent : hinge plate extremely narrow.

\section{Plate XVI. figs. $1,4$.}

Ligula distorta, Mont. Test. Brit. Suppl. (not his original species), p. 166.

Mfya convexa, Wood, General Conch. p. 92, pl. 18, f. 1.-Turt. Conch. Diction. p. 100._Index Testaceol. pl. 2, Mya, f. 3.

Anatina convexa, Tur T. Conch. Dithyra Brit. p. 45, pl. 4, f. 1, 2.-Brit. Marine Conch. p. 41.

Amphidesma convexum, FinM. Brit. Anim. p. 431.

Thracia convexa, Couthouv, Bost. Journ. N. H. vol. ii. p. 140.-Brown, Ill. Conch. G. B. p. 110, pl. 44, f. 3.-H.AnL. Recent Shells, p. 22. " declivis, Macgill. Moll. Aberd. p. 296.

Perhaps the most important feature of this rare shell, which, to the best of our knowledge, has never yet been found elsewhere than in the British islands, where it is reckoned one of our rarest species, is its peculiar inflation; the lesser valve (for it is inequivalve, although less strikingly so than our other Thracias) almost vying in that particular with the larger. The shape is oval triangular, the umbones being remarkably prominent. The texture is thin but not remarkably so, and under a slight ochraceous epidermis, the colour varies from pale ferruginous to orange buff colour. The surface is not shagreened, but merely traversed by the concentric wrinkles of increase, which, however, are 
very numerous upon the larger valve, especially beyond the umbonal rilge. The rentral or lower edge is incurved near the middle, but decidedly convex in front. Both the upper or dursal edges are convex in outline, and slope greatly, especially the front one which thus attenuates the rounded extremity of the anterior side. The termination of the hincier side, which is barely the longer and most obtusely wedge-shaped, is rather peculiar in its contour, the upper end of the convex posterior edge projecting further outward than the lower one. The beaks, which are incurved and reflected. press most closely upon each other, and the umbones, which are tumid, are elevated far above the dorsal line. In front of them, upon the opposite side to the extremely short ligament, the shell, which elsewhere upon the anterior side is distinctly the more ventricose, is retuse. The umbonal ridge, that is to say, the obsolete fold which stretches posterior-ward from the beaks to the end of the ventral margin, is rounded but very distinct. The linge-plate is extremely narrow, and the ossicle very small.

Large examples attain to an inch and a half in breadth, and nearly two inches and a half in length.

The S. Devonshire coast has produced the greater part of the specimens existing in callincts. In Torbay (S. II.) it is occasionally; though very rarely, brought in by the trawlers, who know it by the name of the Ciolden hen, possibly in allusion to the comparatively high price they have obtained for it, or perhapss solely in consequence of its rich yellow colouring. Mr. Clark, whose dredging of shells upon the Deronshire coast extended over a long series of years, remarlis that it is obtained at 'Teignmouth by trawling, and at Exmouth is taken in the dredge; but the specimens are always (in the latter case) small, and rarely if crer alive. Mr. M'Andrew and Professor Forbes procured it in Corn- 
wall ; and $\mathrm{Mr}_{\mathrm{r}}$. Alder has talien some odd valves upon the coast of Northumberland.

In Ireland it has been taken alive by Mr. Warren on the Dublin coast (Thompson), and has likewise been met with in Cork harbour (Humphrey), in Strangford Lough, and near Belfast (Thompson), and in Bantry bay (M'Andrew).

Some single valves have also been found at A rran (Alder). It occurs fossil in pleistocene clays at Belfast. An account of the animal of this remarkable shell is much to be desired.

\section{T. Distonta, Montagu.}

Small, variously-shaped, almost always indented at the margin, shorter in front; umbones not prominent; cardinal plate rounded and projecting.

Plate XVII. fig. 1, 2, 3, 8, and (animal) Plate H. fig. 5.

Mya distorta, Mont. Test. Brit. p. 42, pl. ], f。 1.-Linn. Trans. vol. viii. p. 37. -TurT. Conch. Diction. p. 101.-Wood, General Conch. p. 98.-DiLlw. Recent Shells, vol, i. p. 45,-Index Testac. pl. 2, Mya, f. 15 .

Anatina - - Turt. Dithyra Brit. p. 48, pl. 4, f. 5.-Brit. Marine Conch. p. 43.-HANL. Recent Shells, p. 23.

Amplidesma distortum, FleM. Brit. Anim, p. 432.

Thracia distorta, Brown, Ill. Conch. G. B. p. 110, pl. 44, f. 7.-Loven, Index Moll. Scand. p. 47.

Anatina rupicola, Lam. Anim. s. Vert. (ed. Desh.) vol. vi.p. 80.-Delessert, Rec. Coquil.pl. 3, f. 4.

" truncata, (VARIety,) Turt. Dithyr. Brit. p. 46, pl. 4, f. 6.-Brit. Marine Conch. p. 41.-Hanl. Recent Shells, vol. i. p. 48.

Amphidesma truncatum, Flem. Brit. Anim. p. 431.

Thracia truncata, Brown Ill. Conch. G. B. p. 110, pl. 42, f. 28.

From the nature of its habitat, and the various distortions assumed for the purpose of accommodating itself to the cavity in which it may be lying, this shell, like other rock-dwelling species, is extremely variable in contour. Hence it has happened, that examples in which the growth 
has more regularly proceeded than was the ease with that figured by Montagu, have been separated by Turton, and established as distinct under the name truncata. Its shape varies then from suborbicular, in which state the lower margin is always more or less distorted or simuated, to subrhombiform, with the rentral edge perfectly free from any irregularity. The valves are slightly mequal, and somewhat rentricose, of a dull whitish hue externally, and internally of a more or less pearly-white, which is sometimes even iridescent (rarying in solidity from fragile to moderately strong). The outer surface is minutely shagreened, appearing under a powerful glass crowdedly set with microscopic grains of sand, and is more or less strongly marked with concentric wrinkles of growth, which sometimes, thongh rarely, are elevated at irregular intervals into fine lamine. The general inclination of the rentral edge (which is variously indented) is to convexity, with a disposition to form a slight retusion towards the front. The anterior dorsal margin is always peculiarly sloping, and in the more perfectly and quietly developed specimens is arcuated or at least convex; the hinder dorsal edge is inferior both in convexity and declination, being typically scarcely sloping, and only slightly curved outward. Near its extremity the sides are plainly unequal, the anterior one, whose extremity is irregularly rounded or very obtusely wedge-shaped, being invariably the shorter; and in the rhomboidal shapes this inequality is so considerable, that the hinder is often more than twiee as long as the front portion. The posterior termination is almost always more or less obtusely angulated above, and frequently so beneath, but is there as often rounded. The umbonal ridge is very blunt and often obscure; and the beaks are small, acute, and incurved. The ligament is depressed, buff-coloured, 
and remarkably small; the umbones are not very prominent; and the hinge consists of a strong and rather narrow oblique triangular plate, situated close under the beaks on the posterior side, which is more or less deeply hollowed at the top for the reception of the cartilage, and whose free extremity curves upward in both valves, but is only elevated above the surface in the right one. By careful examination there is to be perceived in the upper part of its front edge an emargination adapted to the size of its most minute moveable ossicle.

This bivalve nerer attains to any considerable size; the largest specimen we know of not exceeding three quarters of an inch in length, and not quite half an inch in breadth; ordinary examples are one-third less, but the breadth often equals the length.

The animal of this species, according to the notes of $\mathrm{Mr}$. Clark and Mr. Alder, appears to differ from its congeners but slightly. It is more or less suborbicular in shape, entirely white, and has the mantle closed, except a small aperture for the passage of a small, oval, linguiform, flat foot; the tubes are rather short, and slightly more united at their origins than in the other British Thracie; the branchial siphon is often extended more than half an inch, whilst the anal remains quiescent; previously to its being retracted, it is always globularly inflated at its extremity, which inflation increases in size until its near approach to the margin of the shell, and then suddenly disappears; when inflated, all signs of the cirrhi are lost, and they only become visible when the tube is at rest. This operation seems to be performed for the purpose of ejecting water and rejectamenta with greater force (Clark). The branchix are large and brown, one lobed on each side; the labial tentacles are nearly equal and pectinated.

VOL. 1 . 
The Thareie distorta is sometimes mistaken for a borer, on account of its habit of inserting itsolf into crevices of rock, where it assumes not unfrequently those eccentric variations of form which have given rise to its specific appellation.

Though on the whole to be regarded as a scarce shell, it is rery generally distributed. We have dredged it in alout ten fithoms water at Torquay, alive and embedded in masses of limestone (S. H.) It has been taken at Exmonth (Clark) and Falmouth. where the rariety truncate occurs (Jeffreys). We liave taken dead valves from the rocks upon the shore at Weymouth, nearly opposite the old rastle (S. H.), and have dredged it at Guemsey (S. H.), lodged in a rery thick oyster-shell. Lieut. Thomas has dredger it alive on a stony bottom in twenty-seven fathoms water off the coast of Northumberland. On the Welsh const Mr. Jeftreys has talien it at Swansea and the adjacent bays, and Mr. Lyons at Tenby. We have dredged it off the Isle of Man (E. F.) In Ireland it was found on the north coast by Mr. W. Thompson, and at Youghal hy Mr. Ball. In Scotland Mr. Jefreys takes it at Tarbert Island, and Mr. M'Andrew in the Hebrides. The Rev. G. Laing communicates it from the Orkneys, and we have found it in the Frith of Forth (E. F.) Laskey long ago recorded it from Dunbar.

It is not known fossil; as a foreign shell, it is recorded from the north-west coasts of Norway by Löven, and the Thracia brevis of Deshayes (Moll. Algér., pl. 81) from the coast of Algiers does not seem materially to differ from it. 


\section{COCHLODESMA, CouthouY.}

Shell transversely ovate, rather compressed, thin, inequivalve, nearly equilateral. Surface nearly smooth, or minutely scabrous, with a fine epidermis. Muscular impressions slight, connected by deeply sinuated palleal impressions; hinge formed of a spoon-shaped horizontal process in each valve, connected by a cartilage. Ligament external and slight; internal surface of valves strengthened by oblique divergent ribs. Beaks fissured.

Animal, according to Couthouy, "compressed, mantle closed, except anteriorly for the broad compressed foot; siphons long, slender, divided in their whole extent." According to Mr. Clark, the characters of the animal closely resemble those of Thracia.

This genus was founded by the distinguished American conchologist, whom we have just quoted, for a small but very distinct group of bivalves, previously confounded with Thracia and Anatina, but conspicuously distinguished by the peculiar structure of the hinge.

\section{C. pretenue, Pulteney.}

Plate XV. fig. 4 .

Mya pratenuis, Pultenex, in Hutchin's Dorset, p. 28.-Dorset Catal. p. 28, pl. 4, f. 7.-Mont. Test. Brit. p. 4l, pl. 1, f, 2.-Linn. Trans. vol. viii. p. 37.-Donov. Brit. Shells, vol. v. pl. 176. -TurT. Conch. Diction. p. 101.-Wood, General Conch. p. 94, pl. 24, f. 7, 8, 9.-Dillw. Recent Shells, vol. i. p. 43. -Index Testac. pl. 2, Mya, f. 5.

Anatina pratenuis, Turt. Dithyra Brit. p. 48, pl. 4, f. 4.-MAcG. Moll. Aberd. p. 294.-Brit. Marine Conch. p. 43.- HANL. Recent Shells, p. 23.

Amplidesma pratenue, FleM. Brit. Anim. p. 432. 
Ligula pretenuis, MoNT. Test. Brit. Suppl.-Brows, Ill. Conch. G. B. p. 106, pl. 42, f. 1.-Recluz, Revue Zool. Soc. Curíerr. 1845. p. 416.

Cochlodesma pratenue, Couthour, Boston Journal Nat. Hist. 1839.

Thracia pratemis, Loves, Index Moll. Scandin, p. 47.

This scarce and interesting bivalve, which appears to be little known to the naturalists of the continent, is of a somewhat oval or of an elongated ovate form, and rather tortuous; it is thin and brittle, rather pellucid, compressed, and of an uniform searecly glossy subnacreous white. The surface, which when recent is covered by an extremely delicate pale yellowish epiclermis, is almost smooth, or only faintly striolate, (being merely marked with the lines of increase, except behind the obsolete umbonal ridge, where it is rendered minutely scabrous by almost microscopic papillæ. The lower edge is convex, or even subarcuated, in front, but rises behind where it is very faintly retuse. The sides are nearly equal; the anterior, which is rather the longer, tapers but little, and is regularly rounded at its extremity; the posterior termination, which in the lesser valve is rounded and attenuated, is subtruncated in the larger one. The front rlorsal margin is very much arched, and slopes but very moderately; the hinder dorsal edge, which declines rather more, especially in the left valve, is straightish, or occasionally even subretuse, at its commencement, but a little convex at its extremity. The umbones which are moderately prominent, are much inclined; the beaks are small and inflected. There is an obtuse umbonal ridge, at whose origin near the beaks is a short linear fissure, and internally a very narrow rib-like fold, the triangular space near which is brilliantly pearly, a character more peeuliarly marlied in the dead specimens, from the ancreral dulness of the surrounding surface. Both extremities are a little gaping. The hinge consists of an hori- 
zontal spoon-shaped lamina, which projects with a forward inclination from the posterior hinge-margin, upon which it is entirely seated, and is strengthened there by a callosity rumning between the beaks and the hinder muscular impression. The umbonal cavities, from the front edge of the lamina being unattached, and the dorsal edge being simple and not margined, are exposed even to the tip of the beaks. The ossicle, which forms a small segment of a circle, is moderately convex on one side, and excavated in the middle of the other.

We had always regarded this as one of the rarest of our British bivalves, since, although not confined to one or two localities, it was no where obtained in any abundance, a specimen or two being the average fruit of a season's dredging. We learn, however, from a recent publication of Professor Macgillivray's, that it is not unfrequently brought up by the fishing-lines from deep water off Aberdeen, and of dimensions (nearly an inch and a half long and an inch broad) far above the average of English examples. "It is not uncommonly dredged from Falmouth Harbour, but mostly single valves; is also found on the south coast of Devon, where we have taken perfect shells" (Mont.). Dr. Pulteney procured it on the coast between Weymouth and Portland, and on the north shore near Brownsea Isle, Dorsetshire. Exmouth (Clark); Torbay, Falmouth (Jeffreys); Penzance, in twenty-five fathoms (M'Andrew and E. F.). It is obtained, though rarely, at Searborough (Bean); at Newbiggin in Northumberland (Alder); the Isle of Man (M'Andrew and E. F.). "It is rather a scarce species on the Irish Coast; found at Magilligan, Dublin, and Cork Coasts" (Thompson); at Kenmare River, in Kerry (Jeff. cab.); Coast of Down (Patterson); Bantry Bay (Miss M. Ball). In Scotland Mr. Jeffreys has 
taken it at Oban; on the Ross Coast; and at Lerwick. Mr. M'Anclew has talien it in sixty fathoms water, twenty miles westwards from the Zetland Coast. It is taken from sandy bays in the Orkneys ('Thomas and Laing); the Murray Firth (M Andrew); and the Frith of Forth, where it was noticed by Laskey. It ranges to the Norwegian seas. It is not known in a fossil state.

The only information we possess of the animal of this interesting shell is derived from a note of Mr. Clark, who describes it as closely resembling that of the several British species of Thracia. Its foot is situated very anteriorly, and similar in shape to that of its allies. The tubes appear also to be similar, and the mantle closed to the same extent. "The branchie are completely similar, being composed of one oblique lamina fastened dorsally and facing ventrally, pectinated in a marked manner. There are two small labia on each side the mouth. The branchial plate is divided by an oblique furrow into two parts, the upper being less in depth than the lower portion."-Clark MSSS.

Note.-It is with regret that we allude to a paper on the Anatinide by M. Recluz, in the "Rerue Zoologique" for 1845 (p. 407), but his positive assertions respecting the species of British Thracice must not pass uncontradicted. IIis erroneous impressions respecting them have arisen from his constant habit of trusting to the language and figures of writers, without correcting his views by the personal examination of typical specimens. Ilis declaring (p. 414) that the name declivis originated from Donovan; his boldly naming (p. 414) the Anatina distortu of Turton, Th. Turtoniana, under the idea that that author had not divined the Montaguian species, which he states is identical with $T h$.corbuloides of Kiener (he has likewise proposed the name Bcaniana for what he calls the Thr. declivis of Sowerby and of Thorpe; we know not where the former was published, the latter was figured from Mr. IIanley's cabinet, and is our phaseolina) - lis denial of an apical fissure to C. pretenue, \&c. \&c. have rendered us, perhaps erroneously, adverse-from want of confidence in his statements-to that separation of pratenue from Cochlodesma, as Ligula proper (the name retained to it alone of the Thracia Syndosmyce and Scrobicularia, confused together in that ill constituted genus), which is urged by an author who displays a minute research and a knowledge of our conchological literature which demands our high respect. 


\section{SOLENIDA.}

\section{THE RAZOR-FISHES.}

A small but important tribe of bivalves, remarkable for the extreme transverse elongation of their shells, and the large development of foot in their animals. The razorfishes, so called on account of their peculiar shape and the sharp edges of their valves, constitute a very natural group, confined almost entirely to a single genus. Their short, united, fimbriated siphons, and thick, elongated, truncated foot, which emerges from one extremity of the elsewhere united lobes of the mantle, furnish excellent distinctive characters. Lamarck constituted the family Solenacées for their reception, associating with the true razor-fishes, however, the very dissimilar genera Glycimeris and Panopace. Deshayes, in 1839, restricted the family to the genera Solemya, Solen, and Solecurtus; but the animal of the last-named genus is too distinct to be placed in the same group with the true Solen. Agassiz, in the same year, included in this family the genera named Psammobia and Sanguinolaria, a still more unnatural assemblage. D'Orbigny has lately placed Solen among the Myacida, alongside of Panopar, Pholadomya, Nya, and Lutraria, but removes Solecurtus to another family. Such differences of opinion respecting the true position and associates of a very natural and defined genus, are sufficient of themselves to warrant our regarding it as probably the type of a distinct family. 
SOLEN, LINNeUS.

Shell transrersely greatly elongated, subcylindrical, more or less compressed, equivalve, inequilateral, gaping at both extremities; surface diagonally comparted, invested with an epictermis. Muscular impressions distinctly marked, dissimilar, the posteal oblong, the anteal greatly elongated; palleal impression with a wide, short sinus at its posterior extremity. IIinge variable in structure and position, sometimes terminal, sometimes subcentral; usually composed of well-defined cardinal teeth and a lateral ligamental fulcrum in each valve. Ligament external, elongated. Valves beneath the linge internally strengthened by a more or less distinct and oblique rib.

Animal very narrow, more or less cylindrical or compressed; mantle united at the borders, except anteriorly, where it opens for the passage of a large, long, thick, oblique, truneated foot. Siphons short, united, their orifices fimbriated. Branchice prolongerl into the inferior siphon. Labial palpi long, narrow, and triangular.

Aristotle, in his "History of Animals," mentions more than once a shell-fish under the name of $\sigma \omega \lambda \eta \nu$, in such expressive terms that we can scarcely doubt its identity with the razor-fish, in all probability the first of the speries to be hereafter described. He states that it buries itself in sand, perpendicularly, even to a depth of two feet, and can rise and sink in, but does not leave its hole; that it does not spin a byssus wherewith to fix itself, like other testacea; that it is alarmed by noise, and buries it-elf rapidly when frightened; that the valves of the shell are connected together at both sides, and that their surfice is smooth. Such an enumeration of character indicates 
how carefully the great philosopher studied razor-fishes, and with what interest he watched their doings and chronicled their fears.

In more modern times, about the commencement of the last century, they had equal attraction for Reaumur, who, as we shall have occasion to shew presently, observed their habits with like interest and care. 'The razor-fishes, however, would scarcely have attracted such attention had it not been for their excellent qualities as articles of food. They are among the most delicious of shell-fish when properly cooked-broiling is the best method-and are eaten in many parts of Britain, as well as abroad. They bury in sand, mostly near low-water mark; but many species are only to be obtained by dredging, and some of the smaller kinds live at very great depths. The valves of the shell, being connected by epidermis, serve at once as a protection and as a lining to their holes. Their powerful foot, with its broad, finger-like extremity, enables them to sink in sand or mud with great rapidity. It is curious that Pliny, and after him Rondeletius, distinguished between male and female Solens, - in their cases a distinction probably fanciful, but worthy of note as a blind anticipation of the later discovery of the bisexuality of Acephalous Mollusea.

The Solens are remarkable for presenting the greatest length and least breadth of all the bivalves.

We find traces of this genus in shells presenting a close similarity of external form among palæozoic fossils. Not until we reach the tertiary epoch do we find remains of species very distinctly allied to such as now live. In beds of the pleistocene epoch they become comparatively abundant, but the genus must be considered rather as belonging to the present than to any former period. The 
existing species are distributed all orer the world, without regard to climate, thowe from tropical seas often closely simulating those from aretic regions, though specifieally distinct.

\section{S. marginatus, Pulteney.}

Straight, margined by a stricture in front; hinge terminal; a single tooth in each valve.

Plate XIV. fig. 1, and (animal, siphon only) Plate I. f. 3.

Solen ragina, Penn. (not Linn.) Brit. Zool. ed. 4, vol. iv, p. 83, pl. 46, f. 3.Mont. Test. Brit. p. 43, and Suppl. p. 25. - Dorset Catal. p. 28, pl. 4, f. 8.-'Turt. Conch. Diction. p. 159 ; Dithyra Brit. p. 79, pl. 6, f. 4.-Fuex. Brit. Anim. p. 458.-Brit. Marine Conch. p. 34.-Brown, Ill. Conch. G. B. p. 112, pl. 47, f. 2.Poli, Testac. Sicil. vol. i. pl. 10, f. 5, 6.-Woon, General Conch. p. 119, pl. 27, f. 1.-Dillw. Recent Shells, p. 57.LAx. Anim. s. Vert. (ed. Desh.) rol.vi. p. 53 (not vars.).-Index Testaceol. pl. 3, Solen, f. 3.-MAwE, Conchology, pl. 5, f. 3.Desh. Elem. Conch. pl. 6, f. 4, 5, 6.-Phit. Moll. Sicil, vol. $i$. p. 4 and rol. ii. p. 4.-HANL. Recent Shells, p. 11.-CHENU, Ill. Conch. Solen, pl. 1, f, 1.-Pun. Neu Conch. Solen, pl. 1, f. 4.-Cuvier, R. Anim. (ed. Croch.) pl. 111. f. 3.-Exped. Scien. Algér. Moll. p. 179 , pl. 10, f. 1, to 5 (shell and animal).

Solen marginatus, Pulteney, in Hutchins' Dorset, p. 28.-Donov. Brit. Shells, rol. iv. pl. 110.

Treve valves of this species, which is longitudinally elongated, the length averaging about six times the brealth, are quite straight, rather solid, and of a somewhat compressed subcylindrical form. They are less shallow than in the two succeding Solens, and when in fine condition, are partially covered with a rather glossy ashy-olivaceous very thin and caducous epirtermis, beneath which the surface, which is almost smooth, or, at most concentrically substriated, is of an uniform tint, being whitish, or tinged with alternately deeper and paler shades of orange buffcolour. The dorsal and ventral margins run parallel to each 
other ; there is, however, a slight contraction of them near the ligament, which is the narrowest portion of the shell. A broad groove-like excavation runs from the terminal beaks to the opposite margin, stricturing as it were the anterior extremity; this latter is subtruncated, but the edge is convex, and but little oblique; the posterior termination, which is, if anything, the broadest part of the valves, is decidedly and almost rectangularly truncated. The interior either partakes of the external colouring, or is of an uniform whitish hue. The hinge is destitute of lateral laminæ, and consists of a single primary greatly compressed prominent semicircular tooth in each valve, applied to the corresponding surface of the other.

The animal of Solen vagina is well known, having frequently attracted the attention of malacologists for more than a century. It differs considerably from that of either of the preceding species; the differences, however, are only of specific value. It is elongated and subcylindrical, the mantle brownish-white, closed in front, and open anteriorly for the passage of an oblong, compressed, yellowish-white foot, which, when at rest, is subcylindrical, with an oblique clavate extremity. The siphons are united to their extremities, the tube so formed long as compared with that of allied species, yellowish, and marked with concentric bands of linear or moniliform brownish spots of unequal dimensions. These circles seem to indicate so many stages of growth, since they are evidently the remains of the brown markings which surrounded the very short tentacles or cirrhi fringing the siphonal orifices. The branchial orifice has an obsoletely fimbriated margin, and a circle of very short cirrhi beyond it; the margin of the anal aperture is plain, but bordered beyond by a similar tentacular circle. The branchiæe are long, linear, and of an orange brown colour, and 
the labial tentacles large, very long, triangular, and acute.

The habits of this species were made the subject of inrestigation by the celebrated Reaumur, who published an account of them, illustrated by figures, in the "Memoires de l'Acarlemie des Sciences," for 1712. It burrows in sand near low water-mark, spring tides, to the depth of from a foot and a half to two feet. The Solens lie in their holes nearly vertical, and their places are marked by perforations shaped like lieyholes, corresponding to the form of the extremities of their united siphons. They are nearly rertical, and do not remain quiet, but rise up and down now and then, shifting themselves partly above the sand, as if to learn what is going on in the world above. When the tide goes out they sink deeper. The fishermen then endeavour to tempt them out as little boys would catch birds if they could-by putting salt on their tails. The salt penetrating the perforation reaches and irritates the extremities of the siphons, and the Solen, annoyed and pained, rises suddenly to clear itself of the nuisance. His vigilant human enemy watches the moment and seizes the opportunity,-and the Solen, if he can catch it; but unless very quick in his motions, those of the Solen may be quicker, and once aware of the danger impending, the sensible shell-fish will not rise again, lout sulmits patiently to the indignity of being salted alive, rather than run the risk of being caught and roasted, or else cut up for bait. But if it be not touched, a second dose of salt will cause it again to rise, which shows that linowledge and recollection of the danger is the impediment to its reappearance in the former casse. Fishermen in England have a queer but absurd fancy that when the razor-fish feels the salt, it thinks the tide is coming in, and therefore rises in its hole. 
If the Solen be taken out of its hole, and placed upon the sand, it immediately prepares to re-bury itself. It stretches out its foot to full length, and then bends it so as to use the extremity as a kind of auger. When the end has sunk into the sand, it draws up its shell, which, first oblique, and afterwards perpendicular, soon becomes immersed, and rapidly disappears. M. Deshayes, during his Algerian researches, observed a remarkable instinct of Solen marginatus to swim, when desirous of changing its locality. When it finds itself on ground too hard to be penetrated by its foot, it fills the cavity of its mantle with water, and then contracting, and closing exactly at the same time its siphonal orifices, elongates its foot; then recontracting that organ, it ejects the water with force from the tubes, and thus propels itself, after the manner of a cuttle-fish, for a foot or two forwards. Then, if it finds the surface favourable, it bores and buries itself; but if not, makes another leap, to try its chance anew.

The ordinary size of our British specimens is about four and a half inches in length, and three quarters of an inch in breadth; those from the Mediterranean appear to be of far smaller dimensions. The species is by no means so common as Siliqua or Ensis, but is sufficiently abundant in certain localities. Amongst others, we may mention the sands between Tenby and Langharne, in Caermarthenshire (S. H.); Exmouth, on the cockle-sands near Lympstone (Clark) ; Anglesea (M'Andrew) ; and the isles of Guernsey and Jersey (S. H.), as peculiarly productive. It is obtained also in the neighbourhood of Swansea (Jeffreys). It is enumerated by Mr. Smith among the shells of the Clyde; but, if a Scottish shell, is certainly a very rare and local species.

"On the Irish coast it is local, inhabiting very extensive 
samdy beaches, as those of Magilligan, and of the counties Dublin and Cork" (Thompson). In eight fathoms, Bangor, County Down, dead (Patterson).

Abroad it has a wide range. Löven enumerates it among the mollusea of Norway. Sonthwards it extends into the Mediterrancan, and Philippi records it as occuring among the shells collected by Ehrenberg and Von Hemprich in the Red Sea.

\section{S. SILIQUa, Linnæus.}

Straight, not margined by a stricture in front ; hinge terminal, two teeth in one valve.

Plate XIV. fig. 3, and (animal) Plate I. f. 1.

Lister, Hist. Conch. pl. 409, f. 255.

Solen silique, LrNv. Syst. Nat. p.1113.-Pens. Brit. Zool. ed. 4, vol. iv. p. 83, pl. 45 , f. 20.-DA Costa, Brit. Conch. p. 236, pl. 17, f. 5.Pulteney, Hutchins Hist. Dorset, p. 28.-Donov. Brit. Shells, vol. ii.pl. 46.-Mont. Test. Brit. p. 46.-Linn. Trans. rol. viii. p. 43. - Dorset Catal. p. 28, pl. 2, f. 5. - TurT. Conch. Diction. p. 158 ; Dithyra Brit. p. 80 , pl. 6, f. 5.Flem. Brit. Anim. p. 459,-Micglid. Moll. Aberd. p. 282.Brit. Marine Conch. p. 35.-Brows, Ill, Conch. G. B. p. 112 , pl. 47 , f. 33. ${ }^{*}$-PoLI, Testac. Sicil. vol, i. pl. 10, f. 7, 11.Woon, General Conch. p. 118, pl. 26, f. 1, 2.-Diclw. Recent Shells, vol. i. p. 59.-Là. Anim. s. Vert. (ed. Desh.) vol. vi. p. 55.-Index Testac. pl. 3, Solen, f. 1.-Desu. Elem. Conch. pl. 6, f. 1, 2, 3.-l'murpri, Moll. Sicil. vol. i. p. 4, and rol. ii. p. 5.-Hant. Recent Shells, vol. i. p. 11.-Desh. Exp. Scien. Algér. Moll. p. 181.

Solen noracula, MoNT. Test. Brit. p. 47.-Linn. Trans, vol, viii. p. 44.-TurT. Conch. Diction. p. 159; Dithyra Brit. p. 80.-FLem. Brit. Anim. p. 459.-Brit. Marine Conch. p. 35.-Woon, General Conch. p. 119.-Dillw. Recent Shells, vol. i. p. 58.

" Ligula, Тurt. Dithyra Brit. p. 82, pl. 6, f. 6.-Brown, 1ll. Conch. G. 13. p. 112, pl, 47, upper f. 2 .

TuE valves of this well-known species are of an elongated greatly compressed eylindrical shape, their length averaging six or seven times their breadth; they are fragile, al- 
though usually of moderate thickness, and are scarcely, if at all, curved. The exterior is almost smooth, or at most concentrically striolate, and is covered with a membranaceous, strong, highly polished, yellowish-green, or olivaceous yellow epidermis, beneath which the shell is whitish, with irregular interrupted concentric bands of a purplish liver colour. The colouring is most profusely displayed upon the hinder area, which is diagonally divided from the other by an imaginary line drawn from the beaks to the posterior corner, behind which the surface is slightly more elevated, again becoming suddenly flattened towards the dorsal margin, where the edges have a tendency to bend outward, instead of curving inwards. The dorsal and ventral margins are almost parallel, both sloping a little upwards at the rather narrower anterior extremity. This latter, as well as the posterior termination, is truncated, the edges descending abruptly, yet not without some degree of convexity, especially in front, to the ventral margin. There is no stricture nor internal callus in front, neither is there any attenuation of the valves at the hinder extremity, which, on the contrary, is broad, and almost rectangularly biangulated. The inside is white, exhibiting in the thinner and younger specimens the external colouring. The hinge, which is terminal, and whose entire length is not equal to one half of the ligamental callus, is furnished in the left valve with two rather solid and closely approximating fang-shaped primary teeth, which admit between them the peculiarly thin and laterally compressed tooth of the other. This latter, when in fine preservation, (which is rarely the case, being almost invariably broken in extracting the animal) is bifid at its apex, and strengthened at its base in the more delicate individuals by a more or less distinct and semicircular horizontal plate. There are, 
moreover, three lateral laminx, two in the left valve, and one in the right valve, whose length is but trifling, and whose extremities curve upwards and outwards.

Althongh rarely attaining to such dimensions, the length is occasionally as much as eight inches, and the breadth fully one inch. It is decidedly the largest of the British Sulens. We have included in our synonymy the S. ligule of Turton, and the $S$. nocacula of Montagn, having talien the former from the Tor Abbey sands, (the indicated locality,) and ascertained with certainty that its dentition, (the sole reason for its specific separation) is that of the perfect siliqua before age has obseured the sharpmess of its ontlines. The latter we have been enabled to determine, by an examination of the individual forwarded to Mr. Dillwyn by Col. Montagu, in compliance with that gentleman's request for information as to his species. The absence of lateral lamina (the distinctive feature of the diagnosis) was in all probability the result of accidental fracture, as they are distinctly present in that typical specimen.

The animal is elongated, thick, and of a yellowish-white colour; its foot is very long and large, thick and white, slightly angular and truneated at the extremity. The base of the foot occupies about the middle of the shell, between which point and the siphons the mantle is closed. At the point where it opens to let the foot pass, its margins are minutely fringed. The posterior extremity is truncated, the truncation being occupied by the very short siphons, each with an orifice surrounded by a double fringe of cirrhi. The margin of the mantles near the siphons is slightly tinged with brown, as are also the siphons themsclves. The labial palpi are larger and narrower than in the next species.

"This shell is common on most of our sandy shores, 
found buried to the depth of a foot or more, near lowwater mark; it frequently elevates one end a little above the surface, and protrudes its body in search of food; upon being disturbed it suddenly recedes. This place is known by a small depression on the surface. In many places it is sought after for food by the common people" (Montagu). The mode in which a dishful of these esculents is rapidly collected by children, might successfully be imitated by conchologists, for other than culinary purposes. A long narrow wire, bent and sharpened at one end is suddenly thrust into the hollows of the sands indicative of the presence of these animals, and passing between the valves, the barbed portion fixes itself on retraction in.the animal, and forces it to the surface.

The species is both abundant and diffused. It is plentiful at Scarborough (Bean), and the North (Alder), and is taken from the South of England up to Shetland (M'Andrew). "It inhabits Dublin Bay, and the sandy coast of Ireland generally" (Thompson); and is found on both the east and west sides of Scotland. Dead valves are occasionally dredged in various depths of water, and as far as five miles from shore on some of our coasts (E. F.) ; but it probably does not extend its true range beyond the laminarian zone. It is distributed throughout the European seas, and is found fossil in tertiary beds of more than one epoch. It appeared in the British seas during the period of the Red Crag and is a common fossil, though usually in a fragmentary condition, in the glacial beds of the Clyde, Ireland, and Bramerton; a good indication of the littoral origin of part of these deposits. 
S. ENSIS, Limmeus.

Resembling S. siliqua, but areuated, and generally more slender.

P'late XIV. fig. 2.

Solen ensis, Lind. Syst. Nat. p. 1114,-PENN. Brit. Zool. ed. 4, vol. iv. p. 84, pl. 45, fo 22.-DA Costa, Brit. Conch. p. 237.-Pultexey, Dorset, p. 23.-Dovov. Brit. Shells, vol. ii. pl. 50.-MoNr. Testac. Brit. p. 48.-Linn. Trans, vol. viii. p 44.-Tunt. Conch. Diction. p. 160, f. 61 ; Dithyra Brit. p. 82.-FLex. Brit. Anim. p. 459. -MIacgill. Moll. Aberd. p. 282.-Brit. Marine Conch. p. 35.Brows, Ill. Conch. G. 13. p. 113 , pl. 47, f. 10.-Chems, Conch. Cab. vol. vi. p. 47, pl. 4, fo 30 and C.-PoL, Testo Sicil, pl. 11. f. 14. - Wood, General Conch. p. 122, pl. 28, f. 1, 2.-Dillw. Recent Shells, vol. i. p. 59.-Lisinrer, Anim. s. Vert. (ed. Desh.) vol. vi. p. 55.-Index Test. pl. 3, Solen, f. 6.-1Burnows. Conch. pl. 4, f. 3, 4.-Philip pi, Moll. Sicil. vol. i. p. 4, and vol. ii. p. 5. -Sowerby, Conch. Manual. f. 60.-Hanl. Recent Shells, p. 11.-Desh. Exp. Scien. Algér. Moll. p. 184, pl. XI. f. 1, 4. (animal).

Solen Sabre, Chexu, Traité Elem. p. 41, f. 126, and pl. 1, f. 1.

Encycl. Méthod. Vers, pl. 223, f. 2.

Tre description of siliqua is so nearly applicable to the present species, that it is only necessary to particularize those few points of difierence by which they may be distinguished from each other.

Of these, the most readily perceptible is the decided arcuation of the valves in ensis, which typically, likewise, is far more slender in proportion, the length of ordinary individuals being cight times their breadth. The anterior extremity, moreorer. is not truncated but rounded, whereas in characteristic examples of the preceding species, the convexity of the front marein is so trifling as searedy to be noticeable. The posterior sille is likewise a little tapering near its termination. The colouring matter is perhaps of a browner tint, and the epidermis, which, as in siliqua, is tramparent and colourless upon the diagonally-parted-oft 
posterior area, usually assumes a chesnut or rusty cast towards the ventral margin and the anterior side.

T'he valves seem slightly more convex, and the extreme difference of size between adult individuals of the usual dimensions belonging to the two species is so marked as almost to merit being regarded as characteristic. There is, however, a variety, a scarce one though, whose amplitude is on a par with that of siliqua; but in general the valves do not attain four inches in length, nor exceed half an inch in width.

Turton is in error when he declares the solitary tooth of the right valve to be simple; it is distinctly, but most delicately, grooved at its rounded apex.

The animal of Solen cnsis has been examined and figured by M. Deshayes. It is very closely allied, as might be expected, to that of siliqua. The siphons are very short, the branchial one having a fringe of tentacula, irregular, but simple, around its orifice, and a second circle of similar organs just below. The anal has the second series only developed, but its margins are slightly scalloped. Both tubes are white below the second circle of cirrhi, but above it they are minutely speckled with brown. The foot is of a clull flesh-colour at the sides, its end paler, and obliquely truncated.

It is an inhabitant of rather deeper water than the last species, ranging from five to fifteen fathoms, the ground sand or shelly sand.

Equally with siliqua, this species is at once both numerous in individuals, and most widely diffused. It is abundant at Scarborough and the North (Bean and Alder); occurs at intervals along the eastern coast, from thence to Devonshire (S. H.); and is common on sandy shores from the south of England to Shetland (M*Andrew). "It 
inhabits the sandy coast generally of Ireland" (Thompson) ; and is taken at Lochs Carron, Kishon, Torridon (Jeffrers), and other parts of Scotland. It ranges throughout the European Seas, and oceurs fossil in Pleistocene beds.

'The $S$. cnsis of transatlantic writers, judging from the description of Gould (Invert. Massachus. p. 28), and the figure of Conrad (Americ. Marine Conch. pl. 5, f. 1,) does not exactly coincide with our shell; it is represented by the latter as of a much more abbreviated form, and as obliquely truncated at the shorter end.

\section{S. pellucidus, Pennant.}

Small, subarcuated, very thin ; the hinge not terminal.

Plate XIII. fig. 3. and (animal) Plate I. f. 2.

Solen pellucidus, Penn. Brit. Zool. ed. 4, vol. iv. p. 84, pl. 46, f. 23 (not Spengler, 179.1).-Mont. Test. Brit. pp. 49, 565.-Donov. Brit. Shells, vol. v. pl. 153.-Linn. Trans. vol. viii. p. 44.Turt. Conch. Diction. p. 160 ; Dithyra Brit.p. 83.-Flem. Brit. Anim. p. 459.-MackiLL. Moll. Aberd. p, 283.-Brit. Marine Conch. p. 35, f. 106.-Brown, Ill. Conch. G. 13. p. 113, pl. 47, f. 4.-Wood, General Conch. p. 123, pl. 28, f. 3.-Dillw. Recent Shells, vol. i. p. 60.

Solen pyymaus, Là. Anim. s. Vert. (ed. Desh.) rol. vi.p. 56.

Solen tenuis (2) Philipri, Moll. Sic. vol, i. p. 6, pl. 1, f. 2.

This delicate and fragile shell is of a linear and slightlyarcuated form, very thin, more or less compressed, and everywhere corered by a polished epidermis of a greenish yellow, beneath which the surface is uniformly whitish, both externally and internally. The length of the valyes is about four times their breadth; they are extremely inequilateral, semi-pellucid, gaping at both extremities (particularly in front, where their margins are reflected), and devoid of all seulpture or marlings. The ventral and dorsal edges run nearly parallel, so that the latter is retuse, 
and the former subarcuated; but, as both extremities are a little attenuated, the ventral effects this by rising at each end, and thus its general curve appears to exceed that of the upper margin. The umbones are rather depressed than otherwise, the beaks almost undefined, but not terminal; so that there is an anterior side, although a very small one, it not being quite equal in length to the ligament, which latter is not peculiarly depressed, and occupies about a sixth of the entire dorsal outline. The front extremity is remarkably well rounded, particularly below ; the posterior termination is bluntly subtruncated. The front dorsal edge is convex and moderately sloping. The hinge occupies a very small space, and closely resembles that of legumen. It consists in the right valve of a single small compressed primary tooth, and an adjacent posterior sublateral lamina, which is rather short, and obliquely projects beyond the hinge-margin. In the left valve is a curved posterior sublateral denticle, a somewhat conical front primary tooth with a posterior inclination, and a large central compound tooth (that of the immature shell, when viewed from above, reminds one of a high-heeled boot), forming with the two preceding ones receptacles for the opposing teeth, and consisting of a small acutely pointed conical primary tooth, and a short sublateral lamina on the same base.

The length of one of our larger specimens, which is at least of the average size, is an inch and a half; its extreme breadth is three-eighths of an inch.

The animal of Solen pellucidus, is of a lanceolate form, and not so thick in proportion to the shell as the other species of this genus. Its siphons are very short, of a tawny or dull orange yellow colour, united to their extremities, and fringed at their orifices. The foot is long, compressed, and obliquely truncated at the extremity; it is of 
a rose colour, paler at the end and base. The epidermic memluane, which eloses the front of the shell, is colourless and almost transparent. Through it shine the yellowtinged mantle and branchix.

This elegant little Solen has an immense range in depth, from six to one hundred fathoms, and appears to be as much at home in shallow as in deep water. Pure sand and sandy mud are the bottoms in which it thrives. It is distributed all round our shores. A few selected localities, illustrative of its range and distribution, may be mentioned: in the south, Guernsey (S. H.); in seven fathoms at Weymouth and Dartmouth, and in from ten to twenty-seven fathoms at various distances from shore, off the coasts of Dorset and Devon (M'Andrew and E. F.). On the east coast, off Kent (Capt. Stanley); Scarborongh (Bean); Northumberland (Alder); in sixty fathoms off Durham (Howse). On the west coast, Ilfricombe, Tenby, and Fishguard (Jefreys); oft Ormeshead in trelve fathom; and Isle of Man twelve to thirty fathoms (M'Andrew and E. F.); in Scotland, Hebrides, and coast of Ross-shire (Jeffreys); Clyde (Smith); Loch Fyne (Barlee); in Ketland alive in seven, sixty, seventy, cighty, and a hundred fithoms, and as far an twenty-five and thirty miles from land (M'Andrew and L. F.); Orkney (Thomas); Murray Firth in from fifteen to thirty-four fathoms ( $\mathrm{I}^{\text {'Andrew }}$ ). Aberdeenshire (Margillivray); Frith of Forth (Thomas and Knap)). In Ireland, "though not a common species, it is found on every side of the coast" (IV. Thompson); Cape Clear in sixty fathoms, and Bantry Bay in fifteen fathoms (I'Anrlew); Coast of Down eight fathoms (P'atterson).

It ranges throughout the European seas. 


\section{SOLECURTIDA.}

WE follow M. Alcide d'Orbigny in considering Solecurtus as the type of a family separate from the true razorfishes. Not only have the shells a habit which at once distinguishes them from their neighbours, but the animals are also essentially different, especially in the arrangement of their siphons, which, instead of being united as in the last tribe, are separated for more than half their length. On this account we have removed the Solen legumen of authors from among the Solens, and constituted for that singular shell a special genus. It forms the connecting link between the Solenide and Solecurtide.

\section{CERATISOLEN. Forbes.}

(

Shell greatly elongated transrersely, compressed, equivalve more or less inequilateral, thin, gaping at the extremities. Surface diagonally comparted, centrally radiatostriate, invested with an epidermis. Muscular impressions distinctly marked, dissimilar, resembling those of Solen; pallial impression with a wide short sinus. Hinge subcentral, complicated, composed as described in $C$. legumen. Ligament external. Valves beneath the hinge strengthened by a strong oblique rib.

Animal compressed, narrow; mantle closed in front, open anteriorly. Foot ovate, elongated, truncate. Siphons separate, diverging with fringed orifices.

According to Mr. Gray, the generic name Pharus is applied to the Solen legumen in the manuseripts of Dr. Leach. No characters being appended, and the name itself too 
dusely resembling Phurus, a genus of Gasteropoda, we do not adopt it here.

\section{LEGUMeN, Linmæus.}

Plate XIII. fig. 2, (under the name of Solen legumen), and (animal)

Plate I. f. 4.

Lister, Hist. Conch. pl. 420, f. 264.

Solen legumen, Linv. Syst. p. 1114.-Pens. Brit. Zool. ed. 4, rol. iv, p. 34. pl. 46, f. 24.-DA Costa, Brit. Conch. p. 238.-Donov. Brit. Shells, vol. ii. pl. 53.-Dorset Catal. p. 29, pl. 4, f. 4.-Moxт. Test. Brit. p. 50.-Linn. Trans, vol, viii. p. 45.-Turt. Conch. Diction. p. 162.-Fuem. Brit. Anim. p. 459.-Brit. Marine Conch. p. 36.-Born, Mus. Cæs. pl. 2, f. 1, 2,-Chems. Conch. Cab. vol. vi. p. 49, pl. 5, f. 32, 33, 34.-Woon, Genemal Conch. p. 121, pl. 28, f. 4.-PouI, Test. Sicil. volo i. pl. 11, f. 15.-Drirw. Recent Shells, rol. i. p. 60.-Lax. Anim. s. Vert. (ed. Desh.) rol. vi. p. 57.-Woodarcu, Conch. ed. 2. pl. 1, f. 9.—Index Testac. pl. 3, Solen, f. 8.-PHiLipri, Moll. Sicil. vol. i. p. 4, and vol, ii. p. 5.-DESH. Elem. Conch. pl. 6, f. 8, 9, 10.-HANL. Recent Shells, p. 13, pl. 3, Solen, f. 8.Criesu, Ill. Conch. Solen, pl. 2, f. 1.-Desn. Exp. Scicn. Algér. Moll. p. 185.

I'sammotia - - Turt. Dithyra Brit. p. 90.

Solenocurtus —-, Brown, Ill. Conch. G. B. p. 113, pl. 47, f. 3, 9, 9.*

Solen gousse, Cureve, Traité Elem. p. 42, f. 132 (hinge).

Encyc. Méth. rers. pl. 226, f. 3.

This graceful bivalve is of an elongated shape, the length averaging about four-and-a-half times the width of the shell. 'The valves are very fragile, thin, more or less transparent, greatly compressed, whitish, and covered with a polished light greenish-yellow epidermis, beneath which the surface is almost smooth, or at most concentrically striolated. The ventral margin is almost straight for the greater part of its extent, if anything slightly retuse near the middle, and rounding off at each extremity; to this the dorsal erlges rum nearly parallel, but both converge a little anteriorly, so that the anteal extremity is the mor tapering; both the front and hinder torsal edges are almost 
straight, but the former is slightly the more sloping, and the latter exhibits a very trifling degree of convexity. Neither the beaks nor the umbones are at all conspicuons; the blackish ligament, which is large and somewhat triangular, expanding greatly behind, does not project above the dorsal line, an incision being made in the valves for its reception; its hinder termination is about the centre of the hinge-margin. The posterior side is nearly double the length of the anterior one, and is rather broad and very obtusely rounded at its termination; the upper side of the attenuated front extremity projects in a trifling degree beyond the lower one, so that the anterior outline is obliquely rounded below, and obsoletely subangulated above. There is no appearance of any umbonal ridge, nor the slightest inflection of the margin on either side of the beaks.

The inside is usually whitish, but is sometimes stained with orange upon the subumbonal region. The hinge is very complicated; the hinge-margin is strengthened near the beaks, in both valves, by a very short obliquely radiating rib-like callosity; in the left valve there is a single upright greatly compressed primary tooth, and an extremely approximate bifid sublateral one juts out beyond the hinge-margin, which ceases near the commencement of the ligament. In the right valve are three teeth, the posterior sublateral a mere denticle, and the central broadly based and bifureated; which two constitute, with the curved posteriorly inclined primary anterior one, a double pair of nipper-like receptacles for the teeth of the opposite valve.

The animal is of a linear oblong shape; its mantle, of a yellowish-white colour, is closed in front, and open anteriorly for the passage of the foot. Its edges at the open- 
ing are fimbriated abore and below, but not at the cxtremity. The foot is of a reddish-purple hue, and when contracted is thick, ovate, and truncate; when extended it presents the form of a pedunculated disk. The siphons are separate and diverging, and of a reddish colour. Their orifices are fringed with short tentacula.

The largest of the individuals, from which collectively we have drawn up our description, measures three and a half inches in length, and three-quarters of an inch in breadth; ocensionally valres are found of four inches in length, and of proportionate width. (Montagu.)

As an English species, it must be accounted rare, although locally abundant at Biddeford Bay in North Devon (Mont.); it is obtained likewise at Exmouth (Clark); and near Liverpool. (M'Andrew.)

In Wales it is frequently met with, as at Swansea and its ricinity (Jeffreys); Tenby and other parts of Caermarthenshire (S. H.); Aberystwith (S. H.); Anglesea. (M·Andrew.)

In Ireland "it inhabits the extensive sandy coasts of the counties of Louth and Dublin, and likewise Bantry Bay; Captain Brown's remark, that it is plentiful on the eastern coast between Cork and Belfast, gives too extensive an idea of its distribution." (Thompson.)

It is essentially a species of southern origin, Britain being its most northern limit. It occurs on the coasts of Spain and Portugal, throughont the Mediterranean, and is recorded as an inhabitant of the shores of Senetgal and of the Red Sea. 


\section{SOLECURTUS, BlaiNVILLE.}

Shell transversely oblong, compressed, equivalve, subequilateral, rounded and gaping at both extremities. Surfice more or less invested with an epidermis, sometimes nearly smooth, sometimes ornamented with oblique grooves. Hinge composed of two fine divergent primary teeth in each valve. Ligament external. Inside of valves with two strong muscular impressions, the anterior largest and lobed; the pallial impression deeply sinuated.

Animal very large and thick in proportion to the shell, oblong; mantle closed in front, widely open anteally for the passage of a large linguiform foot, and posteriorly for the siphons, which are deeply separated at their extremities, united and forming a thick mass at their bases. Labial palpi triangular, narrow, lamellated on their inner sides. A lirge portion of the branchix are lodged in the branchial siphon.

This very natural genus, which from habit many authors have persisted in retaining as a portion of Solen, presents affinities, both of shell and animal, with Lutraria on the one hand, and Psammotia on the other. Solemya is perhaps its nearest ally. It dates from the cretaceous, perhaps from the oolitic period, and shells allied to it occur in still older strata. Very near allies of existing forms are found in the oldest of the tertiaries.

\section{S. conrctatus, Gmelin.}

Surface striated only by concentric lines of growth.

Plate XV. fig, 3 , and (animal) Plate I. fig. 5.

Solen cullellus, Pennant (not Linn.) Brit. Zool. ed. 4, vol. iv. p. 85, pl. 46, f. 25 .

Chama Solen, DA Costa, Brit. Conch. p. 238. 
Solen unyustior, construetus, fo. Cиемs, Conch. Cab. vol, vi. p. 62, pl. 6, f. 45. Solen coctelutus, Giser. (1788) p. 3224.-13rit. Marine Conch. p. 36.-Dulw. Recent Shells, vol. i.p. 64.-Philiers, Moll. Sicil, vol. i. p. 6, and vol. ii. p. 5.-HANL. Recent Shells, p. 14.

Solen emaryinatus, Srenglen, Skrivt. Naturh. Selskab. vol. iii.pt. ii.p. 105. Solcn untiquelus, Pultexey (1799), Hutchins Dorset. p. 28,-Donov. Brit. Shells, vol, iv. pl, 114.-Monr. Test. Brit. p. 52.-Limn. Trans. vol. viii. p. 46.-Dorset Catalog. p. 29.-Tunt. Conch. Diction. p. 162. - FleM. Brit. Anim. p. 460.Wood, General Conch, p. 125, pl. 29, f. 3.-LaM. Anim. s. Vert. (ed. Desh.) vol. vi. p. 59.-Index Testaceol. pl. 3, Solen, f. 10.-Chenv, Illust. Conchyliolog. Solen, pl. 6, f. 8. l'sammobiu antiquata, 'Turt. Dithyra Brit. p. 91.

Solecurtus antiquatus, Desir. Elem. Conch. pl. 5, f. 8 ; Exp. Scient. Algérie, Mollus. p. 210.

A zor antiquatus, Brows, Illus. Conch. G. B. p. 113, pl.47, f. 6, 7 .

It is with some hesitation that we have substituted the nore expressive epithet bestowed upon this species by Cimelin, for that by which it has been more generally known among British writers; since, notwithstanding that the law of priority imperiously demands the establishment of the first name correctly given to a species, so inadequately defined is the S. courctutus of Gmelin, and so entirely dependent for identification upon two somewhat dissimilar figures, that a lind of injustice seems inflicted upon anthor's who have clearly and comprehensively characterized the shell, in denying them the honour of its nomination. P'ennant, who first noticed this shell, mistook it for the Linnean S. cultellus; Da Costa used an objectiomable generic compound; Chemnitz omitted the designation of it by a single appellation; conseruently, Gmelin, whose sole merit is the attachment of a name to a drawing, obtains the credit of creating the species.

The shape of this bivalve is more or less obliquely oblong, and occasionally somewhat elongated ; the texture is "prapue. and tolerably strong. The valves, withont being partieularly shallow, are decidedly eompressed near the 
midille, and even retuse towards the incurved ventral margin. The surface which is devoid of regular sculpture, merely showing a few antiquated lines of growth, which are occasionally almost obsolete, is whitish both externally and internally, and exhibits but little if any lustre. Its dull yellowish-olive, or olivaceous straw-coloured epidermis, (in exotic specimens this is sometimes of a drab or fawncolour,) is strongly wrinkled at each extremity. The sides are very nearly equal; the anterior, however, is rather the shorter, and its dorsal margin very slightly sloping, and barely convex; that of the posterior side declines still less, and is almost rectilinear, but is incurved near the short and prominent ligament. Both extremities are bluntly roumlerl; the upper part of the anterior one is the more projecting, the lower portion being obliquely rounded from the greater ascent of the ventral margin on that side of the shell. The lower corner of the hinder termination is well rounded; there is a trifling angularity at the upper corner, which projects almost as far as the other, owing to the absence of declination in the dorsal edge; the posterior outline is convex.

The umbones are dorsally depressed, and the beaks incurved, and not peculiarly distinct. The umbonal ridge is broad, but not greatly elevated; a corresponding ridge appears from the intervening concavity, to run from the bealis to the front ventral corner, but this is not preceded by any depression of the surface on the other side. The lateral hiation is remarkably ample, the valves only touching at the bealss and at the opposite incurved portion of the ventral edge. The linge is furnished with two primary teeth in each valve, of which the hinder of the left valve is very oblique, laminar, and very caducous; the rest are much elevated, recurved, and extending beyond the mar- 
gin ; the hinter of the right valve is sightly cloven. The palleal sinus is very large. The full average length of examples may be estimated at an inch and three-quarters; their brealth at about seven-eighths of an inch.

'The animal is oblong, rather compressed, entirely white. 'The mantle is closed centrally in front, widely open anteriorly, for the thick, oblong, rather compressed linguiform foot. The lips of the opening are fringed with short cirrhi. The tubes are united for a considerable distance at their bases, thick and fleshy, separated at their extremitien, the anal one with a plain orifice, the branchial slightly fimbriated or rather sealloped. Mr. Clank observes, that "the surface of the tubes is elothed with fine white hairs;" this appearance we have not noticed. He further remarks, that "the animal is continually dilating both tubes to sometimes thrice their ordinary diameter, and then suddenly contracting them." We have seen it break up its tubes voluntarily into fragments in the manner of the Mediterranean Solecurtus strigilatus. The branchia are long, linear, narrow; the upper much shorter than the lower. The labial tentacles are rather long.

Though rather widely distributed, this is a scarce shell, and never occurs in any abundance, even locally. It inlathits moderately deep water, usually in the coralline region. In England it has been dredged alive at Exmouth (Clark); in fifteen fathoms, west hay of Portland, and twenty-five fathoms off Plymouth (M'Audrew and E. F.). Mr. Jeffreys has it from Dawlish, Torbay, and Falmouth. It occurs in the Irish sea off Anglesey, and the Isle of Man. In Scotland it inhabits the Frith of Clyde (Sinith); and the IIebrides (Jeffreys); off Armadale, somul of sliye, alive in twenty-five fithoms ( II Antrew and E. F.). 
In Ireland "it inhabits some of the bays of the Down and Antrim coasts" (Thompson); and is also met with at Dublin (Turton).

It ranges from Sweden (Loven) to the Egean (E. F.).

\section{S. candidus, Renieri.}

With oblique strix.

Plate XV. fig. 1, 2.

Soleni strigilati varietas, Criems. Conch. Cab. vol. vi. p. 60, pl. 6, f. 43.

Solen candidus, Renieri, Tavola Alph. Adriat. (from Philippi).-Brit. Marine Conch. p. 38.-Hand. Recent Shells, p. 14, suppl. pl. 11, f. 31 .

Solen strigilatus, TurT. (not Linn.) Conch. Diction. p. 161, (not his figure, which is from an exotic example.) - Purc. Moll. Sicil. vol. i. p. 5 , var. $\beta$.

Psammobia strigilata, TurT. Dithyra Brit. p. 97, pl. 6, f. 13.-Flem. Brit. Anim. p. 439.

Solecurtus candidus, DEsir. Elem. Conch. p. 122, pl. 6, f. 11, 12 (broader than usual).-Phic. Moll. Sicil. vol. ii. p. 5.-Desh. in Exp. Algér. Moll, p. 208. pl. 10, f. I to 5 (shell and animal.)

Psammobia scopula (Young), Turt. Dithyra Brit. pp. 98, 259, pl. 6, f. 11, 12. -Flem. Brit. Anim. p. 439.-Brit, Marine Conch. p. 38.

Solen scopula, Chenu, 11l. Conch. Solen, pl. 6, f. 7.

The shape of this curiously sculptured shell, which may be reckoned among our rarer species, notwithstanding that single specimens are usually described in the cabinets of the more active collectors, is elongated oblong, and frequently somewhat reniform. The valves, although sufficiently convex, are compressed in the middle, and strongly gaping at either extremity, the apices of the beaks and that portion of the ventral margin which is immediately opposite them being the sole touching points. The surface varies in lustre, but when in perfection is moderately glossy, and provided (at least towards the margins) with an olivaceous yellow epidermis; it is ornamented for about three quarters 
of its area, with profomd oblique more or less curved radiatting stric. which are so graven that each appears to imhri. cate the succeeding. 'Those strix which are beyond the almost olwolete umbonal ridge, are more closely disposed than the more distant ones situated in arlvance of it. from which latter they diverge at acute angles, irregularly uniting with them, and not leaving any intermediate unocenpied space. A larger or smaller triangular surface, extending from the acute sub-central but by no means prominent beaks, is free from all seulpture, except a few antiquated wrinkles which concentrically traverse the entire shell. The sides, although nearly equal, vary a little in this respect, at some the anterior, at others the posterior, being the more produced; both the extremitics are rounded, but assume nevertheless a very different aspect, the hinder being very slightly attenuated and more symmetrically areuated, whilst the front, owing to the absence of declination, and the rectilinear outline of the anterior dorsal edge, is bluntly angulated above, although strongly and obliquely arcuated below. The hinder dorsal margin is slightly retuse near the large and very broad olivaceous prominent ligament, and slopes in lut a very trifling degree, although exceeding the anterior in that respect; the rentral margin is more or less incurved in the middle, and slightly convex at either side, but rather more so anteriorly, where it curves rapinlly up in forming the front extremity. The structure of the adult is firm or even solid, opargue, and of an uniform dirty white externally: within it is of a purer white and often polished. The hinge, which however is very rarely found perfect, consists of two primary teeth in ach valve, variable in obliquity or erectness; those of the right valfer are strongly curved and much elevated, the hinder tooth lecing areatly the longer, but from its compression at the 
base by far the more caducous; the front one is shorter and unguiform. In the opposite valve, interlocking with these, is a strong central greatly curved erect tooth, and behind it a depressed narrow very oblique laminar one. The nymphæ are strong and moderately projecting.

The animal has recently been described and figured by Deshayes, who has shown that its characters are very distinct from those of $S$. strigilatus. It is much too large for the shell, of a brilliant orange colour; the mantle is rather paler towards the margin, closed in front, open widely anteriorly for the passage of a very large orange foot, with a whitish base. A glistening crucial ligament shines through the mantle. The branchial tubes are united at their bases (where the siphonal mass is large and thick), and separated at their extremities; the orifices are fimbriated. Its habits are probably similar to those of $S$. strigilatus, which lives very deeply buried in pure sand, its place marked by perforations on the surface. Deshayes compares the colour of this animal to that of the pulp of an apricot.

Fine specimens occasionally attain to the length of two inches and a quarter, and the breadth of an inch.

In England, it has not to our linowledge been detected on the eastern coast, and is sufficiently rare elsewere to be much prized. It is dredged (but without the mollusk) at Exmouth (Clark); Torbay (Jeffreys, \&c.); Falmouth (S. H.); Penzance (M'Andrew and E. F.); and the Isle of Man (E. F.). In the two last instances it occurred in twentyfive fathoms water, which appears to be its most usual depth. The finest valves we have ever seen came from Bantry bay (Humphreys); it is likewise taken at Howth (Turton); and Dr. Lloyd (Thompson) procured it from Malahide on the Dublin coast. 
Mr. MrAndrew dredged it in the IIebrides, Zetland, amd ofl C'aithnes: (hut never alive); it has also been met with in Sliye by Mr. Barlee (Jeffreys, Aun. Nat. H. vol. xix. p. 314).

It ranges to the Mediterranean.

SPURIOUS.

\section{S. BIDEns, Chemnitz.}

Solen dinisus, SPENG. Skrivt. Nat. Selskab. vol. iii. pt. ii. (1794), p. 96, (from O. FABR. Skriv. Nat. Sclsk. vol.iv. pt, ii. pl. 10, f. 11, 12.

Solen bidens, Chems. Conch. Cab. vol. xi. p. 203, pl. 198, f. 1939.-IJ and. Recent Shells, p. 16.

Solen fragilis, Pultexes, Hutchins Hist. Dorsct (1799), p. 28.-MoNr. Test. Brit. pp. 51, 565, and Suppl. p. 26; Dorset Catal. p. 29, pl. 4, f.5.-Turt. Conch. Diction. p. 163.-Flem. Brit. Anim. p. 460. - Wood, General Conch.p. 126, pl. 29, f. 4, 5; Brit. Narine Conch. p. 37.-Dillw. Recent Shells, vol. i. p. 65.Index Testac. pl. 3, Solen, f. 11.-Gould, Invert. Massachus. p.31.-Conrad, Americ. Mar. Conch. pl. 4.

Solen centralis, SAY, Jour. Ac. Philadelp. vol, ii. p. 316 (fide Gouln).

I'sammobia taniatu, Turt. Dithyra Brit. p. 85.

Elongated-suboval, (not unlike a bean-pod,) not strong, nor opaque, subequilateral, covered with a yellowish drab-coloured or olivaceous yellow epidermis, which is more or less firm and glossy, and is wrinkled posteriorly. Valves smooth, rather compressed, contracted in the middle, white both within and without, with a short and ahnost perpendicular broad, purplish ray under the beaks, and a tinge of the same colour, occasionally ray-shaped, muler the ligament, besides two narrow, approximate, white oblique rays behind the central one, which are visible beneath the epidermis, but become obsolete in aged specimens. Ventral margin incurred, not rising but well arcuated at both extremities. Dorsal edges scarcely at all sloping, their declination almost equal, both very slightly convex. Both extremities simply rounded, that of the hinder side (which is very slightly the longer) rather the more so. Hinder tooth of the right valve erect, peculiarly expanded at its apex, and sublaterally bifid. $1 \frac{3}{4}-\frac{1}{2}$. W. Indies, dic. : introduced as from Dorsetshive by Dr. Pulteney. The name of Spengler, whether it be bidentatus, as asserted by Chemnitz, or 
divisus, as the examination of the engraving of Fabricius would lead us to imagine, not being accompanied by a figure, and not being defined by a Latin diagnosis, loses the right of priority.

\section{SPURIOUS}

\section{S. GibBus, Spengler.}

Lister, Hist. Conch. pl. 421, f. 265.

Solen gibbus, Spengler, Skrivt. Nat. Selskab. vol. iii. pt. ii. (1794), p. 104.

Solen Guineensis, Chems. Conch. Cab. vol. xi. (1795), p. 202, pl. 198, f. 1937.Wood, General Conch. p. 129.

Solen Caribceus, Lam. (1818), Anim. s. Vert. ed. 2, vol. vi. p. 58,-H Hant. Recent Shells, p. 14.

Solen declivis, Turt. Conch. Diction. (1819), p. 164, f. 80.-Flem. Brit. Anim. p. 460 ; Brit. Marine Conch. p. 37.

Psammobia declivis, TurT. Dithyra Brit. p.91.

Solecurtus Caribaus, Gound, Invert. Massach. p. 30. - Deray, N. York Mollus. p. 243, pl. 32, f. 302.

Solen Bouchardii, Potiez, Gal. Mollusq. de Douai, vol. ii.p. 261, pl. 68, f. 4, 5 . Encyclop. Méth. Vers, pl. 226, f. 1.

Elongated oblong, moderately strong, opaque, decidedly convex, but depressed near the umbones, not lustrous, almost smooth, scarcely inequilateral. Surface covered, when fresh, with a dull asparagus-green coloured epidermis, which rarely extends to the umbones, and is more or less coarsely wrinkled at the sides; beneath this, the valves are stained with lighter and darker shades of liquorice brown, and not unfrequently marked near the middle with perpendicular, scattered, scratch like lines. Ventral margin subparallel to the dorsal, but retuse or incurved; dorsal edges nearly straight, scarcely declining, the front one the more elevated, and if anything slightly convex, the hinder just retuse. Anterior side the longer, occupying nearly three-fifths of the entire length; its extremity bluntly subangulated, projecting above, very obliquely rounded below ; posterior termination most bluntly subbiangulated, and rather the more projecting (as usual) below. Inside white; two erect eurved simple primary teeth (of which the hinder is the broader) in the right valve; two smaller oblique incurved ones in the left. Length 3 inches, breadth 1 inch and an $\frac{1}{8}$. N. America, W. Indies, de. Introduced by Dr. Turton, as from the Scilly Isles. 


\section{SPURIOUS.}

\section{S. strigilatus, Linnæus.}

Solen strigilutus, Lins. Syst. Nat. ed. 12, p. 1115 (chiefly). - Turt. Conch. Diction. fig. 53.-Chems. Conch. Cab. vol, vi.pl. 6, f. 41,42 . -Poli, Test. Sicil. pl. 12.-Wood, General Conch. p. 127, pl. 30, f. 1. - Là. Anim. s. Vert. (ed. Desh.) rol.vi. p. 60. -Index Testaccolog. pl. 3, Solen, f. 12.-ReEs, Cyclopxdin.Philipri, Moll, Sicil, vol. i. p. 5.-ReEve, Conch. Systemat. vol. i. pl. 26, f. 3, 4.-Cuvier, Règne Anim. (ed. Croch.) pl. 111, f. 2.-Chenu, Illus. Conchyliol. Solen, pl. 4, f. 1, and pl. 6, f. 1 .

Solccurtus strigilutus, Phinipri, Moll. Sicil. vol, ii. p 5.-Desir, Exped. Scient. Algérie, Moll. p. 207.

Solecurte rose, Crievu, Traité Element, p. 42, f. 135 , and pl. 1, f. 8.

Encyclopédie Méthodique, Vers, pl. 224, f. 3.

A Mediterranean shell; introduced by Turton among the figures of his Conchulugicul Dictionary, from supposing the S. candidus to be a colourless variety of it. The animal as well as the shell are, however, very distinct. 


\title{
TELLINIDA.
}

\author{
THE TELLEN TRIBE.
}

A LARge family of bivalves, often remarkable for elegance of form, delicacy of sculpture, and beauty of colour. Some of our most vividly painted British shells are members of this tribe. The majority of species are thin, fragile, and compressed. Whilst they present a general resemblance of external form, although with many modifications of outline, the internal structure, so far as the linge is concerned, is very different in different genera. The small value of the hinge-characters for indicating mutual affinities is, indeed, strikingly shewn in this group; as examples we may cite Psammotia and Tellina, and contrast them with Syndosmya and Scrobicularia.

The animals, however, of all the genera of Tellinidx are strikingly similar. They have all very slender, separate, diverging siphons, often very long, the orifices of which are either quite plain or slightly fimbriated. The margins of their mantles are widely open, and usually furnished with fine short filaments. The foot is broad, geniculated, and linguiform. Although their shells are often painted with glowing hues, the animals are almost always white or colourless. The Tellens are mostly inhabitants of the littoral and laminarian zones, but many species have great ranges in depth, and some are among the inhabitants of the deepest sea-berls yet explored.

Through Psammobia, they are evidently related to the 


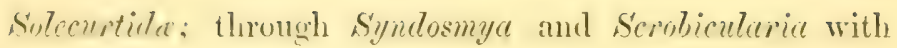
the Mactrada.

PSAMIMOBIA, LAMARCK.

Sirfli, transversely oblong, equivalve, subinequilateral, slightly gaping at the extremities; surface smooth, or transtersely, and more or less radiatingly striated, invested with a thin epiclermis. Muscular impression roumd; pallial sinus strongly marlied. Hinge composed of cardinal teeth, two or a single bifid tooth in one valve, and one in the other; supplementary lamine small, and often obsolete. Ligament prominent, external.

The animal is oblong and compressed; its mantle is open thronghout its length, and bordered by a fringe of fine simple filaments; the siphons are very long, slender, and delicate, marked with longitudinal ciliated lines, which terminate in more or less conspicuous cirrhi, few (six or eight) in number, surrounding their orifices. The foot is rather large, and linguiform. The labial tentacles are triangular, and internally pectinated. One of the branchial leaflets on each side is shorter than the other.

The Psammobic are inhabitants of most seas, though sparingly distributed, and may be traced, though doultfully, far back in time. They live buried in sand or gravelly mud, some in the littoral, some in the laminarian and coralline zones, and several species have a considerable range in depth. Our native cxamples are all shells remarkable for clegance and beanty. The animals are not of dull and torpid habits, but active in their motions, thongh moving about below the surface of the sea-bed. 


\section{P. vespertina, Chemnitz.}

Rather strong, somewhat compressed, rayed with livid pink and white, merely marked with obsolete concentric striæ ; hinder end very bluntly biangulated ; hiuder dorsal edge almost straight, and scarcely sloping; ligament large, and prominent.

Plate xix. fig. $1,2$.

Lux respertina, Chemn. Conch. Cab. vol. vi. p. 72, pl. 7, f. 59, 60.

Tellina depressa, Penv. (not Linn.) Brit. Zool. ed. 4, vol, iv. p. 87, pl. 47, f. 27. variabilis, Pult. in Hutchins' Dorset, p. 29.-Don. vol. ii. pl. 4l, f. 2.

Solen pictus (partly), SPEngler, Skrivt. af Naturhist. Selskab. vol, iii. part 2, p. 107.

Tellina Gari, PouI (not Linn.), Test. Sicil. pl. 15, f. 19, 21, 23.

Solen vespertinus, Mont. Test. Brit. p. 54.-Linn. Trans. vol. viii. p. 47.-Dorset Catal. p. 29, pl. 5, f. 1.-Turt. Conch. Diction. p. 163. -Wood, General Conch. p. 135, pl. 33, f. 2, 3.

Tellina albida, Distw. (of Linn. ?) Recent Shells, vol. i. p. 78.

Psammobia vespertina, LaM. Anim. s. Vert. (ed. Desh.) vol, vi. p. 173.-Turt. Dithyra Brit. p. 92, pl. 6, f. 10 (young).-Brown, Illus. Conch. G. B. p. 102, pl. 40, f. 3.-Philippi, Moll. Sicil. vol. i. p. 22, and vol. ii. p. 21,-HANL. Recent Shells, p. 57.-Cuv. Règne Anim. (ed. Croch.) pl. 111 , bis, f. 2 (animal).

Psammobia florida, Lamarck, Anim. s. Vert. (ed. Desh.) vol. vi. p. 174 (fide Payaud. and Philippi).

Sanguinolaria vespertina, Flem. Brit. Anim. p. 460.-Brit. Marine Conch. p. 65 .

The Setting Sun, as the present species, from its peculiar style of colouring, has poetically, and not inappropriately, been termed, is of an oval-oblong shape, nearly equilateral, tolerably strong, opaque, and rather compressed (particularly in front). The surface, beneath the ashy olivecoloured epidermis, which partly conceals it, and which, except in the very young, is destitute of lustre, is shining, and only obsoletely striated in a concentric direction. The colouring consists of numerous alternate rays of carnation or livid pink and white, the preponderance of each hue varying in different examples. The coloured rays are 
almost invariably mottled. and indeed this speckled appearance not unfrequently pervades the white rays also. The ventral margin is, for the most part, nearly straight, but is moderately convex and sharply ascending in front. The dorsal edges possess but little convexity; the front indeed is inclined to retusion, and is scarcely at all sloping; the hinder declination likewise, although greater, is but very moderate. The anterior side, which is decidedly the narrower, is well rounder at its extremity. The posterior termination is rery bluntly biangulated, the hinder edge being distinctly convex, and the angles (particularly the lower one) rounded off. The ligament is very large, dusky brown, and prominent; the beaks are small, and not at all projecting; and the umborial ridge is quite obsolete. In most specimens the imer surface is highly polished, and of a porcelain white; it is sometimes, however, (as in foreign examples, richly tinted with yellow or purple. The linge consists in the right valve of a very strong simple broadly based anterior tooth, and a less solid, narrorv-based posterior one; in the left valve, of an exactly central rather narrow bifid tooth, with a very oblique simple laminar posterior one, which latter is so extremely thin and fragile as gencrally to be wanting in our calinet specimens; from which circumstance this species is usually describerl as laving only a solitary tooth in one of the valves.

The average size of the valves is about two inches in length, and rather more than one inch in brealth. Young specimens are usually of an uniform pale yellowish lue, with their ligaments of a yellow brown. Those mentioned by Montagu as adorned with a more vivid colouring than the arlult, were, in all probability, the species subsequently called florida by Dr. 'Turton. 
For an account of the animal of this shell, we are indebted to Mr. Clark, who examined and noted living specimens at Exmouth, as long ago as 1835. It is suboval, elongated, compressed, and of a yellowish-white colour throughout. The edges of the mantle are finely fimbriated. The tubes are long, and appear to be rather wider than in the following species. The lower one is usually, though not always, curved shorter than the upper, truncate at its extremity, and perforated with six rays. The upper siphon is curved, and terminates in an irregular margin. The foot is very large, broad, rather thick and linguiform. The branchix hang obliquely from the dorsal range, and consist of a pair on each side, the upper being shorter and smaller than the lower, of a brown colour, rather coarsely pectinated, ench pair united with the opposite pair posteriorly, and each branchial lamina free at its lower edge. There are also a pair on each side of lighter coloured, elongated, pointed, triangular labia, smooth on their outer surface, well pectinated on the inner, nearly lying on each other, and of equal length ; each pair is connected with the other by a membrane surrounding the mouth.

It is a locally abundant shell, and is usually collected upon the sands after a succession of rough gales; it dwells near the shore, and may be taken at low tides in muddy sand, burrowing but a little depth from the surface. Among its localities we may enumerate Scarborough (Bean); Northumberland (Alder); at both which places it is rare; Weymouth (S. H.); Poole (Pulteney); Exmouth (Clark); Torbay (S. H.); Falmouth (Jeff. cab.); West bay of Portland in fifteen fathoms, dead ( $M$ 'Andrew and E. F.) ; Tenby (Lyons); Pwlheli (M'Andrew); near Milford Haven (Lyons); "Bantry, Cork, Youghal" VOL. I. 
(Humphreys and Jeft. cab.). In Scotland it occurs abumdantly and of large size in Loch Ryan (Nicol); Dumbar (Laskey), \&c.; Islet of Herm near Guernsey (S. H.).

$\Lambda$ livid variety is sometimes met with, and valves with a purple interior occur at Ullapool (Jeffreys).

It ranges along the south-western and southern shores of Europe.

\section{P. Ferroensis, Chemnitz.}

With raised concentric strix, which are decussated behind by a few elevated radiating lines.

\section{Platc XIX, fig. 3.}

Tellina incarnata, Pexs. (not Limn.) Brit. Zool. ed. 4, vol. iv. p. 88, pl. 47, f. 21 .

raliala, D. Costa (not Linn.), Brit. Conch.p. 209, pl. 14, f. 1.

trifusciala, Dovov. (not Linn.) Brit. Shells, vol. ii. pl. 60.

Ferrocnsis, Chens, Conch. Cab. vol. vi. p.99, pl.10, f.91 (badly).-

Pulteney, Hutchins Hist. Dorset, p.29.-Linn. Trans, vol.

riii. p. 49.- Dorset Catal. p. 29, pl. 6, f. 1.-T'UrT.

Conch. Diction. p. 171.-Wood, General Conch. p. 164,

pl. 45, f. 1.-Diluw, Recent Shells, vol, i. p. 77.-Index

Testaceol. pl. 4, f. 36.-Mawe, Conch. pl. 6, f. 1.

truncata, SPENGLER (not Linn.), Skriv. Nat. Selsk. vol. iv. part 2, p. 10. - fervensis, GmeL. Syst. Nat. p. 3235.-Mont. Test. Brit. p. 55.

Psammalia Feroensis, Laı. Anim. s. Vert. (ed. Desh.) vol. vi. p. 172.-Tunt. Dithyra Brit. p. 94, pl. 8, f. 1.-FLEM. Brit. Anim. p. 438.-Macgill. Moll, Aberd. p. 284.-13rit. Marine Conch. p. 64.-Brown, Illust. Conch. G. B. p. 101, pl. 40, f. 1, 2.-Sowenby, Conch. Manual, f. 100.-Desir. Elem. Conch. pl. 13, f. 9, 10.-Punuriri, Mioll. Sicil. vol, i, p. 23, pl. 3, f. 7 ; and vol. ii. p. 20. -Hanl. Recent Shells, vol. i. p. 57.

Encyclopédie Méthodique, Vers, pl. 227, f. 5.

From the peculiar character of its sculpture, the $P$. Fe' roensis incurs but little risk of being confomerled with any other of its genus, either native or foreign. It is of an clongated oblong figure, much compressed, tolurably strong, opargue, nearly equilateral, and with the valves more or 
less twisted, and not perfectly equal in depth. When fresh taken it is usually covered with a dull ashy olivecoloured epidermis, beneath which the surface, which possesses but little if any lustre, is either rayed with madderlake and white, (the preponderance of colour varying with the individual) or marbled in a linear fashion, with the former, on a whitish or pale-colourer ground. It is closely striated for its entire length with raised concentric lines, which not unfrequently at their posterior termination dentate the hinder dorsal edge. These strix are decussated beyond the umbonal ridge, which is indicated by a sharp elevated line, by a few fme radiating ones, which in the adult, however, do not quite proceed to the extremity of the shell. The ventral margin is nearly straight in the middle, but ascends (and convexly so anteriorly) at either extremity. The dorsal edges are flattened above; the front one is slightly convex, and but little sloping, the hinder one is subretuse, and scarcely at all declining. The front extremity of the shell is rounded and a little tapering, the hinder termination is perfectly biangulated, the lower angle projecting further than the upper. There is a slight ventral flexure before the umbonal ridge ; the ligament is long, prominent, moderately large, rich brown in the adult, and brownish-yellow in the young; the beaks are acute but small, and not much projecting. The interior, which is highly polished, is white or lilac; the teeth, which are rather small, consist in the left valve of a deeply cloven narrow central, and a very small rudimentary laminar one, the latter lying obliquely behind the former, and being very caducous is usually wanting; in the right valve, of a simple anterior, and a bifid posterior one, the former of which is the more solid.

Individuals which have attained to two inches in length, 
and about seven-eightlis of an inch in breadth, may be considered ats of the full ordinary size, the majority of examples being of rather less imensions. A very beautiful rayles rariety of a rich maroon colour is preserved, without a locality, in the collection of Mr. Hanley; we are not aware, however, that any such have hitherto been taken in this country.

The animal of Psammobia Ferroonsis is white, like its congeners, and differs but little in form from that of the last species. The tubes are long and rather more slender ; their extremities are finely fimbriated, expecially that of the branchial tube. 'The foot is very large, strong, and fleshy, linguiform and apieulaterl. The branchie are of a recldish hue.

This species is well known all round our shores, and is not unfrequently cast on shore after storms. On the south coast it occurs at Torquay and elsewhere in Devonshire (S. II.) ; at Poole, in Dorsetshire, where it was first noticed by Pulteney (E. F.). On the west, at Tenby (Lyons); Oxwich Bay and St. David's (Jefỉeys); Anglesea (MIAndrews); Isle of Man (E. F.). On the east, it is plentiful at Scarlorough (Bean); and on the coast of Northumbertand (Alder). In Treland it is generally distributed along both cant and west coasts. In Scotland it is frequent in the Clyde (Smith); Ilebrides (Jeflreys); Orliney and Zetland (M'Andrew); Moray Frith (M'Andrew); Aberdeenshire (Macrilliviay); F"irth of Forth (E. F.) It ranges on our shores from three fathoms to as deep as ninety. The coralline zone appears to be its favourite locality.

It ranges thronghout the European seas, but becomes scarcer as we proceed southwards. As a fossil it is found in tertiatries of Meiocene, P'liosene, ant Pleristocene ages. 


\section{P. tellinella, Lamarek.}

Small, convex, smooth, not distinctly rayed, tinged with orange or livid flesh-colour or purple, almost always with a red or darkhued short linear ray on the anterior side of the beaks. Ventral margin convex or subarcuated; both dorsal edges slightly convex : hinder end not biangulated. Ligament small, and not prominent; cardinal teeth very small.

Plate XIX. fig. 4, and (animal) Plate K. fig. I.

Psammotia Tellinella, Laм. Anim. s. Vert. (ed. Desh.) vol. vi. p. 177.-Brit. Marine Conch. p. 62,-Brown, Illust. Conch. G.B. p. 102 , and 133, pl. 39, f. 30.-HanL. Recent Shells, p. 58 , suppl. pl. 11, f. 11.

-_ florida, Turt. Dithyra Brit. p. 86, pl. 6, f. 9.-Fuen. Brit. Anim. p. 437 .

This pretty little Psammobia, which was first specifically distinguished in England by Dr. Turton, having previously, in all probability, been regarded as the young of vespertina, is, like it, of an oval-oblong contour, and almost equilateral. It is rather convex upon the umbonal region, not strong but opaque, and at most possesses an extremely thin yellowish epidermis, and a very trifling degree of glossiness; its surface is smooth, and offers a great variety of colouring in different examples. The more usual one consists of irregularly radiating specks of orange or livid flesh colour, on a paler ground of the same tint, and a very short orange-red linear ray in front of the whitish or very pale beaks, with a similar, though less distinct and still smaller one (which is sometimes obsolete), lying behind them; more rarely the valves are of an almost uniform purple, with the anterior streak, however, still perceptible, and often of a deeper purple. The ventral margin is convex, or even subareuated ; the front dorsal edge but slightly conver or sloping, and the hinder one 
still leseso, the degree of convexity and inclination in both being in inverse proportion to that of the ventral margin. The anterior side is the narrower, and tapers to a well rounded extremity; the posterior termination is also rounded, but irregularly so, manifesting in but a very tritling degree that tendeney to biangulation which is almost typical of the genus. The umbonal ridge is perfeetly obrolete: the bealis are depressed, and the ligament is small, of a yellowish-brown, and by no means prominent. The interior is frequently stained with brilliant orange or purple, with a white area or ray beneath the beaks; it is sometimes livid or lilac, and more rarely whitish, with the external red ray equally visible on the inner disk. The teeth are remarkably small, but resemble in other respects those of vespertinc; the laminar denticle is, however, rarely if ever present.

The dorsal edges are often stained with red at irregular intervals, and the ligament is very frepuently barred with rosente brown. For size, an inch in length, and a little more than half that wace in brealth, may be regarded as a firir average.

The animal is entirely white; its mantle is conspienously fimbriated. The siphons are slender, the upper one with eight, the lower with six ciliated ridges; the cirrhi of their extremities are small. The foot is thick amd linguiform. The labial tentacles are laneolate. When placed in a vessel of sea water, with a supply of sand, it is very active, moving about in all directions, and evidently has considerable power of changing place.

Though formerly esteemed rare, it appears to be a widely dithiserd and plentiful shedl. Whilst it has not heen foumd at such great depths as $P$. Ferroensis, it appears to be habitually a resident in decper water than that species, and is not 
so often east on shore. It occurs at Guernsey and Eixmouth (Clark, Metcalfe, S. II.); Falmonth (Jeffreys); Portland in fifteen, Plymouth in twenty-five, and Penzance in twenty fathoms, where a white variety was taken ( $\mathrm{H}^{6} \mathrm{An}$ drew and E. F.); Tenby (S. H.) ; Cardigan Bay (M'Andrew); Bantry in fifteen fathoms (M·Andrew); Cork, Youghal (Humphreys and Jeffreys); Oban, and lochs of the west of Scotland (Jeffreys); Outer Ilebrides (M'Andrew); Zetland in depths from five to fifty fithoms, often in shelly gravel (M'Andrew and E. F.). On the whole, it appears to be a western shell. It occurs fossil in the coralline crag.

$$
\text { P. costulata, Turton. }
$$

Smooth, except at the posterior end, where it is rayed with costelle or elevated striæ.

Plate XIX, fig. 5 .

Psammotia costulata, TurT. Dithyra Brit. p. 87, pl. 6, f. 8.-FLeMr. Brit. Anim. p. 437.-Brit. Marine Conch. p. 62.-Brown, Illus. Conch. G. B. pp. 102, 133, pl. 39, f. 34.-HANL. Recent Shells, p. 59.-PhilıpPI, Moll. Sicil. vol. ii. p. 21. - Philipri, Neu. Conch. Psammobia, pl. 1, f. 3,4 . discors, Philip pi, Moll. Sicil. vol. i. p. 23, pl. 3, f. 8.

This small species, which is most closely allied in shape and general character to Tellinella, is principally distinguished from it by the sculpture upon its posterior side. It is rather thin, but not transparent, nearly equilateral, and moderately convex; the chief profundity is at the umbonal region. The outline is nearly oblong; the front extremity is rounded and distinctly attenuated, and the hinder (from the convexity of the posterior edge) is only bluntly subbiangulated. The external surface is almost devoid of lustre, and in the adult is closely set with concentric, irregularly-disposed wrinkles, which become obsolete upon the 
umbones, and vary in their intensity with different individuals. 'These rugæe usually become more or less indistinct berond the ordinary position of the umbonal ridge, (which is alno-t entirely obsolete.) where the area is adomed by ahout fourteren obliquely-radiating costellie, which constitute the peculiar feature of the shell. The colouring is beautiful but very variable; ranging from pale yellow, mottled or speclied with small livid-red marlings, to purple, merely variegaterl with minute whiti-h speckles. The ventral margin is decidedly convex or even subarcuated, and rises, but not equally, at hoth extremities, ascending rather more in firont. The dorsal edges scarecly slope downwards; the front one is the more (though very slightly) convex, the himeler one being almost straight. The anterior side is rather the longer, and is a little tapering and well-rounded at its extrenity; the posterior extremity is liliewise roumder, the terminal hinder outline, though arcuated, notwithstanding exhibits some slight traces of the ordinary generic biangulation. The ligament is yellowish brown, and neither large nor prominent. The umbones are depressed; the beaks small, acute, and scarcely leaning to either side. The interior is polished and usually tinted with a deeper shacle of the external colouring, (sometimes with the hue of the peach-blosiom,) and is invariably allorned, beneath the umbones, with two short, ray-like blotehes of livid-red or purple, (the intervening space being usually pale or white, one on either side of the bealss, of which the hinder is decidedly the larger, and is evident (more or less distinctly) upon the external surface likewise. The teeth are very small, and consist of a single primary one in the left valve, interlocking between two (of which the front is the more divergent) in the opposite valve. The nymphe project but little. 
We know of no examples which exceed an inch in length, and about half that measurement in breadth.

This is decidedly the scarcest of our Psammobia, and, moreover, one of our rarest bivalves to obtain in a living state. Not that the species is confined to one or two spots, being there gregarious and tolerably plentiful, for, on the contrary, our list of its habitats is tolerably full, but that in no one locality is it taken in abundance, two or three specimens, at the most, rewarding indefatigable research, so that even single valves are not held despicable by any of our collectors.

Dr. Turton, who first recognized the specific value of its distinctive characters, obtained it at Torbay and in the Channel; to this locality we may add Exmouth, in deep water, though rarely alive (Clark); Port Carnow Cove in Cornwall (Miss Lavers); Penzance, in twenty fathoms (M'Andrew and E. F.); St. Peter's Port at Guernsey in nine fathoms (Metcalfe and Hanley); Cork (Humphreys); Isle of Skye (Jeffreys and Barlee); one living specimen from St. Magnus bay in Zetland (M'Andrew).

The only recorded foreign locality is Sicily, where it is stated by Dr. Philippi to be one of the scarcer shells. It occurs also on the coast of Greece (Graves and Spratt).

\section{SPURIOUS.}

\section{P. Lısikeyi, Montagu.}

Tellina Laskeyi, Mont. Test. Brit. Suppl. p. 28, pl. 28, f. 3.-Turt. Conch. Diction. p. 173.-Wood, General Conch. p. 179.

Psammolia —, Tunt. Dithyra Brit. p. 89.-Fuem. Brit. Anim.p. 438.Brit. Marine Conch. p. 63.-Brown, Illust. Conch. G. B. p. 103 , pl. 39, f. 32 .

As very little is known of this pretty bivalve, and its presence is rare even in the larger exotic collections, we have been inVOL. I. 
duced to draw up a more diffuse description of it than is our wont with species of such undeniably foreign extraction.

Its general shape is more or less oblong, and the texture opaque and tolerably strong. The valves are somewhat ventricose or decidedly convex; the profundity is, howerer, chiefly apparent upon the subumbonal region; they are but little inequilateral, and covered with a shining olivaceous yellow or buff-coloured, somewhat corneous epidermis, beneath which the shell is whitish, and more or less clouded with violet stains, which latter are, in the immature examples only, arranged in concentrically-disposed flexuous lines; at this stage, too, there are a pair of paler very narrow rays at no great distance from the posterior extremity. The surface is almost smooth; there are often, however, a few antiquated concentric lines in front near the lower margin, and almost always some rather closely-set inferior subimbricated concentric lines upon and beyond the rather obscure umbonal ridge. The ventral margin, which is moderately convex (but not arcuated) in front, rises obliquely and rather considerably upon that side, becoming nearly straight or very slightly inflected near its posterior termination. Both dorsal edges are subrectilinear; the front one, which in the young is slightly convex, but becomes flattened down with age, slopes in a very trifling degree; the hinder one, which in aged specimens is somewhat retuse and morlerately sloping, declines but little in the younger examples. The anterior side is rather the longer, and tapers but little at its extremity, where it is obliquely rounded off below, but is subangulated above; the front margin is curved, and its chief swell is above the middle. The posterior termination, which becomes almost wedge-shaped in the adult, where the tip, however, is always rounded off, is in the younger shell (whose extremity is not more attenuated than in front) very obtusely and indistinctly subbiangulated; in this stage, its chief swell is below the middle of the side, and the narrow tip is subrectilinear. The umbones do not appear prominent (they are generally a little eroded) nor the beaks acute; the ligament is wanting in all the specimens we have examined, but judging from the rather projecting nymthal callosities, must be of both moderate length and projection. There is no appearance of a lunule; the hinder dorsal surface seems linearly sunken (as in most of the Donaces). The interior is glossy, and more or less mottled with violet; the edge is quite 
entire; the hinge-margin moderately wide; and the palleal sinus very large. The teeth, which are obscure and very small, are stated by Montagu, who had probably the opportunity of examining them in a more perfect state than we had, to consist of two approximate sub-bifid ones, interlocking with the solitary one of the opposite valve. The hinge-margin of the right valve is a little channelled in front, where it becomes slightly broader; there are no lateral teeth. The length of a large single valve was eight-ninths of an inch, and its breadth all but half an inch ; these are, however, beyoud the average dimensions. Introduced by Montagu, as dredged by Laskey in the Frith of Forth : accorching to the late Mr. Humplereys, it is an inhabitant of the shores of the West Indies.

Diodonta, Deshayes.

Shell subequivalve, inequilateral, both valves convex. Surface more or less striated or ridged transversely, not invested with an epidermis. Hinge composed of two primary teeth in one valve and one bifid tooth in the other; no lateral teeth. Ligament external. Muscular and palleal impressions strongly marked. The former oblong and nearly equal; the latter with a very deep and wide sinus.

Animal ovate; mantle open, its margins fimbriated; siphons separated to their bases, unequal, their orifices fimbriated. Foot linguiform. Branchie equal. Labial tentacles triangular, rather large.

The animal of $D$. fragilis has been examined by Philippi and by Deshayes, both of whom have given figures of it. The mantle is freely open in front, and, like the rest of the body, of a yellowish white colour. Its margin is fimbriated. The siphons are separated throughout their length and very unequal, the branchial one much the longest, and having a corrugated brownish base. The branchial orifice 
is six-rayed or fimbriated, the anal eight-rayed. 'The foot is rather large, and hat no bresal groove. The labial palpi are of considerable size.

\section{D. fragilis, Linnæus.}

Plate XXI. fig. 3, and Plate K. f. 2 (animal).

Tellina frayilis, Linn. Syst. Nat, ed. 12, p. 1117.-Tunt. Conch. Diction. p. 166. - Chems. Conch. Cab. vol. vi. p. 95, pl. 9, f. 84.-Poli, 'T'est. Sicil. rol. i. pl. 15, f. 22, 24.-Diu,w. Recent Shells, vol. i. p. 78.--Index Testaceolog. pl. 3, Tellina, f. 7.-Puilippi, Moll. Sicil. vol. i. p. 27, and vol, ii. p. 22.-Philippr, in Wiegm. Archiv. f. Natur. 1845, p. 190, pl. 7, f. 19, 20 (animal).II ANL, in Sow. Thesaur. Conch. vol. i. p. 319, pl. 56, f. 14, and pl. 60, f. 149.

l'etricola ochroleuca, Lam. Anim. s. Vert. (ed. Desh.) vol. vi. p. 157.-Sowerny, Genera Shells, Petricola, f. 4.-Payra ud. Cat. Moll. Corse, pl. 1, f. 9, 10.-Deshayes, Elem. Conch. pl. 12, f. 13, 14, 15.-REeve, Conch. Systemat. pl. 5l, f. 4.-HANL. Recent Shells, p. 52, suppl. pl. 1, Tellina, f. 6.

Psammotaca Turentina, LaM. Anim. s. Vert. (ed. Desh.) vol, vi. p. 183.-DELessert, Rec. Coquilles, pl. 5, f. 1].-IIANx. Recent Shells, p. 60.

Tellina jugosa, Brown, Werner. Memoirs, rol. ii. p. 506, pl. 24, f. 2. Psammolia fragilis, Turt. Dithyra Brit. p. 88, pl. 7, f. 11, 12.-Flem. Brit. Anim. p. 438. - Brit. Marine Conch. p. 62.

Tellina ochroleuca, WoоD, Index Test. suppl. pl. 1, Tellina, f. 6. Psammolia jugosa, Brown, Illust. Conch. G. B. p. 102, pl. 40, f. 4, 5, 6. Diodonta fragilis, Desi. Exped. Sci. Algéric, Moll.pl. 68 (animal, \&c.).

The range of variation permitted to the Divedonta fragitis is very remarkable, extending, as it does, not merely to shape and colour, but liliewise to sculpture. In the Mediterranean examples, the shell is comparatively smooth and fragile; those from Africa are occasionally beautifully lamellated; whilst in the British and northern specimens the valves, which are coarser and stronger, have the lamelle very irregularly developed. 
Our native variety is of a produced ovate or slightly trigonal form, more or less strong, almost opaque, and subventricose or even slightly inflated. It is decidedly inequilateral, almost devoid of lustre, and when fresh, usually tinted externally with brownish saffron. The surface, which is apt to be indented in various places, is wrought with concentric, elevated, somewhat undulated laminar strix, (which are occasionally almost obsolete,) varying in their approximation to each other, and in the distinctness or obscurity of the very minute radiating lines which decussate their interstices. The ventral margin, whose outline is often wavy, is moderately convex; the dorsal edges are very slightly retuse on either side of the beaks, then convex and rather sloping in front, and almost straight and decidedly sloping behind. The anterior side, which is conspicuously the shorter, is broadly rounded at its extremity; the posterior termination is bluntly acuminated, and very slightly subrostrated. The umbonal fold is broad and rather obtuse, the ventral flexure is tolerably evident. The beaks are small, acute, and almost directly inflected, scarcely leaning to either side; the umbones are sufficiently prominent; the ligament is rather large, and moderately projecting. The dorsal lips bend considerably inward in front of the beaks. The interior is either of a dirty white or stained with the external colouring. The hinge is not provided with any distinct lateral teeth; there are two morlerately sized divergent primary teeth in the right valve, which become much more elevated towards the internal edge, and a single broad and very large bipartite subreflected central tooth in the left valve. There appears to be a very thin oblique laminar denticle behind this tooth, but it is so extremely caducous, that it is rarely present. The palleal sinus is extremely large. The length of rather a 
large specimen is an inch and a half, and its breadth slightly exceeds one inch.

'this is a rare shell, for which we know no English locality: in Irelant. it is talken in Dublin, Pantry, and Valentia bays ('Turton); and in Wales, it has been pieked up on a sandy beach about two miles from Tenby (Lyons).

It ranges to the Mediterranean and along the northwest coast of Africa.*

\section{TELLINA, LINNEUS.}

Shell ovate, oblong or rounded, compressed, subequivalve, subinequilateral, marked with an umbonal fold, sometimes nearly obsolete; surface smooth, or marked with transverse, oblique, or radiating stria; inner margin of valves smooth. Hinge with one or two primary teeth in each valve; lateral teeth present in some species, obsolete in others. Ligament external. Muscular impressions

* It seems highly probable that the $T$. polygone of Montagu, stated to have been dredged by Mr. Laskey off Cramond Island in the Frith of Forth, was a young variety of this shell, with which it agrees far better than with the exotic Guinaice of Chemritz (Conch. Cab. vol. x. p. 348, pl. 170, f. 1651, 1652, 1653,) to which (from the want of more characteristic figures) it is referred by its describer.

Tellina polygona, Most. Test. Brit. suppl. p. 27, pl. 28, f. 4.-Tunt. Conch. Diction. p. 180.-Brit. Marine Conch. p. 63.-Brown, Illust. Conch. G. B. p. 102, pl. 39, f. 33.-Index Testaceolog. pl. 4, f. 80.

Tellina Guinaica, DiLlwriv, Recent Shells, vol. i. p. 96.

I'sammolia polygona, Tun t, Dithyra Brit. p. 96.-F Lem. Brit. Anim. p. 439.

"Suborate, suborbicular, of a dirty-white colour, wrought with very fine concentric strix, which are crossed with excessively fine lines not visible to the naked eye; the umbo is small, not central, nor turning to either side; the shorter end is subtruncated and subangulated: the larger end is rounded. Inside not very smooth, the margin uneven : teeth in one valve two, large, and distant (? distinct); in the other one very large, triangular, bifid tooth, with an approximate small one, that might easily be passed unnoticed. Length, ltalf an inch, breadth rather more. The umbo in the only specimen we have examined is ferruginous, but this might have been stained." All the descriptions and delineations cited by us have leen drawn from Laskey's solitary specimen. 
oblong, the posterior one widest; pallial impression with a deep and wide sinus.

Animal ovate, compressed, mantle entirely open in front, its margin fimbriated; siphons long; separate throughout, usually nearly equal, their orifices plain, or very indistinctly toothed. Foot large, triangular, compressed, apiculate. Labial palpi large, lanceolate. Branchial leaflets united in pairs on each side.

The mollusks of this genus live in sand or sandy mud, burier beneath the surface; the majority at low watermark, or in considerable depths. A few species have a range as deep as the coralline zone. The number of known kinds of Tellince exceeds two hundred. They occur in all seas, but more than a third of them are inhabitants of the Indian Ocean. Many species are found also in the West Indian region, and on the west coast of South America. They increase in numbers from the poles to the equator. The arctic forms are squalid and unattractive; those inhabiting the tropics, on the contrary, gaily-coloured and ornamental, so as to be sought after for decorative purposes. Their range in time is not so certainly known, though several Paleozoic and secondary shells have been assigned to this generic group. In the upper part of the cretaceons system, and in beds of the tertiary (especially Eocene) epoch they are distinctly present.

The structure of the branchial and the labial palpi, with the simple character of the extremities of the tubes, distinguish the animals of this genus from those of Psammobia, whilst the shells may usually be distinguished with facility by their umbonal folds and dentition. Nevertheless the two genera are exceedingly closely allied. 
T. crassa, Penmant.

Rounded oval; strong; concentrically grooved; with lateral tecth.

\author{
Plate XX. figs. 1, 2.
}

Lister, Hist. Conch. pl. 299, f. 136.

Tellina crassa, P'EN. Brit. Zool. ed. 4, vol. iv. p. 87, pl. 48, f. 28.-Movr. Test.

Brit. p. 65.-Linn. Trans. vol, viii. p. 55.-Dorset Catalog. p.

30, pl. 7, f. 4.-TurT. Conch. Diction. p. 173.-Turt. Dithyra

Brit. p. 109, pl. 7, f. 2.-FLEM. Brit. Anim. p. 436.-MACGILL.

Moll. Aberd. p. 280.-Brit. Marine Conch. p. 30.-Woon,

General Conch. p. 186, pl. 40, f. 1.-DinLw. Recent Shells, vol.

i. p. 96.-Lax. Anim. s. Vert. (ed. Desh.) vol. vi. p. 201.-

WooD, Index Testaceolog. pl. 4, fig. 75, -MAWE. Conchology,

pl. 6, f. 7.-HANL. Recent Shells, p. 68, pl. 4, f. 75.-HANL.

in Sow. Thesaur. Conch. p. 265, pl.61, f, J69, 173.

2 Pecturculus depressus, DA Costa, Brit. Conch. p. 194, pl. 13, f. 4 (right hand fig.)

Tellina maculute, Adusts, Linn. Trans. rol. iii. p. 252.-Limn. Trans. vol. viii. p. 48.-Turt, Conch. Diction. p. 173, f. 13.-Turt. Dithym Brit. p. 108, pl. 6, f. 7.-Flem. Brit. Anim, p. 436.-Brit. Marine Conch, p. 70.-Wood, General Conch. p. 153.

Tellina rigida, Puldeney, in Hutchins' Hist. Dorset, p. 30.-Donov. Brit.

Shells, vol. iii. pl. 103.

A reopagia crassa, Brown, Illust. Conch. G. B. p. 99, pl. 40, f. 8.

" orata, Brown, Illust. Conch. G. B. p. 99, pl. 40, f. 9, 10 .

Tellina obtusa, Sowerby, Min. Conch. pl. 179, f. 4.

Of a rounded oval form, very inequilateral, and of a solid oparne texture, the valves of this pretty shell are rather ventricose when united, but not quite equal in profunclity, the left being rather the more depressed. The exterior, which is rather dull, and of a more or less squalid white, is usually adorned with narrow rays of crimson red, but is occasionally devoid of any painting: it is likewise most closely, coarsely, and rather irregularly grooved eoncentrically; there is no interstitial decussation. The ventral margin is well areuated, and rises firr more on the posterior side, the chief swell being in front of the shell. 'The anterior side is the more produced, and a little attenuated at 
its well-rounded extremity; its dorsal edge is moderately sloping, and more or less convex. The hinder side is short, its termination is bluntly subangulated below, and its dorsal edge is arenated, and much declining. The umbones are rather prominent, and incline forward; the beaks are small, and the ligament is depressed, but elongated and rather large. There is a very small and narrow excavated lunule; the umbonal ridge is indistinct, the ventral flexure small, but tolerably evident. The interior is usually more or less richly stained with reddish-orange, but is sometimes merely white. The hinge margin is not only furnished with the ordinary primary teeth, but in the right valve with two lateral ones, of which the posterior is distant, and the anterior rather approximate.

The measured breadth of rather a fine specimen, was an inch and three quarters, and its length rather more than two inches. The T. maculata of Turton's cabinet, is merely a dead discoloured specimen of this shell.

This species has a considerable range in depth, extending from low water-mark to below fifty fathoms. Its favourite habitat appears to be in the upper part of the coralline zone, where it lives buried in gravelly sand. In the Islet of Herm, near Guernsey, it is dug out of sand at low water, and is plentiful (S. H.) ; in the Isle of Man it occurs, though not abundantly, under similar circumstances (E. F.). Though generally distributed, it is local. On the south coast it occurs off Hastings, Poole, and Weymouth (S. H.) ; Portland bay, west, in fifteen fathoms, gravel (M'Andrew and E. F.); Exmouth (Clark); Torbay (Aller and S. H.); Plymouth (Jeffreys); Salcomb, Falmouth, and Helford (Montagu); Penzance, in twenty fathoms (M'Andrew and E. F.). On the Welsh coast it has been taken at Langharne (Jeffreys); Tenby (Lyons);

VOL. I. 
Cardigan and Caernarvon bays, and Anglesea, in ten fathoms water (M'Andrew). On the east coast it is not uncommon on the shores of Northumberland (Alder). In Ireland it is generally distributed, but is especially abundant ini bantry bay, becoming comparatively rare northwards (IV. Thompson). It is found on both sides of Scotland; Inelrides; Skye, in forty fathoms, dead; in rarious localities and at considerable depths on the Shetland coast (M-Andrew): alive in twenty-five fithoms, Ela Sound, Orkney ('Thomas); on the Aberdenshire coast (Macgillivray) ; Firth of Forth (Knapp and E. F.).

Abroad this mollusk is confined to the Celtic and Boreal coasts of Europe, ranging as fur north as Bergen (Loven). It appears to be extinct now in the Mediterranean, but inhalited that region during the Glacial Epoch, as we know from the occurrence of its fossil remains in the Sicilian tertiaries. It ranges throughout the Meiocene, Pleiocene, and Pleistocene beds of Britain.

T. balaustina, Linnæus.

Suborbicular, not grooved; with two lateral teeth in one valve.

Plate XXI. fig. 2.

Tellina balaustina, Linnzus, Syst. Nat. ed. 12, p. 1119.-Thompson, Annals Nat. Hist. vol. xviii. p. 335.-JefFreys, ditto, vol, xix. p. 313.-Porr, T'est. Sicil. vol. i. pl. 14, f. 17.-Desir. in Lam. Anim. s. Vert. vol. vi. p. 209.-PHiLippi, Moll. Sicil. vol. i. p. 25, and vol. ii. p. 21.- IIANL. Recent Shells, p. 72, suppl. pl, 9, f, 17.-HANL。 in Sow. Thesaur, Conch. vol. i. p. 253 , pl. 56 , f. 10 .

Lucina $" \quad$ Payrauneau, Cat. Moll. Cors. pl. 1. f. 21, 22.

This recent and very beautiful addition to our Fauna, varies in slape from sulorbicular to obovate, is molerately fim in texture, opraque, and decidedly convex or even sulb- 
ventricose. The surface of specimens in fine condition possesses but little lustre, and is closely set with very delicate membranaceous concentric striulx, but these are usually worn away, and the valves appear smooth and rather glossy. The colouring is elegant, consisting of very numerous narrow rays of a scarlet red upon a ground of pale yellow or white. The ventral margin is strongly arcuated; and rather the more ascending behind; both dorsal edges are but moderately sloping, the convexity of the hinder, which is the more elevated, is but trifling, that of the anterior, after passing the lunule-like depression in front of the beaks, is more decided. The sides are very nearly equal ; the front extremity is symmetrically rounded; the hinder termination is most bluntly subangulated. The umbones are prominent, and often of a rich yellow; the beaks are acute, and directly inflected, not leaning to either side. The ligament is narrow, and by no means projecting; the umbonal rirlge and the ventral flexure not very marked; and the interior is generally more or less profusely tinted with yellow. The primary teeth are small, but the two nearly equidistant (the front one is rather the more approximate, lateral teeth are rather large.

The magnificent shell (belonging to Mr. Jeffreys, from which our engraving has been taken, is of more ample dimensions than any Mediterranean specimens we have ever seen, measuring seven-eightlis of an inch from side to side, and about three-quarters of an inch from the beaks to the opposite margin. It is more fragile and ventricose, likewise, than foreign examples, and does not vie with them in that golden hue, which so often adorns their umbonal region and interior surface. The species was first discovered, as a native of the British seas, by that enterprizing and indefatigable dredger, Mr. Barlee, who obtained it at Birterbuy 
Bay, in Connemara (Thomp. Ann. Nat. H. vol. xviii, p. :3S.5). and subsepuenty procured it from the Island of Sliye and at Stornoway (Jeff. Ann. Nat. H. vol. xix. p. 313). A fresh amd beantifully perfect but pale tinted individual, measuring almost an inch in length, nearly three-quarters in Ineadth, and containing the animal, was purchased in 1848 hy Mrs. (iulson of Exmouth, from a fisherman at Falmoutl, who dredged it along with other undoubted British species. It is a Lusitanian shell, and ranges into the Mediterranean, where it is not rare in six or seven fathoms water.

\section{T. Donacina, Linnæus.}

Elongated, concentrically striated; posterior end short and wedge-shaped; with two lateral teeth in the right valve.

Plate XX. figs. 3, 4, and (animal) Plate K. fig. 4.

Tellina Donacina, Linn. Syst. Nat. ed. 12, p. 1118.-Pulteney, in Hutchins' IIist. Dorset, p. 29.-Moxт. Test. Brit. p. 58.-Linn. Trans. vol. viii. p. 50 pl. 1, f. 7.-Dorset Catalog. p. 29, pl. 12, f. 3, b.-Tunt. Conch. Diction. p. 170.-Turt. Dithyra Brit. p. 102 , pl. 8, fo 4.-FLEM. Brit. Anim. p. 435.Brit. Marine Conch. p. 67.-Brown, Illust. Conch. G. B. p. 101, pl. 40, f. 16.-Woon, General Conch. p. 161, pl.45, f. 5.-DiLiw. Recent Shells, rol. i. p. 89.-LAM. Anim.s. Vert. (ed. Desh.) vol. vi. p. 198.—Deshayes, Elcm. Conch. pl. 14, f. 1, 2, 3.-Philippr, Moll. Sicil. vol. i. p. 24, and vol. ii. p. 21.-HANL. Recent Shells, p. 64.-HANL. in Sow. Thesaur. Conch. vol, i. p. 232, pl. 56, f. 12, and pl. 66, f. 259.-Desi. Exped. Scient. Algér. Moll. pl, 69, f. 1 to 3 (with animal).

Tellina trifusciata, PENn. Brit. Zool. ed. 4, (fide last edit.) p. 88.

"vuriegata, PoLr, T'est. Sicil. vol, i. plate 15, f. 10.

" Llantivyi, Payraudeav, Catal. Moll. Corse, p. 40. pl. 1, fig. 13, 14.

Uniting the peculiar contour of the Donaces to the gorgeous colouring of the typical Tellina, this pretty bivalve is of an oblong shape, tolerably firm in texture, nearly opaque, moderately convex, and very inequilateral. Its 
exterior, which is not lustrous, is yet occasionally glossy, and densely striated in both valves with concentric and subimbricated lines, one half of which disappear on reaching the umbonal fold. The ordinary colouring consists of very numerous interrupted rays of a carnation red upon a whitish or yellowish ground, with the environs of the ligament, the inflected hinder dorsal area (which is narrow or even linear), and a short direct ray which emanates from behind the beaks, all stained with the same brilliant dye. Not unfrequently, also, the surface is zoned with lighter and darker shades of pink or yellow. IVe have figured likewise a beautiful and uncommon variety (from Portland) in which the ground colour is crimson, and the rays, zones, and apices are white. The ventral margin which exhibits the generic flexuosity (the curvature of the posterior side to the right being very distinet) is comparatively straight behind, but arches out moderately in front where it very obliquely ascends in an uninterrupted sweep to the dorsal edge, which being scarcely convex, barely declining, and much produced, the anterior extremity (although the tip is arched) is not rounded symmetrically, and the chief swell is above and not beneath the middle. The posterior side, which is scarcely half the length of the anterior one, is abbreviaterlly wedge-shaped, as the hinder dorsal margin rather abruptly declines in a straightish line, which however becomes convex near its termination, thus rounding of the posterior tip. The ligament is large and prominent. The interior is either stained with rich yellow, displaying the rosy apical ray and the dorsal stains, or faintly exhibits the external colouring. The hinge of the right valve is furnished, in addition to its primary teeth, with two lateral lamine, of which the front one is decidedly the larger and the more approximate. 
An example is recorded by Turton, which measured an inch and a quarter in length, and three-quarters of an inch in breatth. dimensions far exeecting those that are ordinarily met with.

The animal is entirely white and of the same shape as the shell; compressed and oblong. The mantle is freely open, and its margin conspicuously fringed. The siphonal tubes are very long and slender, distinct from each other throughout their lengths, plain at their extremities, marked at their sides by whitish lines, what appears to be ciliciferous. The foot is ovate, acute, and compressed. The labial palpi are narrow.

This is a widely distributed shell and one of our prettiest 'T'ellens. It oceurs at Guernsey (S. H.); and all along the coasts of Dorset, Devon, and Cornwall. At W. Portland bay it occurred alive in fifteen fathoms water, and at Penzance in twenty ( $\mathrm{M}^{\circ}$ Andrew and E. F.). It has been taken at Tenby (Lyons); and on the north coast of Wales in from twelve to more fathoms (M'Andrew and E. F.). On the east coast it occurs at Scarborough (Bean); off Nonfolk (Stanley); and on the coast of Northumberland (Alder). In Ireland it is abundant in Bantry Bay, rare and occasional in the north, as at Strangford and Portmarnock (W. Thompson). It is frequent in the Clyde district (Smith); the Ilebrides (Jeflieys); and the Orkiney, Zetland, and Moray Firth coasts (M $\left.I^{6} \mathrm{Andrew}\right)$; but is apt to be confounded with the following species. In those localities, it and its ally have been taken alive at various depths from five to fifty fathoms. It occurs also in the Forth district.

Abroad it is a conmon inhalitant of the southern coasts of Lurope, but does not extenel its range northwards of Britain, being replaced in the Norwegian seas by $T$. pygmaa. 
It inhabited the British seas as early as the epoch of the Coralline crag.

\section{T. pygmea, Philippi.}

Like Donacina, but very small; the hinder end blunter, the sides still more unequal, and the lateral teeth equally approximate.

\section{Plate XIX. figs. 6,7 .}

Tellina pygmaa, Philippr, in Loven, Index Moll. Sueciæ, p. 42.-Auder, Cat. Northumb. and Durham Moll. p. 88.

This pretty little shell, which for its size is by no means thin or fragile, being tolerable solid in the adult, but always a little transparent, has a narrow, oblong contour; its external surface is more or less glossy, its internal area is shining; the colouring is infinitely diversified, specimens from the same locality being rose, orange, sulphur tinted, or white, and at times of almost an uniform colour, but more usually variegated by greatly interrupted more or less narrow rays of a darker hue, which are most distinctly apparent at the concentric zones of growth. The most common variety is pale yellow with crimson rays, but examples with rosaceous orange rays on an orange yellow ground seem nearly equally abundant. There is often, but not invariably, a short, broad, perpendicular ray of orange or crimson, extending scarcely half way from the beaks to the lower margin, and sometimes a similar oblique and rather longer one running anteriorward, and dilating as it becomes fainter. The line of the interior is either as that of the exterior, or yellow with the abbreviated ray or rays more visible than externally; the valves are convex or even subventricose, and are regularly though delicately 
striolate concentrically, the strula being remarkably elose set; the rentral margin is convex, but not quite symmetrical, the anterior portion being the more arcuated; the front dorsal outline is nearly straight, produced, and seareely at all sloping, the hinder is extremely short and moderately declining; both extremities are roumded, but neither symmetrically, that is to say, with an equal arcuation alove arm below, the extremely blunt subangulation of the po-terior termination forbidling it behind, and the slightness of the front dorsal slope preventing it in front; this character, however, is not so peculiarly evildent as in Donecina; the sides are excessively unequal, the front being twice or even thrice the length of the hinder; the ligament is prominent, but very short, the ventral flexure distinct, but the umbonal fold almost obsolete; there is a linear, lunule-like exearation along the front dorsal edge, which is only at times stained with reddish crimson internally; besides the narrow, simple, and small bifid tooth of each valve, the right possesses a large anterior and a small posterior lateral tooth, which are moderately and equally distant from the former. Although most closely bordering upon $T$. donacina, this beautiful and diminutive species appears to us specifically distinct, and not merely, as has been conjectured by some, a dwarf variety of that long-linown shell. It does not seem, indeed, to have been found at all by the older concloologists, with the exception of Mr. Humphreys of Cork, in whose cabinet it is still preserved; so that whether the sum of its difference from its nearest congener be varied or specific has not yet been mooted among us. In his interesting Prodromus of the shells of Swerlen, Lioven has lately constituted it a species, and to his opinion we assent, in common with those other British concholugists who have deroted their attention to 
the comparison of the two shells; for, independently of the largest known specimens (from L. Carron and L. Alsh) never attaining to quite half an inch in length and a quarter of an inch in breadth, and these are not young fragile shells, but manifesting their adolescence by their solidity; the posterior end is not wedge-shaped but blunt, and the sides are far more unequal than even in Donacina. In proportion to its size it is more convex too, and this convexity is more evenly diffused, there being no posterior compression as in that species; it has striule, not strie, and certain characteristics, as the short red perpendicular ray, and the crimson stain upon the front dorsal edge, which appear permanent in the latter, are by no means so in $p y g-$ maa. The lesser development of its umbonal ridge, and, above all, the different approximation of the lateral teeth to the cardinal, must not be passed over, the front lateral of Donacina being invariably the closer to the primary teeth.

In England it has been taken at Holy Island in Northumberland (Alder); at Whitesand Bay in Devon, and Port Carnow Cove in Cornwall (Jeff. cab.) In Ireland in Cork Harbour (Humphreys), and Galway (Barlee). In Scotland it has been dredged by $\mathrm{Mr}$. $\mathrm{M}^{\circ}$ Andrew from a sandy bottom of from eight to fifty fathoms at Cape IV rath, the Hebrides, Orkneys, and Shetland Islands; and by Messrs. Jeffreys and Barlee at Lochs Alsh, Kishon, Carron, \&c. Abroad it is recorded as an inhabitant of the coasts of Sweden and Norway. 
T. incannata, Limnæus.

Ohlong, subequilateral, compressed, acuminated behind ; right valve with regular concentric striulæ: one or more lateral teeth.

\section{Plate XX. fig. 5.}

Tellina incarnata, Lisw. Syst. Nat. ed. 12, p. $1118 .-$ PoLr, Test. Sicil. pl. 15. f. 1.-Haxl. in Thesaur. Conch. rol. i. p. 283, pl. 60, f. 142 , and pl. 66 , f. 265 .

"squalida, Pulteney, Hutchins, Hist. Dorset. p. 29.-Mont. Test. Brit. p. 56.-Fes. Brit. Anim. p 436.-Rees' Cyclopadia, pl. 5.

" depressa, Doxov. Brit. Shells, vol. v.pl. 163.-Linn. Trans, rol. viii. p. 51. -Turt. Conch. Diction.p. 171.-Tunt. Dithyra Brit. p. 105, pl. 3, f. 6.-Brit. Marine Conch. p. 68.-Dorset Catalog. p. 30 , pl. 5, f. 2.-Brown, Illust. Conch. G. 13. p. 100, pl. 40, f. 12.-Wood, General Conch. p. 171. pl. 45, f. 3.-Dilriv. Recent Shells, vol.i.p. 91.-LAs. Anim.s. Vert. (ed. Desh.) rol. vi. p. 195.-Phicirpi, Moll. Sicil. vol. i. p. 27, and vol. ji. p. 22.-IIsNL. Recent Shells, p. 63.

TVe hare changed the name by which this species is ordinarily designated, in consequence of a careful examination of the original type of Linnæus, which is still preserved in his cabinet at Soho Square. The shape is oblong oval, the texture rather thin, or but moderately strong, and not quite opaque. The valves are almost equilateral, compressed, and of a more or less glossy pale orange, or reddish flesl-colour, (the latter hue is extremely rare in British examples, but is the ordinary tint of the Mediterranean sperimens, which are much more delicate and lustrous than our own,) with two whitish or paler approximate linear raye, adjacent to the umbonal fold, which latter, as well as the ventral flexure, is well marked. 'T'hese rays are most evident in the younger shells, and become oceasionally indistinct in the more aged examples. The right valve is r.losely striolated in a concentric direction; the left valve is (') nuparatively smooth, though concentric subimbricated 
lines are not unfrequently wont to appear in front and towards the lower margin. 'The ventral edge is generally more convex in front than behind; both dorsal margins are comparatively straight, the anterior being more inclined to retusion, the posterior to convexity; the declination of the hinder one is moderate, the front slope is but trifling. The anterior side is rather the longer, its extremity is a little attenuated, and well rounded both above and below. The posterior end forms an acute angle, or imperfect rostrum, which is situated below the middle of the side. The umbones project but little, and are slightly recurved; the beaks are small and acute. The ligament is sunken. Internally the colouring is usually of a deeper tone than it is externally; the hinge margin is rather narrow, and only provided, in addition to the ordinary primary teeth, with a single, rather approximate lateral lamina in the right valve.

Poli describes the animal as having very long rosecoloured, speckled plain siphons, a strongly fimbriated mantle, and a large flesh-coloured foot.

The length of rather a large example was an inch and three-quarters; its brearlth exactly one inch. It is a scarce British shell, and is taken sparingly in Guernsey, South Devon, and Cornwall (Mont. \&c.); Weymouth in seven fathoms (M'Andrew and E. F.); Guernsey (S. II.); Irish Sea (E. F.); Oxwich Bay in Glamorganshire (Jeffreys); Tenby (Lyons and S. H.); Bantry Bay (Jeff. cab.); and other parts of the Irish coast (IV. Thompson). Lamlash Bay, in Arran (Smith, Alder); and various parts of the west of Scotland (Barlee).

It is on the whole a southem shell, and a member of the Lusitanian Fauna. 


\section{T. texuis, Da Costa.}

Suboral, compressed, glossy, devoid of epidermis, smooth, not acuminated behind; a single lateral tooth.

Plate XIX. fig. 8. and (animal) Plate K. fig. 3.

Tellina incarnata, Lister, Hist. Conch. pl. 405, f. 251.

„ " Chexs, (not Linn.) vol. vi. p. 119, pl. 12, f. 110.

" planata, Penv. (not Linn.) Brit. Zool. ed. 4, vol. iv. p. 87, pl. 48, f. 29.

-Burrows, Introd. Conch. pl. 5, f. 3.

" polita, Pulteney, Hutchins, Dorset, p. 29.

" tenuis, DA Costa, Brit. Conch, p. 210.--Dovov. Brit. Shells, vol. i. pl. 19, f. 2.-Most. Test. Brit. p. 59--Linn. 'Trans, vol. viii. p. 52.-Dorset Catal. p. 30, pl. 5, f. 3.-TurT. Conch. Diction. p. 169.-Turt. Dithyra Brit. p. 107.-Flem, Brit. Anim. p. 436.-MAcgli. Moll. Aberd. p. 280.-Brit. Marine Conch. p. 69,-Brown, Illust. Coneh. G. B. p. 100, pl. 40, f. 19.Woon, General Conch. p. 355, pl. 44, f. 3, 4.-LAx. Anim. s. Vert. (ed. Desh.) vol. vi. p. 197. - Index Testaceol. pl. 3, Tell. f. 22.-Philippi, Moll. Sicil. vol. i. p. 26, and vol. ii. p. 22.-HaNL. Recent Shells, p. 64.-HANL. in 'Thesaur. Conch. vol, i, p. 287, pl. 58, f. 8 1, 82.

" exigua (VAR.), PoLI, Test. Sicil. vol. i. pl. 15, f. 15, 17.

" balaustina, Dillw. (not Linn.) Recent Shells, vol. i. p. 93.-Chemn. Conch. Cab. rol. vi. p. 124, pl. 12, f. 117 ?

This pretty and well-known species is of a suboval shape, very thin, translucent, extremely glossy, and, especially the left valve, much compressed. It is not greatly inequilateral; the surface is almost smooth, and extremely variable in colouring, ranging from pale crimson, through orange and yellow, to almost white, and often shaded with paler and darker zones of the same tint, but never rayed, spotted, or marbled. The ventral margin is convex in front, and straighter, less ascending, and subinflected behind. The anterior side is rather the longer, and tapers a little at the extremity, where it is well rounded, the front dorsal eage declines but very moderately, and is more or less convex or even subarcuated. 'The posterior termina- 
tion is subangulated below, but rounded off at the tip; the hinder dorsal edge is straight, and unites itself in an almost uninterrupted line with the convex and very obliquely sloping posterior margin. The umbones project but little ; the bealss are very small, and almost directly inflected; the umbonal ridge is almost, but not quite, obsolete; and the ligament is large, elongated, and prominent. The interior is coloured similarly to the exterior; the teeth are very small, and the hinge of the right valve exhibits an approximate lateral in addition to, and immediately preceding, the primary teeth.

The average size of the full grown shell is nearly one inch in length, and five-eighths of an inch in breadth.

The animal, respecting which we have ample notes by Mr. Clark and sketches by Mr. Alder, is subtriangular and very much compressed. Its mantle is open throughout in front, and finely fringed at its edges. The siphonal tubes are long and slender, separate through their whole length, both somewhat curving upwards, often extended to equal leugths, or liaving one or other alternately the longer, most frequently the branchial being the shorter. The foot is large, broad at the base, rather long, linguiform, and not very acutely pointed. The branchiæ consist of a single large triangular leaf, on each side divided by a line into two parts and finely pectinated. On each side of the mouth there is a pair of long, rather narrow, pointed, labial palps, smooth on their outsides and pectinated very strongly within. The colour of the animal is yellowish white. The tubes are nearly hyaline, and the branchiæ light brown.

This is one of our commonest and prettiest bivalves. It occurs in abundance on most of our sandy shores all round Britain and Ireland; so generally, indeed, that to cite lo- 
calities would be superfluons. It lives at or near low watermark, and ramges a fathom or two below it, buried in sand. Specimens of remarkable size and brilliancy are found both on the northermmost and southernmost of our sandy bays.

Abroad it ranges from the coasts of Finmark to the Merliterranean, everywhere littoral. As a fossil it occurs in beds of the glacial epoelh, but does not appear to extend farther back in time.

T. Fabula, Gronovius.

Ovate-oblong, with oblique strix on one of the valves.

Plate XIX. fig. 9.

Tellina fubula, Gronov. Zoophyl. p. 263, no. 1111, pl. 18, f. 9.-Donov. Brit. Shells, vol. iii. pl. 97.-Mont. 'Test. Brit. p. 61.-Linn. Trans. vol. viii. pl. 52.-Dorset Catalog. p. 30, pl. 12, f. 3 and $3 \Lambda$. Turt. Conch. Diction. p. 170.-Tunt. Dithyra Brit. p. 101. -Fienr. Brit. Anim. p. 435.-Macgll. Moll. Aberd. p. 280. -Brit. Marine Conch. p. 66.-Brown, Illust. Conch. G. B. p. 101, pl. 40, f. 18.-Wood, General Conch. p. 156, pl. 45, f. 4.-Diluw. Recent Shells, vol. i. p. 91.-LaM. Anim. s. Vert. (ed. Desh.) vol. vi. p. 197.-Index 'T'estaceol. pl. 3, f. 23. -ReEs, Cyclop. Shells, pl. 5.-Pinlirpr, Moll. Sicil. vol. i. p. 26, pl. 3, f. 10, and vol. ii. p. 22.-Der.kss. Rec. Coquil. pl. 6, f. 5.-HANu. Recent Shells, p. 64.-HANL. in Thes, Conch. Ilist. vol. i. p. 287, pl. 57, f. 62.

" discors, PUlteney, IIutchins, Dorset, p. 54.

'This 'T'ellen, which, from its peculiar sculpture, is easily di-tinguished from any of our British shells, is of an ovateollong shape, compressed, thin, semi-transparent, lustrous, subequilateral, oecasionally somewhat irideseent, and both cxternally and internally of a somewhat pearly white, fre'fuently stained on the umbones with orange or blush, but never rayed nor uniformly tinted with those or any other colours. 'I'he valves are rather flexuous, their front portion 
bending to the left, their hinder to the right; their surfaces are very different, the left being almost smooth or merely marked with concentric lines of increase, whilst the right is diagonally striated with most delicate and crowded oblique lines, which run from the upper part of the anterior side towards the lower end of the hinder extremity. These lines usually become converted into concentric strix adjacent to the front extremity, and do not cross the umbonal fold (which is but little elevated) posteriorly. The ventral margin is usually but little rounded, and is but slightly inflected behind, where it is ordinarily straightish and but little ascending. The sides are all but equal, the front is well-rounded and but slightly tapering at its extremity, whilst the hinder termination is attenuated below to an obtuse point. The front dorsal edge, which slopes but little, although straightish near the acute and rather projecting beaks, becomes more or less arcuated near the extremity; the hinder dorsal slope is very decided, and its outline, which beneath the large and prominent ligament is retuse, becomes convex near its termination. The posterior tip is rounded. The front dorsal area is very slightly inflected. The hinge of the right valve is furnished with an approximate front lateral lamina in addition to its primary teeth.

The ordinary size of this shell is about four-fifths of an inch, and its breadth not quite half an inch at the widest part. We have figured in plate XXVI. (f. 3), an interesting variety of this shell, observed by Mr. Jeffreys, in which the oblique strix, gradually becoming indistinct anteriorly, wholly vanish near the front extremity. The shape is likewise more abbreviated than in the typical form, and the hinder termination is less attenuated than usual. 
The animal closely resembles that of Tellina temuis, though differing of course materially in its outlines. Its siphonal tuber appear to be rather longer than in that species. It is entirely white.

Wherever the coast exhibits a long expanse of sand, this species is almost invariably present; and almost always in considerable abundance. Localities need not be citerl. as it occurs in all farourable places around England, Scotland, and Ireland, from north to south. Like the last species, it is usually a littoral shell, but ranges deeper, occurring occasionally at a depth of ten or twelve fathoms. It ranges throughout the Celtic and Lusitanian regions of the Furopean seas, but is not cmumerated by Loiven among the mollusks of Scandinavia. It is found fossil in the mammaliferous crag of Southwold.

\section{T. solidula, Pulteney.}

Roundish-ovate; convex or subventricose, smooth; teeth very small, no lateral ones.

Plate XX. fig. 6.

Lister, Hist. Conch.pl. 405 , f. 250.

Tellina carnaria, Pexs. (not Linn.) Brit. Zool. ed. 4, vol. iv. p. 88, pl. 49, f. 32.

" mula, Da Costa, Brit. Conch. p. 211, pl. 12, f. 4.

". solidula, Pultenex, in Ifutchins" Hist. Dorset, p. 29.-MIont. Test.

Brit. p. 63.-Limn. 'I'rans. vol, viii. p. 58.-Dorset Catalog. p. 31, pl. 8, f. 4.-TurT. Conch. Diction. p. 177.-MLAcGLLiv. Moll. $\Lambda$ berdeen, p. 279.-Brit. Marine Conch. p. 70.Brown, Illust. Conch. G. B. p. 101, pl. 40, f. 14.-Woon, General Conch. p. 193, pl. 46, f. 2.-LAar. Anim. s. Vert. (cd. Desh.) vol. vi. p. 206.-Index Testaceolog. pl. 4, f. 84. - Hanl. Recent Shells, p. 70.-HANL, in Sowerb. Thesnur. Conch. p. 318, pl. 59, f. 109, 110.-Löven, Moll. Suecix, pl. 41 .

Tellina zonata, Drusw. Recent Shells, vol. i. p. 100.

I'sammobie solulula, T'urt. Dithyra Brit. p. 95, pl. 8, f. 2.-FleM. Brit. Anim. p. 438.

Tellina Buthica, Phinipri, Moll. Sicil. vol. i. p. 28, and vol. ii.p. 22.-Fonbes, Mem, Geol, Surr, vol. i. p. 411. 
Although the name solidula is well established, the specific appellation mbra was previously bestowed upon this shell by Da Costa, an epithet which we wish not to resuscitate, since not only is it peculiarly unsuited to a shell with so variable a colouring, but emanates likewise from an anthor who, having wilfully passed over the just claims of his predecessors in nomenclature, has forfeited the right of challenging for himself the law of priority. It is by no means certain after all, that this bivalve is specifically distinct from the Balthica of Linnæus; the differences at least, although sufficiently definite, not being greater than what are arowedly induced in other species by the peculiar nature of the waters of the Baltic sea, under whose influence the majority of the marine shells become depauperated.

The form is rounded, ovate, and longer than broad (more rarely suborbicular); the valves are equilateral, opaque, strong, and more or less ventricose, the convexity being most marked near the umbonal region, diminishing below it, and more especially lessening towards the pointed extremity. The surface, except in aged examples, is more or less glossy, and both externally and internally of the same hue, although the interior is frequently of a deeper tone. The colouring matter is often disposed in darker and paler zones, and never in rays or spots; it is infinite in diversity, various shades of yellow, flesh, orange, and pink, occupying the entire surface; the valves more rarely are almost white. There are neither stria nor sulci, but only a few antiquated lines of growth. The ventral margin is well arcuated in front, but becomes straighter and somewhat ascending behind, where it forms an acute angle below with the much declining and scarcely convex dorsal edge.

VOL. I. 
The declination of the front dorsal margin adjacent to the beaks. (where it is almost straight) is very inconsiderable; the outline subsequently becomes arcuated and moderately sloping. The anterior side is a trifle the longer; its extremity is broadly but not symmetrically roumled, there being an oceasional obseure subangulation at the eessation of straightness in the dorsal edge, and the rise of the lower margin exceeding the descent of the upper one. The umbones are rather prominent ; the beals acute, and hardly leaning forward in the least, in front of them exists (in the adult only) a linear pseudo-lunule, which is more evident in the right than in the left valve. The ligament is long, very prominent, and usually dark coloured.

The ventral flexure is almost obsolete. the umbonal fold, which runs adjacent to, anrl almost parallel with, the dorsal margin, is chiefly distinguishable by the depression of the surface behind it, which, in the right ralve, obscurely subangulates it.

The hinge margin is rather broad; there are two very caducous almost rudimentary cardinal teeth in each valve but no lateral laminæ.

The length of a good sized specimen is rather nore than one inch, and its breadth about three-quarters of an inch. A curious variety is found where fresh water mingles with the sea. There is a suborbicular form taken at Southampton, with a peculiarly dull surface, and much arched ventral margin; and the declination of the hinder dorsal edge, so abrupt as materially to diminish the ordinary angulation of the posterior extremity.

The animal is suborbicular, thick, and convex; its manthe is open, and ornamented at the margin with fine white filaments. The two siphons are nearly hyaline, of moderate length, and quite plain at their orifices; the anal one 
is usually curved upwards. Mr. Clark describes the arrangements of the branchial and labial palps to be similar to those of $T$.tenuis, except that the latter are broader. The foot is white, flat, linguiform, rather pointed, bent at the base, and of moderate dimensions. The colour of the animal is yellowish, tinged slightly, especially the branchix with reddish-brown.

"This species," observes Montagu, "is found common on most of the British coasts, particularly the sandy bays and inlets, buried four or five inches beneath the surface." It is indeed universally distributed, and often occurs in vast abundance in suitable localities. It is distributed throughout the European seas, and ranges as far as the Euxine. It is as common fossil in beds of the pleistocene epoch, wherein it makes its first appearance, as on existing shores, and unerringly marks the shallow waters under which such formations were accumulated.

\section{T. proxima, Brown.}

Obovate; compressed, smooth, never glossy, usually provided with an epidermis; no lateral teeth.

\section{Plate XXI. fig. 1.}

Macroma tenera, LEAch, Appendix to Ross's Voyage.

Tellina proxima, Brown, Zoolog. Beechey Voyage, p. 154, pl. 44, f. 4.-Sмiтн, Wern. Men. 8, p. 105, pl. 1, f. 21.-Brit. Marine Conch. p. 246.-Macginliv. Moll, Aberd. p. 340.-JefFreys, Ann. Nat. Hist. vol. xx. p. 19.-Philip PI, Neu Conch. vol. ii. Tellina, pl. 5, f. 4.-Hant. in Sow. Thesaur. Conch. vol, i. p. 313 , pl. 66 , f. 264 , and pl. 59 , f. 115.

Tellina sordida, Couthoux, Boston Journ. Nat. Hist. vol. ii. p. 59, pl. 3, f. 11. Sanguinolaria sordida, Gould, Invert. Massach. p. 67.

Tellina lata, Gmelin, only from figure of List. pl. 407, f. 253.-Loven, Ind. Moll. Suecix, p. 41.

" calcarca, Lyell, Phil. Trans. 1836.-Forbes, Mem. Geol. Surv. vol, i p. 411.

, oralis, WoodWard, Geol. Norfk. pl. 2, f. 11.

, orata, Sow. Min.Conch.pl. 161, f. 2.

" obliqua, Sow. Min. Conch. pl. 161, f. 1. 
The shape of $T$. proxima, which is intermediate between that of soliduld and tenuis, is very variable, but when fully developed in specimens of a larger growth, is rather obliquely oborate; but becomes more or less albbreviated slightly subtrigonal and more oblique in others which have lived under less favourable circumstances. The valves, which are rather thin, and usually much bent, do not appear perfectly equal, one being frequently flatter than the other; both are, however, more or less shallow, of an opaque and rather dull white colour within and without, and almost smooth, being merely marked with minute concentric wrinkles, chiefly apparent at the sides. They are clothed with an olivaceous or ash-coloured epidermis, which is frequently only present towards the lower margin. The ventral edge, which is greatly arcuated in front, is scarcely convex, but much ascending behind; the front dorsal outline, excepting near the bealis, is more or less arcuated or at least convex, whilst the hinder dorsal edge is almost rectilinear or even subretuse, curving out very slightly, however, near its termination. The degree of declination in the dorsal margin is not constant, but typically is rather trifling anteriorly, and only moderate posteriorly, but in many specimens these slopes, although still preserving their relative proportions, are much more decided. The beaks (when not eroded) are acute and a little projecting; they are situated much nearer to the hinder termination, which is bluntly angulated below, than to the rounded extremity of the anterior side, which is consequently much produced. The umbonal ridge, although present, is much depressed and almost obsolete; the ligament is large and prominent. The hinge margin is rather broad; there are no lateral teeth, and the primary are very caducous; when the linge, however, is perfect, one of the teeth is bifureater in each ralve. The pallial sinus is rather large. 
The few specimens which have been dredged in Britain are much smaller than the exotic ones, none which we have seen exceeding three-quarters of an inch in length, and about half an inch in breadth.

It is a very rare shell, and wholly confined to North Britain, where as yet no living example has been taken. Indeer, in despite of the beantiful state of preservation in which the valves are found, we would not vouch for their not being fossils; the species is, however, most certainly found in a living state a little more northward, being an inhabitant of the shores of Sweden and the colder parts of Europe as well as of the United States of America. The small but perfect and fresh-looking valve delineated in our engraving was dredged by Mr. Jeffreys in fiftythree fathoms water off Croulin's Island, Skye ; Mr. M‘Andrew has likewise obtained two valves from Loch Fyne, and Mr. Macgillivray relates that a decayed one was brought up by the lines off Aberdeen. As a fossil it is well known, commencing its existence in the coralline crag. During the pleistocene epoch it was widely spread and plentiful, occurring in Sweden, Russia, and Canada, besides our own seas. The retrocession of glacial conditions probably caused its retirement northwards.

\section{T. bimaculata, Linnæus.}

Tellina bimaculata, Linn. Syst. Nat. p. 1120.-DA Costs, Brit. Conch. p. 213. - Pulteney, Hutchins, Hist. Dorset. p. 70.-Donov. Brit. Shells, vol. i. pl. 19, f. 1. - Mont. Test. Brit. p. 69. - Linn. Trans. vol. viii. p. 57. - Dorset Catalog. p. 31, pl. 5, f. 7.-Turt. Conch. Diction. p. 178.-Turt. Dithyr. Brit. p. 104, pl. 8, f. 5. - Flem. Brit. Anim. p. 435. Brit. Marine Conch. p. 68. - Chemn. Conch, Cab. vol. vi. p. 132, pl. 13, f. 127, 132. - DiLLw. Recent Shells, vol. i. p. 101.-Laм. Anim.s. Vert. (ed. Desh.) vol, vi.p. 207.- 
Index Testaceolog. pl. 4, f. 83.- - H ANL. in Sow. Thesaur. Conch. vol. i. p. 250, pl. 56, f. 16, 19, 20, 21, 22.

Tellina sex radiata, Lam. Anim. s. Vert. (ed. Desh.) rol, ri. p. 207.- Index Testaccolog. Suppl. pl. 11, f. 37 .

Our description of the $T$. bimaculata is drawn up from foreign examples, the great range of variation not being adequately represented by the scattered individuals reported to have been taken upon our shores. The shape varies from ovate to rounded ovate; the valves are equal, thick, opaque, simply convex, almost smooth, and rather glossy. The diversity of colouring is infinite; the principal variations are as follows:-violet, white, orange-red, rich yellow, or pinkish red (either uniform or rayed with purple, the white specimens with usually two lateral internal spots of deep crimson); whitish or yellowish, with narrow interrupted violet rays, which often assume the appearance of arrow-heads; violet, rayed with white; and whitish, with hroad fawn-coloured and narrower purplish rays. The ventral margin, which is often a little inflected at the posterior end, ranges in the middle from merely convex to arcuated. The sides are decidedly unequal; the front one is the longer, and tapers considerably to a rounded extremity, the dorsal edge sloping greatly, but with little convexity; the hinder termination is bluntly biangulated, and its dorsal edge straight, short, and but little declining. The mmbonal ridge is not much marked; the ligament is short, projecting, and rather large; the beaks are acute, and lean slightly backward; the nymphere great and prominent. The primary teeth are large, the lateral, which are oceasionally obsolete, are short, thick, and nearly equidistant. The sinus of the palleal impression is much expanded, straight above, and bluntly rounded in front. Our largest example measures two-thirds of an inch in length, and full three-quarters of an inch in breadth.

"As this species is considered by some naturalists to have been erroneously introduced into our catalogues, it may be stated that Mr. R. Ball has specimens of it colleceted on the coasts of Clare and Cork, and that Mr. Warren of Dublin, obtained one in a living state at Ardmore, 
county Waterford." (Thompson on the Fauna of Ireland, in the Report of the British Association for 1843.) Three more individuals are likewise stated, on credible authority, to have been taken on the coasts of Cork and Waterford. (Thompson.) Da Costa observes, that he has received the species from Hampshire and Lancashire; Pulteney mentions it among his Dorset shells; and Turton ascribes it to the "Western coasts." Modern researches have not confirmed the correctness of the English localities cited by authors notoriously lax upon the question of indigenonsness. Its occasional appearance on our shores is, probably, to be ascribed to the frequent wreck of vessels from the West Indies, where it is most abundant.

\section{SPURIOUS.}

We owe to the kindness of Dr. Fleming the opportunity of describing an interesting shell, which was mentioned (p. 434) in his "History of British Animals," under the supposition that it was the T. fragilis of Pennant, to whose figure indeed (pl. 47, f. 26 ) it bears some resemblance, but is broader, more inequilateral, and more swollen at the front ventral margin. As the teeth of the two specimens, which are otherwise in excellent preservation, are either accidentally broken or naturally obsolete, the generic allocation can only be regarded as hypothetical, the general aspect being equally like a Thracia.

\section{T. fragilis, Fleming (not Linnæus).}

Suboval, solid, opaque, of a shining squalid white externally, dull white internally. Valves unequal ; the right the larger and the more convex, the left the shallower, but not flattened. Exterior somewhat obsoletely sulcated or even subplicated in a concentric direction, and behind the umbonal ridge or indistinct fold, where the surface becomes duller, more or less distinctly marked with fine elevated wrinkles. Ventral margin arcuated in front, ascending and subretuse behind. Anterior side decid- 
edly, and occasionally much, the longer; its dorsal edge not greatly declining, and becoming convex or subarcuated as it recedes from the rather prominent beaks: its extremity wellrounded both above and below. Posterior side truncated at its narrowed termination, the upper angle rather the more projecting; its dorsal slope moderate or considerable, retuse or incurved. Ligament very large, prominent, of an ashy yellowish brown. Umbones eroded (in these examples). Inside with radiating wrinkles; front muscular impression slightly lunate, moderatcly large; hinder scar small, rounded, reniform; palleal sinus short, rounded at the apex; margins acute. Length an inch and a sixth : breadth five-sixths of an inch.

In reference to these shells, Dr. Fleming writes, "I believe I got them as specimens of Tellina fragitis of Pennant, and from Plymouth. This was my conviction at the time, but the foundation of it I cannot now illustrate. Since the publication of the 'British Animals,' I have repeatedly thought they had an outlandish character."

\section{T. PISIFormis, Limnæus.}

Tellina pisiformis, Lrws. Syst. Nat. ed. 12, p. 1]20.-Linn. Trans. vol. viii. p. 67.

Turt. Conch. Díction. p. 178,-Spengler, Skrivt. Nat. Selskab. Kioben. rol. iv. pt. 2, p. 117.-Wood, General Conch. p. 194.-Dillw. Recent Shells, rol. i. p. 102.Hanley, in Sow. Thesaur. Conch. vol. i. p. 261, pl. 56 , f. 30. -l'hulippi, Neu. Conch. Tellina, pl, 4, f. 7.

Cardium discors, Montagu, Test. Brit. p. 84.

Strigillu pisiformis, Tunton, Dithyra Brit. p. 119.

Lucina " Flex. Brit. Anim. p. 442,-Brit. Marine Conch. p. 76.

A West Indian shell, introduced as British with hesitation by Montagn, who picked a single dead specimen from the sand of Falmouth harbour. As this example is no longer to be found, and the Card. discors is not so minutely defined as to determine whether it belongs to the pale variety of pisiformis, or is the flexuosa of Say (J. Acad. N. S. Philadelph. vol, ii.p. 303), wherein the oblique strice change their directions several times at the posterior termination, it is assigned, with some little doubt, to the former. 


\section{T. carnaria, Linnæus.}

Tellina camaric, Linv. Syst. Nat. ed. 12, p. 1119.-Donov. Brit. Shells, vol. ii. pl. 47.-Mont. Test. Brit. p. 73.-Linn. Trans, vol. viii, p. 57.-Dorset Catalog. p. 31, pl. 5, f, 6.-Turt. Conch. Diction. p. 177.-Chemn. Conch, Cab. vol. vi. p. 130, pl. 13, f. 126. -Wood, General Conch. pl. 40, f. 4.-Dillw. Recent Shells, vol. i. p. 100.-Index Testrc. pl, 4, f. 79.-DesH. in Anim. s. Vert. vol. vi. p. 209.-HANL. Recent Shells, vol, i. p. 72, pl. 4 , f. 79 ; in Sowerb. Thesaur. Conch. vol. i. p. 260, pl. 56, f. 37,38 .

Cardium carneosum, Da Costa, Brit. Conch. p. 181.

Lucina carnaria, Lam. Anim. s. Vert. (ed. Desh.) vol. vi. p. 227.-Flem. Brit. Anim. p. 442.-Brit. Marine Conch. p. 75.

Strigilla carnaria, TuRT. Dithyra Brit. p. 118, pl. 7, f. 15.

A West Indian shell ; introduced by Da Costa, as received from Scarborough, Devonshire, and Cornwall.

\section{T. Fausta, Pulteney.}

Lister, Hist. Conch. pl. 266, f. 102.

Tellina remies, Bonn (not Linn.), Mus. Cæs. p. 36, pl. 2, f. 11.-Chean. Conch. Cab. vol.vi. pl. 12, f. 112.-Lam. Anim. s. Vert. (ed. Desh.) vol. vi. p. 199 .

", fausta, Pulteney, in Hutchins" Dorset, p. 29.-Donov. Brit. Shells, vol. iii. pl. 98.-Mont. Test. Brit. p. 64.-Linn. Trans, vol. viii. p. 55, pl. 1, f. 8.-Dorset Catal. p. 30, pl. 5, f. 5.-Tur T. Conch. Diction. p. 175.-Dillw. Recent Shells, vol, i.p. 94.-HANL. in Thes. Conch. p. 256, pl. 64, f, 260, 264.

, lavis, Woon, General Conch. p. 181, pl. 37, f. 1.

A West Indian shell, introduced by Dr. Pulteney as dredged at Weymouth.

\section{T. striata, Chemnitz.}

Tellina striata, Chemertz, Conch. Cab. vol. 10, p. 349, pl. 170, f. 1654, 1655.HaNe. in Thesaur. Conch. vol. i. p. 240, pl.61, f. 161.

" angulosa, GMeLiN, Syst. Nat. p. 3244.

"lata, Pulteney, Hutchins' Hist. Dorset, p. 29 (from his own shells).Mont. Test. Brit. p, 57.

Donax Martinicensis, Lam. Anim. so Vert, (fide Deles. Rec. Coq. pl. '6, fo 15.) Tellina punicea, Turr. Conch. Diction. p. 171 and Dithyrat Brit. p. 100 (certo from specimens).-FLeMr. Brit. Anim. p. 435 (partly).

A. West Indian shell, introduced by Dr. Pulteney as obtained in Dorsetshire.

VOL. I. 


\section{T. PUNicea, Born.}

Tellina punicea, Bonn, Testacen Mus. Coss. Vind. p. 33, pl. 2, f. 2.-Dorset Catal. p. 30, pl. 7, f. 5.-Linn. Trans. vol. viii. p. 50.-13rit. Marine Conch. p. 66 (badly).-Brown, Ill. Conch. G. B. p. 100.-Gmel. Syst. Nat. p. 3239.-LAג. Anim. s. Vert. (ed. Desh.) rol. vi. p. 196.-HANu. in Sow. Thesaur. Conch. vol. i. p. 239, pl. 58, f. 89 , and pl, 60, f. 154 .

Encycl. Méthod. Vers, pl. 291, f. 2.

A West Indian shell, introduced into our Fauna through having been figured in the Dor'set Catalogue as identical with the preceding.

\section{T. In.eQUistriata, Donovan.}

Tellina inaquistriata, Dosov. Brit. Shells, vol. iv. pl. 123.-HANr. in Thesaur. Conch. vol. i. p. 238, pl. 57, pl. 58, and pl. 58, f. 80.

" sanguinea, Wood, General Conch. p. 159, pl. 44, f. 2.-HANu. Recent Shells, p. 67, pl. 4, f. 27.

Inhabits the bay of Guayaquil; was introduced by Donovan, who only surmised that it had been taken by Dr. Pulteney on the Dorset coast.

\section{T. simlis, Sowerby.}

Tellina similis, Sowerny, Brit. Miscellany, pl. 75.-MIont. Test. Brit. Suppl. p. ]67.-Turt. Conch. Diction. p. 170.-Turt. Dithyra Brit. p. 102.-Flen. Brit. Anim. p. 435.-Brit. Marine Conch. p، 67.-Brown, Illust, Conch. G. B. p. 101, pl. 39, f. 35.-PniLippi, Neu. Conch. Tellina, pl. 3, f. 7.-HANL. in Thesaur. Conch. vol. i. p. 285 , pl. 57, f. 65.

A West Indian shell, introduced by Mrr. Sowerby as taken at Brighton.

\section{T. IINEata, 'Turton.}

Tellina Brasiliana, Lam. (not Spengler), Anim. s. Vert. (cd. Desh.) vol. vi. p. 205.-Hanl. Recent Shells, p. 70, Suppl.pl. 9, f. 3.

" striata, Movr. (not Chemn.) Test. Brit, p. 60, pl. 27, f, 2.-Linn. Trans. vol. riii. p. 54.-TURT. Conch. Diction. p. 169; Dithyra Brit. p. 106.-Fen. Brit. Anim, p. 436--Brit. Marine Conch.p. 69.-Dilcw. Recent Shells vol, i.p. 92. 
Tellina lineata, TurT. Conch. Diction. p. 168, f. 16; Dithyra Brit. p. 99, pl. 7, f. 1.-Flem. Brit. Anim. p. 435.-Brit. Marine Conch.p. 65.-Brown, Illust. Conch. G. B. p. 100, pl. 40, f. 15. Phinipre, Neu. Conch. Tellina, pl, 4, f. 6.- Hand. in Thesaur. Conch. vol. i. p. 233 , pl. 56 , f. 35,36 , and pl. 57 , f. 46,47 .

A. Brazilian species, introduced by Montagu as picked up by MI). Bryer on the shore between Weymouth and Portland. In this and the preceding cases of exotic species being enumerated as British, there is no reason to suspect wilful deception: they were probably taken from heaps of foreign ballast.

\section{SYNDOSMYA, Recluz.}

Shell thin, transversely more or less oblong or elongated, equilateral or inequilateral, slightly gaping at the extremities, surface smooth, invested with a thin and deciduous epidermis; muscular impressions rounded or oblong; pallial sinus deep and wide; hinge composed of an oblique spathulate fulcrum in each valve, in the pit of which a cartilage is lodged, and two distinct lateral teeth in one or both valves; primary teeth small or wanting; ligament rather short, partially external.

Animal oblong, compressed, its mantle open throughout, and finely fringed at the margin; the siphons separated throughout, long, slender, the upper one invested with a fine wrinkled epidermis; their orifices plain ; foot linguiform, large, apiculated; labial tentacles triangular, sometimes obseure.

The shells of this genus have been designated by so many generic names, that some of our British conchologists will hardly recognise them under the appellation we have here adopted. Mactra, Amphidesma, Ligula, Erycina, and Abra have at various times numbered them in their ranks; and, had the last-named designation ever 
been accompanied by a distinct diagnosis, it might have been as well to adopt it. As it is, the last name, that given by Recluz, claims the place of honour. 'The species are not remarkable for beauty or singularity. They are small bivalves, mostly northern, living in all depths of water, from the laminarian zone to the deepest explored regions. They bury in sand and mud, and appear to be active creatures of their lind, capable of enduring many vicissitudes of conditions.

\section{S. ALBA, Wood.}

More or less oval, not at all elongated; sides very unequal.

Plate XVIY., fig. 12, 13, 14.

Mfuetre alba, Wood, Linn. Trans, vol. vi. pl. 18, f. 9 to 12.

Mactra Boysï, Moxt. Test. Brit. p. 98, pl. 3, f. 7.-Linn. Trans, vol, viii. p. 72, pl. 1, f. 12.-Dorset Catalog. p. 33, pl. 12, f. 7.-TunT. Conch. Diction. p. 84.-Dillw. Recent Shells, p. 143.-Index Testaceol. pl. 6, Mactra, f. 27.

Amplidesma Boysï, Lamanck, Anim. s. Vert. (ed. Desh.) rol. vi. p. 128.-Turt. Dithyra Brit. p. 53, pl. 5, f. 4, 5.-Brit. Marine Conch. p. 55.-Brown, Ill. Conch. G. B. p. 105, pl. 42, f. 3.Hanl. Recent Shells, p. 42, pl. 6, Mactra, f. 27.

Amphidesma album, Fuem. Brit. Anim. p. 432,-Macgilliv. Moll. Aberd. p. 293. Syndosmya alba, Recluz, Revue Cuv. Zool. 1843, p. 362.-Recluz, in Chenu's Illustrat. Conch. Syndosmya, p. 3. - Löven, Index Moll. Scandinav. p. 44.

Notwithstanding that the epithet albe is peculiarly devoid of significance in the genus syindosmya, we are not at liberty to reject it for the subsequent one of Boysii, although the latter commemorates in some measure the services rendered to Conchology by one of the authors of the "Testacen Minuta Rariora," a work too frequently attributed solely to Wallier, who was merely the engraver of the plates.

'This well-known bivalve is of an oval shape, very thin anl fragile, but not pellucid, of an uniform white under 
a glossy, very thin, yellowish, and evenly spread epidermis, which is at times slightly opaleseent; the valves are rather compressed, though not particularly so for this genus, and their surface is nearly smooth. The sides are distinctly unequal, the front exceeding the hinder by nearly one half its length; the ventral edge is simply arcuated, and both the dorsal margins are more or less convex, the front one but little sloping, the hinder one greatly declining. The anterior extremity is rounded, but not broadly so, the posterior end is obtinsely angulated below; the umbonal ridge is entirely obsolete; the beaks are small and inflected, not leaning to either side; the ligament is very little, and often of a chestnut colour. The inside is more or less nacreous and iridescent; the cartilage-pit is rather large, eurved, and subtriangular upon the hinder side just under the bealis, leans obliquely backward, and contains a rufous orange-coloured cartilage; the two lateral laminæ are large, raised, approximate, and nearly equal, their edges are slightly concave, and form an obtuse or right angle near their termination; the space between their apices occupies one third of the entire hinge-margin.

The measured length of a large Scotch specimen (the northern far exceed the southern in dimensions) was very nearly one incl, and its breadth was one third less: this is at least one fourth larger than the size of any of our English examples.

The animal has very lately been submitted to a most eareful scrutiny by Mr. Clarke; and, as his notes are much fuller than our own, we draw from them the greater part of the following description. It is compressed, subovate, and of a very pale bluish-white hue; the mantle is open, and very finely fringed with short filaments; the branchial and anal tubes are completely separated from 
their hases, and are eminently elastic both longitudinally and laterally; when fully extended they are cylindrical, and very little short of the length of the shell : the animal las the power of inflating them to three times their ordinary diameter; they are of a light brownish colour, the effect of an epidermis, which, when the tubes are half ex-erted, exhibits in the branchial and rather longer one about thirty-five annular corrugations, and in the anal twenty-five; the colour of the true tubes under this epidermis, which is sometimes obsolete, is very pale whitishrellow; their epidermic cases are prolongations of the investment of the shell; the branchial tube is truncate and plain at the orifice, the anal furnished with a tubular hyaline valve. The foot is compressed and museular, large in proportion to the animal: it presents no trace of a brssal groove. The ventral portion of the body is marked with intensely flake-white polymorphous spots; its dorsal range is chiefly oceupied by the liver, which appears of a green colour through its investing membrane; the branchire are white, two on each side of the body.

The Syndosmya alba is a very plentiful shell in most sandy and mudly localities around all our coasts, and is so generally distributed that all our maritime provinces may rank it among their inhabitants. It often occurs gregarious in considerable numbers, and is frequently cast on shore. It ranges from one to forty fathoms, and is most abundant in between ten and fifteen. The localities which have furnished the finest specimens are Deal Voe in the Zetlands (Jeftreys) and Loch Long (M'Andrew). It ranges throughout the European seas from Norway to the Mediterranean, and as a fossil commences its appearance in the coralline erag. It lived within our area also during the pleistocene epoch. 


\section{S. intermedia, Thompson.}

Elongated, ovate, almost equilateral.

Plate XVII. fig. 9, 10, and (Animal) Plate K, fig. 5.

2 Mya nitida, Muller, Prodr. No. 2963, (Not of O. Fabric.)

Amphidesma intermedia, Thompson, Ann. Nat. Hist. vol. xv. p. 318, pl. 19. f. 6. Abra profundissima, (Young) JEFF. Ann. Nat. Hist. vol, xx. p, 19 (not of Fories).

Syndosmya nitida, Löven, Index Moll. Skandinav. p. 44.

It is by no means improbable that Müller intended to indicate this graceful shell, under the name of Myc nitidd, but as his description, which is unaccompanied by any figure, so inadequately defines it, as to leave much room for conjecture, we have preferred to retain the appellation given by the distinguished naturalist who first introduced it into our Fauna.

The shell has an oblong, or rather elongated ovate-form, and is of a brilliant porcelain white beneath the extremely thin and almost imperceptible iridescent epidermidal surface. It is subdiaphanous, exceedingly thin and fragile, compressed, (particularly behind,) and almost entirely smooth, or at most marked with indistinct striulx. The anterior side, which is slightly but decidedly the more produced, is rounder at its extremity, but not equally above and below, since the front dorsal edge, which is barely convex, slopes but little downwards, the rotundity being effected by the ventral margin, which, although straight and sometimes almost subretuse in the middle, rapidly ascends at either extremity and particularly and arcuatedly so in front. The posterior side is attenuated to a more or less acute or obtuse subcentral point; the hinder dorsal edge, after passing the extremely short, small, and olivaceous ash-coloured ligament (which scarcely projects,) slopes very moderately, yet more so than the front one, to its termination, exhibit- 
ing orlinarily in the artult but little convexity of ontline. The beaks are depressed and minute, and scarcely incline to cither side. Thle satfron-coloured cartilage is situated in rather a large subtrigonal spoon-shaped projecting receptatcle; on either side of this (in the right valve only) is an apluminate sublateral lamina, the front one of which is the longer. The valves gape in a remarkable degree at each extremity.

The animal is white, ovate and compressed. The edges of the mantle are free and fincly fringed. The anal siphom is dnsty, and, as if invested with a brownish corrugated or ringert epidermis. The branchial one is transparent, and presents a reticulated appearance. The foot is linguiform and very changeable.

It lives buried in slimy mud in various depths, from six to one hundred fathoms, and appears to be a species of boreal origin, occurring chiefly in the neighbourhoor of the pleistocene deposits of Scotland, and in peculiar localities in the Zetland isles, and on the west and south of Ireland. It was first found by Mr. Ball, Mr. Thompson, and Mr. Forbes, in the bay of Killery, in Connemara, and afterwards by Mr. Thompen, in six fathoms, in Strangford Loch. As it is a rave British shell we mention all the other localities; Loch Fyne in fifty fathoms; Dunstaflnage; Armadale in Sliye, in from fifteen to forty fathoms. St. Magnus hay twenty-one miles cast of IBrassay in seventy fathoms; and twenty-five miles east of Noss in one humdred fathoms, all in Zetland (MacAndrew); Deal Voe, Zetland (Jofleys); Birtertuy bay, in Connemara (Barlee and Farren); and Cape Clear in sixty fathoms (MacAndrew).

It is essentially a northern species, and is recorded as an inhalbitant of the Norwegian seas (Liiven) and the Straits of Oresund (Öersted). 
S. prismatica, Montagit.

Much elongated, very inequilateral.

Plate XVII. fig. 15.

Ligula prismatica, Mont. Test. Brit. Sup. p. 23, pl. 26, f. 3.

IIya prismatica, Turt. Conch. Diction. p. 103.-Wood, General Conch. p. 101.

Dillw. Recent Shells, vol, i.p. 47.-Index Testaceol. pl. 2, Mya, f. 21.

Amphidesma prismatica, Lis. Anim. s. Vert. (ed. Desh.) vol. vi. p. 128.-Turt. Dithyra Brit. p. 52, pl. 5, f. 3.-MACGIL. Moll. Aberd. p. 294.-Brit. Marine Conch. p. 54.-Brown, Ill. Conch. G. B. p. 105, pl. 42, f. 5.-H.1NL. Recent Shells, vol. i. p. 42, pl. 2, Mya, f. 21.

Syndosmya prismatica, RecLuz, Rev. Cuv. Zool. 1843, p. 367 ; in Chenu, Illus. Conch. Syndos. p. 4.-Löven, Index Moll. Skandinaviæ. p. 45.

The iridescent Syndosmyce (not that the iridescence is confined to this species) is of an elongated oblong shape, the length more than doubling the breadth; is extremely inequilateral, much compressed, and gaping slightly at both ends. The texture is very thin and fragile, of a translucent white, which in some specimens is more or less iridescent; and the surface is polished and almost smooth. The anterior side, which is nearly twice as long as the posterior, has its extremity rounded, but not symmetrically so, as the front dorsal edge which is slightly convex is scarcely or but little sloping, whilst the ventral edge which is arcuated in front, curves more or less obliquely upward to meet it. The linder portion of the lower margin is more rectilinear, and even indistinctly retuse near its termination, but ascends equally as much as in front, forming a subcentral rounded off acute angle, with the arcuated and moderately sloping dorsal margin. The posterior termination is somewhat bent. The umbonal ridge is almost entirely obsolete: the beaks are small, very slightly inclined forward and but little

voL. I. 
projecting. 'The ligament is of a yellowish olive colour, and but little prominent. The hinge consists of a curved sub-

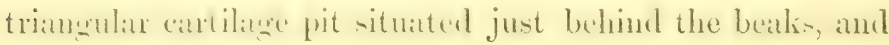
inclining posteriorward, having in one valve a very small apical triangular tooth above it in firont, and an approximate little elevated lateral lamina on either side of it, but unaccompanied by any teeth in the other valve.

The length of a specimen of moderate size is sevencighths of an inch, which is just double the measure of its breadth.

"Animal sub-oval, compressed, with the mantle open throughout it margins, finely fringed. Siphonal tuber long.

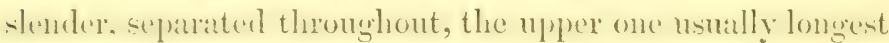
and plain at its orifice. The lower with about six short points or scallops. The foot is compressed, moderately long, linguiform hroad at its base with a slight shoulder, tapering to a not very rounded termination. Labia two, very laree, triangular, smooth externally, peetinated within. Colour pearly-white, the tubes hyaline, the branchiae tinged with light brown."-CLark, MSS. 1835.

Though by no means so common a shell as $S$. alba, it is not unfierquent on many parts of our eoast. It lives in sincly mud, and has a great range in depth, extending from shallows, whence it is occasionally cast on shore by the waves, to beneath one hundred fathoms. Between twenty and fifty fathoms is its farourite region. A few out of many localities may be mentioned; Weymouth (S. H.); Exmouth (Clark); Swansea and Fishouard (Jeftreys); Tsle of Man in twenty fathoms (E. F.); German Ocean,

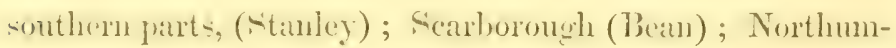
berland (Alder); off' 'lynemouth, in fine sand and mud, from four or five to fifty fathoms (Thomas); Frith of Forth (E. F.); Aberdecnshire (Macgillirray); Orliney (Tho- 
mas); Zetland, in from five fathoms, as at Balta Sound, to one hundred, as it oceurred at twenty-five miles east from Noss (NacAndrew); Skye in twenty fathoms, Loch Fyne in fifty fathoms (NacAndrew and E. F.); Mull of Galloway (Beechey); "Found on all sides of Ireland: thrown ashore at Magilligan, Belfast bay and Dublin coast; dredged by Mr. Hyndman in twenty fathoms, in Belfast bay, and from fifty fathoms off the South Rock, Down. Found in spring in the stomachs of haddocks and flat fish along the eastern coasts" (Thompson). In sixty fathoms off Cape Clear (MacAndrew).

Abroad this species ranges from the seas of Norway to the Egean. As a fossil it occurs in the coralline crag.

\section{S. Tenuis, Montagu.}

Subtriangular, almost equilateral ; breadth and length nearly equal.

Plate XVII. fig. 11.

Mactra tenuis, Mont. Test. Brit. p. 572, pl. 17, f. 7.-Linn. Trans. vol. viii. p. 72.-Dorset Catalog. p. 33.-Turt, Conch. Diction. p. 84.Flem. Brit. Anim, p. 433,-Dillw. Recent Shells, vol, i. p. 142.-Index Testaceolog. pl. 6, Mactra, f. 26.

A mplidesma tenue, Lam. Anim. s. Vert. (ed. Desh.) vol. vi. p. 128.-Turt. Dithyra. Brit, p. 53.-Fuem. Brit. Anim. p. 432,-MACGilurv. Moll. Aberd. p. 293.-Brit. Marine Conch. p. 55, f. 24.-Brown, Ill. Conch. G. B. p. 105, pl. 45, f. 2.Delessert, Recueil Coquilles, pl. 4, f. 6.-Hand. Recent Shells, p. 42 .

Syndosmya tenuis, RecLuz, Revue Cuv. Zool. 1843, p. 366.-RecLUz, in Chenu's Ill. Conch. Syndosmya, p. 3.

This small Syndosmyce is nearly equilateral, subtriangular, very thin and fragile, somewhat translucent, and under a very delicate sallow and slightly concentrically wrinkled epidermis, of a dirty white hue, occasionally somewhat iridescent, and but rarely glossy. The surface is 
moderately convex, and almost smooth, and the shell is a little open at either extremity. The lower margin is simply arcuated, with the arch a little flattened near the midcle; both the upper edges are almost straight, and profoundly and almost equally sloping. The sides are very nearly alike in size, the front one is rounder below, and obtuse above, the hinder is bluntly angulated. The beaks are small, but acute and prominent, and are directly inflected, not turning towards either side. The ligament is very minute, and lies at the bottom of the narrow escutcheon formed by the compression of the hinder dorsal margin. There is also a similar though less evident compression in front, whence originates a false or incipient lunule. No umbonal ridge is present. The hinge is only furnished in the left valve with a single denticle; the right valve has two denticles, and two lateral lamine, of which the hinder is large and more remote, and the front more approximate and decidedly smaller. The cartilage pit is large, much curved, and not at all angular. The length is not quite three-eighths of an inch, and the breadth is about one-sixth less.

Notwithstanding that it is locally abundant, this camnot be considered a very common species, being found in but very few localities. Perhaps a few miles beyoud Portland bridge in Dorsetshire (S. II.), where the ligh water-mark is indicated upon the muddy surface by the copionsly scattered shells of this and other Molluslis, may be regarded as its most prolific site. It has occasionally been taken in Northumberland ( $A$ leler); at Ramsgate (Sowerby, I'Andrew); at l'ortsea and Southampton (Jefíreys); Torhay (Alder); and met with, thongh rarely, at Scarloorough (Bean); and Littlehampton in Sussex (Strickland).

Mr. 'Thompson has received some individuals from Larme Lough in Antrim (Amn. N. II. vol, xiii. p. 433), the only 
Irish locality from which he has seen unquestionable specimens.

The Syndosmya truncata of Recluz (Rerue Zoologique, 1843, p. 368 ; in Chenu, Illust. Conch. Syndos. p. 4,) is entirely constructed from the Amphidesma truncatum of Brown's Illustrations of the Conchology of Great Britain, p. 106, pl. 42 , f. 4 , a species which is rendered peculiarly obscure, through the drawing and description being at variance, an error which, unfortunately, the author's memory is unable to account for. Neither of them, however, suggests to us the idea of its belonging to this genus, the figure, especially as regards the hinge, not being unlike the young of our solitary species of Scrobicularia. The reference to the species so named in Fleming's work on the British Animals, would have led us to the supposition that it was a Thracia, that shell being avowedly the Anatina truncata of Turton, which we know from the types to be a variety of Thracia distorta, but the indicated teeth of the following description are entirely adverse to such a conclusion.

"Subovate, rather convex, oblique, anterior side produced; posterior side rather straight and subtruncated below; with a flexure emanating from the umbo, and terminating on the margin; umbones small, nearly central and slightly inflected, beneath them a lanceolate cavity or lunule, covered with transverse nearly obsolete striæ and wrinkles; surface white, smooth, and glossy; hinge with a double primary tooth in each valve, and a small tooth-like knob in the left valve, locking into a cavity for its reception in the opposite one ; inside smooth, glossy, and white; each valve provided with two large muscular impressions; margins rather thick for the size of the shell. Length three-eighths of an inch; breadth half an inch. Found at Greenock by Stewart Ker, Esq. and is in the cabinet of Lady Jardine.

\section{SCROBICULARIA, SchUMACHER.}

Siretr compressed, subequivalve, dull, nearly smooth or marked by lines of growth. Muscular impressions round, pallial sinus ample. Hinge with small and narrow primary teeth, one or two in each valve; no lateral teeth; spathulate triangular fulcra in each valve with comecting cartilage. Ligament small, narrow, partially external.

Animal compressed, oblong or suborbicular; mantle open, its margins distinctly denticulated. Siphonal tubes long, separated throughout, thcir orifices plain. Foot large, linguiform, compressed. Labial palps large and triangular. 
This genus is closely allied to the last, though there are sufficient distinctions between both shell and animal-distinctions of more consequence than those which separate

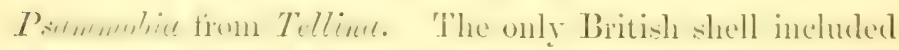
in it has had the felicity of enjoying at various times not fewer than a dozen generic titles. The fow known species live in the mud of estuaries, and are gregarious.

\section{S. prperata, Gmelin.}

I'late XV. fig. 5, and (Animal) Plate K. fig. 6.

List. Ilist. Conch. pl. 253, f. 88.

Mya Mispanica, Crieun. Conch. vol. vi. p. 31, pl. 3, f. 21.

Fonus Borealis, PeNs. (not Linn.) cd. 4, vol. iv. p. 96, pl. 48, f. 28 (badly).

Trigonellu pluna, DA Costa, Brit. Conch. p. 200, pl. 13, f. 1.-Exp. Scient. Algerie, Moll. pl. 44 to 64 (shell, animal, and anatomy).

Mya Gaditara, Guemin, Syst. Nat. p. 3221 (made from figure only).

Mactra Listeri, Guelix, Syst. Nat. p. 3261.-Linn. Trans, vol. viii.p. 71.Dorset Catal. p. 33, pl. 7, f. 1.-T'UnT. Conch. Diction. p. 83. -Index Testac. pl. 6, Mactra, f. 25.

Mactra piperata, Guelis, Syst. Nat. p. 3261.-Dillw. Recent Shells, vol. i. p. 142.

Muctra compressa, Pulteney, in Hutchins' Dorset, p. 31.-MIont. Test. Brit. p. 96 and 570 .

Tellina pluna, Dowov. British Shells, vol. ii. pl. 64, f. 1.

Lutraria compressa, Lax. Anim. s. Vert. (ed. Desh.) vol. vi. p. 91. - Crovch, Introd. Conch.pl.4, f. 3.--IIANL. Recent Shells, p. 27.Cinexu, Ill. Conch. Lutraria, pl. 1, f. 7.-Brown, Ill. Conch. G. 13. p. 109, pl. 43, f. 4.

Lutraria piperata, Las. Anim. s. Vert. (ed. Desh.) vol. vi. p. 92.-Phinep, Moll. Sicil. vol, i. p. 9.

Listera compressa, Tunt. Dithyra Brit. p. 51, pl. 5, f. 1, 2.-Brit. Marine Conch. p. 45.

Lutricola compressa, BLA1Nv. Malac. pl, 77, f. 2 .

Scrobicularia piperata, PHiLippi, MIoll. Sicil. vol. ii. p. 8.

Lutraria Listeri, MLAcgilliv. Moll. Aberd. p. 291.

Lacigno calcinella, RecLuz, III. Conch. Lavigno, p. 3.

Amy hidesma trunstersum, $\mathrm{S}_{A Y}$, Americ. Conch. pl. 20, mid. figures (fide Recluz).

So peculiarly wide a variation of outline seems permitted to this species, that until very lately, the elliptic specimens

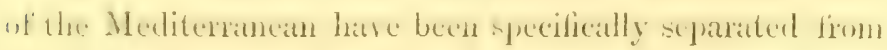


their more trigonal brethren of the Atlantic Ocean. Oux British examples, which all display a certain degree of triangularity, vary in shape from elliptic to suborbieular, the length being, however, always greater than the breadth. The valves are subequilateral, compressed, dull, or but very slightly glossy, and of an uniform squalid white, but very frequently stained black by the colour of the mud in which they are imbedded : they are opaque, fragile, though not particularly thin, and either smooth, or marked with very delicate concentric wrinkles, and more distant stages of growth. The ventral margin is not much arcuated, and whatever degree of ascent exists at its extremity, is almost always straightish, or even at times slightly retuse, near the middle. The dorsal edges vary greatly in the amount of declination, but are always more or less straight, and the ligamental one is generally the more sloping. The anterior side is very slightly the shorter, its extremity is rounded, but more regularly so below than above. The posterior side is but little attenuated at its extremity, which is bluntly subangulated, and situated rather below than above the middle of the side, its exact elevation being dependent upon the greater or lesser rise of the ventral margin posteriorward. The umbones are rather prominent; the beaks acute and incurved, not leaning to either side, nor preceded by any lunule-like depression. The ligament is small and narrow, but rather projecting: there is a certain degree of depression at the hinder dorsal surface of the shell. There is little or no elevation of the umbonal ridge, but there is usually a more or less obsolete shallow groove adjacent to its site. 'The inner surface is of a glossy white, occasionally, but rarely, stained slightly with yellow: the cartilage pit is triangular, and rather large; in front of it lie the small and extremely narrow primary teeth, a simple and solitary one 
in the left value. interlocking between what may cither be regarded as twin narrow tecth, or as a most broadly and profoundly cloven single one. The pallial sinus is of the ment ample matenturle. Fine specimens oceasionally reach the size of two inches in length, and one-and-a-half in breacth: the exact proportions are, however, very fluctuating.

The amimal of this species has heen frequently submitted to examination, and some good figures of it have been publishere : it is sulutriangular, compressed, and rellowish, or pale orange; the mantle is freely open, and the margins are only slightly and distantly fringed, or rather denticulated, so that they sometimes appear as if quite plain; the siphonal tulues are long, rellowish, and separate, their extremities plain: they are very contractile; the foot is large, white, flat, tongue-shaped, and genienlated; the lathia are very large, triangular, and pointed. Elaborate figures of the anatomy of this animal have lately been published by Deshayes in his gorgeous work on the Mollusea of Algeria.

As Montagu remarlis, it is "chiefly found at the months of rivers or inlets not remote from fresh water; and thongh never beyoud the flux of the tide, yet it delights in situations where fresh water is occasionally flowing over. It principally inhabits sludge or muldly places, huried to the depth of five or six inclies." It is from the comparative inaccessibility of such spots, that the species, although most almurlant, is not frequently taken alive, and that cabinets are usually only furnished with dead valves washed on shore after rough weather. It is common at Scarborough (Bam); Liverpool (F. F.); Sllellness, near Rimsugate (S. II.); Littlohimpton in Sussex, and Southend in Fisex (Strickland); in four fathoms near the Nore light, and 
northwards to the Dudgeon, but not farther (Thomas); Swanser and Langland Bay (Jeffreys); near Langharne (S. H.) ; Cork (Humphreys); "in suitable places on each side of the Irish coast" (Thompson); Clyde (Smith); Skye and Frith of Forth (E. F.).

\section{SPURIOUS.}

\section{Amphidesma reticulatum, Linnæus.}

Tellina reticulata, LinNaus, Syst. Nat. ed. 12, p. 1119.-Linn. Trans. vol. viii. p. 54, pl. 1, f. 9.-Dorset Catalog. p. 30, pl, 5, f. 4.-TurT. Conch. Diction. p. 174.-Chens. Conch. Cab. vol, vi. p. 124. pl. 12, f. 118.-Woon, General Conch. p. 182, pl. 42, f. $2,3$. Dillw. Recent Shells, vol. i. p. 470.-Index Testaceol. pl. 4, f. 70 .

Tellina proficux, Pultenex, Hutchins, Dorset, p. 29, pl. 5, f. 4.-Mont. Test. Brit. p. 66.

Amphilesma reticulatum, Sowerby, Genera Shells, Amphid. f. 2.-Crovcr, Introd. Conch. pl. 4, f. 9.-Sowerby, Conch. Man, f. 85.Desh. Encycl. Méthod. Vers, vol. ii. p. 25.

Suborbicular, a little oblique, moderately strong, somewhat translucent near the beaks, moderately convex, umbones and interior rich yellow, elsewhere white; surface with moderately close set concentric little elevated lamine (usually obsolete above), the interstices of which are delicately radiated with very small raised wrinkles. Lower edge strongly arched, ascending posteriorly: beaks curved forward, subcentral. Dorsal edges very moderately sloping, the front one straightish, the hinder one decidedly convex or subarcuated. Both extremities rounded, the posterior one rather obtusely. Two small primary and two short strong approximate lateral teeth in one valve; cartilage pit narrow, triangular; hinder dorsal area with a slight and narrow depression. Diameter an inch and a quarter.

A native of Brazil (?), introduced by Dr. Pulteney as taken at Poole and Weymouth. 


\section{SPURIOUS.}

\section{Sangunolatia deflorata, Linnæus.}

Tenus deforatu, Liss. Syst. Nat. p. 1133.-Penv. Brit. Zool. ed. 4, rol. iv. p. 96, pl. 57, f. 54.-MoNT. Test. Brit. p. 123, pl. 3. f. 4.Linn. Trans. vol. viii. p. 123.-Turt. Conch. Diction. p. 240. Tellina anomala, Criesn. Conch. Cab. vol. vi. p. 93, pl. 9, f. 79 to 82.

Sanguinolaria rugosa, LAM. Anim. s. Vert. (ed. Desh.) vol. vi. p. 170 (in part).Brit. Marine Conch. p. 64 .

Psammobia deflorata, Tunt. Dithyra Brit. p. 93.

Sanguinolaria deflorata, FLEM. Brit. Anim. p. 461.

Psammolia rugosa, Sowerny, Genera Shells, Psammobia, f. 1.-Renve, Conch. Systemat. pl. 53, f. 1 .

Capsa deflorata, Coxrad, Americ. Marine Conch. pl. 17, f. 2.

Sanquinolaire vidée, Chesu, Traité Element. p. 60, f. 208.

Encyclop. Méthod. Vers, pl. 531, f. 3, 4.

An exotic species, introduced by Pennant, of which a single individual was obtained by Montagu in Falmouth Harbour. Touching this last locality, so frequently quoted by our earlier uriters for doubtfully indigenous specics, we fully agree with $\mathrm{MW}$. Alder, who, referring to the large quantity of foreign ballast continually thrown into it, observes, "that no dependence can be placed on the indigenousness of any shell, which has solely been found in that harbour." As there are at least two varieties (?) of the Lamarction Sanguinolaria rugosa, besides the S. dichotoma (Chemnitz, Conch. Cab. vol. vi. pl. 9, f. 83,) which has justly been held specifically distinct by Anton (Verz. Conch. p. 4), we may remark that our pseudo-British one is the West Indian and South Americen shell, altich differs from the Orientul individuets, among other respects, in being less inequilateral, less coarsely and more crowededly ribbed, and in leaving the lower or ventral margin mach less arcuated. 


\section{DONACIDA.}

Turs small tribe is nearly allied to the last. The shells are usually of much stronger and more compact texture, and their hinges, though variable, more highly developed, and provided with conspicuous primary teeth. The animal is often more or less brightly coloured, and is strikingly distinguished by the great development of the cirrhi around the orifices of the rather strong siphons, those of the branchial tubes being more or less pinnated and ciliated. The margin of the mantle, which was almost always fringed in the last tribe, in this is indifferently plain or cirrhigerous, even in the same generic group. The foot is very large, thick, sharp-edged, and not furnished with a byssal groove. The species of this tribe live buried in sand, most of them near the water's edge, and are, on the whole, members of southern and even tropical regions. They rarely occur in the fossil state, their littoral habits being unfavourable to their preservation.

\section{DONAX, LINNAUS.}

Shell rather strong, more or less triangularly wedgeshaped, equivalve, very inequilateral ; posterior side shortest; surface smooth, or radiato-striate, or decussate, covered by a distinct epidermis. Inner margin plain or denticulated; muscular impressions rounded or oblong; pallial sinus wide and deep, its outer edge rather distant 
from the margin. Hinge composed of two primary teeth in one valve, and one in the other, with accessory lateral teeth. Ligament short, external.

Animal oblong, its mantle freely open in front, with fringed, or partially fringed (or plain ?) margins. Siphons seprinted to their bases, the branchial with pimnated cirrhi around its orifices, the anal with simple denticulations. Foot very large, apiculated, sharp-edged. Branchial lamina on each side distinctly separated. Labial palps long and triangular.

\section{D. anatinus, Lamarck.}

Inner margin crenulated; hinge with lateral teeth.

Plate XXI. figs. 4, 5, and 6, and (animal) Plate K. fig. 7.

Lister, Hist. Conch.pl. 376, f. 217.

Donax trunculus, Lisw. Syst. Nat. ed. 12, p. 1127, partly (not of Mus. Ulric.). -PENn. Brit. Zool. ed. 4, vol. iv. p. 93, pl. 55, f. 45.Pulteney, Hutchins, Dorset, p. 32.-Donov. British Shells, rol. i. pl. 29, f. 1.-Mont. Testacea Brit. pt. i. p. 103.Dorset Catalog. p. 33, pl. 6, f. 3.-TurT. Conch. Diction. p. 41.-Turt, Dithyra Brit, p. 123.-Flem. Brit. Anim.p. 433.-Macgilliv. Moll. Aberd. p. 275,-Brit. Marine Conch, p. 77.-Brown, Ill. Conch. G. B. p. 97, pl. 39, f. 11. -Dillw. Recent Shells, vol. i. p. 150.-Index Testaceolog. pl. 6, Donax, f. 5.-MAwe, Conchology, pl. 9, f. 5.Crovcri, Introd. Conch. pl. 6, f. 5 .

Cuners vittalus, D. Costa, Brit. Conch. p. 207, pl. 14, f. 3.

Donux anatinum, Lam. Anim, s. Vert. (ed. Desh.) vol, vi. p. 249,-Hanl. Recent Shells, rol. i. p. 83.

Donax ruber (YOUNG), Turt. Dithyra Brit. p. 127, pl. 10, f. 14.-Flem. Brit. Anim. p. 434.--Brit. Marine Conch. p. 79.Brawn, 1ll. Conch. G. B. p. 97, pl. 13, f. 13.

'This extremely common shell is not the D. trunculus of' Continental writers, although perhaps exually entitled (since both conjointly received this epithet from Limnens) to be termed so; nevertheless, as the appellation cannot be retained for more than one of them, it is hedd advisible 
to yield the name to the Merliterranean species, not only from its being almost universally so desiguated throughout Europe, but likewise from there existing a slight balance in its favour, on weighing the rival claims by the evidence of the original synonymy and descriptions.

The shape of our British species is oblong-cuneiform, and the texture is always more or less firm; although most decidedly inequilateral, for its genus it is less so than usual. Typically it is compressed, but certain solid and gigantic specimens from Stornaway are convex or even subventricose. The exterior is more or less glossy, and is sculptured with fine rather closely set radiating simple strix, which diverge rather widely towards the margin, and do not extend to the front portion or the hinder area; these in many specimens (but not invariably) are decussated by still finer irregular scratch-like concentric lines on the hinder side. Berieath the shining epidermis, which passes from a lighter or darker oil-coloured yellow, almost into olivaceous, the surface is generally tinged with livid lilac of different shades (more rarely being pure white both within and without), sometimes uniform, but frequently with two paler or even white central diverging rays proceeding from the bealss, with the lines of increase indicated by deeper belts of a livid hue: internally the colour ranges from white to the darkest violet. The ventral margin is more or less sinuous, presenting a slight and often almost imperceptible trace of retusion posteriorly, but bulging out anteriorward ere it abruptly ascends at the obtusely rounded front extremity. The dorsal edges are nearly straight (yet always sinuous in some trifling degree), and in ordinary sized specimens the front one scarcely declines, and the hinder one but moderately ; the extent of declination increases, however, in the young, and in the large variety we have 
previousy mentioned. The extremity of the posterior side, which is about half as long as the other, is very bluntly werde--Inaped; its dorsal area is more or less slightly flattened (with the lips, howerer, propecting), and exeepting mear the arute and slightly inclined beaks traversed by more or less close concentric strix, and occasionally even ly some minute crowded radiating strie near the ligament. The umbonal ridge is well developed, but obtuse. The inner edge is finely crenated posteriorly, and very strongly so at the ventral portion of it; anteriorly it is simple. The central triangular primary tooth of the right valve is profomedly bifid, or eren bicuspidate, the broadly diverenging narrow ones of the opposite valve are simple; there are two small approximate lateral teeth in the left valve, of which the anterior is nearly rudimentary, and almost adjacent to the primary.

The average size of specimens is about an inch and a fifth in length, and alout eleven-sixteenths of an inch in breadth; the Stornaway variety exceeds an inch and a half in length, and is of proportionate wilth likewise.

The fry of this species is certainly the D. ruber of 'Turton's Dithyra, as we have ascertained from his cabinet; posibly also that of Montagu ('Test. Brit. Suppl. p. 3S.Thurt. Conch. Dict. p. 4:?), but the firet is not erpually well assured. Youmg shells are almost destitute of any striation; they retain, however, their characteristic form, and are peculiarly and tolerably evenly compressed.

The animal is oblong, and rather thick. Its mantle is freely open in front, and has the margins fimbriated. $\Lambda \mathrm{c}$ cording to Mr. Clark, the edges are double, the outer one plain or slightly crenulated, the imner furnished with a close set fine white fringe every where bordering it, except at the ligament, and composed of alternately longer and 
shorter cirrhi, all being longer in the neighbourhood of the tubes than elsewhere. The tubes are separated throughout, and rather long. The orifice of the branchial siphon has eight principal cirrhi ramifying, or pinnated and ciliated at their extremities; the anal is surrounderl by six short single points. Both are of a pale orange colour, and often marked above and below by deeper bands of the same tint. The foot is yellowish, very large, pointed, and sharp-edged, plaited at the base when retracted, and not furnished with a byssal groove. The labial palps are brownish, very long, triangular, and pointed. The animal is sluggish when removed from its native locality, but is capable of active motion.

Few if any bivalves seem more universally diffused around our coasts. Wherever there exists a wide range of unmixed sand, there they are ordinarily met with in the greatest abundance, buried an inch or two from the surface, towards low water-mark.

The D. fabagella of Lamarck (judging at least from a specimen which we received in Paris from M. Recluz, as having been compared with the original type) is precisely identical in contour; it is, however, distinctly sulcated, and not merely striolate throughout the posterior half, and the radiating striæ appear entirely obsolete on the anterior side. The $D$. venusta of Poli is equally allied, but has, in all stages of its growth, strong and rather remote sulci upon its hinder dorsal area. The entire absence of these latter in the real $D$. trunculus, forms one of the most immediately perceptible marks of its distinctness from the present species. 


\section{D. politus, Poli.}

Inner margin entire.

Plate XXI. fig. $\mathbf{7}$.

Lister, Hist. Conch. pl. 384. f. 227.

Tellina polita, PoLI, Test. Sicilix, pl. 21, f. 14, 15.

Donax complanatus, Mont. Test. Brit. p. 106, pl. 5, f. 4.-Linn. Trans. vol. viii. p. 75.-Turt. Conch. Diction. p. 42,-Turt, Dithyra Brit. p. 125, pl. 7, f. 13, 14.-Fuex. Brit. Anim.p. 433. Brit. Marine Conch.p. 78.-Dillw. Recent Shells, rol. i. p. 150.-Là. Anim. s. Vert. (ed. Desh.) volo vi. p. 249.

-Index Testaceolog. pl. 6, Donax, f。 6 .

Psammotia polita, Costa, Catal. Test. Sicilix, p. 20.

Capsa complanata, Sowerur, Genera Shells, Capsa, f, 2,-Brown, Ill. Conch. G. B. p. 96, pl. 39, f. 10.-PAyraudeau, Cat. Mroll. Corse, p. 46.-Reeve, Conchol. Systemat. pl. 61, f. 2.Hand. Recent Shells, p. 86, pl. 6, Donax, f. 6 .

Donax longa, Puilipri, Moll. Sicil. p. 37, pl. 3, f. 13.

Among our more beautiful shells, must certainly be reckoned the $D$. complanatus of Montagu, its vivid tinting presenting one of the few exceptions to that tameness of coloming which characterises the testacea of the less sumny climates of Europe. WV have allowed to Poli the meed of priority in nomenclature, although he has erroneonsly placed it in the genus. Tellina; but his error is exeusable, from its being so aberrant a Donax as to justify that position in a Linnean arrangement.

The shape is of an elongated subenneiform oblong, and the texture, although tolerably firm, is by no means typically solid. Its convexity is not great, the inclination being rather to compression than otherwise. The exterior, which is entirely devoid of any sculpture whatsoever, is covered with a delicate yellow highly polished epidermis, leneath which it is angularly mottled with liver-colour ol rich brown, varying much in intensity of hue. $\Lambda$ single, 
rather broad, conspicuous white ray runs from the beaks, with but very trifling obliquity, to the commencement of the posterior third of the ventral margin. This latter is comparatively straight, the anterior portion bending but little from its regular curve, and ascending with a moderate "pward inclination to the well-rounded anterior extremity. The dorsal edges are tolerably straight, the front is but little, and the hinder but very moderately sloping. Hence the posterior wedge-shaped termination is very blunt, the tip being rather broad and well-rounded. As the umbonal ridge is rather obscure, the hinder area is not distinctly defined; it is not, however, flattened, and the lips pout, or project outwards. The sides for a Donax are not peculiarly unequal, the anterior one not being quite double the length of the other. The ligament is short, prominent, and of a rich fulvous brown; the lunule is very indistinctly impressed. The beaks, which are by no means prominent, are yet sufficiently acute at their apices, which are scarcely inclinerl, and are sometimes purple, sometimes orange yellow, and sometimes white. One of the more beautiful varieties has the umbonal region of a deep violet, with the beals of a snowy whiteness. The interior of the shell, which has its margins simple and not crenated, is usually of a rich purple or violet; sometimes, however, it is white, somewhat radiatingly stained with purple, and the ricinity of the beaks adormed with a deep and brilliant orange. The hinge of the right valve presents the ordinary solid bifid hinder primary tooth, and the very oblique and almost linear front one, with a rudimentary linear intermediate one (to be met with in many, if not most of this genus); in the right valve, in addition to the divergent narrow almost simple primary teeth, are two small approximate sublateral ones, of which the anterior is so 
immediately adjacent that the term lateral is almost inappropriate.

'The animal, according to Poli, has long divided siphons, of' a bright yellow colour, with orange stripes and pink cirrhi. The foot is large and white.

The largest specimens we have seen came from the Channel Islands, and were almost an inch and a half in length, and about half that space in brealth. 'These dimensions fir exceed, however, the average size of specimens; those from Ireland are generally much smaller, but of more vivid painting. Althongh found in many localitics, it is never common, and is generally prized by collectors. It is oceasionally met with at Exmouth, Dawlish, Falmonth, Milton in South Devon, Looe in Cornwall. (Mont.)

In Ireland it is chiefly procured from Bantry Bay. (Humphreys.)

Mr. Inanley has received from Dr. Philippi an almost colourless and rayless variety from the Mediterranean, with the information that it is rarely met with. We are not aware that this has hitherto been discovered on our own coast.

D. trunculus, Limnæus.

Donax trunculus, Liss. Syst. Nat. ed. 12, p. 1127.-Bons, Mus. Cæs. pl. 4, f. 3, 4.-Chemn. Conch. Cab. vol. vi. pl. 26, f. 253, 254.Poli, Test. Sicil. pl. 19, f. 12, 13.-Lam. Anim. s. Vert. (ed. Desh.) vol. vi. p. 248,-Philippi, Moll. Sicil. vol. i. p. 36, and vol, ii. p. 23.-Desir. Exped. Scient. Algéric, Moll. pl. 74, f. 1 to 5 , and pl. 75 (anatomy).

Capsa " Hand. Recent Shells, p. 87, p]. 11, f. 38. Encyclop. Méthod, Vers. pl. 262, f. 1 .

Although placed in this second section of very uncertain if not solcly exotic species, it is by no means impos- 
sible, when the differences between this and the trunculus of the British conchologists are clearly understood, the discrimination of other individuals may establish a claim for this shell to be regarded as indigenous. At present the sole specimen we have seen, now in the collection of Mr. Metcalfe, was taken (not living) by Dr. Battersby, at Torquay. As that gentleman has no foreign collection, and is of the most unimpeachable veracity, no doubts could rest upon its British origin, were it not that Torquay has for years been so closely investigated, as to render it extremely improbable, supposing the species to be truly mative, that other examples should not exist in some of the numerous collections continually being formed at that attractive watering place.

Hence, from what may not unlikely be esteemed an overcantiousness, we prefer at present regarding it among our doubtful species; indeed, its mention at all, contrary to our usual rule of confining our attention among the supposed spuriously indigenous, to those mentioned in print (for otherwise the number of the excluded would far exceed those of undoubted British origin), is solely owing to the highly respectable authority of the naturalist we have mentioned.

The valves are oblong wedge-shaped, very inequilateral, strong, and not very convex. They are covered with a very thin epidermis, of darker or lighter shades of fulvous or buff-coloured yellow, beneath which the surface is usually of a glossy liver-colour, with often linear paler rays, but sometimes even of a pure uniform white. The ventral margin slightly bulges out anteriorly, and greatly ascends at that extremity which is obtusely rounded, and not much attenuated. The hinder side is scarcely equal to one fourth of the front; its blunted wedge-shaped termination is very abrupt, as the hinder dorsal edge slopes most surdenly and deeply from the ligament; the front dorsal edge is tolerably straight and but slightly declining. The beaks are somewhat inclined, and not acute; the lunule is linear and deeply excavated, and the posterior 
area, which is defined by a very obtuse umbonal ridge, is generally convex (invarialbly, however, with the lips pouting), and perfectly destitute of any sculpture. The interior of the shell is of a riolet or purple east, the lower edge is strongly crenated, but the posterior crenulations do not extend to the ligament. The hinge is destitute of lateral teeth. The size is about seventeen lines in length, by about eight and a half in brealth, and five and two thirds in deptl. It is one of the commonest species of the Mediterranean, replacing, as it were, the anutinus of the colder shores of Europe.

SPURIOUS.

D. denticulatus, Limnæus.

Donax denticulate, Lis. Syst. Nat. ed. 12, p. 1127.-Pultenex, in Ilutchins, Hist. Dorset, p. 32.-Mont. Test. Brit. p. 104.-Linn. Trans, vol. viii. p. 76.-Dorset Catal. p. 34, pl. 5, f. 12.Turt. Conch. Diction. p. 41.-Wurt. Dithyra Brit. p. 124.-F LeM. Brit. Anim. p. 433.-MAcGIL. Moll. Aberd. p. 275.-Brit. Marine Conch. p. 78.-Dillw. Recent Sh. vol. i. p. 151.-Lan. Anim. s. Vert. (ed. Desh.) vol. vi. p. 246.-Hanl. Recent Sh. p. 82, pl. 6, Donax, f. 8.

"punctata, Chems. Conch. Cab. vol. vi. p. 262, pl. 26, f. 256.

" crenulata, Donov. Brit. Shells, vol. i. pl. 24.

A West Indian shell first introduced as British by Da Costa, under the name of Cuneus truncatus. As regards the denticulatus of Pennant, (ed. 1, vol. iv., p. 93, pl. 55, $f .46$, ) neither the drawing nor the language of that author sufficiently coincide with the characters of this well-known Donax, to render the identity at all probable. Indeed the elongated form of his engraved figure, (which bears more resemblance to the true rugosus of Linnows,) supported by his assertion of its exceeding the length of anatinus, must be fatal to such an hypothesis. Several of our British authors have admitted it in their works, but, we believe, no proof of its indigenousness has yet been furnished. Mr. Bean informs us that very many years ago he took a valve from a fishing-boat at Scarborough; but as, during his many years' subsequent residence on 
the same spot, he has never procured a second example we think it most probable that the shell came from some foreign vessel.

\section{ERVILIA, Turton.}

Shell more or less solid, equivalve, inequilateral, oblong, depressed, closed. Surfice transversely striate or nearly smooth. Two diverging teeth in each valve, one of them in the right valve ligh and projecting: a cartilage pit in each for the reception of the comnecting internal cartilage. No lateral teeth. Muscular impressions strong; pallial sinus large and broad.

\section{Animal unknown.}

This genus, which was constituted by Turton for the Mya nitens of Montagu, has lately been revised and redefined by Recluz.* It has considerable relations with Mesodesma, but until the animal shall have been observed, its true position ean only be assigned by analogy, as indicated by the shell alone. The species here described are all which have as yet been enumerated as members of the group.

\section{E. castanea, Montagu.}

Plate XXXI. figs. 5,6 .

Donax castanea, Mont. Test. Brit. p. 573.-Linn. Trans, vol. viii. p. 77.-TurT. Conch. Diction. p. 42.-Dillw. Recent Shells, vol. i. p. 152. -Index Testac. pl. 6, Donax, f. 10.

Capsa castanea, Turt. Dithyra Brit. p. 128, pl. 10, f. 13.-Flem. Brit. Anim. p. 434.-Brown, Ill. Conch. G. B. p. 96, pl. 39, f. 12.

Mesodesma castanca, Brit. Marine Conch. p. 54.

Ervilia castanea, Recluz, Mag. de Zool. 1845, pl. 95.-Recluz, in Chenu Ill. Conch. Ervilia, p. 3.

The shape of this interesting and rare shell, erroneously placed by Dr. Turton in the genus Capsa (which has a

* Revue Zoologique par la Soc. Cuvierienne, March, 1844. 
prominent external ligament), is oblong elliptic, its length being nearly double its breadth. It is solid, opaque, and tolerably convex, the swell diminishing moderately and evenly from the umbones on either side. The colouring is slightly variable, but always of dirlier or lighter tints of warm chestnut, the ground-colour being usually pale or almost whitish (but sometimes decided chestmut), with an almost vertical ray of dark chestnut-brown, which is usually narrow, and does not reach to the beaks, lying almost direetly beneath them, and very slightly eurving to the longer side: the extreme posterior portion is likewise stained with a similar brown tinge, forming a kind of olsolete lnoad ray extermally, but usually displayed more distinctly upon the interior; there is often too a third but almost obsolete ray-like stain adjacent to the anterior extremity. The surface is slightly glossed, and, from the more or less abraded state of our English specimens, is quite smooth; in the living examples, however, it is concentrically substriolate, the striule being more closely and regularly dieposed on the anterior side. The ventral margin is convex or subarcuated, and rises the more anteriorly, where it often forms a slight sulsangulation above with the dorsal ertge, which margin is more or less rectilinear towards the beaks, but subsequently has a tendeney to display convexity. The produced posterior side is attemuated and bluntly rounded at its termination; the anterior varies in these respects, but is more usually narrowed and only romuled below, yet occasionally is rather the broater ent, and rounded both above and below; the hinder dorsal margin is retuse near the beaks, then straightish, and finally just convex; its declination is very trifling, that of the shorter extremity is rather more considerable. The beals, which are acute and rather prominent, are situated 
at two-fiftlis the distance from the shorter end, and lean slightly backward: there is no lunular depression upon the dorsal area. The inner margin is quite entire; the hinge-margin is wide and shelving inward near the beaks. The hinge, which is destitute of lateral tecth, consists of a broad and profound central triangular cartilage pit, preceded in the right valve by a strong but narrow triangular lighly projecting primary tooth, and succeeded by a still narrower very oblique laminar one, which defines it posteriorly and occasionally leans over it; in the left valve the tooth-receptacle is scarcely divided from the cartilagepit by a narrow and hardly raised wall, and is bounder in front by a very oblique and but little elevated lamina; a similar but more indistinct one succeeds the cartilagepit, but the majority of specimens (being worn) display scarcely any traces of dentition in this valve; none of the teeth are cloven. The muscular impressions are seated high up, and are profoundly impressed; the pallial sinus is rather large, and not much attenuated at its extremity.

The ordinary length of the larger shells is nearly half an inch; their breadth is rather more than half this measurement.

The animal is unknown.

Notwithstanding that numerous examples have been procured from Cornwall and the Scilly Isles (the only habitats on the British shores), none but single, and more or less worn, valves have hitherto been detected. As the species is taken alive (and in that state it is very beautiful, the interior being rich violet, the external rays of a deep chocolate, and the intermediate spaces whitish or tinged with violet) in the Red Sea, we might have supposed them the produce of some wrecked vessel, but they have been taken continually in these localities from 
the dirys of Montagn to the most recent period, and not merely ean upon the shores, hut by dredging (S. H. 1848) in deep water in fifty-four futhoms between Scilly and Cornwall (M'Antrew); and in twenty fithoms near Penzance (M'Andrew and E. F.). In a recent state these valves are partially covered ly a slight yellowish epictermis, of a somewhat horny texture.

\section{SPURIOUS.}

\section{E. Nitexs, Montagu.}

Mya nilens, MLost. Test. Brit. Suppl. p. 165.-Turt. Conch. Diction. p. 103.Lasker, in Werner. Memoirs, vol. i. pl. 8, f. 4.-Wood, General Conch. p. 101.-Dil Lw. Recent Shells, vol. i. p. 47.

Amplidesma purpurascens, LaM. Anim. s. Vert. (ed. Desh.) vol. vi. p. 129.HANL. Recent Shells, vol. i. p. 43.

Errilia nitens, Turt. Dithyra Brit. p. 56, pl. 19, f. 4.-Fuem. Brit. Anim. p. 431. - Brit. Marine Conch. p. 5.-Soweru. Conch. Manual, f. 497. -Hant. Recent Shells, p. 43.-Recluz, Mag. de Zool. 1845, Moll. pl. 96.-Recluz, in Chenu, Ill. Conch. Ervilia, p. 3.Philippi, Wiegman's Archiv. f. Naturg. 1847, pl. 3, f. 9.

Syndosmya purpurascons, Recluz, Rev. Cuvier. Zool. 1843, p. 365.

The contour is oval and very slightly oblique, and the valves glossy, tolcrably strong, compressed, and regularly and closely sculptured with concentric strix, which usually cover the entire surface; we possess, however, a young variety differing in no other respect, in which they are entirely obsolete on the longer site. The colouring (which is both externally and internally the same), varies from uniform rose colour to almost pure white, but is usually of a darker or lighter tint of the former, becoming pale or colourless towards the ventral margin and at the shorter side. The valves are devoid of any umbonal ridge, and rounded at both extremities, the front tapering in some degree, and the hinder termination being considerably attenuated. The ventral edge (which is entire within), is considerably, yet not regularly, arcuated, ascending chiefly in front; the dorsal margin slopes decidedly on either side, but more so in front, where it is nearly rectilinenr, than behind, where, as it recedes from the middle of 
the shell, it becomes convex or even subarcuated. The posterior side is about half as long again as the anterior. The beaks are very acute, moderately prominent, not leaning to either side, and preceded and succeeded by a small depression, but no distinct Iunule nor escutcheon.

The hinge consists in the right valve of a very strong highlyprojecting primary tooth situated just in front of the apex, which is subtriangular in shape, and directed forward, in front of which the hinge margin, which is very thick and strong, is somewhat excavated; behind it, aud exactly beneath the apex, is the large triangular cartilage cavity, the front elge of which is perpendicular, and the hinder very oblique; there is also a fine linear excavation running along the posterior hinge margin. In the other valve, the margin on either side of the beaks is elevated so as to simulate two laminar diverging teeth, the broadly-triangular interstice being divided into a narrow and trigonal hollow for the reception of the opposite tooth, and a broader cartilage plate which projects in front beyond the basal line and whose anterior edge is elevated so as to resemble a linear tooth. The cartilage is inserted between a cut in the apices. The ordinary length is about three-eighths of an inch, and the breadth about one-fifth.

A West Indian shell, introduced by Montagu as taken near Dunbar by Mr. Laskey. It is not unimportant to remark, as accounting in some measure for the very considerable number of exotic shells introduced from the neighbourhood of Dunbar by IIr. Laskey, that several vessels from foreign ports had, just before that gentleman's investigation, visited his subsequent dredgingground, and their ballast was in all probability the fertile source of most of his additions to British Conchology, as it has in like manner added not a few spurious species to the Flora of the neighbouring district.

* An Ervilia pellucida has been added to this genus by Professor Macgillivray, which we vainly hoped to have examined before the publication of this sheet, as that gentleman had promised to forward us any of his species we might desire to investigate. Judging only from the description, we feel little doubt that it is merely the fry of a described species, and certainly not the Tellina pellucida of Brown, to which it was referred in the Molluscous Animals of Aberdeenshire, \&c. (p. 341, copied in the British Marine Conchology, p. 245,) which is a full quarter of an inch in length, and smooth in surface, \&c. ; while this is described as being but three-fourths of a line only, and concentrically sulcated. We owe to the kindness of Sir Walter Trevelyan (who found it at Senton, in Durham, an VOL. I. 


\section{SPURIOUS.}

Under the name of Mactra deaurata, Dr. Turton has introduced into our Fauna a species of the genus Mesodesma, stating that it was dredged up in the offing of Exmouth. One of our most assiduous and scientific collectors, Mr. Clark of Bath, whee rescarches in that neighbourhood extended over a period of twenty years, during that long space of time never once procured a single specimen, a strong, although negative, proof of the individual shell described hy the doctor being of forcign importation, and not of native origin. The species is an inhabitant of the Gulf of St. Lawrence, Newfoundland, and does not range to the European seas. Inquiries instituted on the Devonshire coast have enabled us to solve the mystery of the discovery of this and other transatlantic shells in spots so utterly at variance with their known habitats. We find that during many years several vessels from those parts were engaged in prosecuting the Newfoundland fisheries; so that the accidental appearance of a few specimens of northern shells may readily be accounted for, as they frequently are mingled with the ballast of ships. A comparison of the original type with its delineation in the Conchylia Dithyra, compels the remark, that it is represented as more narrow and elongated than nature has shaped it, and enables us to declare its perfect ilentity with examples of the Mesoctesma Jauresii, received by us from North America.

\section{M. deaurata, Turtoll.}

MFactra deaurata, Turt. Dithyra, Brit. p. 71, pl. 5, f. 8.-Flex. Brit. Anim. p. 427.

" denticulata, Index Test. Suppl. pl. 1, Mactra, f. 9.

Mesodesma denticulata, Grdy, Cuv. Anim. King. (ed. Grif.) pl. 22, f. 2.

inspection of the typical example of Tellina pellucida, which, crushed as it unfortunately then was through transmission by post, still remained sufficiently united to enable us to state with certainty that it is not an adult shell, (it was not unlike the fry of Scrobicularia piperata, ) and that the engraving of it (Ill. Conch. G. B. pl. 40 , f. 22) scarcely presents any resemblance to the species, the dorsal edge not being incurred, and the hinder termination not being rounded (as delineated) but subangular. 
Mesodesma Jauresii, De Joannis, Mag. de Zool. 1834, Moll. pl. 54.-Gound, Invert. Massach. p. 58, f. 38.-Deray, New York Moll. p. 231.

" deauratum, HanL. Recent Shells, p. 39, suppl. pl. 1, Mactra, f. 9.Brit. Marine Conch.p. 53.

Somewhat triangularly subovate, thick, heavy, opaque, very inequilateral, moderately convex behind, compressed in front; valves, when young, perfectly smooth and covered with a shining yellow epidermis; when aged, antiquated, and the epidermis olivaceous or dusky brown, beneath which the surface is whitish, or pale reddish brown. The anterior side is nearly double the length of the posterior, and tapers to a rounded extremity, the ventral margin, which is straightish near the middle, strongly ascends anteriorly in an arcuated sweep; the hinder extremity is most bluntly subcuneiform, the tip being broad and slightly rounded. The inclination of the front dorsal edge is very trifling, that of the hinder is much greater, but still moderate; the convexity of both of them is so slight as scarcely to be apparent. The beaks are not greatly elevated, but are rather acute when not eroded, and do not lean to either side; there is a slight flattening of the dorsal edge in front of them, but no lunule. The interior is more or less white, and the margins entire; the cartilage pit is broad, deep, and subtriangular, shelving dowuward so that its base is below the level of the inferior edge of the hinge margin, and appressed upon the subumbonal region; its lower edge is convex. The lateral teeth are remarkably strong and solid, and are more or less coarsely sculptured with raised perpendicular strix; both of them are approximate, and the anterior is distinctly the more produced. A small semicircular posterior sinus alone prevents the pallial impression from being simple.

The full dimensions assigned to it by Dr. Gould are an inch and three-quarters in length, by a little more than an inch in breadth. Our own and Dr. Turton's examples, are far less. The American author, whose opportunities of examining numerous specimens were of course superior to ours, remarks, that, on the anterior edge of the deep spoon-shaped cartilage-pit "is the vestige of a short, widely diverging, V-shaped tooth, which will seldom be found, as it is scarcely possible to open the valves without destroying it." 


\section{Mesonesma cornea, Poli (not Lamarek).}

Mactre comea, PoLl, Test. Sicil. vol. ii. pl. 19, f. 8 to 11.

Donar plebeiu, Pultexey, IIutchins Hist. Dorset, p. 32.-Mont. Test. Britan. p. 107, pl. 5, f. 2.-Dorset Catalog. p. 34, pl. 5, f. 13.-Tunt. Conch. Diction. p. 42.-Turt. Dithyra Brit. p. 126.-Fin.s. Brit. Anim. p. 434.-DrLww. Recent Shells, vol. i. p. 152.Index Testaceolog. pl. 6, Donax, f. 9.

Amplielesma Donacilla, Las. Anim. s. Vert. (ed. Desh.) vol. vi. p. 126.

Erycina plebciu, Sowerbr, Genera Shells, Erycina, f. 3.-Sowerny, Conch. Manual, f. 86 .

Mesodesma Donacillum, Desh. in Lam. Anim. s. Vert. (ed. Desh.) vol. vi. p. 133.-Brit. Marine Conch. p. 53.-Iievve, Conch. System. pl. 45, f. 5.-UANL. Recent Shells, p. 39, suppl. pl. 11, f. 41.-Philipri, Moll. Sicil. vol. ii. p. 29.-DEsr. Exp. Scient. Algérie, Moll. pl. 39, 40, 41, 42. (shell and animal).

Donacilla Lamarclii, Pminrer, Moll. Sicil. rol. i. p. 37.

An inhabitant of the Mediterranean; introduced by Dr. Pulteney as taken at Weymouth. The original specimens of plebcia are still preserved in the doctor's collection at the Linnean Huseum, and are clearly identical (which some have doubted) with the Donacilla of Lamarck. 


\section{MACTRID応。}

More than once we have had occasion to remark on the impossibility of arranging genera and tribes in order of aftinity, and at the same time of maintaining a continuous sequence in a single line. The family before us is an instance; for, whilst there can be no question that it has close affinities with the Veneride, it presents so many features which remind us of the Myada that we seem to have separated it from the last-named tribe by a forced and ummatural barrier when we marshalled the Tellens and their allies in the interspace. Yet they too aftord indications of near affinity - relations which the microscope has confirmed; for we find Dr. Carpenter describing the texture of the shell of MIactra as resembling that of the Tellinida, but presenting more distinct indications of organic structure, exhibiting an unquestionable cellular layer though not definitely developed, on the external surface, and an inner layer of elongated cells with distinct boundarjes.*

The Mactrida have variously shaped, often tumid, shells, sometimes thick, sometimes thin and invested externally with a strong epidermis; most of them are smooth, or merely striated across externally. The valves are connected together by a hinge consisting of a forker diverging tooth in one raised on a ligamental fulcrum, lorlged in a eavity, which is marginated, in the other, a con-

\footnotetext{
* Carpenter, loc, cit. p. 103:
} 
necting cartilage and small external ligament completing the union; the inner surfice of the valves invariably presents a considerable pallial sinus. The animals have their mantles variously open, often with the margins united for a considerable distance in front; the siphons are united and fringed with simple cirrhi at their orifices.

\section{MACTRA, LINNEUS.}

Shell more or less triangular, solid or thin, equivalve, more or less inequilateral, sometimes nearly equilateral, slightly gaping at the extremities; surface smooth or transrersely striated, invested with a striated epidermis; muscular impressions rounded or oblong; pallial sinus shallow, but wide; hinge composed of a $\mathrm{V}$-shaped cardinal tooth in one valve, locking into a marginated pit in the other, and a long lateral tooth on each side of the same valve which like the primary one is lodged in a deep groove with tooth-like margins in the other; cartilage pit triangular, a small external ligament immediately behind it.

Animal triangular or oblong; its mantle freely open in front as far as the siphons, the margins more or less distinctly fringed; the siphons are united to their extremities, which are surrounded with fringes of simple cirrhi; the foot is strong, changeable in shape, linguiform, and geniculated; the labial tentacles are long and pointed, peetinated on their inner sides; the outermost branchial leaflet in each pair is shorter than the other.

The DIactra are found on sandy coasts at varions depths, though the majority of species, and especially the langer kinds, are littoral. Shells of this genus are often cast on shore by the waves. The animals live buried in sand at a small depth beneath the surface. and are active and power- 
ful for their size; some exotic species attain considerable dimensions. More than fifty species of this genus are clearly ascertained; they are found in all seas, but the most beautiful are tropical forms. Few fossil examples occur, except in tertiary strata.

\section{M. solida, Linnæus.}

Oval or subtriangular, equilateral, or almost so, solid, more or less rounded at both extremities, smooth ; dorsal areas grooved concentrically, not much depressed: umbones not greatly prominent; ventral edge not strongly arcuated: lateral teeth grooved.

Plate XXII. figs. 1, 5, and (siphons) Plate L. f. 2.

MIactra solida, Linn. Syst. Nat. ed. 12, p. 1126.-Penn. Brit. Zool. ed. 4, vol. iv. p. 92, pl. 51, f. 43 A, and pl. 52, f. 43.-Pulteney, Dorset. p. 31.-Donov. Brit. Shells, vol, ii. pl. 61, f. 1, 3, 4, 5.-Mont. Test. Brit. p. 92.-Linn. Trans. vol, viii, p. 70.Dorset Catal. p. 32, pl. 12, f. 1.-Tunt. Conch. Diction. p. 81. -Turt. Dithyra Brit. p. 67.-Flem. Brit. Anim. p. 426.MAcGIL. Moll. Aberd. p. 288.-Brit. Marine Conch. p. 46.Brown, 1ll. Conch. G. B. p. 108, pl. 41, f. 3, 4.-Сhemn. Conch. Cab. vol. vi. p. 230, pl. 23, f. 229.-SPENGL. Skriv. Naturh. Selskab. vol. v. part 2, p. 113.-DiLLw. Recent Shells, vol. i. p. 140.-Larr. Anim. s. Vert. (ed. Desh.) vol. vi. p. 104. -Index Testac. pl. 6, Mactra, f. 21.-PhIL. Moll. Sicil. vol. i. p. 11, and vol, ii. p. 10.-HANL. Recent Shells, p. 31 .

Trigonella zonaria, DA CostA, Brit. Zool. p. 197, pl. 15, f. 1. " gallina, DA Cosra, Brit. Zool. p. 199, pl. 14, f. 6. Mactra truncata, TurT. (not Mont.) Dithyra Brit. p. 68 (from type). Mactra dubia and M. ovalis, Sow. Min. Conch. pl. 160.

The shape of the species which we are about to describe is very variable, ranging from simply oval to subtriangular. It is solid, opaque, subequilateral, glossy, and of an uniform white under the ordinarily dull yellowish ash-coloured epidermis, which veils its outer surface. This latter is almost smooth throughout, except occasionally a few scattered antiquated or obsolete concentric furrows; the dorsal areas 
are, howerer, elnecly grooved in a concentric direction with abruptly terminating furrors. The valves are but moderately ventricose, and the convexity is evenly enough dithuser, not being confined to the umbones as in certain wher roctire. The rentral margin is simply convex, and rises equally at either extremity. The dorsal edges are more or less convex, and the declination nearly equal on both sides; the curve of the anterior is, however, greater than that of the higher posterior one; and the degree of slope raxies from slighthty to decidedly declining, according to the greater or lesser disposition toward angularity in the example. The dorsal areas are but little flattened, the himler is the more so; the aljacent umbonal ridge is evident, but is not a prominent character. The sides are rery nearly, if not quite efual; if either, the anterior one is very slightly the longer, and is attenuatedly rounded at its extremity, the most elevater portion of the arch not being subcentral, but below the middle of the shell; the posterior termination is almost rounded, being only very bluntly subangulated towards the lower margin. The lips of the dorsal slopes are elevated or pouting, and not inwarlly inclined; the umbones are not prominent, and the heaks, which are small and in no way remarkable, lean a little forward.

The internal surface is of a polished but not a snowy white; the sears, which are profound, are moderate in size, the pallial sinus is small. The teeth are strong, the lateral ones of morlerate length and transversely grooved, both of them approximate, hint the linder one the more closely so, and sultruncated near the V'-shaped primary denticle; their upper edges are but little convex, and often nearly straight, so as to appear subtruncated above: the cartilage is not very large. 
The length of an ordinary-sized example is about an inch and three-quarters, and its breadth about an inch and two-fifths. "Worn shells frequently become deeply furrowed or zoned with grey or slate-colour and sometimes yellow." (Mont.)

"Animal yellowish white or pale orange, subtriangular, thick, the mantles freely open in front and fringed at the margins. Siphons short, united to their extremities, the branchial orifice rather larger than the anal one, the former surrounded by about sixteen cirrhi, the latter with about twenty, shorter and more regular than those of the branchial tube. Both tubes of a pale yellow, pale brown, pale reddish, or flake-white colour, varying in examples from different localities. Foot large, fleshy, pointed when extended and not furrowed by a byssal groove. By means of its powerful agency the animal can leap for some distance. Branchiæ and labial palps of a reddish brown colour; the latter long, narrow, pointed, and triangular." (Clark, MSS.) We find the animals of young and true specimens of this species to differ from that of Mactra subtinncata, in having the sides of the united siphons smooth, and only faint traces of a scabrous keel on the back of the anal one. The orifice of the latter is furnished with a tubular valve, which can be projected beyond the cirrhi.

The Mactra solida is a common frequenter of most of our sandy coasts all round Britain and Ireland. It is usually a littoral species, burying in sand or gravelly sand near low water-mark. Thence it ranges, if the ground be continuous and favourable, to a depth of fifteen fathoms, (as in the west bay of Portland,) being most abundant in about five or seven fathoms (as in the Frith of Forth). In one instance it was dredged from water as deep as thirty-five fathoms, at a distance of fifteen miles from voL. I. 
Duncansliy ITear (M'Andrew). It delights in estuaries, though some of the laresest varieties oceur in localities away from the neighbourhood of fresh-water, as on the coasts of Lewis. It ranges throughout the European seas, and has inhabited them erer since the epoch of the coralline crag.

\section{M. truncats, Montagu.}

Solid, rounded, triangular, subequilateral; umbones oblique and very prominent; dorsal areas and lateral teeth grooved.

Plate XXIII. fig. 1.

Lister, Hist. Conch. pl. 253, f. 87.

Mactra truncata, Mont. (not of Turt. Dithyra Brit.) Test. Brit. Supplement p. 34. -Turt. Conch. Diction.p. 81.-Fen. Brit. Anim. p. 427. -Brit. Marine Conch. p. 46.-Dillw. Recent Shells, vol. i. p. 140.-HaNL. Recent Shells, p. 32, sup. pl. 9, f. 1.

" subtruncata, Donov. Brit. Shells, vol. iv. pl. 126.

" crassa, Tunt. Dithyra Brit. pp.69, 258, pl. 5, f. 7.

The Mactra trunceta of Montagu is most closely allied to that ancient species the $M$. solida; but although requiring the strictest scrutiny to discriminate it from certain forms of that shell, nevertheless appears, throughout the long series of specimens in all stages of growth and collected in various localities which we have examined, to preserve its peculiar distinctive characters. The contour is rounded-triangular; the texture thick, solid, opaque, and of an uniform dirty white; the surface dull or but very moderately glossy, and more or less evidently marked, in a concentric direction, with regular rather broad stria, which, lowever, very readily become wholly or partially obsolete. The ventral margin is irregularly arcuated in the midllle, and both dorsal edges meet it in a single uninterrupted rapid slope, whence arises the trigonal ontline of the shell. The valves are ventricose and subequilateral, 
the anterior side being, if either, the more produced. Buth extremities are somewhat attenuated, but whilst the front is rounded, the hinder is angulated below, the anterior dorsal slope being strongly arcuated, and the posterior one far more rectilinear. The umbones, which are elevated, very prominent, and oblique, curve forward at their acute apices; on either side of them there is a considerable flattening of the sides of the shell, which are invariably grooved with crowded narrow sulci. This depression is more marked behind, where it is defined by an indistinct umbonal ridge, than in front, where it is confined to the beaks, and is not co-extensive with the sulci. The ligament, cartilage, teeth, and inner margin are similar to those of solida.

The length of the largest specimen we have seen was two inches, and its breadth an inch and three-quarters. It is distinguished from $M$. solida by the great projection of its umbones, its triangular contour, the arcuation of its ventral margin, the profundity of its valves, and, in the more typical examples, the production of its anterior side and its concentric striæ.

The animal closely resembles that of the last species.

This shell is stated by Montagu to be extremely common ou the shores of the Frith of Forth,-where we have dredged it in seven fathoms (E. F.), - and was dredged by 'Turton in the Irish Channel. It is occasionally taken at Tenby (S. H.), and is met with also in Cork harbour and Dublin bay (Humphreys and Jeff. cab.); Bangor bay, Down (Patterson). It is stated by Mr. Conch to inhabit the shores of Cornwall, and is a littoral species at Stronsa in Orkney (Thomas).

It occurs fossil in the glacial beds of the Clyde (Smith). 


\section{M. elLiptica, Brown.}

Elliptic, thin, quite smooth, subequilateral ; epitermis glossy ; dorsal areas not grooved; lateral teeth striated.

Plate XXII. fig. 3, and (animal) Plate L. fig. 1.

Mactra elliptica, Brown, Illust. Conch. G. B. p. 108, pl. 41, f. 6.-Forbes, Malacol. Monensis, p. 48.-Micglluiv. Moll. Aberdeen, p. 288.-Brit. Marine Conch. p. 244, f. 28.-Löven, Ind. Moll. Skandinavix, p. 45.

" solida (partly), Donov. Brit. Shells, vol. ii.pl. 61, f. 2.

Mactia elliptica, although bearing a very close resemblance to $M$. solida, may, nevertheless, without any great diffeulty, be distinguished from it by its lesser solidity, more produced shape, its comparatively glosiy epidermis, and above all by the absence of those regular sulci which invariably roughen the dorsal slopes of the latter species. The shape is elliptical, with a slight tendency in the adult to become trigonal, owing to the greater declination of the dorsal edges in the final stage of growth; the texture is but moderately solid, and the valves are subventricose in the adult, but simply convex in the young; the surface is nearly smooth, being free, even upon the dorsal slopes, from all regular strix, sulci, or other sculpture, and merely marked with a few antiquated lines at the stages of increase, and sometimes irregular concentric wrinkles and striulice towards the extremities. Beneath the smooth and sometimes glossy epidermis, which in the young is entirely buff-coloured, becoming ashy, except at the margin, in specimens of more arlvanced age the shell is white. The ventral edge is straightish towards the middle, and convex at each end. The front dorsal edge, whose slope instead of being depressed has its lips peculituly prominent, is arcuated and moderately declining; the hinder, which in the young is almost symmetrical with 
the anterior, becomes somewhat rectilinear in the adult, and its declination is similarly moderate. The beaks are very nearly central, very depressed, acute at their apices, and almost directly inflected, projecting, however, very slightly forward. The anterior side is, if either, a little the shorter, and is somewhat rounded, but not symmetrically, at its extremity; the posterior termination is subangulated below in the adult, but more rounded when immature. The hinge occupies four-ninths of the entire length of the valves; the cartilage-pit is triangular, oblique, and rectangular in front at the base; the primary teeth occupy nearly the entire breadth of the margin, and have the lobes nearly equal in the left valve. The lateral laminæ are nearly equally approximate, elongated, and very solid, rather flat-topped, and most delicately grooved perpendicularly; these in solida are thicker, and less closely but more strongly sulcated.

The largest example we have ever seen was an inch and a half long, and four-fifths of an inch broad, which we regard as a comparatively gigantic shell, being nearly double the ordinary dimensions.

The animal varies in colour from pale orange-yellow to tawny, siphons, foot, and mantle being all of the same hue; the margins of the mantle are firmly and conspicuously fringed; the siphons are united to their extremities, where both are surrounded by prominent cirrhi, and the anal one is provided with a tubular valve, which it projects beyond the fringe; the sides and back of the siphonal tubes are smooth; the foot is digitiform, and not so large as usual in this genus: it is very extensile, and when the animal is placed on the surface of the sand, it can extend its foot for a great distance, and feel with it in all directions as if with a finger. When in the act of leaping, both foot and siphons are projected very far. 
This very distinet species, which was long confounded with the Mactia solida, and was first distinguished by the sagacity of Captain Brown, is by no means an meommon shell, occurring on all parts of our coast from Jersey (S. H.) to Zetland (E. F.), usually in deeper water than its congeners. It was first observed, however, at low water in the Frith of Forth. We mention a few localities to shew its range in depth: Penzance, twenty fathoms (1I'Andrew and E. F.); Finguard in eighteen fathoms (Jeflieys); Anglesey in nine to twelve fathoms (M'Andrew); Isle of Mim in fifteen to twentyfive fathoms (E. F.); North Sea oft' Norfolk in twentyfive fathoms (Stanley); Cape Wrath in fifty fathoms gravel, and in the same depth on the Lingbanlis off' ' Cetland, forty miles from shore (I'Andrew). Its range on the Irish coast is equally extensive.

Lören enumerates it among Scandinavian shells, ranging as far north as Finmark.

M. subtruncata, Da Costa.

Decirledly ineruilateral, triangular or trigonally vvate ; surfine partially covered with regular concentric grooves; posterior end more or less acutely angulated below : umbones prominent: dorsal areas and lateral tecth sulcated.

Plates XXI. fig. 8, XXII. f. 2. and (siphons) Plate L, fig. 3.

Muctra sultruncata, DA Costs, Brit. Conch. p. 198.-Mont. 'Test. Brit. p. 93, and Suppl. p. 37, pl. 27, f. 1.-Linn. Trans. vol, viii. p. 71, pl. 1, f. 11, (badly).-Dorset Catal. p. 32, pl. 5, f. 10.T'Urt. Conch. Diction. p. 82.-'I'urT. Dithyra Brit. p. 70. -FleM. Brit. Anim. p. 427.-MAcGil. Moll. Aberd. p. 289.-Brit. Marine Conch, p. 47.-Brown, Ill. Conch. G. B. p. 108, pl. 41, f. 7.-Index Testac. pl. 6, f. 23.MIAWE, Conchol. pl. 8, f. 4.-Pinlipri, Neucr Conchyl. Mactra, pl. 1, f. 4 . 
Mactra stultorum, Penv. Brit. Zool. ed. 4, vol. iv. p. 92, pl. 52, f. 42.

" lactea, PoLr, Testac. Sicil.pl. 18, f. 13, 14.

" triangula, Philippi, Moll. Sicil. vol. i. p. 11, and vol. ii. p. 10 (from specimen),-HANL. Recent Shells, sup. pl. 10, f. 40 (copied from Poli).

" crassatella, Lam. Anim. s. Vert. (ed. Desh.) rol. vi. p. 107 (variety).Deless. Rec. Coquill. Lam. pl. 3, f. 6 .

" cuneata, Sow. Min. Conch. pl. 160. f. 7.-Woodward, Geol. Norf. 62. f. 10.

The $M$. subtruncata is of a triangular or trigonally ovate shape, very inequilateral, more or less solid, opaque, and glossy; it varies in convexity from scarcely ventricose to almost tumid, in the majority of examples, however, it is merely subventricose; the valves are of an uniform whitish hue, covered with a very thin cinereous epidermis, which has often a yellowish tinge; their surface has its dorsal areas closely and more or less strongly grooved concentrically, the anterior sulci being continued so as to traverse a greater or smaller portion of the shell. There are two well-marked varieties: the one which has these sulci occupying almost its entire superficies is more ventricose and abbreviated in form; the other, in which they are confined to the front extremity and the vicinity of the lower margin, so that the general surface is smooth, is more produced, being trigonally ovate and comparatively compressed. The ventral margin is nearly straight in the middle, and rises anteriorly; the declination of both dorsal margins is very considerable, particularly of the front one, which, as it recedes from the beals, is more or less arcuated; there is a great tendency to straightness in the hinder dorsal or rather posterior outline. The hinder dorsal area is greatly flattened, the front one is defined by an angulated line rumning to the ventral corner from the apex of the shell, which results from a slight depression of that area, whose lips, however, distinetly project. The 
umbones are remarkably prominent; the beaks are acute and direetly inflected. The anterior extremity is rounded, but with a slight angulation a little below the middle; the posterior side, which is much the longer of the two, is attenuated at its termination and acutely angulated helow; the umbonal ridge, which bounds the hinder dorsal area, is tolerably evident, heing distinguished by the roughness of the epidermis upon it. The interior is of a pure glossy white. The lateral teeth are moderately elongated, strong, and rertically sulcaterl, the firont one flattened at its apex where the hinder one is rounded.

The majority of specimens are not an inch long, nor quite three quarters of an inch broad: the Trish example, delineated in plate XXI, is of unusual magnitude.

The animal is triangular, and thick; the edges of its mantle are not so distinctly fringed as in the other British species, but rather crenated or serrated. The siphons, which are mited to their extremities, vary in colour from recklish to yellowish, or white. Their orifices are thickly fringed at the margins by a double row of cirrhi, and the anal one often projects its tubular valve. The sides of the siphons are scabrous at intervals, and the back of the anal tube is romgh with a serrated licel. The foot is linge, tapering, and of a yellowish white colour.

This shell is miversally distriluted, and extremely common in all sandy localities aromed our coast, being equally a littoral and moderately decp-water species, inhabiting sand, sandly gravel, and eren oceasionally sandy mud. A few localities will serve to mark its range in depth. Low water in sand, Swansea and adjacent bays (Jeffreys); Frith of Forth (E. F.); Clyde (Smith); and Orkney ('Thomas); in seven fithoms, Weymouth; twelve fathoms, Anglesey; and four to seven fathoms, Zetland (M'An- 
drew and E. F.) ; in three to four fathoms, Clew-bay, and elsewhere in the west of Trelind (IV. Thompson, R. Ball, and E. F.) ; in fifteen fathoms, Moray Firth (M`Andrew), and twenty-seven fathoms, eight miles from land, off Dartmouth ( $\mathrm{M}^{6}$ Andrew and E. F.); in twenty-four fathoms, off Norfolk (Stanley); and very common generally in deep water, North Sea (Thomas). "A large, and much produced variety is very common in the Ardrossan sands in Ayrshire; a similar, but smaller one, is also common in Lamlash-bay, Isle of Arran, where it is gathered alive at low water, to feed pigs" (Alder).

It ranges from the Mediterranean to the south of Norway, and appeared in the Celtic seas during the epoch of the red crag, living there through the glacial period.

* We transcribe from the "Illustrations of the Recent Conchology of G. Britain and Ireland" (p. 108) the following description, which we have reason to believe is merely that of an aberrant variety of $M I$. subtruncate; the original shell, now in the collection of Sir W. Jardine, was not accessible up to the time of the printing of this sheet.

"M. striata, (pl. 41, f. 10,) Brown.

"Shell transversely elongated, rather strong; umbones small, subcentral; anterior side subdepressed, and rounded ; posterior side elongated, and subovate: its superior line gently arcuated, as well as the basal margin; surface brownish yellow, covered with strong tranverse equidistant strix; inside smooth, white.

This species bears a strong similitude to $M$. subtruncata, but differs in the posterior side being less acute, the umbones being much smaller in proportion to the size of the shell, in the strix assuming nearly the character of ribs, and in the shell being considerably larger. I procured this species in Lough Strangford, county of Down, Ireland." 


\section{M. stultonum, Linnæus.}

Rather thin, inclined to be trigonal, equilateral; beaks white: dorsal areas never chestnut at the junction of the valves: lateral teeth smooth.

Plate XXII. figs. 4, 6, and Plate XXVI. fig. 2.

Cardium stultorum, Linneus, Syst. Nat. ed. 10, p. 681.

Mactra stultorum, Pulteney, IIutchins Hist. Dorset, p. 31.-Donov. Brit. Shells, vol. iii. pl. 106.-Mont, 'Test. Brit. p. 94.-Limn. Trans. vol. viii. p. 69.-Dorsct Catalogue, p. 32, pl. 8, f. 3.-Turt. Conch. Diction. p. 81.-Turt. Dithyra Brit. p. 72.-FleM. Brit. Anim.p. 427.-Macgill. Moll. Aberd. p. 287.-Brit. Marine Conch. p. 47.-Brown, Illust. Conch. G. B. p. 107.-DilLw, Recent Shells, vol. i. p. 138.-Las. Anim. s. Vert. (ed. Desh.) vol. vi. p. 99. (in part)-MAWE, Conchology, pl. 8, f. 5.-Crover, Introd. Conch. pl. 4, f. 4.-Soweriy, Conch. Manual, fo 79.IIANL. Recent Shells, p. 29.-CuEnu, Illust. Conchyliol. Mactra, pl. 3, f. 3.

Tellina raliata, Pens. Brit. Zool. ed. 4, vol. iv. p. 87. pl. 49, f. 30.

Trigonelle radiata, DA Costa, Brit. Conch. p. 196, pl. 12, f. 3.

Mactra cinerca, Mont. Test. Brit. Suppl. p. 35.-Turt. Dithyra Brit. p. 73.FleMr. Brit. Anim, p. 428.-Brit. Marine Conch. p. 47.

" magna, WoodWard, Geol. Norf. pl. 2, f. 10.

Although not exactly identical with the Limmean type, which comes nearer to the inflata of Philippi (En. Moll. Sic. vol. i. p. 11, pl. 3, f. 1), we have not ventured to regard the differences as of more than varial importance; for a more diffuse dissertation upon the typical stultorum, we must refer our reader's to the "Ipsa Limnxi Conchylia" of Mr. Hanley, the publication of which has been deferred, owing to the present work occupying lis entire time.

Both in shape and colouring this is a very variable shell. The former ranges from simply elliptical to broadly subtriangular; the latter from fawn-coloured, covered with more or less narrow white rays, and generally adormed with paler zones, to an uniform ash-colour, passing through 
pale livid, only diversified by an obseure and partial radiation. The pale subtriangular variety, which is much less common than the more oval one, constitutes the $\boldsymbol{M}$. cinerea of Montagu. The rays, although never broad, vary in relative width upon the same specimen; there is frequently a tinge of purplish liver-colour upon the umbones (not the beaks, which are usually paler), and there is often a stain of fawn-colour beyond the umbonal ridge, even when the rest of the surface is almost devoid of colouring. Less frequently the rays are fawn-coloured upon a paler ground. The valves are rather thin, not quite opaque, and more usually semipellucid ; they are glossy, and almost smooth, being neither striated nor grooved; when magnified, however, a kind of crowded concentric subimbricated wrinklelike lineolation displays itself, especially upon the umbonal fold, and towards the lower margin. Recent examples are covered with an epidermis of a cinereous brown, strawcoloured drab, or yellowish ash-colour, which is most closely and delicately wrinkled in a concentric direction. The valves are rather swollen, the chief profundity being at the subumbonal region, from whence it diminishes with tolerable evemness on either side; there is a slight, but evident flattening of surface upon both dorsal areas, which are equally free from sculpture with the rest of the shell; the hinder area is the more depressed. The amount of this dorsal compression mainly determines the contour of the shell, which, when it is but very trifling, and the lips of the suture pout, the slopes being more or less arcuated, is oval; but when more violent, so that the lips do not pout, and the slopes are comparatively rectilinear, becomes subtrigonal. The front dorsal edge is, however, almost invariably arched below, and its declination, though rlecided, is not quite equal to the produced, and rather ab- 
rupt one, of the posterior side. The ventral margin is more or less regularly subarcuated; the sides are equal, and not very unsymmetrical; they taper a little at their extremities, which are not regularly rounded, both (expe('ially the hinder one) displaring a more or less slight angulation near the lower margin. The umbones are rather prominent; the beaks are more or less acute, lean forward, and do not approach closely to each other. The umbonal fold is sufficiently evident, but neither carinated nor peculiarly angulated. The interior varies from pale lilac to white; the teeth are very large, but thin, the cartilage pit is rather narrow, and the lateral lamina, which are of about the same size and distance, are perfectly free from crenation.

The dimensions of rather a large example were, an inch and five eighths in breatth, and rather more than two inches in length. The dorsal lips of the young specimens project greatly, and their areuation is very considerable.

The following full account of the animal was drawn up by Mr. Clark this summer, and lindly communicated to us by that gentleman, on the value of all whose observations we lay the greatest stress. "Animal suboral, tumid, of the palest bluish-white, with its mantle entirely open, the margins thereof elothed with an intensely white delicate fringe, formed of linear short filaments; the ventral portion of the body is white, and the dorsal, containing the mass of the liver and other viscera, of a duller and more opaque white; the siphonal tubes are short, of the same length, and united to their extremities, and are never, in their ntmost extension, exserted more than threefifths or half an inch; the orifices of the tubes are truncate and furnished with pale, dirty-red cirlhi, the branchial rather the longest in diameter, with from twelve to six- 
teen of moderate though irregular lengths, the anal with about sixteen or twenty finer, shorter, and more even; the colour of the tubes is pale brown, with a reddish tinge. The foot is white, large, and thick, long and tapering to a fine edge, and extensible into every form, from a blunt mass to a very sharp lanceolate termination : it has no byssal groove; there are on each side two branchia of a brown colour, the outer the smaller and overlapping the under one very obliquely; the latter is hung more transversely from the dorsal portion of the body; a pair of labial palps are united on each side of the buccal orifice, and hang from it in long, subtriangular, pointed leaflets of a paler brown and marked with stronger strix, especially on their inner sides, than the branchiæ."

This is a most abundant shell everywhere on our sandy beaches, littoral in its habits, and rarely taken by the dredge except near shore and on a continuous tract of sand, when, as off Ormeshead, it may be taken as deep as twelve fathoms. As it ranges from one end to the other of the British Isles with no restriction save unsuitability of ground, to enumerate localities would be superfluous.

It is distributed generally through the European seas as far north as the south of Norway, where the long range of rocky coasts and deep water of the west interrupt its progress. Philippi mentions it as a species collected by Ehrenberg and Van Hemprich in the Red Sea. As a fossil it oceurs in the red and mammaliferous crags. 


\section{1. ielvacea, Chemnitz.}

Shape inclined to oval, inequilateral ; dorsal area chestnut to the very lips ; beaks coloured: lateral teeth smooth.

\section{Plate XXIII. fig. 2.}

Mactra helvacca, Crems. Conch. Cab. vol, vi. p. 234, pl. 23, f. 232, 233.Las. Anim. s. Vert. (ed. Desh.) vol. vi. p. 99.-Puripry, Moll. Sicil. vol. i. p. 10, and vol. ii. p. 9-CHENv, 111 . Conch. Mactra, pl. 2, f. 4.

. gleuce, Guelin, Syst. Nat. p. 3260.-Donov. Brit. Shells, vol. iv. pl. 125.-Mont. T'est. Brit. p. 571.-Linn. Trans. vol, viii. p. 63.-Dorset Catal. p. 68.-T'unT. Conch. Diction. p. 80.Turt. Dithyra Brit. pp. 73, 258.-FleM. Brit. Anim.p. 428. - Brit. Marine Conch. p. 48.-Brown, Ill. Conch. G. B. p. 107 , pl. 4 l, f. 1.-Spengler, Skrivt. Natur. Selskab. vol. v. pt. 2, pl. 3.-Dillw. Recent Shells, vol. i.p. 144.-Index Testac. pl. 6, Mactra, f. 30.-HaNL. Recent Shells, p. 29, pl. 6, Mactra, f. 30 .

"Ncapolitena, PoLr, 'Test. Sicil. vol. i. pl. 18, f. 1, 2, 3. Encyclop. MÍthodique, Vers, pl. 256, f. 1.

This fine Nactia rery closely resembles the preceding in its general aspect and features. Its contour ranges from simply oval to ovato-trigonal; it is by no means solid, is inequilateral, semipellueid, and thongh decidedly convex, is, for its size, compratively compressel. The convexity gradually, and nearly equably, diminishes on either side, from the subumbonal region; the linder dorsal area is flattened in the alult, but there is no peculiar angulation at the umbonal ridge, which is occasionally wrinkled concentrically in the full-grown examples. The entire surfice is free from grooves or strix, being smooth, more or less glossy, and of a pale fulvous or light rufous, adomed all over with numerous, and not very broal rays of a rufous or livid rufous lue, with which colouring the dorsal areats 
are stained for the most part likewise. In the more recent specimens a tawny or yellowish brown closely-adherent epidermis somewhat obscures the vividness of the radiation. The ventral margin, which is not particularly arcuated, rises the more behind, where it forms a subangulation with the produced and but moderately sloping posterior dorsal, which edge is but very moderately convex in the adult; the hinder extremity is a little attenuated. The anterior side is manifestly, though not very greatly, the shorter, and tapers at the extremity (which is well, but not symmetrically rounded) from the great declination of the dorsal margin, the lips of which are pouting, but the outline not in general arcuated. The umbones do not greatly project, but incline a little forward; the bealis are blunt, not quite close to each other, and not preceded by any concavity. The interior is whitish, or faintly exhibits the external colouring; the teeth are large and thin, and the lateral laminæ perfectly free from sulcation.

The shell we have figured (which, being bleached by the sun, is not so distinctly rayed as in the engraving, where the colouring is restored from an exotic specimen) is about the average size of those picked up on the English coast; foreign examples attain to the dimensions of four inches in length and nearly three inches in breadth.

The animal is figured by Poli, and appears closely to resemble that of $M$. stultorum. Almost all the British examples consist of the worn valves which were obtained by Miss Pocock (1801) from the sands of Hale in Cornwall, and appear to have passed from her hands into the cabinets of several collectors. It was from one of her specimens that Donovan, the original introducer of the species into our Fauna, derived his figure and description. IVe only know of two examples with the valyes united; these 
Mr. Lukis, of St. Peter's Port, Guermsey, ansures us (S. II.) were dug out from a little samdy nook of the aljacent islet of Herm. It is chiefly taken on the coasts of France, Sicily, and the warmer parts of Europe.

\section{SPURIOUS.}

\section{M. rraglus, Chemnitz.}

Mactra fiagilis, Criexw. Conch. Cab. vol. vi. p. 236, pl. 24, f. 235.-Tunt. Dithyra Brit. pl. 4, f. 10.-FLex. Brit. Anin. p. 428,-Brit. Marine Conch. p. 43.-Dicuw. Recent Shells, vol. i. p. 144. -Cosran, Amer. Marine Conch. pl. 14, f. 3.

.. decelbata, P'Ultexey, IJutchins, Hist. Dorset, p. 31.-Mont. Test. Brit. p. 95, pl. 5, f. 1.—Linn. Trans. vol. viii. p. 68, pl. 1, f. 10.Dorset Catalog. p. 32, pl. 7, f. 7.-Tun . Conch. Diction. p. 80.-Fues. Brit. Anim. p. 428.-Brown, Hlust. Conch. G. B. p. 107 , pl. 41 , f. 8,9 .

"Braziliana, LaM. Anim. s. Vert. (ed. Desh.) vol, vi.p. 106.-HaNz. Recent Shells, p. 31, Suppl. pl. 10, f. 60 .

An American shell introduced by Dr. P'ulteney as a native of Dorset. IIaving seen the examples delineated by our English author's, we are enclbled to state that they really belong to the same species, a conclusion which the engravings referred to would scarcely have borne out. 


\section{LUTRARIA, LAMARCK.}

Shell oblong, equivalve, inequilateral, gaping at both extremities; external surface transversely striated or furrowed, invested with an epidermis; edges sharp and smooth ; hinge formed of a more or less prominent spoonshaped fulcrum in each valve, accompanied in the right one by an erect primary tooth, which locks into a pit with laminar tonth-like edges in the left: the greater part of the fulcrum in each valve is oceupied by a wide ligamental pit. Ligament partly internal, partly extermal. Muscular impressions strong; pallial impression with a deep linguiform sinus.

Animal thick, oblong, with much-produced siphonal tubes, which are united almost to their extremities. Mantle closed, except a rather large anterior opening for a foot of considerable dimensions; both it and the siphons partially invested with an epidermic sheath. Orifices of the tube fimbriated. Labial tentacles narrow, triangular, pointed.

The animals of this genus form large and conspicuous shells, not remarkable for their beauty. They live habitually buried in mud, for the most part near low water, or at very moderate depths. The systematic position of Lutraria has been much disputed. Cuvier, Blainville, and very recently D'Orbigny, have placed it beside $M y d a$, and in the same family, whilst Linnæus, Lamarek, and Deshayes have maintained its near affinity to Mactra. The shell presents consirlerable resemblances to that of the latter genus, yet the animal is in many respects nearly related to that of Mya. We place it for the present in the former group, regarding it as an aberrant form of the 
Muetride. 1homeh with com-irleralle hesitation, and only an an arrangement for convenience.

The shell of Lutraria is found by Dr. Carpenter to be composed of elongated fusiform cells, their extremities cropping out, one set above another. The species of this genus chiefly affect temperate seas. Many Lutraric are merorled in lists of forsils, lut their aftinities with existing forms is doubtful. One of our native species, the Lutraria ,lliptice, which now ranges throughout the European seats, anciently inhabited our area even so far back as the epoch of the coralline crag, and has maintained its place near the British shores throughout all the ups and downs of geological change which have disturbed them, even to the present time.

\section{L. elliptica, Lamarek.}

Somewhat elliptic, not at all arcuated.

Plate XII ; and (animal) Plate II. fig. 2.

Mactice lutraria, LiNn. Syst. Nat. ed. 12, p. 1126.-PENN. Brit. Zool. ed. 4, vol. iv. p. 92, pl. 55, f. 44.-Pulteney, Hutchins, Dorset Hist. p. 32.-Dorset Catalog. p. 33, pl. 5, f. 31.-MoNT. Test. Brit. p. 99,-Dovov. Brit. Shells, vol. ii. pl. 58.Limn, Trans, vol. viii. p. 73.-TUnT. Conch. Diction. p. 34. -Cirems. Conch. Cab. vol. vi. p. 239, pl. 24, f. 240, 241. -DiLLW. Recent Shells, p. 146.

Lutraria elliptice, LaA. Anim. s. Vert. (ed. Desh.), vol. vi. p. 90.-Turt. Dithyr. Brit. p. 65.-Brit. Marine Conch. p. 45.-Brown, Ill. Conch. G. 13. p. 109, pl. 43, f. 2, 3.-MACGIL. Moll. Aberd. p. 291.-Philipri, Moll. Sicil. vol. i. p. 9, and vol. ii. p. 7.-II Ant. Recent Shells, p. 26.-Chenv, Ill. Conch. Lutr. pl. 1, f. 10.-Desi. Exp. Scient. Algér. Moll. pl. $33,35,36$ (animal).

"vulgaris, Fem. Brit. Anim. p. 464.

Lutraire clliptique, Crenv, Traité Elem. p. 170, f. 52 (hinge).

List. Hist. Conch. pl. 415, f. 259.--Encycl. Mféth. Vers, pl. 258, f.3.

Of a produced elliptic form, the valves of this shell, which may be reckoned one of our largest bivalves, are, 
although by no means solid for their size, yet sufficiently strong, almost opaque, and decidedly shallow. This compression is very manifest upon the umbonal region, from whence to the ventral margin there is often indeed a slight retusion of the external surface: the hiation is very considerable, the valves merely touching each other at the beals and along the middle portion of their lower margins, and gaping more particularly at the hinder extremity. The outer surface is nearly smooth, or at most concentrically wrinkled by coarse irregular lines of growth; it is of a squalid white, or stained with a reddish rust colour, covered, when recent, with a thin but rather tenacious epidermis, of an ashy olive colour (almost passing into drab in a foreign variety), which is smoothly laid on, and varies in lustre from dull to moderately glossy. The ventral margin is almost straight or somewhat retuse in the middle; from thence becoming convex on either side, it ascends very obliquely and considerably in front, rising far more moderately behind. The anterior side is much the smaller, oceupying, in some examples, not more than onehalf the entire length of the shell: it is liable to great variation in shape from the absence or existence of depression at its nper or dorsal margin. This edge, in very large individuals, where the lips are apt to expand, or become in a degree subreflected, is convex and moderately sloping; but in the majority of specimens (those of average size), is more or less retuse, and not much declining; in "the former case, the lower corner of the front extremity being invariably rounded off, there is only a slight subcentral angulation at the anterior end; but in the latter event, a distinct upper angle. The posterior termination is rounded both above and below, yet not equally so, the chicf swell of the hinder outline being rather above the middle, as the 
hinder dorsal edge, which is the more elevated one, is almost straight, and declines in but a very trifling degree. The mmbones are not very projecting; the beakis, which are incurved and acute, lean scarcely, if at all, to either side. There is no umbonal ridge, nor the slightest appearance of a distinct lunule. The internal surface is of a glosey bluish white; in the left ralve, in advince of the large curred triangular cartilage-pit, is a solid truncated reversed T-shaped primary tooth (which does not reach the basal line of the hinge-marein), preceded by a rery thin lamellar sub-pyramidal one : in the right valve is only the very thin and fingile anterior wall of the cartilage-pit, which resemulles a tooth, and a rather curved slinting anterior laminar one, which is emisiderably elevated at its lower extremity, and acutely pointed.

The largest of our specimens (from the Welsh coast) measures fire inches and a hall" from sile to sille, and three inches from the umbones to the opposite margin. These proportions are not universal, as the breadth of another example of four inches in length is only two inches.

The animal is sub-cylindrical, with a siphonal tube fully as long as the body, or longer. The mantle is closed posteriorly and frontally; anteriorly there is rather a large opening for the passage of the thick, long, white foot, which does not appear to be furnished with a byssal groove. The siphons are united almost to their extremities, which are lut very slightly separated fiom each other. The tube is white, thick, and corrugated at the base, thimer and yellow, speckled with hrown towards the extrenity. "The loranchial tulse," accorting to Mr. Clark, "is clotted with about ten yellow rays, dotted with minute points, and each ray more or less ciliated on one or both sides; the anal tube turns upwards, and has around 
its orifice about thirty slender yellow rays, each ray being alternately dotted with a minute red and yellow point." These dots are analogous to the coloured points or ocelli which we have noticed in describing the Ascidic, where they are conspicuously seen aromd the branchial and anal orifices. The tube and mantle are more or less invested with a thin, wrinkled, brownish epidermis. The branchiæ are of a brownish hue. On each side of the mouth is a pair of narrow, triangular, pointed labial tentacles.

Notwithstanding that fine shells, of this species, are not easily procurable, (their habitat, a moist oozy sand or mud repulsing the less sturdy and zealous collectors,) it is abundantly prolific and sufficiently diffused. We may enumerate among other localities Searborough, where it is common (Bean); Exmouth (Clark); Torbay (Jeff. cab.); the Islet of Herm near Guernsey (S. H.); Oxwich Bay, in Glamorganshire and Laugharne (Jeffreys); Tenby, where the shores are strewed with dead valves (S. H.); in twelve fathoms, Anglesea (E. F.); Isle of Man (E. F.); "Bantry, Dublin Bay, and Cork Harbour" (Humphreys and Jeffreys); and in other "suitable localities on each side of the Irish coast" (Thompson); Frith of Forth (E. F.); Aberdeenshire (Macgillivrny); St. Andrews, abundant (E. F.); the west coast of Scotland (Barlee and Jeffreys); Murray Frith, and the Hebrides (M'Andrew); Lerwick (Jeffreys); Balta Sound, Unst in six fathoms (M'Andrew). 


\section{L. oblonga, Chemnitz.}

listremely inequilateral, arcuated, of a compressed cylindraceus form.

Plate XIII, fig, 1.

Cliama magna, DA Costa, Brit. Conch.p. 230, pl. 17, f. 4 .

Mya ollonga, Chesnitz, Conch. Cab. vol. vi. p. 27, pi. 2, f. 12 (badly).Guelin, Syst. Nat. p. 3221.

Mactra hians, Pulteney, Hutchins, Hist. Dorset, p. 32.-Mont. Test. Brit. p. 101.-Dovov. British Shells, vol. iv. pl. 140,-Linn. Trans. vol. viii. p. 74.-Dorset Catalog. p. 33, pl. 2, f. 4.-T'virT. Conch. Diction. p. 85, f. 41.-Diluw. Recent Shells, vol. i. p. 146.-Index Testaceol. pl. 6, f. 37.

Lutraria oblonge, Tun т. Dithyra Brit. p. 64, pl. 5, f. 6.-Brit. Marine Conch. p. 44.

"Solenoides, Lam. Anim. s. Vert. (ed. Desh.) vol. vi. p. 90.-Brown, 11l. Conch. G. B. p. 109, pl. 43, f. 1.-Sow Er BY, Conch. Manual, f. 78. - Havl. Recent Shells, rol. i. p. 26.Chenv, Illust. Conch. Lutraria, pl, 1, f. 9.-Desu. Exp. Sc. Algérie, Moll. pl. 31, 32 (anatomy).

" lians, Flem. Brit. Anim. p. 465.

Lutricola Solenoides, BLAinv, Malacol. pl. 77, f. 3.

Were it allowalble, we should have preferred the signif(ant appellation of sulenoides, hestowed upon this species ly Lamarck, to its prior name of oblonge, which denotes a character appertaining to most of the restricted genus Luterien, and not confined to this species individually. We may remurk, as an excuse for the ordinary neglect of the Chemnitzian name, that both the description and the lrawing of the Myce oblonga, are most infelicitonsly excented.

Of an elongated oblong and subarcuated form, this -peries may readily be distinguished from the preceding, by the incurvation of its hinder clorsal edge, and the great inequality of its sides. It is solid, opaque, coarse-looking, and subventricose; the convexity, however, is diffused, 
not being peculiarly apparent upon the umbonal region. The valves, which gape most widely at the extremities, and especially at the posterior end, where they are more or less reflected, are of a squalid white (often stained with darker tints from the soil they inhabit), covered with a brownish or dark ash-coloured epidermis which is generally more permanent, wrinkled, and deeper coloured near the posterior extremity. The surface is roughened by coarse wrinkles of growtl, which are sometimes almost pliciform along the course of the somewhat obsolete umbonal ridge. The ventral margin, whose middle course is straightish, or even subretuse, rises very considerably at each extremity, and more particularly in front. The anterior side, which occupies but little more than one-fourth of the entire length, and from the sub-attenuation of its well-rounded extremity even a still less portion of the area of the valves, has its upper or dorsal edge, which is at first almost straight and scarcely sloping, and then convex and very moderately declining, united to the anterior outline without any marked angularity. The posterior extremity, which although the broader one is still slightly attenuated, is more bluntly romnded than the other, but is equally devoid of angularity. The hinder dorsal edge is much incurved, and upon the whole, declines but slightly, its termination not being greatly below the level of the but moderately prominent umbones. The beaks are obtuse and incurved; there is no depression in front of them, but the dorsal outline behind them is a little flattened. The interior is of a pure white. In the left hinge a single rather large primary tooth, whose lower surface is broadly grooved, interlocks between the great thin laminar oblique posterior and the smaller bifurcated anterior one of the opposite valve.

The dimensions assigned to this species by Montagu are 
five inches in length and two inches and a quarter in breadth: specimens of such magnitude, however, are bui rarely met with.

However abundant, or rather diffused, in other parts of Europe, this bivalve is justly esteemed by our shell collectors as one of our less frequent native species. Nevertheles, it is recorded by Montagu as not uncommon in the river between Truro and Falmouth (in the recent Cornish Fauna by Mr. Couch, it is termed "rare or" local"), and as frequently brought up with sea-sand, for manure, to the former place. It is occasionally obtained at Exmonth (Clark); Torbay (Jeff. cab.); and in Salcombe Bay (Alder); the Dorset coast (Pulteney); dead valfes in twenty-five fathoms, Penzance Bay (M'Antrew and E. F.). A few specimens were dug out of sandy mud near low-water mark at the little islet of Herm, near Guernsey (S. H.); they are sometimes taken at Fishgonturl, and Caldy Island in Pembrokeshire (Lyons); and appeatr not mfrecpnent in Ireland, being found "in suitable places on each side of the coast" (Thompson). 


\section{VENERIDA.}

THE VENUS TRIBE.

Most of the tribes, of which we have hitherto described British representatives, are such as severally included forms of shell very different, with animals strikingly similar. In that now before us, the aspect of the shells, though variable, always indicates their natural affinity with each other, whilst many characters in their animals, hitherto of great sectional value, become variable, and, at most, generic. The shells of the Venerida present numerons modifications of colour and sculpture, and are often of considerable thickness; their hinge is always considerably developed, and the teeth strongly marked and distinct; their margin is in some plain, in others crenulated, indicating differences, usually of generic value, in the structure of the mantle; the ligament is external; the muscular impressions are always strongly marked, and the pallial has a conspicuous sinus; the animal has its mantle rather freely open in fiont for the passage of a large and thick foot; the siphons are united or separate, according to the genus, and have their margins either fringed or almost plain. The species of the several divisions have very different habits of life.

Dr. Carpenter's researches shew that the shells of this tribe present little organic structure, and are among the hardest of bivalves, approaching the porcellanous univalves 
in density, and in the almost entire absence of any trace of animal matter.

TAPES, MEgERLE.

This genus consists of a very natural assemblage of Temiele, distimenished hy marked characters of both shell and animal, and by a general habit recognisable at a glance.

Shell solid, transversely oblong, or, more rarely, obliquely sul,triangular, equivalve, inequilateral, closed, the posteal extremity always longest; surface smooth, or transversely striated; immer margins smooth; muscular scars strongly impressed, semicireular, the posteal always largest; beaks not prominent; pallial sinus derp, oblong, romsterl at the extremity; hinge composed of three scarecly diverging primary teeth, two of which are usually bifid on each valve, and a ridge bounding the groove for the ligament, which is external.

Animal shaped as the shell, rather thick, having the mantle freely open in front, its margins either plain or partially plain, or, if fringed, bordered by fine filaments and not by strong scallops ; siphons moderately long, more or less seprarated, sometimes for half their length, sometimes throughout; both branchial and anal orifices bordered by cirrhi, those of the former ciliated; labial palps rather long, lanceolate; foot lanceolate, thick, with a hyssal groove, a structure which con-picuously distinguishes this animal from lenus, and allies it, as well as the shape of the shell, with Petricole. The species of Tapes inhabit all climates, those of the tropies being most brightly coloured. Except the tertiary forms, most of the older fonsil sprecies are doubtfully referred to this genus. They inhabit the littoral, and, more rarely, the laminarian and coralline zones. 


\section{T. Decussata, Linnæus.}

Suboval, subrhombic, coarsely decussated by concentric sulci and radiating strix, verrucose in radiating rows at the posterior extremity : front dorsal edge moderately long; umbones rather prominent: pallial sinus not peculiarly large.

Plate XXV. fig. 1 .

Lister, Hist. Conch. pl. 423, f. 271.

Venus decussata, Linn. Syst. Nat. p. 1135,-Pulteney. Hutchins, Dorset. p. 34 (chiefly).-Donov. British Shells, vol, ii. pl. 67.-MIont. Test. Brit. p. 124.-Linn. Trans, vol. viii. p. 88, pl. 2, f. 6. -Dorset Catalogue, p. 36, pl. 6, f. 4, (not well).-Turt. Conch. Diction. p. 244.-Turt. Dithyra Brit. p. 158, pl. 8, f. 10.-Brit. Marine Conch. p. 93.-Chemnitz, Conch. Cab. vol. vii. p. 58, pl. 43, f. 455, 456.-DщLw. Recent Shells, vol. i. p. 206.-LAм. Anim. s. Vert. (ed. Desh.) vol. vi. p. 357 (not var. 4.)-Index Testaceolog. pl. viii. f. 107.-РнгLIPPI, Moll. Sicil. vol. i. p. 45, pl. 4, f. 11, and vol. ii. p. 35. -Hanl. Recent Shells, p. 122, vol. i. pl. 8. f. 107.

Venus litterata (not of Linn.) Penn. Brit. Zool. ed. 4, vol. iv. p. 96, pl. 57, f. 53. Cuneus reticulatus, DA Costa, Brit. Conch. p. 203 (in part), pl. 14, f. 4 (badly). Venus forida, Poli, Test. Sicil. pl. 21, f. 16, 17.

Venerupis decussata, Flem. Brit. Anim. p. 451.-Macgilliv. Moll. Aberd, p. 339.

Pullastra decussata, Brown, Ill. Conch. G. B. p. 88, pl. 37, f. 5,6 .

The shape of $V$.decussata, whose valves are destitute of lustre, opaque, solid, ventricose, and extremely variable in painting, is suboval and subrhomboidal; its convexity is most apparent around the umbonal region, the sides being comparatively flattened. As respects colouring, our British specimens do not quite display so brilliant a diversity of painting as the continental ones, but exhibit various shades of buff, drab, or rufous, rayed, freckled, or zig-zagged with markings of a deeper tint, with generally more or less of a livid tinge ; occasionally, they are of an uniform reddish cast, but we have rarely met with any of that chalky whiteness which is so common in pullastru. The 
beantiful rariety figured by Turton (so common in the Arriatic), in which the pattern is composed of radiating rows of smoke-coloured, irregularly-shaped spots (not in little rescmbling the Chinese style of writing) npon a ground of bluish-grey, is not of frequent oceurrence upon our coasts. The sculpture (which is coarser in our examples than in the majority of those we receive from the Mediterranean) consists of most closely arranged and rather wary concentric sulci, decussated throughout by racliating strix; the latter are more crowded in the middle area (where the concentric sulci often disippear or become fitinter), are stronger and more remote in front, and behin! the mmbonal slope lose all claim to be held as strie, forming shallow interstitial grooves to the apparently radiating rows of compressed bead-like prominenees, which the intersected sulci there present. The ventral margin is moderately convex in the mildle, and rises greally at the sides, particularly in front; the declination, as well as the convexity, of the hinder dorsal edge is very trifling; the front dorsal edge slopes almost rectilinearly, and rather profoundly; to about the middle of the narrow anterior side, whose extremity is well romded and rather attenuated; the hinder side is about twice as long as the other, and has the appearance of being subtruncated at its $c x-$ tremity, from the posterior edge being but little convex, and not greatly oblique; the posterior termination is broal, and almost biangulated, the lower angle being, lowever, roumled off in the young (at which stage the angulation in shells is always most apparent); the ligament is rather large, yellowish brown, and not much elevated. The lunule is not usually much depressed, and is frequently only defined by its freedom from decussation; its lips, too, except in aged examples, are elevated, not sunken; the 
shape is cordate lanceolate. The umbones are rather prominent, and somewhat inclined; the beaks small, very acute, and much inflected; the internal surface is whitish, with generally a stain of purple behind the teeth; the linge as in aurea. The form is occasionally abbreviated, and the beaks, though rarely, if ever, in our native examples, are stained with a beautiful violet. The length of our largest example is about two inches and a quorter, and its breadth an inch and five-eighths.

The animal of Tapes decusectc has frequently been observed; indeed, considering what a favourite article of food it is in many parts of the continent, it would have been very strange had everybody swallowed it without examination. As long ago as 1710 it was figured and described by Reaumur. It is oval, white and thick, and has the margins of the mantle, which are freely open, ornamented with a conspicuous scalloped white fringe. The siphons are scparate to their bases and equal, yellowish and white, dotted towards the base and centre, marked with tamny or reddish or dark-brown specklings and cloudings near their orifices. These are fringed, the branchial with a double border of twelve long cirrli and as many alternating small ories, the anal with nearly twenty or so simple cirrhi, in both cases of a brown colour. The branchial, according to Mr. Clark, are suboval, the upper the smaller, and all of a pale brown colour. The labial palps are proportionally small and triangular. The foot is large, white, lanceolate, and furnished with a byssal groove.

Except locally, this is rather a searce shell. It is usually dug out near the shore, being rarely, if ever, taken by the dredge. It is sometimes, but seldom, procured on the Northumbrian coast (Alder); and at Scarborough (Bean); on the south-west it is more frequent, occurring at Little- 
hampton (Stricklani); IIastings (S. II.); Weymouth (S. II.) : and is eaptured at Fxmouth (Clark); Torpuny (S. H.) ; and other parts of South Devon, as "the inlet between Kingsbridge and Saleombe at the mouth of the Aum " (Mont.); Falmouth (Coclis); Swansea and its vicinity (Jeflieys); Caldy Island, near Tenlyy (Lyons); Pwllheli (M'Andrew). It oceurs of large size buried in gravel at low-water mark on the shores of Skye and Zetland (E. F.); Bantry and Dublin bays (Jeff. cab.).

It does not appear to range northward of the British sens, lut is very abundant in the Lusitanian and Mediterranean provinces. It ranges sonthwards to the shores of Sencegal, and is said to inhalit the Rerl Sea. As a fossil it oceurs very generally in the newer pliocene beds of Enrope, and appears to have originated in the Lusitanian region. Everywhere it is a littoral shell.

\section{T. pullastra, Wood.}

Suboval, subrhomboidal, finely decussated by concentric stria and radiating striule; front dorsal edge very short; posterior extremity often concentrically sublamellar: umbones obtuse : pallial sinus very large; teeth very narrow, recurved, nearly equal and much elevated.

Plate XXV. figs. 2, 3, and, animal, Plate L. fig. 5 and 5 a.

? Tellina rugosa, Penv. Brit. Zool. ed. 4, p. 88, pl. 57, f. 34 .

Venus pullastra, MoNT. Test. Brit. p. 125.-Linn. Trans. vol. viii. p. 88, pl. 2, f. 7.-Dorset Catal. p. 36, pl. 1, f. 8 (not well).-Tunt. Conch. Diction. p. 244.-TunT. Dithyra Brit. p. 159.Forues, Malacol. Monens. p. 53.-Brit. Marine Conch. p. 94.-Index T'estaceolog. pl. 8, f. 109.-Lan. Anim. s. Vert. (ed. Desh.) vol. vi. p. 358. IIant. Recent Shells, p. 122.

Venus perforens, Mont. Test. Brit. p. 127, pl. 3, f. 6.-Linn. Trans, vol. viii. p. 89.-Turt. Conch. Diction.p 245.-Dilzw. Recent Shells, vol. i. p. 206.-Index T'estaceolog. pl. 8, f. 108.

Venus Screyalensis, DuLww. Recent Shells, vol. i. p. 206. 
Tenemupis perforans, LaM. Anim. s. Vert. (ed. Desh.) vol. vi. p. 162.-TurT. Dithyra Brit. p. 29, pl. 2, f. 15 to 18.-Ftem. Brit. Anim. p. 451.-Brit. Marine Conch. p. 61.-Сrovcr, Introd. Conch. pl. 5, f. 5.-HANL. Recent Shells, p. 54. -Philippr, Wiegm. Archiv. f. Natur 1845, p.190, pl. 7 , f. 15 to 18.

Venempis nucleus, Lam. Anim. s. Vert. (ed. Desh.) vol. vi. p. 162.-Macgilliv, Edin. New Phil.Journ.(Jameson's) 1827, p.370.—DeLes. Rec. Coquilles, pl. 5, f. 1.-Hant. Recent Shells, p. 54.

Venus palustris, Mawe, Lin. Conchology, pl. 10, f. 3.

Venerupis pullastra, F LEM. Brit. Anim. p. 451.-M ACGILliv. Moll. Aberd. p. 269. Venerupis vulgaris, Sowerby, Concholog. Manual, f. 97.

Vemus vulgaris, Broderip, Penny Cyclop. vol. xxvi.p. 211.

Pullastra vulgaris, Brown, Illust. Conch. G. B. p. 89, pl. 37, f. 7.

Pullastra perforans, Brown, Illust. Conch. G. B. p. 89, pl. 37, f. 10.

Venus plagia, (VAR.) JefFreys, Ann. Nat. His. vol. xix. p. 313.

The $V$. pullastrce was long regarded as at most a variety of the preceding, to which alone of our British shells it bears much resemblance. Its distinctness from decussata was first pointed out by Mr. Wood, (the author of a valuable work entitled, "General Conchology," containing figures and descriptions of many rare species, which are hardly to be met with elsewhere,) who founded his separating characters chiefly from the structure of the hinge. The more easily distinguishable differential features, are stated by Colonel Montagn to consist of its smaller size, the greater delicacy of its decussation, (which, moreover, is never verrucose anteriorly, and which posteriorly has a concentric and not a radiating arrangement,) the greater regularity and approximation of its teeth, and the more ample sinus of the pallial impression. To these we may add, the greater shortness and usually lesser declination of the front dorsal margin. The animal is also sufficiently distinct. An examination of a long series of specimens, which clearly connect the rock-dwelling perforans, with its type pullastra, and display the want of permanency in the supposed specifie characters of the former, compels us to unite the two under one appellation. 
The general ontline is whihomboidal, and suboval (typically it is more elongated than the preceding); the valves are moderately strong, opalyue, very inequilateral, and more or less ventriense, the convexity being more evenly diftused than in decusutu. The outer surface is almost entirely devoid of lustre, and is usually of a chalky or dirty-white, which shades into a browner tint in the adult; this is very rarely destitute of marlings, being almost always diversificd by radiating angulaterl spots, and zigzag confluent splotches of a livid brown; occalsionally the entire surface is fincly reticulated. (though usually but fiintly so,) with angular lines of that hue, but the colouring matter is generally more lavishly displayed on the posterior extremity, to which portion occasionally the pencilling is confined. Crowded and wary strie, which are coarser at the extremities, and of which the interstices have a tendency to become imbrieaterl and lamellar at the posterior end, traverse the entire shell in a concentric direction, and are most fincly decussated ly rarliating striulic, which are very closely disposed, and become obsolete towards the bealss. The ventral margin is convex, but usually inclines to straightness near the midhle, though rising greatly and arcuatedly in front, and moderately so behind. The anterior side is very short, occupying but little more than one-fourth of the entire length; its extremity is very narrow and obliquely rounded below, but is very slightly angulated above, owing to the straightness of its extremely short dorsal margin.

The termination of the profluced posterior side is sul)liangulated and broad, the convex, or subarcuated himcler margin, which is but slightly oblique, forming an obtuse angle with the almost rectilinear and searecly in the least Jeclining dorsal edge; the lower angle is rounderl off. 'The ligament is tolerably large, but not at all elevated; the 
lunule ovato-lanceolate, often coloured, and not sunken or well defined; the umbones depressed, and the beaks small, inflected and leaning a little forward. The interior is of a chalky-white, with often a violet or purple stain at the posterior extremity. The pallial sinus is very large.

The teeth, as regards being cloven or simple, are, as usual in this genus; viz., the two last of the right hinge and the two first of the left more or less bifid; they are, however, peculiarly elevated and narrow, the central one of the left valve not exceeding (as in decussata, ) the other two in breadth. They lean outwards, their inner sides being remarkably curved, and the supporting portion of the hingemargin arching out below, and bulging out in front much beyond the level of the remainder.

The length of our largest specimen is about two inches, and its breadth one inch and a quarter; these dimensions, however, are but rarely attained to, the majority of examples being about an inch and a half only in length, and of proportionate width.

Animal oblong, thick, yellowish-white or tinged with pink, the extremities of the siphons variously tinged with brown, black, red, or orange. Mantle freely open in front, plain at the edge except for a short space around the anterior end. Tubes united for half their length, and then diverging; the upper or anal one smallest. Their orifices are fringed ; the branchial with from nine to fifteen ciliated rays, and the anal with from fifteen to twenty-five. The foot is linguiform, fleshy, flat-heeled, and furnished with a byssal groove. The palps are of moderate length, narrow and triangular.

We have often compared the animal of the ordinary or pullastra form of this species with that of the "Tonus perforans," but could find no distinctions. As long ago as VOL. I. $3 \mathrm{D}$ 
159.5, Mr. Clauk had carefully investigated this point, and his observations, which on account of their value, we quote at full, appear to us decisive. "Having dissected," writes that most careful observer, "examined, and compared many of the animals of these hitherto-considered distinct species, I have found that in every respeet they agree with each other, and that there is not even the slightest rariation in the conformation of any of their organs either external or internal. The branchie of the two, in colour and form, are exactly the same. 'The foot has precisely the same slit in its centre for the bystal filaments. and we have seen the one imbedded in its cavity attached by them, and the other maked. from the shingle attached in like manner to particular stones. The margins of the mantle are the same in both. 'The tubes extend, bifurcate, and vary in their rays and ciliations in the same degree in both. In short, we cannot point out any particular organ but what is exactly similar. We are therefore compelled by the force of facts to come to the conclusion that the two are identical; and though the shells of each seem to present greater differences than their animals, still the prineipal form and outline of hoth, with their stric of growth and decussations, are essentially of the same character; the variations are mere morlifications of similar elements dependent on habitat, deprivation of light, or exposure to it, for when the shells are emberlded in the cavities of rocks they are subject to variations of form, and being deprived of light, they are usually colourless and without markings; and not being rubbed by the action of the waves amongst the shingly bearhes, their stric are sharper and more foliaccons. Anongst shingle, where they are free, or if the current be strong, attached by their filaments to stones, and exposed to light and the action of the sea, they are of regular form, 
often beantifully colonred with smoother stria and decussations. In the former case they are the Vemus perforans; in the latter the Venus pullastra of authors."

This shell is littoral, and does not appear ever to range beyond the laminarian zone. It lives buried in gravelly sand, muddy gravel, or in crevices of rocks, and roots of Laminarix. It is very generally distributed around our coast, but rather local; usually, however, plentiful whereever it does occur. Among localities may be cited :Gorey in Jersey, in crevices of submarine granite rocks (S. H.); "Plymouth in hard limestone" (Montagu); Falmouth (Cocks); Exmouth in the shingles near the new rope-walk (Clark); Dartmonth in seven fathoms water, dead (M'Andrew and E. F.); Poole (E. F.) ; at Hastings and at Margate, in bloclis of chalk near the jetty (S. H.); Littlehampton (Strickland); Scarborough abundantly (Bean); not uncommon in the shale rocks of Durham and Northumberland (Alder); Swansea and other places in Sonth Wales (Jeffreys); Anglesea ( $\mathrm{I}^{6}$ Andrew); Isle of Man, but scarce (E. F.); Clyde (Smith); Hebrides (Jeffreys); Zetland, littoral and as deep as seven fathoms (Jeffreys, M'Andrew, E. F.); Aberdeen and Banff, both varieties (Macgillivray); Frith of Forth, plentiful at low water, especially near Newhaven and Cramond (E. F.); Ireland.

The Tapes pullastra is confined to the Celtic and Scandinavian seas, and dates its origin from the Pleistocene epoch. 


\section{T. virginea, Limmus.}

Subcorlate, suboral, glossy, rery inequilateral ; surfice smooth towaris the heaks, elsewhere merely concentrically striated ; ventral edge subarcuated: umbones obtuse, and much inclined forwards: inner surface white or pink.

Plate XXV.fig. 4, 6.

Lister, Hist. Conch. pl. 403, f. 247.

Tenus virginea, Liss. Syst. Nat. ed. 12, p. 1136.-Pultexer, Hutchins, Dorset, p. 34.-Moxт. Test. Brit. pp. 128, 576.-Linn. Trans, vol. viii. p. 89, pl. 2, f. 8.-Dorset Catalog. p. 36, pl. 13, f. 1.-T'vrT. Conch. Diction. p. 246.-Turt. Dithyra Brit.p. 156, pl. 8, f. 8. -Forbes, Malacol. Monensis, p. 53.-Brit. Marine Conch. p. 92.-Dillwys, Recent Shells, vol. 1, p. 207.-Laм. Anim. s. Vert. (ed. Desh.) vol, vi. p. 360.-Index 'Testaceolog. pl. 8, f. 110.-Hanl. Recent Shells, p. 123, pl, 8, f. 110.

I'enus rhomboides, PEN. Brit. Zool. ed. 4, vol. iv. p. 97, pl. 55, f. (omitted). Cuneus fasciatus, DA Costa, Brit. Conch. p. 204.

Venus Sumiensis (VArietx), Tunt. Dithyra Brit. p. 153, pl. 10, f. 6.-Brit. Marine Conch. p. 91.

Tenerupis " (Varietr), Flem. Brit. Anim. p. 452.

Venerupis virginea, Flex. Brit. Anim. p. 452.-MAcGllulv. Moll. Aberd. p. 269.

Pullastra virginea, Brown, Ill. Conch. G. B., p. 89, pl. 37, f. 8, 9, and pl. 36, f. 6 .

Jenus virago, Loven, Index Moll. Skandinavix, p. 40.

Tcllina elliptica (Fry)? Browx, Ill. Conch. G. B., p. 101, pl. 40, f. 20, 21.

By far the most beantiful in painting of our Veneride, is that which we are about to describe. In form it is of a somewhat heart-shaped oval, and is strong, opaque, and very incyuilateral; its valves are morlerately ventrieose, but the convexity is tolerably evenly diflused, and not chiefly confined to the umbonal region. 'The surface, which is glosis, is merely striated in a concentric direction with coarse moderately distant lines, which are not recgularly patrallel. but alumoximate in front, becoming more remote at the hinder part of the eentral disk. These strie are entirely obsolete towards the beaks, and anteriorly have a 
tendency to imbrication. The variety of colouring is almost infinite in patterns, but is generally compounded of pencillings of pink, or various shades of dark or ruddy fleshcolour and white. Very rarely it is of a pure milk-white, and devoid of all painting; more usually the darker are the prevailing tints from the crowded masses of zigzag lines which cover the surface so closely that the white is only visible at the triangular interstices of this net-work, or in the shape of two more or less broad ray-like streaks. One of these latter, is ordinarily placed at about one-third the distance from the anterior end (and this is almost perpendicular); the other, which is very oblique, along the ordinary site of an umbonal ridge. Occasionally, where the entire surface is thus reticulated, or assumes an uniform or slightly mottled tint from the extreme minuteness of the linear zigzags, there are from two to four rays which are chiefly manifested by there being a lesser preponderance of dark markings upon those areas, and sometimes too by the occurrence of angulated spots of a deeper shade than the prevailing colour ; these last are occasionally confluent, and run alongside of the white or paler rays. Occasionally the rays are wholly composed of more or less interrupted obscure markings of a deeper tint than the almost uniform ruddy hue of the ground.

The ventral margin is convex or subarcuated, rising at each end, but particularly in front: the declination of the front dorsal is short, moderate, and straight, or but slightly retuse, that of the hinder one is very trifling, and almost rectilinear in the young, becoming stronger and more convex with increasing age. The anterior side, whose extremity is attenuately rounded, varies from occupying one-third, to only making one-fifth, of the entire length: the posterior end, which, in the young, is somewhat biangulated, (the 
lower angle is. however, always rounded of ') becomes only obsoletely so in the more aged examples; from a similar rommlime wif of the upper angle, the hinder margin is conrex and ol,linge. The ligament is large, yellowish-brown, and not elevated above the dorsal line. The lunule is lanceolate, moderately large, but neither profoundly impressed nor sharply defined; it is often of an mitorm liver-colour. The umbones are not at all prominent, but are much inclined forwards, the heaks are obtuse, and curve both inwards and anteriorward. The inner surface is white or stained with pink; the pallial sinus semi-elliptic. The tewth are dirergent, the extremes forming at least a right angle; the central of the left valve, and the posterior and the central of the right valve are bifid.

The ordinary run of specimens do not generally exceed an inch and a half in length, and half an inch less in breadth; we have, however, an individual now before us which has the large dimensions of nearly two inches and a-half in length, and almost an inch and three-quarters in breadth. Young examples are perfectly smooth. The variety termed Samiensis, by Dr. Turton, is usually of a coniser texture, lighter colour, and rather more rentricose; its concentrice stria are generally closer, and their tendeney to become more remote posteriorward is consequently less distinctly manifested. These characters are, however, rarely all evident in the same specimen, the union between the type and the variety being perfect in gradition. There is a great bluntness or absence of angularity in the ontline of virgined, as compared with that of its British congeners.

The animal of $T$. cirginec resembles, in most of its chatracters, that of the other forms of the genus. It is entirely wi it crant-white hue, except the extremity of the branch- 
ial siphon, which is tinged with red. The siphons are united for more than half their leugth, and then diverge. The foot is not very large in proportion to the body.

This species is chiefly found in the coralline region of depth; very rarely littoral. The most brilliantly-coloured examples are dredged in about seven or eight fathoms water, at Guernsey, where it is excessively abundant (S. H.); it is, indeed, one of our most plentiful species, yet in many localities scarcely a specimen is to be obtained. It is rare in Dorsetshire and Devonshire (Mont.); it has been talien at Falmouth by Mr. Jeffieys and by Mr. Cocks; in twenty fathoms near Penzance, and in fifteen fathoms IVest Bay of Portland (II'Andrew and E. F.); off Poole (E. F.); Scarborough (Bean); Tenby (Lyons); Prllheli and Anglesea, in trolve fathoms (M'Andrew); Isle of Man, on north and east coasts, in from fifteen to twenty-five fathoms, plentiful and very varied in its colours (E. F.); on the east coast of Scotland and northeast of England it is either very rare or absent, not occurring in the copious lists of either Macgilliviay or Alder. On the west and north, however, it is frequent; Ullapool, Loch Carron, Deal Voe, and Lerwick (Barlee and Jeffreys); Clyde, Hebrides, and Shetland Isles, ranging from five to thirty-five fathoms ( $\mathrm{I}^{\prime} \mathrm{Andrew}$ ); Orkneys (Thomas), where it is both littoral and in deep water.

This is one of the species which were dredged by Captain Beechey in a submarine ravine off the Mull of Galloway, at a depth ranging from a hundred and ten to a humdred and forty-five fathoms (W. T. Ann. N. H. vol. x. p. 21). The variety Samiensis is not confined to the Chamnel Islands, but has been dredged likewise upon the Dublin coast by Dr. Loyd, of Malahide (W. T. Ann. N. H. vol. v. p. 13); Bantry Bay, Youghal (Jeflieys and Ball); 
Donaghadec, in eight fathoms (Patterson); north of Ireland, in rarions localities ('Thompson and Hyndman).

It ranges from Norway to the Mediterranean, but its capital is in the Celtic province. As a fossil it dates its appearance from the epoch of the red crag.

\section{'T. aurea, Gmelin.}

Subcordate, suborate, concentrically closely sulcated, sulci not becoming more distant posteriorly; sides not particularly unequal; ventral margin more or less arcuated: umbones ventricose, and rather prominent : inner surface of a deeper or paler yellow.

\section{Plate XXV: fig. 5.}

Vemus aurec, Gurelin, Syst. Nat. p. 3283.-Moxt. Test. Brit. pp. 129, and 576. -Limn. Trans. vol. viii. p. 90, pl. 2, f. 9.-Dorset Catalog. p. 36, pl. 13, f. 3.-Turt. Conch. Diction. p. 247.-Flex. Brit. Anim. p. 449.-Brit. Marine Conch. p. 92.-DiLLw. Recent Shells, p. 207.-Lamanck, Anim. s. Vert. (ed. Desh.) vol. vi. p. 360.-Index Testaceol. pl. 8, f. 111.-Phulirpi, Moll. Sicil. vol. i. \{p. 47, and vol. ii.p. 35.-HANL. Recent Shells, vol. i. p. 123, pl. 8, f. 111.-TunT. Conch. Diction. p. 248.

Vemus nculosa, Pulteney, Hutchins, Hist. Dorset, p. 34.

Venus anea, Turt. Conch. Dithyra Brit. p. 152, pl. 10, f. 7.-Flem. Brit. Anim. p. 449.-Brit. Marine Conch, p. 91.

Venus nitens, Turt, Conch. Diction. p. 247.-Turt. Dithyra Brit. p. 157, pl. 10, f. 8.-FLEMr. Brit. Anim. p. 449.-Brit. Marine Conch. p. 93.

Venus sinuala, Tunt. (not Penn.) Conch. Diction. p. 242.-Tunt. Dithyra Brit. p. 155, pl. 9, f. 7, 3.-Fuzu. Brit. Anim. p. 449.-Brit. Marine Conch. p. 92.

Pullastra aurea, Brown, Ill. Conch. G. B. p. 89, pl. 36, f. 5, 7, 8 .

The subject of our deseription is prone to much variation loth in form and markings, our ortinary British specimens being in proportion so much broader than those of the Mreliterranean, that the identity of the two might alnost le dounted, dir not intermediate gradations definitcly estatWh-h it. It creneral outline is subovate and subcorliform; it is tolerably strong, opaque, moderately inequilateral, 
and rather glossy. The valves are more or less ventricose, the umbones being disposed to tumidity; and their surface is concentrically traversed by close-set not strictly parallel narrow sulci, the interstices of which are often bifureated, and not unfrequently become obtuse costelle, especially in front and towards the lower margin. This sculpture, which has a tendency to become obsolete upon the most swollen portion of the shell, the hinder part of the umbonal region, is indistinctly decussater by impressed radiating lineoles. The ground-colour, which is usually of a pale golden yellow, or creamy hue, often whitish, is most frequently marbled with linear or clondy zigzags of many shades of liver and smoke-colour, differing in various examples in respect to the size and propinquity of markings. More rarely, the shell is perfectly devoid of any variegation, and is of an uniform pale yellow, or white. The velitral margin is always more or less subarcuater, and is usually a little contracted posteriorly in the adult. The declination of the front dorsal edge is retuse, and always more or less strong; that of the hinder one is considerably less, and convex, though frequently but slightly so. The anterior side, which occupies from one-third to two-fifths of the entire length, is well rounded at its extremity, which from its greater or lesser attenuation often appears strikingly projecting. The posterior termination is very variable in its contour; in the younger shell, it is generally more or less bluntly and obliquely subbiangulated; in the adult it is more nearly rounded, and oftentimes is produced attenuated and thoroughly rounder. The lunule is very large, ovately lanceolate, not profound, but defined by a shallow line. There is no posterior escutcheon. The umbones are more or less prominent, and the beaks are very acute, small, and inclined forwards. 
The ligament is rather large, yellowish brown, and not elerated beyond the dorsal line.

'The internal colouring is typically of a rich golden yellow, but is often pale, and has usually more or less extem ive stains of brilliant purple upon the hinge margin. () the there primary teeth, the two hinder are bifid in the right valve; in the lelt hinge the central alone is invarialily cloven, the anterior not being always distinctly bifid : the right anterior and the left posterior are thin, laminar, and oblique.

Some of the larger of our specimens, are fully an inch and a half in length, and at least an inch in breadth; these, however, may be regarded as rather exceeding the average size of examples.

We consider this a locally abundant, but by no means common shell. Mr. Alder remarks, that it is very frequent in Falmouth harbour, and at Helford river in Cornwall, where the shells are more produced in shape, and more elegantly marbled than the ordinary run of specimens. It is likewise olbtaned at Little IIampton, Suswex (Striclitund); Weymonth (S. II.); Portsmouth and l'lymouth (Jeffieys); the Scilly Isles, where it grows to a very large size (M'Andrew); Tenby (Lyons); Pwllheli (M'And.); Clew Bay, in from three to ten fathoms (R. Ball, W. Thompon, and E. F.) ; Birterluy Bay in (onnemara (Farren and Barlec); Bantry Baty (Jeftreys cab.); Youghal (Ball). In scotland it has been certainly foumd only in the extreme south-west: Mr. Smith recording it from Ayr, and Mr. Nicol from Loch Ryan. Laskey's locality of it in the Frith of Forth is probably a mistake. Abroal it ranges form Seandinavia to the Merliterranean.

It is only linown as a British fussil in certain beds, problat1, ly of Pleistocene age, near Dublin, where the stained spe- 
cimens were mistaken for a distinct living species by Dr. Turton, and named Venus anea. It is also found in the Newer Pliocene strata of Sicily.

CYTHEREA, LAMARCI.

Shell solid, equivalve, inequilateral, closed, usually more or less transversely oblong, with slightly prominent and recurved beaks. Surface sometimes sulcated or striated transversely, usually nearly smooth. Muscular impressions ovate; pallial sinus wide, ovate, obtusely pointed. Margins always smooth. Hinge composed usually of four diverging teeth in one valve, and three in the other, with corresponding pits. Ligament external, rather long.

Animal oblong, with its mantle freely open, and plain at the margins. Foot large, linguiform, not furnished with a byssal groove; siphons united nearly to their extremities, orifices of both with (simple) cirrhi.

This genus is rejected by Deshayes, Rang, and D'Orbigny, and many modern malacologists, on the plea of its being entirely artificial. It is maintained by others as a convenient section of a group containing an immense and inconvenient number of species, which the genus Vevus in the sense used by the authors mentioned is. In a scientific treatise, such as we wish this to be, no such plea could be almitted. We adopt this Lamarckian group on ligher grounds, and maintain it because it includes a very natural assemblage of forms, presenting certain important characters in common, both of shell and animal, sufficiently separating them from the true Veneres. In our seas we have only a single representative of this beautiful sectionthat one among our most beautiful indigenous mollusks. In tropical seas they abound, and are remarkable for ele- 
gance of form and brilliancy of colour. 'The majority of' the more ancient for-il Fincider appear to belong to C'ytheieel.

\section{C. chrone, Linnæus.}

Plate XXVII., and animal, Plate L. fig. 8.

Venus Chione, Livi. Syst. Nat. p. 1131.-Pulteney, Hutchins, Dorset, p. 33. -Donor. Brit. Shells, vol, i. pl. 17.-Mont. Test. Brit. p. 115. -Linn. Trans, vol. viii. p. 84.-Dorset Catalog. p. 35, pl.6, f. 7. -Turr. Conch. Diction. p. 239.-Chemn. Conch. Cab. vol, vi. p. 344, pl. 32, f. 343.-Pol, Test. Sicil. pl. 20, f. 1, 2DiLLw. Recent Shells, vol. i. p. 176.-Index Testaceolog. pl. 7, f. 44.-BLanv. Man. Malacol. pl. 74, f. 5.

Pectunculus glaber, DA Costa, Brit. Conchology, p. 184, pl, 14, f. 7.

Cytherea Chione, Larr. Anim. s. Vert. (ed. Desh.) vol, vi. p. 305.-Tunt. Conch.

Dithyra, p. 160, pl. 8, f. 11.-Flen. Brit. Anim. p. 444.-

Brit. Marine Conch. p. 83.-Brown, Ill. Conch. G. 13. p. 91, pl. 37, f. 2.-Desir. Elem. Conch. pl. 19, f. 4, 5.-PinLipri, Moll. Sicil. vol. i. p. 40, and vol. ii. p. 31.-Hanz. Recent Shells, p. 98, pl. 7, f. 44 .

Cythérée fauve, Chenv, Traité Elem. pl. 3, f. 10.

Cytherea nitidula, (Youvg) LaM. Anim. s. Vert. (ed. Desh.) vol. vi.p. 305 (fide Recluz, and Philippi).

Regexfuss, Choix Coquil. pl. 8, f. 17.-Encyclop. MIéthod, Vers. pl. 266, f. 1.

This magnificent bivalve has a somewhat heart-shaped ovate contour, is strong, solid, opaque, glossy, and dccirlexlly inequilateral, but yet for its genus not particularly so. Although, for a Cytherea, it may be termed compressed, it is often somewhat ventricose, though never inflated; the profundity is manife-tly greater behind than in front. The exterior, which is smooth, or merely marked in a concentric direction with obsolete shallow indented folds (and these are confined to the vicinity of the sirles and lower margin), is of a pale but warm chestnut tint (which varies in intensity) copionsly adomerl with broader and narrower rays of a more livid east. These rays, from the colouring natter being deposited in palex and dartier 
zones, have oftentimes (especially in young individuals, and upon the umbonal region of the adult) an interrupted appearance; the beaks, too, have almost invariably three short indistinct ray-like colourless markings proceeding from them, of which the central is the shortest, and the others margin the commencement of the lunule and the ligament. The ventral outline is moderately and tolerably evenly curved; the declination of the binder dorsal edge is very moderate, and slightly convex; that of the front dorsal is stronger, ineurved or retuse at first, and arched at its termination. The anterior side, which occupies about one-third of the shell, is attenuated at its extremity where it is rouncled both above and below ; the posterior side likewise tapers more or less, and is bluntly and unsymmetrically rounded at its termination. The umbones project very considerably forward, but are notswollen; the bealss, which are acute and inflected, are preceded by a very large oval-lanceolate lunule, which is well defined, yet not greatly depressed, and rises or pouts at the rather tortuous seam. The ligament is long, moderately prominent below, but overhung above by the projection of the valves at the umbonal region, the hinder dorsal areas inclining inwards but not forming any excavation or lozenge-like area. The inside is of an uniform white, its margin is blunt and entire. The hinge consists in the right valve of two central entire primary teeth, (of which the front one is the thimner and shorter, and the posterior shelves greatly belind) and an extremely oblique somewhat bifid produced hinder one. Before all these stands the receptacle for the front sublateral Iamina of the left valve, which latter has in addition a central cloven but very erect and narrow primary tooth, behind which is a much more solid entire one, and a third excessively oblique almost linear one adjacent 
to the ligament. The pallial sinus is pointed, or sealpelshaped.

'The largest of our specimens measured nearly three inches and three-quarters in length, and not quite two inches and three-quarters in breadth. The three whitish markings at the umbones are an useful character for distinguishing the species from its nearest exotic congeners (squalida, scc.).

We have never had an opportunity of examining the animal alive, but a good drawing of it, which we have copied, is given in Poli's magnificent work on the "Mollusca of Naples." He figures and describes it as having the matntle freety opene, with thick and, slightly undulated, but not fringed, matrgins of an oramge fleth colour. The siphons are long and united nearly to their extremities, which are each surrounded by a circle of simple cirrhi. The tubes themselves are of a deep orange colour with fleshy stripes; their extremities dusky-striped; the tips of their fringes Whek. 'ithe toot is very large, thick, and of a dark pinlish flesh-colour.

Upon the whole, this, although so frequent abroad, must rank with our rarer bivalves, being taken in but few localities, and those only in the south-west. Of these Plymouth (S. H.), is, perhaps, the most prolific, but other parts of South Devon, as 'I'eigmmouth, Scc. (S. H.); with Falmouth, Nount's Bay (Jeftreys), and other parts of Cornwall, off' which coast it has been dredged in twenty fathoms ( $\mathrm{I}^{\prime}$ Andrew and E. F.), likewise yield specimens in tolcrable plenty. Mr. M'Andrew has also dredged it in twelve fathoms water Caernarvon Bay, which appears to be its most northern station. Living shells are ordinaxily brought in by the trawling vessels, whence we may conclude that they do not very closely approach the shore. 
Abroal it has its chief ecntre in the Lusitanian Provinee, and is abundant in the Mediterranean. It was an inhabitant of our seas as long ago as the epoch of the coralline crag but retired southwards during the prevalence of glacial conditions, and afterwards returned.

\section{SPURIOUS.}

C. circinata, Born.

Venus circinata, Born, Mus. Cæs. Vindob. p. 61, pl. 4, fo 8.-Chenn. Conch. Cab. vol. vi. p. 312, pl. 30, f. 311.-DiLlw. Recent Shells, vol. i. p. 169.

Venus Guincensis, Gmelin, Syst. Nat. p. 3270.-Mont. Test. Brit. Suppl. pp. 48, 168.-Dorset Catalog. p. 35.-TurT. Conch. Diction. p. 237.

Cytherca Guineensis, LAM. Anim. s. Vert. (ed. Desh.) vol. vi. p. 311.-Tunt. Dithyra. Brit. p. 161.-Fues. Brit. Anim. p. 445.Brit. Marine Conch. p. 84.-HANL. Recent Shells. p. 100.

Encyclop. Méthod. Vers. pl. 265, f. 1.

Inhabits the S. Atlantic Ocean; was introduced by Montagn, as taken in the Frith of Forth by Mr. Laskey.

\section{VENUS, LINNEUS.}

Sirell often thick, equivalve, closed, more or less suborbicular or transversely ovate, generally ornamented by concentric ribs or strix, in some species decussated by longitudinal furrows, often brightly coloured. Margin crenated. Beaks prominent. Hinge composed in each valve of three diverging cardinal teeth. Ligament strong, external, lodged in a well-defined area. Lunule well-marked. Muscular impressions rounded, strongly marked. Pallial sinus lanceolate, wide.

Animal ovate or suborbicular, thick; its mantle open throughout, and fringed or furbelowed at the margins. Siphons separate, and diverging, or partially, or even en- 
tirely united to their extremities, where the orifices are surrounded by fringes of cirhi. Foot linguiform, apiculate. not furni-hed with a bysal groore; labial tentacles lanceolate.

This heautiful and extensive group of bivalyes inchules more than a hundred distinct forms, of which the majority are remarkat,le either for elegance of shape or lrilliancy of colour. But few of these range to the British Seas; those which do, however, are among our most attractive shells. Since northwards of our region these are not replaeed by new forms, we may regard ourselves on the outslists of the generie prorines, cepecially as the majority of Fense, and the larerer and more heatiful himds are either tropical or subtropical. The vertical range of the several species is very variable, extemling from low-water mark to great oceanic depths. Some linds are confined to the water's edge, other's inlnabit exclusively the abysses of ocean, whilst not a few have very extensive ranges, as in the instances of Venus striatula and Vonus ovata, both of which live indifferently at the margin of the sea, and beneath a depth of more than one hundred fithoms. Such capacity for enduring great differences of pressure warn us not to lay too great stress on that influence as a regulator of distrilution, the more so as examples of these mollusks drawn suddenly up from very great depths appear to experience no inconvenience from the rapid change of conditions, amr display their siphons and other orgaus as readily in a hasin of sea-water as they could ever have done in the profound recesses of their birth.

Whilst some conchologists object to the separation of Tenus from Cythesea and Tapres, others would divide this group into numerous lesser genera. 'Thus, Venus casina reprenent- the genus Clensine of Brown; Fones striutulu his 
Ortygia; Venus ovate is the type of Timoclea in Leach's arrangement; and the genera Dosina of Gray, Chione of Megerle, and Antigone of Schumacher, are in the same category. Such subdivisions, founded in all cases on mere conchological characters, do not seem to us describable.

\section{V. verrucosa, Linnæus.}

With concentric ribs, which are broken into wart-like tubercles at the sides.

Plate XXIV. fig. 3.

Lister, Hist. Conch. pl. 284, f. 122.

Venus verrucosa, Linn. Syst. Nat. ed. 12, p. 1130.-Pulteney, Hutchins, Dorset, p. 32.-Donov. Brit. Shells, vol. ii. pl. 44.-Mont. Test. Brit. p. 112.-Linn. Trans, vol. viii. p. 78.-Dorset Catalog. p. 34, pl. 8, f. 1.-Tunt. Conch. Diction. p. 231.Turt. Dithyra Brit. p. 140.-Flem. Brit. Anim. p. 446.Brit. Marine Conch. p. 85.-Brown, Ill. Conch. G. B. p. 90. pl. 36, f. 16.*-Bons, Mus. Cæs. Vind. pl. 4, f. 7.Cuemn. Conch. Cab. vol. vi. p. 303, pl. 29, f. 299, 300,Poli, Test. Sicil. pl. 21, f. 18, 19.-Lam. Anim. s. Vert. (ed. Desh.) vol. vi. p. 339 (not varieties).--DiLlw. Recent Shells, vol. i. p. 163.--Index Testac. pl. 7, f. 12.-Crouch, Introd. Conch. pl. 7, f. 6.-Sowerb. Conch. Man. f. 119, a.-Desh. Elem. Conch. pl. 21, f, 1, 2.-Philip. Moll. Sicil. vol, i. p. 43 ; and vol. ii. p. 34.-HANL. Recent Shells, p. 110.

Venus Erycina, Penn. Brit. Zool. ed. 4, vol. iv. p. 94, pl. 54, f. 48.

Pectunoulus strigosus, DA Costa, Brit. Conch. p. 185, pl. 12, f. 1 .

Venus cancellata (Young), Donovan, Brit. Shells, vol. iv. pl. 115? (fide Mont.)-Mont. Test. Brit. p. 574.-Turt. Dithyra Brit. p. 144, pl. 10, f. 3.-Flem. Brit. Anim. p. 447.-Brit. Marine Conch. p. 87.

Venus Lemanii (Young), Payraudeau, Moll. Corse, p. 53, pl. 1, f. 29, 30, 31 (fide Desh. and Recluz, from types).

The peculiar wart-like tubercles give so remarkable an aspect to this solid and coarse-looking bivalve, as to render its separation from its congeners a comparatively easy task. It is of a somewhat heart-shaped obovate form, very strong, generally heavy, decidedly inequilateral, and of at

voL. I. 
paler or darker rusty-brown, oceasionally adorned, but chiefly in the younger examples, with rather indistinct linear zingag marlings, or with abont three obseure rays of livid brown. When adult it is more or less ventricose, or cwon inflater ; the convexity is broally and tolerably evenly diffuser, althongh the valves are slightly more compressed anteriorly. The surface is covered with numerous concentrice much-elevated solid laminar ridges, which are rlosely arranged, somewhat reflected or bending towards the beaks (thus appearing hollowed ont beneath, when examined from ahore), and more or less distinctly indented at their edges. These ridges at both ends, but far more evidently belind, are broken up into rather large and horizontally compressed wart-like tubercles, which form radiatingly livergent rows. The interstices of the ridges are usually traversed by one or two raised concentric lines, and towards the umbones with depressed and rather distant raliating ribs, which in some examples quickly become obsolete, but are continued in others almost to the base of the shell. The ventral margin is more or less arcuated, and rises firr more in front than behind, thus attenuating below the short and tolerably-rounded anterior side. The posterior termination is rather hroad, and very obseurely subbianculaterl, the lower angle being almost entirely rounder off in the actult, though sufficiently manifest in the immature individuals; the posterior margin is more or less conrex. The fiont dorsal edge is short, and rather rapilly declining, its slope is not incurved as the lunule pouts very manifest at the lips; the declination of the hinder dorsal margin is by no means consilerable; it is comparatively rectilinear in the young, and becomes more curved in the aged examples. The umbones are prominent, and, as well as the beaks, incline much forward; the latter are acute, 
and are preceded by a rather large heart-shaped lunule, which is well defined by being laterally sunken, though elevated in the middle, and is concentrically substriated, and usually tortuous at the suture. The ligament, which is rather large when not concealed by the overlapping of the hinder dorsal lips, is seated in a tolerably ample and somewhat shallow lanceolate excavation, which is smooth, and in the left valve, where it is more manifest, is adorned with a few more or less flexuous cross-bars of a livid smokecolour. The interior is of an uniform white; the edge is obtuse, and distinctly but not coarsely crenated, except posteriorly, where it is usually more or less entire. The hinge-margin is broad, and is furnished in each valve with three divergent teeth, of which the anterior in the right valve is very short (not reaching to the margin), and the central only subbifid; the two front teeth of the opposite valve are generally more or less cloven when young.

The fry, being far more angular in shape, and having the ridges thininer, the radiating costellæ more apparent, and the tubercles not yet developed, has erroneously been condered a distinct species, and separated under the name of cancellata. The shell so named in Donovan, and which is referred by Montagu to the present species, seems to bear an at least equal resemblance to striatula.

We possess foreign examples which are two inches and a half in length, and two inches and a third in breadth; but know of no British specimens approaching these dimensions.

The animal is suborbicular, very thick, and of a pale yellowish-white colour. The mantle is freely open from the tubes to the anterior adductor muscles; its edges are serrated or fringed, presenting more or less of a furbelower aspect. The siphons are short, but well separated, and of a yellowish-white colour, with tawny specks or dark grey 
spots, lines and small blotches. The orifice of the branchial tube is surrounded by a double series of cirrhi, the longer ones, about twenty in number, being sinple. There are only about ten simple and shorter filaments around the anal orifice : it is furnished with a prominent tubular valve. The foot is white, moderately long, linguiform, pointed, and, when at rest, of a securiform shape. It presents no traces of a byssal groove. The branchie are subcircular, free, of a brown colour, coarsely peetinated, the upper part as usual smaller than the under one. The labbial palps are rather small and narrow. (Clark MSS., Deshayes.)

The Venus vernucosa is a southern species on our coasts, and dues not range northwards beyond the British shores. Mr. Bean states that it occurs, though rarely, at Scarborough, and it is recorded from the coast of Northumberlind, though we are inclince, with Mr. Alder, to suspect that the specimens have been imported with ballast. In the English Channel it is tolerably abundant, as on the Devonshire coast (Clark); Cornwal and the Scilly islands (M'Andrew); Weymouth, dredged in seven fathoms (M'Andrew and E. F.); and Littlehampton (Stricliland). In the islet of Herm, near Guernsey, it is collected for eating from the small pools between the rocks at low-water (S. H.). In Wales it is taken at Milfordlaven (M'Andrew and E. F.), and as far north as P'wllheli (M'Andrew). In Ireland it occurs at Youghal and Bantry bays (Jeffreys); and on the west coast as firr north as the county of Sligo (IV. Thompson).

It is a characteristic Lusitanian mollusk, and ranges thronghout the Mediterranean. It extends as firr sonth as Senegral (Adinnon), and the Canaries (IVebb), and is recorded as a Red Sea species by Ehrenberg. It is not known as a fossil in British strata of older date than beds 
of the glacial epoch, and in them have only been found in their southernmost portions, in Ireland, where it was discovered by Captain James, R.E., during the researches of the Geological Survey.

\section{CASINA, Linnæus.}

Suborbicular, or subquadrate, either whitish, or with a few roseate rays; rough with numerous lamella: hinder dorsal area never lineated.

Plate XXIV. figs. 1, 5, 6 .

Venus casina, Linv. Syst. Nat. p. 1130.--Linn. Trans. vol, viii. p. 79, pl. 2, f. 1.-Mont. Test. Brit. Suppl. p. 47.-Turt. Conch. Diction. p. 232 ; Dithyra Brit. p. 141, pl. 9, f. 1.-FleMing, Brit. Anim. p. 446. - Macgilliv. Moll. Aberd. p. 264. - Brit. Marine Conch. p. 86.-Brown, Ill. Conch. G. B. p. 90, pl. 36, f. 15.*Chemn. Conch. Cab. vol.vi. p. 306, pl.29, f. 301, 302.-Diltw. Recent Shells, vol. i. p. 165.-LaM. Anim. s. Vert. (ed. Desh.) vol. vi. p. 340.-Index Testaceolog. pl. 7, f. 14.-Hant. Recent Shells, p. 111.-Löven, Ind. Moll. Sueciæ, p. 39.

P'cclunculus membranaceus, $\mathrm{DA}_{\mathrm{A}}$ CostA, Brit. Conch.p. 193, pl. 13, f. 4 (on the left). Ienus reflexa, (VAR.) Mont. Test. Brit. Suppl. pp. 41, 168.-Mem. Werner. Soc. vol. i. pl. 8, f. 1 (badly).-Turt. Conch. Diction. p. 233 ; Dithyra Brit. p. 142, pl. 10, f. 1, 2.-FLEM. Brit. Anim. p. 446.-Macgilliv. Moll. Aberd. p. 264.-Dillw. Recent Shells, vol. i. p. 168.-HanL. Recent Shells, p. 110, suppl. pl. 16, f. 10 .

Venus luctca, Donov. Brit. Shells, vol. v. pl. 149.-Linn. Trans. vol, viii. p. 79. -Mont. Test. Brit. Suppl. p. 46.

Venus discina, La «. Anim. s. Vert. (ed. Desh.) vol. vi. p. 338.-Brit. Marine Conch. p. 86.

Venus Rusterucii (Young) Payraudeau, Moll. Cors. p. 52, pl. 1, f. 26, 27, 28. Cytherea reflexa, Couch, Cornish Fauna, pt. 2, p. 26.

This handsome bivalve being liable to certain modifications of form and colouring, has been subdivided into two species, casina and reflexa; but as their distinctive features so merge into each other that it is often impossible to decide to which of them a specimen would belong, we have regarded the latter as merely a variety of the earlier known and more commonly diffused casina. 
The general finm is mbyuadrate and suborbienlar, and the profundity, which varies from actually ventricose to but moderately convex, is always more marked behind than in front. The valves are extremely inequilateral, strong (not imfrequently thick and heary), opraque, but moderately glussr, whitish, pale ferruginous brown, or cream colourerl, and oceasionally painted with from one to three rosy-red more or less interrupted rays, which are not particulanly broarl, and are often partially indistinet, the one which runs from behind the beaks to the lower pusterior corner being least liable to become obsolete. 'The exterior is covered with very numerous concentric laminar simple (not fimloriated) much elevated plates, which are more solid depressed and closely set in front, bend towards the beaks in the middle, and become erect, or even deflected, behind. Their interstices are not decussated by any radiating strix or costelle, but are often subdivided by irregular concentric strix or incipient lamellæ. In the young, and upon the umbonal region of the adult, these plates are rather thin, but usually become more or less solid towards the ventral margin. This latter is decidedly arrenated, and rises the more in front. The anterior side is not merely very short,-for it occupies ordinarily but onefourth, and frepuently a still le's proportion of the entire length, - but is likewise much narrower than the hinder extremity, its extent being diminished as well by the ascent of the lower margin, as by the more or less rapid declination of the upper one. The general inclination of the front dorsal edge is, from the pouting of the lips of the lumule (which latter is latrge, heart-shaped, and strongly defined l,y leeing sunk betow the general level at its margin), neatrly rectilinear; the front extremity is narrowed, and unsymmurtrieally romeded. The hinder termination is broat and 
sub-biangulated (the upper angle is the more distinct, and generally is the more projecting), the posterior elge being more or less perpendicular; the hinder dorsal edge, which in the young is straightish, becomes convex, or even arcuated, in the adult, but never slopes to any considerable extent, and not unfrequently declines in but a very trifling degree. The umbones lean remarkably forward, but are not by any means prominent; the beaks are aente and distinct. The ligament, which is sunken and moderately large, occupies about one-half the length of the not very profound dorsal excavation or lozenge, whose shelving and subequal sides are either colourless, or only irregularly painted. The lunule is rather short, and often rufous. The interior is of an uniform whitish hue; the muscular scars are large, and the pallial sinus rather small and abbreviately linguiform; the basal margin, which is very broad, is strongly but finely and very closely crenated. Besides the three very divergent teeth (of which the central, by far the largest, is subbifid in the left valve), there is a minute anterior denticle at the lower part of the hinge margin in the left valve, and a corresponding indistinct socket in the right one.

Fine examples occasionally attain to the length of two inches; their breadth is somewhat less. The animal is thick and white; but the details of its structure have yet to be observed.

This is one of our least common Veneres, and is rarely obtained in any abundance. It is occasionally taken in Northumberland and Durham (Alder); at Scarborough (Bean); West Bay of Portland in fifteen fathoms (MI'A. and E. F.); South Devon (Mont.); Guernsey (S. H.); Milford Haven (M‘Andrew and E. F.), and elsewhere on the Welsh coast. In from twelve to twenty-five fathoms on the Manx Coast (E. F.). Both sides of Ireland (Thomp- 
son): Youghal and Bantry Bay (Humphreys); Ohan, Loch Carron, skye (Jeflices); Orkney in twelve fathoms, ame Fonla cighty fathoms, Copenhaw Head forty fathoms, Cilpe Wrath fifty to seventy fithoms (M Andrew); the Mull of Galloway from fifty to one hundred and forty-five fithoms (Beechey); thirty-five fathoms of the Staples and east coast of Scotland (Thomas). It occurs in the Scandinarian seas and more rarely in the Lusitanian, where it was more common during the newer pliocene epoch.

The V.casinula of Deshayes (Exp. Morée, p. 101, pl. 18, f. 18, 19 ; V. casina, Philippi, Moll. Sicil. vol. ii. p. 33) scarcely differs from our variety reflexa; its shape, however, is more elongated, its front dorsal slope is longer in proportion, and its lamelle in general are more closely disposed.

\section{V. striatula, Donovan.}

Triangular-heart-shaped; if coloured, painted with delicate rigzalg lines: sulcated or costellated (if lamellar, the shape elongated) : hinder dorsal area flexuously lineated.

Plate XXIII. fig. 4, Plate XXIV. fig. 4, and Plate XXVI. figs. 9, 10, 11.

List. Hist. Conch. pl. 282, f. 120.

Pectunculus striatulus, DA CostA, Brit. Conch. p. 191, pl. 12, f. 2.

Venus casina, (not of Linn.) PulteNey, Hutchins, Hist, Dorset, p. 33.

" striatula, Donovan, British Shells, vol. ii. pl. 68.-Mont. 'Test. Brit. p. 113.-Löven, Ind. Moll. Skandin. p. 39.

Venus gallina, MAton and Racisett, Linn. Trans, vol. viii. p. 32 - Dorset Catalog. p. 35 , pl. 8, f. 2.-Turt. Conch. Diction. p. 234, f. 65 (cxecrably); Dithyra Brit. p. 149, pl. 9, f. 2. - Flem. Brit. Anim. p. 448.-MackinLrv. Moll. Aberd. p. 265.Brit. Marine Conch. p. 39.-Brown, Ill. Conch. G. B. p. 89, pl. 36, f. 11.-ALDEr, Northumb. and Durham Mollus. p. 85. -Dirlw. Recent Shells, p. 168.-Lam. Anim. s. Vert. (ed. Desh.) vol. vi. p. 347 (in part).-Index Testaceolog. pl. 7, f. 23.-11 1 NL. Recent Shells, p. 115. 
Venus Pennantii, Forbes, Malac. Monens. p. 52.

" laminosa, * Turt. Conch. Diction. p. 233 (except the description of the hinge, which is copied from Montagu); Dithyra Brit. p. 148, pl. 10, f. 4.-Brit. Marine Conch. p. 89.-HanL. Recent Shells, suppl. pl. 16, f. 11.

,

,

9,

9

mugosa, Penn. Brit. Zool, vol. iv. p 95, pl. 56, f. 50.-Frem. Brit.

Anim. p. 448.-Brown, Illust. Conch. G. B. p. 90, pl. 36, f. 14.

Prideauxiana, Covch, Cornish Fauna, pt. 2, p. 26.-MACGilliv. Moll.

Aberdeenshire, p. 266.

sulcata, Brown, Ill. Conch. G. B. p. 90, pl. 36, f. 12.

costata, Brown, Ill. Conch. G. B. p. 90, pl. 36, f. 13.

A reference to the tenth edition of the "Systema Nature" will convince our readers that the Venus gallince of Linnæus [Chenn. Conch. Cab. vol. vi. p. 311, pl. 30, f. 308, 309, 310.-Pou, Test. Sicil. pl. 21, f. 5, 6, 7.Philippr, Moll. Sicil. vol. i. p. 44, and vol. ii. p. 34.HanL. Recent Shells, suppl. pl. 16, f. 42,] is the shell so named by those who have illustrated the conchology of the Mediterranean. It is perhaps a matter of

* Venus laminosa, Mont. Test. Brit. Suppl. p. 38.-Laskey, Memoirs Wernerian Soc. vol. i. p. 384, pl. 8, f. 16.-Brown, Illust. Conch. G. B. p. 90, pl. 37, f. 14, 15 (copied from last).

We have not ventured to assert the identity of the $V$. laminosa of Montagu and Laskey with that of Turton, owing principally to the dentition assigned to the former in the Testacea Britannica. Nevertheless, it is highly probable that the general belief of collectors (the tradition, if we may so term it) is not unfounded, and that the species was established upon an aged example of that variety of striatula termed rugosa by Pennant and Brown, in which some peculiar distortion of the cardinal edge misled the author and induced him to attribute to it the hinge of a Cytherea. That no known species of the latter genus (tortuosa is, perhaps, the nearest) will accord with the figure in the Wernerian Memoirs, which is exactly like a swollen example of the produced (but generally compressed) variety of striatula is an additional argument in favour of the traditionary hypothesis. We subjoin the original description.

"Shell ovate, with numerous concentric laminar ridges, very little reflected; these ridges are not quite regular nor equidistant, but so thin as to be almost membranaceous; between the ridges about the umbonal region where a natural decortication has taken place, it is finely striated in the longitudinal direction, which shews that younger specimens are more generally furnished with such

VOL. I. 
controversy, whether that species is specifically distinet from the one so designated by the British writers; we subjoin, therefore, a brief digest of the more striking points of difference. The valves of gallina are always more or less inflated, or at least ventricose, and their surfice corered with distant subimbricated grooves, which are so peculiarly irregular as searcely to be concentric (characters even more fully evident in the young than in the old), their ventral margin is very strongly arenated, and their front dorsal edge short and much incurved; internally the hinder extremity, or the muscular sear, is almost invariably stained with purple; the crenations are coarse, and not particularly numerous, and the sinus of the pallial impression is remarkably short. In striatula, on the contrary, the valves, whose shape is much more trigonal, are frequently compressed, and very rarely are even ventricose; the surface, especially upon the umbones and in the younger shells, is girt with distinct costellie, which are by no means; peculiarly irregular, and, if distant, change into lamellæ; the arcuation of the lower edge is not remarkalle; the front dorsal margin is long; and not strongly in-

strix ; but in the only large specimen we have had an opportunity of examining, scarcely any such markings were observed but where the old shell had been superficially separated : the umbo is pointed and much reclined to one side, beneath which is a broad cordiform depression; but neither this nor the cartilage slope differs in colour from the rest of the shell, which is wholly of a dirty-white. Inside white: hinge furnished with four teeth in each valve, but the outer one above the cordiform depression in one ralve is obsolete, or formed only by a cavity for the reception of the corresponding tooth in the opposite valve: the margin is fincly crenulated. Length (breadth) more than in inch; breadth (length) above an inch and a quarter.

The above description is taken from a shell in the cabinet of Mr. Laskey, who assured us he took it by dredging off the Isle of May, in the Frith of Forth, in the year 1804. In our cabinet is a single ralve of about half the size of that before described, which was found in Devonshire; in this the longitudinal striae are evident by the assistance of a lens, in the sulci between the tranverse ridges." 
curved, and the interior is of an uniform white, with the marginal crenations extremely small and very numerous; the pallial sinus, too, is sublanceolate, and is half as long again as the adjacent muscular impression.

The species even thus restricted exhibits a remarkable latiturle of variation in form, sculpture, and colouring; but these varieties are inseparably connected by intermediate gradations. The general contour is heart-shaped, but differs greatly from being at times produced and therefore subovate, at times abbreviated, and consequently subtriangular. The convexity, likewise, is subject to great variation, some examples being decidedly ventricose, whilst others, being merely convex, are for Veneres comparatively compressed. In the ordinary intermediate specimens, the chief swell is rather behind the subumbonal region, and the chief compression at the anterior extremity. The valves are opaque, more or less solid, and almost entirely devoid of lustre; the ordinary and more typical examples are variegated, upon a whitish or cream-coloured ground, with extremely numerous and very fine linear zigzag markings of a livid chestnut, or reddish liver colour, which not unfrequently give an appearance of crenation to the concentric sculpture. The majority of individuals are adorned with three more or less distinct broader or narrower rays, which are never of an uniform colour, but appear mottled, being composed of the more thickly clustered interlacements of the lineation previously mentioned, which usually becomes of a darker colour, and rather broader character on these parts. Occasionally, and especially in the younger shells, there are two white and widely separated rays, sometimes only a single subposterior one, with the commencement of the second visible at the umbones; sometimes, too, both the white and dark rays are present in the same individual, 
vecationally the colouring matter is almost or entirely absent from the general surface, but whenever present is, when chesely examined, composed of linear painting, and alway exists upon the hinder clorsal area. The diversity of its sculpture is not less striking. This is solely composer of concentric costellie, or laminar strie, which vary considerally in thichness, elevation, distance, and, conserpuently, number. In the ordinary or typical form, they are extremely numerons, slightly irregular, tolerably strong, rounded above, and very closely disposed. These costelle, in the more elongated and compressed varieties, become converted into shary laminie, whose interstices when highly magnified appear radiated with very delicate and scarcely distinct striula, which are never broad or greatly elevated, and range in approximation to each other from closely disposed to moderately distant; in the former case they are so acute as almost to resemble raised strix, and oceasionally retain their richer colouring and radiated markings (we have figured one also which is completely destitute of all lineation, except upon the hinder dorsal slope); in the latter case the painting is almost wholly absent.

The ventral margin is arcuated, particularly in front, where it rises to the dorsal edge in an undisturbed sweep. The front dorsal margin is hut moderately incurved and extremely sloping, the hinder one is typically subarcuated, produced, and much declining: these characters in the most aberrant variety are somewhat modified.

'The anterior side is only about half the length of the postrior, amd taper's very considerably at its extremity, where it is centrally subangulated. 'The hinder termination is either subangulated below, or if much attenuated, then bluntly subbiangulated.

'The umbones are prominent, but not swollen; they in- 
cline much forward. The beaks, which are very distinct and acute, are preceded by a large impressed and well-defined lunule, which is more or less heart-shaped and devoid of any sculpture, unless we regard as such the concentric lines of growth. The ligament, which is of a moderate size, not at all concealed, and usually of a fulvous or yellowish hue, is seated in a peculiarly large moderately excavated area, which is almost smooth, and not limited by any carination, though its boundaries are more or less angulated. In this excavation the breadth, as well as the bevelling of edges, is equal in both valves; but the left valve is decidedly the smoother.

The interior is of an uniform white; the hinder teeth are so thin as occasionally to become almost obsolete in one or both valves: the inner margin is very fincly crenulated; the pallial sinus is moderately large.

The length of a fine example is nearly an inch and a half, and the breadth about an inch and a fifth.

Having had ample opportunities of observing the animal, we can confidently assert the distinctness of its characters, as well as the shell, from those of the true gallina, of which a good representation has lately been given by Deshayes in the "Mollusques d'Algerie." The two species differ most materially in the structure of their siphons. In our British one the siphonal tubes are united to their extremities; in the Mediterranean form they are not only much shorter, but diverge considerably: their orifices in the former are fringed with few and very inconspicuous cirrhi; in the latter the cirrhi are numerous and conspicuous. The animal of striatula may, indeed, be regarded as an aberrant form in its genus, whereas that of gallina presents the ordinary characters of its congeners.

The body of the animal of Venus striatula partakes of 
the shape of the shell, but is prolonged anteriorly into two smoth slemeler completely-united tubes, forming a single siphonal process. The anal tube is much smaller than the branchial, and its orifice is separated only in the slightest and almost imperceptible degree. Mr. Clark has observed ten cirrhi, and intermediate shorter ones around the branchial orifice, and ten around the anal. In several specimens which we have examined we found the cirrhi of the branchial orifice rather more numerous, but very short and inconcpicuons, and could only distinguish them as denticles on the anal margin. Both tubes are of a pale sulphur-yellow; in some examples slightly tinged with rose around their extremities. They may be extended to a length very nearly equalling the brealth of the shell. The mantle is freely open, and is of a yellowish-white colour; $i^{t}$ is fringed by cirrhi or fimbriations, which are fasciculated so that it appears to be sinuous, and bordered by a series of little tufts. The foot is large, fleshy, white, linguiform, and geniculated. Mr. Clark has observed that the branchia on one side are very unerual, the upper being much shorter than the lower. The animal in confinement is rather sluggish.

'This is one of our commonest shells, occurring everywhere upon our sandy coasts, and ranging to the greatest depths as yet explored in the British seats. Some of its numcrous varieties, especially that termed sulcate by Captain Brown, are however rare. It is so generally distributed that to specify localities would be to enumerate almost every point explored where the bottom was sand or samely mul. The form generally thrown up on the shore lives in sandy tracts near low-water mark, but the lamellateil kinds inhabit deeper water. Specimens dredged by Mr. M'Andrew in depthis between eighty and one hundred 
fathoms, at considerable distances from the shores of the Zetland Isles, are remarkable for their deficiency of colour.

The species appears to have commenced its existence during the Newer Pliocene epoch, and occurs abundantly in many of the Glacial-drift deposits.

\section{Fasctata, Donovan.}

Triangular; the adult with broad and flattened ribs; the young lamellar, the lamellæ few and distant.

Plate XXIII. fig. 3, Plate XXVI. f. 7, and (Animal) Plate L. f. 7.

Pectunculus fasciatus, DA Costa, Brit. Conch. p. 138, pl. 13, f. 3.

Venus Paphic, Pultenex, (not Linn.) Hutchins, Hist. Dorset, p. 33.-Mont. Test. Brit. p. 110.

Venus fasciata, Donov. Brit. Shells, vol. v. pl, 170,-Linn. Trans. vol, viii. p. 80.-Dorset Catalog. p. 34, pl. 7, f. 3.-Turr. Conch. Diction. p. 234 ; Dithyra Brit. p. 146, pl. 8, f. 9.-Flem. Brit. Anim. p. 447.-Forbes, Malac. Monens. p 52.-Mucgilliv. Moll. Aberd. p. 267.-Brit. Marine Conch. p. 88.-Brown, IIl. Conch. G. B. p. 91, pl. 36, f. 10.-Burrows, Elem. Conchology, pl. 7, f. 2.-DiLLw. Recent Shells, vol. i. p. 159. -Desh. in Lam. Anim. s. Vert. (ed. Desh.) vol. vi. p. 371 ; Elem. Conch. pl. 20, f. 4, 5.-Hand. Recent Shells, vol. i. p. 412.-Phil. Moll. Sicil. vol. ii. p. 34 .

Venus Brogniarti, Payraudeav, Moll. Corse, p. 51, pl. 1, f. 23, 24, 25.-PhILIPpI, Moll. Sicil. vol. i. p. 43.

The $V$. fasciata is subtriangular, suborbicular, and a little heart-shaped, very strong, solid, and heavy; opaque, but slightly glossy, and not greatly inequilateral: in convexity it varies from compressed (which is the more typical state) to subventricose, the young being the former, the aged not unfrequently the latter. The diversity of its painting, not so much as regards the colours, which are almost invariably orange or roseate-brown on a paler or whitish ground, as their disposition, is almost infinite, but never devoid of gracefulness. Ordinarily there are three 
or four simple or interrupted, lighter or dirlier, broader or narrower-coloured rars, on a very pale or whitish ground; sometimes but two remarkably broal orange-hrown rays, which are occasionally more or less distinctly edged with very small linear markings of a darker hue. More rarely the entire surface is of an uniform white, but where colour is present at all, the rays seem always more or less developed, though frequently only composed of confluent linear marlingss. A kind of obseure reticulation, formed by short and crowded minute coloured lines, or small clots, is very prevalent, especially in specimens from Guernsey and the warmer portions of our coast: where this pattern is peculiarly distinct, the rays are usually of a dark roseate-lorown, and the general effect of colouring remarkably rich.

The great alteration of the sculpture with age has been the cause of the immature state being regarded as a distinct species. In its most typical stage the surface is covered with not very numerous broad and but little elevated obtuse belts, separated by shallow and much narrower smooth interstices. The fry have only crowded and rather depressed fine concentric costelle; in the earlier stages concentric recurved lamine often arise, which, grarlually becoming solid with age, form laminar belts which are solid and shelving below, but hollow and recurved above: at these periods the interstices are at least as broad as the elevations, usually diminishing in width as age advances.

In certain examples the hinder dorsal slope is coarsely dentated, as it were, by the projection and abrupt termination of the laminar belts; this does not take place, however, in the full-grown shells, where the belts at once diminish in elevation at the posterior extremity. The ventral margin is always more or less areuated, rises greatly 
at the sides, and is finely and closely crenulated within. The anterior side, which is rather the shorter, and is well rounded below, appears to project with an upward inclination owing to the rapid declination of the more or less long and incurved dorsal slope.

The hinder side is sub-angulated below, the angulation becoming less manifest in the older shells; its dorsal edge is produced, sloping and curved, the elongation declivity and arcuation becoming more marked as age advances. The lunule is sub-angularty heart-shaped, not profound, rather large, pouting in the young, and usually more or less stained with coloming matter; the lozenge is large, rather profoundly excavated, and generally lineated. The ligament is sunken, and so extremely narrow as scarcely to be visible. The umbones are more or less compressed, and very prominent; the beaks are remarkably distinct, small, and acute, leaning most decidedly both forward and inwarls. The interior is generally white, but occasionally of a brilliant reddish-purple; the margins, except the posterior dorsal, are minutely lut closely and distinctly crenulated. The hinge margin is rather broad, and is furnished in the right valve with a subtriangular central tooth, which is the largest of the three, and shelves inward and posteriorward, being more elevated in front, and diminishing in height as it widens from its somewhat truncated and slightly bifid apex; preceding this is a small and very oblique laminar tooth, and behind it lies an elongated more or less bifid solid one. In the opposite valve, the central tooth is similarly shelving and the broadest, but the front one, which is curved and subtrigonal, is the most elevated, whilst the hinder one is depressed, linear, and indistinct. The muscular impressions are strongly marked, the pallial sinus is extremely small, and more or less angulated.

voL. I. 
The length does not greatly exceed an inch, and the breadth, except in the young, is not much inferior.

The animal has been observed by Mr. Clark, Mr. Alder, and ourselves. It is triangularly suborbicular, and rather thick. The mantle is freely open in front, of a yellowishwhite colour, and furnished with a fine white fringe, bordered by a reddish line. The tubes are short and united, except near their extremities, where they become separate and diverge. Their orifices are furnished with cirrhi; those of the branchial are largest and most conspicuous, and are about sixteen or twenty in number. The tubes and cirrhi are of a sulphur-yellow colour, tinged with pale red flakes towards their orifices. The foot is sub-compressed, and moderately long. "The branchice are composed of a pair of unequal plates on each side, the upper being much smaller than the lower. The labial palps are small." (Clark.) This animal is very sluggish, and, when kept in confinement, is very shy of exhibiting either its foot or siphons.

Vonus fasciata inhabits for the most part gravelly sand, or gravel within the coralline zone. It has a wide range, even from four to sixty fathoms, in our seas. It is very generally diffused, and sometimes occurs in considerable numbers. On the south and west coasts it is especially common, and is very abmolant in the Irish sea. A few localities illustrative of its vertical range may be mentioned:- IIerm near Guernsey, very vividly coloured, alive on the long beach (S. H.); off Portland in fifteen fathoms, Penzance in twenty fathoms, and Milford in ten fathoms (M'Andrew and E. $\left.F_{.}\right)$; off Cape Clear in forty fathoms, and Kinsale in sixty fathoms (M'Andrew); Cape Wrath in fifty-five fathoms, Sit. Magnus' Jay, 'Zetland, in forty-five fathoms, and Stornaway in four fathoms (M'Andrew); Eda Sound, in 
Orkney, in sixteen fathoms (Thomas); Isle of Man in twenty-five fathoms (E. F.); rare on the Northumberland coast (Alder); at Scarborough (Bean). Mr Jeffreys has taken it in many localities in the Hebrides, and Mr. Thompson records it from all round the Irish coast.

As a foreign shell it ranges from the Mediterranean, where it lies as deep as forty fathoms (E. F.), to the shores of Norway. Mr. M'Andrew has taken it on the Atlantic coast of Spain. It commenced its existence within our area, as far back as the epoch of the coralline crag.

\section{V. ovata, Pennant.}

With crowded radiating costellæ, which are concentrically decussated by very closely set elevated striulæ.

Plate XXIV. fig. 2, Plate XXVI. f. 1, and (animal) Plate L. f. 6.

Tenus ovata, Penn. Brit. Zool. ed. 4, vol. iv. p. 97, pl. 56, f. 56.-Mont. Test. Brit. p. 120.-Linn. Trans. vol, viii. p. 85, pl. 2, f. 4.-Dorset Catalog. p. 35, pl. 1, f. 15.-Turr. Conch. Diction. p. 239 ; Dithyra Brit. p. 150, pl. 9, f. 3.-Forees, Mal. Monensis, p. 52.-Macgilliv. Moll. Aberd. p. 267.-Brit. Marine Conch. p. 90.-Brown, Ill. Conch. G. B. p. 91, pl. 37, f. 11._Dilew. Recent Shells, p. 171.-LaM. Anim. s. Vert. (ed. Desh.) vol. vi. p. 370.-Index Testaceol. pl. 7, f. 30.-MAWE, Conchology, pl. 10, f. 5.-HaNL. Recent Shells, p. 116.

Venus pectinula, LaM. Anim. s. Vert. (ed. Desh.) vol. vi. p. 348.

Cytherea orata, FleM. Brit. Anim. p. 445.

Venus raeliata, Phulrppr, Moll. Sicil. vol. i. p. 44, and vol. ii. p. 34.-Deshayes, Elem. Conch. pl. 20, f. 17, 18.

The ordinary outline of the Venus ovata is, as its name implies, egg-shaped, but both the fry and some of the more aged examples, are of a less elongated form. The valves, which are decidedly, but not particularly, inequilateral, are tolerably strong, opaque, lustreless, at most subventricose, and much more frequently are still less swollen; 
the convexity is broadly diffused, and diminishes in nearly an even ratio at either extremity. The exterior, which is ordinarily of a rulous flesh-colour, generally variegated in the younger examples with amorphous stains of a deeper tint, but which occasionally, though very rarely, is in the northern shells of an uniform chally white, is rayed with cxtremely numerous narrow ribs, which near their termination become divided by a groove, but not bifurcated, and are much more closely set in front than beyond the umbenal ridge, behind which they are replaced by most crowled and clevated radiating striac; these, as woll ats the preceding costellie, are concentrically decussated by raised lines. This decussation exhibits itself upon the striae in contimuous concentric series of sublumate scales (the last five or six are not affected by it), and forms somewhat tubercular rows of crence upon the ribs, but is not usually distinct in their interstices, which occasionally are subdivided by a still narrower costella. The crene are generally less marked upon the hinder ribs, and in a very rare variety are altugether converted into seales. The northern eximples lave their ribs in general rather further apart, and somewhat more elevated and square-topped than the southern ones, but never deviate so far from the typical character as to have them remote or much raised.

'I'he ventral margin is moderately curved, and rises rather the more in front, where it is more or less arcuated. The anterior side is the shorter, and tapers a little at its extremity, which is better romded below than above. The posterior termination is attenuaterl, lut rounded at the tip. 'The dorsal edges are moderate in both convexity and slope, the front never being incurver, as in most of the Teneres, and the hinder being almost straight, and searcely declining as far as the liganent extends. This latter is ex- 
tremely narrow, small, and not at all projecting. The lunule is rather large, very ill defined, not sunken, but, on the contrary, pouting at the lips; it is not free from the ribs which traverse the rest of the exterior. The umbones are moderately prominent, and incline a little forward; the beaks are not acute. The interior is whitish or fleshcoloured, with the disk occasionally of a fine reddish-purple or lilac hue; the inner margin is everywhere very delicately but quite distinctly crenated. The hinge-margin is moderately broad, and is furnished in the right valve with an anterior simple and almost laminar tooth, which is so oblique as almost to lie adjacent to the upper margin: both the other teeth are triangular, somewhat bifid, and tolerably strong. The central of the left valve is bifid and rather broad; both the others are simple, narrow, and very oblique.

Our engraving represents the ordinary size of fine examples of the adult shell.

The animal is yellowish-white, ovate, and has very short tubes. The margins of the mantle are finely scalloped, and fringed and marked with reddish lineations. The tubes are united nearly to their orifices, where they diverge; around the openings of each are about twenty slender and conspicuous cirrhi. The colour of the tubes is sulphuryellow; between each pair of cirrhi is a red dot. The anal valve is very conspicuous. The foot is compressed and linguiform, geniculated at the base. The branchice are pale-brown.

The Venus ovata is universally diffused throughout the British seas, inhabiting all depths of water between three and nearly one hundred fathoms, often excessively abundant. It seems to have a preference for a gravelly-sand bottom. Southern specimens are often more brightly- 
coloured than those from the north; and examples from very de'p water off' '/etland, talien by $M \mathrm{Ir}$. M'Andrew, are of a challiy whiteness. Abroad it ranges throughout the European seas, and in the Mediterranean has been taken as deep as one hundred and thirty fathoms (E. F.). As a fussil it is known from the Coralline Crag; during the formation of which stratum it inhabited our area, and has never since departed. This long and continuous range in time is coincident with its wide distribution at present.

\section{V. pallida, Turton.}

Vemes pallida, Turton, Dithyra Brit. p. 150, pl. 10, f. 5.-Fueming, Brit. Anim. p. 448.-Brit. Marine Conch. p. 90.

We found two specimens thus named in Dr. Turton's collection, of which one was manifestly a very worn 'xample of $T$. strictula, and still exhibited traces of its peculiar colouring. The other, which we regard as the sole type, being the individual delineated and described by the author, presents to the eye certain features which distingui:al it as well from strietula, its nearest congener apparently, as from any of the very numerous members of this extensive genus with which we are aequainted. We liesitate, however, to consider it a distinct British species on the anthority of the single worn example said to have been found at Dawlish.

The shell is triamgular heart-shaped, decidedly inequilateral, and of an uniform yellowish white; the valves are thin but oparue, and rather compressed except at the umhones, which are moderately rentricose; their outer surface is lut slightly glossy; the interior is entirely white, and its margin is most finely and closely crenated. The raised concentries strice (their elevation is seareely sufficient for 
the term lamelle), which gird the entire exterior, become very closely disposed near the lower margin, but are much more distant towards the beaks. These strix are radiatingly decussated by elevated and crowded lines, which appear more or less distinctly to traverse them, and not to be confined to their interstices.

The ventral margin is arcuated, and rises considerably at both extremities. The declination of both dorsal edges is likewise considerable; the front one is incurved, somewhat abrupt, and rather longer than is usual in the genus; the hinder, which is of moderate length, slopes with but little convexity, except near the prominent beaks (which are very acute and curve peculiarly forward), to the ventral margin, with which it forms a rather narrow subangulation. The front extremity is narrow, well rounded below, but less distinctly so above. The lunule is large, elongated-cordate, and profoundly impressed; the hinder dorsal area is rather broad, flattened, and a little retuse: the ligament, though not prominent, is very distinct. The dentition is that of striatula.

The length of the individual we have been describing is full eleven lines; its breadth is four-fifths of an inch.

\section{SPURIOUS.}

Venus subcordata, Mont. Test. Brit. p. 121, pl. 3, f. 1.-Linn. Trans. vol. viii. p. $82 .-$ TurT. Conch. Diction. p. 237 ; Dithyra Brit. p. 145. -Flen. Brit. Anim.p. 447.-Brit. Marine Conch.p. 87.Index Testaceol. pl. 7, f. 16.-DiLLw. Recent Shells, vol. i. p. 166.

Although we regard the $V$. subcordata of Montagu, whose type is still preserved in our National Museum, as only the immature state of the $V$. radiata of Chemnitz (Conch. Cab. vol. vi. p. 371, pl. 36. f. 386.-DiLlw. Recent Shells, vol. i. p. 189), we have preferred drawing up our description from that stage, as, 
in the event of others not coinciding with our views of its affilintion, we shall, at least, have enabled them more readily to comprehend what was intended by Montagu, by redescribing the species from the original type (which is sadly broken), and its exact but perfect facsimiles from the coast of the West Indian Islands. The epithet radiata was bestowed on the species, through the presence of a character in the described individual, which is rather exceptional than constant.

Somewhat ovately cordate, solid, opaque, not particularly incruilateral (the front heing at least half the length of the hinder side), rather dull, more or less ventricose, profundity rather less in front: exterior whitish, adorned with thin, short, concentric lamellæ, which are rendered wavy by the very closely disposed simple radiating interstitial costell $\infty$, and become extremely crowded near the lower edge, but are less so in the very young, and upon the umbonal region of the adult. Ventral margin more or less subarcuated, a little flattened in the middle. Anterior side tapering to a rounded extremity; the declination of the upper elge (which is straightish near the beaks) moderate, but not equal to the rise of the lower margin. Hinder dorsal edge moderately sloping, and not very convex; hinder termination attenuated, subangulated in the middle. Ligament small. Umbones rather prominent; beaks acute, leaning forward, and preceded by a large cordate lunule, which is well defined by a groove, but not much sunken nor yet smooth, possessing, though olscurely, the general sculpture. Ilinder dorsal area large, deeply and equally excavated in either valve, but remotely cross-barred with chocolate colour in the left valve only. Inside white, or tinged on the disk with flesh-colour; hinge-margin broadish, stained with purplish chocolate behind. Front and lower edges crenated within.

Introduced as British with doubt by MLontagu, who had taken a single valve from the sand of Falmouth harbour. It is a native of the West Indies and of the shores of Central America. 


\section{V. cancellata, Gronovius.}

Venus cancellata, Growov. Zoophylac. fasc. 3, pl. 1, f. 8, No. 1149, p. 270.Lam. (ed. Desh.) vol. vi. p. 341.-HAnL. Recent Shells, p. 112, pl. 7, f. 6 .

Venus Dysera, Mont. Test. Brit. Suppl. p. 43.-Tunt. Conch. Diction. p. 237 ; Dithyra Brit. p. 147, pl. 9, f. 4.-Flem. Brit. Anim. p. 447.Chems. Conch. Cab. vol. vi. p. 294 (partly), pl. 28, f. 289.Reeve, Conchol. Systemat. pl. 68, f. 2.

Tenus cingenda, Dillw. Recent Shells, vol. i. p. 161.-Index Testaceolog. pl. 7, f. 6 .

Tenus elevata, SAY, Journ. Ac. Philad. vol. ii. p. 272.

Encyclop. Méthod. Vers, pl. 268, f. 1.

A West Indian shell; introduced by Montagu, from Mr. Laskey having found some worn valves in the Frith of Forth. We have found valves of it ourselves on the shore near Birkenhead in the Mersey, evidently derived from ballast.

\section{Granulata, Gmelin.}

Venus Marica, Born (not Linn.), Mus. Cæs. Vind. p. 59, pl. 4, f. 5, 6. Venus Marica-spuria, Chemn. Conch. Cab. vol. vi. p. 314, pl, 30, f. 313. Venus granulata, Gmelin, Syst. Nat. p. 3277.-Donov. British Shells, vol. iii. pl. 83.-Mont. Test. Brit. p. 122.-Linn. Trans, vol, viii. p. 85.-Turt. Conch. Diction. p. 240 ; Dithyra Brit. p. 145. -Flen. Brit. Anim. p. 447.-Brit. Marine Conch. p. 88.DiLlw. Recent Shells, p. 171.-Index Testaceol. pl.7, f. 29. -Lam. Anim. s. Vert. (ed. Desh.) vol, vi. p. 344.-HanL. Recent Shells, vol. i. p. 114, pl. 7, f. 29.

A West Indian shell; introduced by Donovan as British from a small one having been said to have been found on the Comish cocest.

\section{PAPHia, Linnæus.}

Lister, Hist. Conch. pl. 279.-Knorr, Verg. vol. ii. pl. 28. f. 2.Regenfuss, Choix Coquill. pl. 7, f. 11.

Venus Paphia, Linn. Syst. Nat. p. 1129.-Chemn. Conch. Cab. vol. vi. p. 267, pl. 27, f. 274, 275, 276.-DilLw. Recent Shells, vol. i. p. 159. -Index Testaceolog. pl. 7, f. 2.-DEsH. in Lam. Anim. s. Vert. (ed. Desh.) vol. vi. p. 371.-Hant. Recent Shells, vol. i. p. 112. Venus vetula, Da Costa, British Conchology, p. 190, pl. 13, f. 5 .

VOL. I. 
A West Indian shell; introduced, without any specified locality, by Da Costa (who became aware of his error after publication), from merely having seen it, in a collector's cabinet, as a British production.

We have appended as a note to the I'cneres the original description (from whence all the others have been abridged) of the V'enus subrhomboidca of Montagu, not because we consider it a true Venus (for that, at least, the bidentate hinge will certify), but solely from the extreme uncertainty of its actual generic position, which, if determined without examination of the original specimen, must, of course, be conjectural. Had the Venerupis Irus been found so far north, our suspicions would certainly have inclined to the supposition that it was only a distorted individual of that species, with the hinge imperfectly developed; and our inference from the language of MIontagu (we may remark, by the bye, that he uses the word "behind," in the above description, in a different sense from his usual one, as the figure-which evidently represents a distorted and probably lithodomous shell-shews the replication to be on that side usually called the anterior or front one, by the writers of the Linnean school,) would rather have led to our placing it with Petricola, than, as Turton has done, with Astarte, the large pallial sinus forbidding its admission into the latter genus:-

Venus subrhomboidec, Mont. Test. Brit. Suppl. p. 49, pl.28, f. 2.-Turt. Conch. Diction. p. 246.-FLEM. Brit. Anim. p. 448.

Crassina - TurT. Dithyra Brit. p. 129.

"Shell subrhomboidal, rounded at one end, truncated at the other, and irregularly wrinkled concentrically, especially towards the margin, where the ridges are prominent but obtuse ; these are decussated by extremely fine approximate longitudinal strix ; umbo small and nearly central, but the benk reclines to one side; the colour is white, with a tinge of rufous at the truncated end. The inside is white, with a dash of purple at that part which is rufous on the outside; the margin is plain; cicatrix broad, spreading half across the shell: the hinge is singularly formed; in each valve are two strong, plain tecth, one of which stands very oblique; behind these the margin projects inward, and then doubling back, forms a smooth replication and a cavity between it and the exterior edge of the shell behind the umbo for the connecting cartilage. Length half an inch; breadth threc-quarters."

"A single specimen (in a living state) is recorded to have been dredged by Mr. Laskey off St. Abb's Head, in the Frith of Forth. It bore the most marked resemblance to Venerupis Irus, but differed in the closeness of its strix, the absence of thin membranaceous ridges, the replication of the hinge margin, and by its dentition exhibiting only two simple teeth in each valve." 
Shell suborbicular, more or less strong, equivalve, closed; surface concentrically striated; inner margins entire. Muscular impressions oblong, nearly equal; pallial sinus lanceolate, acute, deep, oblique. Hinge strong, composed of three diverging teeth in one valve, and four in the other. Ligament external, sunken, rather long; lunule strongly defined.

Animal suborbicular, its mantle freely open, the margins entire, or only partially serrated. Siphonal tubes long, united to their extremities, margins of their orifices fimbriated. Foot semilunar.

This well-marked group was constituted by Poli; the habit and characters of both shell and animal evince its very natural constitution. Common as the two species which inhabit our seas are, our linowledge of their construction, however, is almost entirely derived from the observations of the distinguished Neapolitan naturalist who founded the genus. It too often happens that whilst the animals of the rarer shells are carefully observed, noted, and drawn, we are apt to neglect those most abundant, fancying they are always at hand. Guilty of this crime, and confessing our guilt as a warning to others, we are obliged to content ourselves for the present with a very imperfect notice of these mollusks, but, before the completion of our work, hope to present our readers with a full and original account of them. 


\section{A. exoleta, Linnæus.}

Strico not very closely arranged; surface generally rayed, or variegaterl; hinder dorsal edge straightish, and scarcely sloping; lunule generally coloured; hinder dorsal area not flattened.

\section{Plate XXIII. fig. 3,4 .}

V'enus exoleta, Linn. Syst. Nat. ed. 12, p. 1134.-Pens. Brit. Zool. ed. 4, vol. iv. p. 95. pl. 54, f. 49, A. (as variety.) - PulteNey, Hutchins, Hist. Dorset, p. 34.-Donov. Brit. Shells, vol, ii. pl. 42, f. 1.-MIont. 'Test. Brit. p. 116 (chiefly).-Linn. Trans, vol. viii. p. 87, pl. 3, f. 1.-Dorset Catalog. p. 35, pl. 8, f, 5.-Turr. Conch. Diction. p. 241.-Born, Mus. Cxs. Vind. pl. 5, f. 9.-Chesn. Conch. Cab. vol. vii. p. 18 (partly), pl. 38, f. 404.-PoLI, Test. Sicil. pl. 21, f. 9, ]., J1.-DiLLw. Recent Shells, vol. i. p. 195 (partly).-Index Testaceol. pl. 8, f. 83.-BLdinv. Manuel Malacol. pl. 74, f. 2.

Pectuneulus capillaceus, DA Costa, Brit. Conch. p. 187, pl. 12, f. 5.

Cytherea cxoleta, Lam. Anim. s. Vert. (ed Desh.) vol. vi. p. 314.-T'rnt. Dithyra Brit. p. 162, pl. 8, f. 7, and (as sinuetu) pl. 10, f. 10, 11.Flem. Brit. Anim. p. 445,-MacgiLliv. Moll. Aberd. p. 262.-Brit. Marine Conch. p. 84.-Philippi, Moll. Sicil. vol. i. p. 41, and vol. ii. p. 32,-HANL. Recent Shells, p. 102.

Arthemis exoleta, Desir. Elem. Conch. pl. 20, f. 9, 10, 11.-Philipri, Neu. Conch, vol, i. p. 171.

Artemis exoleta, Forbes, Malac. Monensis, p. 51,-Brown, Ill. Conch. G. B. p. 92 , pl. 36, f. 1,3 .

The shape is suborbicular, but with a slight tendency to squareness; the length is more usually (but not invariably) slightly superior to the breatth. 'The valves, which are opaque, solicl, oceasionally ponderous, and, when arlult, almost entirely devoid of lustre, are probably, although not vieing in this respect with the succeeding species, rather above than below the average convexity of this genus, being subentricose; they are deridedly ineruilateral, the hinder side being nearly twice as long as the front one. 'The external surfice, which is never of a pure white, is of a pale ream colour, almost invariably adorned with livid red 
markings, either disposed in linear zigzags (more rarely clouded ones), or in numerous narrow rays (which are generally rather interrupted), or in two or three broad (and usually continuous) ones. The irregularity of the concentric striæ, by which it is roughened, and the strongly marked lines of increase give it a very coarse and subimbricated appearance; the closely set interstitial spaces look, when magnified, like large and elevated striæ. There is no radiating sculpture whatsoever, nor are the striæ-like lines raised into lamelle at their extremities or elsewhere. The ventral margin is moderately arenated, and has a tendency to rise rather the more anteriorward. The declination of the dorsal edges is remarkably trifling; the front one is extremely short, and, from the peculiarity of the lumule, appears deeply incurved, although when examined internally its outline is actually a little convex; the hinder one, which is very manifestly the higher margin, is at first subrectilinear and scarcely sloping, increasing afterwards in convexity and declivity, its termination, except in aged individuals, is usually above or on a par with the level of that of the anterior dorsal. Both upper corners are slightly angulated, both lower ones are thoroughly rounded. The posterior side is decidedly the broader; its edge, as well as that of the anterior extremity, is at its upper part rather perpendicular and not greatly curved. The umbones are not very prominent; and the beaks, which are acute, distinct, and not coloured, turn very considerably forward; in front of them is a very deeply impressed heart-shaped lunule, which is not abbreviated in shape, is almost invariably coloured, and whose lips are almost always more or less pouting. The sunken ligament is almost entirely concealed; there is neither a flattening nor the slightest excavation of the posterior dorsal surface. The interior is 
pure white, but rarely, if ever, glossy, except towards the morgin, which is more or less flexuous, and is destitute of all crenation. The hinge margin is moderately but not peculiarly broad.

The length of a fair-sized individual when measured was :m inch and seven-eighths, its brealth was an inch and three-quarters.

This common, though rather handsome shell, inhabits sandy ground in various depths, from low-water mark to seventy or eighty fathoms all round our coasts. Among its numerons localities, we may mention Guernsey (S. II.); Littlehnpton, Sussex (Strichland); Exmouth (Clark); Penzance, in twenty fithoms, and Scilly Isles ( $\mathrm{I}^{\prime} \mathrm{A}$ Andrew); Bristol Chamnel (Jeftreys); Caternarvon Bay, in twelve fithoms (M Andrew); Mochruss (Eyton); Isle of Min, in twelve to twenty-five fathoms (E.F.); Scarborough (Buan); Northumberland (Alder); Clyde (Smith); Hebrides (E. F.); in fifty, seventy, and eighty fathoms around Zetland, also, in from four to seven fathoms on the same coasts (MIAndrew and E. F.); Orkneys (Thomas); East coast of Scotlind; plentiful in seven fathoms, Frith of Forth (E. F.); "all round the Irish coast in suitable localities" (IV. Thompson). There is a marked diflerence in the anpect of most specimens of this species found on the western coasts as compared with the majority of those from the eastern.

Artemis exulcte ranges throughout the European seas, and is fossil in pleistocene formations. 


\section{A. Lincta, Pulteney.}

Strise extremely delicate and most closely disposed; surface not rayed or variegated; hinder dorsal edge curved and moderately sloping; posterior dorsal area flattened.

\section{Plate XXVIII. Fig. 5,6 .}

\section{Lister, Hist. Conch. pl. 290, f. 126.}

Venus lincta, Pulteney, Hutchins, Dorset, p. 34.

Venus exoleta, Penn. Brit. Zoul. ed. 4, vol. iv. p. 94, pl. 56, f. 49.

"6 "Var. Linn. Trans. vol. viii. p. 87, pl. 3, f, 2.-Dorset Catalog. p. 35, pl. $1, \mathrm{f}, 13$.

Venus sinuata, Turt. Conch. Diction. p. 242.

Cytherea lincta, LaM. Anim. s. Vert. (ed. Desh.) vol. vi. p. 315.-FLEM. Brit. Anim. p. 445.-M Macgrlliv. Moll. Aberd. p. 262.-Brit. Marine Conch. p. 84.-HANL. Recent Shells, vol, i. p. 102.

Cylherea sinuata, Turton, Dithyra Brit. p. 163 (not var. nor figure).

Arthemis lincta, Deshayes, Elem. Conch. pl. 20, f. 12, 13.-Brown, Ill. Conch. G. B. p. 92, pl. 36, f. 2, 4.-Philippi, Neu. Conch. (not Cytherea lincta of Moll. Sicil.) vol i. p. 171.

The contour of this shell is suborbicular as, indeed, is more or less the case in every Artemis, and the breadth of the adult habitually, but not invariably, exceeds the length. The valves are opaque, more or less strong, and ventricose or subventricose when mature, their profundity rapidly decreasing from the centre. The surface is more or less glossy, of an uniform soiled ivory white (occasionally tinged with livid brown, or with the umbones richly stained with orange), and is never rayed or variegated with coloured markings. The concentric strie which form its sole sculpture, there being neither lateral lamellæ, nor radiating lines, are most closely and delicately engraved, and, by slightly widening at each extremity, convert their interstices into fine elevated and crowdedly-arranged striæ. The ventral margin is much arcuated, ascending in an uninterrupted sweep on either side to the dorsal edges, so that 
the lower corners of the shell are perfectly free from angulation. The dorsal ertge. whose declination exeeds that of cxot, te, is in front short, rather strongly sloping, and with its general inclination, though not its actual outline, incurved; behind it is far more elevated, curved, and ranges from very moderately to decidedly sloping. There is a manifest, although slight, flattening (but no excavation) of the hinder dorsal surface.

Both sides are somewhat angulated above, and are rounded below; the front and hinder edges are more or lees convex. The ligament, though plainly visible, is sunken ; the umbones are very prominent, and bend considerably forward; in front of them is a large heart-shaped deeply impressed lunule, with pouting lips, which is rarely if ever stained with any colouring matter. The beaks are very acute, and rarely adorned with painting different from that of the umbones; but in a scarce northern variety are purple. The interior is of an uniform white, and is for the most part devoid of lustre; its margin, which is very slightly flexuous, is perfectly free from crenation.

This species never attains to the dimensions of the preceding, its diameter rarcly measuring an inch and a thircl. From the greater declination of the dorsal lines the adult shell appears to taper in some degree towards the umbones. The exquisite delieacy and crowder disposition of its concentric lines, the alsence of coloured markings, and the flattening of the linder dorsal surface, enable us with facility to distinguish it from exoleta.

The Artemis lincta is nearly equally common with its British congener, though not always occurring in the same localities. It has as great a range in depth, extending from near low-water mark in some places to as deep as sixty fathoms in others. As instances of its distribu- 
tion, may be mentioned Exmouth (Clark); Penzance, in twenty fathoms, and Plymouth in twenty-five ( $\mathrm{M}^{6} \mathrm{An}-$ drew and E. F.); Torbay and Falmouth (S. H. and Alder); Scarborough (Bean); Northmmberland (Alder); Irish Sea (E. F.); IIelorides, as at Sliye, in from seventeen to forty fathoms ( $M^{6}$ Andrew and E. F.); Clyde (Smith); St. Magnus Bay, Zetland, in sixty fathoms; Balta Sound, in from five to ten fathoms; also in the Moray Frith, fifteen fathoms ( $\mathrm{I}^{\prime}$ Andrew); in sand at lowwater, and also in thirty-five and forty fathoms, Orlineys (Thomas); Aberdeenshire (Macgillivray); St. Andrews (Knapp); Frith of Forth (E. F.); "general, around Ireland in suitable localities" (IV. Thompson); Bantry Bay in fifteen fathoms, and off Cape Clear in sixty fathoms (M'Andrew); Birterbuy Bay, Connemara (Barlee).

This species ranges throughout the Celtic and sonthern regions of the European seas. Mr. Alder remarlis, from a comparison of specimens, that the Artemis compta of Löven is identical with one of our British varieties of it. As a fossil it occurs in both red and coralline crags.

LUCinopsis, Forhes and Hanley.

Shell more or less orbicular, rather thin, equivalve slightly inequilateral, closed; surface smoothish or concentrically striated; inner margins entire; muscular impressions oblong or suborbicular, nearly equal; pallial sinus wide, deep, central, obtuse. Hinge composed of two diverging primary teeth, one of which is bificl, in the right valve, and three, the central one bifid, in the left. Ligament external, prominent, rather long; no defined lumule.

Animal suborbicular, its mantle freely open, the margins entire. Siphonal tubes short, diverging, separate, the VOL. I. 
branchial with its orifice fringed, the anal simple. Foot lanceolate. Labial palps small, triangular.

We have constituted this genus for the reception of the Trites indete of authors, a shell which has been now placed in one group, now in another, as the inclinations of the systematist may have directed, but always with a doubt respecting its true position. Presenting the external appearanee of a Laciue, whilst its intemal structure linked it more closely with Vonus and its allies, it had become a sort of conchological puzzle, and yet, thongh many a shell with ferrer claims to distinction had been elevated to the rank of a generic type, distrust respecting its true nature seems to have prevented this one enjoying such an honour. The deep pallial sinms should have shewn thowe who associated it with the Lucinide that it hard no place in that family. Its evident affinities were with the Venus tribe, but from lines proper and equally from Cutheree and Pullestio marlied features of dentition or margin, independent of peculiarity of habit, separated it. With Artemis it had more connection, chiefly, however, in external aspect, for its hinge and pallial sinus are very different. The diseorery of the amimal has shewn that it- peculiarities indicate essential differences in the organization also, and that the characters of its foot, mantle, and siphon, are such as to place its claim to generic rank beyond a question. It seems to have consideral,le afhinity with the fossil genus Thetis, in which, however, the pallial sinus is lanceolate and prolonged almont to the beaks, whilst the external surfice is curionsly punctated. 
L. undata, Pennant.

Plate XXVIII. fig. 1, 2, and (Animal) plate M. fig. 2.

Vemus andata, Penn. Brit. Zool. ed. 4, vol, iv. p. 95, pl. 55, f. 51.-Mont. Test. Brit. p. 117.-Donov. Brit. Shells, vol. iv. pl, 121.-Linn. Trans. vol. viii. p. 86.-Turr. Conch. Diction. p. 241, f. 54.Fuem. Brit. Anim. p. 448.-Dilwyn, Recent Shells, vol. i. p. 197.-Index Testaceol. pl. 8, f. 87.- Philippi, Moll. Sicil. vol. ii. p. 34 .

Venus sinuosa, (monstrosity, ) Penn. Brit. Zool. ed. 4, vol. iv. p. 95, pl. 55, f. 51 A.-Mont. Test. Brit. p. 120.-Linn. Trans. vol, viii. p. 90. Lucina undata, Turt. Dithyra Brit. p. 115,-Brit. Marine Conch. p. 73.Brown, Ill. Conch. G. B. p. 98, pl. 39, f. 1, 2.-LAM. Anim. s. Vert. (ed. Desh.) vol, vi.p. 229,-Hank. Recent Shells, p. 76. Venus incompta. Philippi, Moll. Sicil. vol. i. p. 44, pl. 4. f. 9.

Cytherea undata, MAcGildiv. Moll. Aberd. p. 263.

Artemis undata, Alder, Cat. Northumberl. and Durham Moll. p. 84.

The shape of this inelegant but peculiar shell, is suborbicular, with a slight tendency to squareness. The valves which are subventricose rather above the middle, become depressed towards the lower margin, and lessen in convexity almost equally on either side; their surface, however, is not evenly curved, appearing somewhat angulated owing to the slight flattening from the umbonal region downwards, and a similar one at the posterior side. They are opaque, brittle, more or less glossy, not very solid, and of a paler or deeper fawn colour, irregularly wrinkled in a concentric direction with very numerous and extremely fine lines, and occasionally marked here and there with concentric very shallow somewhat pliciform indentations. There is no other sculpture or division of surface whatsoever. The ventral margin is not very convex, and usually rises rather the more in front; the anterior dorsal edge is more or less retuse, and rather strongly sloping; the hinder dorsal edge is almost straight, and scareely de- 
clining. The anterior side is rery much the smaller, being hardly more than half the size of the posterior, its extremity is rather narrowed, and is rounded both above and below. The hinder termination is broad and sub-biangulated ; the posterior margin being somewhat straightened in the middle, and its inclination almost perpendicular, thongh rightly bencling forwand inferiorly. The mulnones are rather swollen and prominent; the beaks acute and incurved; in front of them is a dorsal depression, but no defined lunule. The ligament is large and broad, but not at all projecting; there is no excavation or depression of the hinder dorsal surface. The interior is white, the margin acute, entire. and decidedly flexuous. 'The hinige, considering the fragility of the valves, is rather strong, and consists in the right valve of two divergent primary teeth, of which the hinder is bifid, and the front one simple; and in the left valve of three divergent cardinal ones, of which the central is much the largest, and very profoundly bificl, or rather reversed $V$-shaped, and the others simple and extremely narrow. The pallial sinus is very large, and runs slightly obliquely into the middle of the disk.

The average breadth does not much exceed an inch and a quarter, and the length is slightly superior. Although there is no difficulty in procuring dead examples of this interesting shell, we seldom meet with it in the living state, probibly owing to the nature of the localities in which it buries itself. During the winter season it is occasionally thrown alive on the shore by storms, but is rarely so taken in the dredge. Only very recently have we been able, after many endeavours, both of our own and of numerous indefatigalle friends, to oltain suflicient information re-pecting it:s anmal constructor-one of the many obligattions we owe to our invaluable correspondent Mr. Clark. 
By that gentleman we have been furnished with the accompruying description and sketch.-Animal lentiform, subcompressed, mantle open, margin plain, produced posteriorly into two short siphonal tubes, separate from their bases and divergent. The branchial one is conical, pale yellow, with sulphur-coloured, flaky, irregular, subrotund blotches, marked with short dark lines around the orifice, giving it the appearance of a minute fringe; from this circle spring about fourteen rather long white cirrhi. The anal tube is also conical, shorter than the branchial, bluish hyaline, and quite plain at the orifice; these tubes are never protruded more than one-sixth of an inch, at least in the specimens examined, and are very delicate to external view, but on opening the animal they appear long, strong; cylindrical, corrugated, of the same length, lying parallel to each other at nearly the middle of the shell in the large vertical sinus in the mantle. The body is very small, pale brown, with a moderately long hyaline lanceolate foot attached to it. On each side the body is a pair of suboval almost hyaline branchix, the upper the smallest, most delicately pectinated; also small triangular palps more strongly striated, but of the same hyaline character.

Lucinopsis undata inhabits sandy ground, from a very few fathoms to as deep as eighty fathoms, rarely plentiful any where, though very generally distributed around the coast. Among localities may be mentioned Exmouth (Clark); Southampton (Jeffreys); Weymouth in seven fathoms, and Dartmouth in twenty-seren fathoms (M‘Andrew and E. F.); British Chamnel (Jeffreys); Isle of Man in twelve to twenty fathoms (E. F.); Scarborough (Bean); Northumbrian coast, in deepish water (Alder); on the edge of the Dogger bank, sixty miles east off Sunderland in fifty fathoms water (King); Sana Island in forty fathoms 
(Iyndman); IIehrides (Jeflieys); west of Zetland in from four to seven fathoms ( $M^{6}$ Andrew and E. F.); Orliners in fitteen fathoms, and almost littoral (Thomas); Aherdeenshire in deep water, and east on the beade (Macgilliviay); St. Andrews and Frith of Forth (E.F.); all romel the Irish coast in suitalle localities (W. Thompson); in from three to ten fathoms, Killiries (E. F., R. Ball, and W. T.) ; off Cape Clear alive in thirty fathoms (M'Andrew).

Abroad it ranges from the shores of Norway to the AEgean. It is a pleistocene fossil. 


\section{CYPRINID㤅.}

Is the arrangements of the older conchologists many shells were associated with Venus which, though they bore a near resemblance to the true members of that group, so far as external aspect and characters of dentition went, presented an unsinuated pallial impression, thereby indicating a very differently formed animal. Among these were the shells out of which the genera Cyprina and Astarte were constituted. We associate with them in one family the Venus minima of Montagu, and the Isocardia cor.

The members of this family have substantial shells, often thick and heary, almost always strong in proportion to their size, and frequently invested with a strongly-developed epidermis; some of them are very brilliantly coloured, others dull and dusky. Their surface is either smooth, or nearly so, or, if sculptured, marked with concentric striæ or furrows. The greater or less prominence and direction of the beaks, and the presence or absence of a lunule, are variable characters, and serve to distinguish the genera. The hinge has strongly developed cardinal teeth, and the ligament is well formed and external. The pallial impression is either quite entire, or presents only the slightest indication of a sinus. This depends on the peculiar feature in the organization of the animal, which has, instead of distinct and produced siphonal tubes, only rudimentary ones in the shape of two scarcely separated 
mifien. The foot is theck and linguiform. resembling that of the Veneride.

Whilst the last family appears to have increased in numbers upwards in time, until its maximum was attained in existing seas, this seems to have been chiefly developed during past epochs, and to be now in progress of diminution. The two groups may be regarded as to a certain extent successive in time.

M. Alcide d'Orbigny styles this family Astatida, and gives as prominent characters the absence of a distinct buceal siphon, and the shortness of the foot, both of which do not apply to any of the animals of the group examined by us. In the last arrangement by Mr. J. E. Gray, Circe is placer in one division of the Feneride, Cyploind in another, whilst Asterte and Isocerdice form part of distinct fimilies in a separate order from that to which the Teneride themselves are assigned. It would loe interesting to linow upon what principle so curious a disposition of these genera has been proposed.

\section{CYPIINA, LaMaRCK.}

S'Thell more or less sul,orbicular, solirl, equivalve, closed, smooth. or eomentrically striaterl, inrested with an epirlermis; beaks prominent, incurved; no lunule; margins smooth. Hinge composed of a lateral tooth, and three or four primaries in one valve, and of three primaries only in the other. Ligament well developed, conspicuons; pallial impression simple, muscular impressions oval.

Animal suborbicular; its mantie freely open, with pliun or serrated edges. Siphonal orifices sessile, or nearly so, their margins fringed, the brauchial largest. Foot large, linguiform; labial palps moderately long, triangular. 
The Cyprina live in gravelly sand or mud, and are not remarkable for beanty, though often of considerable size. They are chiefly found in moderately deep water. Anciently they were much more abundant than now, and within our own area several well marked species lived at the commencement of the cretaceous epoch, apparently having similar habits with their existing congeners. The absence of the pallial sinus in the casts serves readily to distinguish between fossil species of Cyprina and Tenus otherwise very nearly alike.

\section{Islandica, Linnæus.}

Plate XXIX, and (animal) Plate M. Fig. 4.

Venus Islandica, Linn. Syst. Nat, ed. 12, p. 1131 (not of O. Fabr. Fauna Groenlandica, p. 411).-Pulteney, Hutchins, Dorset p. 33.Donov. Brit. Shells, vol. iii. pl. 77.-Mont. Test. Brit. p. 114.-Linn. Trans. vol. viii. p. 83.-Dorset Catalog. p. 35, pl. 6, f. 5.--Turt. Conch. Diction. p. 238.- Chems. Conch. Cab. vol. vi. p. 340, pl. 32, f. 341, 342. - Muller, Zool. Dan. pl. 28.-Dillw. Recent Shells, vol. i. p. 176. 一Index Testaceolog. pl. 7, f. 41.

Venus mercenaria, (not of Limn.) PENn. Brit. Zool. ed. 4, vol. iv. p. 94, pl. 53, f. 47 .

Pectunculus crassus, DA Costa, Brit. Conch. p. 183, pl. 14, f. 5.

Cyprina Islandica, Lam. Anim. s. Vert. (ed. Desh.) rol. vi. p. 290.-Turt. Dithyra Brit. p. 135.-Filem. Brit. Anim. p. 443.Macgilliv. Moll. Aberd. p. 257.-Brit. Marine Conch. p. 81.-Crouch, Introd. Conch. pl. 7, f. 2.-Blainv. Man. Malacol. pl. 70, bis, f. 5.-Deshayes, Elem. Conch. pl. 18, f. 8, 9, 10.-Gould, Invert. Massach. p. 82.Hand. Recent Shells, vol. i. p. 95.

Cyprina vulgaris, Sowerby, Genera Shells.-Brown, Ill. Conch. G. B. p. 93, pl. 37, f. 1, and pl. 38, f. 11.-Sow. Conch. Manual, f. 116.-Reeve, Conchol. Systemat. pl. 65.

Cyprine d' Islande, CHEvv, Traité Elem. p. 68, f. 243 (hinge).

The general form is suborbicular and somewhat heartshaped; the valves are solid, often ponderous, moderately inequilateral, and ventricose; the convexity being chiefly VOL. I. 
manifest upon the umbonal region, and diminishe more rapidly and decidedly in front than behind. The surface, which is of a reddish white, although neither striated nor groored, is not smooth, being more or less wrinkled irregularly in a concentric direction. Very fine and crowded concentric wrinkles are also visible upon the thick epidermis which covers the entire exterior, and is of an uniform more or less glossy fawn colour, becoming of a pitchy hue in aged individuals. The ventral margin, which is internally simple and acute, is well areuated throughout, and ascends rather the more upon the anterior side. 'The front dorsal edge, which at first subretuse, becomes eventually convex or even arcuated, declines but moderately, not quite rivalling the upward slope of the opposite lower margin. 'The declination of the hinder dorsal edge is rather trifling in the arlult, but is proportionately more consideral,le in the young; this edge is much the more elevated, and excepting torards its termination is almost straight. The anterior extremity is narrow, and rounded both above and below; the posterior extremity is broad, and obtusely rounded, or sometimes obsoletely sub-biangulated, the lower angle being rounded off, and the upper being very obscure, and often almost obsolete; the middle of the posterior edge is, however, not unfrequently (cspecially in the young) straight and perpendicular, which is the chise cause of the slight angularity of that side of the shell. 'The umbones are situated at about two-fiftlis the distance from the commencement of the shell; they are swollen, rather prominent, and incline forward; the beaks are acute, much inflected, and not precerted by any lunule, the area in front of them is, howerer, much drepereded. The ligament though ample is not particularly projecting. The interior is of an miform challiy white, and is almost totally deroid of lustre. 
The hinge-margin is moderately broad, and is furnished in the right valve in addition to its remote, and not much projecting posterior lateral lamina, with four primary teeth, of which the hinder is very oblique, acutely edged, and much shelving anteriorward, the two middle are simple (not bifid), and do not extend to the extreme margin, whilst the fourth, which is a mere denticle, is adjacent to the interior edge, and looks rather like a somewhat divergent interrupted continuation of the preceding one, than a distinct and separate tooth.

In the left valve there is no lateral tooth, and of the three primary ones, the front is short and rather divergent, the middle one, which is nearer to the former than to the succeeding, is long and bifid, and the posterior is produced oblique and very narrow.

The Iceland specimens which have been held distinct by one of our most eminent Conchologists, who has consequently reserved the specific name Islandica for them alone, appear to us not to differ from the British examples in essentials, but only in such points as are invariably subject to modification through difference of climate. Their form is rounder, their hinder dorsal edge more sloping, and somewhat convex at its extremity, which almost or entirely destroys the slight angularity observable at the hinder termination of our own specimens; their epidermis looser, and of a reddish cast. We know not whether these features be permanent or not in this variety, as it is of rare occurrence in the museums of England. The examples still preserved in the cabinet of Linnæus are exactly identical with our British ones.

This is one of our largest shells, measuring occasionally four inches and a half in breadth, and an inch more in length (Brown); the ordinary size is not, liowever, beyond 
three inches and a half long, and about two and a half broad.

The animal, which was long ago figured and describer by O. F. Niuiller, is orbicular and thick; its mantle freely open and finely serrated at the edges. The siphons project a little, their orifices are sessile and quite mited, fringed at the margins, and partially so at the sides. They are red, with brownish markings near the openings. The foot is large, thick, and linguiform; both it and the mantle are of a yellowish-white hue. "The branchia," aceording to Mr. Clark, "are pale brown, unequal, coarsely pectinated, the outer leaflets more triangular, and much less than the inner, extending posteriorly to the siphons, and anteriorly to the mouth and labia, of which there are a pair on each side, pectinated, not very long, and of a triangular form, and rather pointed."

The Cyprina Islandica is essentially a northern species, although it ranges all round the British shores, and is sufficiently frequent as not to be considered rare in any district. Most commonly it is brought in by the trawlers, but inhabits all deptlss of water over a sea-bed of sandy mud. It is equally common in the Irish Sea and German Ocean, living in from five to twenty-five fathoms water. On the south it is very frequent off Weymouth (S. II.); and Poole (E. F.); but becomes rare about Devon and Cornwall, thongh frecuent again on the Welsh coast and in the British Chamel (Jeffreys). It oceurs throughout the Ilebrides and off the Zetland Isles, where Mr. M'Andrew has taken it alive in water as deep as seventy and eighty fathoms, forty miles from land, and has procured dead valves in one hundred fathoms water; whilst at Balta Sound in Unst, anong the sime islands, le found it living in from five to ten fithoms. Lientenant Thomas states 
that he takes it among the Orkneys in all depths, and quite as large in seven as in forty fathoms. We have gathered it exposed alive at very low tides in the Frith of Forth. On the Irish coast it inhabits the northern, eastern, and southern shores, occurring on the first in from five to twenty-five fathoms (Thompson); and on the last as deep as sixty (M'Andrew).

The peculiarities of its distribution are very interesting, as this is one of the Mollusca common to European and North American seas, and a member of the faunas of all the crags. The remarliably wille bathymetrical range of so large a shell indicates a capacity for enduring many changes of conditions which illustrates strikingly the cause of its great geographical and geological extension. A species so constituted must be expected to present considerable variations, and we cannot admit the separation of its fossil representatives into distinct specific types, as has been done by Professor Agassiz, on account of slight variations in the degrees of their tumidity. Every British sea-going collector lnows how variable living specimens are in this respect. Even Agassiz himself, however, though he endeavoured with earnest good-will to draw a line between the fossil specimens from the Clyde glacial beds and living examples, could not do it. The hair was too fine to split. During the glacial epoch this and a few other boreal Mollusks had extended their range to the Mediterranean, whence they have long disappeared, though their remairs are preserved in the upheaved newer pliocene strata of Sicily. 
CirCE, SCHumacher.

Shell more or less subtrigonal, solid, equivalve, closed; surface concentrically striated or grooved; beaks not very prominent; a distinct lunule; margins smooth. Hinge composed in each valve of three primary tecth, and a lateral lannina ; ligament external, linear, and much sunlien. P'allial impres-ion with scarcely any traces of a sinuation; muscular impressions roundish or oblong.

Animal suborbicular ; its mantle freely open, and slighty denticulated at the marwin, cloning postcriorly to torm two siphonal orifices very slightly separated from each other, and scarcely projecting; the branchial one the largest; both fringed with short close-set cirrhi. Foot lather large, geniculated, linguiform. Labbial palps long and linear-lanceolate.

We follow Mr. King in referring the Venus minima of British anthors to the genus Circe of Schumacher, though not without doubts of the propriety of the reference. The characters we have given have special reference to our native species, and the features of the animal are now made known for the first time. 'They connect in a very satisfactory mamner this genus with Cyprina, and it with Astarte. 'The habits of the species are those of the laminated Veneres.

$$
\text { C. minima, Montagu. }
$$

P'late XXVI. figs, 4, 5, 6, 8, and (Animal) Plate M. fig. 3.

Vemus minima, Most. Test. 13rit. p. 121, pl. 3, f. 3.-Linn. 'Trans. vol. viii. p. 81.-TurT. Conch. Diction. p. 236.-DiLLw. Recent Shells, vol. i. p. 166.-Index Testaceolog. pl. 7, f. 17.

Venus triengularis, MoxT. 'I'est. Brit. H. 577.-Limm. 'T'rans. vol. viii. p. 83.T'unT. Conch. Diction. p. 238.-Index Testaceolog. pl. 7, f. 35. 
Cyprina minima, Turr. Dithyra Brit. p. 137.-Flem. Brit. Anim. p. 444.Brit. Marine Conch. p. 82, f. 102.-HanL. Recent Shells, vol, i. p. 95.

Cyprina triangularis, Turt. Dithyra Brit. p. 136, pl. 11, f. 19, 20.-Flem. Brit. Anim. p. 444.-Brit. Marine Conch. p. 82.-H.ANL. Recent Shells, vol, i. p. 95.

Cytherea triangularis, Micgilliv. Moll. Aberd. p. 268.

Cytherea apiculis, Philipri, Moll. Sicil. vol. i. p. 40, pl. 4, f. 5.

Circe triangularis, Kıng, Ann. Nat. Hist. vol. xv. p. 112.

Cytherea Cyrilli, Prirtrpi, Moll. Sicil. vol, ii.p. 32,-HANu. Recent Shells, suppl. pl. 15, f. 26.

Cytherea minima, Brown, Ill. Conch. G. B. p. 92, pl. 37, f. 3.

Cytherea minuta, Brown, Ill. Conch. G. B. p. 92, pl. 37, f. 4,

Montagu having first established his Tenus minima from the young of the more rounded variety, subsequently founded his $V$.triangularis upon the aberrant colourless triangular form which is chiefly obtained in our more northern waters. The subsequent discovery of intermediate examples has compelled us to unite these two shells.

The shape is rounded subtrigonal, and the valves are solid, opaque, glossy, typically somewhat compressed, but occasionally even subventricose; the convexity is about equal on either side. The exterior of the shell, which is not greatly inequilateral, is covered with broad and rather unsymmetrical concentric grooves, which are disposed at moderate distances from each other; their interstices in certain examples assume the appearance of depressed concentric costellæ. The colouring is infinite in diversity; sometimes the extcrnal surface is pure and ummixed white, more frequently, however, the exterior is variegated with larger or smaller pyramidal spots of a livid red, arranged in one or two subcentral rays (which rarely commence at the umbones); sometimes, too, these spots are squarish or amorphous and very distant. One variety is of an uniform pale livid lilac, another is entirely of a rich roseate fleshcolour, another subradiatingly mottled with livid or brown- 
ish flesth-celour. The variety of painting is indect great; one of the prettiest consists of a delieate network of lorown lines upon a white ground. The ventral margin which rises much more behind, where it slopes uninterruptedly without angulation to the dorsal edge (with which it forms a more or less distinct angle), is not particularly areuated in the middle. Both dorsal margins are elongated, the front one, which is always the more sloping, is straight, the hinder one barely convex; in extent of declination they vary much, but always observe their relative proportion, the front slope being sometimes abrupt, and the hinder very decided, in which case the contour is almost triangular; when, on the contrary, the front slope is only morerate, and the hinder one rather slight, the contour then approaches a rounded oval. The anterior side, which although the shorter is often not greatly so, is subangulated below, the angle being rounded ofl'; the most projecting part of the hinder termination is above the middle. The umbones are prominent, and lean a little forward; the beaks, which are very acute and obliquely inflected, are preceded by a large lunule of an elongated heartshape, which is not sunken, but defined by a groove. The hinder dorsal area is neither peculiarly flattened nor excavated; the ligament is either totally concealed or linear and sunken. The interior is white, or tinged with flesh colour on the disk, but never stained with any dark colour upon the hinder side or upon the hinge margin. The hinge is furnished in the left valve with a rather large approximate front lateral lamina, and three dirergent primary teeth, of which the anterior one is bifid; in the right valve with three primary ones, the central of which is very indistinctly cloven, and a tooth-like receptacle for the opposite lamina. 'The immer margin is quite entire. 
Fine examples attain to five-eighths of an inch in Jength, and usually a trifle less in breadth; in the more triangular specimens these proportions are reversed, the breadth a little exceeding the length.

The animal is orbicular and compressed, its texture not very solid. The mantle is freely open, and indistinctly fimbriated or denticulated, white with obscure dots. Posteriorly it projects a little, and is closed to form two siphonal orifices, the branchial much larger than the anal, the margins of each with a close-set fringe of short cirrhi, which are dusky or dotted with brown or red, varying in different examples. The foot is white, linguiform, and geniculated, resembling that of $T^{T}$ enus. It can be projected to a considerable distance, and when protruded is acute. The branchiæ are yellowish-white, the liver dark brown. The labial palps are long, linear, and pointed. Its habits are rather sluggish.

Until lately the Circe minima was regarded as one of our rarest testacea, and specimens were not often to be seen in our collections. Those which Montagu examined were very small and in poor condition. The activity of scientific dredgers, during the last few years, has made it comparatively common; large and beautifully coloured British examples now decorate all our best cabinets. It is, however, still to be respected as one of our scarcer species, for, though plentiful in certain localities, it does not fall within every collector's reach. The largest and most brilliant individuals we know are dredged in about eight fathoms water off St. Peter's Port, in the island of Guernsey (S. H.). On the coast of Cornwall, it was noticed by Montagu, and we have taken it in twenty fathoms off Penzance; on the Welsh coast it is both remarkably abundant and beautifil in ten fathoms in Milford Haven (M'Andrew and E. F.). In

VoL. .

$3 \mathrm{M}$ 
Scotland it is frequent in the Clyde (Smith); and Hebricles (Jeffreys, \&e.). At Oban it occurred in fiftem fathoms; off Mull in twenty; of 'Skye in twenty-five; and in forty and fifty fathoms in the Minch (M'Andrew). On the Zetland shores it lives chiefly in from fifteen to twenty fathoms, and oceurs on the Lingbank, forty miles west of Zetland, in fifty fathoms ( $\mathbf{M}$ 'Andrew and E. F.). Lientenant Thomas takes it among nullipore and broken shells in fifteen fathoms, Eda Sound, Orkney. Mr. Thompson communicates the following note on its Irish range. "I have seen it from the following localities on the Irish coast, two specimens were dredged from eight to ten fathoms in Belfast Bay in 1834 by Mr. Hyndman and mystlf; Erris in Mayo; Birterbuy liay (Farran, Barlee); Niltown Malbay (W. II. Iarrey); Bantry Bay (IIunphreys); Youghal (Miss M. Ball)."

Its distribution on our shores indicates that it is a member of a southern fama, spreating along our oceanic coasti. Aceordingly, whilst we fund it plentiful in the Lusitanian and Mediterranean regions, it does not range north of Britain.

ASTARTE, SOWERBY.

Shell oblong, suborlicular, or triangular, solid, equivalve more or less inequilateral, sometimes nearly equilateral, closed; surface smooth, or transversely furrowed, and covered by a conspicuons epidermic. Muscular impressions ovate, strongly marked; pallial impression simple, rather distant from the margin. Ininge composed of two strong diverging jumary teeth in one valve, and a primary tooth with a lesser supplementary one, which is sometimes obsolete, in the other. Ligament external, elongated, 
usually lodged in a lozenge. Lunule almost always distinct.

Animal of the shape of the shell, and never exceeding it; its mantle freely open, with plain (always?) margins, slightly united posteriorly at two points so as to form two siphonal orifices, both with simple edges. Foot linguiform, strong but not large. Labial tentacles large, lanceolate; leaflets of each pair of branchix equal or nearly so.

This genus is of very ancient origin, species of it appearing very far back in time, and abounding during the middle secondary period. The number of living species is inconsirlerable as compared with the assemblage of them which existed even within our own limited area during some ancient geological epochs. It is curious to note that whilst at present the predominance of Astartes in a collection made at any particular though unknown locality, would lead the conchologist to infer that they had been gathered in an arctic or boreal region, such an inference would, most probably, be incorrect if drawn from a similar assemblage of fossils, for during the oolitic and cretaceons epochs the abundance of Astartes was associated with the presence of numerous tropical or subtropical forms of mollusks and zoophytes. In the upper tertiaries, however, an increase in the number of species and individuals of this genus is usually coincident with the advent of boreal or glacial conditions.

The members of this genus have a wide range in depth, but are never, at least in our seas, found littoral. They constitute a favourite food of many fishes of the cod tribe. Many of the species are remarkable for presenting variations in the characters of the inner margin and sculpture which, in neighbouring genera, would be of specific, or 
even generie value, though in this, of only individual importance. Mr. Searles Wood has suggested that the dirlerence in the marwin may inclicate sexual distinctions; an observation deserving of minute inquiry.

\section{A. Sulcata, Da Costa.}

More or less convex, never elliptical ; ribs occupying the entire surface, not peculiarly close set : lower margin crenated in the adult.

Plate XXX. fig. 6, (A. Danmonicnsis) and (Animal) Plate M. fig. 5.

Pectunculus sulcatus, DA CostA, (1778) Brit. Conch. p. 192.

Tenus Lorcalis, (in part) Cinesn. Conch. Cab. volo vii. p. 26, pl. 39, f. 413.

"Scotice, MLatox, Limn. Trans, vol. viii. (1807) p. 81, pl. 2, f. 3.-Most. 'Test. Brit. Suppl. p. 44.-Turt. Conch. Diction. p. 236,-Lax. Anim. s. Vert. (ed. Desh.) vol. vi. p. 360.-DiLLw. Recent Shells, vol. i. p. 167.-Index Testaceologic. pl. 7, f. 20.

"Danmonia, Moxt. Test. Brit. Suppl. (1808) p. 45, pl. 29, f. 4.-Dillw. Recent Shells, vol. i. p. 167.-Index T'estaceol. pl. 7, f. 21.

C'rassina Danmonicnsis, LaM. Anim. s. Vert. (ed. Desh.) vol, vi. p. 257.-Brit. Marine Conch. p. 80.-Brown, Ill. Conch. G. B. p. 95, pl. 38, f. 1.-Crouch, Introd. Conch. pl. 6, f. 7. -Delessert, Rec. Coquil. pl. 7, f. 1.

I'enus sulcata, Turt. Conch. Diction. p. 235.

C'rassina Scotica, Tunt. Dithyra Brit. p. 130, pl. 11, f. 3, 4.-Brit. Marine Conch. p. 79.-Brown, Ill. Conch. G. B. p. 95, pl. 38, f. 9. -IIAvL. Recent Shells, vol. i. p. 87.

" sulcata, T'vnt. Conch. Dithyra Brit. p. 131, pl. 11, f. 1, 2.-Hanz. Recent Shells, vol. i. p. 87.

Asturte Scotica, FiEM. Brit. Anim. p. 440.-MAceILL. Moll. Aberd. p. 258.-

Puilippr, Neuer Conch. vol. ii. p. 56, Astarte, pl. 1, f. 3.Lové, Index Moll. Skandinav. p. 36.

Dunmoniensis, SoweruY, Genera Shells, $\Lambda$ starte, f. 1, 2, 3.-FLem. Brit. Anim. p. 440.-M.icG. Moll. Aberd. p. 258.-REEVE, Conch. Systemat. pl. 66, f. 1, 2, 3.-Sowerib. Conch. Man. f. 110.

"sutecte, MACgilitr. Moll. Aberd. p. 250,-Brit. Marine Conch. p. 247.Phul. Neuer Conch. Astarte, vol. ii. p. 56, pl. 1, f. 4.

Crassine crassatellee, Crisvu, Traité Elem. f. 232, 233.

* I) Costa's name has been preferred, not so much for its priority, as that, through its adoption, we are enabled to include under one epithet both scoticc and the subsequent Danmonicnsis. 
The union of $A$. Scotica with A. Danmoniensis may excite some little surprise and hesitation among naturalists, and, indeerl, was only acceded to by ourselves after a protracted scrutiny, and the examination of some hundreds of specimens assembled from the widest range of localities. In no respect did individuals of the former differ from those of the latter variety, excepting in the crenulation of the margin, and as specific differs from varietal diversity mainly by the greater number of permanent distinctive characteristics, we cannot separate into two species shells only unlike in the presence or absence of a single feature. With regard to the greater or lesser approximation of the ribs, and their consequent proportion to the interstices, no stress can be laid upon this point, as the more rapid is the growth of the animal, the more remote do these become; thus, in the southern Astartes, which are more speedily developed, the ribs are more distant, whilst in the more northern examples, whose progress to maturity is more sluggisl, and whose growth is not unfrequently stunted, they are sharper defined, and more closely arranged.

Like most of the Astartes, its contour is very variable; it is, however, longer than broad, and more or less subtriangularly heart-shaped; some northern individuals, however, are so abbreviated in shape that their breadth nearly (but not quite) equals their length, and their form consequently becomes suborbicularly trigonal. The valves are always solid and opaque, more or less convex, at times even ventricose, and are covered with an unpolished cuticle or thick adherent epidermis, which varies in colouring from bright yellow to rufous chestnut; beneath this the surface is whitish, or pale rufous, and concentrically lyrated with from about twenty to thirty more or less elevated ribs, which are almost always, if not invariably, 
narrower than their interstices, and are rarely if ever much depressed or at all broad. 'They typically cover the entire surface down to the ventral margin, excepting that they usually vanish (but not in the young), beyond the ordinary site of the obsolete umbonal ridge towards its extreme termination, but are generally visible for about half-way down that posterior area. Besides these ribs which, moreover, continue quite down to the rentral margin, which is always more or less convex, and at times (when the declination of the dorsal edges is more than ordinarily strong), is even areuated, there is no sculpture. The sides are unequal, but for the genus not particularly so, the beaks, which are acute, prominent, and a little inclined, being situated about one-fifth, at mont, before the midille of the dorsal edge. This latter is coneave and greatly sloping in front from the deep excavation of the very large lanceolate or ovato-lanceolate lunule, which, as well as the linear lozenge ruming nearly the entire length of the hinder dorsal margin, is perfectly smooth; the hinder edge is by no means so sloping as the front one, but varies from slightly to moderately declining. 'The ligament is small and yellowish, and is seated in the lozenge of whose length it only occupies abont two-fifths. The anterior extremity is well rounded; the hinder termination is more or less huntly liangulated, and in the youmerery broadly so. The interior is usually white, a small northern variety is, however, of a reddish liver colour. The edges are adorned typirally in the adult with closely-wet beal-like elevations, ex(repting "upon the hinge-margin, which is morlerately broad, and provided in the right valve, with a solid central simple triangular tooth, which shelves inwards, the highest point not being, as in most shells, at its lower end, but midway from the base of the margin; in the other valve a 
similarly shelving, but narrower, simple tooth, diverges on either side of the receptional cavity for the opposite tooth. The elevation of the outer sides of the dental pits, in the right valve, at times induces the surmise of there being three teeth in one valve.

The size of the largest of the very numerous examples which have furnished the materials for our description, is an inch and three-eighths in length, by an inch and one-eighth in breadth. With regard to crenation of edge, a character which is typically proper to this species, it is absent from immature shells, and such as have the edges acute from a new costa being scarcely or not yet commenced; almost all which terminate ventrally in a fullyformed rib have the margin thick and beaded.

The animal is more or less tinged with flesh-colour. The mantle is freely open in front, plain at the margins, and bordered by a narrow belt of orange. The siphonal openings are quite sessile, and but slightly separated from each other; their edges are plain, and, like the mantle, bordered with orange. The foot is linguiform, not large in proportion to the shell, and of a pale flesh or fawn colour. The visceral mass is variegated with bright rose colour and dusky green, the former hue appertaining to the reproductive organs, the latter to the liver. The branchiæ are of a pale yellowish hue. The labial palps are rather large, of a lanceolato-triangular shape, strongly striated externally, and of a pale tawny colour. Its habits are sluggish.

Astarte Danmoniensis received its name from the coast of Devon where, however, though not unfrequently procured by trawlers, it is not nearly so common as in numerous other localities. It is very generally distributed round our coast, living in muddy sand, at various deptlis, from eight to eighty fathoms. On the south coast of England, Devon 
and Cornwall are its chief habitats (S. H.). On the east coast, it is taken off Scarborough (Bean); and Northumberland (Alder). On the west, it occurs in the Bristol Channel (Jeftreys); Milford Haven, in eight to twelve fathoms, and of Anglesea in twelve fathoms (M'Andrew and E. F.); the Isle of Man in twelve to twenty-five fathoms (E. F.). It is almumlant throughout the IJebrides, most plentiful in from fifteen to twenty fathoms water. On the Zetland coast it is common, and occurs at great depths, ats in serenty fithoms, thirty miles from Noss, and in eighty fathoms on the west coast ( $\mathrm{M}^{\prime}$ Andrew). $\Lambda$ long the east coast of Scotland it is also not unfrequent, and has been taken in thirty-four fathoms in the Moray Firth. "It is dredged sparingly in Ireland all along the Antrim coast, and in Belfist and strangford Lough from eight to twentyfive fathoms in sand and mud (Hyudman and W. T.); Bray ('Turton and Brown); rarely obtained at Youghal and Cork" (IV. Thompson). Bantry Bay (Mrs. Puxley).

As a foreign shell it ranges all along the European coasts, but diminishes in numbers as we proceed southwards from Britain. It is known as a pleistocene fossil, though very searce as compared with elliptica.

\section{A. crebricostata, Forbes.}

Concentrically lyrated with very numerous sharply defined narrow ribs, which become obsolete posteriorly; ventral margin internally crenated.

Plate XXX. fig. 9.

Astarte crelricostata, Forbes, Annals Nat. Hist. vol. xix. p. 98, pl. 9, fo 4.

The perfect condition in which pleistocene fossils are found in many of the glacial beds on the coast of Scot- 
land, is such that it becomes very difficult to draw a line between recent and fossil examples of many of our boreal species. This difficulty is greatly increased when the specimens are procured from a considerable depth of water. The shell we have now to describe has only been taken in a state much more ancient to appearance than most of our pleistocene Astartes, yet we prefer describing it as an existing form, on account of the locality in which it was first procured presenting no traces of the vicinity of pleistocene strata, and because no fossil examples of it have ever occurred in beds of that age, which having been upheaved, have undergone close scrutiny. Only odd valves of this curious species have been taken; these valves are subtriangular, longer than broad, solid, opaque, and rather compressed ; they are destitute of any cpidermis, are of a dirty or pale reddish-white colour; look slightly porous, and feel harsh to the touch. There is not the least appearance of lustre; and their only sculpture consists of very numerous (at the least thirty) and crowded concentric ribs, which are sharply defined, extremely narrow, and extend the entire distance from the bealis to the ventral margin, but become obsolete upon and beyond the ordinary site of an umbonal ridge. The interstices are simple, that is to say, are not traversed by either longitudinal or transverse strix, and are for the most part rectangularly grooved out, the cdges of the ribs being usually but little, if at all, shelving. The sides are unequal, but not particularly so; the hinder, which is the longer, has its termination somewhat attenuated, and obtusely sub-biangulated, and its tip subrectilinear, or scarcely convex; the front extremity is rounded, but not symmetrically, as the arch of its lower portion is far more bowed out than its upper outline. The declination of the dorsal edge (a character of little value in VOL. I. 
Astarte). seems rather considerable, and neither aecompanied by much convexity posteriorly, or very marked concavity anteriorly, The curve of the ventral margin is not unfrequently a little depressed towarls the midllle, but areuated at each extremity. The umbones are not elevated or prominent, and the beaks when not eroded seem tolerably acute. The lunule is large, not very profoundly exeavated, but acutely defined at the edges; the matrgins of the linear much elongated lozenge appear similarly well defined. None of our specimens exhibit a ligament. The second or posterior primary tooth of the right valve is clearly distincet (it is often rudimentary or obsolete in this genus); the muscular impressions are ly no means peculiarly large, but rather the contrary; and the lower internal margins are strongly crenated.

The only British Astarte at all akin to crebricostata, is sulcata, to which it is also allied in being of similar dimensions, no other ribber species possessing likewise a crenated rim; from this, however, the posterior cessation of its narrower and more crowdedly set costæ, aftords a ready mark for discrimination.

The average length of the finer specimens was an inch and one-fifth, their breadth being but little inferior to that measurement.

Some single valves were dredged by Mr. M'Andrew on the west coast of Zetland; and one has sinice heen obtained (Ann. Nat. Hist. 1847, vol. xix. p. 314) by Mr. Jeffreys, in forty fathoms off Croulin Isand, the Iste of skye, where it has also been taken by Mr. M'Andrew. 


\section{A. elliptica, Brown.}

Elliptically or ovately subcordate, typically compressed, much produced and obtusely (but not broadly) biangulated behind, covered with a rufous chestnut or olivaceous brown cuticle, concentrically ribbed and striolate; costre rounded, more or less depressed, not crowded, as broad as their interstices, either not extending to the ventral margin, or growing obsolete at the lower posterior corner and along the hinder shelving area: inner margins quite entire; scars large.

Plate XXX. fig. 8.

Crassina ovata, Brown (not Smith) Edinb. Journal of Natur. and Geogr. Science, vol. i. p. 12, pl. 1, f. 8, 9.-Brown, Illust. Conch. G. B. p. 96, pl. 38, f. $12,13$.

" sulcata, Nilson, (not Maton, Turt. nor Lam.) Nov. Act. Holm. 1822, p. 187, pl. 2, f. 1, 2 .

" elliptica, Hanz. Recent Shells, suppl. pl. 14, f. 36.-Brit. Marine Conch. p. 246, f. 107 (not well).-Brown, Illust. Conch. G. B. p. 96, pl. 38, f. 3 .

Astarte elliptica, Mackitliv. Moll. Aberd. p. 259.

" semisulcata, (not of Leach) MöLler, Ind. Moll. Gröen (from type).Philippi, Neuer Conch. vol. ii.p. 57, Astarte, pl. 1, f. 10. -LovéN, Ind. Moll. Skandin. p. 37 (from type).

Although to determine by the pen the exact limits between this and the preceding species demands a certain prolixity of diagnosis, the eye most readily discriminates them when mingled together. For no difficulty can occur in separating the fully developed shells, as the inner margins are so widely at variance; and if we compare the immature sulcata with the present shell in any stage of growth, we shitl find the ribs of the former most sharply defined, and not at all obsolete towards the posterior corner or at the ventral margin, whilst those of the latter (and particularly in the young) are depressed and obsolete at one or both of those areas.

The typical form is elliptically heart-shaped, but the abbreviated variety is ovate-cordiform, and most closely 
resembles that of sulcata. The valves are usually compressed (more rarely convex), not heary, and only moderately solid, opaque, and covered with a rufous or, less commonly, wivaceons brown cuticle, becoming fulvous upon the umbones, beneath which the surface, as well as the interior, is of a more or less squalid white. The more or less deperwed and rounded ribs, which traverse the shell concentrically, and are usually at least as broad as their interstices, yet not very closely arranged, generally grow faint or utterly vanish towards the ventral margin, and always cease, excepting those in immediate proximity to the beaks, beyond the site of the obsolete umbonal ridge. The concentric striulæ, which are only occasionally met with in sulcata, are here permanently characteristic, and pervade the ribs as well as the interstices. The ventral margin is convex or subarenaterl; the front dorsal edge concave, and decider!ly sloping, lut rarying in intensity of curve and declination; the slope of the linder dorsal edge, whose convexity is by no means strong, is trifling or very morlerate. The beaks which are inclined, tolerahly acute, and not very prominent, are situated at about one-third the distance from the rounded anterior extremity to the obtuscly and not broadly, biangulated termination of the postrrior sile. 'T'he hunule, lozenge, hinge, and ligament, are similar to those of the preceding species; the two first are perhaps more deeply excavated, and the last darker and possibly larger. The inner surface of the margins is entirely free from crenulation, even in the most aged examples. The muscular impresions are nearly double the size of those of sulcata. The dimensions of rather a large specimen are an inch and a quarter in length, by eighi-ninths of an inch in breadth.

This shell appears to be almost wholly confined on our 
shores to the coast of Scotland, where we have often taken it, mixed with sulcata, but in far less abundance. It is, however, not uncommon in mud at from five to ten fathoms in depth, and has been dredged at Oban, Loch Carron, Ullapool, Lerwick, Loch Gair, Stomoway, and Skye, (M'Andrew, Jeffreys, and Barlee.) It was first " discovered near Helensburgh, mouth of the Clyde, by $\mathrm{H}$. Witham, Esq., where it appears to be not uncommon." (Brown.) The earlier specimens which found their way into collections, were chiefly collected by Mr. W. Nicol, and distributed under the MS. name of Gairensis. It ranges from ten to forty fathoms, usually on a muddy bottom. It occurs also on the north-east coast of Scotland (Macgillivray), where it has been dredged by Lieut. Thomas in thirty-five fathoms water. Mr. Alder states that the Rev. G. C. Abbes has met with valves evidently recent on the coast of Northumberland. It ranges to the shores of Fimmark and Greenland, and is one of the most abundant of pleistocene fossils.

\section{A. anctica, Gray.}

Decidedly inequilateral, subcordate, very solid, almost smooth, or only obsoletely sulcated, and never costellated (except slightly at the beaks); epidermis chestnut coloured, fibrous at the base; ligament half the length of the lozenge : lower margin arcuated and entire.

Plate XXX. fig. 7.

Venus borealis (not of Linn.), Crens. Conch. Cab. vol. vii. pl. 39, f. 412, (fide Lovén).

" compressa, Mont. Test. Brit. Suppl. (not desc.) pl. 26, lower f. 1, 1.

Cressina arctica, Gray, Appendix to Parry's Voyage (from types).-Hani. Recent Shells, vol. i. p. 88.

" borculis, Nilson, Nov. Act. Holm.1822, p. 188, pl. 2, f. 3, 4.

Astarte Cyprinoides, Duval, Revue Zoolog. Cuv. Soc. 1841, p. 278.-HanL.

Recent Shells, suppl. pl. 14, f. 40. 
Astarte compresse, Mracgithiv. Moll. Aberd. p. 261.-Brit. Marine Conch.p. 247 .

Crassina compressu, 13rowx, Illust. Conch. G. B. p. 96, pl. 38, f. 4, 5 .

" corrugata, Brown, Illust. Conch. G. B. p. 96, pl. 40 , f. 24.

Astarte borcalis, Pinlipri, Neuer Conch. vol. ii. p. 58, Astarte, pl. 1, f. 11.Fories, Memoirs Geol. Survey G. B. rol, i. p. 412 ; $A$ m. Nat. Hist. vol, xix. p. 98.

" comagata, Lové, Index Moll. Skandinav. p. 37 (from types).

" plana, Sowerby, Min. Conch. pl. 179, f. 2.

"Withami, Brows, Wern. Mem. vol. viii. pl. 1, f. 24, 25.

This rearee and interenting livalye assumes such various forms, that shape can scarcely be held characteristic in the species; indeed, it scems somewhat debatable whether the outline of any Astarte is of specific importance. The contour, which is almost always somewhat triangularly subrordate, is suborate in most adult individuals, as the length in that stage generally exceeds, and very decidedly, the breadth; but, the immature valves, and certain full-grown ones likerwise, have their length and breadth nearly equal; in which case the hinder termination becomes broad, and more or less triangular, instead of, as in the produced forms, rounded and somewhat tapering. The valves are rarely at all rentricose, and are usually shallow, becoming more rapidly so in front than behind. The sides, although unequal, are not greatly so for the genus, the posterior s.dem oecupring two-thirds of the entire length. The shell, which is often heavy, and always solid, opaque, and of a lighter or darker rufous tint, is covered by a fibrous chestnutcoloured epidermis, which has a silliy lustre, is thimner towards the beaks, and becomes thicker, and with the fibres arranged so as to resemble crowded concentric striulie towards the lower margin. This latter, which is quite entire within, is arcuated, and rises anteriorly with greater conwexity and rapidity, generally forming a slight angle with the upper edge. Both dorsal slopes are more or less con- 
siderable, and in general peculiarly straight, the front incurvation being usually very trifling, but rather elongated. The external surface is not plicated, but is sculptured with strong impressed enncentric wrinkles at the umbonal region, and is elsewhere smooth, or only obsoletely substriated in a concentric direction. The umbones, which are never eroded, are prominent; the beaks are acute, inflected, and lean slightly forward. The lunule is remarkably profound, and ranges from lanceolate to ovato-lanceolate. The ligament, which is very large and broad, is seated in a lanceolate depression of twice its length. The whitish hue of the interior has a bluish cast and more shining surface below the very high-seated pallial impression, above which it becomes squalid, or slightly embrowned. The hinge-margin is extremely broad, and is furnished, in addition to the primary teeth, with an indistinct rudimentary front lateral one in the right valve. The muscular impressions are large.

The example we have figured, which has evidently not arrived at its full growth, measures an inch and a half in length, and an inch and three-eighths in breadth. The length of a more produced form (exotic) of the same breadth, was an inch and two-thirds.

This is one of the rarest of our bivalves, of which the first-recorded example was that figured by Montagu in his Supplement to the "Testacea Britannica" as a large growth of the Astaite compressa, and may be inferred, from his language, to have been taken at Dunbar by Mr. Laskey. The large dead valves, mentioned by Dr. Fleming in his description of A. compressa as having been taken in St. Andrew's Bay, likewise belong to this species, as one of them, still preserved in our National Museum, distinctly evidences. It has been captured in Aberdeenshire (Mac- 
gilliviay); and a fresh single valve has likewise been dredgenl in righty fathoms water, forty miles to the west of the Mainland of Zetland (E. F. and $\mathrm{M}^{6}$ Andrew). The beantiful and perfect specimen delineated in our engraving was procured from Loch Riden by Capt. Brown, to whose courtesy we are indebted for the loan of it.

It is a strictly boreal shell, and is chiefly obtained from Spitzbergen and Sweden, but is by no means common in the museums and private collections of England. The A. semisulcata of Leach (Appendix to Ross's Voyage), of which the young was fignred in the Supplement to the "Index Testaceologicus," under the name of Mactra Veneriformis (we speals from an examination of the orighinal types), is most clesely allied to this species, lut is generally more elliptical in shape, has broader and more manifest umbonal plice, eroded umbones (in the adult), and a somewhat different-looking epidermis. It oceurs fossil in pleistocene strata of Britain, Northern Europe, and Boreal America.

\section{A. compressa, Montagu.}

Small, subtriangular, subequilateral, usually as broad as long, never elliptical; either traversed concentrically and en tirely with most crowded and very narrow costellæ, or smooth, excepting at the beaks, which are always thus costellated. Epidermis yellowish or olivaceous, never chestnut nor fibrous, glossy. Beaks very prominent and acute. Ventral margin quite entire.

Plate XXX. fig. 1, 2, 3.

Yenus compressa, Mont. Test. Brit. Suppl. p. 43, pl. 26, f。 1.

Venus Montagui, Dillw. Recent Shells, vol. i. p. 167.-'T'urT. Conch. Diction. p. 243.-Index Testaceol. pl. 7, f. 19.

Cyprina compressa, Turt. Dithyra Brit. p. 137, pl. 11, f. 22, 23.

Astarte compressa, Fuem. (not Macgil.) Brit. Anim. p. 440.

C'rassina Montagui, Gray, Ann. P'hil. 1825, p. 136.-IANL. Recent Shells, vol, i. p. 83.

Astarte striata, Brown, Ill. Conch. G. B. p. 96, pl. 38, f. 6, 7, 8.-Lovén, Index Moll. Skandinavix, p. 37. 
Crassina compressa, Brit. Marine Conch. p. 80.

Astarte multicostata, MacgrL. (not Smith) Moll. Aberd. p. 260.-PHiL. Neuer Conchyl. vol. ii. p. 59, Astarte, pl. 1, f. 8 .

, Banksii, Loven (not Leach nor Hanley) Index Mollusc. Skandinaviæ, p. 38 (from specimens).

There are certain genera which appear to admit of a much wider range of variation in their species, than others, and pre-eminence in this respect may perhaps be claimed for Astarte, so comparatively independent of form and sculpture, do the true and permanent specific characters in this genus appear to be. In diversity of variation, the present species stands almost withont a rival in its genus, each locality, comparatively speaking, yielding its own peculiar variety, yet so intimately connected by minute gradations with the most apparently opposite examples, that it seems utterly impossible that they can collectively constitute more than a single species.

We conceive the typical form to be subtrigonal, and equally broad as long, either almost smooth,-excepting always more or less obsolete costellæ at the beaks,-or much more usually entirely covered with most closely set or crowded costelle, which are thirty in number at the fewest, but more frequently forty, or even more, and are never much elevated, the valves seeming as it were sulcated rather than ribbed. The interstices are simple and narrow. The valves are almost equilateral, and vary from compressed to ventricose, the ordinary rule being, that the more triangular is the shell, the more ventricose will it be; they are always small, strong, opaque, and covered with a smooth more or less glossy strongly attached yellowish epidermis. The swell of the ventral margin ranges from simple convexity to full arcuation, and the declination in the dorsal edges increases in like proportion with the arcuation of the former, yet typically is moderate and barely convex behind, but

VOI. I. 
always profound and incurved in front. The anterior extremity is narrowed and rounded; the posterior termination is obtuse, but displays a more or less manifest tendency to biangulation. The bealis are acute and inclined, and the umbones remarkably prominent. 'The dorsal impresions, but especially the linder one, are large, and not very profound; the lunule is lanceolate or ovato-lancedate. 'The ligament, which is, as usual, imbedded, is rather broad, enlarged at its termination, and not much depressed; it ocenpies two-fifths of the lozenge, and is yellow, or fulvous brown. The internal surface is white, and its margin perfectly entire. The hinge consists in the left valve of two rather narrow slightly divergent simple teeth, with a cavity between them for the reception of the large solid central simple tooth of the right valve, which has, besides, an almost rudimentary one running nearly parallel with, and adjacent to, the hinder dorsal margin. The front extremity of the linge margin of the latter valve frequently also assumes the appearance of a distant lateral tooth.

A remarkable variety has been taken in North Britain, which demands especial notice, approximating as it does to the shape of sulcata, from which, however, the integrity of its solid margin, the smallness of its size compared with its solidity, and the closeness, depression, and narrowness of its ribs, suffice to distinguish it. It is longer in proportion to its breadth, than in the type, and has fewer and broader ribs; its front extremity not unfre'quently projects so that the anterior side is equal in length to the posterior. This variety, however, appears to unite with the type by almost imperceptible gradations. We may remark, that the smooth variety is always the more compressed one.

'The animal has a plain edged mantle, with sessile si- 
phonal orifices, and a white linguiform foot. The length or breadth of the shell rarely exceeds half an inch, and the average size of specimens is much less. It is obtained (the smooth variety) at Scarborough (Bean); and is not uncommonly dredged on the Northumbrian coast (Alder); in the mid-channel opposite Hampshire (Damon); Bantry Bay (Dillwyn). On the coast of Scotland it is much more abundant, occurring not uncommonly in the Hebrides and the lochs of the west coast. Mr. M'Andrew has dredged it in forty fathoms, muddy bottom off Sliye, and as reep as seventy fathoms in the Zetland seas, where both smooth and ribbed forms are found, as also in the Moray Firth, in from eight to forty fathoms. In the Frith of Forth it is not rare on the oyster banks in seven to fourteen fathoms (E. F.). It is a Norwegian as well as British species, and is a common pleistocene fossil.

Crassina striata of Nilsson in the "Nova Acta Holmiæ" 1822, p. 189, pl. 2, f. 6 , is probably this species; but the rudeness of the figure, and the brevity of the diagnosis, forbid our positively asserting so. The Nicania striata of Leach (Hanl. Recent Shells, suppl. pl. 14, f. 38), so imperfectly described in the Appendix to Ross's voyage, may possibly prove also identical, but is much less angular in outline, \&c.

\section{A. triangularis, Montagu.}

Very small, obliquely triangular, broader than long, quite smooth, typically crenated at the ventral margin; beaks extremely prominent; no dorsal impressions.

Plate XXX. fig. 4, 5 .

Mactra triangularis, Mont. Test. Brit. p. 99, pl. 3, f. 5.-MATon and RACisetT, Linn. Trans. vol, viii, p. 72.-Turt. Conch. Diction. p. 82.-DiLLw. Recent Shells, vol, i. p. 143.-Index Testaceol. pl. 6, Mactra, f. 28. 
Mactra minutissimu, MoNт. Test. Brit. Suppl. p. 37.-TurT. Conch. Diction. p. 83.-DiLLW. Recent Shells, vol. i. p. 143.

Goodallia triangularis, Tовт. Dithyra Brit. p. 77, pl. 6, f. 14.-FLeM. Brit. Anim. p. 429.-Macgilliv. Moll. Aberd. p. 289.Brit. Marine Conch. p. 49.

" minutissima, Tunt. Dithyra Brit. p. 77, pl, 6, f. 15.-Flex. Brit. Anim. p. 429.-Macgirirv. Moll. Aberd. p. 290.Brit. Marine Conch. p. 50.

Mactrina triangularis, Brown, Ill. Conch. G. B. p. 108, pl. 40, f. 25.

" minutissima, Brows, Ill. Conch. G. B. p. 108, pl. 42, f. 25, 26.

From the imperfect condition of the original specimens of this minute Astarte, arose the error, which, by denying the shell an external ligament, and thus severing it from its kindred species, led to the construction of the ill-based gemis Goondus.s. As the only permanent lifference between the G.triangularis and minima consists of the non-crenation of the margin in the latter (which we are not at all sure is ever the case with the adult), we are induced to unite them as one species.

'The contour of this shell is obliquely triangular, and broader than long; for its size it is remarkably solid, oparue, and perfectly smooth. Both externally ans intermally it is of a rich yellowish chestnut, either indistinctly rayed with the same hue, lut of a darker tint, or uniformly coloured, although when the animal is not removed, there is frepuently a slightly mottled or even zoned appearance. Excepting upon the umbones, the valves are rather compressed; the ventral margin is more or less arcuated, and rises in firont, whence originates the pecouliar appearance of obliquity in the valves. The anterior side which is decidedly the shorter, is rounded at its extremity, the front dorsal edge descending with great abruptness, and but trifling convexity to the ventral, without the interposition of any anterior margin.

The posterior side is produced below; its dorsal edge is 
much elongated, greatly sloping, and almost straight, being very slightly retuse near the beaks, and not much convex subsequently; the hinder termination is well rounded and projecting. There is neither lunule nor lozenge, but there is a slight undefined depression or flattening of the sides, both to the right and left of the umbones; which latter are remarkably prominent, but the beaks are neither acute nor at all inclined. The ligament is very short, but not depressed. Internally the lower margins are coarsely crenated, with raised bead-like projections, which, however, do not always exist in the immature specimens. There are two diverging central simple teeth in the right hinge, and a large simple inwardly-sloping central tooth in the other: the muscular scars are by no means large.

Examples which are equal to the eighth of an inch in breadth, and the ninth or tenth of an inch in length, may be regarded as fine ones, the ordinary run of specimens being somewhat less.

It seems far more abundant in Scotland than in England, where it is always held a very rare shell, and is dredged (but usually in not very shallow water) at Scarborough (Bean); the Fern Islands (Alder); Exmouth (Clark); Plymouth and Whitesand Bay (Jeffreys); Falmouth (Mont. and Jeffreys); the Scilly Islands (M'Andrew); Guernsey (S.H.); Isle of Man, in fifteen fathoms (E. F.); Langland Bay, in Glamorganshire, in twenty-five fathoms sand (Jeffreys); Tenby (Lyons); Fishguard (Jeffreys). Among Scottish localities may be mentioned, - Icolmkill, very abundant in five fathoms, and equally plentiful in fifty-five fathoms, off Cape Wrath (M'Andrew); in from five to fifty fathoms on the Zetland Coast, and thirty-five off Duncansby Head; also in the Moray Firth (M'An(lrew). It is a rare pleistocene fossil. 


\section{SPURIOUS.}

$A$ representation occurs in the eighth volume of the Linnean 'Iransactions, accompanying Maton and Rackett's Descriptive ('itallune of the British T'estacea, of a shell previously described by Montagu, but not so characteristically indicated as usual; hence doubts have arisen as to the species of the two works being actually identical. The following passage in the "Testacea Britannica," has not only satisfied us of this, but enabled us, through the examination of the referred to type, positively to declare its identity with one of the varieties of Say's Astarte castanea, "It is marked in Dr. Pulteney's cabinet Venus sulcata, but he did not know it had ever been found in this country, nor did he believe it had ever been described, and therefore named it himself."

Its claims to be held British, were never of much weight, being merely the assertion of one individual, who had received it from the Duchess of Portland as such, that similar ones (in all probability the valves of compressa or arctica) had since been found in the North of Scotland; and that Montagu had himself received it (without specified locality) from Mr. Sowerby as English. It is a common and well-known North American species.

\section{A. Castanea, Say.}

Tenus sulcuta, Mont. (not Pectunc. sulcatus of Da Costa) Test. Brit. p. 131.Maton and Rack. Linn. 'Trans. vol. viii. p. 31, pl. 2, f. 2.DrLlw. Recent Shells, vol. i. p. 166.

", custuneu, SAY, Jour. Acad. Philad. vol. iv. p. 273.

Astarle custanea, Say, Americ. Conch. pl. 1.-Conr. Amer. Mar. Conch. pl. 17, f. 3.-Gould, Invert. Massach. p. 76, f. 45.-HANL. Recent Shells, suppl. pl. 9, f. 27.- Print. Neuer Conch. vol. ii. p. 57, Astarte, pl. 1, f. 2.-DEKAv, New York Moll. p. 220, pl. 28, f. 280 .

"sulcata, Flem. Brit. Anim. p. 439.

Crassina custunea, Desir. in Lam. Anim. 8. Vert. (ed. Desh.) vol, vi. p. 258.HANL. Recent Shells, vol i. p. 88.

, sulcale, Brown, Hllus. Conch. G. B. p. 96, pl. 38, f. 10. 
Subtriangularly suborbicular, equally broad as long, thick, ponderous, opaque, moderately convex, covered with a tar-coloured or yellowish chestnut glossy epidermis, which is ordinarily adorned with darker and lighter concentric zones, beneath which it is externally and internally whitish. The entire outer surface is either smooth, or more rarely marked with obsoletely elevated broad belts. Ventral margin much arcuated; dorsal slopes strong, the front moderately incurved, the hinder more or less straight. Sides not greatly unequal; the anterior the shorter, and well rounded at its extremity; the posterior obtusely rounded, its extreme tip convex. Beaks nearly central, greatly elevated, a little inclined forwards; lunule ovato-lanceolate, rather deeply excavated, of a darker hue than the general colouring; lozenge not much impressed, the ligament occupying two-fifths of it at least. No umbonal ridge. Hinge margin very broad; muscular impressions profound, of moderate size; lower margins internally crenated. Diameter, an inch.

THE following description appears to apply to one of the fossil forms of Astarte, so common in our pleistocene strata :-

Crassina depressa, Brown, Ill. Conch. G. B. p. 96, pl. 38, f. 2.

"Shell compressed, transversely and obliquely subovate, umbones rather prominent and slightly reflexed, with a lanceolate deep lunule under them; colour of a dark reddish brown, with many flattened transverse ridges, and narrow shallow intervening furrows; inside white, smooth; margin plain, and slightly thickened in the edge. Length, nine-eighths of an inch ; breadth, nearly eleveneighths. This differs from $\mathbf{C}$. Scotica in leing more transcersely clongated, oblique, more compressed, with the basal line more parallel, the transverse ridges more numerous, very fluttened, and almost obsolete. Found in the Frith of Forth, but I have hitherto only met with dead and detached valves." 
ISOCARDIA, LAMARCK.

Shell inflated, heart-shaped, equivalve, rather strong, smootl, or furrowed, with or without an investing epidermis; beaks very prominent and contorted; margins entire; muscular impressions small, no pallial sinus. Hinge comprosed of two ereet primary teeth (one of them indented) parallel with the margin in one valve, and three in the other; a lateral tooth and tooth-like socket. Ligament external, furcated anteriorly. No defined lunule.

Animal shaped like the shell, open in front for the broad triangular, compressed, pointed foot. Siphonal orifices sessile, their margins fringed. Mantle double edged.

This remarkal,le genus may be regarderl as contituting a connecting link between the Cyprinids and Cardiada, whilst its affinities with Chama and its associates are also not small. Our only British species is rather an exeeptional form, and isolated from its tropical congeners by the possession of a highly developed epidermis. In British strata even as old as the oolitic formations, we have fossil examples of Isocardia, but all of them bear more resemblance to those now existing in the seas of warm regions, than to that about to be described.

\section{CoR, Linnæus.}

Plate XXXIV. f. 2, and (Animal) Plate N. f. 6.

Lister, Hist. Conch. pl. 275.-Gualtieri, Index Test. pl. 71, f. E.-Ginani, Opere Postume, vol. ii, pl. 19, f. 129.Kinorr, Delices des Yeux, pt. vi. pl. 8, f. 1.

Cardium humanum, Lisw. Syst. Natura, ed, 10, p. 682 (badly).

Chema cor, Lisw. Syst. Nat. ed. 12, p. 1137 ; Mus. Ulrica, p. 516.-Mont.

Test. Brit. pp. 134, 578, and Sup. p. 50-Dosovas, Brit. Shells, vol. iv. pl. 134.-Lasies, Mem. Werner. Soc, vol. i. pl. 3, f. 7.-Tunr. Conch. Diction. p. 32, pl. 17.-Brown, Mem. 
Werner. Soc. vol. ii. pp. 511, 535.-Born, Testacen Mrus. Cas. Vind. p. 30.-Chems. Conch. Cab. vol. vii. pl. 48, f. 433.—Poli, Test. 'Siciliæ, vol. ii. p. 213, pl. 23, f. 1, 2, 3.-Diluw. Recent Shells, vol. i. p. 212.-Index Testaceolog. pl. 9, Chama, f. I.

Carlita cor, Bruguiere, Encyelop. Méthod. Vers, vol. i. p. 403.

Isocardia cor, LAM. Anim, s. Vert. (ed. Desh.) vol. vi.p. 445.-Turt. Dithyra Brit. p. 193, pl. 14. - FleM. Brit. Anim. p. 419. - Brit. Marine Conch, p. 100.-Brown, Ill. Conch. G. B. p. 86 , p. 30, f. 9, and pl. $30, *$ f. 5.- Sowerby, Genera Shells, Isocardia f. 1, 2.-Bulwer, Zool. Journal, vol. ii. p. 258, suppl. pl. 15. - Blainv. Manuel Malacologie, pl.69, f. 2.-Crovch, Introd. Conch. pl. 8, f. 7.-Deshayes, Fncycl. Méthod. Vers, vol. ii. p. 321 ; Elem. Conch.pl. 23, f. 10, 11.- Puictepr, Moll. Sicil. vol. i. p. 56, and vol. ii. p. 41.-REEve, Conch. System. pl. 78, f. 1, 2. - Hanl. Recent Shells, vol. i. p. 150, pl. 9, Chama, f. 1.

" Hibernica, ReEve, Conchol. Icon. Isocardia, pl. 1, f. 4.

Encyclop. Méthodique, Vers, pl. 232.

We are not disposed to consider the slight differences which exist between the Irish and Mediterranean examples of this remarkable shell, as of essential or specific importance, but esteem them rather as contingent upon climate, depth, food, or some of those multifarious causes which induce variation.

The lateral contour is exactly heart-shaped, whence its popular name of the Heart Shell; the general outline of each valve is cordate-truncated, the lower angle of the heart being as it were lopped off by the obtuse truncation of the posterior extremity. The valves are solid, opaque, much inflated, and under a rather thin and yellowishbrown concentrically wrinkled epidermis, of a dirty white, closely reticulc ted by delicate angular radiatingly-arranged lineations, of a livid red, or fawn-colour, which are chiefly apparent (partly from the abrasion of the epidermis at that point) upon the swollen umbones, belind which they become so thickly clustered as to present an almost uniform tint. The surface is devoid of either lustre or sculpture, exhibiting only the more or less coarse concentric stages of VOL. I. 
increase, which as usual become more marked as age advances. The ventral margin is areuated, and rises sharply in front; the hinder dorsal edge is convex, and slopes so little (indeed it slightly ascends at first) as almost to be sub-parallel with the opposite margin. The front dorsal slope is short, incurved, and rather abrupt. The anterior extremity is angulated, the angle being, in the adult, above the middle of the side, and its tip rounded off; the posterior termination is rather broad, and very bluntly biangulated. The umbones are contorted, and project considerably forward, so as to appear subterminal; the beaks are so much inflected as almost to appear spiral, and so diverge from each other as to be widely sundered at their apices, which are very acute, and lean upward. The ligament, which, though sufficiently ample, is not particularly prominent, is divided anteriorly, and runs in a narrow slip along the base of each umbo. There is no defined lumule, but a very expansive hollow in front of the umbones; the dorsal lips, however, are elevated. Within, the surface is of a whitish hue, with occasionally a slight tinge of buft or flesh-colour upon its disk; the inner edge is sharp and simple. The teeth of the hinge are erect, and lie parallel with the margin; in the left valve the front one is very large, truncato-trigonal, indented at its apex so as at times almost to appear double, and impressed below by the opposing tooth; the hinder one is thin, laminar, and dorsal. Of the two strong front primary teeth of the right valve, which lie parallel with each other, the upper is senicircular and situated less forward, the lower one is the shorter, and more trigonal; the hinder tooth is laminar, and not peculiarly solid. The lateral tooth (and its tooth-like receptacle) are strong, posterior, and remote from the beaks, lying beyond the termination of the ligament. 
The fry, which is very rarely to be met with in cabinets, is very thin, transparent, and of a subcordiform obovate shape. It is of an uniform whitish hue, and remarkable for its somewhat opaline diaphanous yellowish epidermis, which is studded with minute hairs in radiating series. This peculiarity is observable likewise under the lens in well preserved middle-aged specimens. The epidermis in the Mediterranean examples (which do not appear to reach the dimensions of the northern shell) is smoother, rather more shining, and of a ruddier cast.

The following interesting account of the animal and its habits was communicated by the Rev. James Bulwer to the 2nd volume of the Zoological Journal.

"Mantle completely lining the shell, double at the onter" edge; exterior fold divided in front, open at each end; at the posterior end forming two short siphons or tubes, ciliated at the upper orifices; colour yellowish white; margin orange. Foot very muscular, broad, triangular, compressed, pointed, orange. Branchiæ external, concealed between the mantle and the body. Body soft, completely included within the valves. On being placed in a vessel of sea-water the valves of the shell gradually opened, to the extent represented in the drawing; the feelers or ciliated fringe of the upper orifice of the mantle moved slowly, as if in search of animalculæ. Having remained in this situation about ten minutes, water was ejected with considerable force from the lower orifice, which till now had remained motionless. The expulsion of the water appeared to be effected by a sudden contraction of the muscles, because this was never done without the valves nearly closing at the same instant. After a few seconds the valves gradually returned to their open position, and remained quiescent as before, till the water was again ejected with a 
jerk; this alternating process was repeated at merpal intervals during the whole time my specimens were under examination, but at shorter intervals on receiving fresh supplies of sea-water, when I suppose food (its quality I could not ascertain) was more abundant.

"The animal appears to be insensible both to somd and light, an the presence or absence of either dicl not at all interrupt its movements; but its sense of feeling appeared to be very delicate, minute substances being dropped into the orifice of the mantle instantly excited the animal, and a column of water strongly directed expelled them from the shell. With so much strength was the water in some instances ejected, that it rose above the surface of 3 inches of superincumbent fluid. Animal small in proportion to its shell, occupying when dead barely a third of the space enclosed in the ralves. Its mantle is slightly attached to the shell, and to the epidermis at the margin, and appears to be liept distended and in contact with the interior of the valves, by the included water. The valves fit so closely that the animal can remain two days or more without permitting a single drop of fluid to escape. Locomotion very confined; it is capable, with the assistance of its foot, which it uses in the same manner (but in a much more limiter degree) as the Cardiacea, of fixing itself firmly in the riml, generally choosing to have the mubones covered by it, and the orifices of the tubes of the mantle nearly perpendicular. Resting in this position on the margin of a sand bank, of which the surrounding soil is mud, at too great a depth to be disturbed by storms, the Isocardia of wur hrish sea paticutly collects its food from the surrounding element, assisted in its choice by the current it is capable of creating by the alternate opening and closing of its ralves." 
The chief locality of this fine shell in the British seas is off' the Dublin coast, where specimens are sometimes obtained in considerable abundance. It is also procured in deep water off the Cornish coast; and is brought in by fishermen at Falmouth (Cocks, Alder). Bantry Bay (Turton); and the Cove of Cork (Brown), are among its Irish southern habitats. It occurs in the Hebrides, living, as near Oban, in mud at a depth of fifteen fathoms, and dead in forty fathoms off Skye (M'Andrew and E. F.). Laskey recorded it from Icolmkill, and also from near St. Abb's Head. Abroad it ranges to the Mediterranean. 



\title{
EXPLANATION OF THE PLATES OF ANIMALS.
}

\section{SERIES I.}

\author{
GENERA OF TUNICATA, ACEPHALA AND P'TEROPODA.
}

Plates A and B.-1. Aptidium fallax. 2. Sidnyum turbinatumboth from specimens taken on the shores of the Isle of Man (E. F.). 3. Polyclinum aurantium (misealled gelatinosum in Plate B). 4. Amouroucium argus. 5. Leptoclinum gelatinosum. 6. Distoma mbrum. 7. Botryllus polycyclus. 8. Botrylloides albicans. The figures of Plate A, from 3 to 6 , and fig. 8, are after Milne Edwards. Those of Plate B are mostly after Savigny, and represent (greatly magnified) the individual mollusks extracted from the common masses.

Peate C.-1. Ascidia mentula. 2. A. virginea. 3. A.scabra. 4. A. echinata. 5. Molgula tubulosa (arenosa of Alder); all from life (E.F.).

Plate D.-1. Cynthia quadrangularis. 2. C. morus. 3. C. tessellata. 4. C. limacina. 5. C. aggregata, 5. a. the tadpole of the last highly magnified. 6. Mrolgula oculata, adhering to a Pecten, and encrusted with shells and sand; all from life (E. F.).

Plate E.-1. Clavellina lepadiformis, a. natural size of a group of examples; $b$. a single individual magnified. 2. Perophora Listeri, $a$. of the natural size, upon a fucus; $b$. the same highly magnified. 3. $a$. and $b$. Pelonaia glabra, in different states of contraction. 4. Pelonaia corrugata; all from life (E. F.). 5. The solitary, and 6. The aggregate individuals of Salpa muncinata, from specimens taken in the Scottish seas by Lieut. Thomas, R,N.

Plate F.-1. Animal of a Teredo; the upper figure representing the siphonal extremity, magnified. 2. Xylophaga dorsalis, after a sketch and specimens communicated by the Rev. D. Landsborough; the siphons, however, are not collateral at the cxtremity of the

VOL. I. 
tube, ns here represented. See note in rol. ii.p. 375. We have not been able to procure a fresh figure, as there promised. 3. Pholas parra, from life. 4. Pleoladidea papyracea, the siphons only, after preserved specimens and a sketch by Mr. Clark. 5. Gastrochecra modiolina, and 6. Saxicara mugosa.

Pistr G.-1. Petricola lithophaga (after Philippi). 2. Tenerupis irus (after Deshayes). 3. Corbula nucleus. 4 and 5. Necera cuspidata. 6. Its siphons and their appendages, greatly magnified. 7. The orifices of the siphons. 8. Necera costellata, and 9. its foot, all from life; as also 10. Pandora obtusa.

Piste H.-1. Nya truncata. 2. Lutraria elliptica, and 2. a. its siphonal apertures. 3. Lyonsia norregica. 4. Thracia phaseolina. 5. Thracia distorta.

P'uate I.-1. Solen siliqua. 2. Solen pellucidus: these and 5. Solecurtus courctatus (the shell reversed by mistake), with 6. its siphons, are from life (E. F.). 3. The siphons of Solen marginatus (after Deshayes). 4. Ceratisolen legumen (shell reversed by error).

l'uAte K.-1. Psammobice tellinella, and 1. a. its siphons. 2. Diodonta fragilis (after Deshayes). 3. Tellina tenuis, and 3. a. its siphons with part of mantle. 4. and 4. a. Similar figures of Tellina donacina. 5. and 5. a. Ditto of Syndosmya intermedia. 6. Scrobicularia piperita (lettered compressa). 7. Donax anatinus. 8. Siphons of Mesodesma, introduced for comparison (E. F.).

Pi,ATE L.-1. Mactra elliptica. 2. Siphons of II. solida. 3. Those of M. subtruncata. 4. Those of M. stultomem. 5. T'apes pullastra, and 5. a. its siphons. 6. Siphons of Vonzes ovata. 7. Vonus fasciata. 8. Cytherea chione.

PIATE M.-1. Artemis lincta (after Poli). 2. Lucinopsis undata (from sketch by Mr. Clark). 3. Circe minima (from a specimen dredged in Milford Haven). 4. Cyprina islandica (the beaks are turned the wrong way in the engraving). 5. Astarte sulcata, var. Danmoniensis. 6. Lucina borealis (from sketeh by Mr. Alder). 7. Diplodonta rotundata (from sketeh by $\mathrm{Mr}$. Clark).

P'iATE N.-1. Cardium norvegicum. 1. a. portion of the branchinl siphon. 2. Cardium pygmaum. 3. C. fasciatum. 4. C. echinatum, junior. 5. Siphons of C. edule. 6. Isocardia cor (after Bulwer).

Puate O.-1. Turtonia minuta, called purpurea on the plate; the shell in this figure is reversed by mistake (see vol, ii.p. 375). 2. Montacuta substriata. 3. Kellia rubra. 4. and 4. a. Kellia suborbicularis. 5. Galeomma Turtoni (partly after Mittre). 6. Lepton squamosum. 7. Cyclas calyoulata. 8. Pisidium amnicum. 9. P'isidium pusillum. The figures of ficllice and of Lepton are from drawings by Mr. Alder. 
P'late 1'-1. Arca tetragona, with 1. a. its byssus. 2. Leda caudata, and 2. a. the expanded disk of its foot. 3. Leda pygmeed. 4. Nucula nucleus. 5. Nucula tenuis. 6. Pectunculus glycimeris, called pilosus on the plate. The drawing of 1. is by Mr. Alder; the others are from our own sketches after life.

P'iste Q.-1. Cyclas rivicola. 2. Unio pictorum. 3. Anodonta cygnea, with 3. a. its mantle-fringe. 4. Dreissena polymorpha, 4. a. and b. details of its siphons, after sketches by Mr. J. de C. Sowerby. 5 . Mytilus edulis, and 5. a. part of its mantle-fringe. 6. Modiola tulipa. 7. Crenella nigra (after a drawing by Mr. Alder).

P'iste R.-Lima hians (under Turton's name of L. tenera). 1. and 2. different views of the animal fully expanded. 3. its foot. 4. one of the cirrhi highly magnified. The beautiful drawings from which these figures were engraved, are among the many favours we owe to the peneil and observation of our accomplished friend, Mr. Alder.

Plate S.-1. Pecten similis. 2. P. striatus, and 2. a. a portion of its mantle highly magnified. $3 . P$. niveus, with 3 . a. portion of its mantle. 4. Avicula tarentina, drawn from a living Mediterranean specimen (E. F.).

Plate T,-1. Ostrea edulis (this beautiful figure was most kindly drawn and engraved from the living animal by Mr. J. de Carle Sowerby). 2. Anomia ephippirem. 3. Sphcenia Binghami, from a drawing by Mr. Spence Bate.

Plate U.-1. Terebratula caput-serpentis, 1. b. the under valve, and 1. c. the upper valve, laid open, from living specimens taken in Loch Fyne. 2 Crania norvegica. 3. Hyalcea trispinosa, and 4. Spirialis (after Souleyet), named Peracle on plate.

Plate W.-1. Panopaea norvegica, after a drawing from the living British specimen by Mr. Richard Howse. 2. Poromya granulata, after a sketch by Mr. M'Andrew. 3. Appendicularia, a slight sketch from a British example.

[Plates X, Y, Z, no such plates].

\section{SERIES II.}

\section{GENERA OF GASTEROPODA AND CEPHALOPODA.}

Plate AA.-1. Patella (Patina) pellucida. 2. Acmoca testudinalis, -2. a. and $\mathrm{b}$. one of the articulations of the tongue. 3. Pitidium fulvum, with 3. a. its head, showing the eyeless tentacles, and 3. b. articulations of its tongue. 4. Propilidium ancyloide, with 4. a. umder side of its head, and 4. b, upper side of its head and position 
of the two branchial plumes. 5. Chiton asellus, and 5. a. its head, scen in profile. 6. Chiton ruber. All from original drawings.

Puate 13B.-1. Emarginula rosea. 2. An enlarged view of its head and neighbouring parts scen from above; and 3 . the same seen laterally. 4. Puncturella noachina, secn sideways. 5. The sime from below, and 6. its head. 7. Fissurella retioulata. 8. Calyptrace sinensis, seen from below; 9 . Its head; 10. Shell of the fry; 11. Head and neek of the fry; 12, and 13. 'Tongue. All from original drawings.

Plate CC.-1. Patella vulgata. 2. Emarginula crassce. 3. Maliotis tuberculata. 4. and 4*. Trochus helicinus. 5. and 5*. Pileopsis hungaricus, from a half-grown example. Figures 2, 4, and 5, are from drawings by Mr. Alder.

P'tate DD.-1. Trochus cinerarius, and 1, a. its head and lobes (the right lateral lobe should be simple-edged, not crenated). 2. T. tumiclus. 3. T. magus. 4. T. granulatus. 5. Phasianclla pullus, and 5. a. its head: the sceond lateral filament should be shorter than the others. Fig. 2 is by Mr. Alder.

P'LATE EL.-1. a. Trochus ziziphinus, from below; 1. b. the same, front view; 1. c. its head and tentacles; 1. d. a lateral filament ; 1. e. its opereuligerous lobe and tail; 1 . f. the branchial plume; 1. g. branchial lamellæ very highly magnified. 2. a. Trochus alabastrum (misprinted alabastrites); 2. b. its head, tentacles, Jateral and capital lobes, and the anterior portion of its foot.

PLate FF.-1. Scalaria Trevelyana, showing the head and siphonal fold of mantle. 2. The same crawling. 3. Head and anterior portion of the foot seen from above. 4. Chemnitzia fulvocineta, under the name of rufa. 5. Head, de. of C. scalcuris. 6. C. rufescens. 7. Eulimella Scillce (named Chemmitzia Hacdndrei, on plate). 8. Odostomia spiralis. 9, and 10. I'runcatella truncatula.

Plate GG.- l. Skenea planorbis, and 1. n. the same seen crawling, so as to show its operculigerous lobe. 2. Littorina rudis, var. patula; 2. $\pi$. its foot seen from below. 3. Head of Littorina littorea. 4. and 4. a. Lacunx vineta. 5. Some stages of development of Lacuna palliclula; and 5. a, ova of that species clustered on a fucus, both from the drawings of Mr. Spenee 13ate.

P'ate HH.-1. Neritina fluviatilis. 2. P'aludina vivipara; 2. a. its head and neck-lobes. 3. Bithinia tentaculata; and 3. a. its head and neck-lobes. 4. B. Leachii. 5. Valvata eristata; and 5. $\Omega$. its head and front of foot. 6. Assiminea Grayana. All from original drawings.

P'AтE II.-1. Trichotropis borcalis. 2. and 2. a. Cerithium reticulatum. 3. Aporihais pes-peleccini; and 3. a. its foot. 4. and 4. a. Thiritella communis. All from drawings by Mr. Alder. 
Plate JJ.-1. and 1. a. Jeffreysia diaphana; 1. b. part of its head; 1. c. d. e. its opereulum. 2. Opereulum of Jeffreysia opalina, all from drawings by Mr. Alder. 3. Rissoa abyssicola. 4. R. cingillus; and 4. a. its operculum. 5. R. parva. 6. Head of $R$. labiosa. 7. Head of $R$. rufilabris. 8. R. ulva.

Plate KK.-1. Coecum trachea, a. from the side; b. from below; c. its head. 2. Eutima polita, var. nitida (wrongly labelled $E$. nitida on plate). 3. a. and b. E. polita, typical form (wrongly E. nitida, var. politix, on plate). 4. a. and b. E. distorta. 5. Anterior portion of E. bilineata.

Puate LL.-1. and 1. a. Nassa incrassata. 2. and 2, a. N. pygmeea (called $N$. varicosa on plate). 3. $N$. reticulata. 4. Purpura lapillus; and 4. a. its head, seen from above. 5. Buccinum undatum.

Plate MM.-1. Spirialis Flemingii, from living specimens off the coast of Skye, $2 \mathrm{a}$ and b. Jeffreysia opalina, after a drawing by Mr. Alder. 3. a. and b. Assiminea littorea (see Appendix): this is the Rissoa littorea of Plate lxxxi. figs. 6 and 7 , after living specimens taken on the coast of the Isle of Wight. 4. Rissoa vitrea, from a specimen taken off Oban. 5. Aclis supranitida, after a sketch by Mr. Hanley.

Plate NN.-1.2. 4. Ovula patula (under the name Volva patula); and 3. its head. 5. 6. 7. Cyproca europesa; and 7. its head, seen from below. 8. Marginella levis; and 9. its head.

Plate OO.-1.a. b. and c. Cerithiopsis tubercularis; and 2. its operculum. 3. Operculum of Cerithium reticulatum. 4. Otina otis. 5. Stilifer Turtonis. (All from drawings by Mr. Alder.) 6. a, and b. Velutina flexilis (under the name of $V$.plicatilis). 7. Velutina lovigata.

Plate PP.-1. a. b. c. Lamellaria perspicua. 2. L. tentaculata (after a drawing by Mr. Spence Bate), 3. Natica sordida. 4. N. Montagui (after a drawing by Mr. Alder). 5. N. Alderi ( $N$. nitida of text). 6. N. monilifera (lettered $N$. canrena by a mistake); and 7. a. and b. its nidus (after drawings by Mr. Spence Bate).

[Plate QQ, no such plate].

Plate RR.-1. a. Mangelia Leufroyi; 1. b. its anterior portion; 1. c. its tail. 2. a. M. brachystoma; 2. b. its anterior portion; and 2. c. its tril. 3. a. M. teres; and 3. b. its head. 4. a. M. costata (after a sketch by Mr. Adder); 4. b. its head, from another drawing. $4 *$. its lingual denticles. 5. Head and anterior parts of $M$. attenuata. 6. M. linearis. 7. Head and tail of M. nebula. 8. M. gracilis (after a drawing by Mr. Alder).

Puate SS.-1. Fusus propinquus, (drawn from life by Mr. Alder). 2. a. Fusus islendicus; 2. b. its head; and 2. c. its lingual denti- 
tion. 3. a. Trophon clathratus (as Bamfium); and 3. b. its lingual dentition. 4. a. T. Barvicensis; and 4. b. its head. 5. T. muricatus (under the name of $T$. echinatum); and 5. b. its head.

PLATE T'T.-1. a. and b. Hurex erinaceus; and 1. c. its lingual dentition. 2. a. and 2. b. MKangelia (Bela) turricula; and 2. d. its lingual dentition. 3. M. (Bela septangularis). 4. a. M. (Bela) mefa; and 4 b. its heal. (Figs. 2, a. and 3, are from drawings by Mr. Alder.)

Peate UU. -1. a. and b. Bulleea (or Philine) aperta; 1. c. its lingual dentition. 2. a. and b. Amphisphyra hyalina; 2. c. its lingual dentition. 3. Bulla hydatis. 4. Philine (Bullca) catena, and Philine (Bulleca) punctate. All the figures on this plate are from drawings by Mr. Alder.

P'late VV.-1. Pliline (Bulleca) scabra. 2. Bulla Cranchii. 3. Cylichna cylindracea. 4. C. truncata (after a sketch by Mr. A. Alder); and 4. a. its lingual dentition. 5. Scaphander lignaria. 6. Akera bullata. 7.. and b. Tomatella fasciata (T. tornatilis on plate).

PLate XX.-1. Pleurobranchus plumula. 2. P. membranaceus. After drawings by Mr. Alder. A few impressions of this plate were issued, marked SS.

Plate YY.-1. Aplysia hybrida. 2. Doris coccinea. 3. Goniodoris nodosa (these two figures are after drawings by Mr. Alder). 4. Idatia incequalis. 5. Polycera quadritineata.

Plate ZZ.-1. Hermaed dendritica. 2. Proctonotus mucroniferus. 3. Lomonotus marmoratus. 4. Ancula cristata. 5. Dendronotus arborescens (all after the figures by Alder and Hancock).

PLite AAA.-1. Triopa claviger. 2. Egirus punctilucens (thesc figures are after Alder and Hancock). 3. Tritonia Hombergi (copied from the figure by Mrs. Johnston). 4. Doto coronata. 4.* D. fragilis. 5. Seylleca pelagica.

P'late BBB.-1. Eolis papillosa, var. Zetlandica. 2. E. coronata, from our drawing of the original specimen. 3. E. viridis, from a Cornish example. 4. E. exigua, after Mr. Alder's drawing. 5. Embletonia minuta. 6. Antiopa cristata (under the name of A. splendida, see note in Appendix); after Mr. Spence Bate's drawing.

Puate CCC.-1. Alderia modesta. 2. Runcina Hancochi. 3. Elysia viridis. 4. Limapontia nigra. 5. Acteonia corrugata. 6. Cenia Cocksii. All from Mr. Alder's drawings, exeept the first, which is from a figure by Mr. Spenec Bate.

P'LATE DDD.-1. a. Arion empiricorum; 1.b. the same, at rest and contracted; 1. c. part of the surface of its shicld and borly magnified. ('This figure is relerred to wrongly in vol. iv. p. 7, as fig. 4. 
of his plate.) 2. a. Limax cinereus; 2. b. part of its surface niagnified; 2. c. its shell (referred to as fig. 1. in text). 3. a. Limax agrestis; 3. b. the same, at rest ; 3. c. part of surface magnified; 3. d. its shell (referred to as fig. 2. in text). 4. a. Limax gagates; 4 . b. the same, at rest ; 4 . c. part of surface magnificd; 4. d. its shell (referred to as fig. 3 . in text).

Puate EEe.-1. a. Limax flaves; 1. b. part of surface magnified; 1. c. its shell. 2. a. Limax arborum (written arboreus on plate); 2. b. the same, at rest; 2. e. part of surface magnified; 2. d. its shell. 3. a. Limax Sowerbii; 3. b. the same at rest; 3. c. part of the surface magnified; 3. d. its shell.

[Plate FFF. A few impressions were issued of a plate so marked; these should be altered to GGG. There is no plate FFF.]

Plate FFF.*-1. a. Arion hortensis; 1. b. portion of surface magnified. 2. a. Arion flaver; 2. b. the same, at rest (from a drawing by Mr. Alder). 3. Limax tenellus (from a drawing by Mr. Alder). 4. Limax brumeus (from a drawing by Mr. Alder). 5. Geomalacus maculosus (after Dr. Allman's drawing). 6. Onchidium celticum, from a specimen taken by Mr. Couch.

Puate GGG.-1. Helix hispida. 2. H. rotundata. 3. Zonites cellaria (written Helix). 4. Helix fusca. 5. Zua lubrica. 6. Bulimus acutus.

Plate HHH.-1. Titrina pellucida. 2. Clansilia plicatula. 3. C. laminata. 4. Balea fragitis, under the name of perversa. 5. Pupa muscorum, called marginata on plate. 6. Pupa umbilicata.

Plate III.-1. a. Testacella haliotoidea (referred to in text, by error, as GGG. fig. 1.) ; and 1. b. its eggs. (This figure was engraved from life, with the assistance of a drawing by Mr. S. P. Woodward.) 1.c. and 1.d. its shell. 2. a. Limnaeus pereger; and 2. b. its head, 3. Physa hypnorum (after a drawing by Mr. Spence Bate). 4. Planorbis vortex. 5. Succinea putris. 6. S. oblonga (these two figures after drawings by Mr. Spence Bate). 7. Conovulus denticulatus (after a drawing by Mr. Alder).

Plate JJJ.-1. Physa fontinalis. 2. Achatina acicula. 3. Carychium minimum. 4. Limax agrestis, a remarkable monstrosity, taken by Mr. Gibbs at Sandown. 5. Cyclostoma elegans. 6. Ancylus.

Plate KKK.-1.2.3. Diphyllidea lineata. 4. Eledone ventricosaboth from drawings by Mr. Alder.

Plate LLL.-Loligo vulgaris, after drawing by Mr. Alder.

Plate MMM.-1. a. Eledone cirrhosus, attitude when at rest; and 1. b. portion of arm with suckers. 2. a. Sepiola Atlantica, from a specimen taken off Skye; 2, b. one of its lower arms, showing the peculiar arrangement of the terminal suckers; 2. c. portion of an 


\section{6}

EXPLANATION OF THE PLATES OF ANIMALS.

arm with suckers, much mngnified; 2. d. its pen. (Both the preecding species were drawn from the living animal.) 3, a. outline of Sepiola Rondeletii, from a British specimen, taken by Mr. Alder, and preserved in spirits; $3 . \mathrm{b}$. one of the arms; 3 . c. termination of one of the lower arms, showing the peeuliar arrangement of the suckers; 3. d. its pen.

Plate NNN.-1. Rossia macrosoma, from an Irish specimen, in spirits, in the Muscum to Trinity College, Dublin; presented by Dr. R. 13all. (The reference in the text is misprinted MMM. fig. 1.) 2. Octopus vulgaris, after the figure of a British specimen, by Sowerby.

Plate OOO.-Sepia officinalis; drawn from life by Mr. Bailey; the specimen was taken by Mr. Mackie, off Folkestone.

PLate PPP.-1. a. Under surface of the "bone" or shell of Sepia officinalis; 1.b. side view; 1. e. lower part of back of the same. 2. ^. under side of shell of Sepia bisserialis; 2. b. upper side; 2. c. side view; from drawings by Mr. Alder of a British specimen. Plate QQQ.-1. a. Loligo media, dorsal surface; 1, b. another specimen, ventral surface; and 1. e. the pen. Drawn from the life by Mr. Alder. 2. a. Loligo marmore; and 2. b. its pen. From an Irish specimen taken by Dr. Robert Ball, and preserved in the Museum of Trinity College, Dublin.

Plate RRR.-1. Ommastrephes sagittatus; drawn by E. F. from a living specimen obtained by the Marchioness of Hastings, off Brighton. 2. Ommastrephes todarus; from a drawing by Mr. Alder, of a British example.

Plate SSS.-1. Rossia Ovenii. 2. Ommastreptes Eblane; both from Irish specimens, taken by Dr. Robert Ball, and preserved in the Museum of Trinity College, Dublin. 



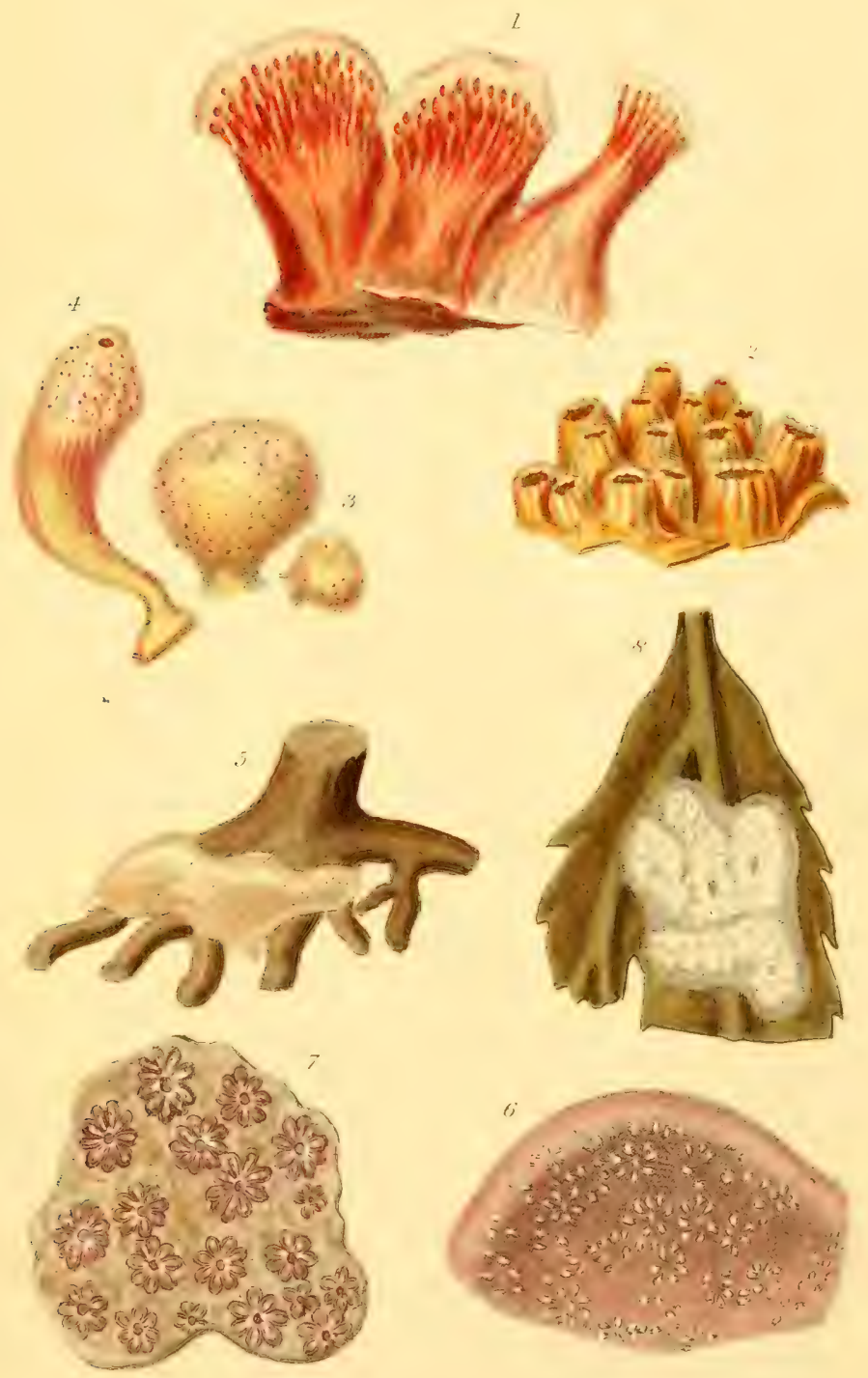

1. Aplidium fallax. 2. Sidnyum turbinatum.

3. Polyclinum aurantium. 4. Amouroucium argus.

5. Leptoclinum gelatinosum. 6. Distoma rubrum.

7. Botryllus polycyclus. 8. Botrylloides albicans. 



PLATE B.

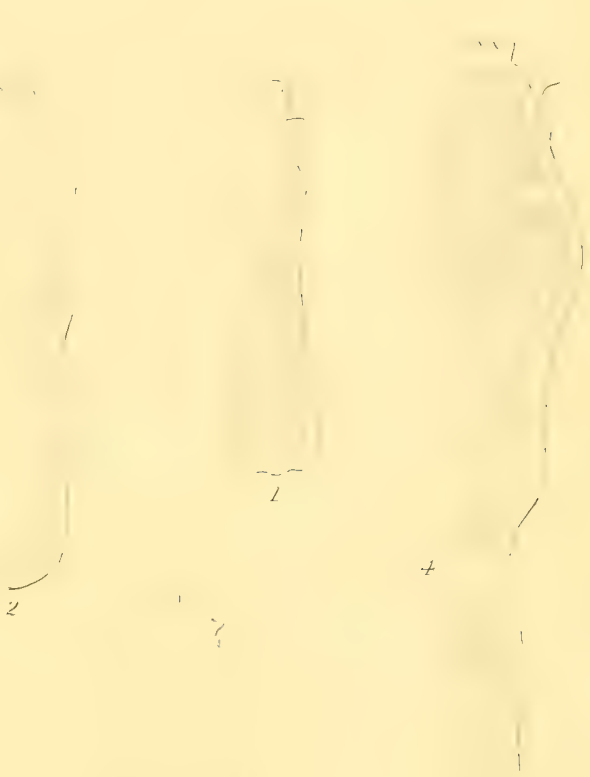

8

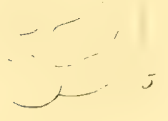

i

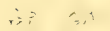

7
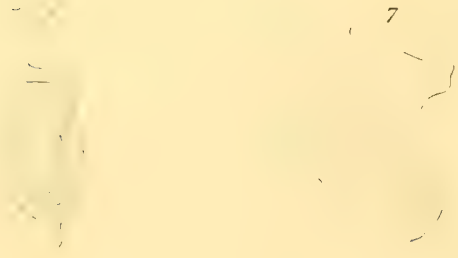

T.De Cante Sowerly ex:

1. Aplidium fallax. 2. Sidnyum turbinatum.

3. Polyclinum aurantium. 1.Amouroucium argis.

5.Leptoclinum g̈clatinosum. 6 1)istoma.

7. Botryllus. 8. Botrylloides . 



PLATE C .
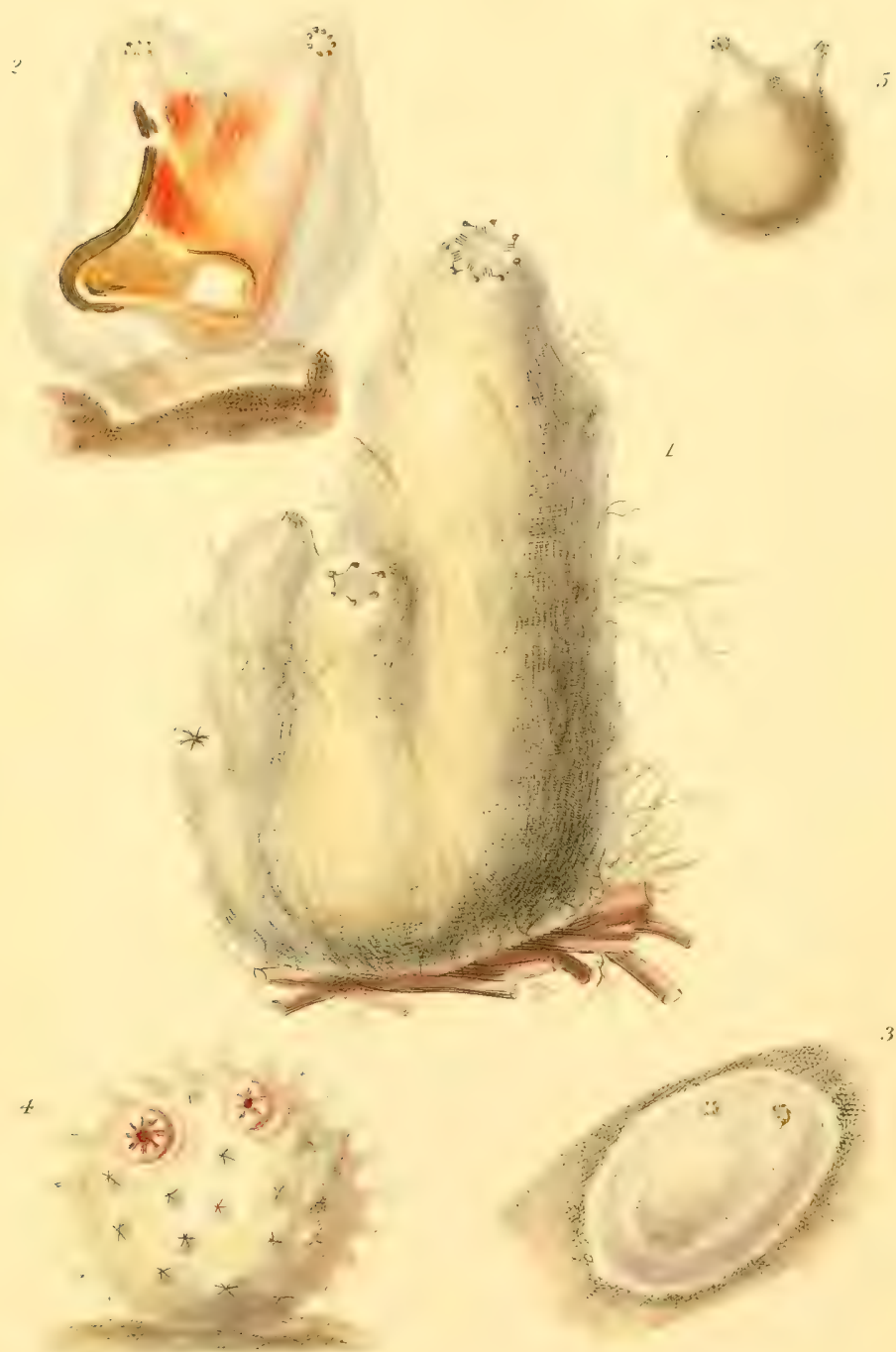

1. Ascidia mentula. 2. A.virginea. 3. A.scabra.

t. A.echinata. 5. Molgula tubulosa. 




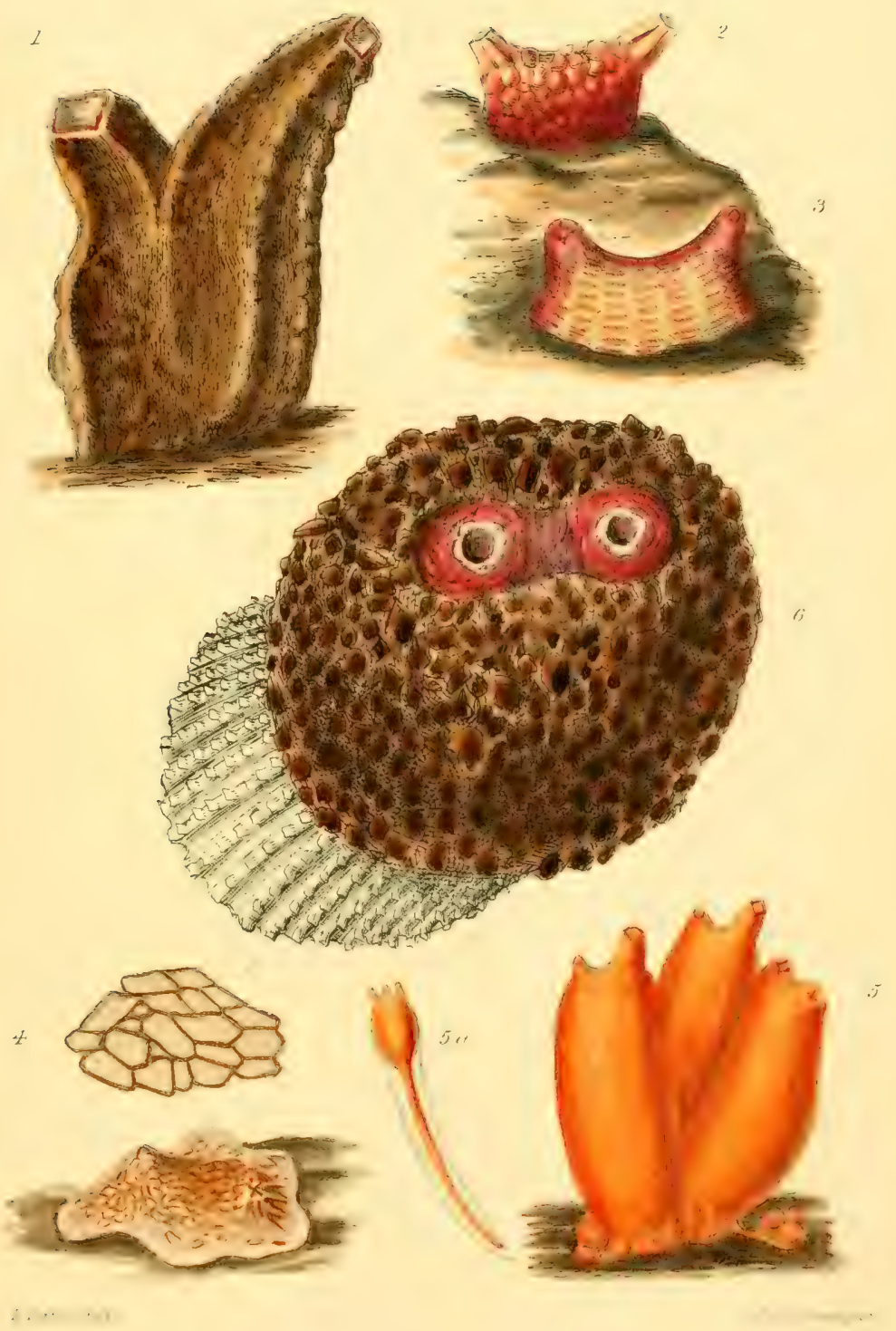

1.Crnthia quadrangularis. 2. C.morus.

3. C.tessellata. 4. C. limacina. 5. C. aguregata \&.its tadpole. 


PIATE, E.
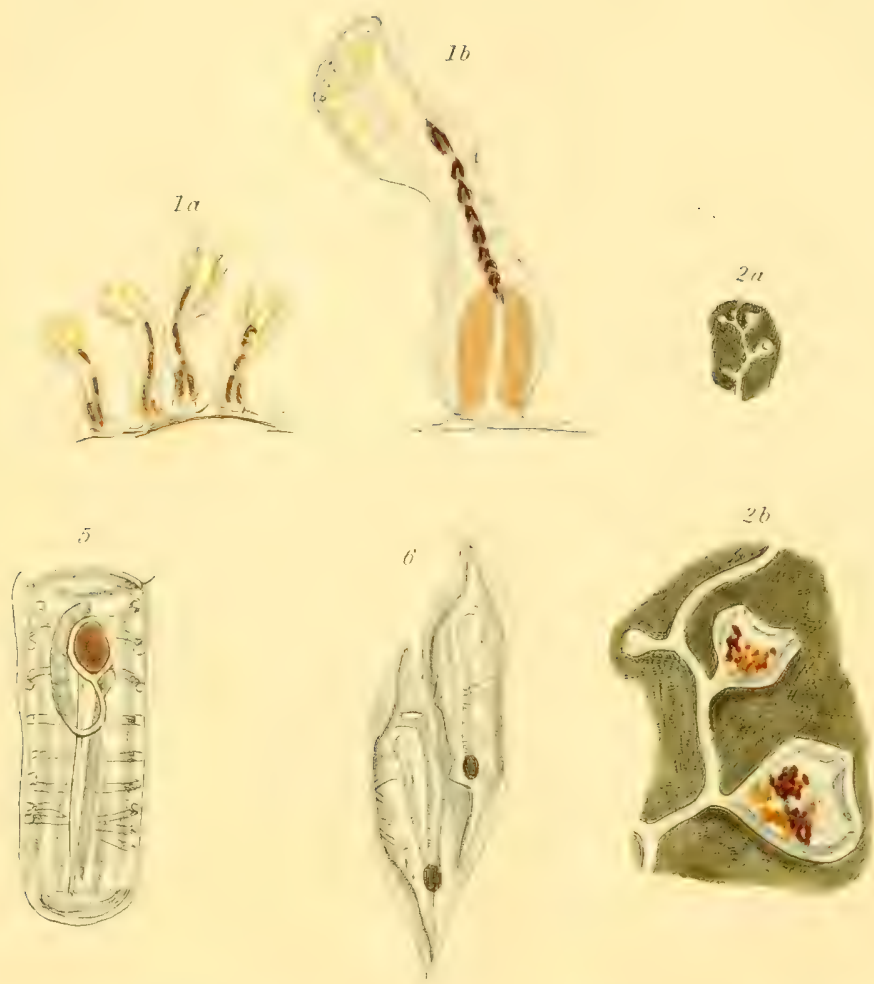

3el

36
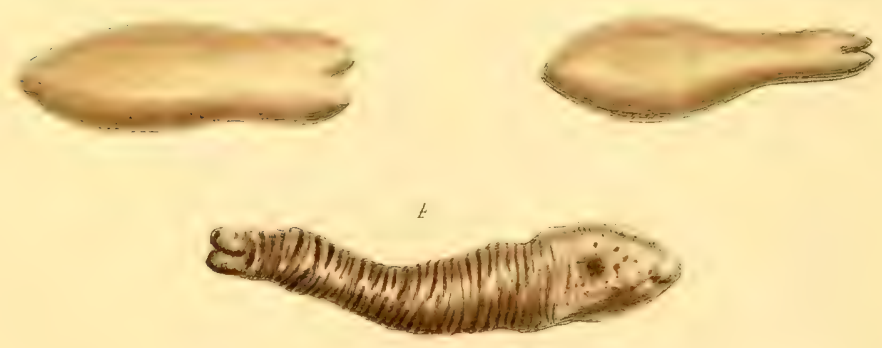

1. Clarelina lepadiformis. 2. Perophora Listeri .

3. Pelonaia glabra. 4. Pclonaia corrugata .

$5 \& 6$. Salpa runcinata. 



PLATE F
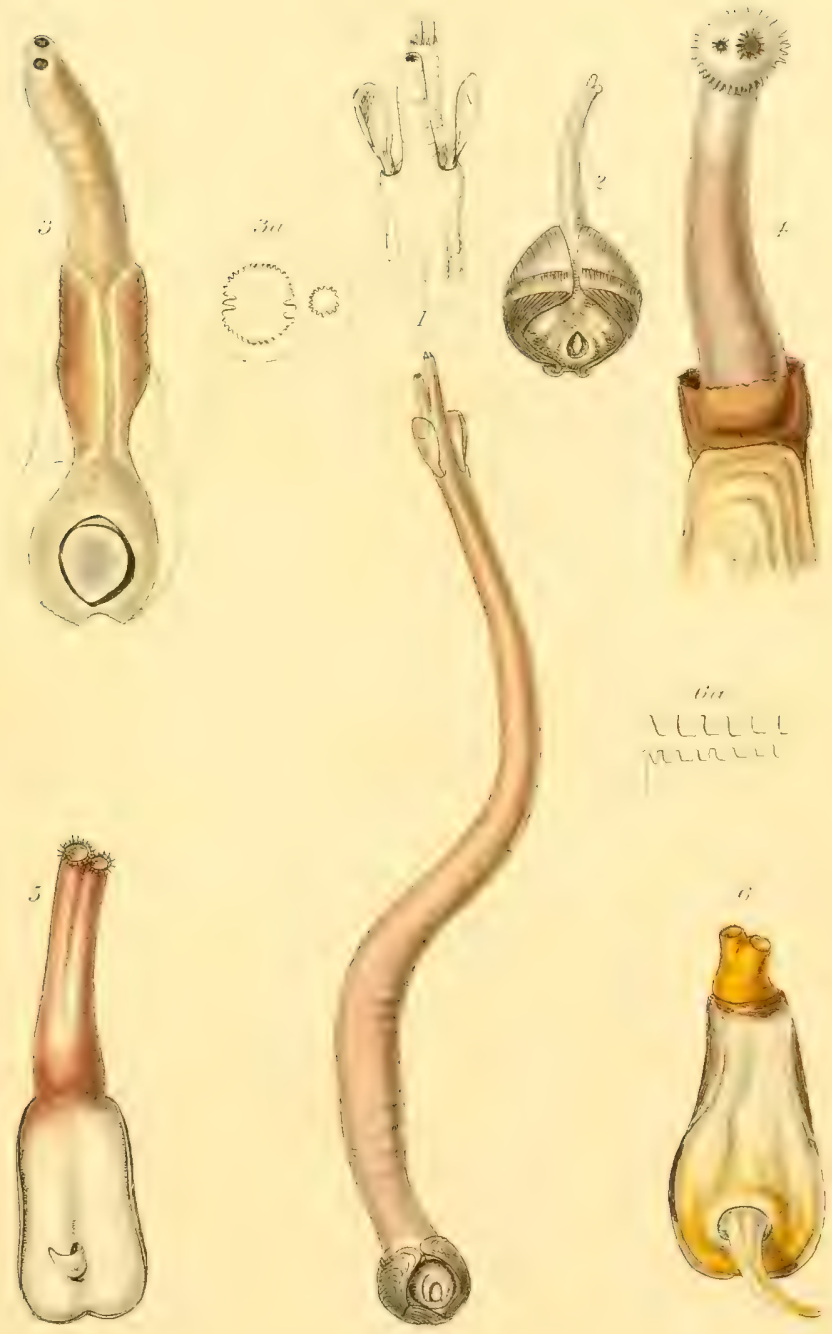

iir

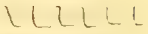

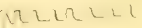

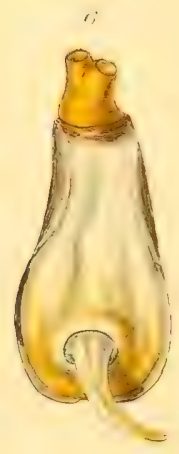

EFrbes deet

1. Teredo. 2. Jylophao dorsalis.

3. Pholas parra. 4. Hholadidea papyracea (the siphons and "up.)

5. Gastrochæna modiolina. 6. Saxicam rugiosa. 



PLATE G.
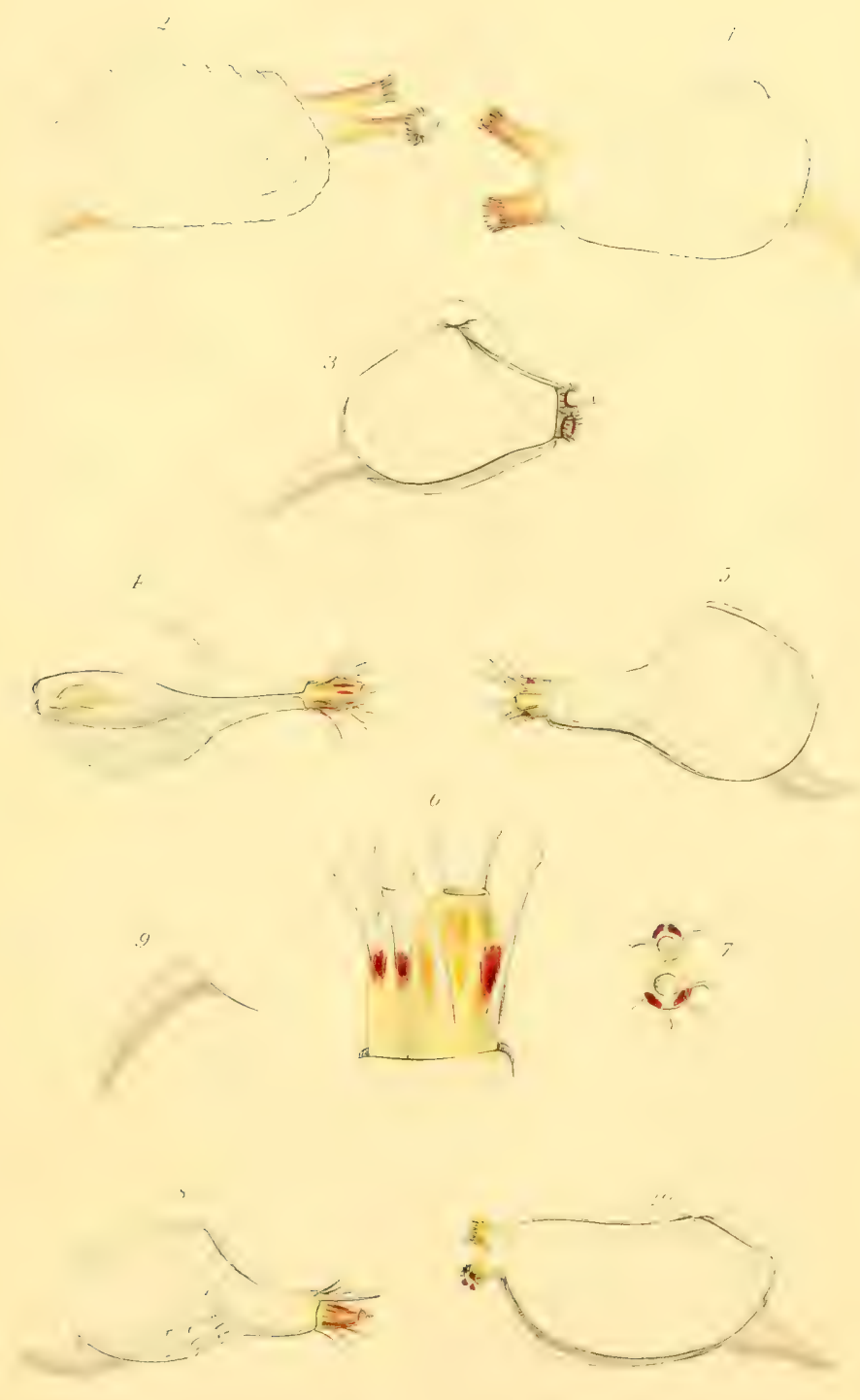

F. Tries ald:

1. Petricola lithophaga. 2. Tenerupis Irus

3. Corbula nucleus. 4,5,6.7. Neara cuspidatat.

5.9. Neara costellata. 10. Pantora ohtusit. 





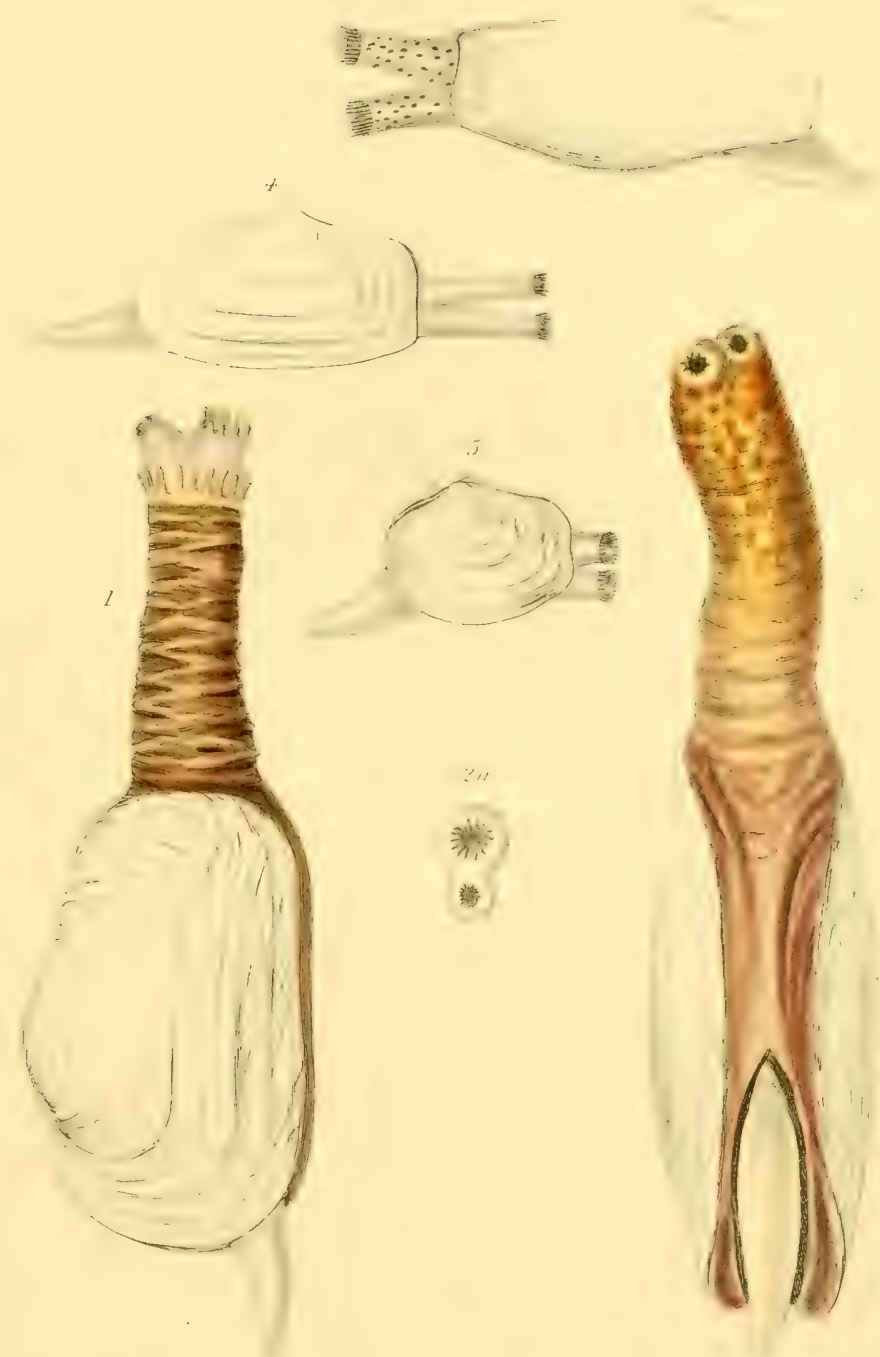

1. Mva truncata. 2. Lutuaria ejliphira.

3. Lvonsia norveơica t.Thracia phaspolina.

5. Theracia distortat. 




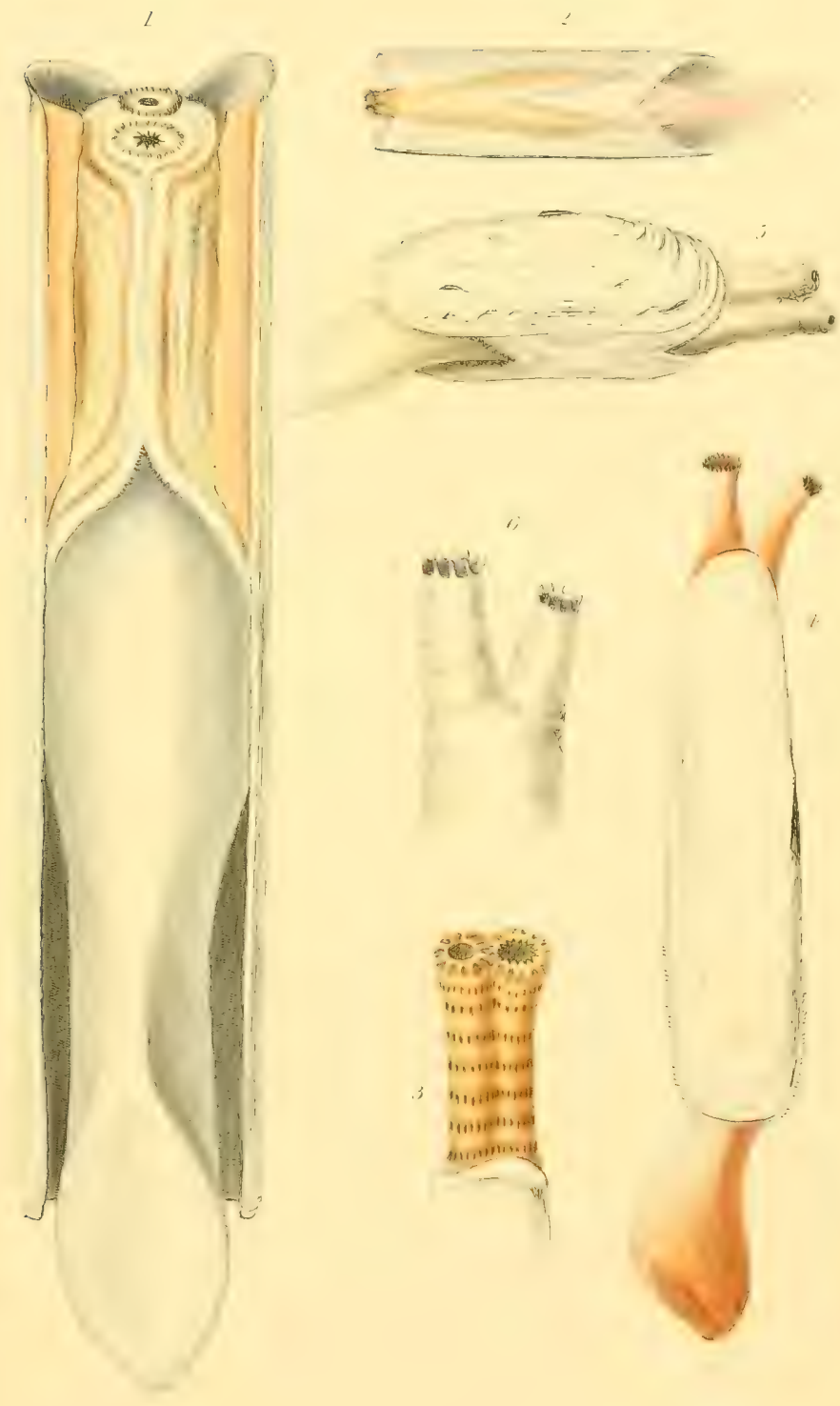

EPorbes dete
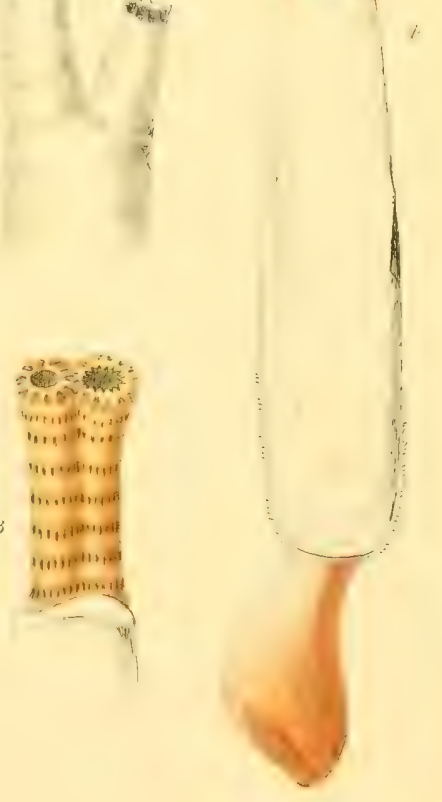

1. Solen siliqua. 2. Solen pellucidus. 3. siphons of Solen marọinatus.
4. Ceratisolen legumen.
5. Solecurtus coarctatus.
6.its siphons. 





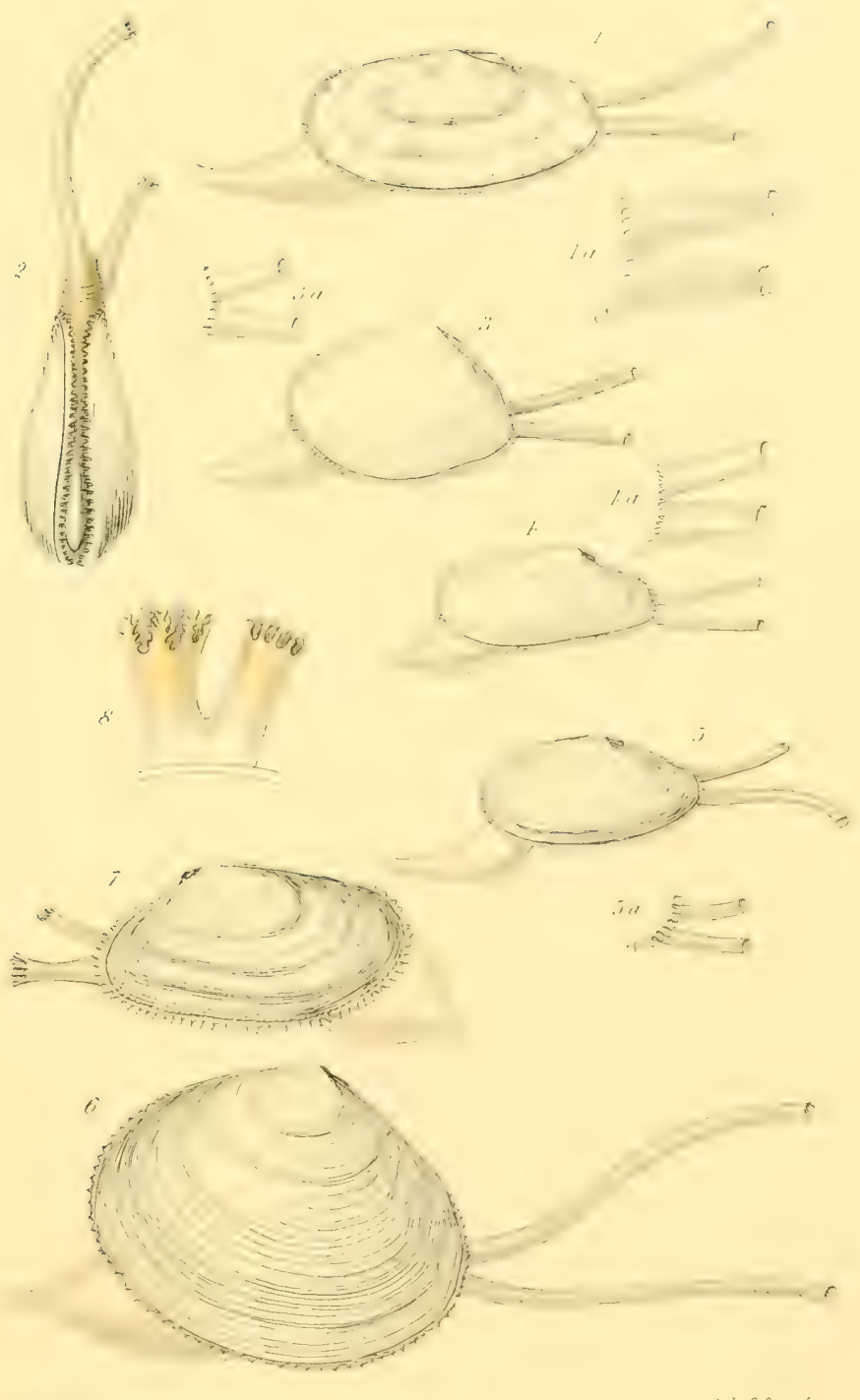

E. Thrbes det.

1. Psanmobia tellinella. "D Dortonta liagilis.

3 Tellina tenuss. 4.Tellina donacina. 5.Syndossuya intermerlia.

6. Scrobicularia compressa. 7. Donax anatinum. 8. Siphons of Nesodesma 



PLATE T.
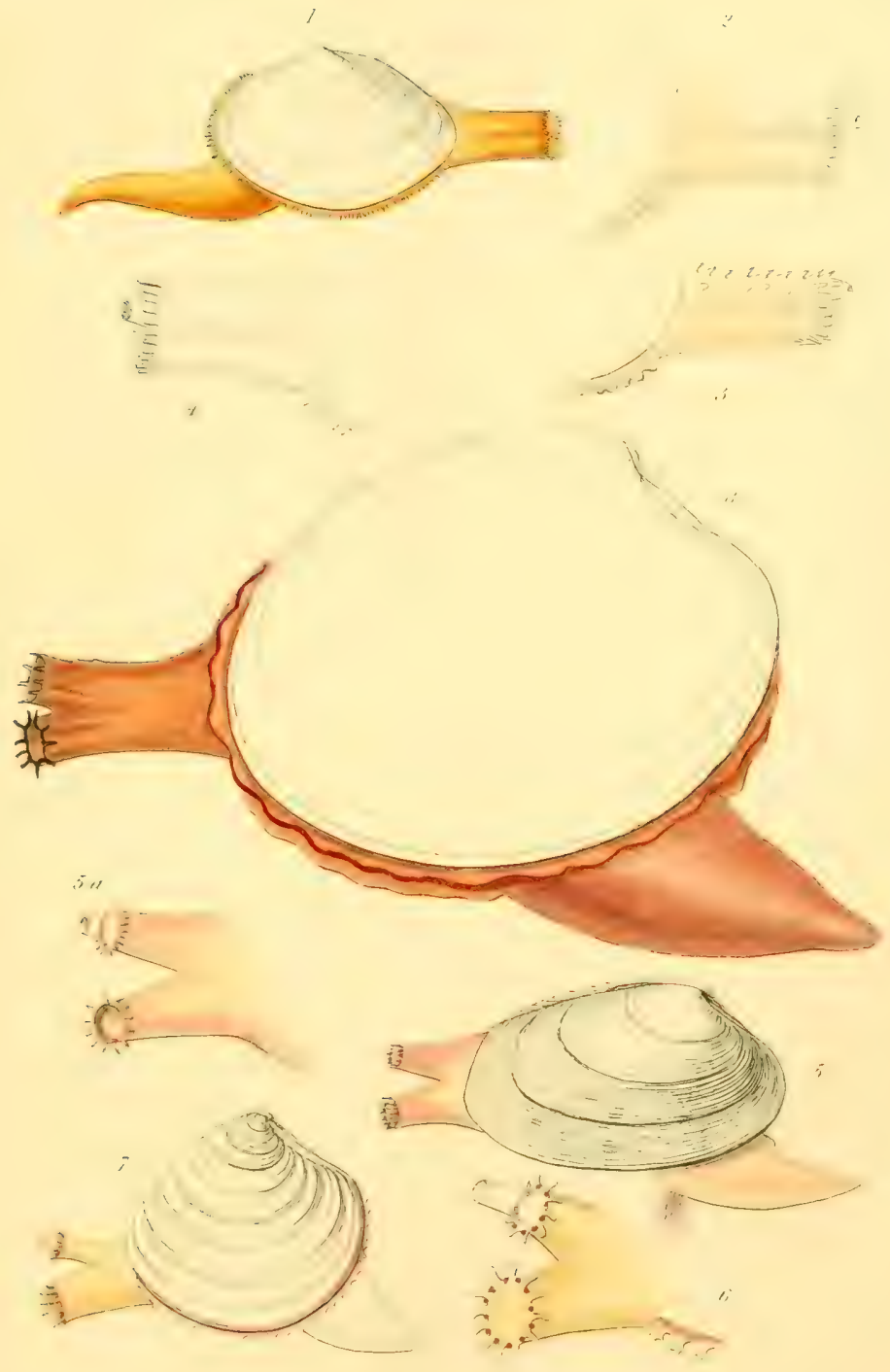

1. Mactra elliptica. 2. Siphons of M.solida.

3.S. of ML. subtrumeala. 4 S. of M.stultorum. 5. Tapes pullastrat.

6. 5. of Tenus orata. 7. Tenus fasciata. 8. Cytheren chione. 


PLATE II
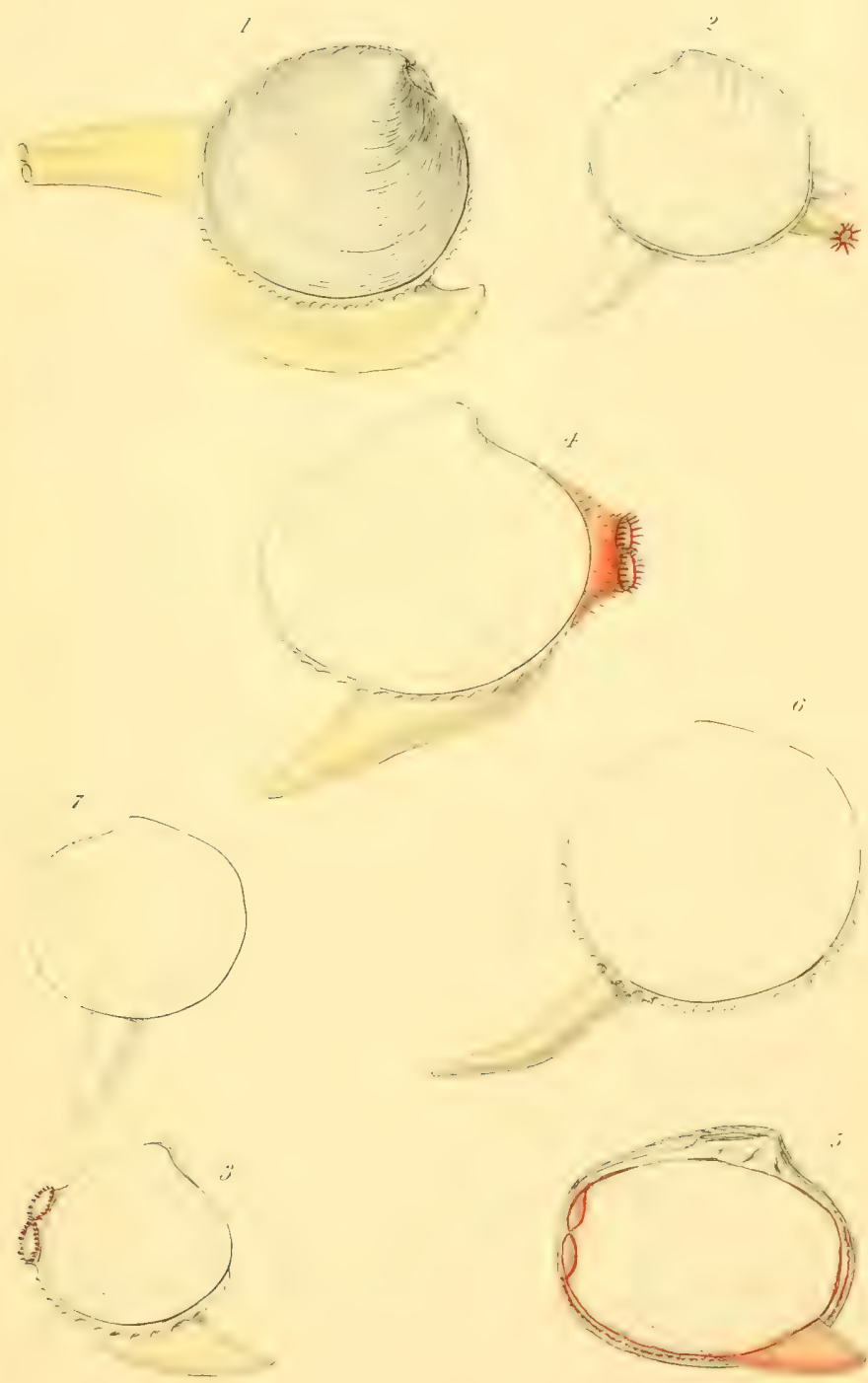

EForbes det

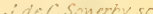

1. Artemis lincta. 2. Lucinopsis undata.

3. Circe minima. t. Crprina isIundica. 5. Astarte danmoniensis

6. Lucina borealis. 7. Diplodonta rotundata 



PLATE N.

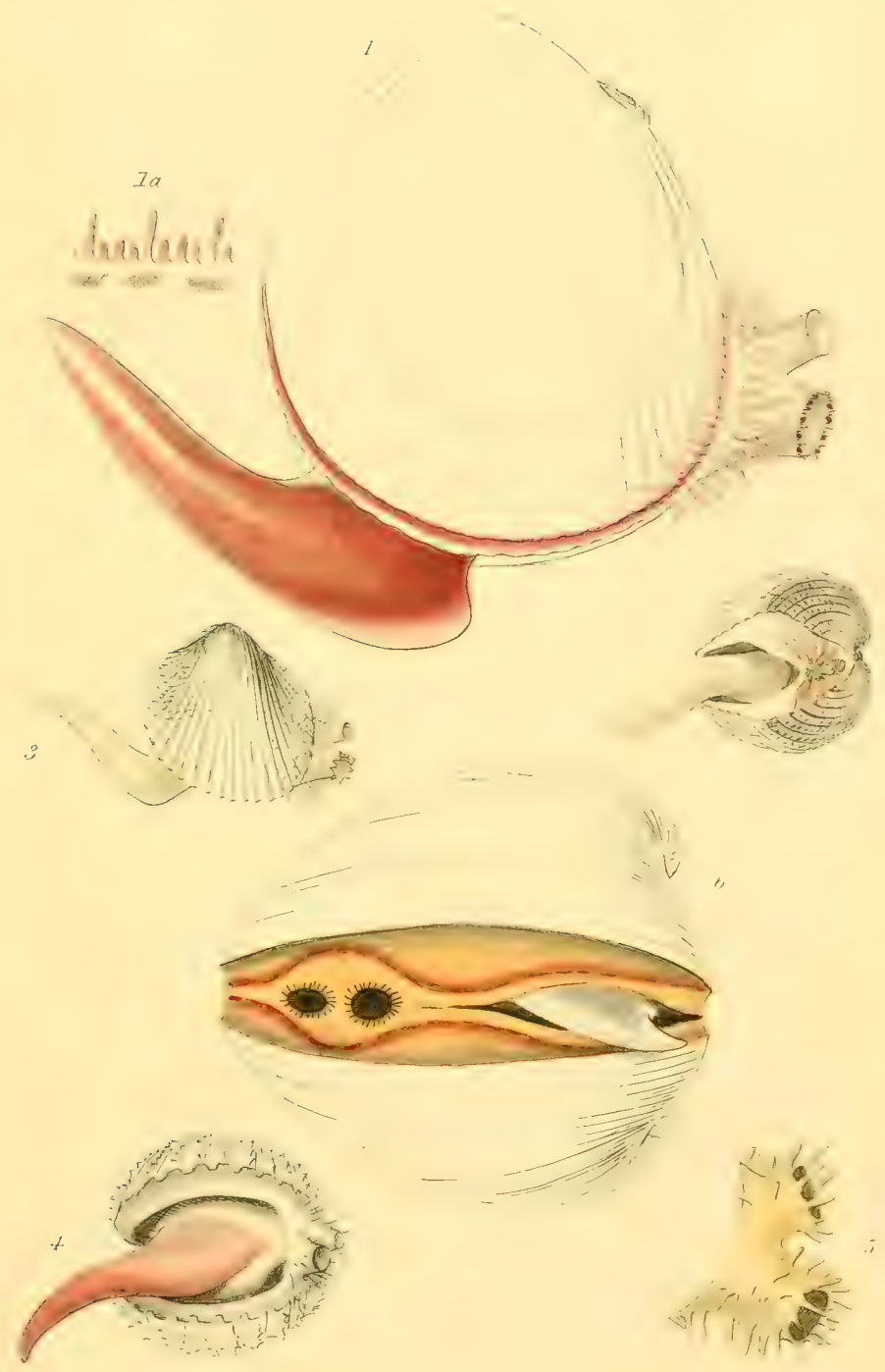

1. Cardium norveñicum. 2.C.pyọmæum. 3. C. fasciatum.

4. C. echinatum. jun ${ }^{\mathrm{T}}$ 5. Siphons of C edule. 6. Isocardia cor. 

PIATE 0 .
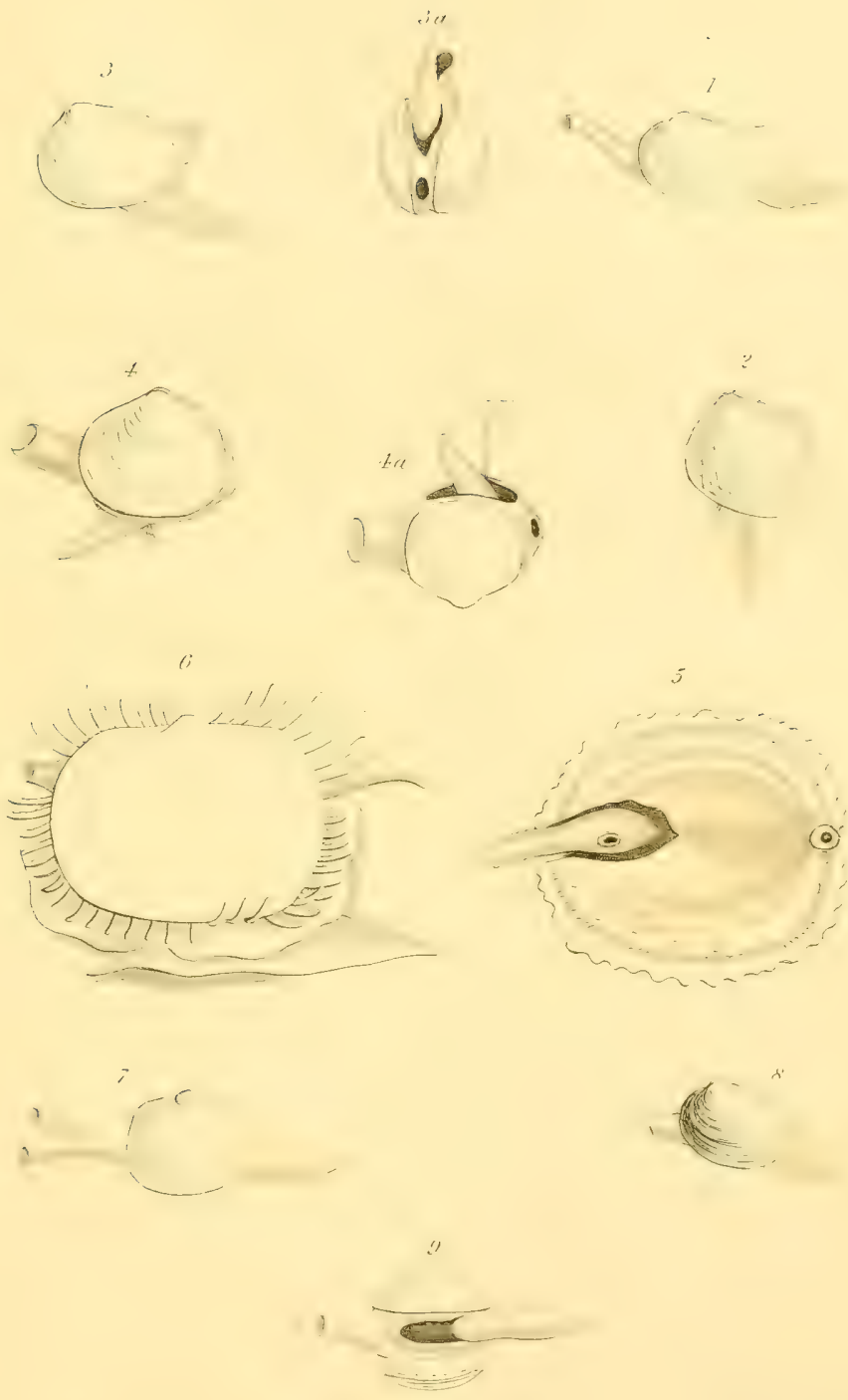

E. Firkes die

1.Turtonia purpurea. 2. Montacuta substriata. 3. Kellia rubra.

4. Kellia suborbicularis. 5. Galcomma Turtoni. 6. Lepton squamosum.

7. Cyclas colveulata. 8.Pisidium ammicum. 9. Pisidinm pusillum. 




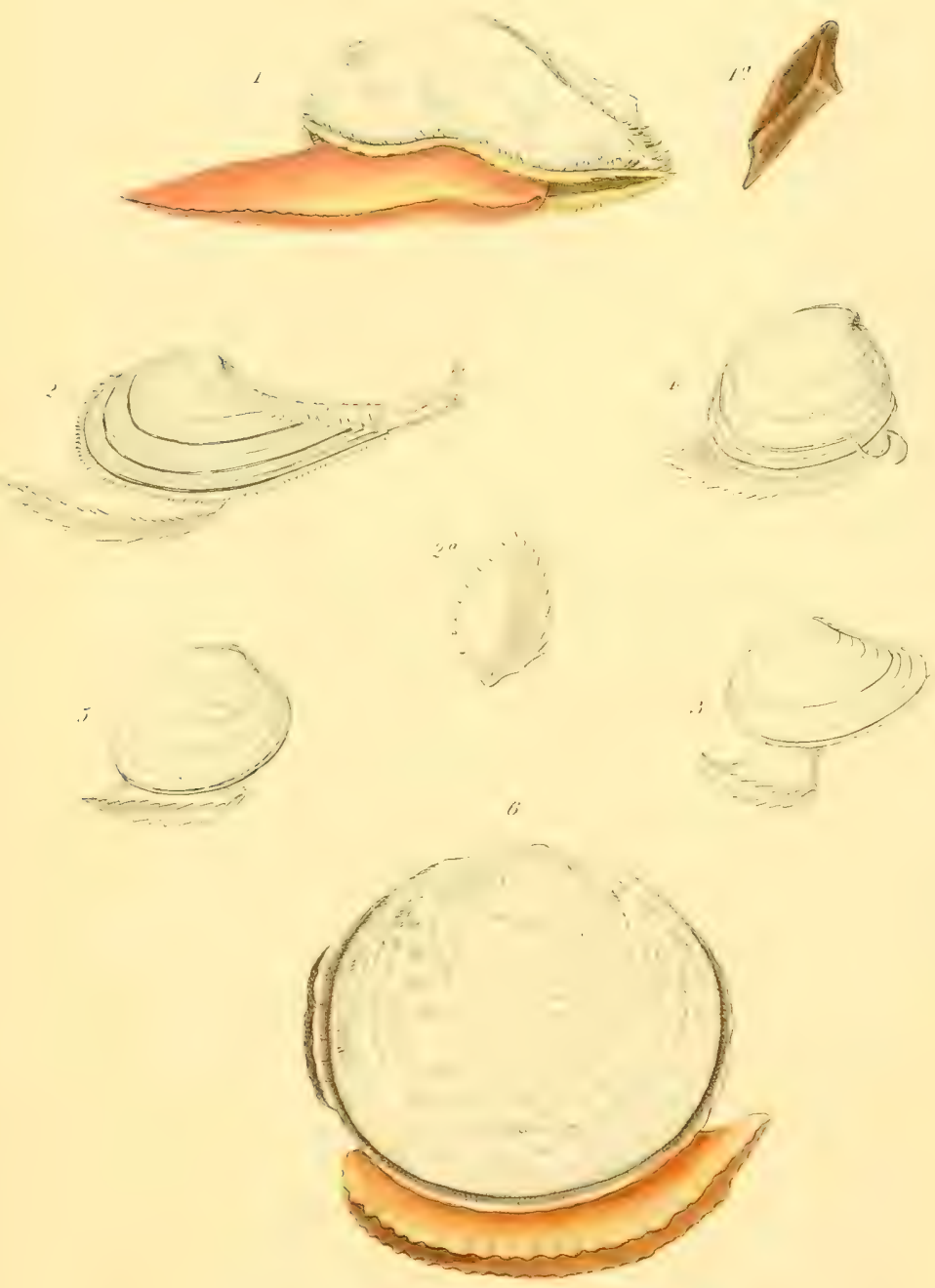

EFones deZ

I. Area tetragona. 1: its byfisal appendage.

2. Leda caudata. 2? its disk

3. Leda pyomma. 4. Nucula nucleus .

5. Nucula tenuis. 6. Pectunculus pilosus. 


PLATE Q .

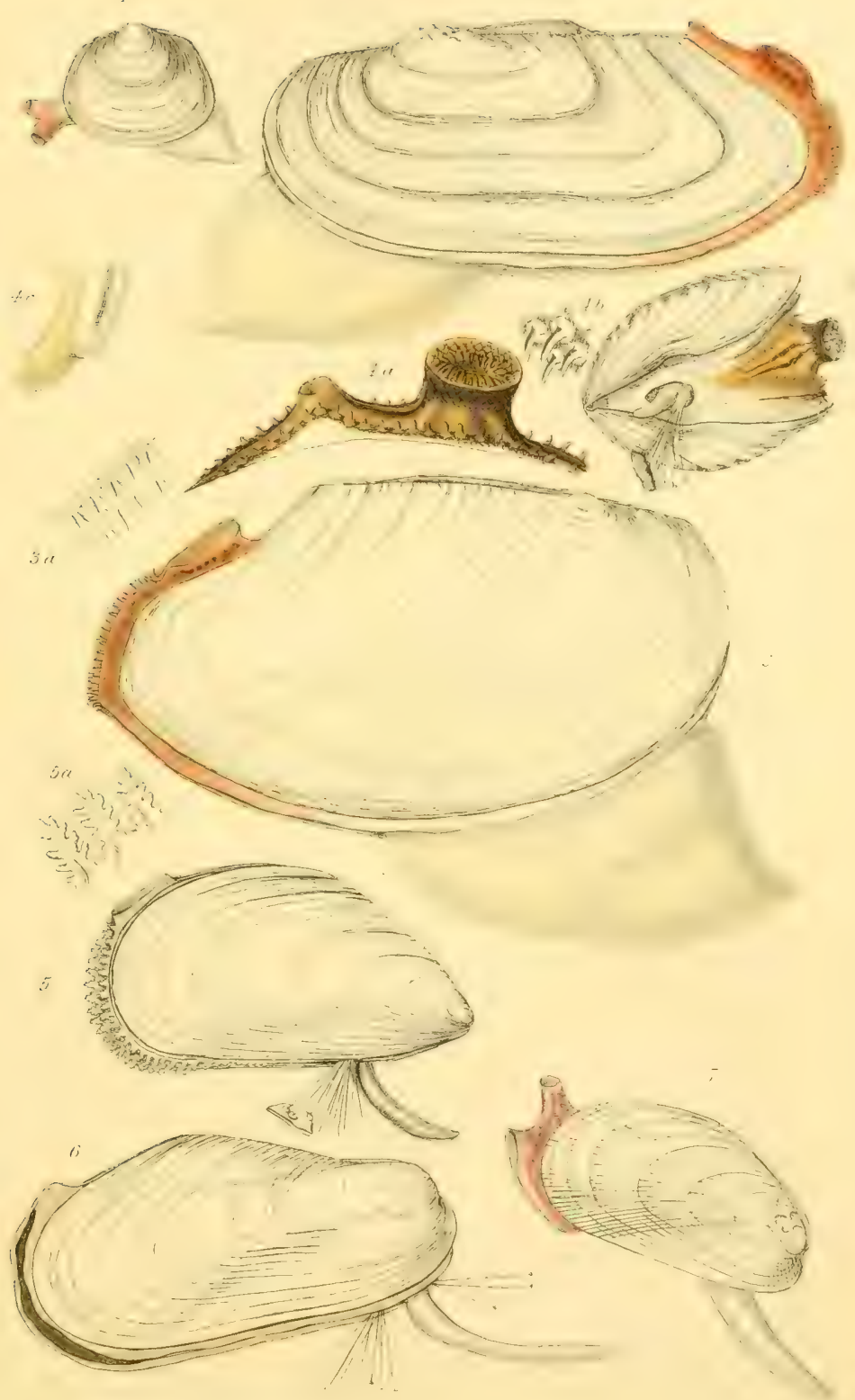

EForbes, ded.

1.Crclas rivicola. 2. Tnio pictorum.

3. Anodonta cyónea. 4.Dreissena polymorpha. 5. Mytilus edulis.

6.Modiola tulipa. 7. Crenella niòra. 




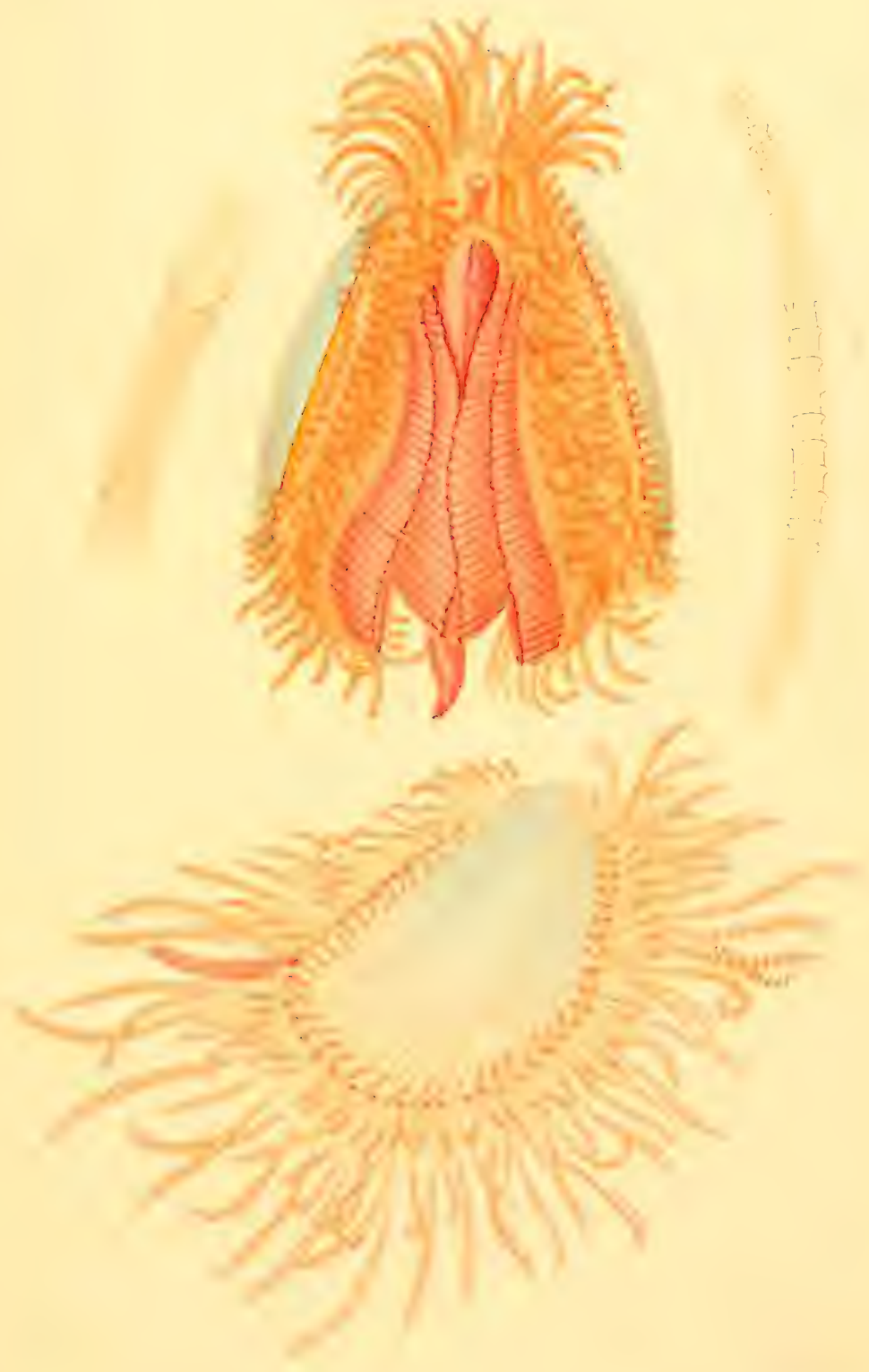




I'LATE S

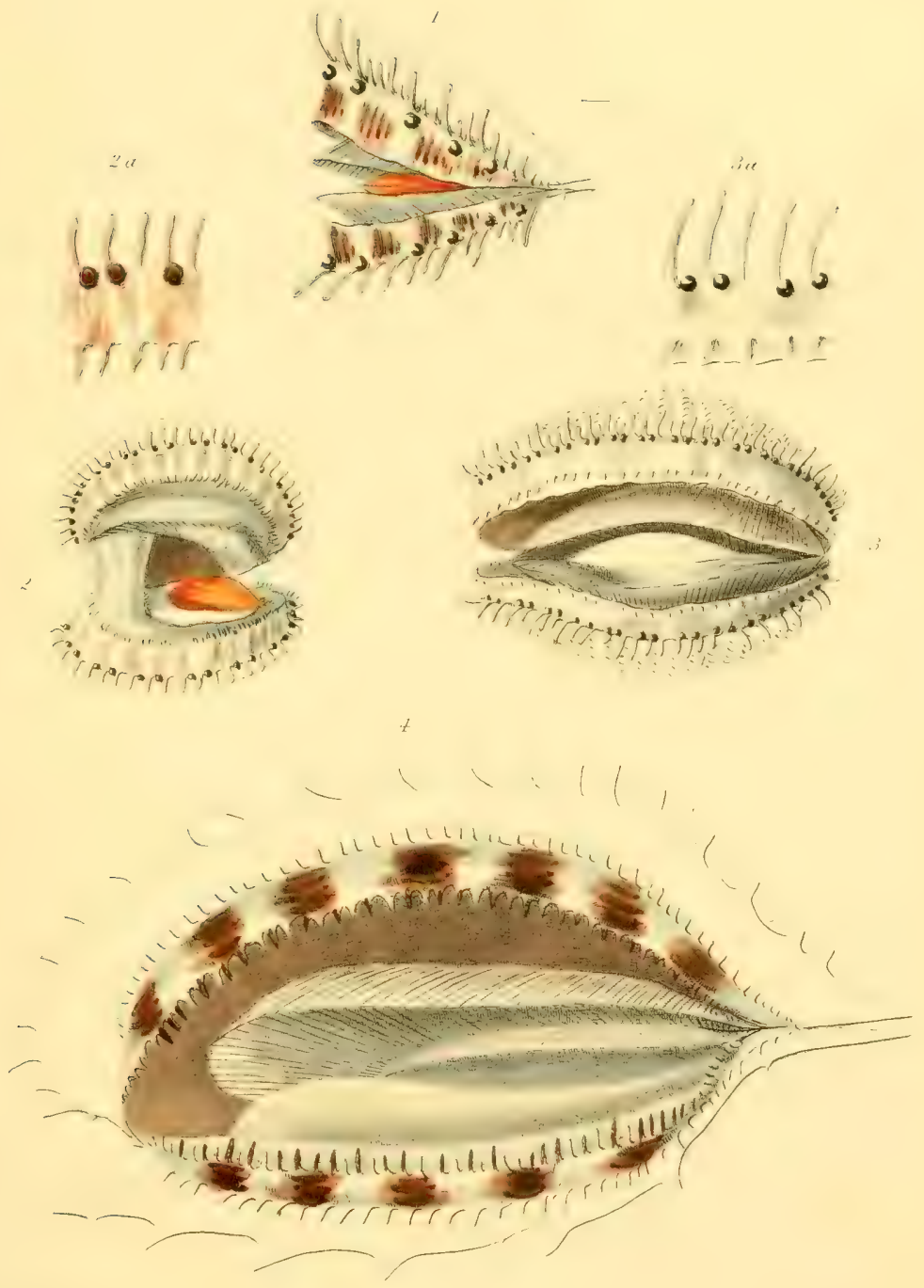

1. Peeten similis. 2.P. striatus. 3.l'niresus.

1. Arienla tarentima. 




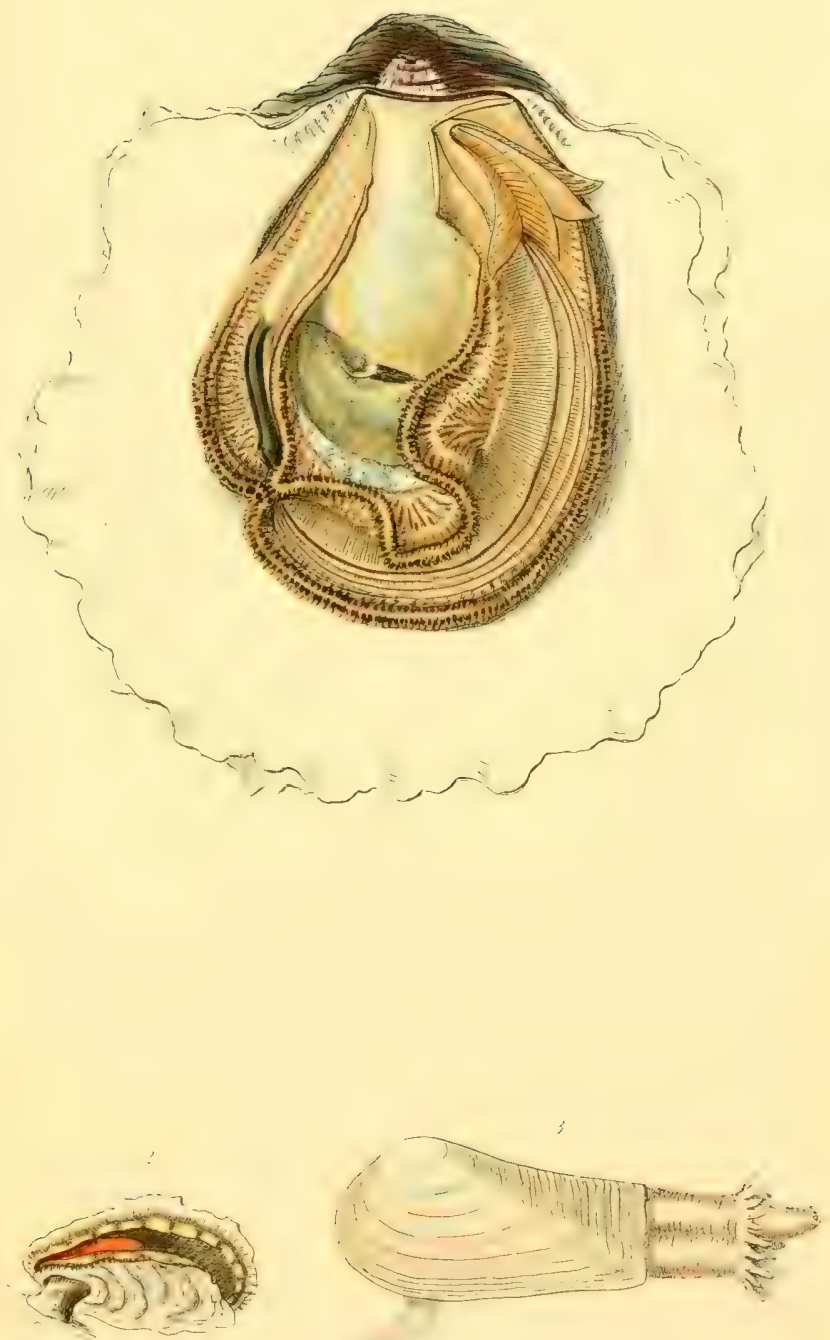

1. Ostrea edulis. 2. Anomia ephippium

3. Sphænia Binghami 




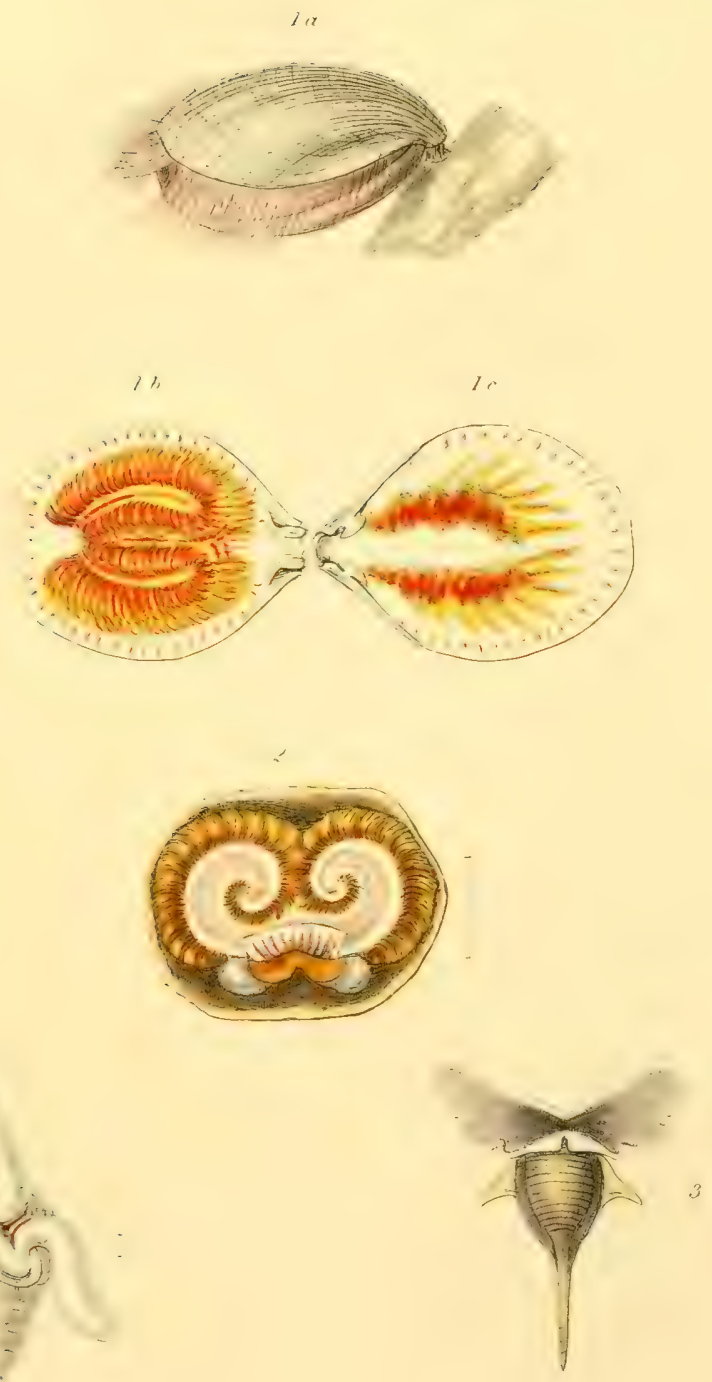

1. Terebratula caput serpentis

2. Cramia norvesica. 3.Hralrea trispinosa.

4. animal of a Peracle. (after Souletet) 


PIATE W
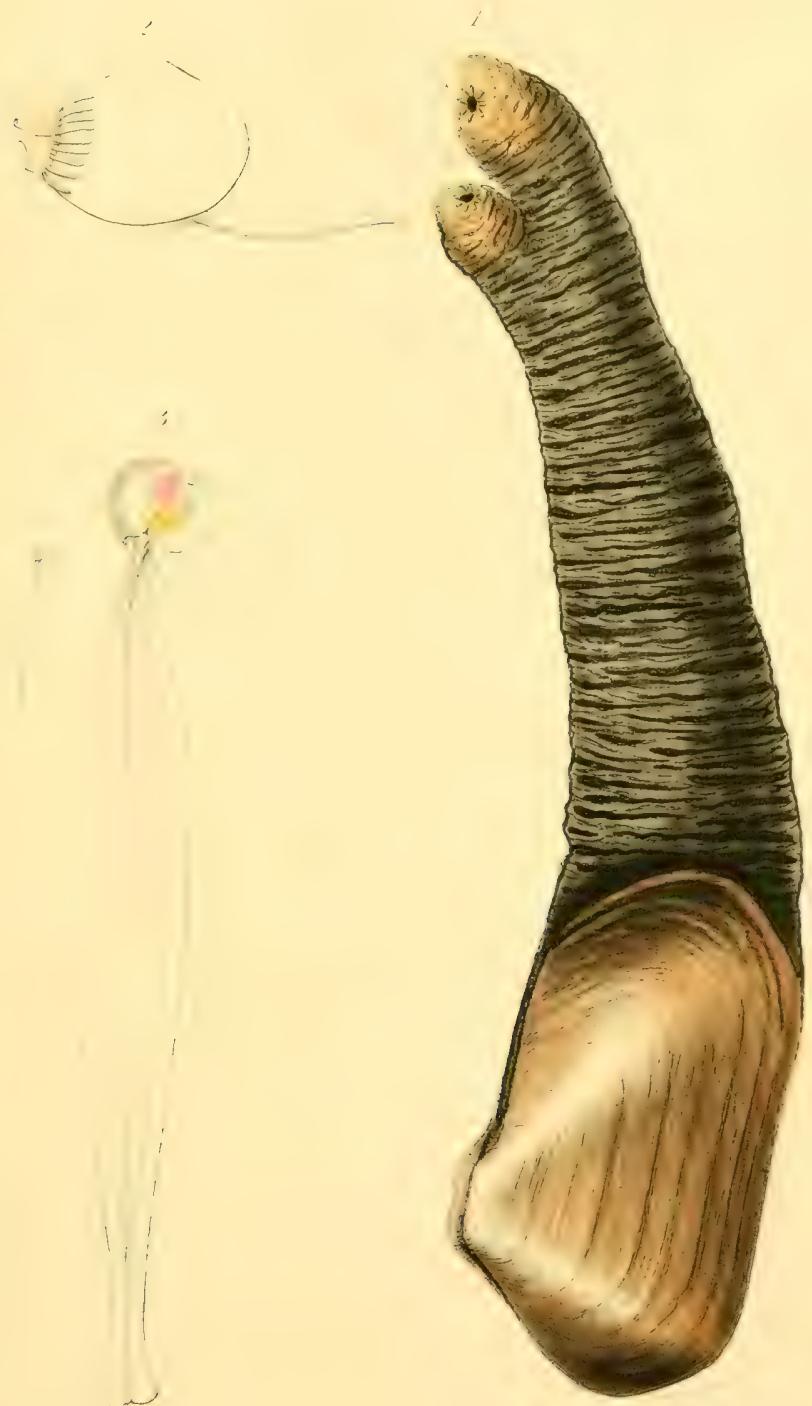

FHEER dVI
1. Panopæa norveóica.
2. Poronya srantalat

3. Appendicnlaria 




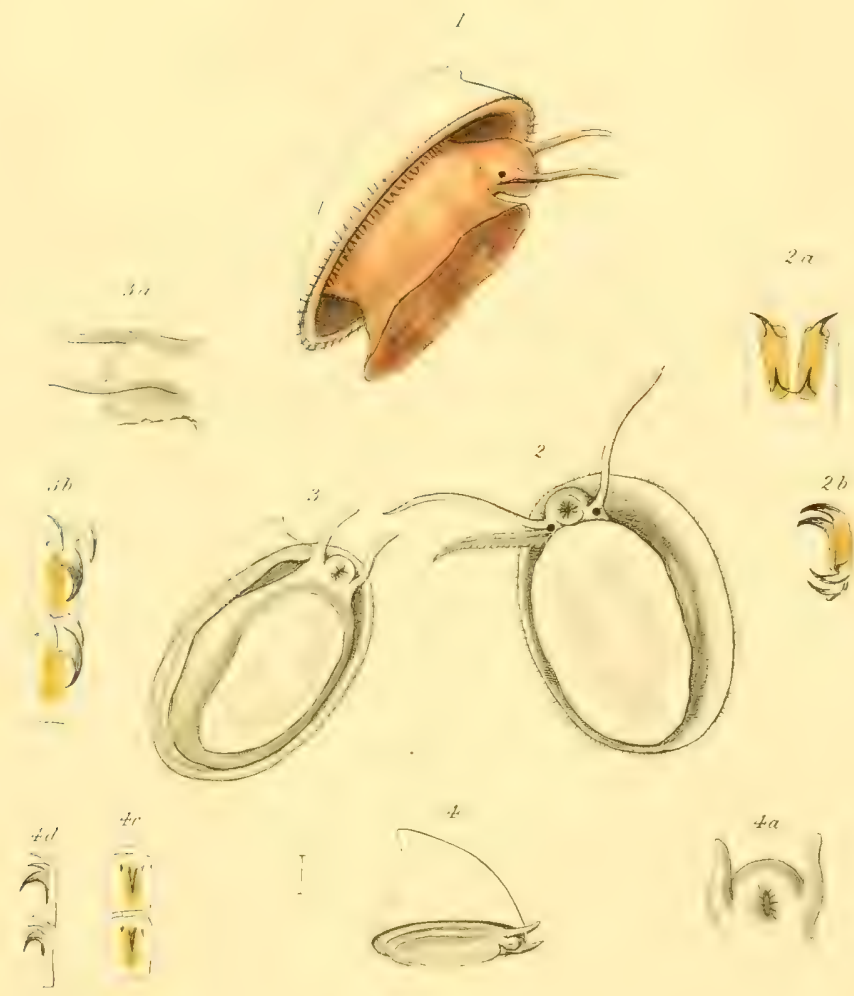

i
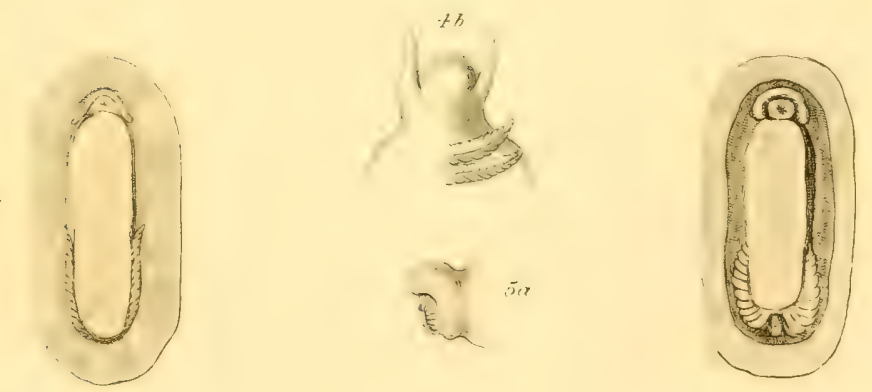

1.Patclla pellucida. 2.Acmæa testudinalis.

3. Pilidium fulsum. t. Propilidium ancyloide.

5. Cliton asellus. G. Chiton ruber. 




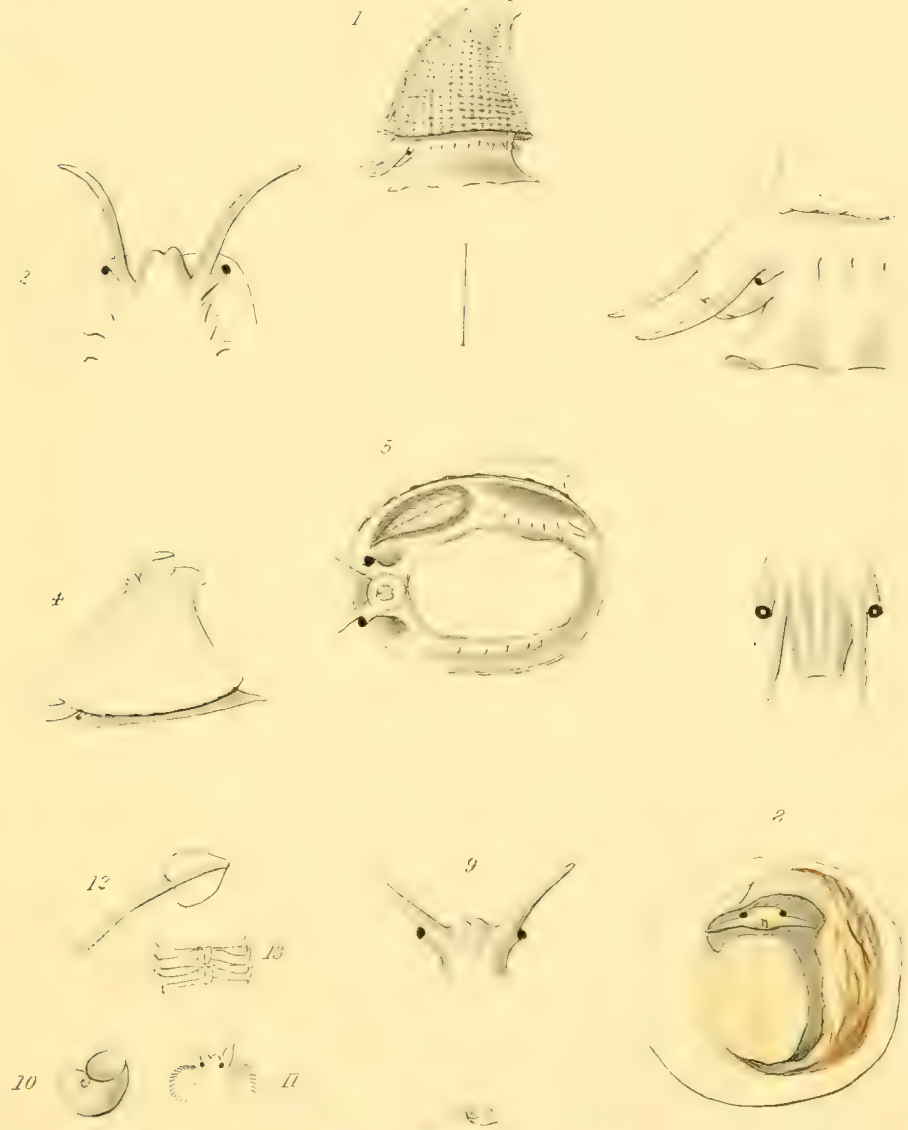

$\div$

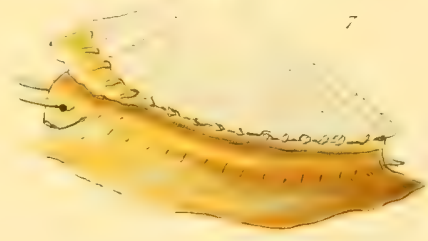

1.2.3. Emarcinula rosea. $\quad$ t.5.6. Puncturella Noachina.

7. Fissurella reticulata. 3 to 13. Calyptræa Smensis . 




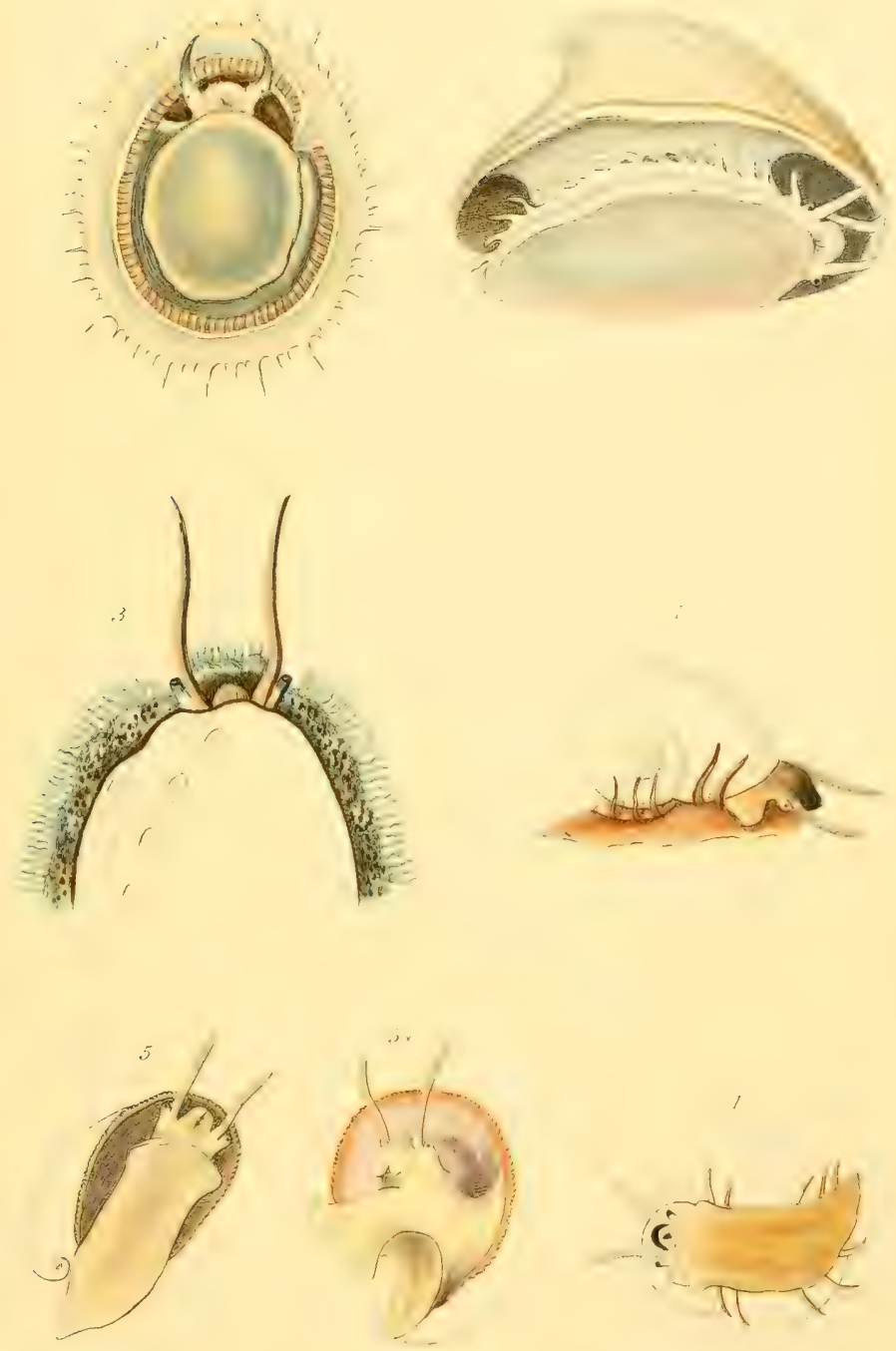

1. Patella vilciata. 2. Emaroinula crassa.

3. Haliotis tuberculata. 4. Trochus helicinus.

5. l'ileopsis hunơiaricus. 



PI. ATE II)
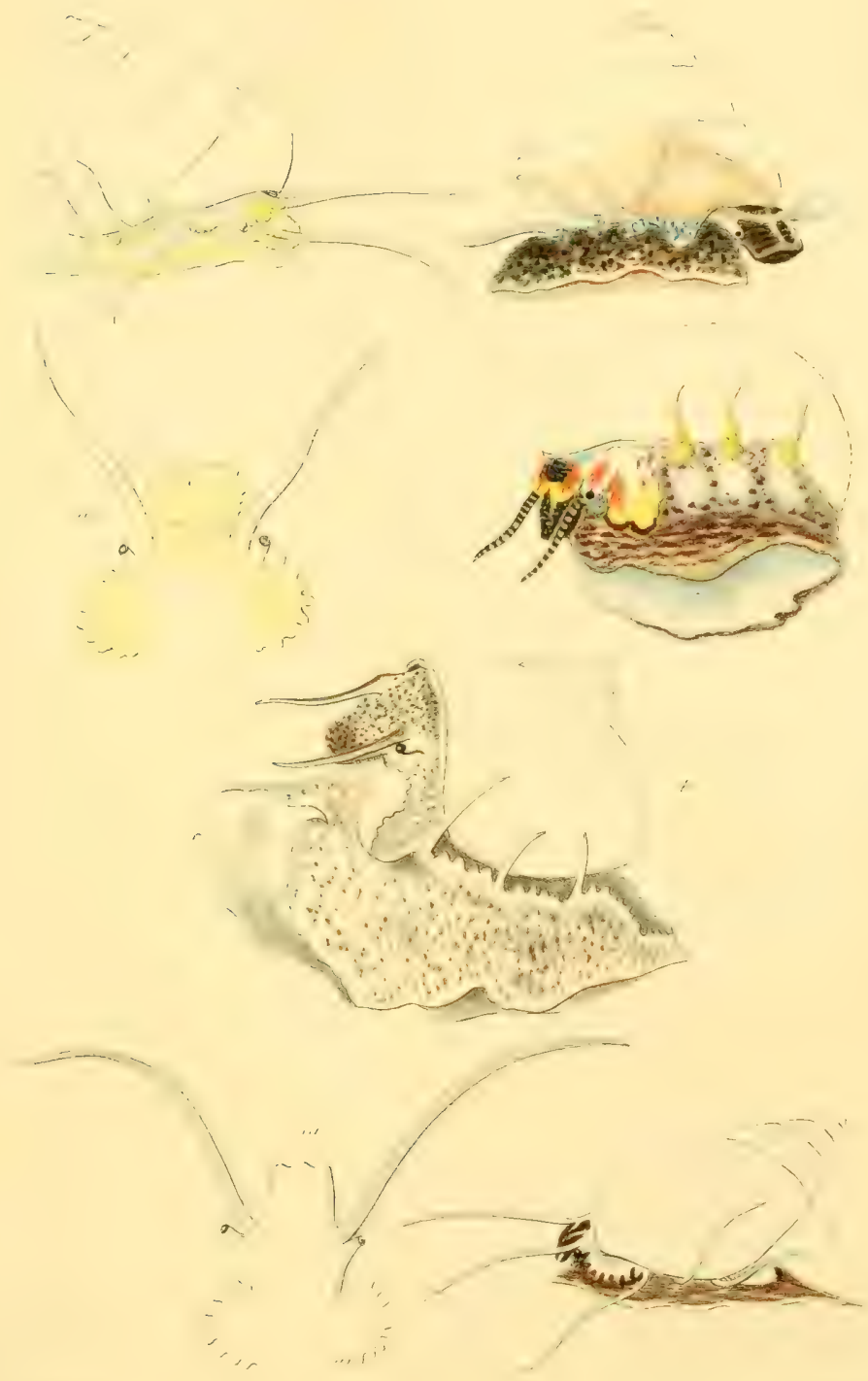

1. Trochus cinerarius. 2.T.tumidas. 3. T'. Ifgus.

†. T. granulatus. 5 I'hasianella pollus. 




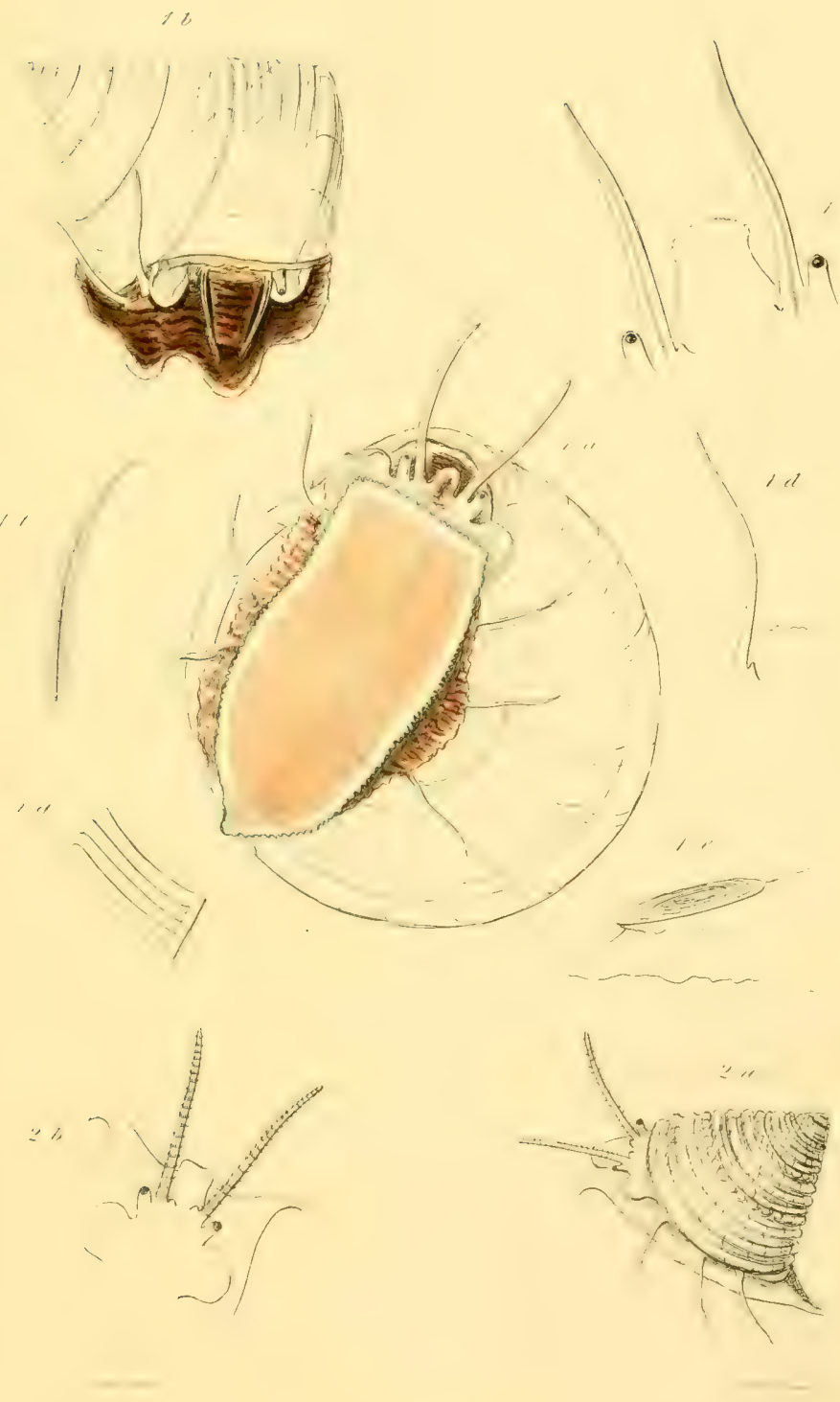

1. Trochus ziziphinns. 2 Trochts alabasurites. 


PIATE FF
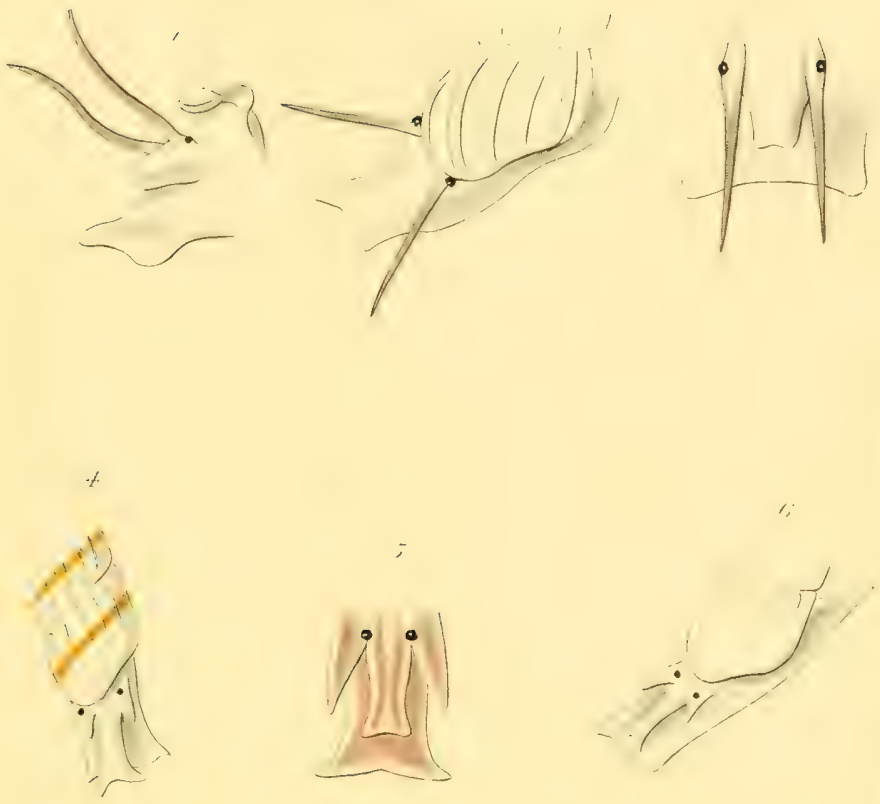

.
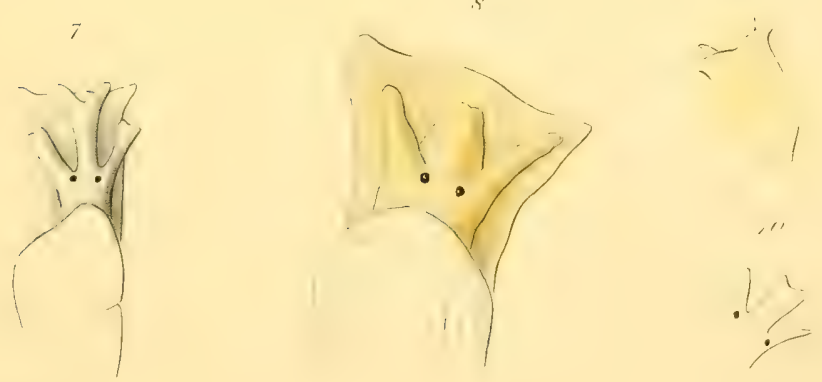

1.2. 3. Scalaria Trevelyana. t. Chemnitzia rnfa.

5. C. scalaris 6. C. rufescens. 7. C. Mac Andrei

S.9. Odostomia spiralis. 10. Truncatella Irruncarula 




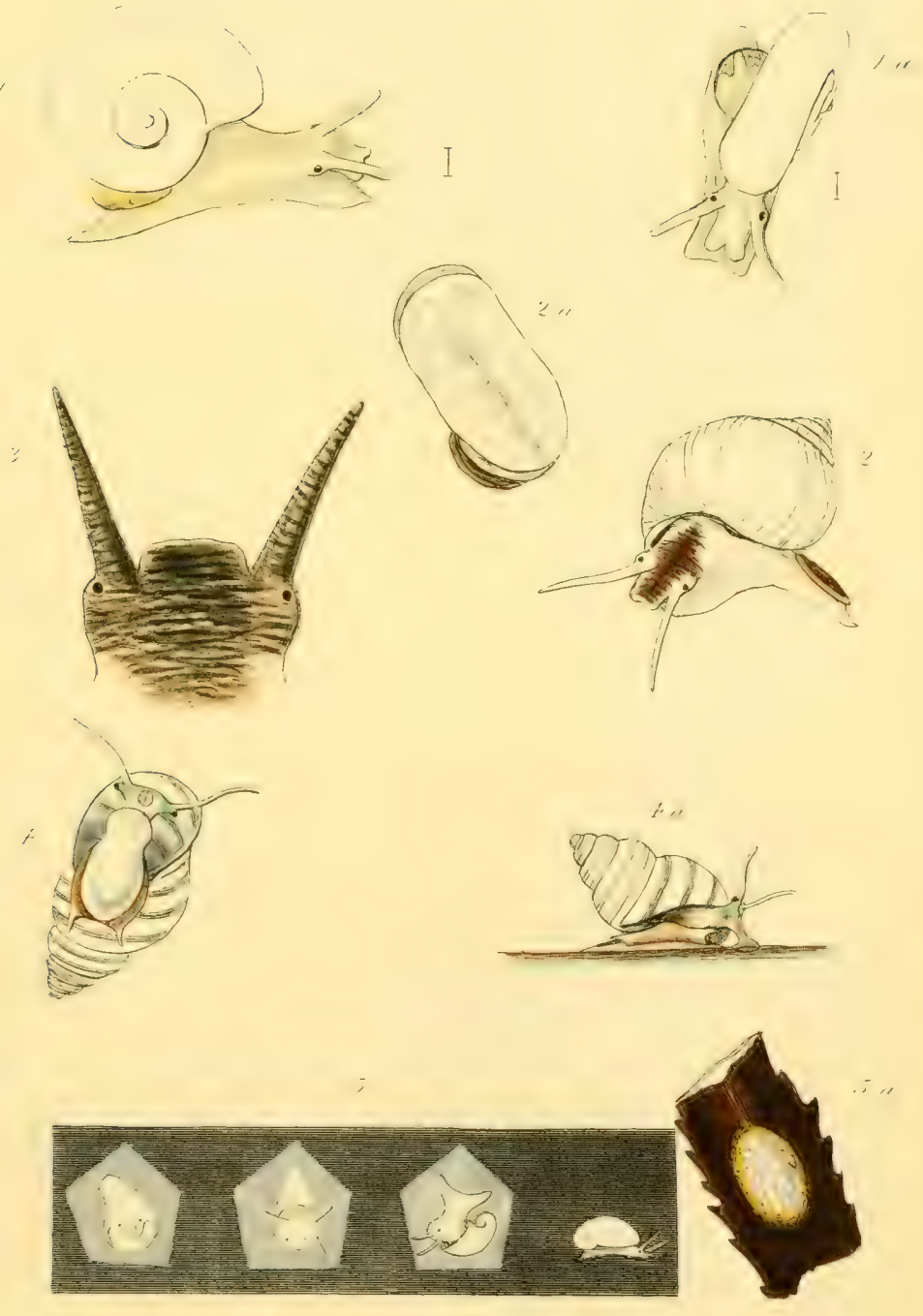

4y.

1. Slienea planorbis. 2. Litlorina patula.

3. Litlorina littorea. I. Lacuna vincta.

5. development of Lacuna pallidula. 

PLATE HT.
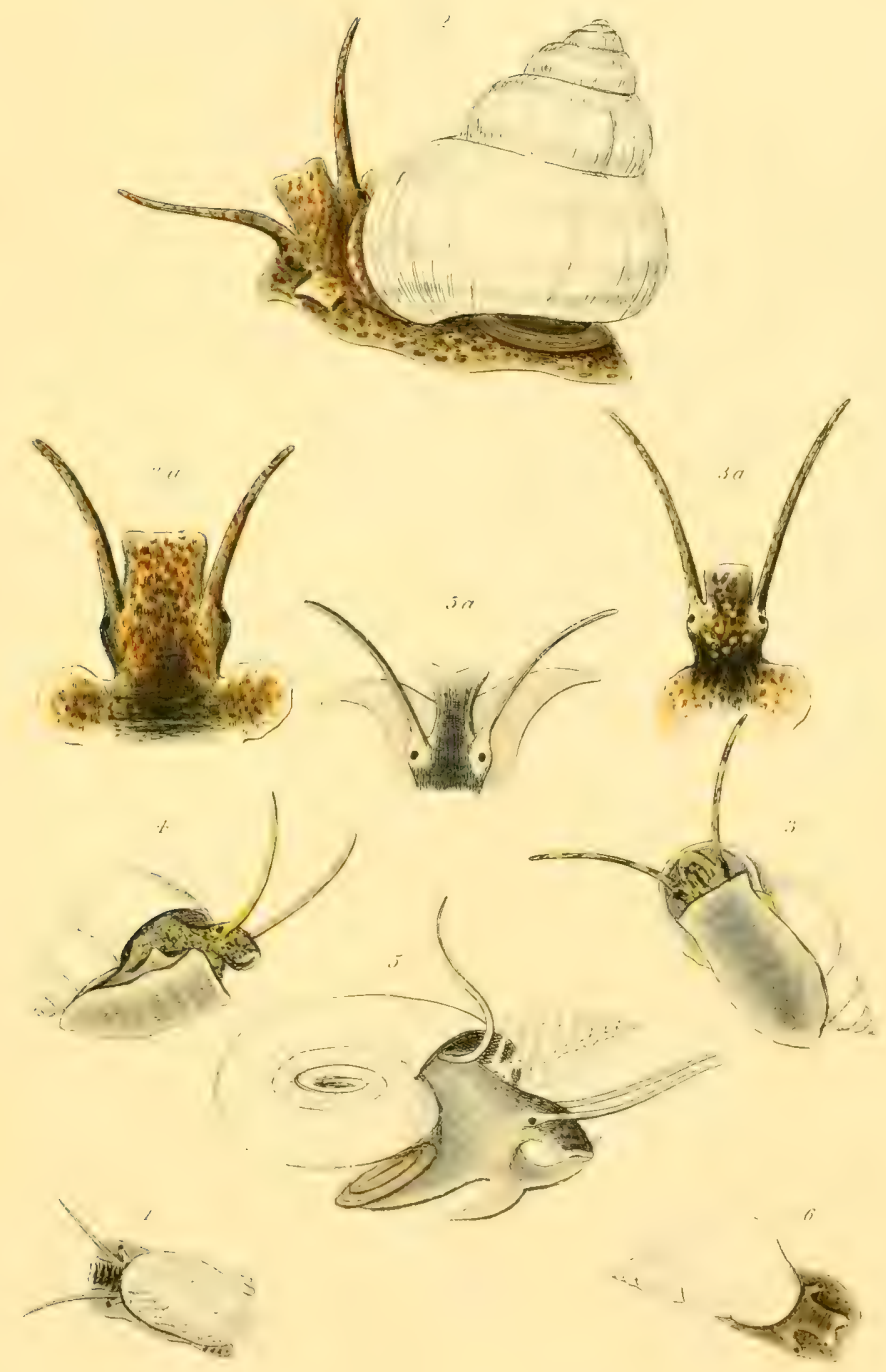

L. Toritina flaviatilis. 2. P'aludinn vivipara .

A. Bithinia tentamblata. t.B.Tenehii.

5. Valvata cristata. 6.Assiminea Cimanat. 




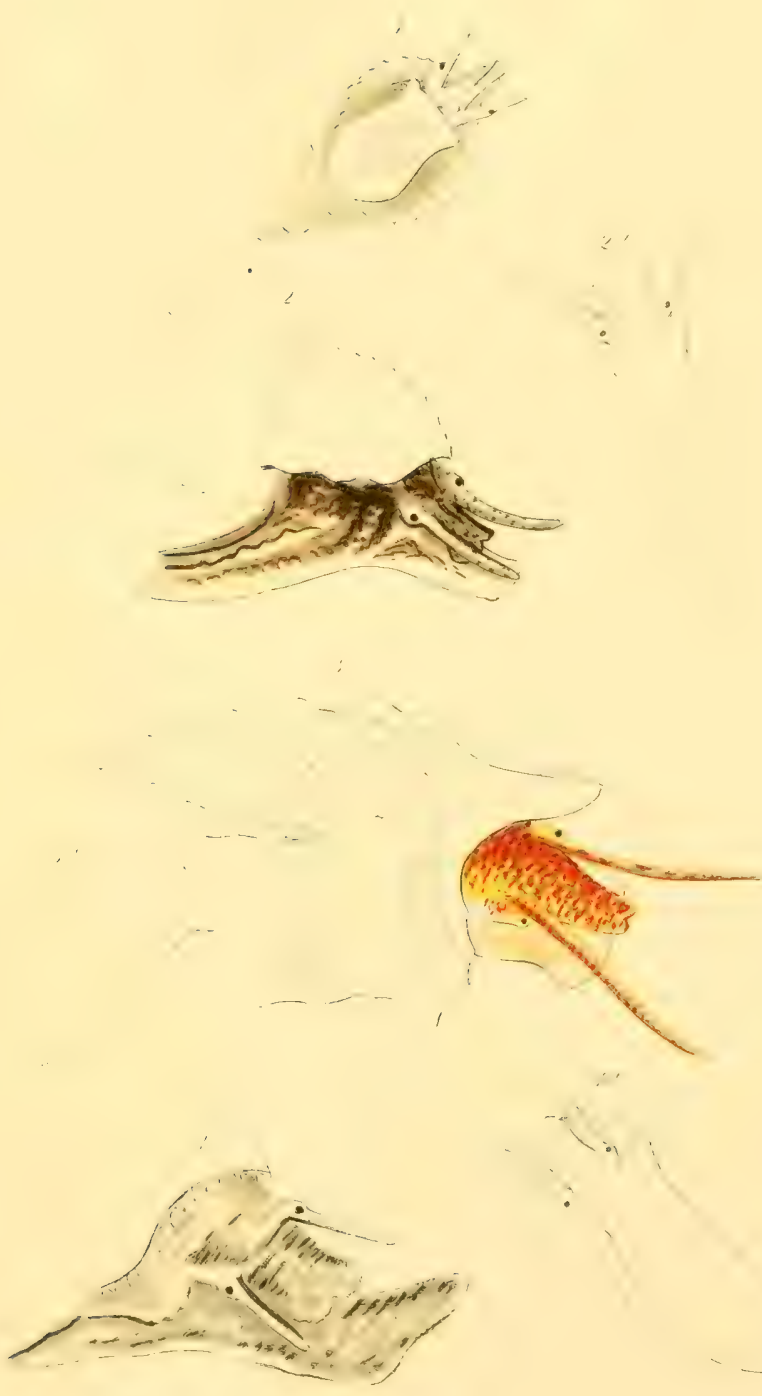

1. "liphotropis borcalis.

2. Cerithinm rensenlostum. 3. Aporthis pespelecani

1. 'Timpitella conmumuis 



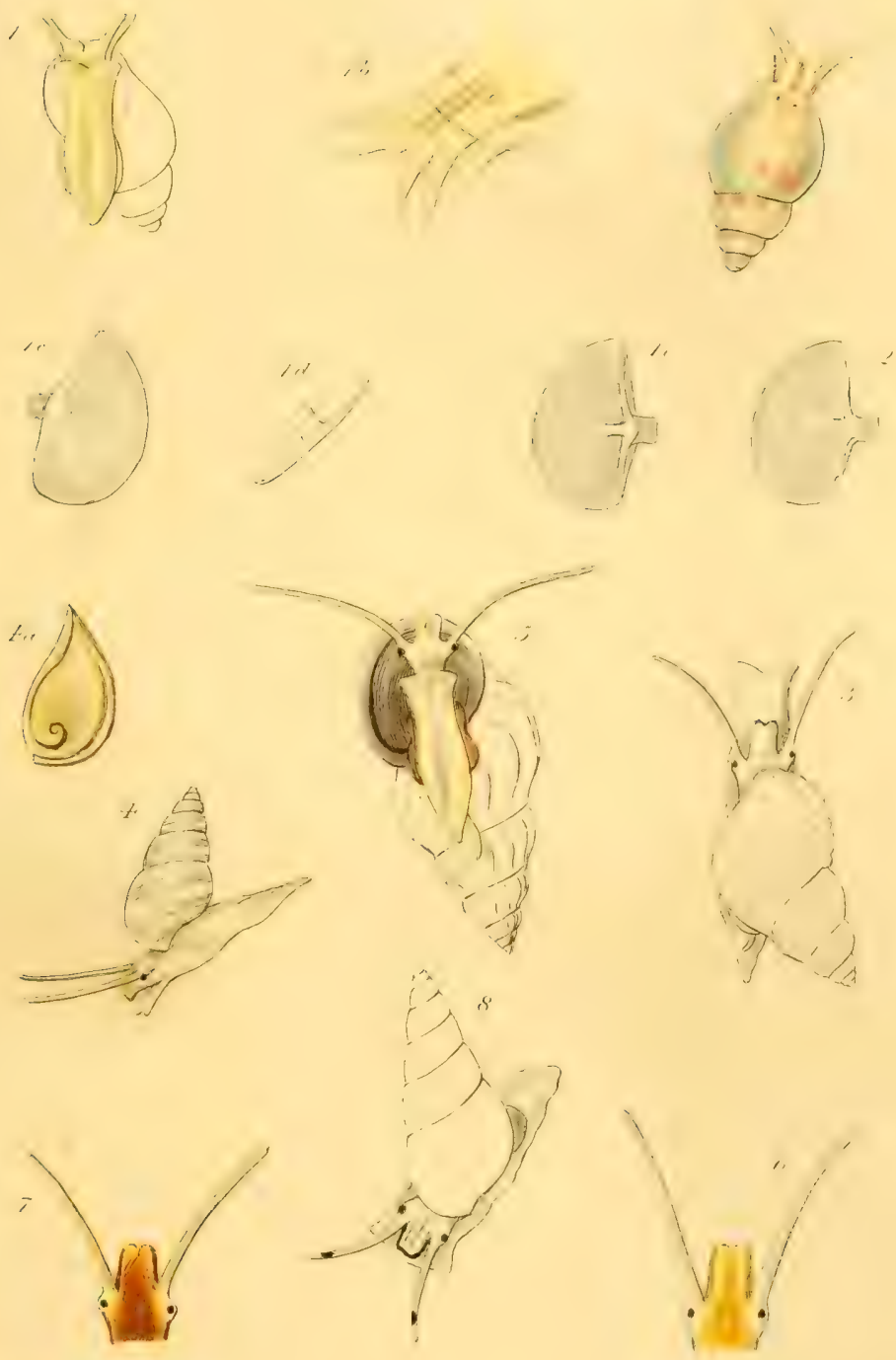

1. Meflieysia eliaphana foperentum. 2. Oper"? of Iefressia epalina. 3. Rissua abysicola. t. R. cinoillus \&operm .j. R. parva.
i. R. Iabiosa
7. R. rufilabris.
8. R. ${ }_{11} \mid \mathrm{r}$, 



PI,ATE , K K

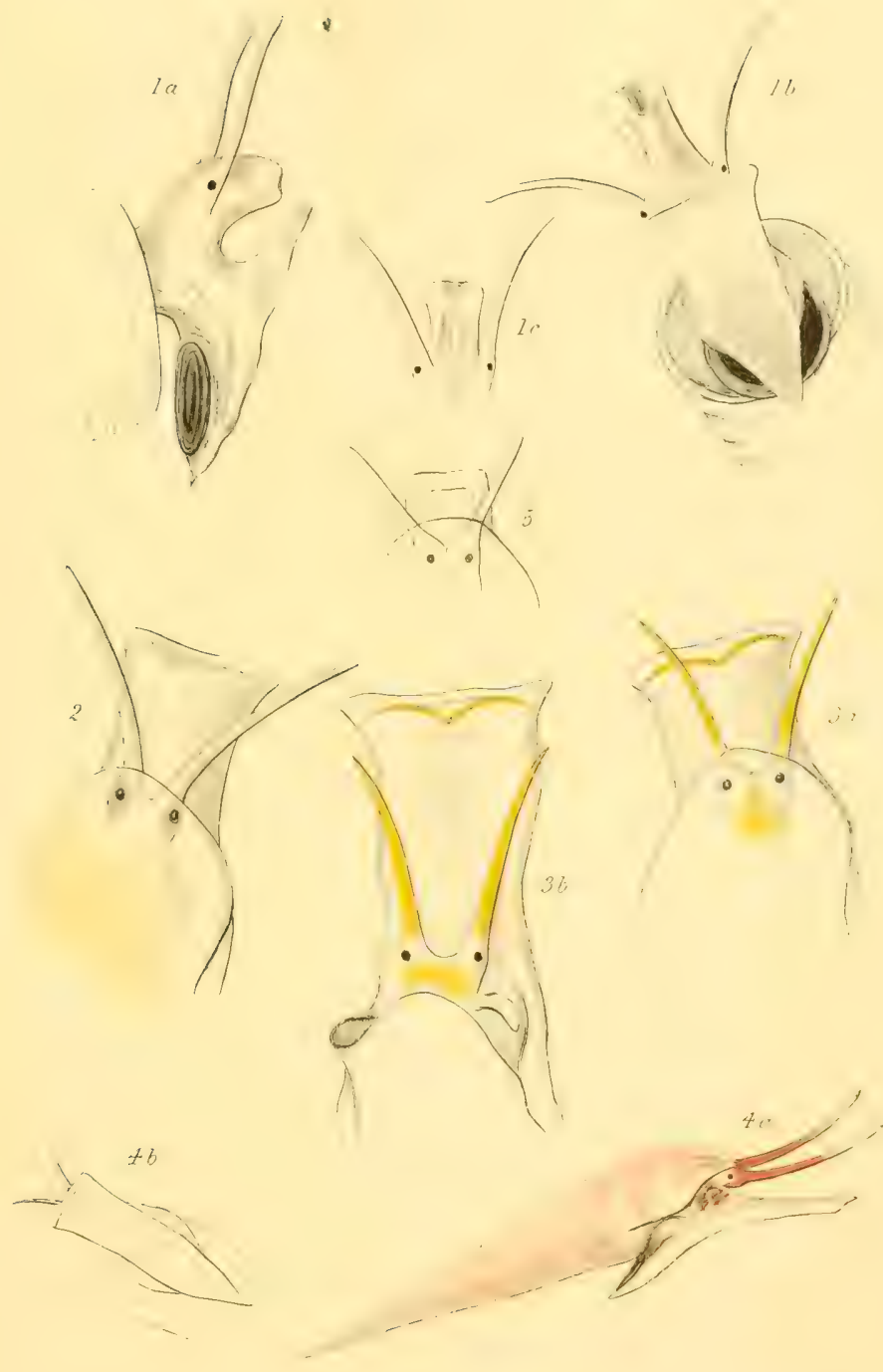

E. Forbes det

1. Cæcum trachea. 2. Eulima nitida.

3.E nitida, var polita. 4.E. distorta. 5. F. Jilineata. 




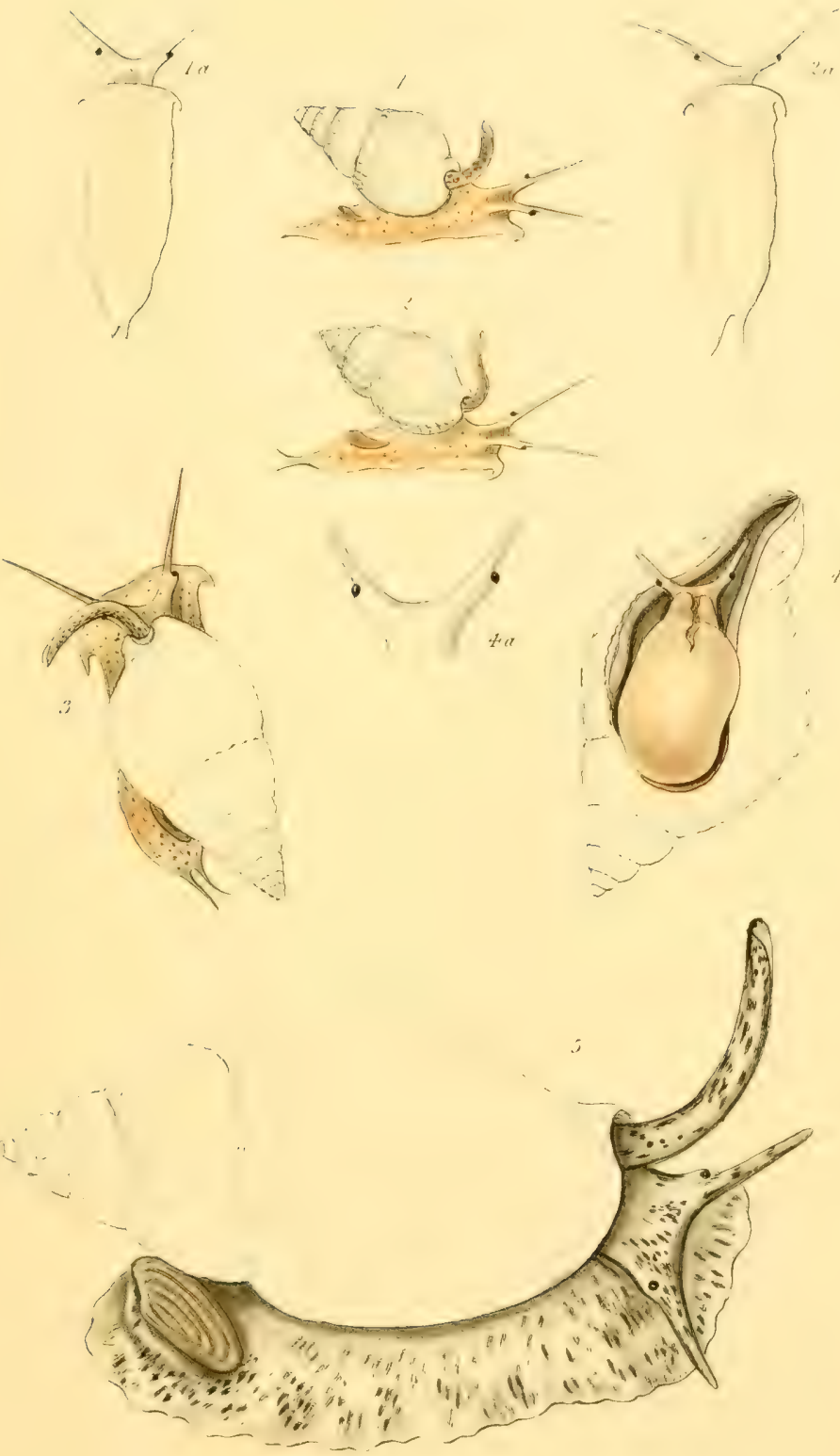

L. Nassa inerassata. 2. Nassa varicosa. 3. N. reticulata.

ঊ. Purpura lapillus. 5. Buccinom unclatum. 



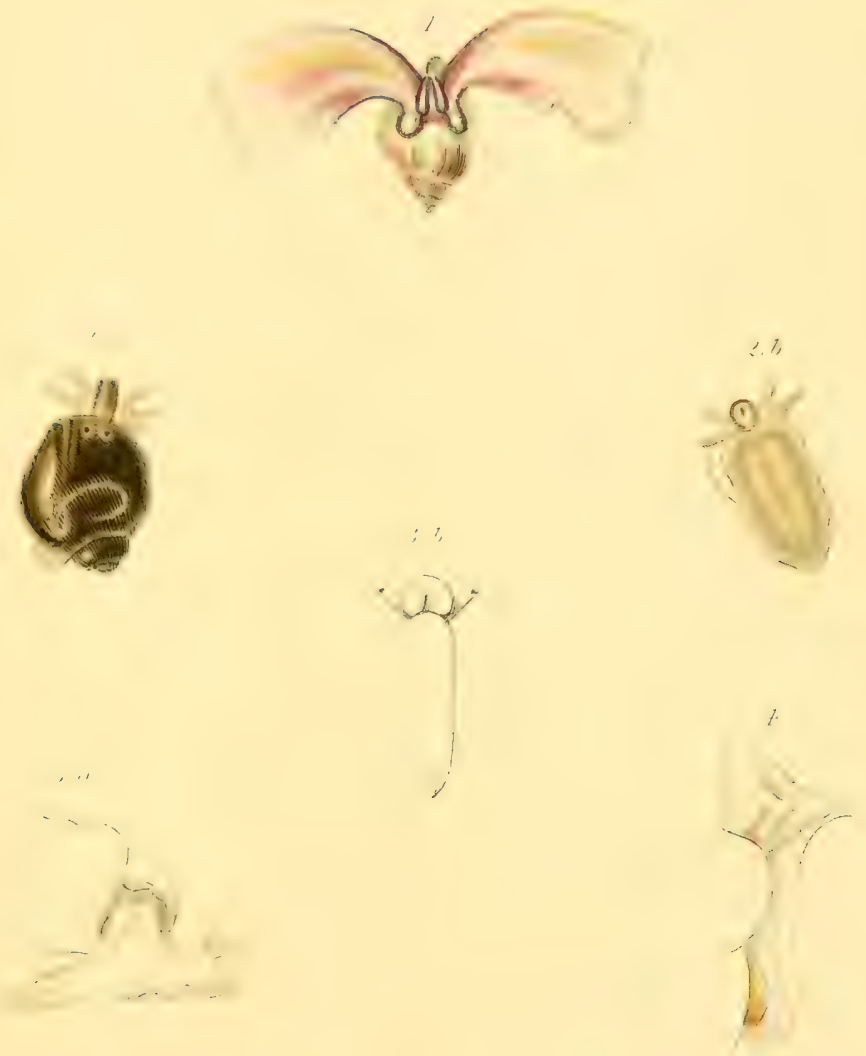

$\cdots$
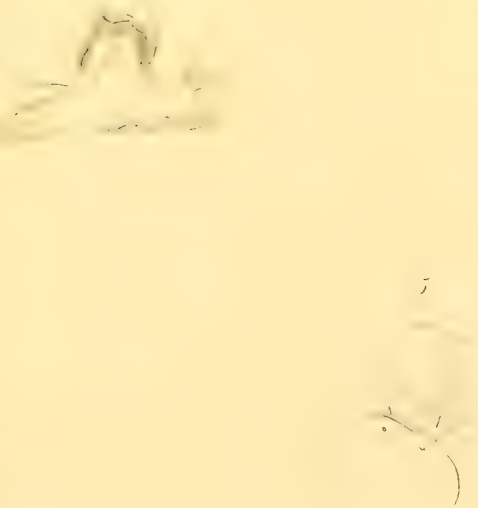

1. Sprriatis Fleminoii. 2. Jeftiossia opalma.
3 Assiminea littorea.
4. Risson vites.

5. Aclis supranitida. 


PL. ATE NN.

I
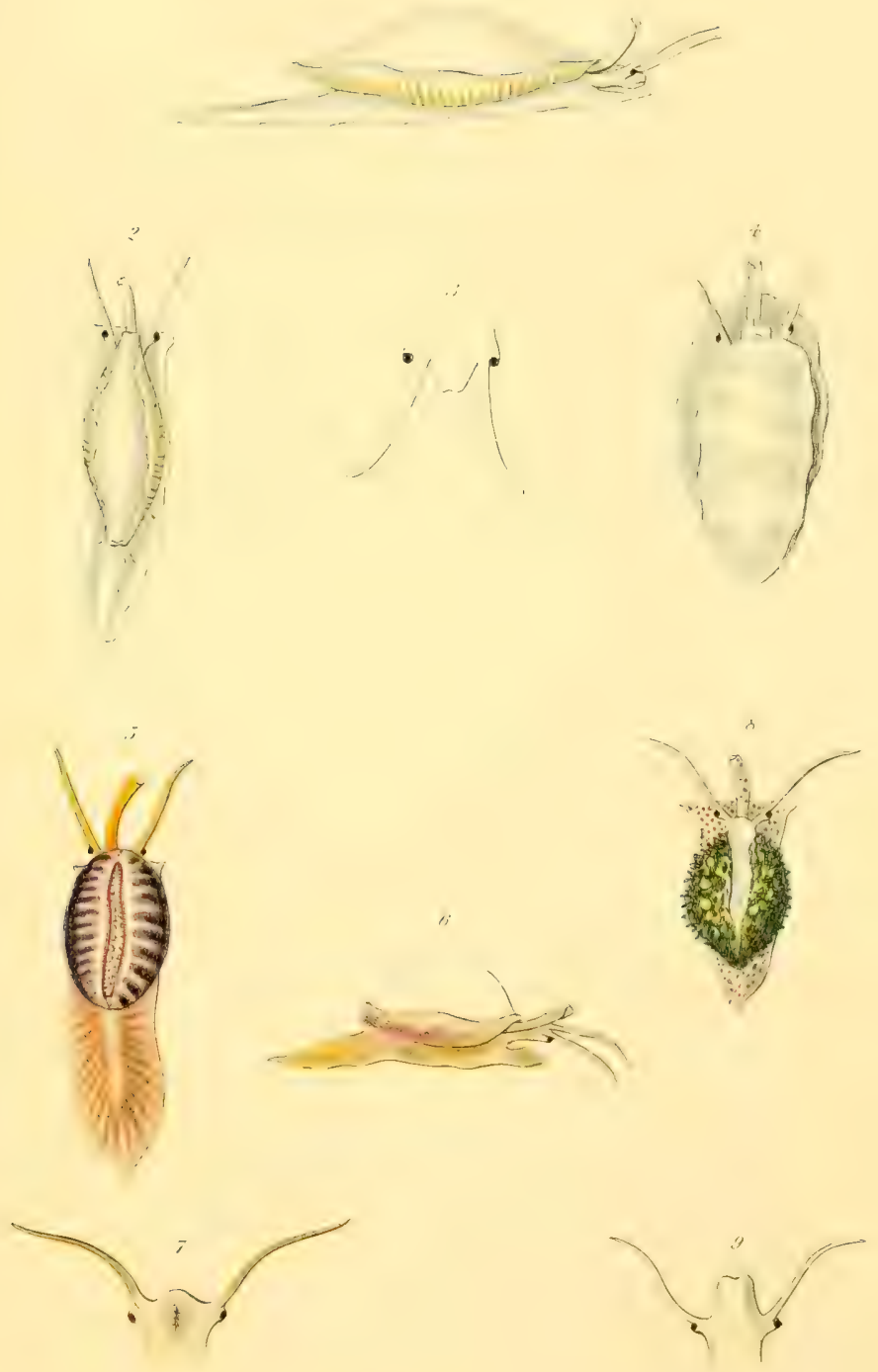

1.4. Tolra patula. 5_7. Cypræa europæa.

3.9. MFaroinella lovis . 




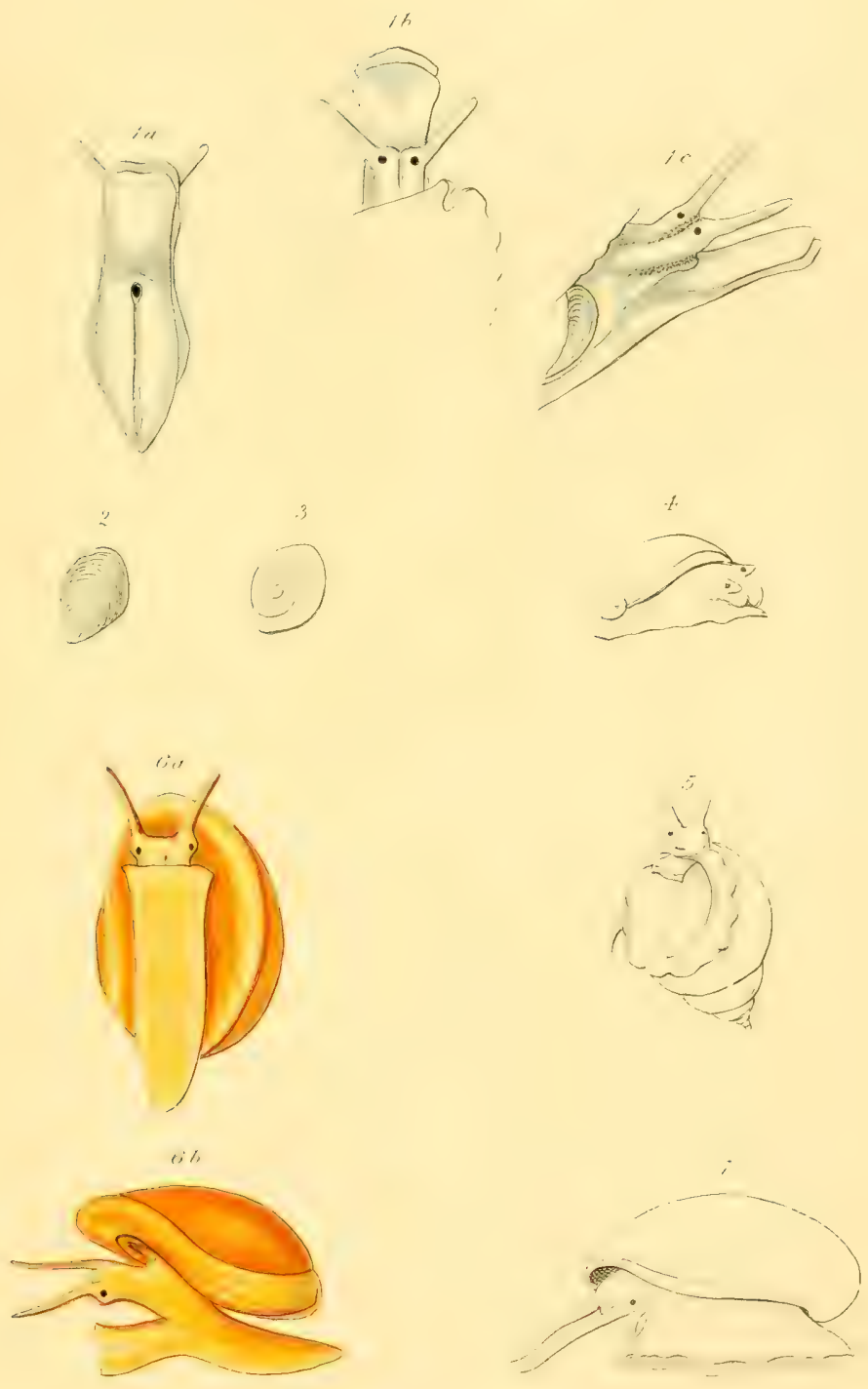

1. Cerithiopsis Tubercularis \&2 its operculum.

3. Opere of Cerithum reticalatum. 4. Otina stis. 5. Stilifer 'Turtonis.

6. Velutina plicatilis. 7. Velutima læriģata. 





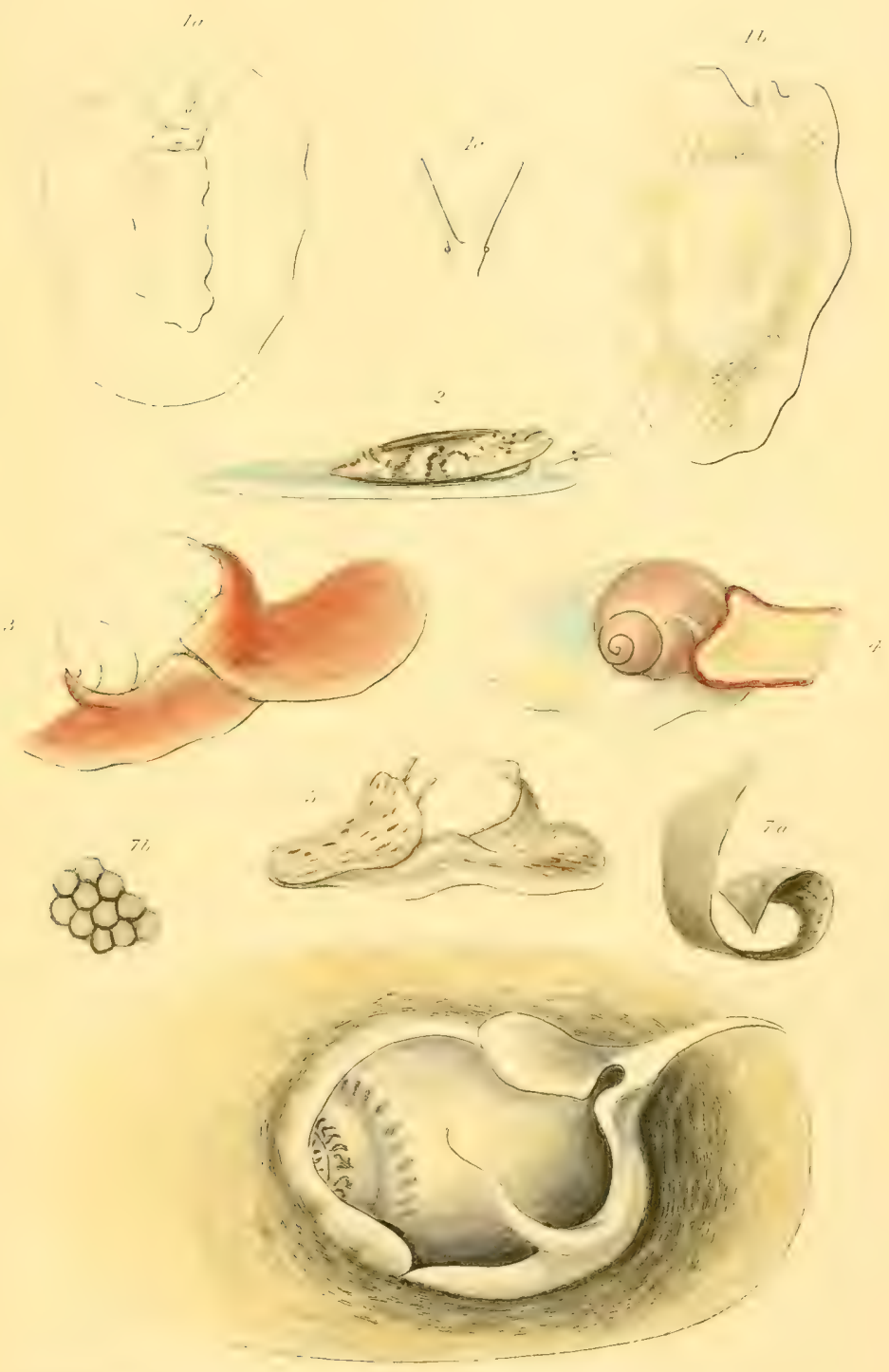

1. Lamellaria perspicua. 2. L. 1muticulata.

3. Natica sordida. 4.N.Montanori. 5. N. Alderi.

6. N. cantenci-and T its spawn. 




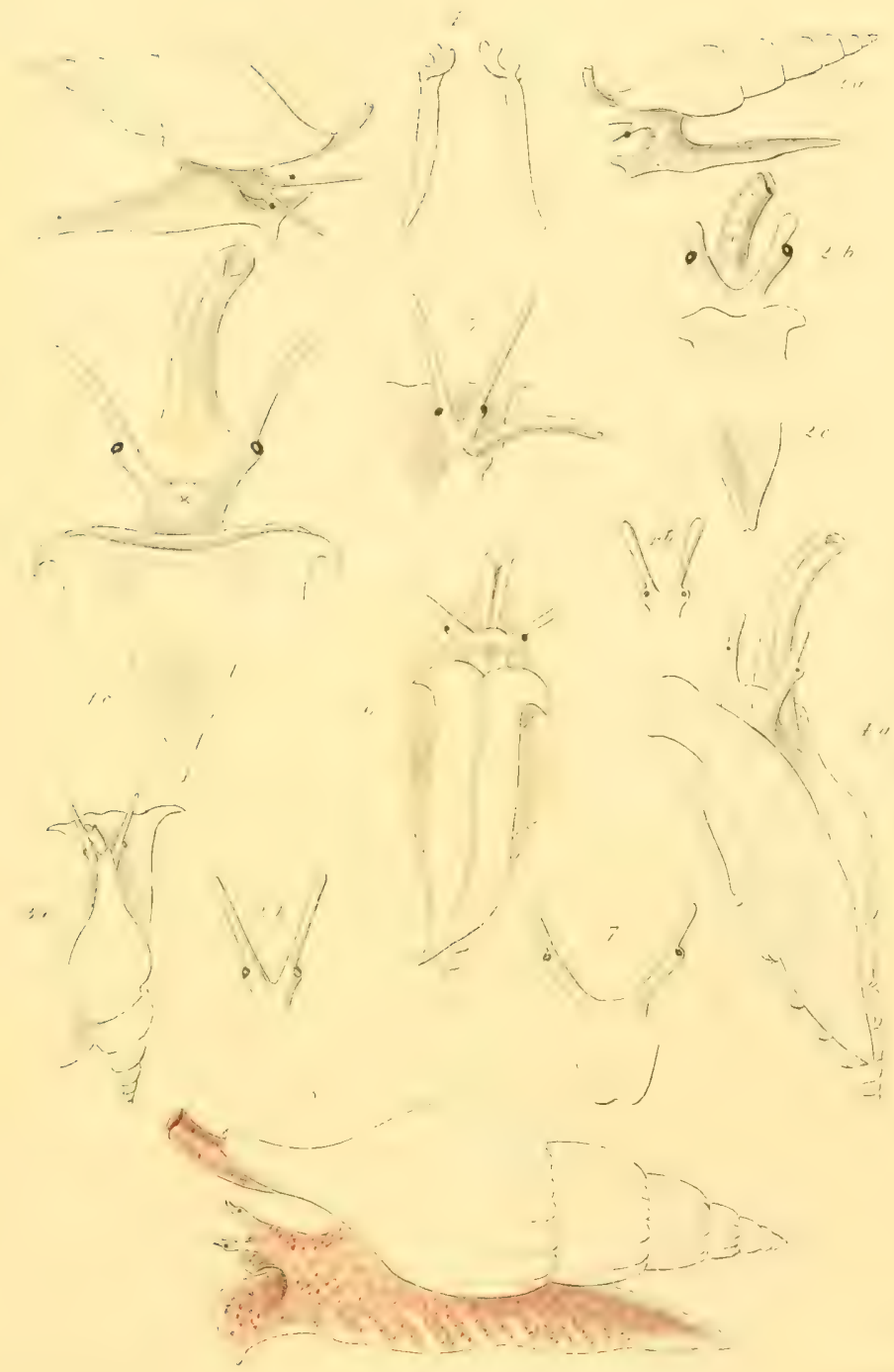

E.Fentis ient

1. Manôdia Lefroyi. 2. M. braclirstoma. 3. M.teres

4.M.costata. 5. M. attenuata. 6. M. linearis.

7. M. nebula. S. N. gracilis 




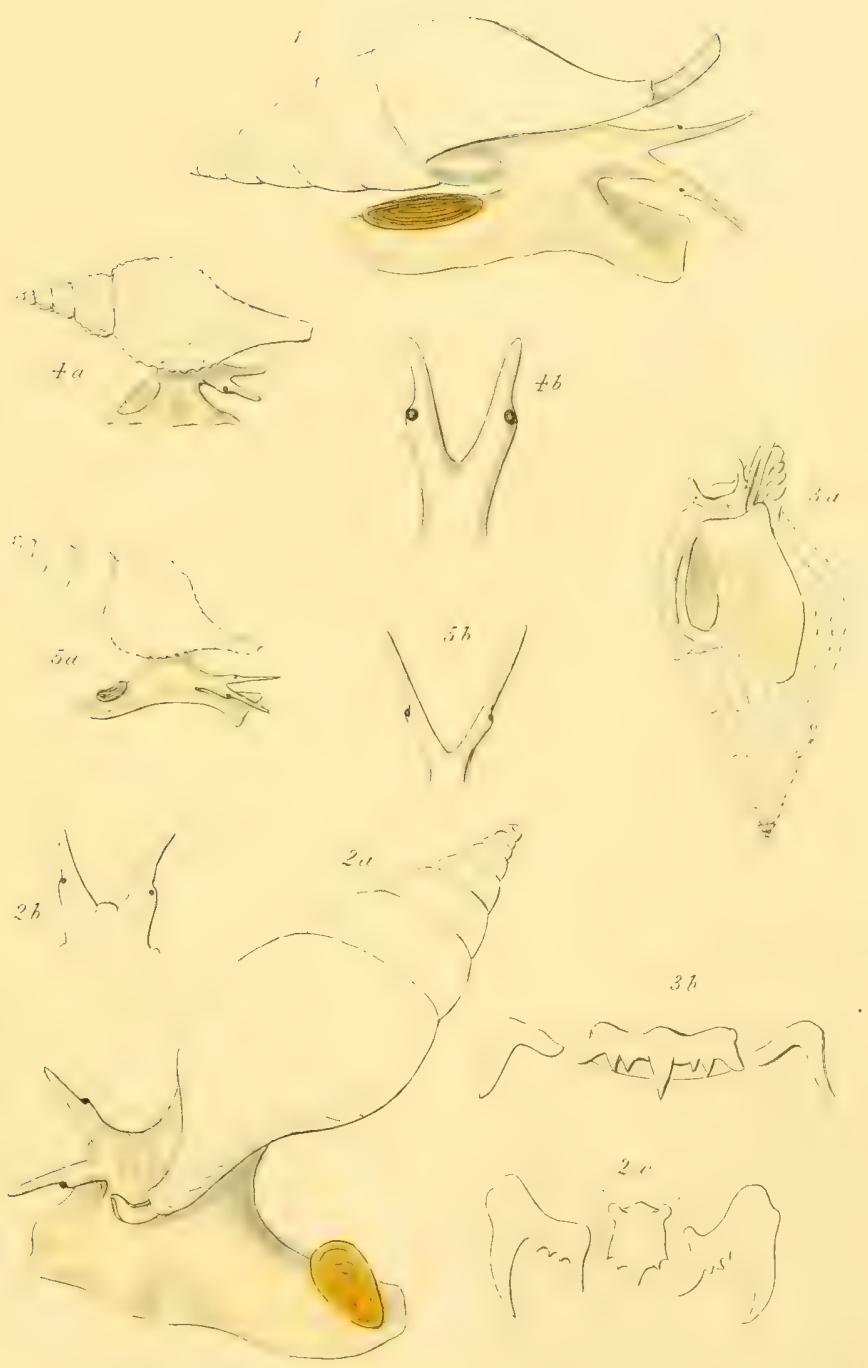

1. Fusus propinquus. 2. Fusus islandicus.

3. Trophon Bamfium. 5. T. echinatum.

4. T. Barvicense. 




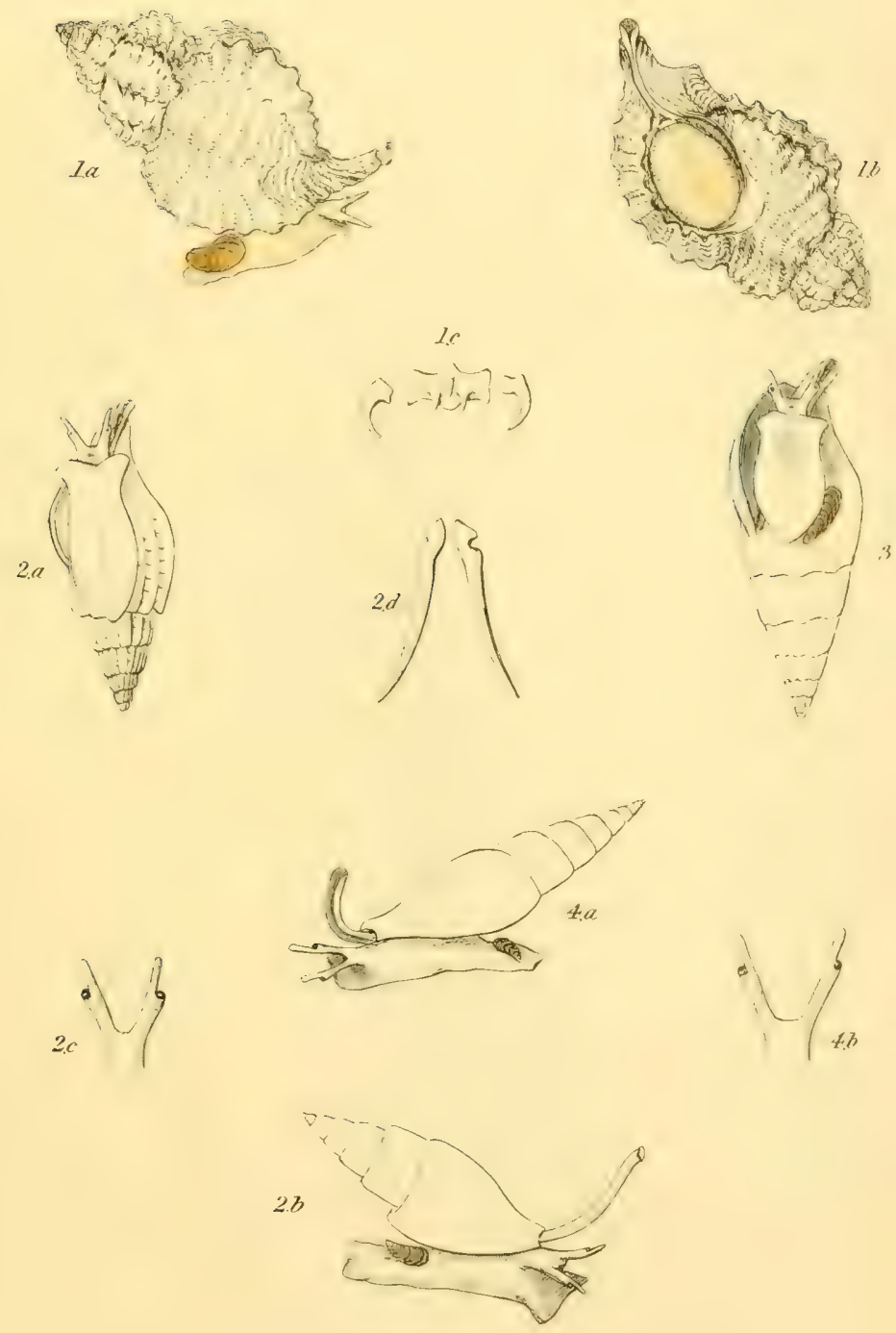

1. Murex erinaceus. 2. Mangelia (Bela) tnrricula.

3. M(Bela.) septanğularis. 4. MI.(Bela)rufa. 



PLATE UV

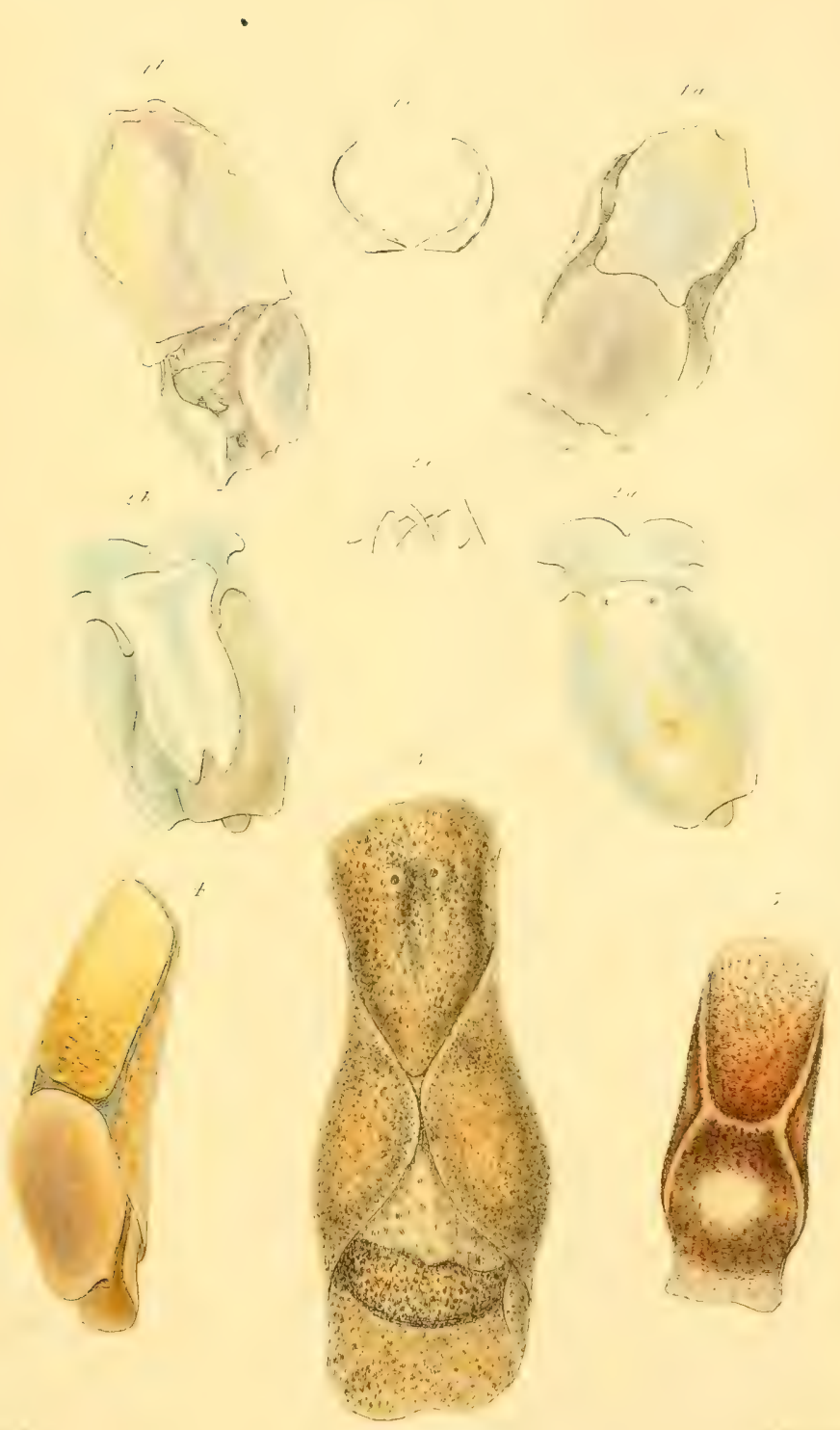

1. Bullra aperta. 2. Amphisphyra hvalina.

3. Bulla hydatis. 4.Bullæa catena.

6. Balløa punctata. 




$$
\frac{4}{a \infty}
$$





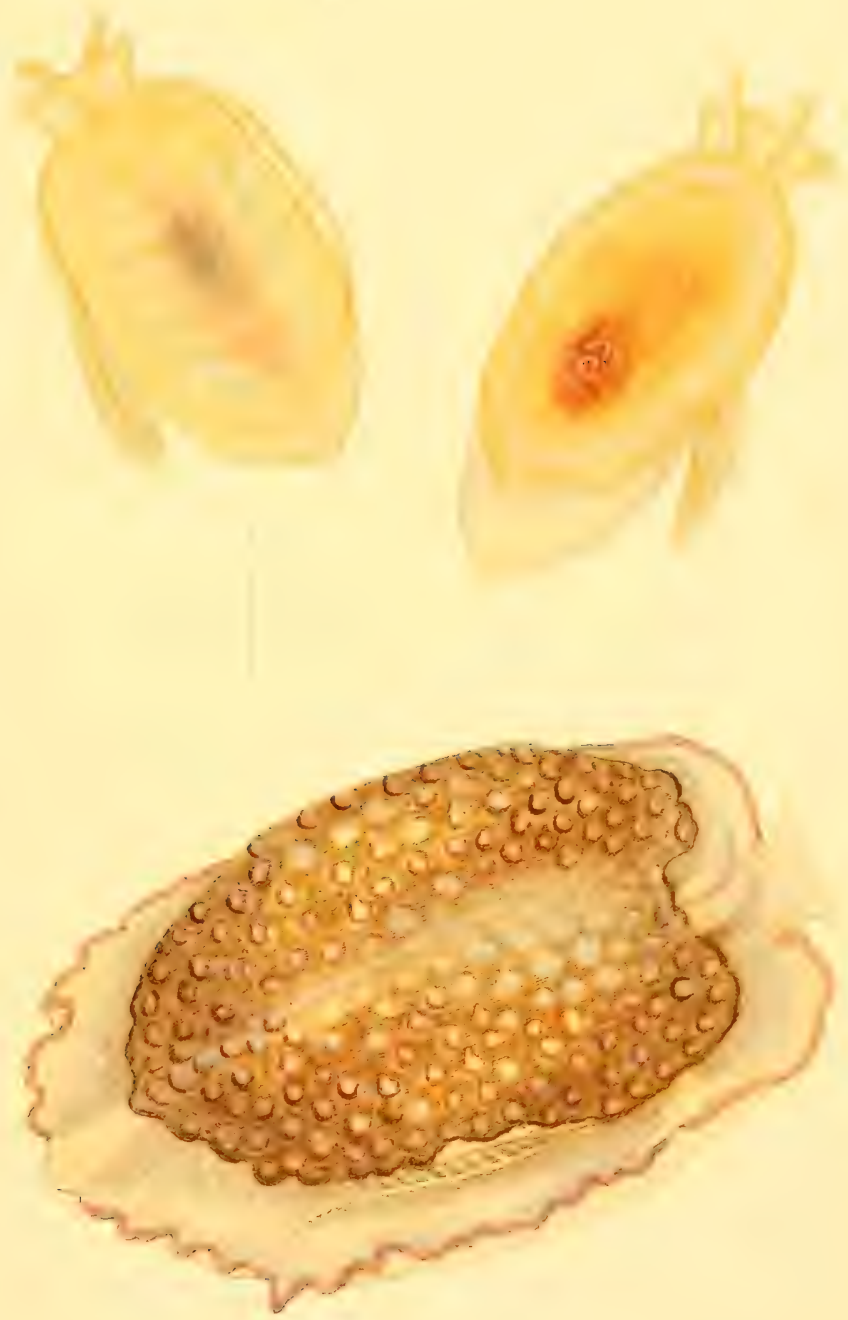

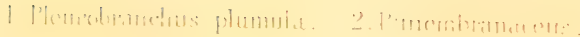






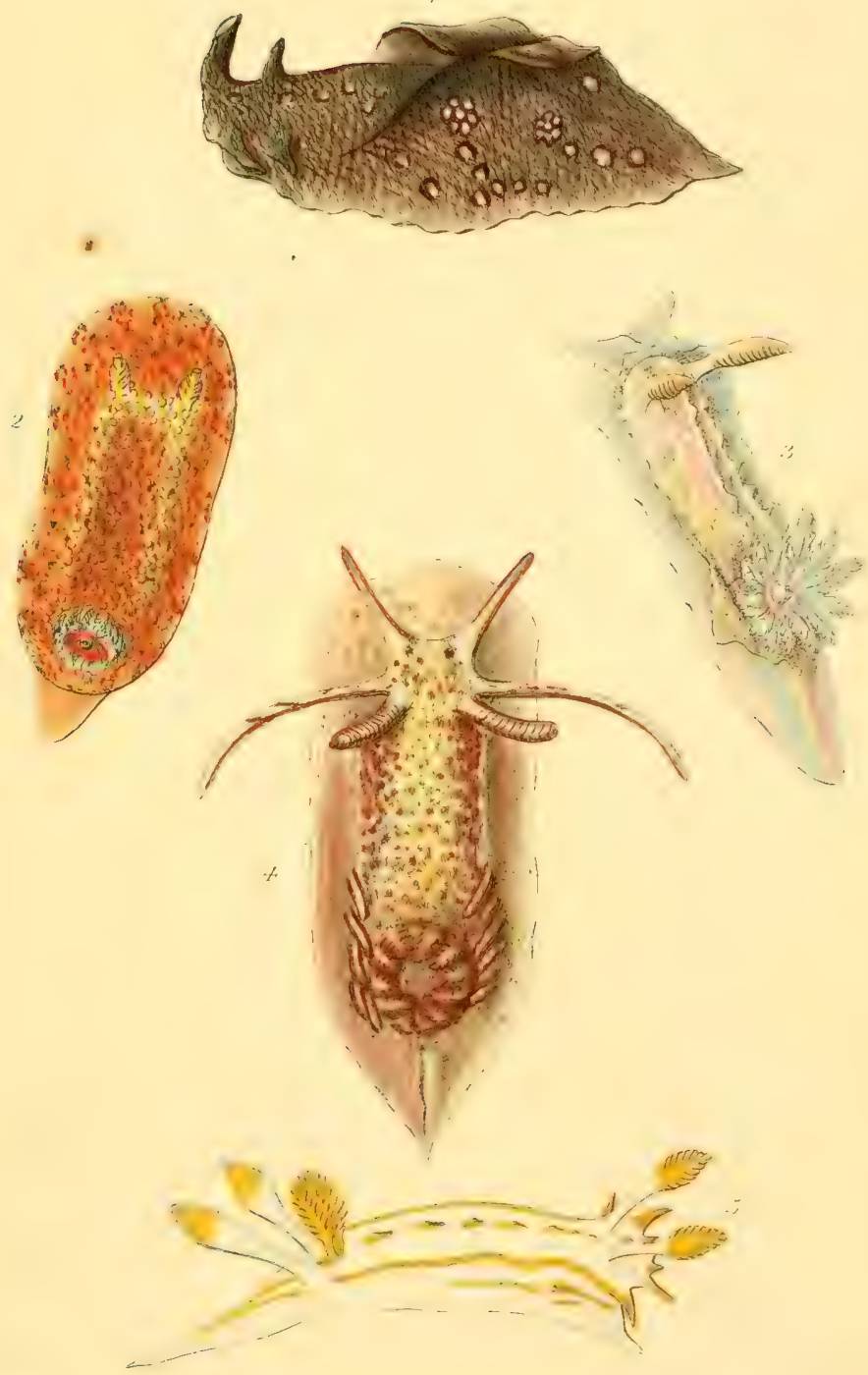

1: Aplysia hybrida.

3. Goniodoris nodosa
2. Doris coccinea.

4. Idalia inaequalis.

5. Polycera quadri lineata. 




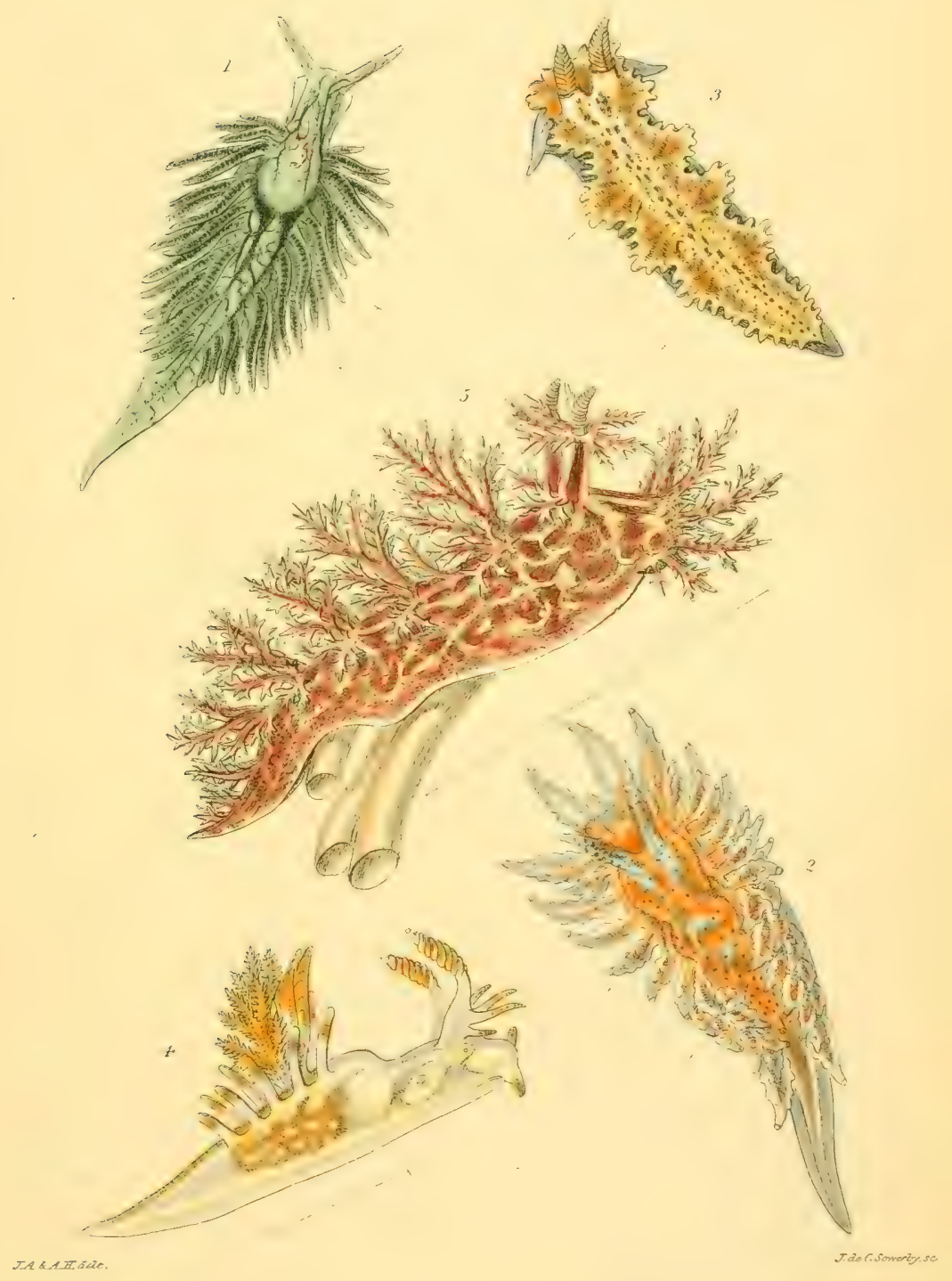

1.Hermoea dendritica. 2.Proctonotns mucroniferos.

B. Lomonotus marmoratus. 4. Aneula eristata.

5. Dendronotas arborescens. 



PLATE A.A.A
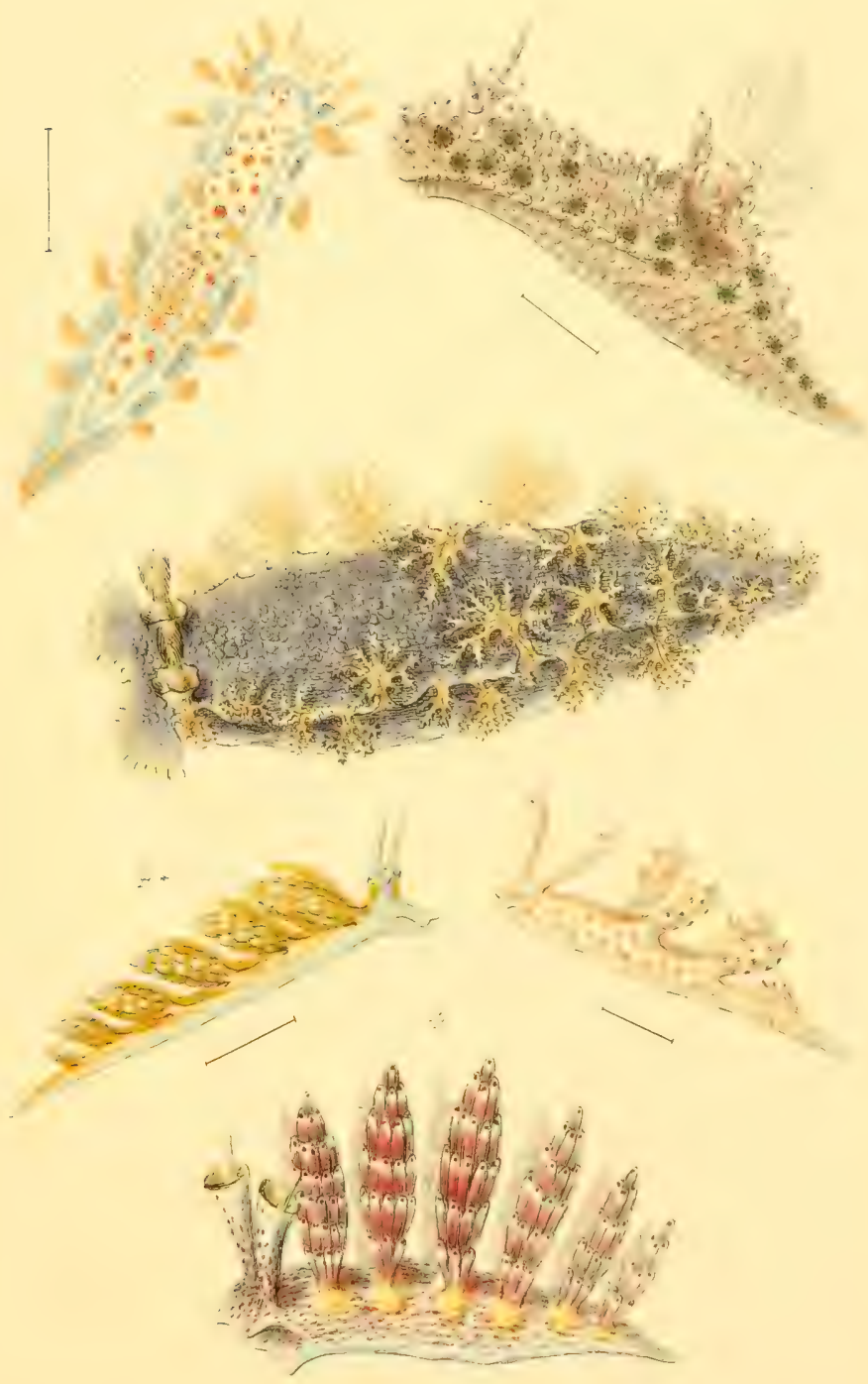

E.E. 50 \& C 5 th

1. Triopa claviỏer. 2. Eörus pumctilucens. 3. Tritonia Homberơi

4. Doto coronata. 4". Doto fraplitis.

5. Scylioa peliöica. 





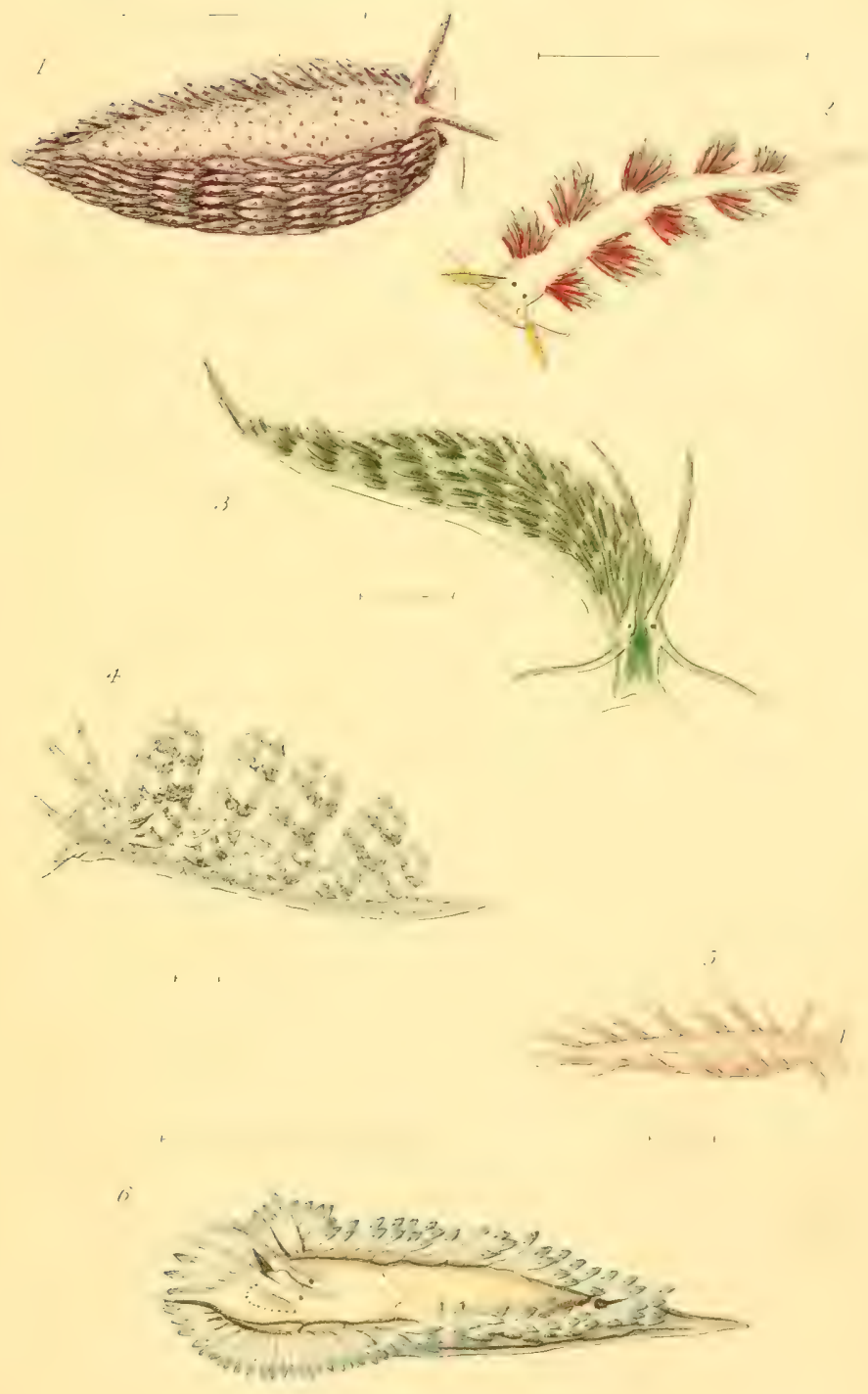

1.Eolis papillosa. 2.E.cornuta. 3.E. rimalis. H. Liexigina.
5. Fimbletonia miunta.
6. Antiopa splendida. 



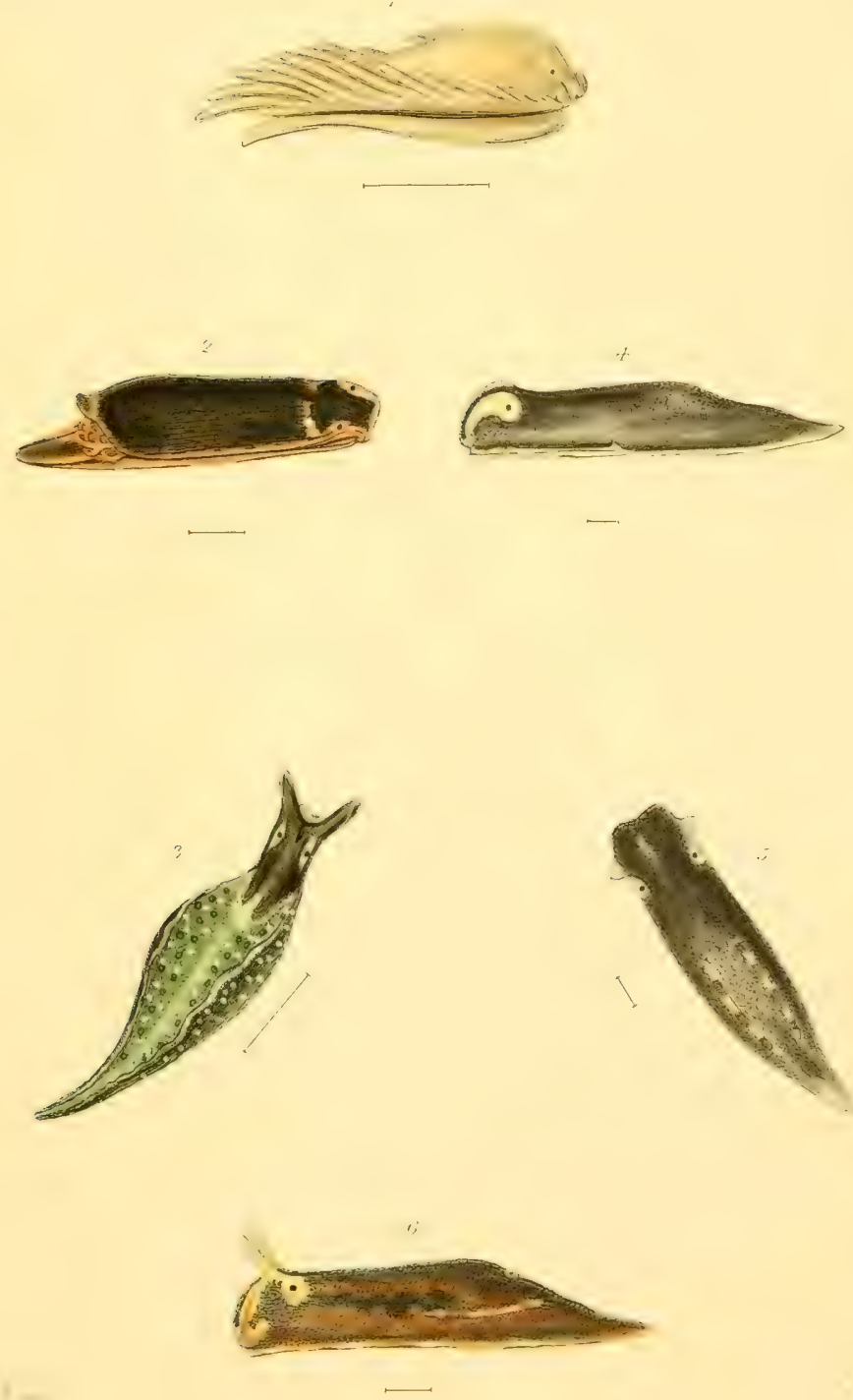

1. Alderia modesta. 2. Runcina Hancocki.

3. Elysia viridis. 4. Limapontia niopa. 5. Acteonia cormogat: 6. Cenia Cocksii. 



$$
\text { SO }
$$




$$
2
$$


PLA'E D I) I)

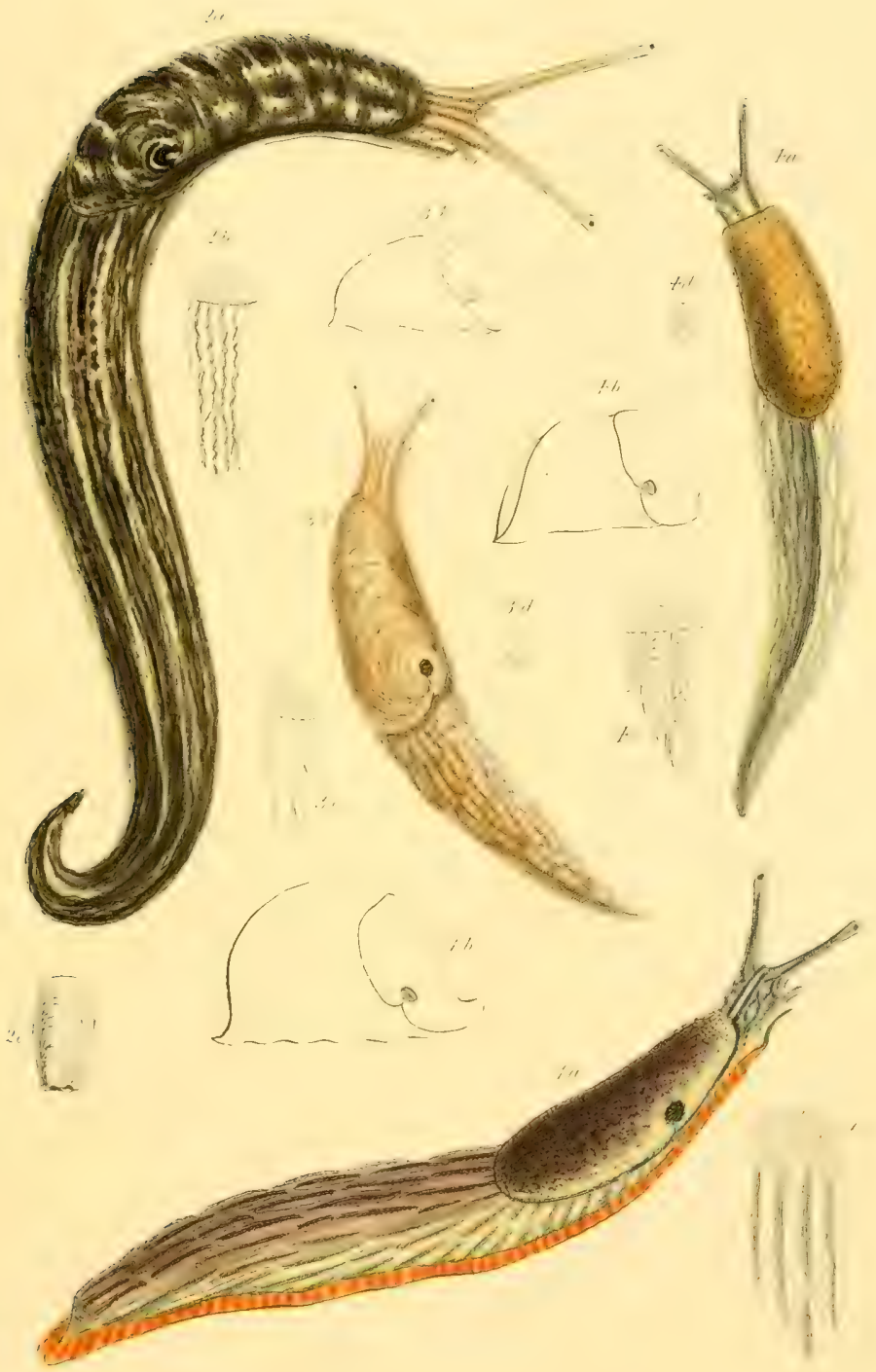

1. Arion empiricoram.

2. Limax cinerens

3. Limax aǵrestus. 4. Limax ogagates 



PLATE, E,E,E

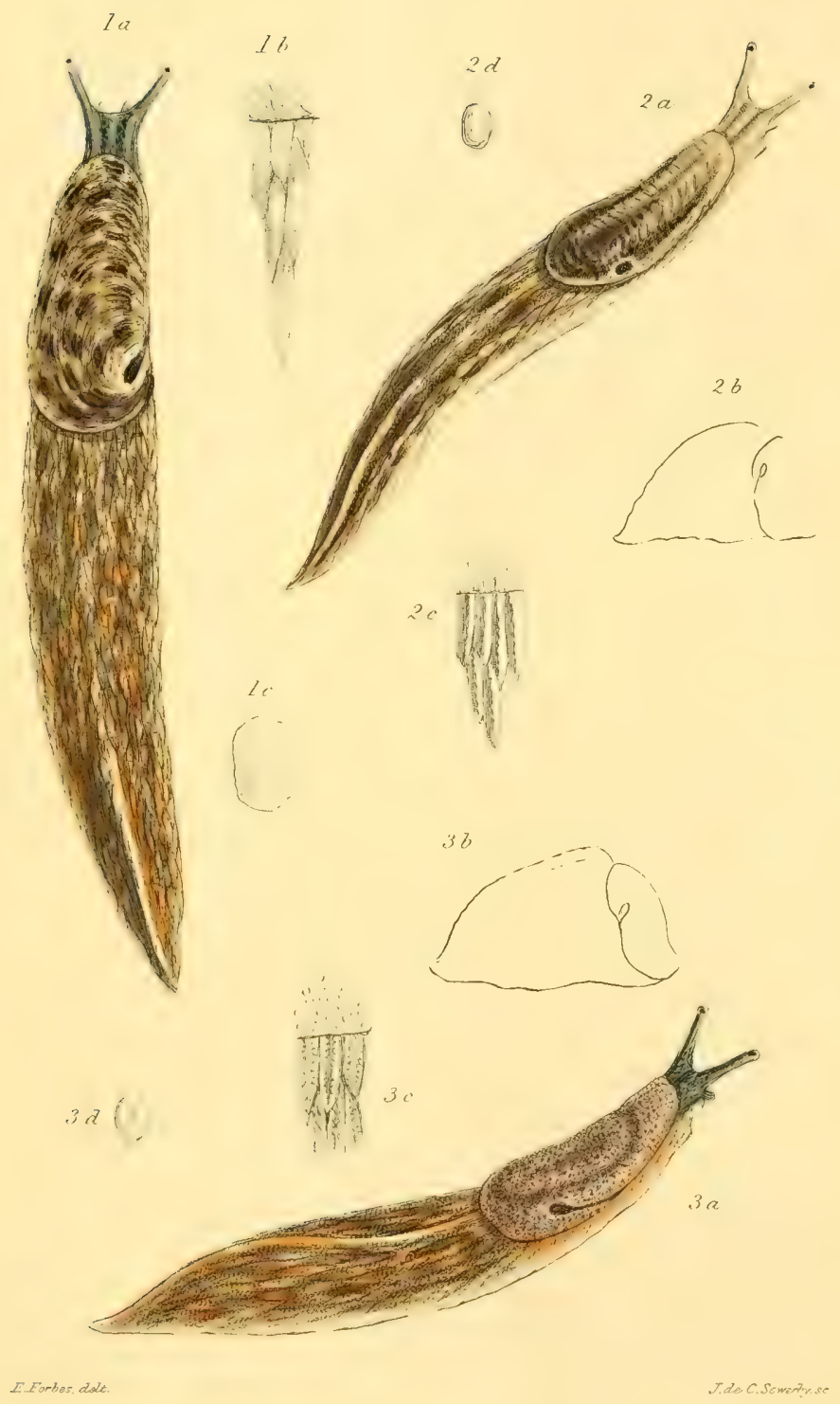

1. Timax flavas. 2. L arborens. 3.L.Sowerhï. 



PLATE.F.F, F *
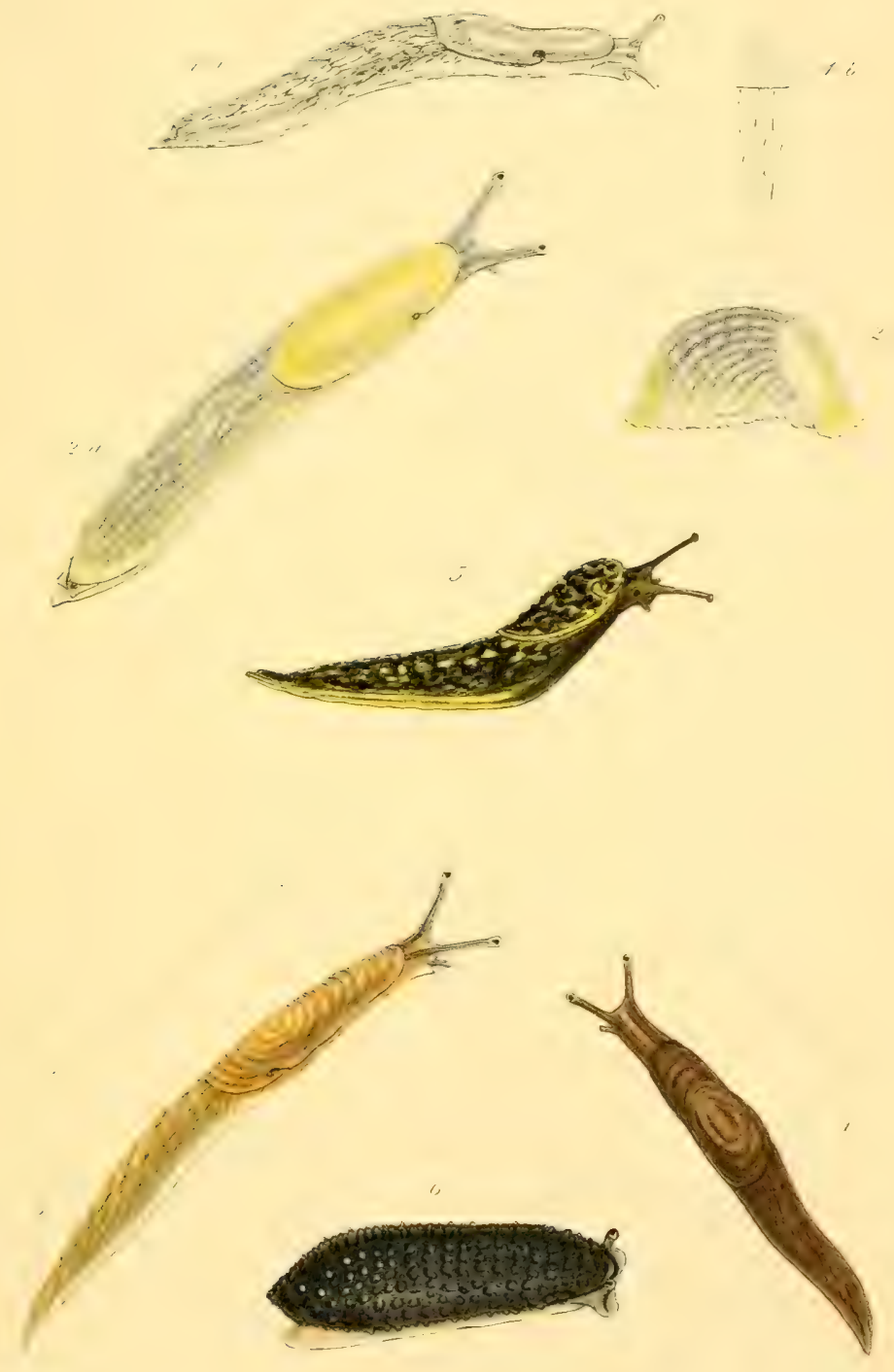

$-\because \cdots+$.

1. Arion hortensis. 2.4 flaras 3. Limax tenellts

4. Limar brtnnens. 5. Geomalacns macnlosns

6. Onchidium celticnm 




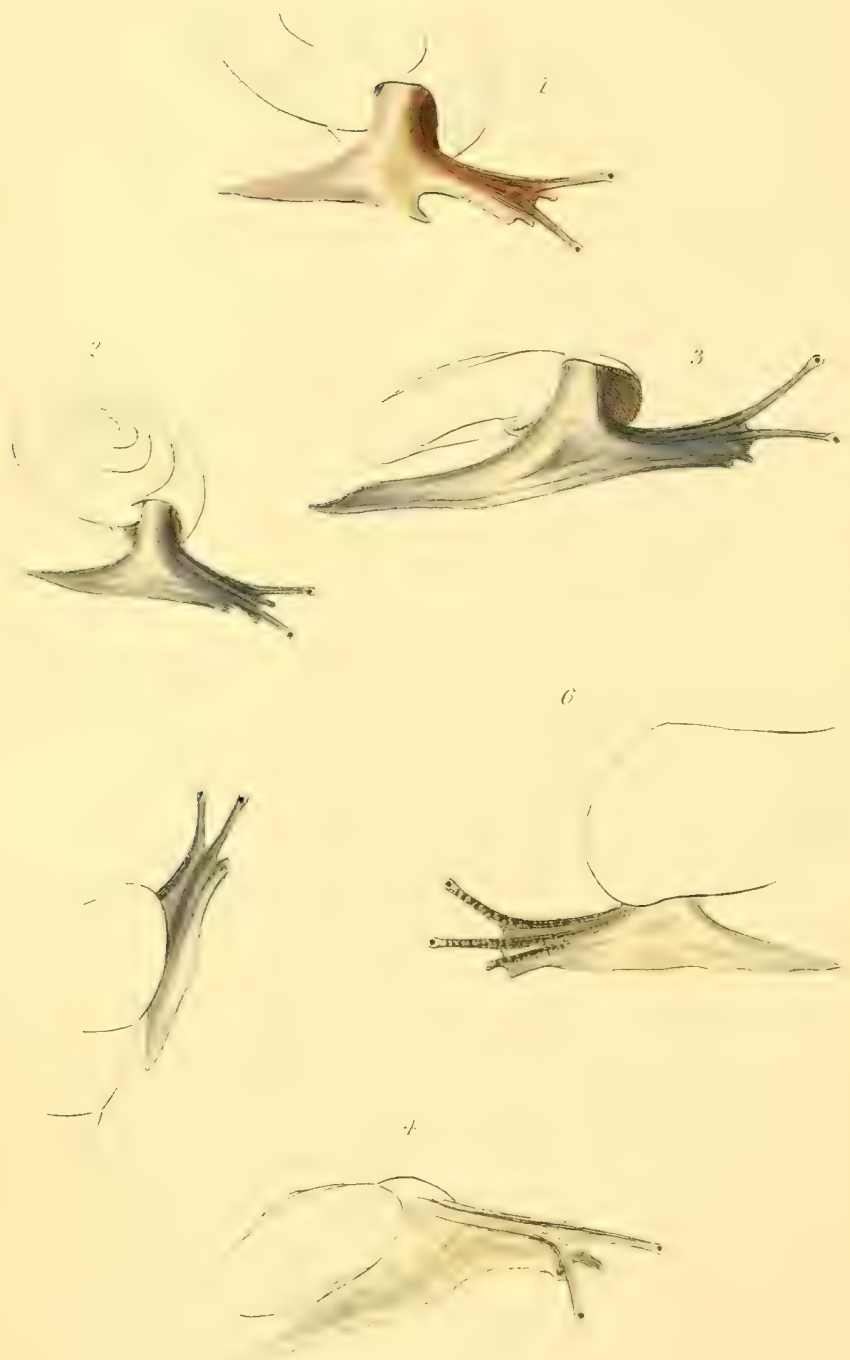

1.Helix hispida. 2.H.rotundata. 3. I.cellaria. +.H.fusca.
5. \% a Iubrica.
6. Brilimns nentns. 





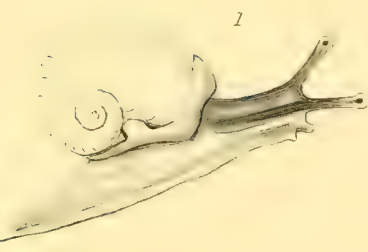

2

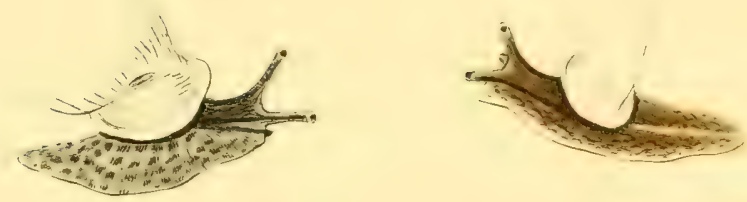

$t$
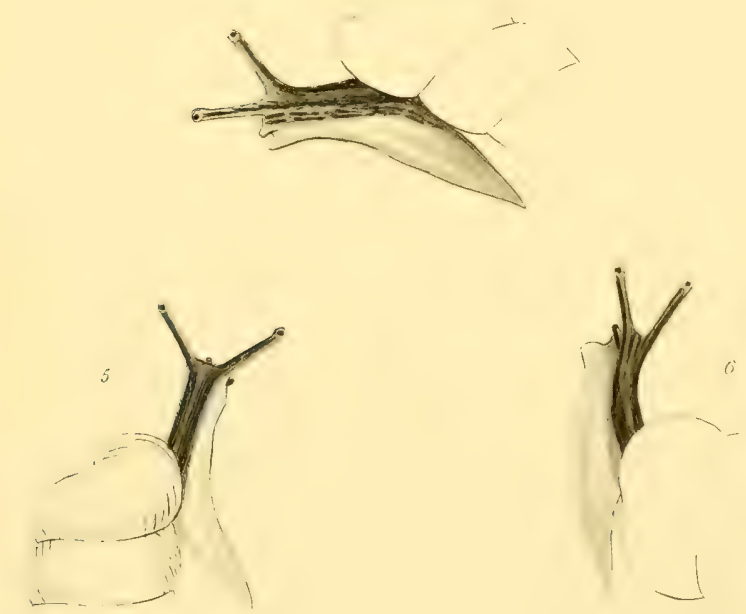

FF Fories dintc

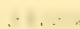

1. Vitrina pellucida. 2. Clausilia plicatola 3.C.laminata.

4. Balea pertersa.

5. Papa marsimata. 6. Pupa umbilicata. 




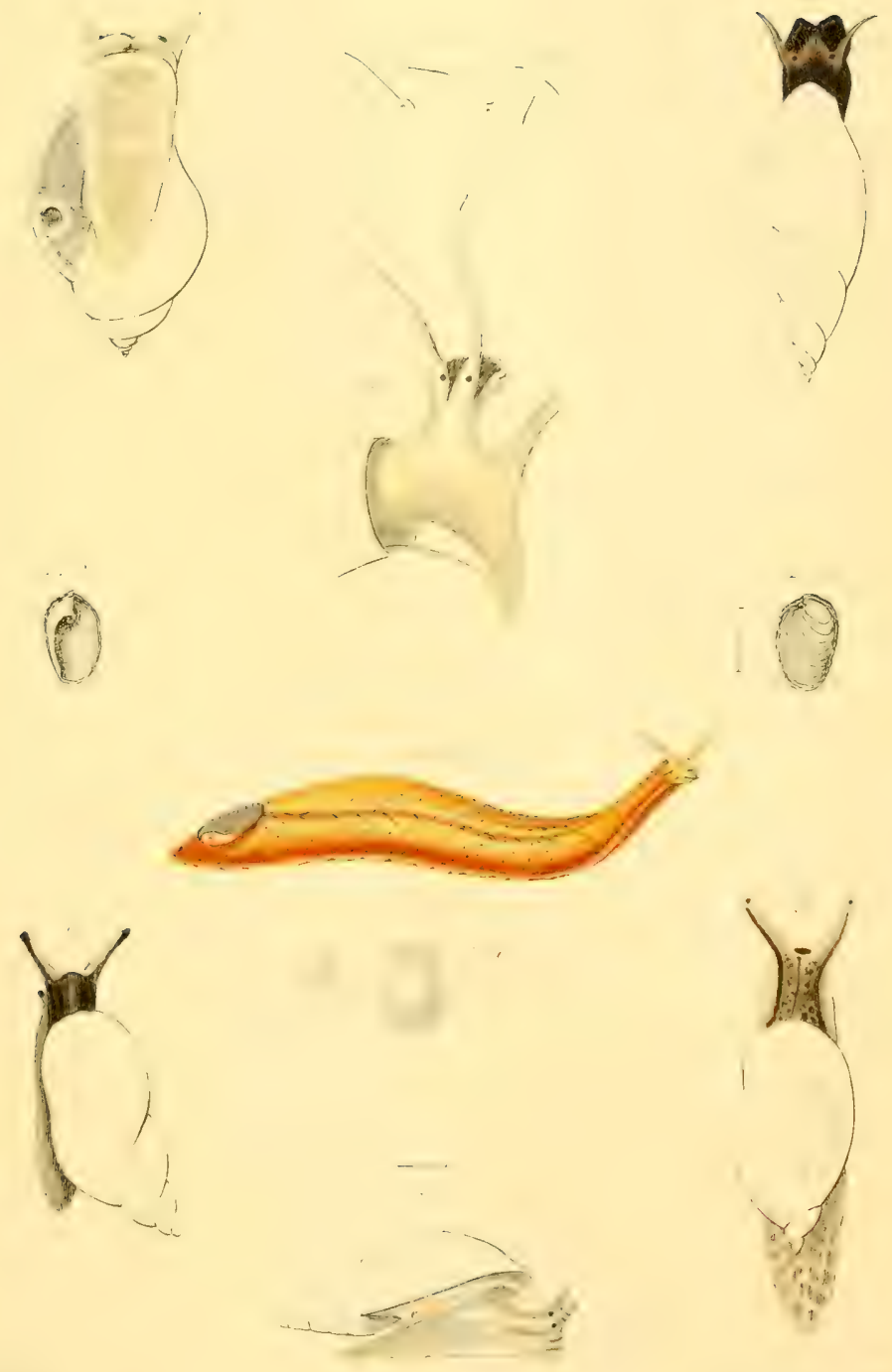

1. Testacella haliotoidea. 2. Limmins pereg̈er.

3. Physa hypnormi. 4. Planorbis vortex.

5. Succinea puris. 6. S, oblonoia. 7. Conorulus denticulatas. 




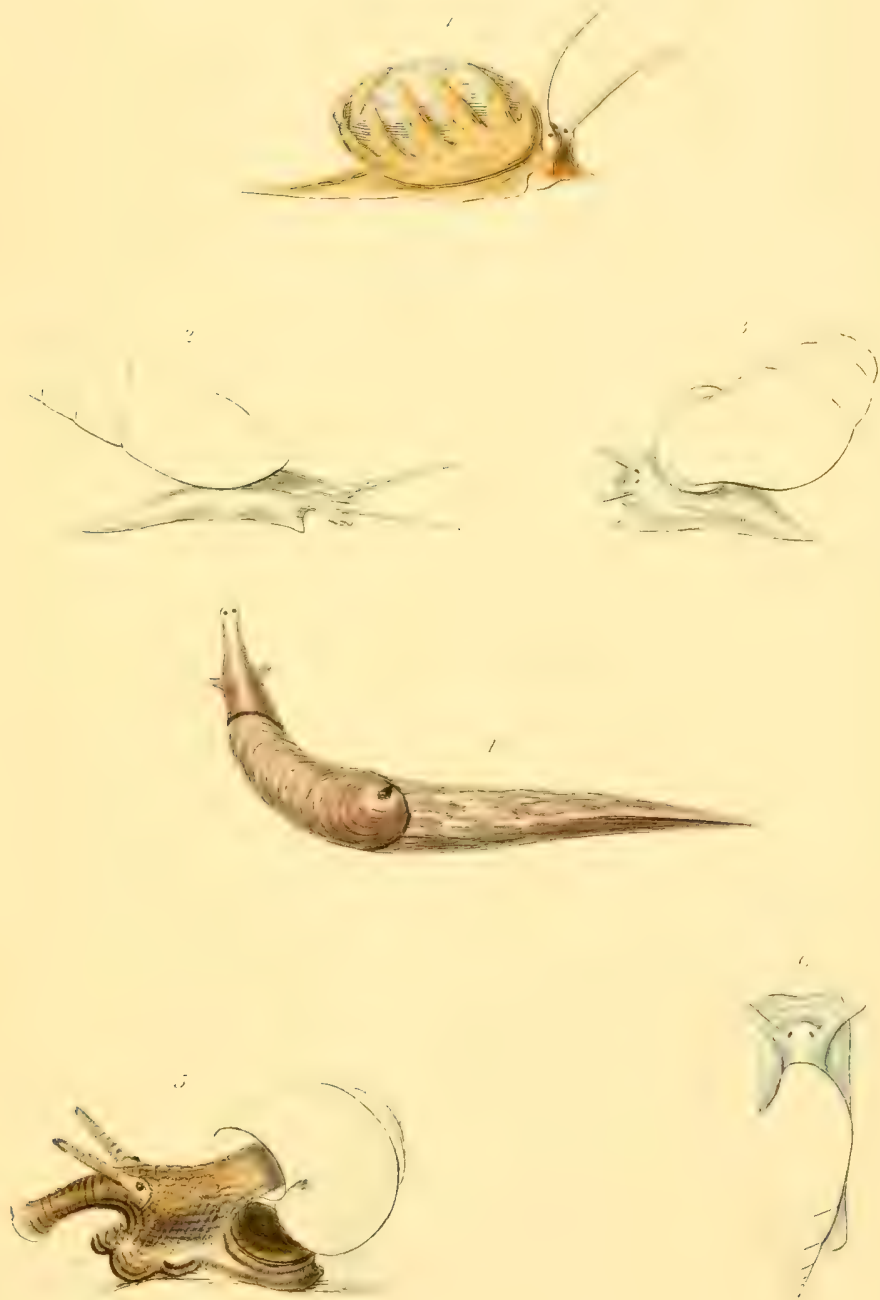

1. Physa fontinalis. 2. Achatina acicula

3. Canclium minimnm I. Limax asrestis monster

5. Cyclostoma eleoams. 6. Conovulus bidentatus. 




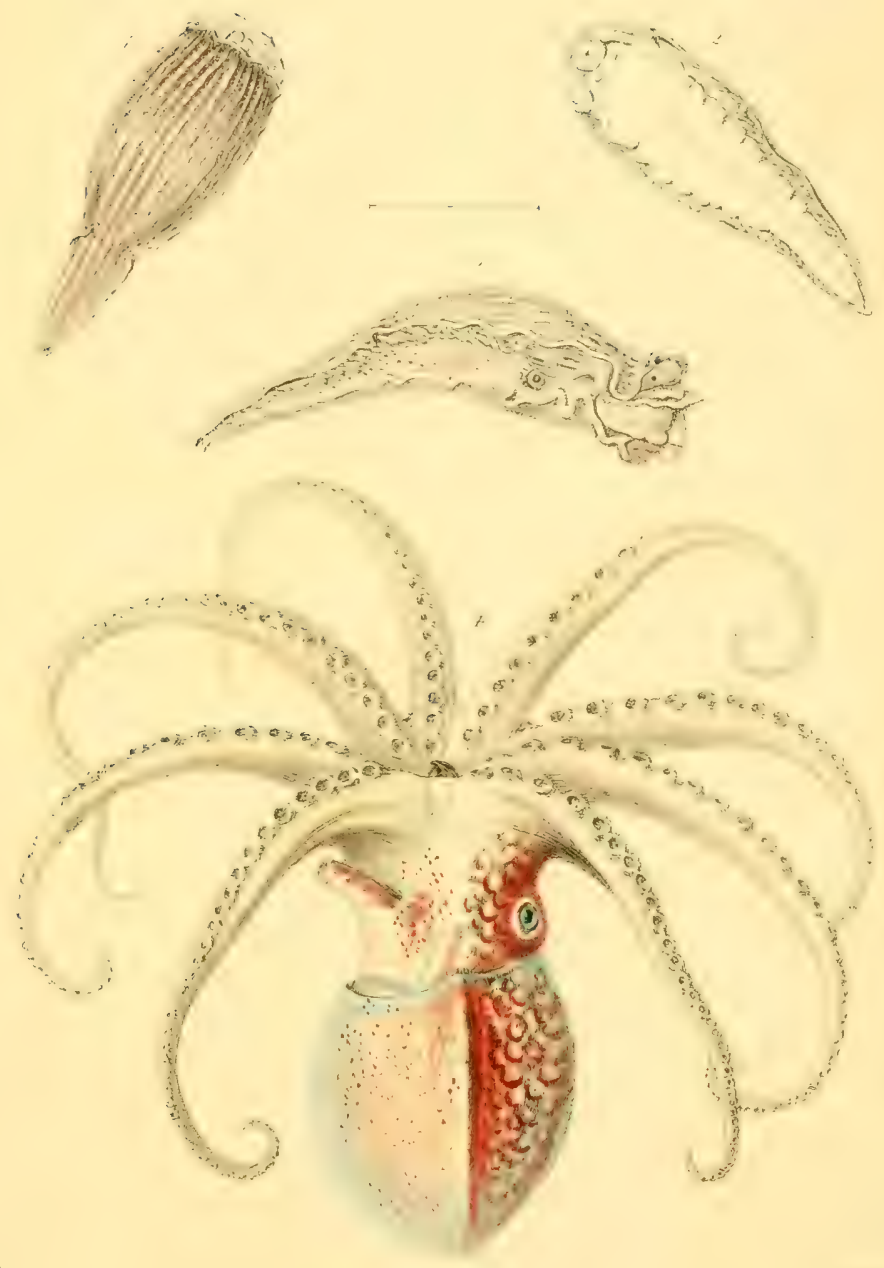

1.2.3. Diphyllidia lineata. 4. Eledone cirrhosns. 


PLATE I.I.I

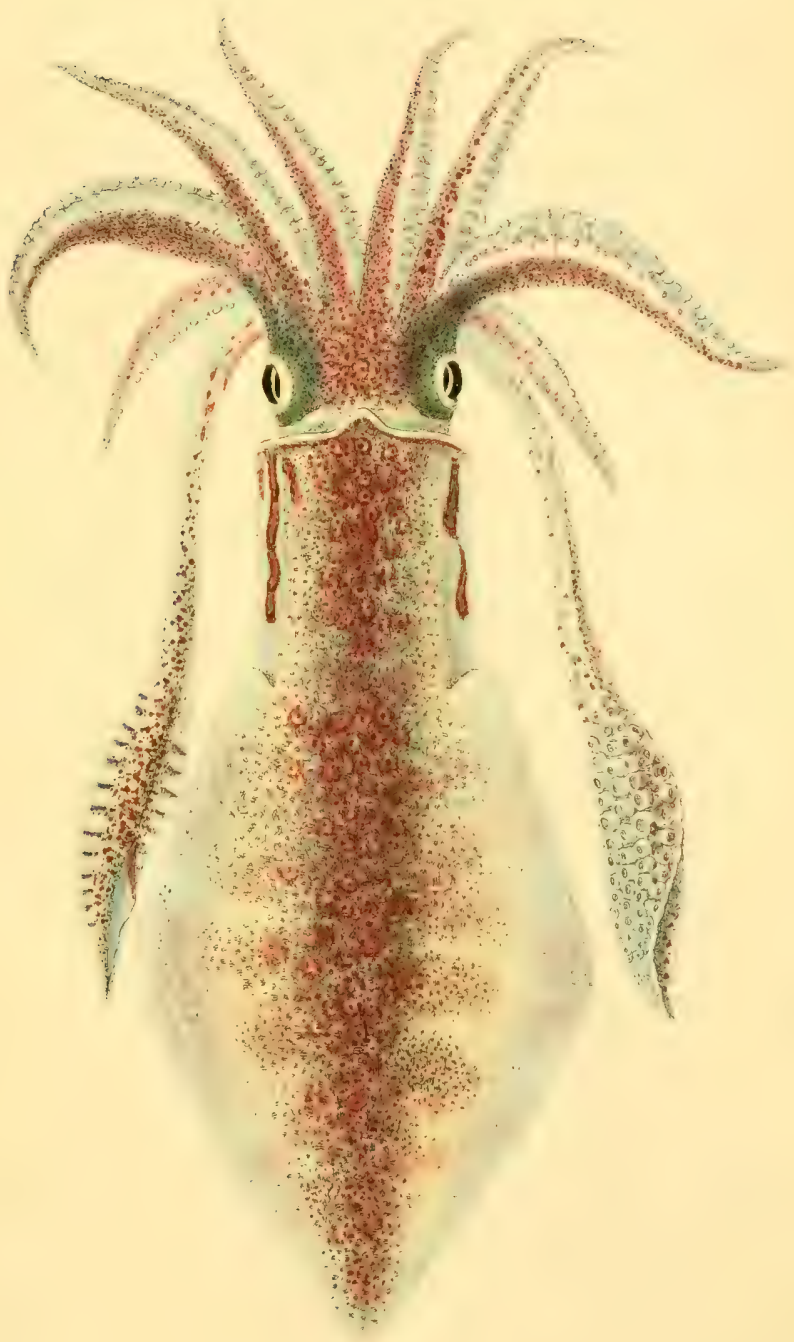

Loligo valǵaris. 





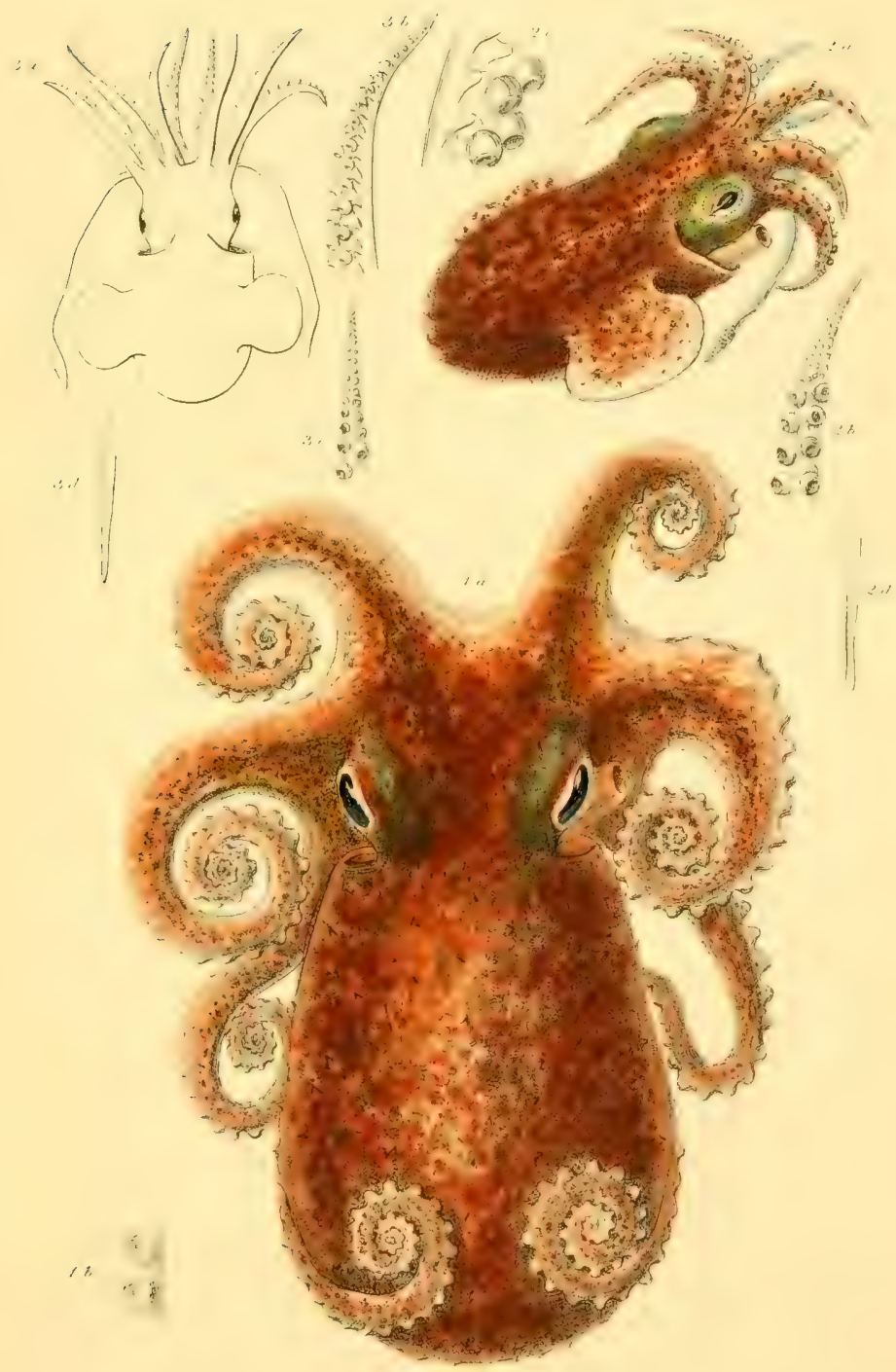







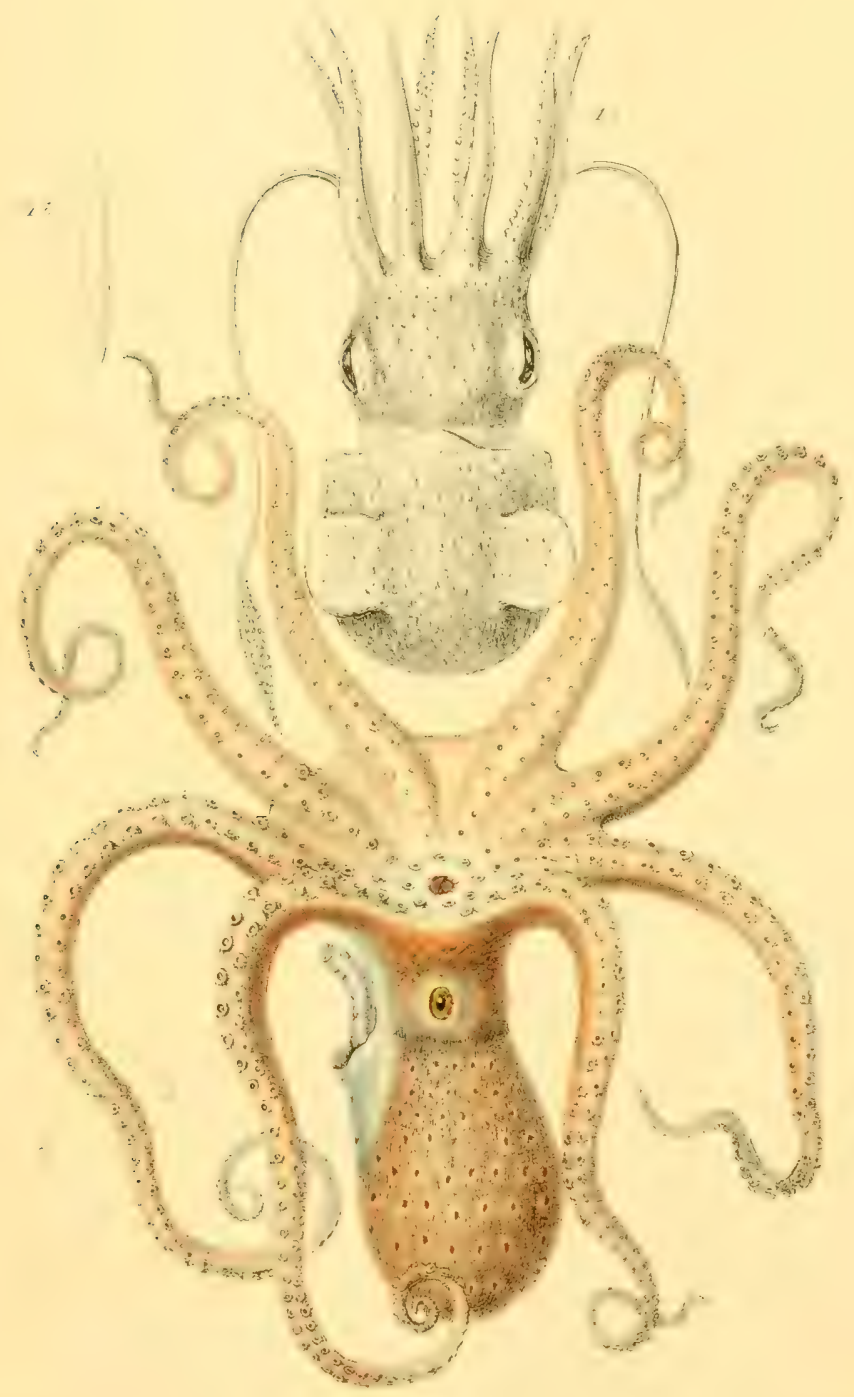

1. Rossia macrosoma.

2. Octoprs mbloris 



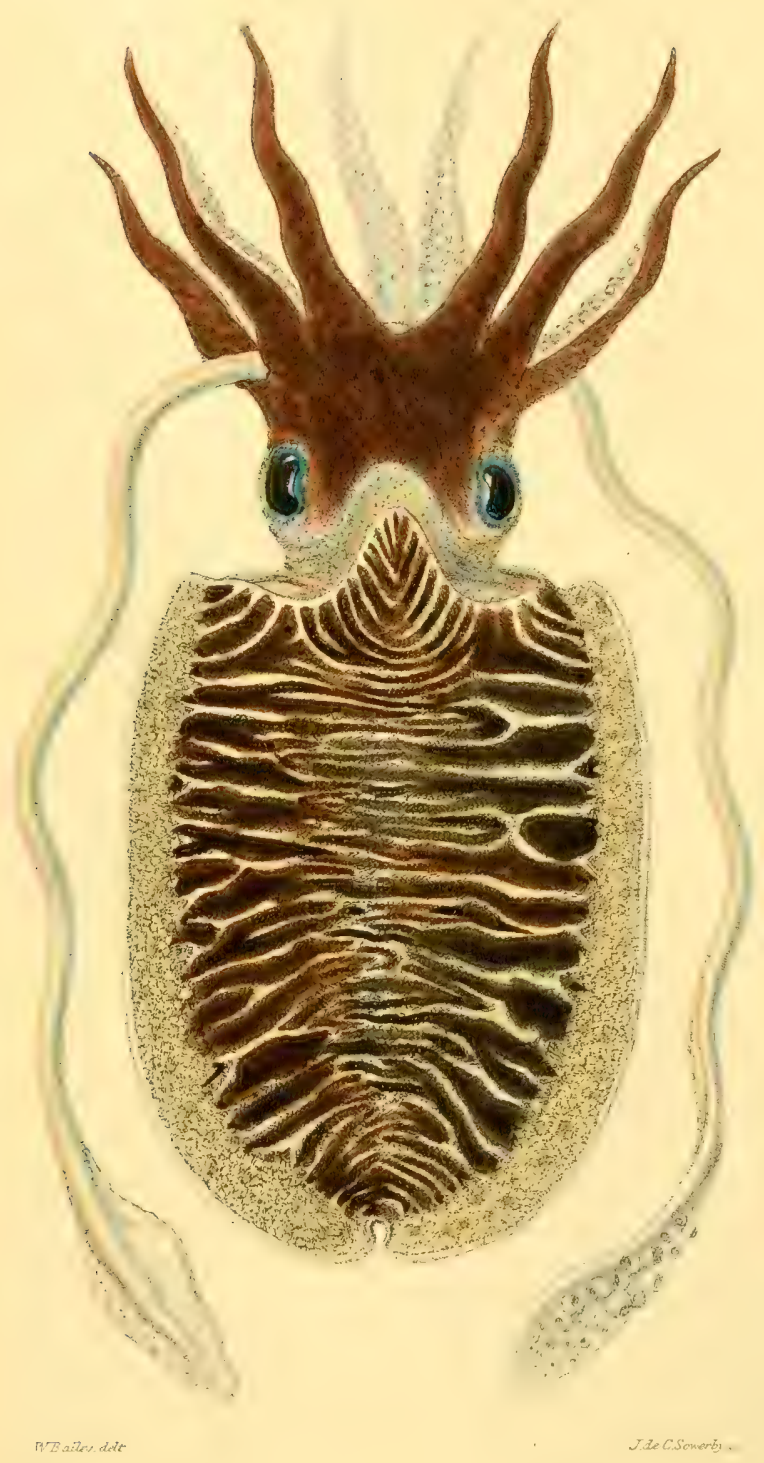

Sepia Othicinalis 


PIATE I'Y'

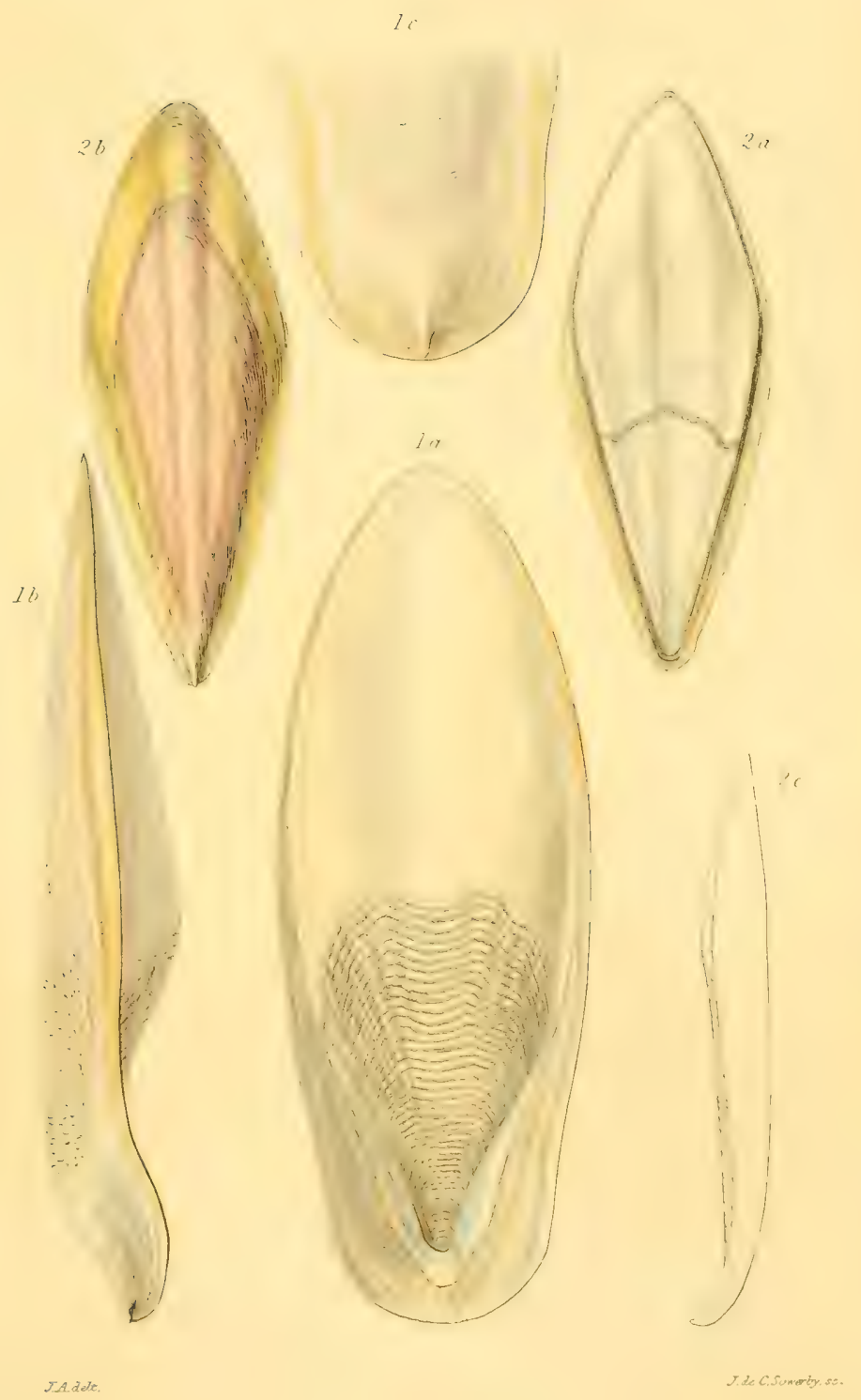

1. Sepia officinalis. 2.S.bisserialis . 


PLATE Q.Q.Q

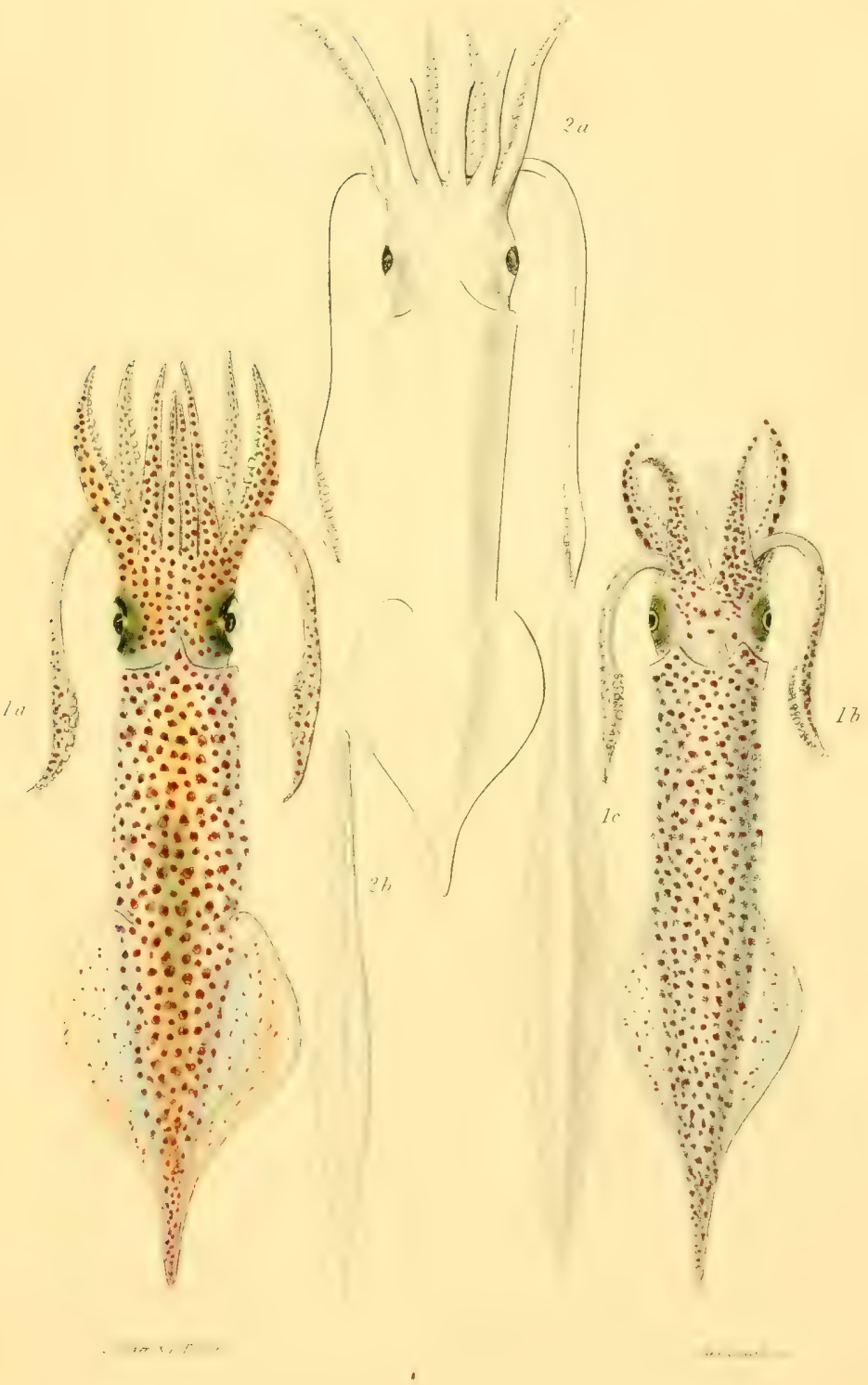

1.Loligo Media. 2. Loliỏo Marnore. 




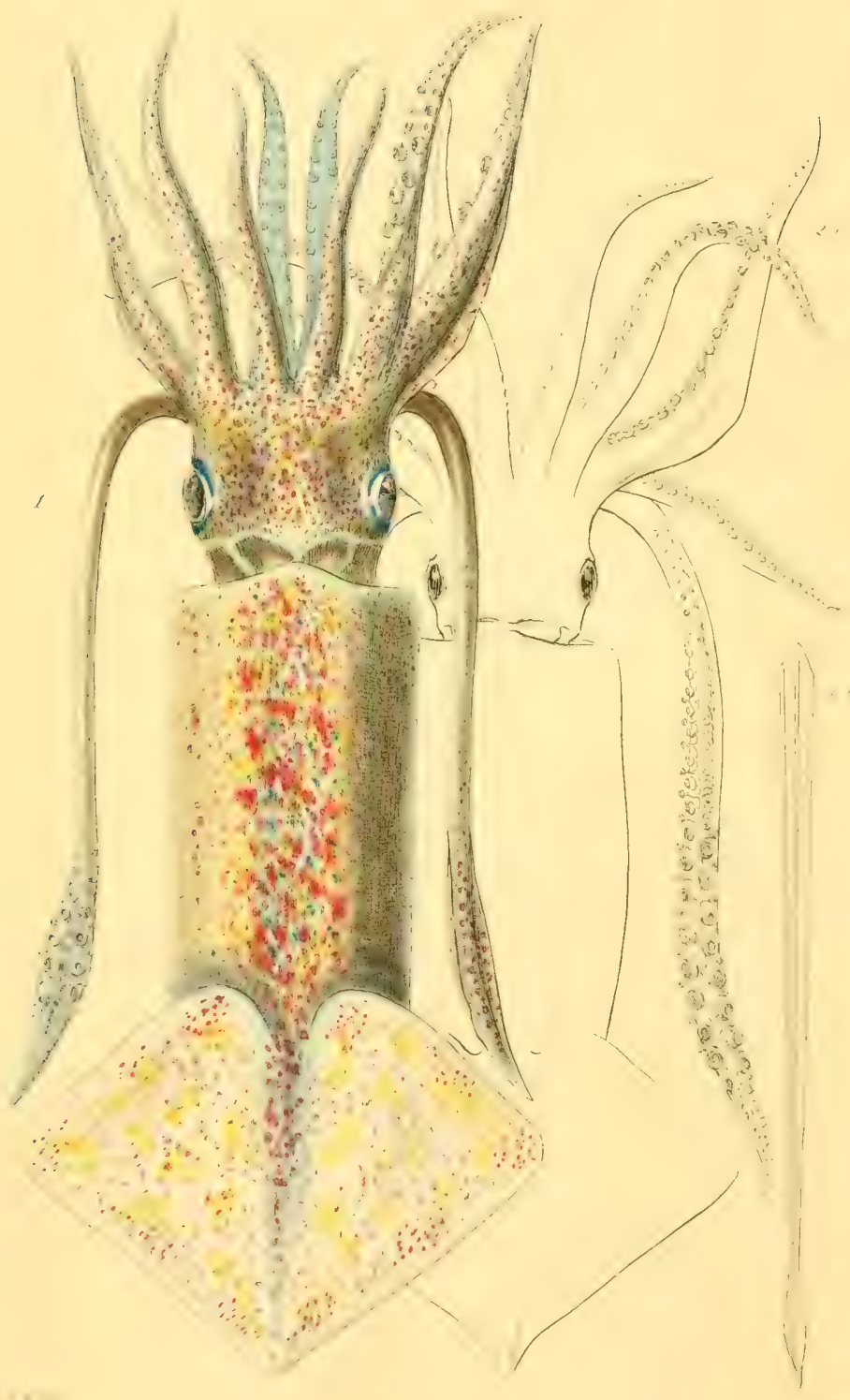

1. Ommastrephes sagitlatns. 2.0.10dams. 


PLATE S.S.S.

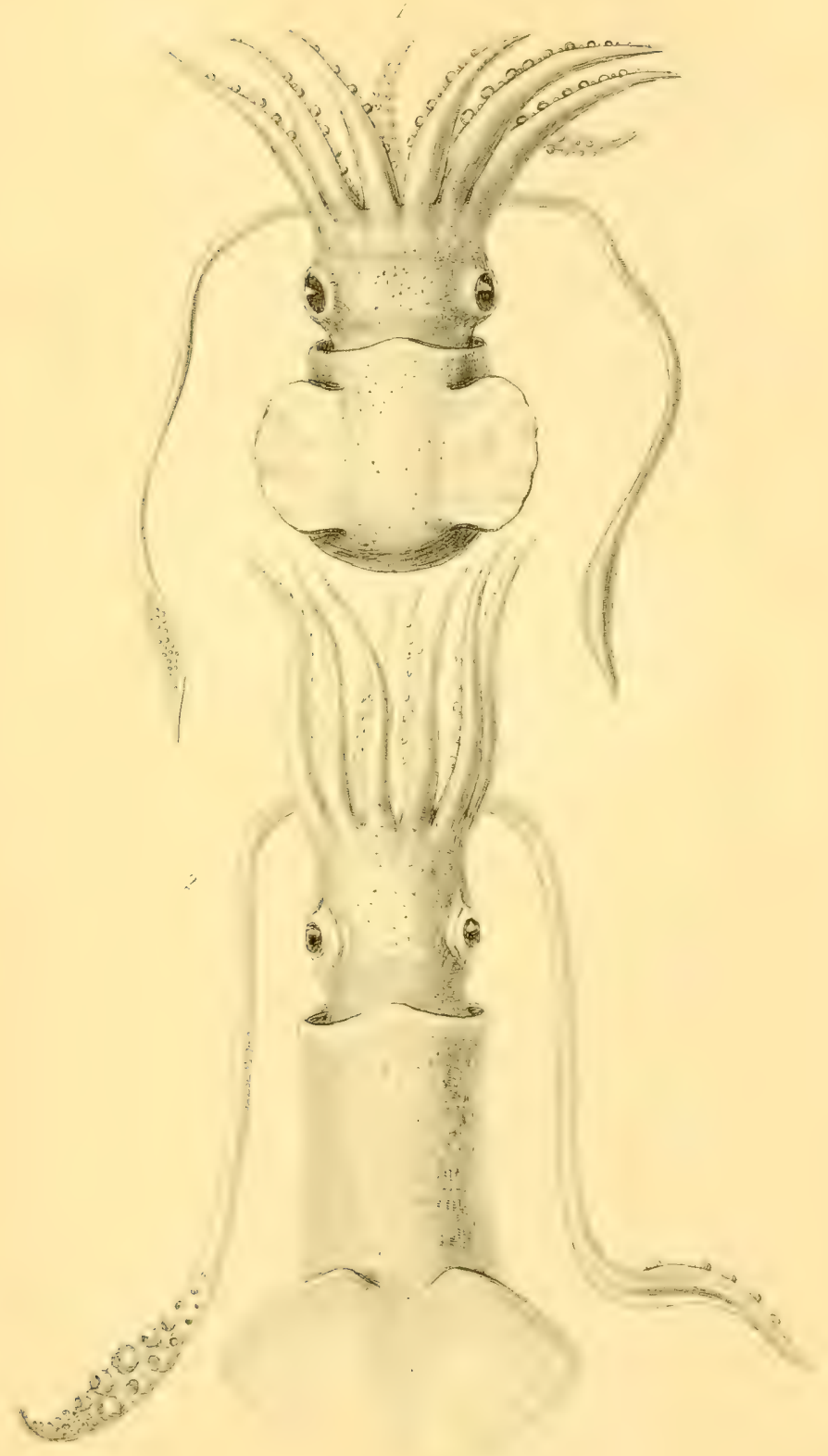

1. Rossia Owenii 2-Ommastrephes Eblamas. 







\section{Date Due}

- $4 J u n 50$ AUG 1950 


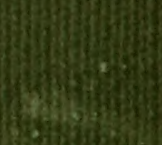

